\title{
A LIST AND INDEX OF THE PUBLICATIONS OF THE UNITED STATES NATIONAL MUSEUM (1875-1946)
}

Compiled in the Editorial Division, Smithsonian Institution

\section{PREFACE}

NLY once before has there been issued a complete list, with index, of the publications of the National Museum. This was entitled "A List of the Publications of the United States National Museum (1875-1900)" and was published in 1902 as U. S. National Museum Bulletin No. 51. It was compiled by Randolph I. Geare, chief of the Division of Correspondence and Documents, and aggregated 168 printed pages. A supplement was issued four years later, bringing the list through the year 1906.

Forty years have thus elapsed, and it is therefore felt that the present work is long overdue. Inasmuch as publication (i.e., the "diffusion of knowledge") is one of the two prime functions of the Smithsonian Institution, another complete list is especially appropriate this year (1946) when the one-hundredth anniversary of the Institution's founding is being observed. Since Bulletin 51 has long been out of print, the present list has been made all-inclusive, covering the entire 71-year span of Museum publication.

The publications of the National Museum have appeared in five series as follows: the Annual Reports, the Bulletins, the Proceedings, the Special Bulletins, and the Circulars. The Reports previous to 1905 were large volumes containing, in addition to the administrative reports, papers based upon the Museum collections and upon its explorations and researches. Examples of these are such monumental contributions as Donaldson's monograph on the George Catlin Indian Gallery, Hornaday's "Extinction of the American Bison," Goode's "The Museums of the Future," and Ridgway's "The Humming Birds." Since 1905 the Reports have been without the supplemental papers but have continued the lists of all the accessions received each year by the Museum.

The first of the Bulletins was issued in 1875. This series contains separate publications of monographic proportions-systematic treatises, faunal works, reports of expeditions, catalogs of type specimens and special collections -and in all fields of the Museum's scientific work. To date, 193 Bulletins have been issued, some of them in several volumes (as Nos. 47, 50, 71, 82, $100,104)$. In this series also are included the Contributions from the United States National Herbarium, now in their thirtieth volume, containing papers relating to the botanical collections of the Museum. In all, therefore, the Bulletin series aggregates nearly 300 separate volumes.

Of the Proceedings, begun in 1878, 96 volumes have been published, comprising a total of 3,204 separate papers. This series, for the most part, 
contains technical papers in biology, geology, and anthropology, based on the Museum's collections in these fields. Most of them are taxonomic in character, since one of the principal tasks of Museum curators is to name and arrange in systematic order the specimens and objects under their care. Copies of each paper, in pamphlet form, are distributed as published to libraries and scientific organizations and to specialists and others interested in the different subjects. The dates at which these separate papers are published are recorded in the table of contents of each of the completed volumes.

No Circular has been issued since 1929, and the quarto series of Special Bulletins stopped with the final part of No. 4 in 1915.

There have been three editors of the National Museum publications: A. Howard Clark, who served from 1879 to 1896; Marcus Benjamin, from 1896 to 1931; and Paul H. Oehser, the present editor, who succeeded Dr. Benjamin in 1931.

The original distribution of all Museum publications is designed to make them as widely available as possible, in view of the relatively small editions printed. They are sent free to libraries and scientific establishments throughout the world, to specialists in the particular fields of science involved, and to others interested who may request copies. Small editions of the Bulletins and Reports are printed for sale by the Superintendent of Documents, United States Government Printing Office. Only the most recent publications are now available, the earlier numbers (except in rare instances) being long out of print. Information as to the availability of any particular number may be obtained by addressing the Division of Publications, Smithsonian Institution, Washington 25, D. C.

The present list and index have been compiled in the Editorial Division of the Smithsonian Institution, under the direction of Webster P. True, chief, and Paul H. Oehser, assistant chief. The classified index of titles is the work of Miss Gladys O. Visel, editorial clerk; while Mrs. Phyllis W. Prescott and Miss Ruth B. MacManus have aided in assembling the list. Lester E. Commerford, chief of the Division of Publications, has been most helpful in supplying dates and other information.

Scientific bibliographies and indexes rarely need apology, since they are the acknowledged indispensable tools of scientists, teachers, students, librarians, and editors. The present list is no exception, the only regret being that it was not found practicable at this time to list under one cover all the publications of the Smithsonian Institution. Such a comprehensive list would include the publications of the Smithsonian proper, the Bureau of American Ethnology, the Astrophysical Observatory, the Freer Gallery of Art, and the National Collection of Fine Arts, as well as those of the National Museum. In lieu of that, the present work is offered, and those who are familiar with matters of scientific literature will know that it represents a notable achievement in the "diffusion of knowledge among men" and one of which James Smithson, founder of the Smithsonian Institution, would have been truly proud. 


\section{ANNUAL REPORTS}

Report of the Assistant Director of the United States National Museum, G. Brown

Goode, for the year 1881. ${ }^{1}$ From the Smithsonian Report for 1881. Pp. 1-79.

Report of the Assistant Director of the United States National Museum, G. Brown

Goode, for the year 1882. From the Smithsonian Report for 1882. Pp. 1-145.

Report of the Assistant Director and of the curators of the United States National

Museum for the year 1883. From the Smithsonian Report for 1883. Pp. 1-200.

Report of the United States National Museum for the year 1884. (Pt. 2 of the

Annual Report of the Board of Regents of the Smithsonian Institution for the year 1884.)

Pt. 1. Report upon condition and progress of the Museum. By G. Brown Goode. Pp. 1-72.

Pt. 2. Reports of the curators. Pp. 73-276.

Pt. 3. Scientific papers:

No. 1. Throwing-sticks in the National Museum. By Otis T. Mason. Pp. 279-291, 17 pls.

No. 2. Basket-work of the North American aborigines. By Otis T. Mason. Pp. 291-306, 64 pls.

No. 3. A study of the Eskimo bows in the U. S. National Museum. By John Murdoch. Pp. 307-316, 12 pls.

No. 4. On a spotted dolphin apparently identical with the Prodelphinus doris of Gray. By Frederick W. True. Pp. 317-324, 6 pls.

No. 5. The Florida muskrat (Neofiber alleni True). By Frederick W. True. Pp. 325-330, 3 pls.

No. 6. On the West Indian seal (Monachus tropicalis Gray). By Frederick W. True and F. A. Lucas. Pp. 331-335, 3 pls.

Pt. 4. Bibliography of the U. S. National Museum for the year 1884. Pp. 337-381.

Pt. 5. List of accessions to the U. S. National Museum during 1884. Pp. 383-428.

Report of the United States National Museum for the half year ending June 30, 1885.'

(Pt. 2 of the Annual Report of the Board of Regents of the Smithsonian Insti-

tution to July 1885.)

Pt. 1. Report upon condition and progress of the Museum. By G. Brown Goode. Pp. 1-54.

Pt. 2. Reports of the curators. Pp. 55-147.

Pt. 3. Bibliography of the Museum. Pp. 149-174.

Pt. 4. List of accessions with descriptive notes and indices. Pp. 175-243.

Pt. 5. The George Catlin Indian Gallery. By Thomas Donaldson. Pp. i-vii, 1-939, 142 pls.

Report of the United States National Museum for the year ending June 30, 1886. (Pt.

2 of the Annual Report of the Board of Regents of the Smithsonian Institution for the year ending June $30,1886$.

Pt. 1. Report upon condition and progress of the Museum. By G. Brown Goode. Pp. 1-83.

Pt. 2. Reports of the curators. Pp. 87-252.

Pt. 3. Papers describing and illustrating the collections in the U. S. National Museum.

No. 1. The meteorite collection in the U. S. National Museum; a catalogue of meteorites represented November 1, 1886. By F. W. Clarke. Pp. 255-265, $1 \mathrm{pl}$.

\footnotetext{
1 This was the first report on the operations of the National Museum printed under a separate cover. The reports of the Museum for 1881,1882 , and 1883 were first printed in the reports of the Institution for those years and were afterward issued in pamphlet form. The Museum Report for 1884 was the first one to occupy a separate volume of the Smithsonian Report and to be accompanied by papers based upon the collections.

2 This volume covers only the first six months of the year 1885, since it was decided to issue future reports by fiscal year instead of by calendar year.
} 
No. 2. Gem collection of the U. S. National Museum. By George F. Kunz. Pp. 267-275.

No. 3. The collection of building and ornamental stones in the U. S. National Museum: A hand-book and catalogue. By George P. Merrill. Pp. 277-648, 9 pls.

No. 4. List of specimens of textile fibers and fabrics in the reference series of the Section of Textile Industries of the U. S. National National Museum, June 30, 1886. By Romyn Hitchcock. Pp. 649-655.

No. 5. Preparation of microscopical mounts of vegetable textile fibers. By Romyn Hitchcock. Pp. 657-658.

No. 6. How to collect mammal skins for purposes of study and for mounting. By William T. Hornaday. Pp. 659-670, 9 figs.

Pt. 4. Bibliography of the Museum. Pp. 671-699.

Pt. 5. List of accessions with descriptive notes and indices. Pp. 701-811.

Report of the United States National Museum for the year ending June 30, 1887. (Pt.

2 of the Annual Report of the Board of Regents of the Smithsonian Institution for the year ending June $30,1887$.

Pt. 1. Report upon condition and progress of the Museum. By G. Brown Goode. Pp. 1-62.

Pt. 2. Reports of the curators. Pp. 65-158, 2 figs., 1 pl.

Pt. 3. Papers illustrative of the collections in the U. S. National Museum.

No. 1. Cradles of the American aborigines. By Otis T. Mason. Pp. 161212, 45 figs.

No. 2. Notes on the artificial deformation of children among savage and civilized peoples. [With bibliography.] By J. H. Porter. Pp. 213235.

No. 3. The human beast of burden. By Otis T. Mason. Pp. 237-295, 54 figs.

No. 4. Ethno-conchology: A study of primitive money. By Robert E. C. Stearns. Pp. 297-334, 22 figs., 9 pls.

No. 5. A preliminary catalogue of the Eskimo collection in the U. S. National Museum, arranged geographically and by uses. By T. Dix Bolles. Pp. 335-365.

No. 6. The extermination of the American bison, with a sketch of its discovery and life history. By William T. Hornaday. Pp. 367-548, 21 pls., 1 map.

No. 7. The preservation of museum specimens from insects and the effects of dampness. By Walter Hough. Pp. 549-558, 4 figs.

Pt. 4. Bibliography of the Museum. Pp. 561-594.

Pt. 5. List of accessions, with descriptive notes. Pp. 597-725.

Report of the United States National Museum for the year ending June 30, 1888. (Pt.

2 of the Annual Report of the Board of Regents of the Smithsonian Institution for the year ending June 30, 1888.)

Pt. 1. Report upon condition and progress of the Museum. By G. Brown Goode. Pp. 1-84.

Pt. 2. Reports of the curators. Pp. 85-222.

Pt. 3. Papers describing and illustrating the collections in the U. S. National Museum.

No. 1. The Coast Indians of southern Alaska and northern British Columbia. By Albert P. Niblack. Pp. 225-386, 360 figs. (most of them appearing on 70 pls., a few in the text), 2 charts.

No. 2. A catalogue of the Hippisley collection of Chinese porcelains: With a sketch of the history of ceramic art in China. By Alfred E. Hippisley. Pp. 387-491.

No. 3. The expedition to Funk Island, with observations upon the history and anatomy of the great auk. By Frederic A. Lucas. Pp. 493-529, 3 pls. 
No. 4. Fire-making apparatus in the U. S. National Museum. By Walter Hough. Pp. 531-587, 60 figs. (some of them appearing on 8 pls.).

No. 5 The collection of Korean mortuary pottery in the U. S. National Museum. By Pierre Louis Jouy. Pp. 589-596, 5 pls., 1 map.

No. 6. A study of prehistoric anthropology. By Thomas Wilson. Pp. 597671,43 figs., 20 pls.

No. 7. Ancient Indian matting-from Petit Anse Island, Louisiana. By Thomas Wilson. Pp. 673-675, 1 pl.

No. 8. Results of an inquiry as to the existence of man in North America during the Paleolithic period of the Stone Age. By Thomas Wilson. Pp. 677-702, 14 figs.

Pt. 4. Bibliography of the Museum. Pp. 705-734.

Pt. 5. List of accessions. Pp. 737-819.

Report of the United States National Museum for the year ending June 30, 1889.

Pt. 1. Report upon condition and progress of the Museum. By G. Brown Goode. Pp. 1-277.

Pt. 2. Reports of the curators. Pp. 281-423, 11 pls.

Pt. 3. Papers describing and illustrating the collections in the U. S. National Museum.

No. 1. The museums of the future. By G. Brown Goode. Pp. 427-445.

No. 2. Te Pito Te Henua, or Easter Island. By William J. Thomson. Pp. 447-552, 20 figs., 49 pls.

No. 3. Aboriginal skin-dressing; a study based on material in the U. S. National Museum. By Otis T. Mason. Pp. 553-589, 33 pls.

No. 4. The puma, or American lion (Felis concolor of Linnaeus). By Frederick W. True. Pp. 591-608, 1 pl.

No. 5. Animals recently extinct or threatened with extermination, as represented in the collections of the U. S. National Museum. By Frederic A. Lucas. Pp. 609-649, 2 figs., 7 maps, 10 pls.

No. 6. The development of the American rail and track, as illustrated by the collection in the U. S. National Museum. By J. Elfreth Watkins. Pp. 651-708, 115 figs.

No. 7. Explorations in Newfoundland and Labrador in 1887 , made in connection with the cruise of the U. S. Fish Commission schooner Grampus. By Frederic A. Lucas. Pp. 709-728, 1 pl.

No. 8. On a bronze Buddha in the U. S. National Museum. By Charles De Kay. Pp. 729-735, 1 pl.

Pt. 4. Bibliography of the Museum. Pp. 739-776.

Pt. 5. List of accessions. Pp. 779-843.

Appendix E. Preliminary handbook of the Department of Geology in the

U. S. National Museum. Pp. 1-50.

Report of the United States National Museum for the year ending June 30, 1890.

Pt. 1. Report upon condition and progress of the Museum. By G. Brown Goode. Pp. 1-116.

Pt. 2. Reports of the curators. Pp. 119-249.

Pt. 3. Papers describing and illustrating the collections in the U. S. National Museum.

No. 1. The humming birds. By Robert Ridgway. Pp. 253-383, 47 figs., 46 pls.

No. 2. White-line engraving for relief-printing in the 15 th and 16 th centuries. By S. R. Koehler. Pp. 385-394, 3 figs., 4 pls.

No. 3. The methods of fire-making. By Walter Hough. Pp. 395-409, 13 figs., 1 pl.

No. 4. The ulu, or woman's knife, of the Eskimo. By Otis T. Mason. Pp. 411-416, 21 pls.

No. 5. The ancient pit-dwellers of Yezo. By Romyn Hitchcock. Pp. 417-427, 4 figs., 8 pls.

No. 6. The Ainos of Yezo, Japan. By Romyn Hitchcock. Pp. 429-502, 21 figs., 37 pls. 
No. 7. Handbook for the Department of Geology in the U. S. National Museum. Part 1. Geognosy: The materials of the earth's cruat. By George P. Merrill. Pp. 503-591, 10 figs., 12 pls.

No. 8. The Catlin Collection of Indian paintings. By Washington Matthews. Pp. 593-610, 21 pls.

No. 9. The log of the Savannah. By J. Elfreth Watkins. Pp. 611-639, 6 pis.

No. 10. Anthropology at the Paris Exposition in 1889. By Thomas Wilson. Pp. 641-680, 7 pls.

Pt. 4. Bibliography of the Museum. Pp. 683-716.

Pt. 5. List of accessions. Pp. 719-788.

Report of the United States National Museum for the year ending June 30, 1891.

Pt. 1. Report upon condition and progress of the Museum. By G. Brown Goode. Pp. 1-131.

Pt. 2. Reports of the curators. Pp. 135-270, 1 pl.

Pt. 3. Papers describing and illustrating the collections in the U. S. National Museum.

No. 1. The genesis of the National Museum. By G. Brown Goode. Pp. 273-380.

No. 2. Ethnological collections in the U. S. National Museum from KilimaNjaro, East Africa. By W. L. Abbott. Pp. 381-428, 24 figs.

No. 3. The Bernadou, Allen, and Jouy Korean Collections, in the U. S. National Museum. By Walter Hough. Pp. 429-488, 31 pls.

No. 4. Shinto, or the mythology of the Japanese. By Romyn Hitchcock. Pp. 489-509.

No. 5. The ancient burial mounds of Japan. By Romyn Hitchcock. Pp. 511-523, 31 pls.

No. 6. Some ancient relics in Japan. By Romyn Hitchcock. Pp. 525-526, 4 pls.

No. 7. Prehistoric naval architecture of the North of Europe. By George H. Boehmer. Pp. 527-647, 127 figs., 17 pls.

No. 8. First draft of a system of classification for the World's Columbian Exposition. By G. Brown Goode. Pp. 649-735.

Pt. 4. Bibliography of the Museum. Pp. 739-764.

Pt. 5. List of accessions. Pp. 767-837.

Report of the United States National Museum for the year ending June 30, 1892.

Pt. 1. Report upon condition and progress of the Museum. By G. Brown Goode. Pp. 1-97.

Pt. 2. Reports of the curators. Pp. 101-217, 3 pls.

Pt. 3. Papers describing and illustrating the collections in the U. S. National Museum.

No. 1. Japanese wood-cutting and wood-cut printing. Communicated by $T$. Tokuno, and edited by S. R. Koehler. Pp. 221-244, 5 figs., 10 pls.

No. 2. The relation of biology to geological investigation. By Charles A. White. Pp. 245-368, 1 pl.

No. 3. Scientific taxidermy for museums. Based on a study of the United States Government Collections. By R. W. Shufeldt. Pp. 369-436, 83 pls.

No. 4. The shofar-its use and origin. Pp. $437-450,4$ pls.

No. 5. The Crump burial cave. (Biount County, Alabama.) By Frank Burns. Pp. 451-454, 1 pl.

No. 6. Minute stone implements from India. By Thomas Wilson. Pp. 455460,2 pls.

No. 7. Comparative oölogy of North American birds. By R. W. Shufeldt. Pp. 461-493.

Pt. 4. Bibliography of the Museum. Pp. 497-526.

Pt. 3. List of accessions. Pp. 529-601.

Report of the United States National Museum for the year ending June 30, 1893.

Pt. 1. Report upon condition and progress of the Museum. By G. Brown Goode. Pp. 1-334, 59 pls. 
Pt. 2. Papers describing and illustrating the collections in the U. S. National Museum.

No. 1. The poisonous snakes of North America. By Leonhard Stejneger. Pp. $339-487,70$ figs., 19 pls.

No. 2. Chinese games with dice and dominoes. By Stewart Culin. Pp. 491-537, 33 figs., 12 pls.

No. 3. The onyx marbles: Their origin, composition, and uses, both ancient and modern. By George P. Merrill. Pp. 541-585, 18 pls.

No. 4. The cowbirds. By Charles Bendire. Pp. 589-624, 3 pls.

No. 5. Primitive American armor. By Walter Hough. Pp. 627-651, 5 figs., 22 pls.

No. 6. The weapons and wings of birds. By Frederic A. Lucas. Pp. 655663, 8 figs., 1 pl.

No. 7. Notes on the ethnology of Tibet. [Based on collections in the U. S. National Museum.] By William Woodville Rockhill. Pp. 669747, 52 pls.

No. 8. Two Persepolitan casts in the U. S. National Museum. By Cyrus Adler. Pp. 751-753, 2 pls.

No. 9. Museum collections to illustrate religious history and ceremonials. By Cyrus Adler. Pp. 757-768.

No. 10. If public libraries, why not public museums? By Edward S. Morse. Pp. 771-780.

Report of the United States National Museum for the year ending June 30, 1894.

Pt. 1. Report on condition and progress of the Museum. By G. Brown Goode. Pp. 1-233.

Pt. 2. Papers describing and illustrating the collections in the U. S. National Museum.

No. 1. Primitive travel and transportation. By Otis Tufton Mason. Pp. 237-593, 260 figs., 25 pls.

No. 2. Mancala: The nationa! game of Africa. By Stewart Culin. Pp. 595607,15 figs., 5 pls.

No. 3. The golden patera of Rennes. By Thomas Wilson. Pp. 609-617, 1 fig., 1 pl.

No. 4. The wooden statue of Baron Ii Kamon-no-Kami Naosuké, pioneer diplomat of Japan. Translated from the Japanese, by H. Satoh. Pp. 621-622, 1 pl.

No. 5. A study of the primitive methods of drilling. By J. D. McGuire. Pp. 623-756, 201 figs.

No. 6. The swastika. By Thomas Wilson. Pp. 757-1011, 374 figs., 25 pls.

Report of the United States National Museum for the year ending June 30, 1895.

Pt. 1. Report on condition and progress of the Museum. By G. Brown Goode. Pp. 1-308.

Pt. 2. Papers describing and illustrating collections in the U. S. National Museum.

No. 1. The social organization and the secret societies of the Kwakiutl Indians. By Franz Boas. Pp. 309-738, 215 figs., 51 pls.

No. 2. The graphic art of the Eskimos. By Walter James Hoffman. Pp. 739-968, 154 figs., 82 pls.

No. 3. Notes on the geology and natural history of the Peninsula of Lower California. By George P. Merrill. Pp. 969-994, 10 pls.

No. 4. The mineralogical collections in the U. S. National Museum. By Wirt Tassin. Pp. 995-1000, 1 pl.

No. 5. The tongues of birds. By Frederic A. Lucas. Pp. 1001-1020, 13 figs., 2 pls.

No. 6. The Ontonagon copper bowlder in the U. S. National Museum. By Charles Moore. Pp. 1021-1030, 2 pls.

No. 7. Taxidermical methods in the Leyden Museum, Holland. By R. W. Shufeldt. Pp. 1031-1037, 6 pls. 
No. 8. The antiquity of the Red Race in America. By Thomas Wilson. Pp. 1039-1045.

Report of the United States National Museum for the year ending June 30, 1896.

Pt. 1. Report on condition and progress of the Museum. By G. Brown Goode. Pp. 1-284, 4 pls.

Pt. 2. Papers describing and illustrating collections in the U. S. National Museum.

No. 1. An account of the United States National Museum. By Frederick W. True. Pp. 287-324.

No. 2. Prehistoric art; or, the origin of art as manifested in the works of prehistoric man. By Thomas Wilson. Pp. 325-664, 325 figs., 74 pls., frontispiece.

No. 3. Chess and playing-cards. Catalogue of games and implements for divination exhibited by the United States National Museum in connection with the Department of Archaeology and Paleontology of the University of Pennsylvania at the Cotton States and International Exposition, Atlanta, Georgia, 1895. By Stewart Culin. Pp. 665-942, 226 figs., 50 pls.

No. 4. Biblical antiquities. A description of the exhibit at the Cotton States International Exposition, Atlanta, 1895. By Cyrus Adler and I. M. Casanowicz. Pp. 943-1023, 46 pls.

No. 5. The lamp of the Eskimo. By Walter Hough. Pp. 1025-1057, 4 figs., 24 pls.

Report of the United States National Museum for the year ending June 30, 1897. Vol. 1.

Pt. 1. Report on condition and progress of the Museum. By Charles D. Walcott. Pp. 1-245.

Pt. 2. Papers describing and illustrating collections in the U. S. National Museum.

No. 1. Recent Foraminifera. A descriptive catalogue of specimens dredged by the U. S. Fish Commission steamer Albatross. By James M. Flint. Pp. 249-349, 80 pls.

No. 2. Pipes and smoking customs of the American aborigines, based on material in the U. S. National Museum. By Joseph D. McGuire. Pp. 351-645, 239 figs., 4 pls.

No. 3. Catalogue of the series illustrating the properties of minerals. By Wirt Tassin. Pp. 647-688.

No. 4. Te Pito Te Henua, known as Rapa Nui; commonly called Easter Island, South Pacific Ocean. Latitude $27^{\circ} 10^{\prime}$ S., Longitude $109^{\circ}$ $26^{\prime}$ W. By George H. Cooke. Pp. 689-723.

No. 5. The man's knife among the North American Indians. By Otis Tufton Mason. Pp. 725-745, 17 figs.

No. 6. Classification of the mineral collections in the U. S. National Museum. By Wirt Tassin. Pp. 747-810.

No. 7. Arrowpoints, spearheads, and knives of prehistoric times. By Thomas Wilson. Pp. 811-988, 201 figs., 65 pls.

Report of the United States National Museum for the year ending June 30, 1897. Vol.

2. A memorial of George Brown Goode, together with a selection of his papers on museums and on the history of science in America.

Memorial Meeting.

Invitation. P. 3.

Programme. P. 4.

Introductory remarks. By Gardiner Greene Hubbard. Pp. 5-6.

Opening address. By Samuel Pierpont Langley. Pp. 7-11.

Goode as a historian and citizen. By William Lyne Wilson. Pp. 13-16.

Goode as a naturalist. By Henry Fairfield Osborn. Pp. 17-24.

Goode's activities in relation to American science. By William Healey Dall. Pp. 24-31.

Resolutions and messages of sympathy. Pp. 33-38. 
Memoir of George Brown Goode. By Samuel Pierpont Langley. Pp. 39-61.

Papers by George Brown Goode. Pp. 63-477, 103 pls.

Museum-history and museums of history. Pp. 63-81.

The genesis of the United States National Museum. Pp. 83-191.

The principles of museum administration. Pp. 193-240.

The museums of the future. Pp. 241-262.

The origin of the national scientific and educational institutions of the United States. Pp. 263-354.

The beginnings of natural history in America. Pp. 355-406.

The beginnings of American science: The third century. Pp. 407-466.

The first national scientific congress (Washington, April, 1844), and its connection with the organization of the American Association. Pp. 467-477.

The published writings of George Brown Goode. By Randolph Iltyd Geare. Pp. 481-500, 6 pls.

Report of the United States National Museum for the year ending June 30, 1898.

Pt. 1. Report on condition and progress of the Museum. By Charles D. Walcott. Pp. 1-149.

Pt. 2. The crocodilians, lizards, and snakes of North America. By Edward Drinker Cope. Pp. 153-1270, 347 figs., 36 pls.

Report of the United States National Museum for the year ending June 30, 1899.

Pt. 1. Report on condition and progress of the Museum. By Richard Rathbun. Pp. 1-152.

Pt. 2. Papers describing and illustrating collections in the U. S. National Museum.

No. 1. Guide to the study of the collections in the section of applied geology: The nonmetallic minerals. By George P. Merrill. Pp. 155-483, 12 figs., $30 \mathrm{pls}$.

No. 2. A primitive frame for weaving narrow fabrics. By Otis Tufton Mason. Pp. 485-510, 19 figs., 9 pls.

No. 3. An early West Virginia pottery. By Walter Hough. Pp. 511-521, $18 \mathrm{pls}$.

No. 4. Pointed bark canoes of the Kutenai and Amur. By Otis T. Mason. Pp. 523-537, 6 figs., 5 pls.

No. 5. Descriptive catalogue of a collection of objects of Jewish ceremonial deposited in the U. S. National Museum by Hadji Ephraim Benguiat. By Cyrus Adler and I. M. Casanowicz. Pp. 539-561, 36 pls.

Report of the United States National Museum for the year ending June 30, 1900.

Pt. 1. Report on condition and progress of the Museum. By Richard Rathbun. Pp. 1-152, 9 pls.

Pt. 2. Papers describing and illustrating collections in the U. S. National Museum.

No. 1. Anthropological studies in California. By William Henry Holmes. Pp. 1-187, 50 pls.

No. 2. Aboriginal American harpoons: A study in ethnic distribution and invention. By Otis Tufton Mason. Pp. 189-304, 92 figs., 19 pls.

No. 3. A sketch of the history of ceramic art in China, with a catalogue of the Hippisley Collection of Chinese porcelains. By Alfred E. Hippisley. Pp. 305-416, 21 pls.

No. 4. Contributions to the history of musical scales. By Charles Kasson Wead. Pp. 417-462, 8 figs., 10 pls.

No. 5. A collection of Hopi ceremonial pigments. By Walter Hough. Pp. 465-471.

No. 6. Descriptive catalogue of the collections of gems in the United States National Museum. By Wirt Tassin. Pp. 473-670, 26 figs., 9 pls.

No. 7. Descriptive catalogue of the meteorite collection in the United States National Museum, to January 1, 1902. By Wirt Tassin. Pp. 671698,4 pls. 
Report of the United States National Museum for the year ending June 30, 1901.

Pt. 1. Report on condition and progress of Museum. By Richard Rathbun. Pp. $1-174$.

Pt. 2. Papers describing and illustrating collections in the U. S. National Museum.

No. 1. Report on the exhibit of the United States National Museum at the Pan-American Exposition, Buffalo, New York, 1901. By Frederick W. True, William H. Holmes, and George P. Merrill. Pp. 177231, 72 pls.

No. 2. Flint implements and fossil remains from a sulphur spring at Afton, Indian Territory. By William Henry Holmes. Pp. 233-252, 26 pls.

No. 3. Classification and arrangement of the exhibits of an anthropological museum. By William Henry Holmes. Pp. 253-278, 7 figs.

No. 4. Archeological field work in northeastern Arizona. The MuseumGates Expedition of 1901. By Walter Hough. Pp. 279-358, 101 pls.

No. 5. Narrative of a visit to Indian tribes of the Purus River, Brazil. By Joseph Beal Steere. Pp. 359-393. 15 figs., 9 pls.

Report of the United States National Museum for the year ending June 30, 1902.

Pt. 1. Report on condition and progress of Museum. By Richard Rathbun. Pp. 1-168.

Pt. 2. Papers describing and illustrating collections in the U. S. National Museum.

No. 1. Aboriginal American basketry: Studies in a textile art without machinery. By Otis Tufton Mason. Pp. 171-548, 212 figs., 248 pls.

No. 2. The herpetology of Porto Rico. By Leonhard Stejneger. Pp. 549724, 197 figs., 1 pl.

No. 3. Wokas, a primitive food of the Klamath Indians. By Frederick Vernon Coville. Pp. 725-739, 13 pls.

Report of the United States National Museum for the year ending June 30, 1903.

Pt. 1. Report on condition and progress of Museum. By Richard Rathbun. Pp. $1-174$.

Pt. 2. Papers descriptive of Museum Buildings.

No. 1. The United States National Museum: An account of the buildings occupied by the national collections. By Richard Rathbun. Pp. $177-308,29$ pls.

No. 2. Studies of the museums and kindred institutions of New York City, Albany, Buffalo, and Chicago, with notes on some European institutions. By A. B. Meyer. Pp. 311-608, 120 figs., 40 pls.

Report of the United States National Museum for the year ending June 30, 1904.

Pt. 1. Report on condition and progress of Museum. By Richard Rathbun. Pp. 1-186.

Pt. 2. Papers describing and illustrating collections in the U. S. National Museum.

No. 1. Contributions to the history of American geology. By George P. Merrill. Pp. 187-733, 141 figs., 37 pls.

No. 2. The S. S. Howland collection of Buddhist religious art in the National Museum. By Immanuel M. Casanowicz. Pp. 735-744, 17 pls.

No. 3. Flint implements of the Fayum, Egypt. By Heywood Walter SetonKarr. Pp. 745-751, 12 pls.

Report of the United States National Museum for 1905 (forming part of the Annual Report of the Board of Regents of the Smithsonian Institution). By Richard Rathbun. Pp. 1-132.

Report of the United States National Museum for 1906 (forming part of the Annual Report of the Board of Regents of the Smithsonian Institution). By Richard Rathbun. Pp. 1-120.

Report on the progress and condition of the United States National Museum for the year ending June 30, 1907. By Richard Rathbun. Pp. 1-118.

Report on the progress and condition of the United States National Museum for the year ending June 30, 1908. By Richard Rathbun. Pp. 1-138. 
Report on the progress and condition of the United States National Museum for the year ending June 30, 1909. By Richard Rathbun. Pp. 1-141.

Report on the progress and condition of the United States National Museum for the year ending June 30,1910. By Richard Rathbun. Pp. 1-146.

Report on the progress and condition of the United States National Museum for the year ending June 30, 1911. By Richard Rathbun. Pp. 1-147.

Report on the progress and condition of the United States National Museum for the year ending June 30, 1912. By Richard Rathbun. Pp. 1-165.

Report on the progress and condition of the United States National Museum for the year ending June 30, 1913. By Richard Rathbun. Pp. 1-201.

Report on the progress and condition of the United States National Museum for the year ending June 30,1914. By Richard Rathbun. Pp. 1-252.

Report on the progress and condition of the United States National Museum for the year ending June 30, 1915. By Richard Rathbun. Pp. 1-215.

Report on the progress and condition of the United States National Museum for the year ending June 30, 1916. By Richard Rathbun. Pp. 1-219.

Report on the progress and condition of the United States National Museum for the year ending June 30, 1917. By Richard Rathbun. Pp. 1-184.

Report on the progress and condition of the United States National Museum for the year ending June 30,1918. By William DeC. Ravenel. Pp. 1-175.

Report on the progress and condition of the United States National Museum for the year ending June 30, 1919. By William deC. Ravenel. Pp. 1-211

Report on the progress and condition of the United States National Museum for the year ending June 30, 1920. By William deC. Ravenel. Pp. 1-210.

Report on the progress and condition of the United States National Museum for the year ending June 30, 1921. By William deC. Ravenel. Pp. 1-219.

Report on the progress and condition of the United States National Museum for the year ending June 30, 1922. By William deC. Ravenel. Pp. 1-210.

Report on the progress and condition of the United States National Museum for the year ending June 30, 1923. By William deC. Ravenel. Pp. 1-205.

Report on the progress and condition of the United States National Museum for the year ended June 30, 1924. By William deC. Ravenel. Pp. 1-205.

Report on the progress and condition of the United States National Museum for the year ended June 30, 1925. By Alexander Wetmore. Pp. 1-206.

Report on the progress and condition of the United States National Museum for the year ended June 30, 1926. By Alexander Wetmore. Pp. 1-205.

Report on the progress and condition of the United States National Museum for the year ended June 30, 1927. By Alexander Wetmore. Pp. 1-221.

Report on the progress and condition of the United States National Museum for the year ended June 30, 1928. By Alexander Wetmore. Pp. 1-216.

Report on the progress and condition of the United States National Museum for the year ended June 30, 1929. By Alexander Wetmore. Pp. 1-207.

Report on the progress and condition of the United States National Museum for the year ended June 30, 1930. By Alexander Wetmore. Pp. 1-219.

Report on the progress and condition of the United States National Museum for the year ended June 30, 1931. By Alexander Wetmore. Pp. 1-223.

Report on the progress and condition of the United States National Museum for the year ended June 30, 1932. By Alexander Wetmore. Pp. 1-181.

Report of the United States National Museum for 1933. (Part 2 of the Report of the Secretary of the Smithsonian Institution for the year ended June 30, 1933). By Alexander Wetmore. Pp. 1-194.

Report on the progress and condition of the United States National Museum for the year ended June 30, 1934. By Alexander Wetmore. Pp. 1-109.

Report on the progress and condition of the United States National Museum for the year ended June 30,1935. By Alexander Wetmore. Pp. 1-121.

Report on the progress and condition of the United States National Museum for the year ended June 30, 1936. By Alexander Wetmore. Pp. 1-115.

Report on the progress and condition of the United States National Museum for the year ended June 30, 1937. By Alexander Wetmore. Pp. 1-120. 
Report on the progress and condition of the United States National Museum for the year ended June 30, 1938. By Alexander Wetmore. Pp. 1-121.

Report on the progress and condition of the United States National Museum for the year ended June 30, 1939. By Alexander Wetmore. Pp. 1-128.

Report on the progress and condition of the United States National Museum for the year ending June 30,1940. By Alexander Wetmore. Pp. 1-118.

Report on the progress and condition of the United States National Museum for the year ended June 30, 1941. By Alexander Wetmore. Pp. 1-118.

Report on the progress and condition of the United States National Museum for the year ended June 30, 1942. By Alexander Wetmore. Pp. 1-118.

Report on the progress and condition of the United States National Museum for the year ended June 30, 1943. By Alexander Wetmore. Pp. 1-108.

Report on the progress and condition of the United States National Museum for the year ended June 30, 1944. By Alexander Wetmore. Pp. 1-100.

Report on the progress and condition of the United States National Museum for the year ended June 30, 1945. By Alexander Wetmore. Pp. 1-112.

Report on the progress and condition of the United States National Museum for the year ended June 30, 1946. By Alexander Wetmore. Pp. 1-113.

\section{Bull.}

No.

1.

2. Contributions to the natural history of Kerguelen Island, made in connection with the American [United States] Transit-of-Venus Expedition, 1874-75. By J. H. Kidder. I. Ornithology: Edited by Elliott Coues. Pp. i-ix and 1-51. 1875.

3. Contributions to the natural history of Kerguelen Island, made in connection with the United States Transit-of-Venus Expedition, 1874-75. By J. H. Kidder. II. Pp. 1-122. 1876.

Oology, etc. By J. H. Kidder and Elliott Coues, pp. 7-20.

Botany. A. Phaenogamia, Filices, et Lycopodiacea. Revised by A. Gray, pp. 21-25. B. Musci. Determined by Thomas P. James, pp. 25-27. C. Lichenes. Determined by Edw. Tuckerman, pp. 27-30. Algae. Determined by W. G. Farlow, pp. 30-31.

Geology. Determined by F. M. Endlich, pp. 33-38.

Fish. Identified by Theo. Gill, pp. 41-42.

Mollusks. By W. H. Dall, pp. 42-48.

Diptera. Identified by C. R. Osten Sacken, pp. 51-52.

Pseudo-neuroptera. By H. A. Hagen, pp. 52-57.

Crustaceans. Described by S. I. Smith, pp. 57-64.

Annelids and Echinoderms. By A. E. Verrill, pp. 64-77.

Appendix. Surgeon E. Kershner's collection, pp. 79-83.

A study of Chionis minor with reference to its structure and systematic position. By J. H. Kidder and Elliott Coues, pp. 85-116.

4. Birds of southwestern Mexico. Collected by Francis E. Sumichrast for the United States National Museum. By George N. Lawrence. Pp. 1-56. 1875.

5. Catalogue of the fishes of the Bermudas. Based chiefly upon the collections of the United States National Museum. By G. Brown Goode. Pp. 1-82. 1876.

6. Classification of the collection to illustrate the animal resources of the United States. A list of substances derived from the animal kingdom, with synopsis of the useful and injurious animals and a classification of the methods of capture and utilization. [International Exhibition, 1876.] By G. Brown Goode. Pp. i-xiii and 1-126. 1876.

7. Contributions to the natural history of the Hawaiian and Fanning Islands and Lower California, made in connection with the United States North Pacific Surveving Expedition. 1873-75. By Thomas H. Streets. PD. 1-172. 1877. 
8. Index to the names which have been applied to the subdivisions of the class Brachiopoda excluding the rudistes previous to the year 1877. By W. H. Dall. Pp. 1-88. 1877.

9. Contributions to North American ichthyology. Based primarily on the collections of the United States National Museum. I. Review of Rafinesque's Memoirs on North American Fishes. By. David S. Jordan. Pp. 1-53. 1877.

10. Contributions to North American ichthyology. Based primarily on the collections of the United States National Museum. II. A.- Notes on Cottidae, Etheostomatidae, Percidae, Centrarchidae, Aphododeridae, Dorysomatidae, and Cyprinidae, with revisions of the genera and descriptions of new or little known species. B.-Synopsis of the Siluridae of the fresh waters of North America. By David S. Jordan. Pp. 1-120, 45 pls. 1877.

11. Bibliography of the fishes of the Pacific coast of the United States to the end of 1879. By Theodore Gill. Pp. 1-73. 1882.

12. Contributions to North American ichthyology. Based primarily on the collections of the United States National Museum. III. A.-On the distribution of the fishes of the Alleghany region of South Carolina, Georgia, and Tennessee, with descriptions of new or little known species. By David S. Jordan and Alembert W. Brayton. B.-A synopsis of the family Catostomidae. By David S. Jordan. Pp. 1-237. 1878.

13. The flora of St. Croix and the Virgin Islands. By H. F. A. Eggers. Pp. 1-133, 1879.

14. Catalogue of the collection to illustrate the animal resources and the fisheries of the United States, exhibited at Philadelphia in 1876 by the Smithsonian Institution and the United States Fish Commission, and forming a part of the United States National Museum. [International Exhibition, 1876.] Prepared under the direction of G. Brown Goode. Pp. i-xvi and 1-351. 1879.

Pt. [1]. Section A. List of animals of North America beneficial or injurious to man. Pp. 1-70.

Section B. Means of pursuit and capture. Pp. 71-167.

Section C. Methods of preparation. Pp. 168-178.

Section D. Animal products and their applications. Pp. 179-232.

Section E. Protection and culture of useful animals. Pp. 233248.

Pt. [2]. Catalogue of illustrations of the economical invertebrates of the American coasts. By W. H. Dall. Pp. 249-271.

Pt. [3]. Commercial statistics of animal products in the United States:

A review of a portion of the report of the Chief of the Bureau of Statistics for the fiscal year ending June 30, 1877. By G. Brown Goode. Pp. 272-300.

15. Contributions to the natural history of Arctic America, made in connection with the Howgate Polar Expedition, 1877-78. By Ludwig Kumlien. Pp. 1-179. 1879.

Introduction. By Ludwig Kumlien. Pp. 5-9.

Ethnology. Fragmentary notes on the Eskimo of Cumberland Sound. By Ludwig Kumlien. Pp. 11-46.

Mammals. Fragmentary notes on the Mammalia of Cumberland Sound. By Ludwig Kumlien. Pp. 47-67.

Birds. By Ludwig Kumlien. Pp. 69-105.

Fishes collected in Cumberland Gulf and Disko Bay. By Tarleton H. Bean. Pp. 107-138.

Crustacea. By S. I. Smith. Pp. 139-140.

Annelides. By A. E. Verrill. Pp. 141-143.

- Mollusks. List of shells obtained by Mr. Ludwig Kumlien, naturalist to the Howgate Expedition, 1877-78, at points in Cumberland Sound, Arctic region, west from Baffin's Bay. By W. H. Dall. Pp. 145-146.

Molluscoids. By A. E. Verrill. Pp. 147-150.

Radiates. By A. E. Verrill. Pp. 151-153.

Insects: Diurnal Lepidoptera. By W. H. Edwards. Pp. 155-157. 
Insects: Hymenoptera, Nocturnal Lepidoptera, Diptera, Coleoptera, Neuroptera, and Arachnida. By S. H. Scudder and others. Pp. 159-161. (Hymenoptera, E. T. Cresson; Lepidoptera, A. R. Grote; Diptera, E. Burgess; Coleoptera, J. L. LeConte; Neuroptera, H. Hagen; Arachnida, J. H. Emerton.)

Plants. List of the plants collected at points in Cumberland Sound between the Sixty-sixth and Sixty-seventh Parallels of North Latitude and on the south shores of Disko Island, Greenland. By Asa Gray. Pp. 163-166.

Lichens. List of lichens collected in the vicinity of Annanactook Harbor, Cumberland Sound, at about lat. $67^{\circ}$ N., long. $68^{\circ} 49^{\prime}$ W. By Edward Tuckerman. Pp. 167-168.

Algae. By W. G. Farlow. Pp. 169.

Minerals. By F. M. Endlich. P. 171.

16. Synopsis of the fishes of North America. By David S. Jordan and Charles $\mathbf{H}$. Gilbert. Pp. i-lvi, 1-1018. 1882.

17. On the zoological position of Texas. By Edward D. Cope. Pp. 1-51. 1880.

18. Exhibit of the fisheries and fish culture of the United States of America, at the Internationale Fischerei-Ausstellung, held at Berlin, April 20, 1880, and forming a part of the collections of the National Museum, made by the United States Fish Commission. Prepared under the direction of G. Brown Goode. Pp. i-xv, 1-263. 1880.

19. Nomenclator Zoologicus. An alphabetical list of all generic names that have been employed by naturalists for recent and fossil animals from the earliest times to the close of the year 1879. In 2 parts: I. Supplemental list. II. Universal index. By Samuel H. Scudder. Pp. i-xxi, 1-376, 1-340. 1882.

20. Bibliographies of American naturalists. I. The published writing of Spencer Fullerton Baird, 1843-1882. By George Brown Goode. Pp. 1-xvi, 1-377. 1883.

21. Nomenclature of North American birds chiefly contained in the United States National Museum. By Robert Ridgway. Pp. 1-94. 1881.

22. Guide to the flora of Washington and vicinity. By Lester F. Ward. Pp. 1-264, 1 map. 1881.

23. Bibliographies of American naturalists. II. The published wrtings of Isaac Lea, LL.D. By Newton Pratt Scudder. Pp. i-lix, 1-278, 1 pl. 1885.

24. Check list of North American Reptilia and Batrachia, with catalogue of specimens in U. S. National Museum. By H. C. Yarrow. Pp. i-v, 1-249. 1882.

25. Contributions to the natural history of the Bermudas. Edited by J. Matthew Jones and George Brown Goode. Pp. i-xxiii, 1-353, 12 pis. 1884.

Pt. 1. Geology. By William North Rice. Pp. 1-32, 5 pls.

Pt. 2. Botany. By John Henry Lefroy. Pp. 33-141.

Pt. 3. Mammals. By J. Matthew Jones. Pp. 143-161.

Pt. 4. Birds. By Savile G. Reid. Pp. 163-279.

Pt. 5. Notes on birds. By C. Hart Merriman. Pp. 281-284.

Pt. 6. Reptiles. By Samuel Garman. Pp. 285-303.

Pt. 7. Annelids. By H. E. Webster. Pp. 305-327, 6 pls.

26. Avifauna Columbiana: being a list of birds ascertained to inhabit the District of Columbia, with the times of arrival and departure of such as non-residents, and brief notices of habits, etc. The second edition, revised to date, and entirely rewritten. By Elliott Coues and D. Webster Prentiss. Pp. 1-133, 100 figs., 2 pls. 1883.

27. Descriptive catalogues of the collections sent from the United States to the International Fisheries Exhibition, London, 1883, constituting a report upon the American section. Prepared under the direction of G. Brown Goode. Pp. i-liv, 1-1279. 1884.

Pt. A. Preliminary catalogue, and synopsis of the collections exhibited by the United States Fish Commission, and by special exhibitors. Pp. 1-85.

Pt. AA. Concordance to the official classification for the use of the juries. Pp. 87-105. 
Pt. B. Collection of economic crustaceans, worms, echinoderms, and sponges. By Richard Rathbun. Pp. 107-137.

Pt. C. Catalogue of the aquatic and fish-eating birds exhibited by the United States National Museum. By Rober Ridgway. Pp. 139-184.

Pt. D. Catalogue of the economic Mollusca and the apparatus and appliances used in their capture and preparation for market. By Francis Winslow. Pp. 185-270.

Pt. E. The whale fishery and its appliances. By James Temple Brown. Pp. 271-386.

Pt. F. Catalogue of the collection of fishes exhibited by the United States National Museum. By Tarleton H. Bean. Pp. 387-510.

Pt. G. Descriptive catalogue of the collection illustrating the scientific investigation of the sea and fresh waters. Pp. 511-622.

Pt. H. Catalogue of the aquatic mammals exhibited by the United States National Museum. By Frederick W. True. Pp. 623-644.

Pt. I. Catalogue of the collection illustrating the fishing vessels and boats and their equipment; the economic condition of fishermen; anglers' outfits, etc. By Joseph W. Collins. Pp. 645-823.

Pt. J. Catalogue of the apparatus for the capture of fish. By R. Edward Earll. Pp. 825-1030.

Pt. K. Catalogue of fishery products and of the apparatus used in their preparation. By A. Howard Clark. Pp. 1031-1154.

Pt. L. Catalogue of the fish-cultural exhibit of the United States Fish Commission. Pp. 1155-1249.

28. A manual of American land shells. By W. G. Binney. Pp. 1-528, 516 figs. 1885.

29. Results of ornithological explorations in the Commander Islands and in Kamtschatka. By Leonhard Stejneger. Pp. 1-382, 8 figs., 8 pls. 1885.

30. Bibliographies of American naturalists. III. Bibliography of publications relating to the collection of fossil invertebrates in the United States National Museum, including complete lists of the writings of Fielding B. Meek, Charles A. White, and Charles D. Walcott. By John Belknap Marcou. Pp. 1-333. 1885.

31. Synopsis of the North American Syrphidae. By Samuel W. Williamson. Pp. i-xxx, 1-335, 12 pls. 1886.

32. Catalogue of batrachians and reptiles of Central America and Mexico. By E. D. Cope. Pp. 1-98. 1887.

33. Catalogue of minerals and synonyms. By T. Egleston. Pp. 1-19S. 1887.

34. The Batrachia of North America. By E. D. Cope. Pp. 1-525, 119 figs., 86 pls. 1889.

35. Bibliographical catalogue of the described transformations of North American Lepidoptera. By Henry Edwards. Pp. 1-147. 1889.

36. Contributions to the natural history of the cetaceans. A review of the family Delphinidae. By Frederick W. True. Pp. 1-181, 47 pls. 1889.

37. A preliminary catalogue of the shell-bearing marine mollusks and brachiopods of the southeastern coast of the United States, with illustrations of many of the species. By William Healey Dall. Pp. 1-221, 74 pls. 1889. (New ed., 1903 , included 21 additional pls.)

38. Contribution toward a monograph of the insects of the lepidopterous family Noctuidae of temperate North America. Revision of the species of the genus Agrotis. By John B. Smith. Pp. i-iv, 1-237, 5 pls. 1890.

39. Directions for collecting and preserving specimens.

Pt. A. Directions for collecting birds. By Robert Ridgway. Pp. 1-27, 9 figs. 1891.

Pt. B. Directions for collecting Recent and fossil plants. By F. H. Knowlton (with notes on collecting and preserving fresh-water algae, by Frank S. Collins). Pp. 1-46, 10 figs. 1891. 
Pt. C. Notes on the preparation of rough skeletons. By Frederic A. Lucas. Pp. 1-11, 12 figs. 1891.

Pt. D. Directions for collecting, preparing, and preserving birds' eggs and nests. By Charles Bendire. Pp. 1-10, 7 figs. 1891.

Pt. E. Directions for collecting reptiles and batrachians. [With supplementary note giving directions for preserving small herpetological specimens in formalin.] By Leonhard Stejneger. Pp. 1-13, 5 figs. 1891.

Pt. F. Directions for collecting and preserving insects. By C. V. Riley. Pp. 1-147, 139 figs., 1 pl. 1892.

Pt. G. Instructions for collecting mollusks, and other useful hints for the conchologist. By William H. Dall. Pp. 1-56, 8 figs. 1892.

Pt. H. Directions for collecting minerals. By Wirt Tassin. Pp. 1-6, 8 figs. 1895.

Pt. I. Directions for collecting rocks and for the preparation of thin sections. By George P. Merrill. Pp. 1-15, 17 figs. 1895.

Pt. J. Directions for collecting specimens and information illustrating the aboriginal uses of plants. By Frederick V. Coville. Pp. 1-8. 1895.

Pt. K. Directions for collecting and preparing fossils. By Charles Schuchert. Pp. 1-31, 13 figs. 1895.

Pt. L. Directions for collecting and preserving scale insects (Coccidae). By T. D. A. Cockerell. Pp. 1-9. 1897.

Pt. M. The methods employed at the Naples Zoological Station for the preservation of marine animals. By Salvatore Lo Bianco. Translated from the original Italian by Edmund Otis Hovey. Pp. 1-42, 1 pl. 1899.

Pt. N. Directions for preparing study specimens of small mammals. By Gerrit S. Miller, Jr. Pp. 1-10, 1 fig. 1899. (2d ed., rev., with abstracts in German, French, and Spanish, issued in 1901; 3d ed., under new title, "Directions for Preparing Specimens of Mammals," and with additional figures, 1912; 4th ed., 1914; 5th ed., 1925; 6th ed., 1932.)

Pt. O. Directions for collecting and rearing dragon flies, stone flies, and may flies. By James G. Needham. Pp. 1-9, 4 figs. 1899.

Pt. P. Directions for collectors of American basketry. By Otis T. Mason. Pp. 1-31, 44 figs. 1902.

Pt. Q. Instructions to collectors of historical and anthropological specimens. By William Henry Holmes and Otis Tufton Mason. Pp. 1-16. 1902.

Pt. R. Directions for collecting information and specimens for physical anthropology. By Aleš Hrdlička. Pp. 1-25, 8 pls. 1904.

Pt. S. Directions for collecting information and objects illustrating the history of medicine. By James M. Flint. Pp. 1-5. 1905.

40. Bibliographies of American naturalists. IV. The published writings of George Newbold Lawrence, 1844-1891. By L. S. Foster. Pp. i-xi, 1-124, 1 pl. 1892.

41. Bibliographies of American naturalists. V. The published writings of Dr. Charles Girard. By George Brown Goode. Pp. i-vi, 1-141, 1 pl. 1891.

42. A preliminary descriptive catalogue of the systematic collections in economic geology and metallurgy in the United States National Museum. By Frederic P. Dewey. Pp. i-xviii, 1-256, 10 figs., 34 pls. 1891.

43. A monograph of the bats of North America. By Harrison Allen. Pp. i-ix, 1-198, 1 fig., 38 pls. 1893.

44. A catalogue, bibliographical and synonymical, of the species of moths of the lepidopterous superfamily Noctuidae, found in boreal America, with critical notes. By John B. Smith. Pp. 1-424. 1893.

45. A monograph of the North American Proctotrypidae. By William H. Ashmead. Pp. 1-472, 2 figs., 18 pls. 1893. 
46. The Myriapoda of North America. By Charles Harvey Bollman. Edited by L. M. Underwood. Pp. 1-210. 1893.

47. The fishes of North and Middle America: A descriptive catalogue of the species of fish-like vertebrates found in the waters of North America, north of the Isthmus of Panama. By David Starr Jordan and Barton Warren Evermann. Pp. 1-3313, 392 pls.

Pt. 1. Pp. i-lx, 1-1240. 1896.

Pt. 2. Pp. i-xxx, 1241-2183. 1898.

Pt. 3. Pp. i-xxiv, 2183a-3136. 1898.

Pt. 4. Pp. i-ci, 3137-3313, 392 pls. 1900.

48. Contributions toward a monograph of the insects of the lepidopterous family Noctuidae of boreal North America. A revision of the deltoid moths. By John B. Smith. Pp. i-vi, 1-129, 14 pls. 1895.

49. The published writings of Philip Lutley Sclater, 1844-1896. Prepared under the direction of G. Brown Goode. Pp. i-xix, 1-135, 1 pl. 1896.

50. The birds of North and Middle America: A descriptive catalogue of the higher groups, genera, species, and subspecies of birds known to occur in North America, from the Arctic lands to the Isthmus of Panama, the West Indies and other islands of the Caribbean Sea, and the Galapagos Archipelago.

Pt. 1. Family Fringillidae-The Finches. By Robert Ridgway. Pp. i-xox, 1-715, 20 pls. 1901.

Pt. 2. Families Tanagridae, Icteridae, Coerebidae, Mniotiltidae. By Robert Ridgway. Pp. i-xx, 1-834, 22 pls. 1902.

Pt. 3. Families Motacillidae, Hirundinidae, Ampelidae, Ptilogonatidae, Dulidae, Vireonidae, Lamidae, Corvidae, Paridae, Sittidae, Certhiidae, Troglodytidae, Cinclidae, Chamaeidae, Sylviidae. By Robert Ridgway. Pp. i-xx, 1-801, 19 pls. 1904.

Pt. 4. Families Turdidae, Zeledoniidae, Mimidae, Sturnidae, Ploceidae, Alaudidae, Oxyruncidae, Tyrannidae, Pipridae, Cotingidae. By Robert Ridgway. Pp. i-xxii, 1-973, 34 pls. 1907.

Pt. 5. Families Pteroptochidae, Formicariidae, Furnariidae, Dendrocolaptidae, Trochilidae, Micropodidae, Trogonidae. By Robert Ridgway. Pp. i-xxiii, 1-859, 33 pls. 1911.

Pt. 6. Families Picidae, Capitonidae, Ramphastidae, Bucconidae, Galbulidae, Alcedinidae, Todidae, Momotidae, Caprimulgidae, Nyctibiidae, Tytonidae, Bubonidae. By Robert Ridgway. Pp. i-xx, 1-882, 36 pls. 1914.

Pt. 7. Families Cuculidae, Psittacidae, Columbidae. By Robert Ridgway. Pp. i-xiii, 1-543, 24 pls. 1916.

Pt. 8. Families Jacanidae, Oedicnemidae, Haematopodidae, Arenariidae, Aphrizidae, Charadriidae, Scolopacidae, Phalaropodidae, Recurvirostridae, Rynchopidae, Sternidae, Laridae, Stercorariidae, Alcidae. By Robert Ridgway. Pp. i-xvi, 1-852, 34 pls. 1919.

Pt. 9. Families Gruidae, Rallidae, Heliornithidae, Eurypygidae. By Robert Ridgway and Herbert Friedmann. Pp. i-ix, 1-254, 16 figs. Oct. 2, 1941.

Pt. 10. Families Cracidae, Tetraonidae, Phasianidae, Numididae, Meleagrididae. By Robert Ridgway and Herbert Friedmann. Pp. i-xii, 1-484, 28 figs. Dec. 18, 1946.

51. A list of the publications of the United States National Museum (1875-1900). By Randolph I. Geare. Pp. i-vi, 1-168. 1902. (Suppl. 1, pp. 1-40, covering period 1901-1906, issued in 1906.)

52. A list of North American Lepidoptera and key to the literature of this order of insects. By Harrison G. Dyar, assisted by C. H. Fernald, George D. Hulst, and August Busck. Pp. i-xix, 1-723. 1902.

53. Catalogue of the type and figured specimens of fossils, minerals, rocks and ores in the Department of Geology, United States National Museum. Prepared under the direction of George P. Merrill. 
Pt. 1. Fossil invertebrates. Section 1. Catalogue of the type specimens of fossil invertebrates in the Department of Geology, United States National Museum. By Charles Schuchert, assisted by W. H. Dall, T. W. Stanton, and R. S. Bassler. Pp. i-v, 1-704. 1905.

Pt. 2. Fossil vertebrates; fossil plants; minerals, rocks, and ores. Section 2. Catalogue of the types, cotypes, and figured specimens of fossil vertebrates in the Department of Geology, United States National Museum. Begun by F. A. Lucas, completed by J. W. Gidley and C. W. Gilmore, assisted by Mrs. M. S. F. Jouy and Miss M. W. Moodey. Pp. 1-82. 1907. Section 3. Catalogue of the types and illustrated specimens of fossil plants in the Department of Geology, United States National Museum. By A. C. Peale, with cooperation of David White and F. H. Knowlton, assisted by Mrs. M. S. F. Jouy, Miss L. M. Graves, and Miss M. W. Moodey. Pp. 85-350. 1907. Section 4. List of minerals, meteorites, rocks, and ores that have been the subject of special investigation and publication, and are now in the Department of Geology, U. S. National Museum. By George P. Merrill and Wirt Tassin. Pp. 351-370. 1907.

54. A monograph on the isopods of North America. By Harriet Richardson. Pp. i-liii, 1-727, 740 figs. 1905.

55. A contribution to the oceanography of the Pacific. Compiled from data collected by the United States steamer Nero while engaged in the survey of a route for a trans-Pacific cable. By James M. Flint. Pp. i-v, 1-62, 14 pls. 1905.

56. Mammals of the Mexican Boundary of the United States. A descriptive catalogue of the species of mammals occurring in that region; with a general summary of the natural history, and a list of trees. By Edgar Alexander Mearns. Part 1. Families Didelphiidae to Muridae. Pp. i-xv, 1-530, 126 figs., 13 pls. Apr. 13, 1907.

57. The families and genera of bats. By Gerrit S. Miller, Jr. Pp. i-xvii, 1-282, 49 figs., 14 pls. 1907.

58. Herpetology of Japan and adjacent territory. By Leonhard Stejneger. Pp. i-xxx, 1-577, 409 figs., 35 pls. July 22, 1907.

59. Recent Madreporaria of the Hawaiian Islands and Laysan. By T. Wayland Vaughan. Pp. i-ix, 1-427, 96 pls. July 12, 1907.

60. The barnacles (Cirripedia) contained in the collection of the U. S. National Museum. By Henry A. Pilsbry. Pp. i-x, 1-122, 36 figs., 11 pls. Nov. 8, 1907.

61. Variations and genetic relationships of the garter-snakes. By Alexander G. Ruthven. Pp. i-xii, 1-201, 82 figs., 1 pl. June 24, 1908.

62. Catalogue of the type-specimens of mammals in the United States National Museum, including the Biological Survey collection. By Marcus Ward Lyon, Jr., and Wilfred Hudson Osgood. Pp. i-x, 1-325. 1909.

63. A monographic revision of the Coleoptera belonging to the tenebrionide tribe Eleodiini inhabiting the United States, Lower California, and adjacent islands. By Frank E. Blaisdell, Sr. Pp. i-xi, 1-524, 8 figs., 13 pls. June 24, 1909.

64. A critical summary of Troost's unpublished manuscript on the crinoids of Tennessee. By Elvira Wood. Pp. i-xi, 1-150, 16 pls. May 8, 1909.

65. Dendroid graptolites of the Niagaran dolomites at Hamilton, Ontario. Compiled by Ray S. Bassler. Pp. i-ix, 1-76, 91 figs., 5 pls. July 10, 1909.

66. A monographic revision of the twisted winged insects comprising the order Strepsiptera Kirby. By W. Dwight Pierce. Pp. i-xii, 1-232, 3 figs., 15 pls., 1 map. Dec. 6, 1909.

67. Directions for collecting and preserving insects. By Nathan Banks. Pp. i-xiii, 1-135, 188 figs., 1 pl. Oct. 7, 1909.

68. A monograph of West American pyramidellid mollusks. By William Healey Dall and Paul Bartsch. Pp. i-xi, 1-258, 30 pls. Dec. 13, 1909.

69. The taenioid cestodes of North American birds. By Brayton Howard Ransom. Pp. 1-141, 43 figs. Dec. 31, 1909. 
70. The National Gallery of Art. Department of Fine Arts of the National Museum. By Richard Rathbun. Pp. 1-140, 26 pls. July 1, 1909. (Reprinted, with additions, January 1916.)

71. A monograph of the Forminifera of the North Pacific Ocean. By Joseph Augustine Cushman.

Pt. 1. Astrorhizidae and Lituolidae. Pp. i-xiv, 1-134, 203 figs. June 30, 1910.

Pt. 2. Textulariidae. Pp. i-xiii, 1-108, 156 figs. June 30, 1911.

Pt. 3. Lagenidae. Pp. i-ix, 1-125, 47 pls. Dec. 12, 1913.

Pt. 4. Chilostomellidae, Globigerinidae, Nummulitidae. Pp. i-vi, 1-46, 19 pls. Feb. 28, 1914.

Pt. 5. Rotaliidae. Pp. i-vii, 1-87, 63 figs., 31 pls. Apr. 24, 1915.

Pt. 6. Miliolidae. Pp. i-vii, 52 figs., 39 pls. June 15, 1917.

72. Catalogue of Nearctic spiders. By Nathan Banks. Pp. i-iii, 1-80. Apr. 30, 1910.

73. An account of the beaked whales of the family Ziphiidae in the collection of the United States National Museum, with remarks on some specimens in other American museums. By Frederick W. True. Pp. i-v, 1-89, 42 pls. Sept. 28, 1910.

74. On some West Indian echinoids. By Theodor Mortensen. Oct. 3, 1910. Pp. i-v, 1-31, 17 pls.

75. North Pacific ophiurans in the collection of the United States National Museum. By Hubert Lyman Clark. Pp. i-xvi, 1-302, 144 figs. Feb. 23, 1911.

76. Asteroidea of the North Pacific and adjacent waters. By Walter Kenrick Fisher.

Pt. 1. Phanerozonia and Spinulosa. Pp. i-vi, 1-419, 122 pls. June 30, 1911.

Pt. 2. Forcipulata (part). Pp. i-iii, 1-245, 81 pls. June 23, 1928.

Pt. 3. Forcipulata (concluded). Pp. i-iii, 1-356, 93 pls. 1930.

77. The early Paleozoic Bryozoa of the Baltic Provinces. By Ray S. Bassler. Pp. i-xxi, 1-382, 226 figs., 13 pls. Dec. 23, 1911.

78. Catalogue of a selection of art objects from the Freer Collection exhibited in the new building of the National Museum, April 15 to June 15, 1912. Pp. 1-39. 1912.

79. List of North American land mammals in the United States National Museum, 1911. By Gerrit S. Miller, Jr. Pp. i-xiv, 1-455. Dec. 31, 1912.

80. A descriptive account of the building recently erected for the departments of natural history of the United States National Museum. By Richard Rathbun. Pp. 1-131, 34 pis. 1913.

81. Synopsis of the Rotatoria. By Harry K. Harring. Pp. 1-226. June 28, 1913.

82. A monograph of the existing crinoids. By Austin Hobart Clark. Vol. 1, The comatulids:

Pt. 1. [General.] Pp. i-vi, 1-406, 513 figs., 17 pls. June 10, 1915.

Pt. 2. [General.] Pp. i-xxv, 1-795, 949 figs., 57 pls. 1921.

Pt. 3. Superfamily Comasterida. Pp. i-vii, 1-816, 82 pls. 1931.

Pt. 4a. Superfamily Mariametrida (except the family Colobometridae). Pp. i-vii, 1-603, 61 pls. Aug. 5, 1941.

83. Type species of the genera of ichneumon flies. By Henry L. Viereck. Pp. i-v, 1-186. Jan. 31, 1914.

84. A contribution to the study of ophiurans of the United States National Museum. By René Koehler. Pp. i-vii, 1-173, 18 pls. Apr. 9, 1914.

85. A monograph of the jumping plant-lice or Psyllidae of the New World. By David L. Crawford. Pp. i-ix, 1-186, 30 pls. June 3, 1914.

86. A monograph of the genus Chordeiles Swainson, type of a new family of goatsuckers. By Harry C. Oberholser. Pp. i-vii, 1-123, 6 pls. Apr. 6, 1914.

87. Culture of the ancient Pueblos of the Upper Gila River region, New Mexico and Arizona. Second Museum-Gates Expedition. By Walter Hough. Pp. i-xiv, 1-139, 348 figs., 29 pls. Mar. 21, 1914.

88. Revision of Paleozoic Stelleroidea with special reference to North American Asteroidea. By Charles Schuchert. Pp. 1-311, 41 figs., 38 pls. Mar. 20, 1915.

89. Osteology of the armored Dinosauria in the United States National Museum, with special reference to the genus Stegosaurus. By Charles Whitney Gilmore. Pp. i-xi, 1-143, 73 figs., 37 pls. Dec. 31, 1914. 
90. A monograph of the molluscan fauna of the Orthaulax pugnax zone of the Oligocene of Tampa, Florida. By William Healey Dall. Pp. i-xv, 1-173, 26 pls. Jan. 21, 1915.

91. Report on the Turton collection of South African marine mollusks, with additional notes on other South African shells contained in the United States National Museum. By Paul Bartsch. Pp. i-xii, 1-305, 54 pls. July 28, 1915.

92. Bibliographic index of American Ordovician and Silurian fossils. By Ray S. Bassler. Vol. 1, pp. i-viii, 1-718, Nov. 1, 1915. Vol. 2, pp. i-iv, 719-1521, 4 pls., Nov. 1, 1915.

93. The sessile barnacles (Cirripedia) contained in the collections of the U. S. National Museum; including a monograph of the American species. By Henry A. Pilsbry. Pp. i-xi, 1-366, 99 figs., 76 pls. July 31, 1916.

94. Handbook and descriptive catalogue of the meteorite collections in the United States National Museum. By George P. Merrill. Pp. i-x, 1-207, 41 pls. May $25,1916$.

95. The fishes of the west coast of Peru and the Titicaca Basin. By Barton Warren Evermann and Lewis Radcliffe. Pp. i-xi, 1-166, 14 pls. Aug. 1, 1917.

96. A synopsis of American Early Tertiary cheilostome Bryozoa. By Ferdinand Canu and Ray S. Bassler. Pp. 1-87, 6 pls. Feb. 27, 1917.

97. The grapsoid crabs of America. By Mary J. Rathbun. Pp. i-xxii, 1-461, 172 figs., 161 pls. Jan. 25, 1918.

98. The birds of the Anamba Islands. By Harry C. Oberholser. Pp. i-v, 1-75, 2 pls. June 30, 1917.

99. East African mammals in the United States National Museum. By N. Hollister. Pt. 1. Insectivora, Chiroptera, and Carnivora. Pp. 1-194, 3 figs., 55 pls. Aug. 16, 1918.

Pt. 2. Rodentia, Lagomorpha, and Tubulidentata. Pp. i-x, 1-184, 1 fig., 44 pls. May 16, 1919.

Pt. 3. Primates, Artiodactyla, Perissodactyla, Proboscidea, and Hyracoidea. Pp. i-viii, 1-164, 1 fig., 57 pls. June 20, 1924.

100. Contributions to the biology of the Philippine Archipelago and adjacent regions. Vol. 1. Papers on collections gathered by the Albatross Philippine Expedition, 1907-1910. Pp. i-rv, 1-649, 193 figs., 54 pls. Dec. 20, 1928.

Pt. 1. The Philippine land shells of the genus Amphidromus. By Paul Bartsch. Pp. 1-47, 22 pls. Sept. 22, 1917.

Pt. 2. Ascidians from the Philippines and adjacent waters. By Willard G. Van Name. Pp. 49-174, 115 figs., 11 pls. May 4, 1918.

Pt. 3. Report upon the Scyphomedusae collected by the United States Bureau of Fisheries steamer Albatross in the Philippine Islands and Malay Archipelago. By Alfred Goldsborough Mayer. Pp. 175-233, 24 figs. Dec. 22, 1917.

Pt. 4. Report on the Chaetognatha collected by the United States Bureau of Fisheries steamer Albatross during the Philippine Expedition, 1907-1910. By Ellis L. Michael. Pp. 235-277, 5 pls. May 19, 1919.

Pt. 5. Hydromedusae, siphonophores, and ctenophores of the Albatross Philippine Expedition. By Henry B. Bigelow. Pp. 279-362, 5 pls. May 22, 1919.

Pt. 6. The relationships of the genera Calcarina, Tinoporus, and Baculogypsina as indicated by recent Philippine material. By Joseph A. Cushman. Pp. 363-368, 2 pls. Oct. 7, 1919.

Pt. 7. The macrouroid fishes of the Philippine Islands and the East Indies. By Charles Henry Gilbert and Carl L. Hubbs. Pp. 369-588, 40 figs. Oct. 5, 1920.

Pt. 8. Polychaetous annelids collected by the United States Fisheries steamer Albatross in the waters adjacent to the Philippine Islands in 1907-1910. By A. L. Treadwell. Pp. 589-602, 8 figs. Jan. 26, 1921. 
Pt. 9. Polychaetous annelids collected by the United States Fisheries steamer Albatross during the Philippine Expedition of 1907-1910. By Ruth A. Hoagland. Pp. 603-634, 7 pls. Mar. 24, 1921.

Pt. 10. The polyclad turbellarians from the Philippine Islands. By Tokio Kaburaki. Pp. 635-649, 6 figs., 2 pls. Jan. 14, 1924.

Vol. 2. Papers on collections gathered by the Albatross Philippine Expedition, 1907-1910. Pp. i-vii, 1-562, 159 figs., 60 pls. Apr. 21, 1932.

Pt. 1. The Salpidae collected by the United States Fisheries steamer Albatross in Philippine waters during the years 1908 and 1909. By Maynard M. Metcalf. Pp. 1-4. May 7, 1919.

Pt. 2. The Salpidae: A taxonomic study. By Maynard M. Metcalf, with the assistance of Mary M. Bell. Pp. 5-193, 150 figs., 14 pls. Apr. 29, 1919.

Pt. 3. Pyrosoma: A taxonomic study based upon the collections of the United States Bureau of Fisheries and the United States National Museum. By Maynard M. Metcalf and Hoyt S. Hopkins. Pp. 195-272, 9 figs., 22 pls. July 19, 1919.

Pt. 4. Silicious and horny sponges collected by the U. S. Fisheries steamer Albatross during the Philippine Expedition, 1907-1910. By H. V. Wilson. Pp. 273-532, 16 pls. Oct. 19, 1925.

Pt. 5. The shipworms of the Philippine Islands. By Paul Bartsch. Pp. 533-562, 1 fig., 8 pls. Apr. 28, 1927.

Vol. 3. Starfishes of the Philippine seas and adjacent waters. By Walter $\mathbf{K}$. Fisher. Pp. i-xi, 1-712, 156 pls. June 27, 1919.

Vol. 4. Foraminifera of the Philippine and adjacent seas. By Joseph A. Cushman. Pp. 1-608, 52 figs., 100 pls. Aug. 18, 1921.

Vol. 5. Ophiurans of the Philippine seas and adjacent waters. By René Koehler. Pp. i-x, 1-486, 103 pls. Apr. 6, 1923.

Vol. 6. Papers on Philippine diatoms, annelids, hydroids, echinoids, and mollusks. Pp. i-viii, 1-567, 47 figs., 120 pls. Jan. 19, 1940.

Pt. 1. Marine diatoms of the Philippine Islands. By Albert Mann. Pp. 1-182, 39 pls. June 27, 1925.

Pt. 2. Additions to the polychaetous annelids collected by the United States Fisheries steamer Albatross, 1907-1910, including one new genus and three new species. By Aaron L. Treadwell. Pp. 183-193, 20 figs. Nov. 20, 1926.

Pt. 3. Report on the Hydroida collected by the United States Fisheries steamer Albatross in the Philippine region, 1907-1010. By Charles C. Nutting. Pp. 195-242, 8 pls. Apr. 27, 1927.

Pt. 4. Report on the Echinoidea collected by the United States Fisheries steamer Albatross during the Philippine Expedition, 1907-1910. Part 1. The Cidaridae. By Theodor Mortensen. Pp. 243-312, 22 figs., 33 pls. Sept. 10, 1927.

Pt. 5. Four new species of polychaetous annelids collected by the United States Fisheries steamer Albatross during the Philippine Expedition of 1907-1910. By Aaron L. Treadwell. Pp. 313-321, 4 figs. Oct. 31, 1931.

Pt. 6. The Philippine land mollusks of the genus Opisthoporus. By Paul Bartsch. Pp. 323-327, 1 fig., 2 pls. June 18, 1932.

> Pt. 7. The Philippine land mollusks Cochlostyla rufogaster and Obba marmorata and their races. By Paul Bartsch. Pp. 329-342, 4 pls. Aug. 20, 1932.

- Pt. 8. The land shells of the genus Obba from Mindoro Province, Philippine Islands. By Paul Bartsch. Pp. 343-371, 7 pls. Apr. 1, 1933.

- Pt. 9. The tree snails of the genus Cochlostyla of Mindoro Province, Philippine Islands. By Paul Bartsch. Pp. 373-533, 27 plo. Feb. 26, 1938. 
Vol. 7. The fishes of the families Pomacentridae, Labridae, and Callyodontidae, collected by the United States Bureau of Fisheries steamer Albatross, chiefly in Philippine seas and adjacent waters. By Henry W. Fowler and Barton A. Bean. Pp. i-viii, 1-525, 49 pls. Apr. 17, 1928.

Vol. 8. The fishes of the series Capriformes, Ephippiformes, and Squamipennes, collected by the United States Bureau of Fisheries steamer Albatross, chiefly in Philippine seas and adjacent waters. By Henry W. Fowler and Barton A. Bean. Pp. i-xi, 1-352, 25 figs. Mar. 11, 1929.

Vol. 9. Bryozoa of the Philippine region. By Ferdinand Canu and Ray S. Bassler. Pp. i-xi, 1-685, 224 figs., 94 pls. Oct. 28, 1929.

Vol. 10. The fishes of the families Amiidae, Chandidae, Duleidae, and Serranidae, obtained by the United States Bureau of Fisheries steamer Albatross in 1907 to 1910, chiefly in the Philippine Islands and adjacent seas. By Henry W. Fowler and Barton A. Bean. Pp. i-xi, 1-334, 27 figs. Mar. 21, 1930.

Vol. 11. The fishes of the families Pseudochromidae, Lobotidae, Pempheridae, Priacanthidae, Lutjanidae, Pomadasyidae, and Teraponidae, collected by the United States Bureau of Fisheries steamer Albatross, chiefly in Philippine seas and adjacent waters. By Henry W. Fowler. Pp. i-xi, 1-388, 29 figs. May 8, 1931.

Vol. 12. The fishes of the families Banjosidae, Lethrinidae, Sparidae, Girellidae, Kyphosidae, Oplegnathidae, Gerridae, Mullidae, Emmelichthyidae, Sciaenidae, Sillaginidae, Arripidae, and Enoplosidae, collected by the United States Bureau of Fisheries steamer Albatross, chiefly in Philippine seas and adjacent waters. By Henry W. Fowler. Pp. i-vi, 1-465, 32 figs. May 19, 1933.

Vol. 13. The fishes of the groups Elasmobranchii, Holocephali, Isospondyli, and Ostarophysi obtained by the United States Bureau of Fisheries steamer Albatross in 1907 to 1910, chiefly in the Philippine Islands and adjacent seas. By Henry W. Fowler. Pp. i-x, 1-879, 30 figs. Mar. 10, 1941.

Vol. 14. Part 1. Report on the Echinoidea collected by the United States Fisheries steamer Albatross during the Philippine Expedition, 1907-1910. Part 2. The Echinothuridae, Saleniidae, Arbaciidae, Aspidodiadematidae, Micropygidae, Diadematidae, Pedinidae, Temnopleuridae, Toxopneustidae, and Echinometridae. By Theodor Mortensen. Pp. i-vi, 1-52, 3 figs., 1 pl. July 25, 1940.

Part 2. Descriptions and figures of new fishes obtained in Philippine seas and adjacent waters by the United States Bureau of Fisheries steamer Albatross. By Henry W. Fowler. Pp. i-iii, 53-91, 22 figs. July 19, 1943.

101. The Columbian Institute for the promotion of arts and sciences. By Richard Rathbun. Pp. i-iii, 1-85. Oct. 18, 1917.

102. The mineral industries of the United States. Vol. 1. The energy resources of the United States: A field for reconstruction. By Chester G. Gilbert and Joseph E. Pogue. Pp. i-x, 1-165, 15 figs., 8 pls. May 15, 1919.

Pt. 1. Coal products: An object lesson in resource administration. By Chester G. Gilbert. Pp. 1-16, 11 pls. Nov. 17, 1917.

Pt. 2. Fertilizers: An interpretation of the situation in the United States. By Joseph E. Pogue. Pp. 1-22, 1 chart. Oct. 10, 1917.

Pt. 3. Sulphur: An example of industrial independence. By Joseph E. Pogue. Pp. 1-10, 1 chart, 3 pls. Nov. 7, 1917.

Pt. 4. Coal: The resource and its full utilization. By Chester G. Gilbert and Joseph E. Pogue. Pp. 1-27. Feb. 21, 1918.

Pt. 5. Power: Its significance and needs. By Chester $G$. Gilbert and Joseph E. Pogue. Pp. 1-53, 2 figs. Sept. 21, 1918.

Pt. 6. Petroleum: A resource interpretation. By Chester G. Gilbert and Joseph E. Pogue. Pp. i-v, 1-76, 12 figs., 3 pls. Aug. 7, 1918. 
Pt. 7. Natural gas: Its production, service, and conservation. By Samuel S. Wyer. Pp. 1-67, 20 figs., 8 pls. Dec. 28, 1918.

Pt. 8. Manufactured gas in the home. By Samuel S. Wyer. Pp. i-vi, 1-24, 11 figs. June 9, 1923.

103. Contributions to the geology and paleontology of the Canal Zone, Panama, and geologically related areas in Central America and the West Indies. Prepared under the direction of Thomas Wayland Vaughan. Pp. i-xviii, 1-612, 27 figs., 154 pls. Feb. 21, 1920.

Pt. 1. On some fossil and recent Lithothamnieae of the Panama Canal Zone. By Marshall A. Howe. Pp. 1-13, i, 11 pls. Feb. 9, 1919.

Pt. 2. The fossil higher plants from the Canal Zone. By Edward W. Berry. Pp. 15-44, i, 7 pls. Jan. 11, 1919.

Pt. 3. The smaller fossil Foraminifera of the Panama Canal Zone. By Joseph Augustine Cushman. Pp. 45-87, i-ii, 15 pls. Feb. 18, 1919.

Pt. 4. The larger fossil Foraminifera of the Panama Canal Zone. By Joseph Augustine Cushman. Pp. 89-102, i, 12 pls. Jan. 7, 1919.

Pt. 5. Fossil Echini of the Panama Canal Zone and Costa Rica. By Robert Tracy Jackson. Pp. 103-116, i, 3 figs., 7 pls. Feb. 9, 1919.

Pt. 6. Bryozoa of the Canal Zone and related areas. By Ferdinand Canu and Ray S. Bassler. Pp. 117-122, i, 1 pl. Jan. 28, 1919.

Pt. 7. Decapod crustaceans from the Panama region. By Mary J. Rathbun. Pp. 123-184, i-iii, 13 pls. Jan. 8, 1919.

Pt. 8. Cirripedia from the Panama Canal Zone. By Henry A. Pilsbry. Pp. 185-188, 1 pl. Jan. 28, 1919.

Pt. 9. Fossil corals from Central America, Cuba, and Porto Rico, with an account of the American Tertiary, Pleistocene, and Recent coral reefs. By Thomas Wayland Vaughan. Pp. 189-524, i-xiv, 22 figs., 85 pls. July 11, 1919.

Pt. 10. The sedimentary formations of the Panama Canal Zone, with special reference to the stratigraphic relations of the fossiliferous beds. By Donald Francis MacDonald. Pp. 525-545, 2 figs., 2 pls. May 16, 1919.

Pt. 11. The biologic character and geologic correlation of the sedimentary formations of Panama in their relation to the geologic history of Central America and the West Indies. By Thomas Wayland Vaughan. Pp. 547-612. May 19, 1919.

104. The Foraminifera of the Atlantic Ocean. By Joseph Augustine Cushman.

Pt. 1. Astrorhizidae. Pp. i-vii, 1-111, 39 pls. July 1, 1918.

Pt. 2. Lituolidae. Pp. i-vii, 1-111, 18 pls. Oct. 6, 1920.

Pt. 3. Textulariidae. Pp. i-viii, 1-149, 26 pls. June 28, 1922.

Pt. 4. Lagenidae. Pp. i-x, 1-228, 42 pls. Sept. 27, 1923.

Pt. 5. Chilostomellidae and Globigerinidae. Pp. i-v, 1-55, 8 pls. May 20, 1924.

Pt. 6. Miliolidae, Ophthalmidiidae, and Fischerinidae. Pp. i-viii, 1-129, 22 pls. June 29, 1929.

Pt. 7. Nonionidae, Camerinidae, Peneroplidae, and Alveolinellidae. Pp. i-vi, 1-79, 18 pls. Feb. 25, 1930.

Pt. 8. Rotaliidae, Amphisteginidae, Calcarinidae, Cymbaloporettidae, Globorotaliidae, Anomalinidae, Planorbulinidae, Rupertiidae, and Homotremidae. Pp. i-ix, 1-179, 26 pls. July 25, 1931.

105. Catalogue of the postage stamps and stamped envelopes of the United States and possessions, issued prior to January 1, 1919. Compiled by Joseph B. Leavy. Pp. i-ix, 1-204, 3 pls. May 7, 1919.

106. North American Early Tertiary Bryozoa. By Ferdinand Canu and Ray S. Bassler. Pp. i-xx, 1-879, 279 figs., 162 pls. (Text and plates in separate vols.) June 30, 1920.

107. Life histories of North American diving birds: Order Pygopodes. By Arthur Cleveland Bent. Pp. i-xiii, 1-245, 55 pls. Aug. 1, 1919. 
108. A revision of the Nearctic termites. By Nathan Banks. With notes on biology and geographic distribution by Thomas E. Snyder. Pp. i-viii, 1-228, 70 figs., 35 pls. Apr. 13, 1920.

109. Contributions to a history of American State geological and natural history surveys. Edited and compiled by George P. Merrill. Pp. i-xviii, 1-549, 37 pls. Aug. 2, 1920.

110. Osteology of the carnivorous Dinosauria in the United States National Museum, with special reference to the genera Antrodemus (Allosaurus) and Ceratosaurus. By Charles Whitney Gilmore. Pp. i-xi, 1-159, 79 figs., 36 pls. Sept. 9, 1920.

111. A monograph of the East American scaphopod mollusks. By John B. Henderson. Pp. i-vi, 1-177, 20 pls. Oct. 6, 1920.

112. Summary of the marine shellbearing mollusks of the northwest coast of America, from San Diego, California, to the Polar Sea, mostly contained in the collection of the United States National Museum, with illustrations of hitherto unfigured species. By William Healey Dall. Pp. i-iii, 1-217, 22 pls. Feb. 24, 1921.

113. Life histories of North American gulls and terns: Order Longipennes. By Arthur Cleveland Bent. Pp. i-x, 1-345, 93 pls. Aug. 27, 1921.

114. A revision of the king snakes: Genus Lampropeltis. By Frank N. Blanchard. Pp. i-vi, 1-260, 78 figs. Sept. 15, 1921.

115. The fossil crinoid genus Dolatocrinus and its allies. By Frank Springer. Pp. i-v, 1-78, 6 figs., 16 pls. Apr. 6, 1921.

116. The dipterous genus Dolichopus Latreille in North America. By M. C. Van Duzee, F. R. Cole, and J. M. Aldrich. Pp. i-vi, 1-304, 16 pls. Mar. 21, 1921.

117. The distribution of bird life in the Urubamba Valley of Peru. A report on the birds collected by the Yale University-National Geographic Society's Expeditions. By Frank M. Chapman. Pp. 1-138, 3 figs., 9 pls. June 29, 1921.

118. Handbook and descriptive catalogue of the collections of gems and precious stones in the United States National Museum. By George P. Merrill, assisted by Margaret W. Moodey and Edgar T. Wherry. Pp. i-viii, 1-225, 26 figs., 14 pls. Apr. 26, 1922.

119. Catalogue of the mechanical engineering collection in the United States National Museum. Motors, locomotives, and self-propelled vehicles. Edited and compiled by Carl W. Mitman. Pp. 1-118, 59 figs., 2 pls. Feb. 3, 1922.

120. The opalinid ciliate infusorians. By Maynard M. Metcalf. Pp. i-vii, 1-484, 258 figs. June 9, 1923.

121. Life histories of North American petrels and pelicans and their allies: Order Tubinares and order Steganopodes. By Arthur Cleveland Bent. Pp. i-xii, 1-343, 69 pls. Oct. 19, 1922.

122. A monograph of the American shipworms. By Paul Bartsch. Pp. i-iii, 1-51, 1 fig., 37 pls. Aug. 4, 1922.

123. Revision of the North American moths of the subfamily Eucosminae of the family Olethreutidae. By Carl Heinrich. Pp. i-iv, 1-298, 1 fig, 59 pls. Apr. 12, 1923.

124. The type species of the genera of Chalcidoidea or chalcid-flies. By A. B. Gahan and Margaret M. Fagan. Pp. i-iii, 1-173. Apr. 6, 1923.

125. North American Later Tertiary and Quaternary Bryozoa. By Ferdinand Canu and Ray S. Bassler. Pp. i-vii, 1-302, 38 figs., 47 pls. July 16, 1923.

126. Life histories of North American wild fowl: Order Anseres (Part). By Arthur Cleveland Bent. Pp. i-ix, 1-250, 46 pls. May 25, 1923.

127. Catalogue of the watercraft collection in the United States National Museum. Compiled and edited by Carl W. Mitman. Pp. i-v, 1-298, 96 figs., 1 pl. July $17,1923$.

128. List of North American Recent mammals, 1923. By Gerrit S. Miller, Jr. Pp. i-xvi, 1-673. Apr. 29, 1924.

129. The spider crabs of America. By Mary J. Rathbun. Pp. i-xx, 1-613, 153 figs., 283 pls. June 19, 1925. 
130. Life histories of North American wild fowl: Order Anseres (Part). By Arthur Cleveland Bent. Pp. i-x, 1-376, 60 pls. June 27, 1925.

131. The minerals of Idaho. By Earl V. Shannon. Pp. i-vii, 1-483, 170 figs., 19 pls. Apr. 9, 1926.

132. Revision of the North American moths of the subfamilies Laspeyresiinae and Olethreutinae. By Carl Heinrich. Pp. i-v, 1-216, 2 figs., 76 pls. Feb. 2, 1926.

133. Observations on the birds of Argentina, Paraguay, Uruguay, and Chile. By Alexander Wetmore. Pp. i-iv, 1-448, 20 pls. Feb. 1, 1926.

134. Material culture of the people of southeastern Panama, based on specimens in the United States National Museum. By Herbert W. Krieger. Pp. i-v, 1-141, 1 fig., 37 pls. Nov. 4, 1926.

135. Life histories of North American marsh birds. Orders Odontoglossae, Herodiones, and Paludicolae. By Arthur Cleveland Bent. Pp. i-xii, 1-490, 98 pls. Mar. 11, 1927.

136. Handbook of the collection of musical instruments in the United States National Museum. By Frances Densmore. Pp. i-iii, 1-164, 48 pls. May 26, 1927.

137. The collection of primitive weapons and armor of the Philippine Islands in the United States National Museum. By Herbert W. Krieger. Pp. i-iii, 1-128, map, 21 pls. Dec. 1, 1926.

138. The fossil stalk-eyed Crustacea of the Pacific slope of North America. By Mary J. Rathbun. Pp. i-vii, 1-155, 6 figs., 39 pls. Dec. 30, 1926.

139. Fire as an agent in human culture. By Walter Hough. Pp. i-xiv, 1-270, 4 figs., 41 pls. Dec. 30, 1926.

140. Bird parasites of the nematode suborders Strongylata, Ascaridata, and Spirurata. By Eloise B. Cram. Pp. i-xvii, 1-465, 444 figs. June 30, 1927.

141. Collection of heating and lighting utensils in the United States National Museum. By Walter Hough. Pp. i-viii, 1-113, 99 pls. Feb. 17, 1928.

142. Life histories of North American shore birds. Order Limicolae (Part 1). By Arthur Cleveland Bent. Pp. i-ix, 1-420, 55 pls. Dec. 31, 1927.

143. Biological and taxonomic investigations on the mutillid wasps. By Clarence $\mathbf{E}$. Mickel. Pp. i-ix, 1-351, 28 figs., 5 pls. Apr. 23, 1928.

144. The American bats of the genera Myotis and Pizonyx. By Gerrit S. Miller, Jr., and Glover M. Allen. Pp. i-viii, 1-218, 13 maps. May 25, 1928.

145. A revision of the North American species of buprestid beetles belonging to the genus Agrilus. By W. S. Fisher. Pp. i-v, 1-347, 11 pls. Dec. 21, 1928.

146. Life histories of North American shore birds. Order Limicolae (Part 2). By Arthur Cleveland Bent. Pp. i-ix, 1-412, 66 pls. Mar. 27, 1929.

147. Archeological and historical investigations in Samaná, Dominican Republic. By Herbert W. Krieger. Pp. i-iv, 1-91, 1 map, 27 pls. Sept. 9, 1929.

148. Collections of objects of religious ceremonial in the United States National Museum. By Immanuel Moses Casanowicz. Pp. i-viii, 1-207, 75 pls. Dec. 31, 1929.

149. Composition and structure of meteorites. By George P. Merrill. Pp. i-vi, 1-62, 32 pls. Feb. 26, 1930.

150. Revision of the fishes of the family Liparidae. By Victor Burke. Pp. i-xii, 1-204, 110 figs. May 27, 1930.

151. East African reptiles and amphibians in the United States National Museum. By Arthur Loveridge. Pp. i-v, 1-135, 1 pl. Dec. 31, 1929.

152. The cancroid crabs of America of the families Euryalidae, Portunidae, Atelecyclidae, Cancridae, and Xanthidae. By Mary J. Rathbun. Pp. i-xvi, 1-609, 85 figs., 230 pls. May 29, 1930.

153. Birds collected by the Childs Frick Expedition to Ethiopia and Kenya Colony. By Herbert Friedmann.

Pt. 1. Non-Passeres. Pp. i-xiii, 1-516, 22 figs., 12 pls. June 10, 1930.

Pt. 2. Passeres. Pp. i-xii, 1-506, 30 figs., 14 pls. June 23, 1937.

154. A study of the teiid lizards of the genus Cnemidophorus, with special reference to their phylogenetic relationships. By Charles E. Burt. Pp. i-viii, 1-286, 38 figs. Apr. 24, 1931. 
155. The birds of Haiti and the Dominican Republic. By Alexander Wetmore and Bradshaw H. Swales. Pp, i-iv, 1-483, 26 pls. Mar. 7, 1931.

156. Aboriginal Indian pottery of the Dominican Republic. By Herbert W. Krieger. Pp. i-iii, 1-165, 56 pls. Dec. 31, 1931.

157. The butterflies of the District of Columbia and vicinity. By Austin H. Clark. Pp. i-ix, 1-337, 64 pls. Feb. 13, 1932.

158. The copepods of the Woods Hole region, Massachusetts. By Charles Branch Wilson. Pp. i-xix, 1-635, 316 figs., 41 pls. Oct. 26, 1932.

159. The birds of the Natuna Islands. By Harry C. Oberholser. Pp. i-vi, 1-137, 1 fig. Feb. 12, 1932.

160. Mexican tailless amphibians in the United States National Museum. By Remington Kellogg. Pp. i-iv, 1-224, 24 figs., 1 pl. May 19, 1932.

161. The Foraminifera of the tropical Pacific collections of the Albatross, 1899-1900. By Joseph Augustine Cushman.

Pt. 1. Astrorhizidae to Trochamminidae. Pp. i-iv, 1-88, 1 fig., 17 pls. June 18, 1932.

Pt. 2. Lagenidae to Alveolinellidae. Pp. i-vi, 1-79, 19 pls. Aug. 23, 1933.

Pt. 3. Heterohelicidae and Buliminidac. Pp. i-v, 1-67, 15 pls. Feb. 10, 1942.

162. Life histories of North American gallinaceous birds (orders Galliformes and Columbiformes). By Arthur Cleveland Bent. Pp. i-xi, 1-490, 93 pls. May 25, 1932.

163. American and European swords in the historical collections of the United States National Museum. By Theodore T. Belote. Pp. i-vii, 1-163, 46 pls. July 1, 1932.

164. The Canadian and Ordovician formations and fossils of South Manchuria. By Riuji Endo. Pp. i-iii, 1-152, 40 pls. Aug. 3, 1932.

165. The bryozoan fauna of the Vincentown limesand. By Ferdinand Canu and Ray S. Bassler. Pp. i-v, 1-108, 21 pls. Dec. 4, 1933.

166. The oxystomatous and allied crabs of America. By Mary J. Rathbun. Pp. i-vi, 1-278, 47 figs., 86 pls. Oct. 14, 1937.

167. Life histories of North American birds of prey. Part 1. Order Falconiformes. By Arthur Cleveland Bent. Pp. i-viii, 1-409, 102 pls. May 3, 1937.

168. Nearctic Collembola, or springtails, of the family Isotomidae. By J. W. Folsom. Pp. i-iii, 1-144, 39 pls. July 1, 1937.

169. The Fort Union of the Crazy Mountain Field, Montana, and its mammalian faunas. By George Gaylord Simpson. Pp. i-x, 1-287, 80 figs., 10 pls. Aug. $21,1937$.

170. Life histories of North American birds of prey. Part 2. Orders Falconiformes and Strigiformes. By Arthur Cleveland Bent. Pp. i-viii, 1-482, 92 pls. Aug. 8, 1938.

171. The Pleistocene vertebrate fauna from Cumberland Cave, Maryland. By James W. Gidley and C. Lewis Gazin. Pp. i-vi, 1-99, 50 figs., 10 pls. May 5, 1938.

172. Birds from Siam and the Malay Peninsula in the United States National Museum collected by Drs. Hugh M. Smith and William L. Abbott. By J. H. Riley. Pp. i-iv, 1-581. Dec. 3, 1938.

173. Catalog of the mechanical collections of the Division of Engineering, United States National Museum. By Frank A. Taylor. Pp. i-viii, 1-203, 37 pls. Mar. 2, 1939.

174. Life histories of North American wookpeckers. Order Piciformes. By Arthur Cleveland Bent. Pp. i-viii, 1-334, 39 pls. May 23, 1939.

175. Variations and relationships in the snakes of the genus Pituophis. By Olive Griffith Stull. Pp. i-vi, 1-225, 84 figs. June 26, 1940.

176. Life histories of North American cuckoos, goatsuckers, hummingbirds, and their allies. Orders Psittaciformes, Cuculiformes, Trogoniformes, Coraciiformes, Caprimulgiformes, and Micropodiiformes. By Arthur Cleveland Bent. Pp. i-viii, 1-506, 73 pls. July $20,1940$.

177. The herpetology of Hispaniola. By Doris M. Cochran. Pp. i-vii, 1-398, 120 figs., 12 pls. July 8. 1941. 
178. Catalog of the type specimens of mammals in the United States National Museum, including the Biological Surveys collection. By Arthur J. Poole and Viola S. Schantz. Pp. i-xiii, 1-705. Apr. 8, 1942.

179. Life histories of North American flycatchers, larks, swallows, and their allies. Order Passeriformes (Families Cotingidae, Tyrannidae, Alaudidae, and Hirundinidae). By Arthur Cleveland Bent. Pp. i-xi, 1-555, 70 pls. May 8, 1942.

180. Fishes of the Phoenix and Samoan Islands collected in 1939 during the expedition of the U.S.S. Bushnell. By Leonard P. Schultz. Pp. i-x, 1-316, 27 figs., 9 pls. Jan. 20, 1943.

181. The cyclophorid operculate land mollusiks of America. By Carlos de la Torre, Paul Bartsch, and Joseph P. E. Morrison. Pp. i-iv, 1-306, 42 pls. Aug. 21, 1942.

182. Monograph of the West Indian beetles of the family Staphylinidae. By Richard E. Blackweider. Pp. i-viii, 1-658, 3 figs., 19 maps. Jan. 27, 1943.

183. Archeological investigations in Platte and Clay Counties, Missouri. By Waldo R. Wedel. With Appendix, "Skeletal Remains from Platte and Clay Counties, Missouri," by T. Dale Stewart. Pp. i-viii, 1-284, 22 figs., 50 pls. Oct. 1, 1943.

184. The metallography of meteoric iron. By Stuart H. Perry. Pp. i-vii, 1-206, 9 figs., 78 pls. Feb. 15, 1944.

185. Checklist of the coleopterous insects of Mexico, Central America, the West Indies, and South America. Compiled by Richard E. Blackwelder.

Pt. 1. Pp. i-xii, 1-188. Mar. 7, 1944.

Pt. 2. Pp. i-iii, 189-341. June 30, 1944.

Pt. 3. Pp. i-iv, 343-550. May 21, 1945.

Pt. 4. Pp. i-iii, 551-763. May 13, 1946.

[To be completed.]

186. The birds of northern Thailand. [An account of the birds of Chiang Rae Province and those parts of the provinces of the Mae Hong Son, Chiang Mai, Lamphun, Lampang, Phrae, and Nan lying north of latitude $17^{\circ} 47^{\prime} \mathrm{N}$.] By H. G. Deignan. Pp. i-v, 1-616, 4 maps, 9 pls. Sept. 17, 1945.

187. An annotated checklist and key to the snakes of Mexico. By Hobart M. Smith and Edward H. Taylor. Pp. i-iv, 1-239. Oct. 5, 1945.

188. The fresh-water fishes of Siam, or Thailand. By Hugh M. Smith. Pp. i-xi, 1-622, 107 figs., 9 pls. Nov. 13, 1945.

189. A descriptive catalog of the shore fịshes of Peru. By Samuel F. Hildebrand. Pp. i-xi, 1-530, 95 figs. Feb. 26, 1946.

190. The North American clear-wing moths of the family Aegeriidae. By George P. Engelhardt. Pp. i-vi, 1-222, 32 pls. June 28, 1946.

191. Life histories of North American jays, crows, and titmice. Families Corvidae and Paridae. By Arthur Cleveland Bent. Pp. i-xi, 1-495, 68 pls.

192. The operculate land mollusks of the family Annulariidae of the island of Hispaniola and the Bahama Archipelago. By Paul Bartsch. Pp. i-iv, 1-264, 38 pls. Oct. 3, 1946.

193. A list of the publications of the United States National Museum (1875-1946). Compiled in the Editorial Division, Smithsonian Institution. Pp. 1-305. 


\section{Volume 1}

Reports on collections, and miscellaneous papers. Pp. i-viii (title page, note, prefatory note, contents, and list of illustrations); pp. 1-368 (papers 1-9); pp. 393-434 (index) ; 10 figs., 35 pls. $1890-1895$.

No.

1. Plants from southern California. By George Vasey and J. N. Rose. Pp. 1-8. June $16,1890$.

List of plants collected by Dr. Edward Palmer in Lower California in 1889. By George Vasey and J. N. Rose. Pp. 9-28. June 16, 1890.

2. Upon a collection of plants made by Mr. G. C. Nealley, in the region of the Rio Grande, in Texas, from Brazos Santiago to El Paso County. By John Coulter. Pp. 29-61. July 18, 1890.

3. List of plants collected by Dr. Edward Palmer in Lower California and western Mexico in 1890. By George Vasey and J. N. Rose. Pp. 63-90, 1 pl. Nov. 8, 1890.

4. List of plants collected by Dr. Edward Palmer in western Mexico and Arizona in 1890. By J. N. Rose. Pp. 91-116, 10 pls. June 30, 1891.

List of plants collected by Dr. E. Palmer in Arizona in 1890. By J. N. Rose. Pp. 117-127. June 30, 1891.

5. List of plants collected by Dr. Edward Palmer in 1890 on Carmen Island. By J. N. Rose. Pp. 129-134, 3 pls. Sept. 20, 1892.

List of plants collected by the U.S.S. Albatross in 1887-'91 along the western coast of America. 1. List of plants from Cocos Island. By J. N. Rose. P. 135. 2. List of plants from Galapagos Islands. By J. N. Rose. Pp. 136-138. 3. List of ferns from southern Patagonia. By Daniel C. Eaton. P. 138. 4. List of mosses from Fuegia and Patagonia. By Daniel C. Eaton. Pp. 138-139. 5. List of liverworts from southern Patagonia. By A. W. Evans. Pp. 140-142. 6. List of lichens from southern Patagonia. By J. W. Eckfeldt. P. 142. 2 pls. Sept. 20, 1892.

Revision of the North American species of Hoffmanseggia. By E. M. Fisher. Pp. 143-150. Sept. 20, 1892.

Systematic and alphabetic index of new species of North American phanerogams and pteridophytes, published in 1891. Compiled by Josephine A. Clark. Pp. 151-188. Sept. 20, 1892.

6. List of plants collected by C. S. Sheldon and M. A. Carleton in Indian Territory in 1891. By J. M. Holzinger. Pp. 189-219, 2 pls. Dec. 6, 1892.

Observations on the native plants of Oklahoma Territory and adjacent districts. By M. A. Carleton. Pp. 220-232. Dec. 6, 1892.

7. Systematic and alphabetic index to new species of North American phanerogams and pteridophytes published in 1892. By Josephine A. Clark. Pp. 233-264. July 15, 1892.

8. Notes on some Pacific coast grasses. By George Vasey. Pp. 265-266. Oct. 31, 1893.

Descriptions of new or noteworthy grasses from the United States. By George Vasey. Pp. 267-280. Oct. 31, 1893.

Descriptions of new grasses from Mexico. By George Vasey. Pp. 281-285, 1 pl. Oct. 31, 1893.

Descriptions of four new plants from Texas and Colorado. By J. M. Holzinger. Pp. 286-287, 2 pls. Oct. 31, 1893.

List of plants new to Florida. By J. M. Holzinger. P. 288. Oct. 31, 1893.

Descriptions of three new plants. By J. N. Rose. Pp. 289-290, 2 pls. Oct. 31, 1893.

List of lichens from California and Mexico, collected by Dr. Edward Palmer from 1888 to 1892. By J. W. Eckfeldt. Pp. 291-292. Oct. 31, 1893.

9. Report on a collection of plants made in the states of Sonora and Colima, Mexico, by Dr. Edward Palmer, in the years 1890 and 1891. By J. N. Rose. Pp. 293366, 10 figs., 13 pls. Jan. 31, 1895.

Three new species of Sapindaceae from western Mexico and Lower California. By L. Radlkofer. Pp. 367-368. Jan. 31, 1895.

- Volumes 1-8 of the Contributions were published by the U. S. Department of Agriculture. 


\section{Volume 2}

Botany of western Texas. Pp. i-v (title page, note, prefatory note, table of contents, and list of plates); pp. 1-568 (papers 1-3); pp. 569-588 (index); 3 pls. 1891-1894.

No.

1. Manual of the phanerogams and pteridophytes of western Texas: Polypetalae. By John M. Coulter. Pp. 1-152, 1 pl. June 27, 1891.

2. Manual of the phanerogams and pteridophytes of western Texas: Gamopetalae. By John M. Coulter. Pp. 153-345, 2 pls. July 1, 1892.

3. Manual of the phanerogams and pteridophytes of western Texas: Apetalae, Monocotyledonae, Pteridophyta. By John M. Coulter. Pp. 347-568. May 10, 1894.

\section{Volume 3}

Reports on collections, revisions of groups, and miscellaneous papers. Pp. i-vii (title page, note, errata and addenda, prefatory note, contents, and list of illustrations); pp. 1-578 (papers 1-9) ; 579-612 (index); 28 pls. 1892-1896.

No.

1. Monograph of the grasses of the United States and British America. By George Vasey. Pp. 1-89. Feb. 25, 1892.

2. Preliminary revision of the North American species of Cactus, Anhalonium, and Lophophora. By John M. Coulter. Pp. 91-132. June 10, 1894.

3. Flora of the sand hills of Nebraska. By P. A. Rydberg. Pp. 133-203, 1 fig., 2 pls. Sept. 14, 1895.

4. Report on a collection of plants made by J. H. Sandberg and assistants in northern Idaho in the year 1892. By John M. Holzinger. Pp. 205-287, 2 pls. Nov. 23, 1895.

5. Report on Mexican Umbelliferae, mostly from the state of Oaxaca, recently collected by C. G. Pringle and E. W. Nelson. By John M. Coulter and J. N. Rose. Pp. 289-309, 6 pls. Dec. 14, 1895.

Descriptions of plants, mostly new, from Mexico and the United States. By J. N. Rose. Pp. 311-323, 6 pls. Dec. 14, 1895.

6. Botany of Yakutat Bay, Alaska. I.-Field report. By Frederick Funston. II.Botanical report. By Frederick Vernon Coville. Pp. 325-353. Jan. 15, 1896.

7. Preliminary revision of the North American species of Echinocactus, Cereus, and Opuntia. By John M. Coulter. Pp. 355-462. Apr. 1, 1896.

8. Flora of the Back Hills of South Dakota. By P. A. Rydberg. Pp. 463-536, 4 pls. June 13, 1896.

9. Report on a collection of plants made by C. H. Thompson in southwestern Kansas in 1893. By A. S. Hitchcock. Pp. 537-557. Aug. 5, 1896.

Crepis occidentalis and its allies. By Frederick V. Coville. Pp. 559-565, 6 pls. Aug. 6, 1896.

Plants from the Big Horn Mountains of Wyoming. By J. N. Rose. Pp. 567-574. Aug. 5, 1896.

Leibergia, a new genus of Umbelliferae from the Columbia River region. By John M. Coulter and J. N. Rose. Pp. 575-576, 1 pl. Aug. 5, 1896.

Roseanthus, a new genus of Cucurbitaceae from Acapulco, Mexico. By Alfred Cogniaux. Pp. 577-578, 1 pl. Aug. 5, 1896.

\section{Volume 4}

Botany of the Death Valley Expedition. By Frederick Vernon Coville. Pp. i-viii (title page, note, letter of transmittal, letter of submittal, contents, and list of illustrations) ; 363 pp., 22 pls., 1 map. Nov. 29, 1893.

\section{Volume 5}

Systematic, economic, and ecological investigations. Pp. i-x (title page, note, prefatory note, contents, and illustrations); pp. 1-550 (papers 1-6); pp. 551-585 (index) ; 77 pls., 90 figs., 2 maps. 1897-1901.

No.

1. General report on a botanical survey of the Coeur d'Alene Mountains in Idaho during the summer of 1895. By John B. Leiberg. Pp. 1-86, 1 pl. Jan. 25, 1897. $711175-47-3$ 
2. Notes .on the plants used by the Klamath Indians of Oregon. By Frederick V. Coville. Pp. 87-108. June 9, 1897.

3. Studies of Mexican and Central American plants. By J. N. Rose. Pp. 109-144, 6 figs., 16 pls. Aug. 27, 1897.

4. Studies of Mexican and Central American Plants-No. 2. By J. N. Rose. (With a section on "Ferns Collected in Mexico by J. N. Rose during the Months of August and September, 1897," pp. 146-151, by George E. Davenport.) Pp. 145-200, 24 figs., 8 pls. Oct. 31, 1899.

Two new species of plants from the northwestern United States. By L. F. Henderson. Pp. 201-202, 1 pl. Oct. 31, 1899.

Hesperogenia, a new genus of Umbelliferae from Mount Rainier. By John M. Coulter and J. N. Rose. P. 203, 1 pl. Oct. 31, 1899.

Three new species of Tradescantia from the United States. By J. N. Rose. Pp. 204-206. Oct. 31, 1899.

Treleasea, a new genus of Commelinaceae. By J. N. Rose. Pp. 207-208. Oct. 31, 1899.

Notes on useful plants of Mexico. By J. N. Rose. Pp. 209-259, 2 figs., 37 pls. Oct. 31, 1899.

5. The plant covering of Ocracoke Island; a study in the ecology of the North Carolina strand vegetation. By Thomas H. Kearney, Jr. Pp. 261-319, 18 figs. Aug. 1, 1900 .

6. Report on a botanical survey of the Dismal Swamp region. By Thomas H. Kearney. Pp. 321-550, 40 figs., 13 pls., 2 maps. Sept. 6, 1901.

\section{Volume 6}

Plant life of Alabama. By Charles Mohr. Pp. 1-921, 13 pls. July 31, 1901.

\section{Volume 7}

Systematic and geographic botany and aboriginal uses of plants. Pp. 1-8 (title page, contents, and note); pp. 9-408 (papers 1-3) ; 21 pls., 78 figs. 1900-1902.

No.

1. Monograph of the North American Umbelliferae. By John M. Coulter and J. N. Rose. Pp. 9-256, 65 figs., 9 pls. Dec. 31, 1900.

2. The origin and distribution of the cocoa palm. By O. F. Cook. Pp. 257-293. Sept. 24, 1901.

3. Plants used by the Indians of Mendocino County, California. By V. K. Chesnut. Pp. 295-408, 13 figs., 12 pls. Jan. 24, 1902.

\section{Volume 8}

Mexican, Central American, and Porto Rican plants. Pp. i-xiii (title, advertisement, title page, note, preface, contents, and illustrations); pp. 1-339 (parts 1-4); pp. 341-373 (index) ; 19 figs., 73 pls. 1903-1905.

Part

1. Studies of Mexican and Central American plants-No. 3. By J. N. Rose. Pp. 1-55, 11 figs., 12 pls. June 16, 1903.

2. Economic plants of Porto Rico. By O. F. Cook and G. N. Collins. Pp. 57-270, 2 figs., 47 pls. June $27,1903$.

3. A study of certain Mexican and Guatemalan species of Polypodium. By William R. Maxon. Pp. 271-280, 2 pls. June 27, 1903.

4. Studies of Mexican and Central American plants-No. 4. By J. N. Rose. Pp. 281-339, 6 figs., 10 pls. Apr. 20, 1905.

\section{Volume 9}

The useful plants of the Island of Guam. By William Edwin Safford. Pp. 1-416, 70 pls. Apr. 8, 1905. 


\section{Volume 10}

Systematic investigations in phanerogams, ferns, and diatoms. Pp. i-xii (title, advertisement, title page, note, preface, contents, and illustrations); pp. 1-508 (parts 1-7); pp. 509-535 (index); 6 figs., 56 pls. 1906-1908.

Part

1. North American species of Festuca. By Charles V. Piper. Pp. 1-48, 15 pls. Mar. 30, 1906.

2. The genus Ptelea in the western and southwestern United States and Mexico. By Edward L. Greene. Pp. 49-78. July 16, 1906.

3. Studies of Mexican and Central American plants-No. 5. By J. N. Rose. Pp. 79-132, 6 figs., 28 pls. Dec. 5, 1906.

4. The Leguminosae of Porto Rico. By J. Perkins. Pp. 133-220. June 10, 1907.

5. Report on the diatoms of the Albatross voyages in the Pacific Ocean, 1888-1904.

By Albert Mann. (Assisted in the bibliography and citations by P. L. Ricker.) Pp. 221-442, 11 pls. July 11, 1907.

6. The Cyperaceae of Costa Rica. By C. B. Clarke. Pp. 443-472. Jan. 21, 1908.

7. Studies of tropical American ferns-No. 1. By William R. Maxon. Pp. 473-508, 2 pls. Mar. 30, 1908.

\section{Volume 11}

Flora of the State of Washington. By Charles V. Piper. Pp. 1-637, 22 pls., 1 map. Oct. 8, 1906.

\section{Volume 12}

Systematic investigations and bibliography. Pp. i-xvi (title, advertisement, title page, note, preface, contents, and illustrations; pp. 1-455 (parts 1-10) ; pp. 457474 (index) ; 67 figs., 85 pls. 1908-1909.

Part

1. Catalogue of the botanical library of John Donnell Smith, presented in $\mathbf{1 9 0 5}$ to the Smithsonian Institution. Compiled by Alice Cary Atwood. Pp. 1-94. Apr. 23, 1908.

2. The Lecythidaceae of Costa Rica. By H. Pittier de Fábrega. Pp. 95-101, 4 figs., 8 pls. May 20, 1908.

Tonduzia, a new genus of Apocynaceae from Central America. By H. Pittier de Fábrega. Pp. 103-104, 2 figs., 1 pl. May 20, 1908.

A collection of plants from the vicinity of La Guaira, Venezuela. By J. R. Johnston. Pp. 105-111. May 20, 1908.

3. Types of American grasses: A study of the American species of grasses described by Linnaeus, Gronovius, Sloane, Swartz, and Michaux. By A. S. Hitchcock. Pp. 113-158. June 18, 1908.

4. The Mexican and Central American species of Sapium. By Henry Pittier. Pp. 159-169, 4 figs., 8 pls. Oct. 6, 1908.

5. New or noteworthy plants from Colombia and Central America. By Henry Pittier. Pp. 171-181, 9 figs., 2 pls. Jan. 27, 1909.

6. Catalogue of the grasses of Cuba. By A. S. Hitchcock. Pp. 183-258. Mar. 23, 1909.

7. Studies of Mexican and Central American plants-No. 6. By J. N. Rose. Pp. 259-302, 29 figs., 7 pls. Apr. 12, 1909.

8. The Allioniaceae of the United States, with notes on Mexican species. By Paul C. Standley. Pp. 303-389, 19 figs., 16 pls. Apr. 23, 1909.

9. Thompsonella, a new genus of Crassulaceae from Mexico. By N. L. Britton and J. N. Rose. Pp. 391-392, 2 pls. May 10, 1909.

Rediscovery of Echeveria carnicolor. By J. N. Rose. P. 393, 1 pl. May 10, 1909.

Three new species of Crassulaceae from Guatemala. By J. N. Rose. Pp. 395-396, 2 pls. May 10, 1909.

Rediscovery of Cereus nudiflorus. By J. N. Rose. Pp. 397-398, 3 pls. May 10, 1909.

A species of Pereskia from Guatemala. By J. N. Rose. P. 399, 3 pls. May $10,1909$. 
New species of Opuntia from Arizona. By J. N. Rose. Pp. 401-402, 1 pl. May 10, 1909.

Echinocereus baileyi, a new cactus from Oklahoma. By J. N. Rose. P. 403, 2 pls. May 10, 1909.

Nopalea lutea, a new cactus from Guatemala. By J. N. Rose. P. 405, 1 pl. May 10, 1909.

Conzattia a new genus of Caesalpiniaceae. By J. N. Rose. Pp. 407-408, 1 pl. May 10, 1909.

Two new species of Acacia of the series Filicinae. By J. N. Rose. P. 409. May 10, 1909.

A new spleenwort from China. By William R. Maxon. P. 411, 1 pl. May 10, 1909. 10. The genus Cereus and its allies in North America. By N. L. Britton and J. N.

Rose. Pp. 413-437, 16 pls. July 21, 1909.

Five new species of Crassulaceae from Mexico. By J. N. Rose. Pp. 439-440, 5 pls. July 21, 1909.

Supplement to the monograph of the North American Umbelliferae. By John

M. Coulter and J. N. Rose. Pp. 441-451, 2 pls. July 21, 1909.

Apogamy in the maize plant. By G. N. Collins. Pp. 453-455, 2 pls. July 21, 1909.

\section{Volume 13}

Systematic and ecological investigations and bibliography. Pp. i-xvi (title, advertisement, title page, note, preface, contents, and illustrations); pp. 1-466 (parts 1-12); pp. 467-489 (index); 91 figs., 96 pls., 1 map. 1909-1912.

Studies of tropical American ferns-No. 2. By William R. Maxon. Pp. 1-43, 1 fig., 9 pls. June 30, 1909.

2. Three new species of Echeveria from southern Mexico. By J. N. Rose and J. A. Purpus. Pp. 45-46, 5 pls. Feb. 21, 1910.

3. The grasses of Alaska. By F. Lamson-Scribner and Elmer D. Merrill. Pp. 47-92, 2 pls. June 8, 1910.

4. New or noteworthy plants from Colombia and Central America-2. By Henry Pittier. Pp. 93-132, 40 figs., 4 pls. June 11, 1910.

5. Relationships of the ivory palms. By O. F. Cook. Pp. 133-141, 3 figs. June 22, 1910.

6. 1. The type localities of plants first described from New Mexico. By Paul C. Standley. Pp. 143-227. 2. A bibliography of New Mexican botany. By Paul C. Standley. Pp. 229-246. 1 pl., 1 map. Oct. 31, 1910.

7. A preliminary treatment of the genus Castilla. By Henry Pittier. Pp. 247-279, 10 figs., 22 pls. Dec. 31, 1910.

8. The genus Talinum in Mexico. By J. N. Rose and Paul C. Standley. Pp. 281-288, 2 pls. Feb. 24, 1911.

Two new species of Harperella. By J. N. Rose. Pp. 289-290. Feb. 24, 1911.

9. Studies of Mexican and Central American plants-No. 7. By J. N. Rose. Pp. 291-312, 1 fig., 22 pls. Apr. 11, 1911.

10. The Gyrophoraceae of California. By Albert W. C. T. Herre. Pp. 313-321, 6 pls. June 8, 1911.

The plant life of Ellis, Great, Little, and Long Lakes in North Carolina. By William H. Brown. Pp. 323-341, 1 fig. June 8, 1911.

A revision of the subgenus Cyclobothra of the genus Calochortus. By Joseph H. Painter. Pp. 343-350. June 8, 1911.

A revision of the cichoriaceous genera Krigia, Cynthia, and Cymbia. By Paul C. Standley. Pp. 351-357. June 8, 1911.

New or noteworthy plants from the eastern United States. By Edward S. Steele. Pp. 359-374. June 8, 1911.

Two new shrubs from Lower California. By Paul C. Standley and E. A. Goldman. P. 375. June 8, 1911.

11. The Allioniaceae of Mexico and Central America. By Paul C. Standley. Pp. 377-430, 4 pls. July 12, 1911.

12. New or noteworthy plants from Colombia and Central America. By Henry Pittier. Pp. 431-466, 35 figs., 19 pls. Jan. 5, 1912. 


\section{Volume 14}

Lichens of Minnesota; history of coconut palm; grama grasses. Pp. i-xiv (title, advertisement, title page, note, preface, contents, and illustrations); pp. 1-428

Part (parts 1-3) ; pp. 429-444 (index) ; 63 figs., 84 pls. 1910-1912.

1. The lichens of Minnesota. By Bruce Fink. Pp. 1-269, 18 figs., 52 pls. June 1, 1910.

2. History of the coconut palm in America. By O. F. Cook. Pp. 271-342, 15 pls. Dec. 31, 1910.

3. The grama grasses: Bouteloua and related genera. By David Griffiths. Pp. 343-428, 45 figs., 17 pls. Feb. 24, 1912.

\section{Volume 15}

The North American species of Panicum. By A. S. Hitchcock and Agnes Chase. Pp. 1-396, 370 figs. Oct. 22, 1910.

\section{Volume 16}

Systematic investigations in phanerogams, ferns, and mosses. Pp. i-xv (title, advertisement, title page, note, preface, contents, and illustrations); pp. 1-371 Part (parts 1-14) ; pp. 373-389 (index) ; 54 figs., 133 pls., 1 map. 1912-1916.

1. The relationship of Asplenium andrewsii. By William R. Maxon. Pp. 1-3, 2 pls. Feb. 13, 1912.

Report on a collection of plants from the Pinacate region of Sonora. By J. N. Rose and Paul C. Standley. Pp. 5-20, 1 fig., 14 pls. Feb. 13, 1912.

Tumamoca, a new genus of Cucurbitaceae. By J. N. Rose. P. 21, 1 pl. Feb. 13, 1912.

New or interesting mosses from Panama. By R. S. Williams. Pp. 23-24. Feb. 13, 1912.

2. Studies of tropical American ferns-No. 3. By William R. Maxon. Pp. 25-62, 17 pls. June 19, 1912.

3. The North American species of Nymphaea. By Gerrit S. Miller, Jr., and Paul C. Standley. Pp. 63-108, 39 figs., 13 pls. July 6, 1912.

4. Descriptions of new plants preliminary to a report upon the flora of New Mexico. By E. O. Wooton and Paul C. Standley. Pp. 109-196, 3 pls. Feb. 12, 1913.

5. Supplementary notes on American species of Festuca. By Charles V. Piper. Pp. 197-199. Feb. 11, 1913.

Delphinium simplex and its immediate allies. By Charles V. Piper. Pp. 201-203. Feb. 11, 1913.

The identity of Heuchera cylindrica. By Charles V. Piper. Pp. 205-206. Feb. 11, 1913.

New or noteworthy species of Pacific coast plants. By Charles V. Piper. Pp. 207-210. Feb. 11, 1913.

The American species of Meibomia of the section Nephromeria. By J. N. Rose and Paul C. Standley. Pp. 211-216, 1 pl. Feb. 11, 1913.

Raimonaia, a new genus of Annonaceae from Colombia. By W. E. Safford. Pp. 217-219, 2 pls. Feb. 11, 1913.

Four new species of goldenrod from the eastern United States. By E. S. Steele. Pp. 221-224. Feb. 11, 1913.

6. Three new genera of stilt palms (Iriarteaceae) from Colombia, with a synoptical review of the family. By O. F. Cook and C. B. Doyle. Pp. 225-238, 1 fig., 12 pls. Feb. 21, 1913.

7. Studies in Cactaceae-1. By N. L. Britton and J. N. Rose. Fp. 239-242, 8 pls. Apr. 10, 1913.

8. Relationships of the false date palm of the Florida Keys, with a synoptical key to the families of American palms. By O. F. Cook. Pp. 243-254, 4 pls. May 14, 1913. 
9. The genus Epiphyllum and its allies. By N. L. Britton and J. N. Rose. Pp. 255-262, 7 pls. June 6, 1913.

10. Annona sericea and its allies. By William E. Safford. Pp. 263-275, 3 figs., 15 pls. Dec. 13, 1913.

11. Nomenclature of the sapote and the sapodilla. By O. F. Cook. Pp. 277-285, 2 pls. Dec. 13, 1913.

12. A monograph of the Hauyeae and Gongylocarpeae, tribes of the Onagraceae. By John Donnell Smith and J. N. Rose. Pp. 287-298, 10 figs. Aug. 23, 1913.

13. Botrychium virginianum and its forms. By Ivar Tidestrom. Pp. 299-303, 1 pl. Dec. 29, 1913.

Sphenoclea zeylanica and Caperonia palustris in the southern United States. By Ivar Tidestrom. Pp. 305-307, 1 pl. Dec. 29, 1913.

14. Plant records of an expedition to Lower California. By Edward A. Goldman. Pp. 309-371, 30 pls. Feb. 10, 1916.

\section{Volume 17}

Systematic investigations in lichens and ferns, grasses and other phanerogams. Pp. i-xiv (title, advertisement, title page, note, preface, contents, and illustrations): Part pp. 1-625 (parts 1-8) ; pp. 627-647 (index); 149 figs., 54 pls. 1913-1916.

1. The lichen flora of southern California. By Hermann Edward Hasse. Pp. 1-132. June 19, 1913.

2. Studies of tropical American ferns-No. 4. By William R. Maxon. Pp. 133-179, 7 figs., 10 pls. June 20, 1913.

3. Mexican grasses in the United States National Herbarium. By A. S. Hitchcock. Pp. 181-389. July 15, 1913.

4. Studies of tropical American ferns-No. 5. By William R. Maxon. Pp. 391-425, 3 figs., 13 pls. Jan. 21, 1914.

5. Studies of tropical American phanerogams-No. 1. By Paul C. Standley. Pp. 427-458, 8 pls. Jan. 30, 1914.

6. Tropical North American species of Panicum. By A. S. Hitchcock and Agnes Chase. Pp. 459-539, 139 figs. July 24, 1915.

7. Studies of tropical American ferns-No. 6. By William R. Maxon. Pp. 541-608, 12 pls. May 23, 1916.

8. Branching and flowering habits of cacao and patashte. By O. F. Cook. Pp. 609-625, 11 pls. June 28, 1916.

\section{Volume 18}

Systematic investigations of tropical American plants. Pp. i-xvii (title, advertisement, title page, note, preface, contents, and illustrations); pp. 1-471 (parts 1-7); pp. 473-494 (index); 104 figs., 106 pls. 1914-1917.

Part

1. Classification of the genus Annona, with descriptions of new and imperfectly known species. By W. E. Safford. Pp. 1-68, 75 figs., 41 pls. June 17, 1914.

2. New or noteworthy plants from Colombia and Central America-4. By Henry Pittier. Pp. 69-86, 12 figs., 15 pls. Apr. 16, 1914.

3. Studies of tropical American phanerogams-No. 2. By Paul C. Standley. Pp. 87-142. Feb. 11, 1916.

4. New or noteworthy plants from Colombia and Central America-5. By Henry Pittier. Pp. 143-171, 10 figs., 24 pls. Mar. 3, 1916.

5. Preliminary revision of the genus Inga. By Henry Pittier. Pp. 173-223, 25 pls. Oct. 30, 1916.

6. New or noteworthy plants from Colombia and Central America-6. By Henry Pittier. Pp. 225-259, 7 figs., 1 pl. Sept. 22, 1917.

7. Grasses of the West Indies. By A. S. Hitchcock and Agnes Chase. Pp. 261-471. Sept. 1, 1917.

\section{Volume 19}

Flora of New Mexico. By E. O. Wooton and Paul C. Standley. Pp. 1-794. June 24, 1915. 


\section{Volume 20}

Systematic studies of American plants. Pp. i-xv (title, advertisement, title page, note, preface, contents, and illustrations) ; pp. 1-588 (parts 1-14) ; pp. 589-605 (index); 70 figs., 51 pls. 1917-1925.

Part

1. The Mexican and Central American species of Ficus. By Paul C. Standley. Pp. 1-35. May 31, 1917.

2. The Middle American species of Lonchocarpus. By Henry Pittier. Pp. 37-93, 43 figs., 6 pls. Aug. 3, 1917.

3. New or noteworthy plants from Colombia and Central America-7. By Henry Pittier. Pp. 95-132, 19 figs., 1 pl. June 18, 1917.

4. The North American species of Aquilegia. By Edwin Blake Payson. Pp. 133-157, 7 pls. Oct. 14, 1918.

5. The allies of Selaginella rupestris in the southeastern United States. By G. P. Van Eseltine. Pp. 159-172, 8 figs., 8 pls. Oct. 1, 1918.

6. Studies of tropical American phanerogams. By Paul C. Standley. Pp. 173-220. Aug. 29, 1919.

7. The genus Homalium in America. By S. F. Blake. Pp. 221-235. Sept. 9, 1919.

New South American spermatophytes collected by H. M. Curran. By S. F. Blake. Pp. 237-245. Sept. 9, 1919.

8. The North American species of Asterella. By Alexander W. Evans. Pp. 247-312. Apr. 29, 1920.

9. Scrophulariaceae of the central Rocky Mountain States. By Francis W. Pennell. Pp. 313-381. Apr. 29, 1920.

10. Revision of the genus Acanthospermum. By S. F. Blake. Pp. 383-392, 1 pl. June 20, 1921.

Revision of the genus Flourensia. By S. F. Blake. Pp. 393-409. June 20, 1921.

Revision of the genus Oyedaea. By S. F. Blake. Pp. 411-422. June 20, 1921.

Revision of the genus Tithonia. By S. F. Blake. Pp. 423-436. June 20, 1921.

11. The identification of Berberis aquifolium and Berberis repens. By Charles V. Piper. Pp. 437-451, 3 pls. Jan. 26, 1922.

12. New or noteworthy plants from Colombia and Central America-8. By Henry Pittier. Pp. 453-490, 4 pls. Jan. 9, 1922.

13 Revision of the American species of Rinorea. By S. F. Blake. Pp. 491-518, 7 pls. July 19, 1924.

New plants from Venezuela. By S. F. Blake. Pp. 519-541, 10 pls. July 19, 1924.

Hemibaccharis, a new genus of Baccharidinae. By S. F. Blake. Pp. 543-554, 4 pls. July 19, 1924.

14. The American species of Canavalia and Wenderothia. By C. V. Piper. Pp. 555-588. Apr. 27, 1925.

\section{Volume 21}

Flora of the District of Columbia and vicinity. By A. S. Hitchcock and Paul C. Standley. Pp. 1-329, 1 fig., 42 pls. 1919.

\section{Volume 22}

Systematic plant studies, chiefly tropical American. Pp. i-xiv (title, advertisement, title page, note, preface, contents, and illustrations); pp. 1-748 (parts 1-10);

Part pp. 749-777 (index) ; 87 figs., 64 pls. 1920-1927.

1. Revisions of North American grasses: The North American species of Ichnanthus. By A. S. Hitchcock. Pp. 1-12, 9 pls.; The North American species of Lasiacis. By A. S. Hitchcock. Pp. 13-31, 15 pls.; The North American species of Brachiaria. By Agnes Chase. Pp. 33-43, 6 figs.; The North American species of Cenchrus. By Agnes Chase. Pp. 45-77, 14 figs. Mar. 29, 1920.

2. A study of Allocarya. By Charles V. Piper. Pp. 79-113. Mar. 13, 1920.

3. Revisions of North American grasses: The North American species of Isachne. By A. S. Hitchcock. Pp. 115-121, 8 pls.; The North American species of 
Oplismenus. By A. S. Hitchcock. Pp. 123-132, 4 figs.; The North American species of Echinochloa. By A. S. Hitchcock. Pp. 133-153, 11 figs.; The North American species of Chaetochloa. By A. S. Hitchcock. Pp. 155-208, 27 figs. Nov. 1, 1920.

4. The North American species of Pennisetum. By Agnes Chase. Pp. 209-234, 14 figs. Feb. 2, 1921.

5. Flora of Glacier National Park, Montana. By Paul C. Standley. Pp. 235-438, 20 pls. Mar. 16, 1921.

6. Grasses of British Guiana. By A. S. Hitchcock. Pp. 439-515, 10 figs., 1 pl. May 24, 1922.

7. The North American species of Aristida. By A. S. Hitchcock. Pp. 517-586. May 21, 1924.

8. New American Asteraceae. By S. F. Blake. Pp. 587-661, 1 fig., 10 pls. May $22,1924$.

9. Studies in American Phaseolineae. By C. V. Piper. Pp. 663-701, 1 pl. June 12, 1926.

10. The North American species of Scutellaria. By Emery C. Leonard. Pp. 703-748. Feb. 9, 1927.

\section{Volume 23}

Trees and shrubs of Mexico. By Paul C. Standley. Pp. i-vii (title, advertisement, note, preface, contents) ; pp. 1-1681 (parts 1-5) ; pp. 1683-1721 (index). 1920-1926. Part

1. Gleicheniaceae-Betulaceae. Pp. 1-169. Oct. 11, 1920.

2. Fagaceae-Fabaceae. Pp. 171-515. July 14, 1922.

3. Oxalidaceae-Turneraceae. Pp. 517-848. July 18, 1923.

4. Passifloraceae-Scrophulariaceae. Pp. 849-1312. Dec. 31, 1924.

5. Bignoniaceae-Asteraceae. Pp. 1313-1681. Nov. 15, 1926.

\section{Volume 24}

Plant studies, chiefly tropical American. Pp. i-xii (title, advertisement, title page, note, preface, contents, and illustrations); pp. 1-762 (parts 1-9); pp. 763-802 Part (index); 4 figs., 52 pls. 1922-1930.

1. New plants from Guatemala and Honduras. By S. F. Blake. Pp. 1-32, 4 figs., 10 pls. Jan. 11, 1922.

2. Studies of tropical American ferns-No. 7. By William R. Maxon. Pp. 33-63, 10 pls. Aug. 15, 1922.

3. Key to genus Diplostephium, with descriptions of new species. By S. F. Blake. Pp. 65-86, 8 pls. Aug. 11, 1946.

4. Native names and uses of some plants of eastern Guatemala and Honduras. By S. F. Blake. Pp. 87-100, 5 pls. Aug. 18, 1922.

5. Economic fruit-bearing plants of Ecuador. By Wilson Popenoe. Pp. 101-134, 16 pls. May 28, 1924.

6. A bibliographic study of Beauvois' Agrostographie. By Cornelia D. Niles. With introduction and botanical notes, by Agnes Chase. Pp. 135-214. Aug. 20, 1925.

7. The North American species of Stipa. By A. S. Hitchcock. Pp. 215-262, 3 pls. Nov. 20, 1925.

Synopsis of the South American species of Stipa. By A. S. Hitchcock. Pp. 263-289. Nov. 20, 1925.

8. The grasses of Ecuador, Peru, and Bolivia. By A. S. Hitchcock. Pp. 291-556. May 4, 1927.

9. The grasses of Central America. By A. S. Hitchcock. Pp. 557-762. Feb. 12, 1930.

\section{Volume 25}

Flora of Utah and Nevada. By Ivar Tidestrom. Pp. 1-655, 2 figs., 15 pls., 1 map. Oct. 31, 1925. 


\section{Volume 26}

Systematic plant studies: mainly tropical America. Pp. i-xii (title, advertisement, title page, dates of publication, errata, preface, contents, and illustrations); pp. 1-530 (parts 1-10) ; pp. 531-554 (index); 39 figs., 40 pls. 1927-1939.

Part

The Lecythidaceae of Central America. By H. Pittier. Pp. 1-14, 12 pls. May 2, 1927.

2. The Piperaceae of Panama. By William Trelease. Pp. 15-50. May 21, 1927.

3. Costa Rican mosses collected by Paul C. Standley in 1924-1926. By Edwin B. Bartram. Pp. 51-114, 39 figs. Oct. 31, 1928.

4. The Piperaceae of Costa Rica. By William Trelease. Pp. 115-226. Dec. 31, 1929.

5. Notes on certain type specimens of American Asteraceae in European herbaria. By S. F. Blake. Pp. 227-263. Mar. 10, 1930.

6. Asiatic Pteridophyta collected by Joseph F. Rock, 1920-1924. By Carl Christensen. Pp. 265-337, 17 pls. Apr. 2, 1931.

7. The Mexican and Central American species of Viburnum. By C. V. Morton. Pp. 339-366. Nov. 16, 1933.

8. New species of Pilea from the Andes. By Ellsworth P. Killip. Pp. 367-394. Jan. 30, 1936.

9. A revision of Besleria. By C. V. Morton. Pp. 395-474. May 9, 1939.

10. The Andean species of Pilea. By Ellsworth P. Killip. Pp. 475-530, 11 pls. June 14, 1939.

\section{Volume 27}

Flora of the Panama Canal Zone. By Paul C. Standley. Pp. i-x, 1-416, 7 figs., 67 pls. Jan. 31, 1928.

\section{Volume 28}

Systematic plant studies. Pp. i-xii (title, advertisement, title page, dates of publication, errata, preface, contents, and illustrations); pp. 1-675 (parts 1-4); pp. 677-694 (index) ; 144 figs., \$27 pls. 1929-1941.

Part
677-694 (index); 14 figs, \$27 pls. 1929-1941.

1. The North American species of Paspalum. By Agnes Chase. Pp. 1-310, 142 figs. June 28, 1929.

2. The American species of Thibaudieae. By Albert C. Smith. Pp. 311-547, 1 fig., 19 pls. June 27, 1932.

3. Marine algae of the Smithsonian-Hartford Expedition to the West Indies, 1937. By William Randolph Taylor. Pp. 549-561, 1 pl. June 12, 1940.

4. Plants collected by R. C. Ching in southern Mongolia and Kansu Province, China. By Egbert H. Walker. Pp. 563-675, 1 fig., 7 pls. July 22, 1941.

\section{Volume 29}

[Volume in progress.]

Part

1. Taxonomic studies of tropical American plants. By C. V. Morton. Pp. 1-86. Mar. 23, 1944.

2. Mexican phanerogams described by M. E. Jones. By C. V. Morton. Pp. 87-116. May 21, 1945.

Asteraceae described from Mexico and the southwestern United States by M. E. Jones, 1908-1935. By S. F. Blake. Pp. 117-137. May 21, 1945.

3. The American species of Hymenophyllum, section Sphaerocionium. By C. V. Morton. (In press.)

[Volume in progress.]

Part

\section{Volume 30}

1. A botanical bibliography of the islands of the Pacific. By Elmer D. Merrill. (In press.)

A subject index to Elmer D. Merrill's "A Botanical Bibliography of the Islands of the Pacific." By Egbert H. Walker. (In press.) 


\section{SPECIAL BULLETINS}

No.

1. Life histories of North American birds with special reference to their breeding habits and eggs. By Charles Bendire. Pp. viii, 1-446, 12 pls. (col.). 1892.

2. Oceanic ichthyology, a treatise on the deep-sea and pelagic fishes of the world, based chiefly upon the collections made by the steamers Blake, Albatross, and Fish Hawk in the Northwestern Atlantic. By George Brown Goode and Tarleton H. Bean. Vol. 1, pp. xxxv, 1-553, 24 figs., 1 diagram; Vol. 2, pp. xxiii, 1-26, 123 pls. 1895.

3. Life histories of North American birds, from the parrots to the grackles, with special reference to the breeding habits and eggs. By Charles Bendire. Pp. ix, $1-518,7$ pls. (col.). 1895.

4. American hydroids. By Charles Cleveland Nutting. Pt. 1, The Plumularidae, pp. ii, 1-285, 124 figs., 34 pls., 1900. Pt. 2, The Sertularidae, pp. ii, 1-325; 139 figs., 41 pls., 1904. Pt. 3, The Campanularidae and the Bonneviellidae, pp. iii, 1-126, 68 figs., 27 pls., 1915. 


\section{PROCEEDINGS}

\section{Volume 1}

Proceedings of the United States National Museum, vol. 1. Pp. i-iv (title page and table of contents); pp. 1-488 (Proceedings papers 1-61); pp. 489-520 (index); 7 figs., 8 pls. 1879.

Proc.

No.

1. Descriptions of new forms of mollusks from Alaska contained in the collections of the National Museum. By W. H. Dall. Pp. 1-3. Mar. 27, 1878. ${ }^{3}$

2. Postpliocene fossils in the coast range of California. By W. H. Dall. P. 3. Mar. 27, 1878.

3. Notes on the American species of the genus Cybium. By Felipe Poey. Pp. 3-5. Mar. 27, 1878.

4. The Clupea tyrannus of Latrobe. By G. Brown Goode. Pp. 5-6. Mar. 27, 1878.

5. The occurrence of Belone latimanus in Buzzard's Bay, Massachusetts. By G. Brown Goode. Pp. 6-7. Mar. 27, 1878.

6. The voices of crustaceans. By G. Brown Goode. Pp. 7-8. Mar. 27, 1878.

7. On a new humming bird (Atthis ellioti) from Guatemala. By Robert Ridgway. Pp. 8-10, 2 figs. Mar. 27, 1878.

Fossil mollusks from later Tertiaries of California. By W. H. Dall. Pp. 10-16. Mar. 27, 1878.

9. The manufacture of porpoise-oil. By Caleb Cook. P. 16, Mar. 27, 1878; pp. 17-18. Sept. 12, 1878.

10. The Craig flounder of Europe, Glyptocephalus cynoglossus, on the coast of North America. By G. Brown Goode and Tarleton H. Bean. Pp. 19-23. Sept. 12, 1878.

11. Note on shells from Costa Rica kitchenmidden, collected by Drs. Flint and Bransford. By W. H. Dall. Pp. 23-24. Sept. 12, 1878.

12. Arsenic acid for protecting anatomical preparations from insects. By J. B. S. Jackson. P. 24. Sept. 12, 1878.

13. The oceanic bonito on the coast of the United States. By G. Brown Goode and Tarleton H. Bean. Pp. 24-26. Sept. 12, 1878.

14. Distribution of Californian Tertiary fossils. By W. H. Dall. Pp. 26-30. Sept. 12, 1878.

15. A revision of the American species of the genus Brevoortia, with a description of a new species from the Gulf of Mexico. By G. Brown Goode. Pp. 30-42. Sept. 12, 1878.

16. Description of Caulolatilus microps, a new species of fish from the Gulf coast of Florida. By G. Brown Goode and Tarleton H. Bean. Pp. 42-45. Sept. 12, 1878.

17. The occurrence of Hippocampus antiquorum, or an allied form, on Saint George's Banks. By G. Brown Goode. Pp. 45-46. Sept. 12, 1878.

18. Descriptions of new species of shells from California in the collections of the National Museum. By W. H. Dall. Pp. 46-47. Sept. 12, 1878.

19. Catalogue of the birds of Dominica from collections made for the Smithsonian Institution by Frederick A. Ober, together with his notes and observations. By George N. Lawrence. Pp. 48-69. Sept. 12, 1878.

20. Notes on a collection of fishes from Clackamas River, Oregon. By David S. Jordan. Pp. 69-85. Sept. 12, 1878.

21. A review of the American species of the genus Scops, Savigny. By Robert Ridgway. Pp. 85-112, Sept. 12, 1878; pp. 113-117. Oct. 9, 1878.

22. Notes on the ornithology of southern Texas, being a list of birds observed in the vicinity of Fort Brown, Texas, from February, 1876, to June, 1878. By James C. Merrill. Pp. 118-160, Oct. 9, 1878; pp. 161-173, 3 pls., Oct. 24, 1878.

1 Proceedings papers Nos. 1-760 were issued by signatures, and when the published date for a signature differs from the date it was received from the printer at the National Museum, the latter date has been used here as the actual date of publication. After No. 760 each article has its actual date of publication recorded in the completed volume of Proceedings. 
Proc.

No.

23. On a new serranoid fish, Epinephelus drummond-hayi, from the Bermudas and Florida. By G. Brown Goode and Tarleton H. Bean. Pp. 173-175. Oct. 24, 1878.

24. Descriptions of two new species of fishes, Lutjanus blackfordii and Lutjanus stearnsii, from the coast of Florida. By G. Brown Goode and Tarleton H. Bean. P. 176, Oct. 24, 1878; pp. 177-181, Oct. 28, 1878.

25. A note on the Gulf menhaden, Brevoortia patronus, Goode. By Silas Stearns. Pp. 181-182. Oct. 28, 1878.

26. A note upon the black grouper (Epinephelus nigritus) (Holbrook, Gill) of the southern coast. By G. Brown Goode and Tarleton H. Bean. Pp. 182184. Oct. 28, 1878.

27. Catalogue of the birds of St. Vincent, from collections made by Mr. Fred A. Ober, under the directions of the Smithsonian Institution, with his notes thereon. By George N. Lawrence. Pp. 185-198. Oct. 28, 1878.

28. Description of a new sparoid fish, Sargus holbrookii, from Savannah Bank. By Tarleton H. Bean. Pp. 198-200. Oct. 28, 1878.

29. Catalogue of casts taken by Clark Mills, Esq., of the heads of sixty-four Indian prisoners of various western tribes, and held at Fort Marion, Saint Augustine, Fla., in charge of Capt. R. H. Pratt, U. S. A. [By R. H. Pratt.] Pp. 201-208, Oct. 28, 1878; pp. 209-214, Dec. 18, 1878.

30. Synopsis of the pediculate fishes of the eastern coast of extratropical North America. By Theodore Gill. Pp. 215-221. Dec. 18, 1878.

31. Note on the Antennariidae. By Theodore Gill. Pp. 221-222. Dec. 18, 1878.

32. On the proper specific name of the common antennariid Pterophryne. By Theodore Gill. Pp. 223-224, Dec. 18, 1878; pp. 225-226, Dec. 23, 1878.

33. Note on the Ceratiidae. By Theodore Gill. Pp. 227-231. Dec. 23, 1878.

34. Note on the Maltheidae. By Theodore Gill. Pp. 231-232. Dec. 23, 1878.

35. Catalogue of the birds of Antigua and Barbuda, from collections made for the Smithsonian Institution, by Mr. Fred A. Ober, with his observations. By George N. Lawrence. Pp. 232-240, Dec. 23, 1878; pp. 241-242, 1878? (exact date of publication unknown).

36. Note on Perca flavescens. By Franz Steindachner. P. 243. 1878? (exact date of publication unknown).

37. On the destruction of fish in the vicinity of the Tortugas during the months of September and October, 1878. By J. P. Jefferson, Joseph Y. Porter, and Thomas Moore. Pp. 244-246. 1878? (exact date of publication unknown).

38. Descriptions of several new species and geographical races of birds contained in the collection of the United States National Museum. By Robert Ridgway. Pp. 247-252. 1878? (exact date of publication unknown).

39. Description of two new species of birds from Costa Rica, and notes on other rare species from that country. By Robert Ridgway. Pp. 252-255. 1878? (exact date of publication unknown).

40. Description of two gadoid fishes, Phycis chesteri and Haloporphyrus viola, from the deep-sea fauna of the northwestern Atlantic. By G. Brown Goode and Tarleton H. Bean. P. 256, 1878? (exact date of publication unknown); pp. 257-260, Feb. 5, 1879.

41. Description of Argentina syrtensium, a new deep-sea fish from Sable Island Bank. By G. Brown Goode and Tarleton H. Bean. Pp. 261-263. Feb. 5, 1879.

42. On the occurrence of the oceanic bonito, Orcynus pelamys, (Linné) Poey, in Vineyard Sound, Massachusetts. By Vinal N. Edwards. P. 263. Feb. $5,1879$.

43. Notes on the western gizzard shad, Dorosoma cepedianum heterurum, (Raf.) Jordan. By Samuel Wilmot. Pp. 263-264. Feb. 5, 1879.

44. The occurrence of the Canada porcupine in West Virginia. By G. Brown Goode. Pp. 264-265. Feb. 5, 1879. 
Proc.

No.

45. Catalogue of the birds of Grenada, from a collection made by Mr. Fred. A. Ober for the Smithsonian Institution, including others seen by him, but not obtained. By George N. Lawrence. Pp. 265-272, Feb. 5, 1879; pp. 273-278, Feb. 15, 1879.

46. On the breeding habits of the sea-catfish (Ariopsis milberti?). By N. T. Lupton. Pp. 278-279. Feb. 15, 1879.

47. On the occurrence of Stichaeus punctatus, (Fabr.) Kröyer, at St. Michael's, Alaska. By Tarieton H. Bean. Pp. 279-281. Feb. 15, 1879.

48. Report on the limpets and chitons of the Alaskan and Arctic regions, with descriptions of genera and species believed to be new. By W. H. Dall. Pp. 281-288, figs. A-C, Feb. 15, 1879; pp. 289-336, figs. D, E, Feb. 17, 1879; pp. 337-344, 5 pls., Feb. 19, 1879.

49. On the identity of Euchalarodus putnami, Gill, with Pleuronectes glaber, (Storer) Gill, with notes on the habits of the species. By Tarleton H. Bean. Pp. 345-348. Feb. 19, 1879.

50. The identity of Rhinonemus caudacuta (Storer) Gill with Gadus cimbrius, Linn. By G. Brown Goode and Tarleton H. Bean. Pp. 348-349. Feb. 19, 1879.

51. Catalogue of the birds collected in Martinique by Mr. Fred. A. Ober for the Smithsonian Institution. By George N. Lawrence. Pp. 349-352, Feb. 19, 1879; pp. 353-360, Mar. 17, 1879.

52. Notes on Platessa ferruginea, D. H. Storer, and Platessa rostrata, H. R. Storer. By G. Brown Goode and Tarleton H. Bean. Pp. 361-362. Mar. 17, 1879.

53. On the identity of Brosmius americanus, Gill, with Brosmius brosme, (Müller) White. By G. Brown Goode and Tarleton H. Bean. Pp. 362-363. Mar. $17,1879$.

54. On the mortality of fishes in the Gulf of Mexico in 1878. By J. P. Jefferson. Pp. 363-364. Mar. 17, 1879.

55. Notes on the fishes of Beaufort Harbor, North Carolina. By David S. Jordan and Charles H. Gilbert. Pp. 365-384, Mar. 17, 1879; pp. 385-388, Mar. 25, 1879.

56. A partial list of the birds of central California. By L. Belding. [Edited by R. Ridgway.] Pp. 388-432, Mar. 25, 1879; pp. 433-448, Mar. 28, 1879; p. 449 , ?Apr. $30,1879$.

57. Catalogue of a collection of birds obtained in Guadeloupe for the Smithsonian Institution, by Mr. Fred. A. Ober. By George N. Lawrence. Pp. 449-462. ?Apr. 30, 1879.

58. On two fishes from the Bermudas mistakenly described as new by Dr. Günther. By G. Brown Goode. Pp. 462-463. ?Apr. 30, 1879.

59. Description of a species of Lycodes (L. turneri) from Alaska, believed to be undescribed. By Tarleton H. Bean. Pp. 463-466. ?Apr. 30, 1879.

60. Descriptions of new species and races of American birds, including a synopsis of the genus Tyrannus, Cuvier. By Robert Ridgway. Pp. 466-480, ?Apr. 30, 1879; pp. 481-486, May ? 1879.

61. A general catalogue of the birds noted from the islands of the Lesser Antilles visited by Mr. Fred. A. Oter; with a table showing their distribution, and those found in the United States. By George N. Lawrence. Pp. 486-488. May ? 1879.

\section{Volume 2}

Proceedings of the United States National Museum, vol. 2. Pp. i-iv (title page and table of contents); pp. 1-482 (Proceedings papers 62-101); pp. 483-499 (index); 2 figs., 7 pls. 1880.

62. Notes on the nests and eggs of the eight North American species of Empidonaces. By T. M. Brewer. Pp. 1-10. May 2?, 1879.

63. A list of European fishes in the collection of the United States National Museum. By Tarleton H. Bean. Pp. 10-16, May 2?, 1879; pp. 17-32, May 6, 1879; pp. 33-44, July 7, 1879. 
64. Description of a species of Lycodes (L. paxillus) obtained by the United States Fish Commission. By G. Brown Goode and Tarleton H. Bean. Pp. 44-46. July 7, 1879.

65. Description of a new species of Liparis ( $L$. ranula) obtained by the United States Fish Commission off Halifax, Nova Scotia. By G. Brown Goode and Tarleton H. Bean. Pp. 46-48. July 7, 1879.

66. Description of a new species of amber fish (Seriola stearnsii) obtained near Pensacola, Florida, by Mr. Silas Stearns. By G. Brown Goode and Tarleton H. Bean. Pp. 48-51. July 7, 1879.

67. On the birds of Heligoland. By H. Gätke. Pp. 51-55. July 7, 1879.

68. Description of Alepocephalus bairdii, a new species of fish from the deepsea fauna of the western Atlantic. By $G$. Brown Goode and Tarleton H. Bean. Pp. 55-57. July 7, 1879.

69. On the species of Astroscopus of the eastern United States. By Tarleton H. Bean. Pp. 57-63. July 7, 1879.

70. On the occurrence of Hippoglossus vulgaris, Flem., at Unalashka and St. Michael's, Alaska. By Tarleton H. Bean. Pp. 63-66. July 7, 1879.

71. Description of an apparently new species of Gasterosteus (G. atkinsii) from the Schoodic Lakes, Maine. By Tarleton H. Bean. Pp. 67-69. July 7, 1879.

72. Review of the Pleuronectidae of San Francisco. By W. N. Lockington. Pp. 69-80, July 7, 1879; pp. 81-96, July 15, 1879; pp. 97-108, 1879 (exact date of publication unknown).

73. A preliminary catalogue of the fishes of the St. John's River and the east coast of Florida, with descriptions of a new genus and three new species. By G. Brown Goode. Pp. 108-121. 1879 (exact date of publication unknown).

74. Catalogue of a collection of fishes sent from Pensacola, Florida, and vicinity, by Mr. Silas Stearns, with descriptions of six new species. By G. Brown Goode and Tarleton H. Bean. Pp. 121-128, 1879 (exact date of publication unknown) ; pp. 129-144, Sept. 25, 1879; pp. 145-156, Nov. 14, 1879.

75. Notes on New England Isopoda. By Oscar Harger. Pp. 157-165. Nov. 14, 1879.

76. Notice of recent additions to the marine Invertebrata of the northeastern coast of America, with descriptions of new genera and species and critical remarks on others. Part 1-Annelida, Gephyraea, Nemertina, Nematoda, Polyzoa, Tunicata, Mollusca, Anthozoa, Echinodermata, Porifera. By A. E. Verrill. Pp. 165-192, Nov. 14, 1879; pp. 193-205. Nov. 12, 1879.

77. Description of a new genus and species of fish, Lopholatilus chamaeleonticeps, from the south coast of New England. By G. Brown Goode and Tarleton H. Bean. Pp. 205-208, Nov. 12, 1879; p. 209, Dec. 17, 1879.

78. On the occurrence of Lycodes vahlii, Reinhardt, on La Have and Grand Banks. By G. Brown Goode and Tarleton H. Bean. Pp. 209-210. Dec. 17, 1879.

79. List of names, age, tribe, etc., of Indian boys and girls at Hampton Normal and Agricultural Institute, Virginia, plaster casts of whose heads were taken by Clark Mills, Esq., March, 1879. By R. H. Pratt. P. 211. Dec. 17, 1879.

80. Description of a new fish from Alaska (Anarrhichas lepturus), with notes upon other species of the genus Anarrhichas. By Tarleton H. Bean. Pp. 212-218. Dec. 17, 1879.

81. Notes on certain typical specimens of American fishes in the British Museum and in the Museum d'Histoire Naturelle at Paris. By David S. Jordan. Pp. 218-224, Dec. 17, 1879; pp. 225-226, Feb. 3, 1880.

82. List of marine Invertebrata from the New England coast, distributed by the U. S. Commission of Fish and Fisheries. Series I. [By Richard Rathbun.] Pp. 227-232. Feb. 3, 1880.

83. Occurrence of Chelura terebrans, a crustacean destructive to the timber of submarine structures, on the coast of the United States. By Sidney I. Smith. Pp. 232-235, 2 figs. Feb. 3, 1880.

84. Description of new species of North American fishes. By David S. Jordan. Pp. 235-241. Feb. 3, 1880. 
Proc.

No.

85. On the migrations and nesting habits of west-coast birds. By J. G. Cooper. Pp. 241-251. Feb. 3, 1880.

86. Descriptions of new species of Carboniferous invertebrate fossils. By C. A. White. Pp. 252-256, Feb. 3, 1880; pp. 257-260, 1 pl., Feb. 21, 1880.

87. A study of the trunk-fishes (Ostraciontidae), with notes upon the American species of the family. By G. Brown Goode. Pp. 261-272, Feb. 21, 1880; pp. 273-283, Mar. 30, 1880.

88. On the habits of the Rocky Mountain goat. By James C. Merrill. Pp. 283-284. Mar. 30, 1880.

89. Notes on a collection of fishes from eastern Georgia. By Tarleton H. Bean. Pp. 284-286. Mar. 30, 1880.

90. Description of a new species of Amiurus ( $A$. ponderosus) from the Mississippi River. By Tarleton H. Bean. Pp. 286-290. Mar. 30, 1880.

91. Note on Endothyra ornata. By C. A. White. P. 291. Mar. 30, 1880.

92. Note on Criocardium and Ethmocardium. By C. A. White. Pp. 291-292. Mar. $30,1880$.

93. Descriptions of new Cretaceous invertebrate fossils from Kansas and Texas. By C. A. White. Pp. 292-298, 5 pls. Mar. 30, 1880.

94. Notes on a collection of fishes obtained in the streams of Guanajuato and in Chapala Lake, Mexico, by Prof. A. Dugès. By David S. Jordan. Pp. 298301. Mar. 30. 1880.

95. Descriptions of two species of fishes collected by Prof. A. Dugès in central Mexico. By Tarleton H. Bean. Pp. 302-304, Mar. 30, 1880; p. 305, Mar. 31, 1880.

96. Report of experiments upon the animal heat of fishes, made at Provincetown, Mass., during the summer of 1879 , in connection with operations of the United States Fish Commission. By J. H. Kidder. Pp. 306-326. Mar. 31, 1880.

97. Descriptions of new genera and species of fishes from the coast of California. By W. N. Lockington. Pp. 326-332. Mar. 31, 1880.

98. Catalogue of a collection of fishes obtained in the Gulf of Mexico, by Dr. J. W. Velie, with descriptions of seven new species. By G. Brown Goode and Tarleton H. Bean. Pp. 333-345. Mar. 31, 1880.

99. Notice of a new species of the "Willemoesia group of Crustacea" (Recent Eryontidae). By Sidney I. Smith. Pp. 345-352, Mar. 31, 1880; p. 353, 1 pl., Apr. 8, 1880.

100. Descriptions of some genera and species of Alaskan fishes. By Tarleton $\mathbf{H}$. Bean. Pp. 353-359. Apr. 8, 1880.

101. Fourth instalment of ornithological bibliography: Being a list of faunal publications relating to British birds. By Elliott Coues. Pp. 359-368, Apr. 8, 1880 ; pp. $369-384$, Apr. 16,1880 ; pp. $385-400$, Apr. 19 , 1880; 401-416, Apr. 16,1880 ; pp. $417-432$, Apr. 19,1880 ; pp. 433-448, May 5, 1880 ; pp. 449-464, 1880 (exact date of publication unknown) ; 465-480, June 28,$1880 ; 481-482$, July 6, 1880.

\section{Volume 3}

Proceedings of the United States National Museum, vol. 3. Pp. i-v (title page and table of contents); pp. 1-537 (Proceedings papers 102-184); pp. 539-589 (index); 11 figs., 2 pls. 1881.

102. Revisions of nomenclature of certain North American birds. By Robert Ridgway. Pp. 1-16, 1880 (exact date of publication unknown).

103. Description of a new species of bird of the family Turdidae, from the Island of Dominica, W. I. By Geo. N. Lawrence. Pp. 16-17, 1880 (exact date of publication unknown).

104. Notes on a collection of fishes from east Florida, obtained by Dr. J. A. Henshall. By David S. Jordan. Pp. 17-21, 1880 (exact date of publication unknown).

105. Notes on a collection of fishes from Saint John's River, Florida, obtained by Mr. A. H. Curtiss. By David S. Jordan. P. 22, 1880 (exact date of publication unknown). 
106. Notes on a collection of fishes from San Diego, California. By David S. Jordan and Charles H. Gilbert. Pp. 23-32, 1880 (exact date of publication unknown); pp. 33-34, May 18, 1880.

107. Description of a new flounder (Xystreurys liolepis), from Santa Catalina Island, California. By David S. Jordan and Charles H. Gilbert. Pp. 34-36. May $18,1880$.

108. Description of a new ray (Platyrhina triseriata), from the coast of California. By David S. Jordan and Charles H. Gilbert. Pp. 36-38. May 18, 1880.

109. Description of a new species of "rock cod" (Sebastichthys serriceps), from the coast of California. By David S. Jordan and Charles H. Gilbert. Pp. 38-40. May 18, 1880.

110. On the occurrence of Cephaloscyllium laticeps (Duméril) Gill, on the coast of California. By David S. Jordan and Charles H. Gilbert. Pp. 40-42. May $18,1880$.

111. On the oil-shark of southern California (Galeorhinus galeus). By David S. Jordan and Charles H. Gilbert. Pp. 42-43. May 18, 1880.

112. The surf-smelt of the Northwest coast, and the method of taking them by the Quillehute Indians, west coast of Washington Territory. By James G. Swan. Pp. 43-46. May 18, 1880.

113. Note on the occurrence of Productus giganteus in California. By C. A. White. Pp. 46-47, 1 pl. May 18, 1880.

114. Note on Acrothele. By C. A. White. P. 47. May 18, 1880.

115. Description of a new Cretaccous Pinna from New Mexico. By C. A. White. Pp. 47-48. May 18, 1880.

116. Note on the occurrence of Stricklandinia salteri and S. davidsoni in Georgia. Pp. 48-49. May 18, 1880.

117. Description of a new flounder (Pleuronichthys verticalis), from the coast of California, with notes on other species. By David S. Jordan and Charles $\mathrm{H}$. Gilbert. Pp. 49-51. May 18, 1880.

118. Notes on sharks from the coast of California. By David S. Jordan and Chas. H. Gilbert. Pp. 51-52. May 18, 1880.

119. On the generic relations of Platyrhina exasperata. By David S. Jordan and Charles H. Gilbert. P. 53. May 18, 1880.

120. Remarks on the species of the genus Chirus found in San Francisco market, including one hitherto undescribed. By W. N. Lockington. Pp. 53-57. May $18,1880$.

121. Description of a new fish from Alaska (Uranidea microstoma). By W. N. Lockington. Pp. 58-59. May 18, 1880.

122. Description of a new species of Agonidae (Brachyopsis verrucosus), from the coast of California. By W. N. Lockington. Pp. 60-63. May 18, 1880.

123. Description of a new genus and some new species of California fishes (Icosteus aenigmaticus and Osmerus attenuatus). By W. N. Lockington. Pp. 63-64, May 18,1880 ; pp. 65-68, July 8, 1880.

124. Description of a new hake (Phycis earllii), from south California, and a note on the occurrence of Phycis regius in North Carolina. By Tarleton H. Bean. Pp. 69-70. July 8, 1880.

125. Description of a new species of Sebastichthys (Sebastichthys miniatus), from Monterey Bay, California. By David S. Jordan and Charles H. Gilbert. Pp. 70-73. July 8, 1880.

126. Description of a new species of "rock-fish" (Sebastichthys carnatus), from the coast of California. By David S. Jordan and Charles H. Gilbert. Pp. 7375. July $8,1880$.

127. Check-list of duplicates of North American fishes distributed by the Smithsonian Institution in behalf of the United States National Museum, 18771880. Prepared by Tarleton H. Bean. Pp. 75-96, July 8, 1880; pp. 97-116. July $10,1880$.

128. The littoral marine fauna of Provincetown, Cape Cod, Massachusetts. By Richard Rathbun. Pp. 116-128, July 10, 1880; pp. 129-133, 1880 (exact date of publication unknown). 
129. Description of a new species of ray (Raia stellulata) from Monterey, California. By David S. Jordan and Charles H. Gilbert. Pp. 133-135. 1880 (exact date of publication unknown).

130. Descriptions of new species of Xiphister and Apodichthys, from Monterey, California. By David S. Jordan and Charles H. Gilbert. Pp. 135-140. 1880 (exact date of publication unknown).

131. Description of a very large fossil gasteropod from the state of Puebla, Mexico. By C. A. White. Pp. 140-142. 1 pl. 1880 (exact date of publication unknown).

132. Description of two new species of Sebastichthys (Sebastichthys entomelas and Sebastichthys rhodochloris), from Monterey Bay, California. By David S. Jordan and Charles H. Gilbert. Pp. 142-144, 1880 (exact date of publication unknown); pp. 145-146, July 8, 1880.

133. On the occurrence of a species of Cremnobates at San Diego, California. By Rosa Smith. Pp. 147-149. July 8, 1880.

134. On some new species of Eocene Mollusca from the southern United States. By Angelo Heilprin. Pp. 149-152, 1 pl. July 8, 1880.

135. Description of a new agonoid fish (Brachyopsis xyosternus), from Monterey Bay, California. By David S. Jordan and Charles H. Gilbert. Pp. 152-154. July 8, 1880.

136. Description of a new flounder (Hippoglossoides exilis), from the coast of California. By David S. Jordan and Charles H. Gilbert. Pp. 154-156. July 8, 1880.

137. Descriptions of new invertebrate fossils from the Mesozoic and Cenozoic rocks of Arkansas, Wyoming, Colorado, and Utah. By C. A. White. Pp. 157-160, July 8, 1880; pp. 161-162, Aug. 27, 1880.

138. A catalogue of the birds of North America. By Robert Ridgway. Pp. 163-208, Aug. 27, 1880; pp. 209-224, Sept. 9, 1880; pp. 225-246, Sept. 15, 1880.

139. On the identity of the genus Leurynnis, Lockington, with Lycodopsis, Collett. By Theodore Gill. Pp. 247-248. Sept. 15, 1880.

140. Description of a new chiroid fish, Myriolepis zonifer, from Monterey Bay, California. By W. N. Lockington. Pp. 248-251. Sept. 15, 1880.

141. Description of a new species of ray, Raia rhina, from the coast of California. By David S. Jordan and Charles H. Gilbert. Pp. 251-253. Sept. 15, 1880.

142. Description of a new species of parrot of the genus Chrysotis, from the Island of Dominica. By George N. Lawrence. Pp. 254-256, Sept. 15, 1880; p. 257, Sept. 22, 1880.

143. The eulachon or candle-fish of the Northwest coast. By James G. Swan. Pp. 257-264. Sept. 22, 1880.

144. Description of two new species of fishes, Ascelichthys rhodorus and Scytalina cerdale, from Neah Bay, Washington Territory. By David S. Jordan and Charles H. Gilbert. Pp. 264-268. Sept. 22, 1880.

145. On Camaraphysema, a new type of sponge. By John A. Ryder. Pp. 269-272, 7 figs. Sept. 22, 1880.

146. Description of two new species of scopeloid fishes, Sudis ringens and Myctophum crenulare, from Santa Barbara Channel, California. By David S. Jordan and Charles H. Gilbert. Pp. 273-276. Oct. 2, 1880.

147. Description of two new species of flounders (Parophrys ischyrus and Hippoglossoides elassodon), from Puget's Sound. By David S. Jordan and Charles H. Gilbert. Pp. 276-280. Oct. 2, 1880.

148. On the genitalia of male eels and their sexual characters. By S. Th. Cattie. Pp. 280-284, 1 fig. Oct. 2, 1880.

149. Description of a new sparoid fish (Sparus brachysomus), from Lower California. By W. N. Lockington. Pp. 284-286. Oct. 2, 1880.

150. Description of seven new species of sebastoid fishes, from the coast of California. By David S. Jordan and Charles H. Gilbert. Pp. 287-298. Oct. 2, 1880.

151. Description of a new embiotocoid (Abeona aurora), from Monterey, California, with notes on a related species. By David S. Jordan and Charles H. Gilbert. Pp. 299-301. Oct. 2, 1880. 
152. Description of a new flounder (Platysomatichthys stomias), from the coast of California. By David S. Jordan and Charles H. Gilbert. Pp. 301-303. Oct. 2, 1880 .

153. Description of a new embiotocoid fish (Cymatogaster rosaceus), from the coast of California. By David S. Jordan and Charles H. Gilbert. Pp. 303-304, Oct. 2,1880 ; p. 305 , Oct. $18,1880$.

154. Description of a new species of deep-water fish (Icichthys lockingtoni), from the coast of California. By David S. Jordan and Charles H. Gilbert. Pp. 305-308. Oct. 18, 1880.

155. Catalogue of Trochilidae in the collection of the United States National Museum. By Robert Ridgway. Pp. 308-320. Oct. 18, 1880.

156. Description of a new embiotocoid fish (Ditrema atripes), from the coast of California. By David S. Jordan and Charles H. Gilbert. P. 320, Oct. 18, 1880 ; pp. 321-322, Nov. 2, 1880.

157. Description of a new scorpaenoid fish (Sebastichthys maliger), from the coast of California. By David S. Jordan and Charles H. Gilbert. Pp. 322-324. Nov. 2, 1880.

158 Note on a new flat-fish (Lepidopsetta isolepis) found in the markets of San Francisco. By W. N. Lockington. P. 325. Nov. 2, 1880.

159. Note on a forgotten paper of Dr. Ayres and its bearing on the nomenclature of the cyprinoid fishes of the San Francisco markets. By David S. Jordan. Pp. 325-327. Nov. 2, 1880.

160. Note on "Sema" and "Dacentrus." By David S. Jordan. P. 327. Nov. 2, 1880.

161. Description of a new scorpaenoid fish (Sebastichthys proriger), from Monterey Bay, California. By David S. Jordan and Charles H. Gilbert. Pp. 327-329. Nov. 2, 1880.

162. Description of a new agonoid (Agonus vulsus), from the coast of California. By David S. Jordan and Charles H. Gilbert. Pp. 330-332. Nov. 2, 1880.

163. List of species and varieties of minerals in the National Museum of the United States in 1879. By Fred. M. Endlich. Pp. 333-335. Nov. 2, 1880.

164. Description of a new species of Hemirhamphus (Hemirhamphus rosae), from the coast of California. By David S. Jordan and Charles H. Gilbert. Pp. 335-336. Nov. 2, 1880.

165. Descriptions of seven new species of fishes from deep soundings on the southern New England coast, with diagnoses of two undescribed genera of flounders and a genus related to Merlucius. By G. Brown Goode. Pp. 337350. Dec. $30,1880$.

166. Description of a new species of Icterus from the West Indies. By George N. Lawrence. P. 351. Dec. 30, 1880.

167. Description of a new species of notidanoid shark (Hexanchus corinus), from the Pacific coast of the United States. By David S. Jordan and Charles $\mathbf{H}$. Gilbert. Pp. 352-355. Dec. 30, 1880.

168. Notice of recent additions to the marine Invertebrata, of the northeastern coast of America, with descriptions of new genera and species and critical remarks on others. Part II.-Mollusca, with notes on Annelida, Echinodermata, etc., collected by the United States Fish Commission. By A. E. Verrill. Pp. $356-384$, Dec. 30 , 1880 ; pp. 385-400, Jan. 10 , 1881; pp. 401-405, Jan. 14, 1881.

169. [Notice of recent additions to the marine Invertebrata, of the northeastern coast of America, with descriptions of new genera and species and critical remarks on others.] Part III.-Catalogue of Mollusca recently added to the fauna of southern New England. By A. E. Verrill. Pp. 405-409. Jan. 14, 1881.

170. Description of a new species of Nemichthys (Nemichthys avocetta), from Puget Sound. By David S. Jordan and Charles H. Gilbert. Pp. 409-410. Jan. 14, 1881.

171. Description of a new species of Paralepis (Paralepis coruscans), from the Straits of Juan de Fuca. By David S. Jordan and Charles H. Gilbert. Pp. 411-413. Jan. 14, 1881. 
172. Preliminary notice of the Crustacea dredged, in 64 to 325 fathoms, off the south coast of New England, by the United States Fish Commission in 1880. By S. I. Smith. Pp. 413-416, Jan. 14, 1881 ; pp. 417-432, Jan. 15, 1881; pp. 433448, Jan. 17, 1881 ; pp. 449-452, Feb. 4, 1881.

173. List of fishes of the Pacific coast of the United States, with a table showing the distribution of the species. By David S. Jordan and Charles H. Gilbert. P. 452-458. Feb. 4, 1881.

174. On the generic relations of Belone exilis Girard. By David S. Jordan and Charles H. Gilbert. P. 459. Feb. 4, 1881.

175. Notes on a collection of fishes from Utah Lake. By David S. Jordan and Charles H. Gilbert. Pp. 459-464, Feb. 4, 1881; p. 465, Feb. 25, 1881.

176. Description of a new species of "rock-fish" (Sebastichthys chrysomelas), from the coast of California. By David S. Jordan and Charles H. Gilbert. Pp. 465-466. Feb. 25, 1881.

177. Fishes from the deep water on the south coast of New England and obtained by the United States Fish Commission in the summer of 1880 . By G. Brown Goode. Pp. 467-480, Feb. 25, 1881; pp. 481-486, Feb. 23, 1881.

178. Description of a new species of Caranx (Caranx beani), from Beaufort, North Carolina. By David S. Jordan. Pp. 486-488. Feb. 23, 1881.

179. On a collection of fishes from eastern Mississippi. By O. P. Hay. Pp. 488-515. Feb. 23, 1881.

180. Synopsis and descriptions of the American Rhinobatidae. By Samuel Garman. Pp. 516-523. Feb. 23, 1881.

181. List of the North American species of myriapods belonging to the family of the Lysiopetalidae, with a description of a blind form from Luray Cave, Virginia. By John A. Ryder. Pp. 524-528, 3 figs., Feb. 23, 1881; p. 529, Apr. 28, 1881.

182. Description of a new species of Prionolus (Prionstus stephanophrys), from the coast of California. By W. N. Lockington. Pp. 529-532. Apr. 28, 1881.

183. The frigate mackerel, Auxis rochei, on the New England coast. By G. Brown Goode. Pp. 532-535. Apr. 28, 1881.

184. Notacanthus phasganorus, a new species of Notacanthidae from the Grand Banks of Newfoundland. By G. Brown Goode. Pp. 535-537. Apr. 28, 1881.

\section{Volume 4}

Proceedings of the United States National Museum, vol. 4. Pp. i-v (title page and table of contents); pp. 1-475 (Proceedings papers 185-256); pp. 477-534 (index); 13 figs., 1 pl. (With Appendix, 146 pp., circulars 1-18, individually paged.) 1882.

185. Check-list of duplicates of fishes from the Pacific coast of North America, distributed by the Smithsonian Institution in behalf of the United States National Museum, 1881. Prepared by David S. Jordan and Pierre L. Jouy. Pp. 1-18. Apr. 22, 1881.

186. Description of a new species of Squalius (Squalius aliciae), from Utah Lake. By Pierre Louis Jouy. P. 19. Apr. 22, 1881.

187. Description of a new gobioid fish (Athonops eos), from San Diego, California. By Rosa Smith. Pp. 19-21. Apr. 22, 1881.

188. On a duck new to the North American fauna. By Robert Ridgway. Pp. 22-24. Apr. 22, 1881.

189. On Amazilia yucatanesis (Cabot) and A. cerviniventris, Gould. By Robert Ridgway. Pp. 25-26. Apr. 22, 1881.

190. Descriptions of new species of fishes (Uranidea marginata, Potamocottus bendirei) and of Myctophum crenulare J. and G. By Tarleton H. Bean. Pp. 26-29. Apr. 22, 1881.

191. Notes on the fishes of the Pacific coast of the United States. By David S. Jordan and Charles H. Gilbert. Pp. 29-48, Apr. 22, 1881; pp. 49-64, May 9, 1881; pp. 65-70, May 10, 1881. 
Proc.

No.

192. Description of Sebastichthys mystinus. By David S. Jordan and Charles H. Gilbert. Pp. 70-72. May 10, 1881.

193. Description of a new species of Ptychochilus (Ptychochilus harfordi), from Sacramento River. By David S. Jordan and Charles H. Gilbert. Pp. 72-73. May 10, 1881.

194. Notes on Raia inornata. By David S. Jordan and Charles H. Gilbert. Pp. 7374. May 10, 1881.

195. On the fish-mortality in the Gulf of Mexico. By Ernest Ingersoll. Pp. 74-80. May 10, 1881.

196. Notes on Salmonidae of the upper Columbia. By Charles Bendire. Pp. 81-87, 1 fig. July 18, 1881.

197. A review of the genera and species of the family Centrarchidae, with a description of one new species. By Charles L. McKay. Pp. 87-93. July 18, 1881.

198. A review of the genus Centurus, Swainson. By Robert Ridgway. Pp. 93-119. July $18,1881$.

199. Observations on Siredon lichenoides. By Wm. E. Carlin. Pp. 120-121. July $18,1881$.

200. On the destruction of fish by poisonous water in the Gulf of Mexico. By Joseph Y. Porter. Pp. 121-123. July 18, 1881.

201. An analysis of water destructive to fish in the Gulf of Mexico. By F. M. Endlich. P. 124. July 18, 1881.

202. Fish mortality in the Gulf of Mexico. By M. A. Moore. Pp. 125-126. July 18, 1881.

203. On the destruction of fish by polluted waters in the Gulf of Mexico. By W. C. W. Glazier. Pp. 126-127. July 18, 1881.

204. Notes on some fishes from Hudson's Bay. By Tarleton H. Bean. Pp. 127-129. July $18,1881$.

205. On the mineralogical composition of the normal Mesozoic diabase upon the Atlantic border. By George W. Hawes. Pp. 129-134. July 18, 1881.

206. On the determination of feldspar in thin sections of rocks. By George W. Hawes. Pp. 134-136. July 18, 1881.

207. On certain Cretaceous fossils from Arkansas and Colorado. By C. A. White. Pp. 136-139, 1 pl. July 18, 1881.

208. Description of a new species of Gobiesox (Gobiesox rhessodon) from San Diego, California. By Rosa Smith. Pp. 140-141. July 18, 1881.

209. Description of a new genus and species of Cittidae. By W. N. Lockington. Pp. 141-144. July 18, 1881.

210. Descriptions of new fishes from Alaska and Siberia. By Tarleton H. Bean. Pp. 144-159. July 18, 1881.

211. Description of a new species of fish, Apogon pandionis, from the deep water off the mouth of Chesapeake Bay. By G. Brown Goode and Tarleton H. Bean. P. 160, July 18, 1881; p. 161, Aug. 20, 1881.

212. Metallic castings of delicate natural objects. [Translated.] P. 161. Aug. 20, 1881.

213. The occurrence of the Canada porcupine in Maryland. By Otto Lugger. Pp. 161-162. Aug. 20, 1881.

214. Note on the latiloid genera. By Theodore Gill. Pp. 162-164. Aug. 20, 1881.

215. List of species of Middle and South American birds not contained in the United States National Museum. By Robert Ridgway. Pp. 165-192, Aug. 20,1881; pp. 193-203, Nov. 25, 1881.

216. Description of a new sub-species of Loxigilla from the Island of St. Christopher, West Indies. By George N. Lawrence. Pp. 204-205. Nov. 25, 1881.

217. Notes on the mortality among fishes of the Gulf of Mexico. By S. H. Johnson. P. 205. Nov. 25, 1881.

218. The comparative action of dry heat and sulphurous acid upon putrefactive bacteria. [Based on experiments by Dr. Wermch.] P. 206. Nov. 25, 1881.

219. List of special desiderata among North American birds. By Robert Ridgway. Pp. 207-208, Nov. 25, 1881; pp. 209-223, Dec. 8, 1881. 
Proc.

No.

220. On Semper's method of making dry preparations. [Abstract, with remarks by J. A. Ryder.] P. 224, Dec. 8, 1881; p. 225, Jan. 4, 1882.

221. Notes on a collection of fishes, made by Lieut. Henry E. Nichols, U.S.N., on the west coast of Mexico, with descriptions of new species. By David S. Jordan and Charles H. Gilbert. Pp. 225-233. Jan. 4, 1882.

222. Report on the contents of two bottles of water from the Gulf of Mexico, forwarded by the Smithsonian Institution. By W. G. Farlow. P. 234. Jan. 4, 1882.

223. Remains of the walrus (?) in Maine. By C. H. Boyd. Pp. 234-235. Jan. 4, 1882.

224. Directions for collecting and preserving fish. By Tarleton H. Bean. Pp. 235238. Jan. 4, 1882.

225. A preliminary catalogue of the fishes of Alaskan and adjacent waters. By Tarleton H. Bean. Pp. 239-240, Jan. 4, 1882; pp. 241-256, Jan. 9, 1882; pp. 257-272, Jan. 4, 1882.

226. Methods of making and preserving plaster casts. By Anthony Pirz. P. 272, Jan. 4, 1882; p. 273, Feb. 1, 1882.

227. List of fishes collected by Lieut. Henry E. Nichols, U.S.N., in the Gulf of California and on the west coast of Lower California, with descriptions of four new species. By David S. Jordan and Charles H. Gilbert. Pp. 273-279. Feb. 1, 1882.

228. On the genera of chitons. By W. H. Dall. Pp. 279-288, Feb. 1, 1882; pp. 289291, Mar. 13, 1882.

229. Notes on certain aboriginal shell mounds on the coast of New Brunswick and of New England. By S. F. Baird. Pp. 292-297. Mar. 13, 1882.

230. List of marine invertebrates, mainly from the New England coast, distributed by the United States National Museum. Series II. Prepared by Richard Rathbun. Pp. 298-303. Mar. 13, 1882.

231. List of marine invertebrates from the New England coast, distributed by the United States National Museum. Series III.-Educational Series. Prepared by Richard Rathbun. P. 304, Mar. 13, 1882; pp. 305-307, Mar. 15, 1882.

232. Catalogue of a collection of Japanese woods presented to the United States National Museum by the University of Tokio, Japan. [Prepared by Lester F. Ward.] Pp. 308-311. Mar. 15, 1882.

233. A partial bibliography of the fishes of the Pacific coast of the United States and of Alaska, for the year 1880. By Tarleton H. Bean. Pp. 312-317. Mar. $15,1882$.

234. Catalogue of Old World birds in the United States National Museum. By Robert Ridgway. Pp. 317-320, Mar. 15, 1882; pp. 321-333, Mar. 16, 1882.

235. Notes on some Costa Rican birds. By Robert Ridgway. Pp. 333-336, Mar. 16, 1882 ; p. 337, Apr. 6, 1882.

236. Description of a new fly-catcher and a supposed new petrel from the Sandwich Islands. By Robert Ridgway. Pp. 337-338. Apr. 6, 1882.

237. Descriptions of thirty-three new species of fishes from Mazatlan, Mexico. By David S. Jordan and Charles H. Gilbert. Pp. 338-365. Apr. 6, 1882.

238. Description of a new owl from Porto Rico. By Robert Ridgway. Pp. 366-368, Apr. 6, 1882; pp. 369-371, Apr. 13, 1882.

239. Description of two new races of Myadestes obscurus Lafr. By Leonhard Stejneger. Pp. 371-374. Apr. 13, 1882.

240. Descriptions of two new thrushes from the United States. By Robert Ridgway. Pp. 374-379. Apr. 13, 1882.

241. Benthodesmus, a new genus of deep-sea fishes, allied to Lepidopus. By G. Brown Goode and Tarleton H. Bean. Pp. 379-383. Apr. 13, 1882.

242. Description of a new species of Pomadasys from Mazatlan, with a key to the species known to inhabit the Pacific coasts of tropical America. By David S. Jordan and Charles H. Gilbert. Pp. 383-384, Apr. 13, 1882; pp. 385-388, Apr. 25, 1882.

243. The rapid preparation of large myological specimens. By Félix Plateau. Pp. 388-391. Apr. 25, 1882. 
On the Chinnook names of the salmon in the Columbia River. By Silas B. Smith. Pp. 391-392. Apr. 25, 1882.

245. Remarks upon the osteology of Opheosaurus ventralis. By R. W. Shufeldt. Pp. 392-400, 9 figs. Apr. 25, 1882.

246. On certain limpets and chitons from the deep waters off the eastern coast of the United States. By W. H. Dall. P. 400, Apr. 25, 1882; pp. 401-414, May $5,1882$.

247. On two recent additions to the North American bird fauna, by L. Belding. By Robert Ridgway. Pp. 414-415. May 5, 1882.

248. The taxonomic relations and geographical distribution of the members of the sword-fish family, Xiphiidae. By G. Brown Goode. Pp. 315-416, May 5, 1882; pp. 417-432, May 10, 1882; p. 433, May 18, 1882.

249. On the North American land tortoises of the genus Xerobates. By Frederick W. True. Pp. 434-448, May 18, 1882; p. 449, 3 figs., 1882 (exact date of publication unknown).

250. Catalogue of a collection of Japanese cotton fiber presented to the United States National Museum by the Government of Japan, together with the amount of the annual crop of Japan and the price of cotton. [Prepared by the Japanese Legation.] Pp. 449-452. 1882 (exact date of publication unknown).

251. Brief account of cotton husbandry. [Prepared by the Japanese Legation.] Pp. 452-453. 1882 (exact date of publication unknown).

252. Description of a new species of Xenichthys (Xenichthys xenurus) from the west coast of Central America. By David S. Jordan and Charles H. Gilbert. P. 454. 1882 (exact date of publication unknown).

253. List of anthropological publications of Charles Rau. 1859-1882. Pp. 455-458. 1882 (exact date of publication unknown).

254. Description of five new species of fishes from Mazatlan, Mexico. By David S. Jordan and Charles H. Gilbert. Pp. 458-463. 1882 (exact date of publication unknown).

255. Notes on a collection of fishes made by Captain Henry E. Nichols, U.S.N., in British Columbia and southern Alaska, with descriptions of new species and a new genus (Delolepis). By Tarleton H. Bean. Pp. 463-464, 1882 (exact date of publication unknown); pp. 465-474, Aug. 16, 1882.

256. On the rare rodent, Cricetodipus parvus (Baird) Coues. By Frederick W. True. Pp. 474-475. Aug. 16, 1882.

\section{Volume 5}

Proceedings of the United States National Museum, vol. 5. Pp. i-xi (title page, advertisement, table of contents, list of illustrations, and list of corrections); pp. 1-663 (Proceedings papers 257-342) ; pp. 665-703 (index); 52 figs., 12 pls. 1883.

257. Information concerning some fossil trees in the United States National Museum. P. T. Swaine and J. T. C. Hegewald. Pp. 1-3. June 14, 1882.

258. A study of the Phronimidae of the North Pacific Surveying Expedition. By Thos. H. Streets. Pp. 3-9, 1 pl. June 14, 1882.

259. Description of several new races of American birds. By Robert Ridgway. Pp. 9-15. June 14, 1882.

260. Synopsis of the West Indian Myadestes. By Leonhard Stejneger. Pp. 15-16, June 14, 1882; pp. 17-27, 1 pl., June 12, 1882.

261. On some generic and specific appellations of North American and European birds. By Leonhard Stejneger. Pp. 28-32, June 12, 1882; pp. 33-43, June 13, 1882.

262. On the genera Harporhynchus, Cabanis, and Methriopterus, Reichenbach, with a description of a new genus of Miminae. Pp. 43-46. June 13, 1882.

263. On a phosphatic sandstone from Hawthorne, in Florida. By George W. Hawes. Pp. 46-48. June 13, 1882. 
264. Notes on the native trees of the lower Wabash and White River Valleys, in Illinois and Indiana. By Robert Ridgway. Pp. 49-88. June 24, 1882.

265. Notes on fishes collected by Capt. Chas. Bendire, U. S. A., in Washington Territory and Oregon, May to October, 1881. By Tarleton H. Bean. Pp. 89-93. June 24, 1882.

266. New molluscan forms from the Laramie and Green River groups, with discussion of some associated forms heretofore known. By C. A. White. Pp. 94-96, June 24, 1882; pp. 97-99, 2 pls., July 3, 1882.

267. The molluscan fauna of the Truckee group, including a new form. By C. A. White. Pp. 99-102, 1 pl. July 3, 1882.

268. Description of four new species of sharks, from Mazatlan, Mexico. By David S. Jordan and Charles H. Gilbert. Pp. 102-110. July 3, 1882.

269. Description of a new shark (Carcharias lamiella) from San Diego, California. By David S. Jordan and Charles H. Gilbert. Pp. 110-111. July 3, 1882.

270. Critical remarks on the tree-creepers (Certhia) of Europe and North America. By Robert Ridgway. Pp. 111-112, July 3, 1882; pp. 113-116, July 21, 1882.

271. Note on the occurrence of a silver lamprey, Ichthyomyzon castaneus, Girard, in Louisiana. By Tarleton H. Bean. Pp. 117-119. July 21, 1882.

272. Notes on a collection of fishes from Johnston's Island, including descriptions of five new species. By Rosa Smith and Joseph Swain. Pp. 119-143. July 21, 1882.

273. Description of a new cyprinodont (Zygonectes inurus), from southern Illinois. By David S. Jordan and Charles H. Gilbert. Pp. 143-144. July 21, 1882.

274. Notes on birds collected during the summer of 1880 in Alaska and Siberia. By Tarleton H. Bean. Pp. 144-160, July 21, 1882; pp. 161-173, Aug. 5, 1882.

275. Outlines of a monograph of the Cygninae. By Leonhard Stejneger. Pp. 174. 221. Aug. 5, 1882.

276. Note on the habits and the rearing of the axolotl, Amblystoma mexicanum By M. Carbonnier. Pp. 221-222. Aug. 5, 1882.

277. Description of a new species of Uranidea (Uranidea pollicaris) from Lake Michigan. By David S. Jordan and Charles H. Gilbert. Pp. 222-223. Aug. 5, 1882.

278. Observations on four mules in milk. Alfred Dugès. Pp. 223-225. Aug. 5, 1882.

279. On Lagopus mutus, Leach, and its allies. By Lucien M. Turner. Pp. 225-233. Aug. 5, 1882.

280. Genera of the Scolopendrellidae. By J. A. Ryder. P. 234. Aug. 5, 1882.

281. A list of the species of fishes recorded as occurring in the Gulf of Mexico. By G. Brown Goode and Tarleton H. Bean. Pp. 234-240. Aug. 5, 1882.

282. Notes on fishes observed about Pensacola, Florida, and Galveston, Texas, with description of new species. By David S. Jordan and Charles H. Gilbert. Pp. 241-272, Aug. 16, 1882; pp. 273-307, Aug. 22, 1882.

283. A review of the Syngnathinae of the United States, with a description of one new species. By Joseph Swain. Pp. 307-315. Aug. 22, 1882.

284. Notice of recent additions to the marine invertebrata of the northeastern coast of America, with descriptions of new genera and species and critical remarks on others. Part IV.-Additions to the deep-water Mollusca, taken off Martha's Vineyard, in 1880 and 1881. By A. E. Verrill. Pp. 315-320, Aug. 22, 1881 ; pp. 321-336, Sept. 16, 1882; pp. 337-343, Sept. 11, 1882.

285. Descriptions of some new North American birds. By Robert Ridgway. Pp. 343346. Sept. 11, 1882.

286. Description of a new species of Uranidea (Uranidea rhothea) from Spokane River, Washington Territory. By Rosa Smith. Pp. 347-348. Sept. 11, 1882.

287. On the eastward distribution of the black-tailed deer (Cariacus columbianus). By Chas. Bendire. Pp. 348-349. Sept. 11, 1882.

288. Description of a new species of blenny (Isesthes gilberti) from Santa Barbara, California. By David S. Jordan. Pp. 349-351. Sept. 11, 1882.

289. Description of a new species of Conodon (Conodon serrifer), from Boca Soledad, Lower California. By David S. Jordan and Charles H. Gilbert. Pp. 351352. Sept. 11, 1882. 
290. Catalogue of the fishes collected by Mr. John Xantus at Cape San Lucas, which are now in the United States National Museum, with descriptions of eight new species. By David S. Jordan and Charles H. Gilbert. Pp. 353-371. Sept. 16, 1882.

291. List of fishes collected by John Xantus at Colima, Mexico. By David S. Jordan and Charles H. Gilbert. Pp. 371-372. Sept. 16, 1882.

292. List of fishes collected at Panama by Captain John M. Dow, now in the United States National Museum. By David S. Jordan and Charles H. Gilbert. Pp. 373-378. Sept. 16, 1882.

293. List of a collection of fishes made by Mr. L. Belding near Cape San Lucas, Lower California. By David S. Jordan and Charles H. Gilbert. Pp. 378-381. Sept. 16, 1882.

294. List of fishes collected at Panama, by Rev. Mr. Rowell, now preserved in the United States National Museum. By David S. Jordan and Charles H. Gilbert. Pp. 381-382. Sept. 16, 1882.

295. On a collection of birds from the Hacienda "La Palma," Gulf of Nicoya, Costa Rica. By C. C. Nutting. (With critical notes by R. Ridgway.) Pp. 382-409. Sept. $16,1882$.

296. Description of two new species of fishes (Sebastichthys umbrosus and Citharichihys stigmaeus) collected at Santa Barbara, California, by Andrea Larco. By David S. Jordan and Charles H. Gilbert. Pp. 410-412. Sept. 16, 1882.

297. Descriptions of twenty-five new species of fish from the southern United States, and three new genera, Letharcus, Ioglossus, and Chriodorus. By G. Brown Goode and Tarleton H. Bean. Pp. 412-416, Sept. 16, 1882; pp. 417-437, Nov. $11,1882$.

298. Description of a new species of goby (Gobiosoma ios) from Vancouver's Island. By David S. Jordan and Charles H. Gilbert. Pp. 437-438. Nov. 11, 1882.

299. Descriptions of new species of reptiles and amphibians in the United States National Museum. By H. C. Yarrow. Pp. 438-443. Nov. 11, 1882.

300. Contribution to the Miocene flora of Alaska. By L. Lesquereux. Pp. 443-448, Nov. 11, 1882; p. 449, 5 pls., Feb. 23, 1883.

301. Remarks on the systematic arrangement of the American Turdidae. By Leonhard Stejneger. Pp. 449-480, Feb. 23, 1883; pp. 481-483, 33 figs., Mar. 5, 1883.

302. On the family Centropomidae. By Theodore Gill. Pp. 484-485, 1 pl. Mar. $5,1883$.

303. Nomenclature of the xiphiids. By Theodore Gill. Pp. 485-486. Mar. 5, 1883.

304. On the family and subfamilies of Carangidae. By Theodore Gill. Pp. 487493. Mar. 5, 1883.

305. Catalogue of a collection of birds made in the interior of Costa Rica by Mr. C. C. Nutting. By Robert Ridgway. Pp. 493-502. Mar. 5, 1883.

306. Brief descriptions of fossil plants, chiefly Tertiary, from western North America. By J. S. Newberry. Pp. 502-512, Mar. 5, 1883; pp. 513-514, Apr. $3,1883$.

307. Note on the leptocardians. By Theodore Gill. Pp. 515-516. Apr. 3, 1883.

308. Note on the myzonts or marsipobranchiates. By Theodore Gill. Pp. 516-517. Apr. 3, 1883.

309. Note on the Bdellostomidae and Myxinidae. By Theodore Gill. Pp. 517-520. Apr. 3, 1883.

310. Note on the petromyzontids. By Theodore Gill. Pp. 521-525. Apr. 3, 1883.

311. Description of a new warbler from the Island of Santa Lucia, West Indies. By Robert Ridgway. Pp. 525-526. Apr. 3, 1883.

312. Description of a supposed new plover from Chili. By Robert Ridgway. Pp. 526-527. Apr. 3, 1883.

313. Catalogue of a collection of birds made at various points along the western coast of Lower California, north of Cape St. Eugenio. By L. Belding. [Edited by R. Ridgway.] Pp. 527-532. Apr. 3, 1883. 
Proc.

No.

314. Catalogue of a collection of birds made near the southern extremity of the peninsula of Lower California. By L. Belding. [Edited by R. Ridgway.] Pp. 532-550. Apr. 3, 1883.

315. On the genus Tantalus, Linn., and its allies. By Robert Ridgway. Pp. 550551. Apr. 3, 1883.

316. Supplementary note on the Pediculati. By Theodore Gill. Pp. 551-556. Apr. 3, 1883.

317. Note on the Pomatomidae. By Theodore Gill. P. 557. Apr. 3, 1883.

318. Note on the affinities of the ephippiids. By Theodore Gill. Pp. 557-560. Apr. 3, 1883.

319. On the relations of the family Lobotidae. By Theodore Gill. Pp. 560-561. Apr. 3, 1883.

320. Note on the relationships of the echeneidids. By Theodore Gill. Pp. 561-566, 1 pl. Apr. 3, 1883.

321. Note on the genus Sparus. By Theodore Gill. Pp. 566-567. Apr. 3, 1883.

322. On the proper name of the blue fish. By Theodore Gill. Pp. 567-570. Apr. 3, 1883.

323. Does the panther (Felis concolor) go into the water to kill fish? By Livingston Stone. P. 570. Apr. 3, 1883.

324. On certain neglected generic names of La Cépède. By David S. Jordan and Charles H. Gilbert. Pp. 570-576. Apr. 3, 1883.

325. On the synonymy of the genus Bothus Rafinesque. By David S. Jordan and Charles H. Gilbert. P. 576, Apr. 3, 1883; p. 577, Apr. 28, 1883.

326. Description of a new species of Artedius (Artedius fenestralis) from Puget Sound. By David S. Jordan and Charles H. Gilbert. Pp. 577-579. Apr. 28, 1883.

327. Description of a new species of Urolophus (Urolophus asterias), from Mazatlan and Panama. By David S. Jordan and Charles H. Gilbert. Pp. 579-580. Apr. 28, 1883.

328. Notes on a collection of fishes from Charleston, South Carolina, with descriptions of three new species. By David S. Jordan and Charles H. Gilbert. Pp. 580-592, Apr. 28, 1883; pp. 593-620, May 22, 1883.

329. List of fishes now in the museum of Yale College, collected by Prof. Frank H. Bradley, at Panama, with descriptions of three new species. By David S. Jordan and Charles H. Gilbert. Pp. 620-624, May 22, 1883; pp. 625-632, May 29, 1883.

330. Jumping seeds and galls. By Charles V. Riley. Pp. 632-635, 1 fig. May 29, 1883.

331. Note on cluster flies. By W. H. Dall. Pp. 635-637. May 29, 1883.

332. A review of the genus Noturus, with a description of one new species. By Joseph Swain and George B. Kalb. Pp. 638-644. May 29, 1883.

333. Catalogue of a collection of samples of raw cotton presented to the United States National Museum by the International Cotton Exposition, Atlanta, Georgia, 1881. By S. M. Inman. Pp. 644-645. May 29, 1883.

334. Description of two new species of fishes (Myrophis vafer and Chloroscombrus orqueta) from Panama. By David S. Jordan and Charles H. Gilbert. Pp. 645-647. May 29, 1883.

335. Description of a new eel (Sidera castanea) from Mazatlan, Mexico. By David S. Jordan and Charles H. Gilbert. Pp. 647-648. May 29, 1883.

336. On the nomenclature of the genus Ophichthys. By David S. Jordan and Charles H. Gilbert. Pp. 648-651. May 29, 1883.

337. On the life coloration of the young of Pomacentrus rubicundus. By Rosa Smith. Pp. 652-653. May 29, 1883.

338. On a cinnamon bear from Pennsylvania. By Frederick W. True. Pp. 653-656. May 29, 1383.

339. Description of a new petrel from Alaska. By Robert Ridgway. P. 656, May 29, 1883 ; pp. 657-658, June 30, 1883.

340. Description of a species of whitefish, Coregonus hoyi (Gill) Jordan, called "smelt" in some parts of New York. By Tarleton H. Bean. Pp. 658-660. June 30, 1883. 
Proc.

No.

341. Note on a Potsdam sandstone, or conglomerate, from Berks County, Pennsylvania. By George P. Merrill. Pp. 660-661. June 30, 1883.

342. Description of a new species of Alepidosaurus ( $A$. aesculapius) from Alaska. By Tarleton H. Bean. Pp. 661-663. June 30, 1883.

\section{Volume 6}

Proceedings of the United States National Museum, vol. 6. Pp. I-vii (title page, advertisement, table of contents, list of illustrations, and list of corrections): pp. 1-429 (Proceedings papers 343-396); pp. 431-497, (circulars 19-23); pp. 499-530 (index) ; pp. 532-558 (explanation of plates); 6 figs., 14 pls. 1884.

343. Preliminary report on the Brachyura and Anomura dredged in deep water off the south coast of New England by the United States Fish Commission in 1880, 1881, and 1882. By Sidney I. Smith. Pp. 1-57, 6 pls. June 30, 1883.

344. Contributions to the history of the Commander Islands. No. 1.-Notes on the natural history, including descriptions of new cetaceans. By Leonhard Stejneger. Pp. 58-80, June 30, 1883; pp. 81-89, Aug. 2, 1883.

345. Descriptions of some birds supposed to be undescribed, from the Commander Islands and Petropaulovski, collected by Dr. Leonhard Stejneger, U. S. Signal Service. By Robert Ridgway. Pp. 90-96. Aug. 2, 1883.

346. Description of a new genus and species of alcyonoid polyp, from Japanese waters, with remarks on the structure and habits of related forms, etc. By Robert E. C. Stearns. Pp. 96-101, 1 pl. Aug. 2, 1883.

347. Report on a fragment of cloth taken from a mound in Ohio. By J. G. Hunt. Pp. 101-102. Aug. 2, 1883.

348. Lucilia macellaria infesting man. By Fred. Humbert. Pp. 103-105. Aug. 2, 1883.

349. Fish mortality in the Gulf of Mexico. By S. T. Walker. Pp. 105-109. Aug. 2, 1883.

350. The generic names Amitra and Thyris replaced. By G. Brown Goode. P. 109. Aug. 2, 1883.

351. Shell beds in Westchester, N. Y. By Merritt Willis. P. 109. Aug. 2, 1883.

352. Notes on the nomenclature of certain North American fishes. By David S. Jordan and Charles H. Gilbert. Pp. 110-111. Aug. 2, 1883.

353. Notes on the natural history of Labrador. By W. A. Stearns. Pp. 111-112, Aug. 2, 1883 ; pp. 113-128, Aug. 8, 1883; pp. 129-137, Sept. 27, 1883.

354. On the black nodules or so-called inclusions in the Maine granites. By George P. Merrill. Pp. 137-141. Sept. 27, 1883.

355. Description of two new species of fishes (Aprion ariommus and Ophidium beani) from Pensacola, Florida. By David S. Jordan and Charles H. Gilbert. Pp. 142-144. Sept. 27, 1883.

356. On the probable identity of Motacilla ocularis Swinhoe and M. amurensis Seebohm, with remarks on an allied supposed species, $M$. blakistoni Seebohm. P. 144, Sept. 27, 1883; pp. 145-147, Oct. 11, 1883.

357. The first occurrence of Pseudotriacis microdon, Capello, on the coast of the United States. By Tarleton H. Bean. Pp. 147-150. Oct. 11, 1883.

358. On a pair of abnormal antlers of the Virginia deer. By Frederick W. True. P. 151, 1 fig. Oct. 11, 1883.

359. Description of a new species of reptiles in the United States National Museum. By H. C. Yarrow. Pp. 152-154. Oct. 11, 1883.

360. Descriptions of some new birds from Lower California, collected by Mr. L. Belding. By Robert Ridgway. Pp. 154-156. Oct. 11, 1883.

361. Anthus cervinus (Pallas) in Lower California. By Robert Ridgway. Pp. 156 157. Oct. 11, 1883.

362. Note on Merula confinis (Baird) By Robert Ridgway. Pp. 158-159. Oct. 11, 1883.

363. Preliminary note on the crystalline schists of the District of Columbia. By George P. Merrill. Pp. 159-160, Oct. 11, 1883; p. 161, Oct. 12, 1883. 
364. Catalogue of a collection of ethnological specimens obtained from the Ugashagmut tribe, Ugashak River, Bristol Bay, Alaska. By William J. Fisher. Pp. 161-165. Oct. 12, 1883.

365. On the collection of Maine building stones in the United States National Museum. By George P. Merrill. Pp. 165-176, Oct. 12, 1883; pp. 177-183, Oct. 11, 1883.

366. On the Macrocheilus of Phillips, Plectostylus of Conrad, and Soleniscus of Meek \& Worthen. By Charles A. White. Pp. 184-187, 1 pl. Oct. 11, 1883.

367. A review of the American Caranginae. By David S. Jordan and Charles $\mathbf{H}$. Gilbert. Pp. 188-192, Oct. 11, 1883; pp. 193-207, Oct. 12, 1883.

368. Note on the genera of Petromyzontidae. By David S. Jordan and Charles $\mathrm{H}$. Gilbert. P. 208. Oct. 12, 1883.

369. Description of a new muraenoid eel (Sidera chlevastes) from the Galapagos Islands. By David S. Jordan and Charles H. Gilbert. Pp. 208-210. Oct. 12, 1883.

370. Description of a new species of Rhinobatus (Rhinobatus glaucostigma) from Mazatlan, Mexico. By David S. Jordan and Charles H. Gilbert. Pp. 210211. Oct. 12, 1883.

371. List of duplicate marine invertebrates distributed by the United States National Museum. Series IV.-Educational Series No. 2. Prepared by R. S. Tarr. Pp. 212-216. Oct. 12, 1883.

372. The life colors of Cremnobates integripinnis. By Rosa Smith. Pp. 216-217. Oct. 12, 1883.

373. Note on the occurrence of Gasterosteus williamsoni Grd., in an artesian well at San Bernardino, Cal. By Rosa Smith. P. 217. Oct. 12, 1883.

374. List of the Crustacea dredged on the coast of Labrador by the expedition under the direction of W. A. Stearns, in 1882. By Sidney I. Smith. Pp. 218222. Oct. 12, 1883.

375. Review of the marine Crustacea of Labrador. By Sidney I. Smith. Pp. 223224, Oct. 12, 1883; pp. 225-232, Nov. 3, 1883.

376. Notes on the fishes of Todos Santos Bay, Lower California. By Rosa Smith. Pp. 232-236. Nov. 3, 1883.

377. Catalogue of Mollusca and Echinodermata dredged on the coast of Labrador by the expedition under the direction of Mr. W. A. Stearns, in 1882. By Katherine J. Bush. Pp. 236-240, Nov. 3, 1883; pp. 241-247, 1 pl., Dec. 5, 1883.

378. List of fishes collected in the Clear Fork of the Cumberland, Whitley County, Kentucky, with descriptions of three new species. By David S. Jordan and Joseph Swain. Pp. 248-251. Dec. 5, 1883.

379. A description of a new species of Hadropterus (Hadropierus scierus) from southern Indiana. By Joseph Swain. P. 252. Dec. 5, 1883.

380. Diagnosis of new genera and species of deep-sea fishlike vertebrates. By Theodore Gill. Pp. 253-260. Dec. 5, 1883.

381. Diagnoses of new genera of nemichthyoid eels. By Theodore Gill and John A. Ryder. Pp. 260-262. Dec. 5, 1883.

382. On the anatomy and relations of the Eurypharyngidae. By Theodore Gill and John A. Ryder. Pp. 262-272, Dec. 5, 1883; p. 273, Dec. 20, 1883.

383. Ornithological notes on collections made in Japan from June to December, 1882. By Pierre Louis Jouy. Pp. 273-288, Dec. 20, 1883 ; pp. 289-304, Dec. 26, 1883 ; pp. 305-318, Jan. 4, 1884.

384. On a collection of shells sent from Florida by Mr. Henry Hemphill. By W. H. Dall. Pp. 318-320, Jan. 4, 1884; pp. 321-342, 1 pl., Jan. 9, 1884.

385. List of birds found at Guaymas, Sonora, in December, 1882, and April, 1883. By L. Belding. Pp. 343-344. Jan. 9, 1884.

386. Second catalogue of a collection of birds made near the southern extremity of Lower California. By L. Belding. [Edited by R. Ridgway.] Pp. 344 352. Jan. 9, 1884. 
Notes on a collection of fishes made in 1882 and 1883 by Capt. Henry E. Nichols, U.S.N., in Alaska and British Columbia, with a description of a new genus and species, Prionistius macellus. By Tarleton H. Bean. Pp. 353-361. Jan. 18, 1884.

388. Notes on some fishes collected by James G. Swan in Washington Territory, including a new species of Macrurus. By Tarleton H. Bean. Pp. 362-364. Jan. 18, 1884.

389. Notes on fishes observed at the head of Chesapeake Bay in the spring of 1882; and upon other species of the same region. By Tarleton H. Bean. Pp. 365-367. Jan. 18, 1884.

390. Notes on some Japanese birds related to North American species. By Robert Ridgway. P. 368, Jan. 18, 1884; pp. 369-371, Apr. 23, 1884.

391. On a collection of birds from Nicaragua. By Charles C. Nutting. [Edited by R. Ridgway.] Pp. 372-384, Apr. 23, 1884; pp. 385-410, Apr. 26, 1884.

392. On some Costa Rican birds, with descriptions of several supposed new species. By Robert Ridgway. Pp. 410-415. Apr. 26, 1884.

393. On an antique Roman mosaic from Carthage, now in the United States National Museum. By G. H. Heap. Pp. 415-416, Apr. 26, 1884; p. 417, May 22, 1884.

394. On the skeleton of Phoca (Histriophoca) fasciata, Zimmerman. By Frederick W. True. Pp. 417-426, 1 fig., 4 pls. May 22, 1884.

395. On the source of the jadeite implements of the Alaskan Innuits. By E. W. Nelson. Pp. 426-427. May 22, 1884.

396. On the origin of the fossil bones discovered in the vicinity of Tise's Ford, Florida. By S. T. Walker. Pp. 427-429. May 22, 1884.

\section{Volume 7}

Proceedings of the United States National Museum, vol. 7. Pp. i-viii (title page, advertisement, table of contents, list of illustrations, and list of corrections); pp. 1-553 (Proceedings papers 397-469); pp. 555-624 (Appendix, circulars 23-31); pp. 625-661 (index); 15 figs., 2 pls. 1885.

397. List of, and notes upon, the lichens collected by Dr. T. H. Bean in Alaska and the adjacent region in 1880. By J. T. Rothrock. Pp. 1-9. July 8, 1884.

398. On the chlorophylloid granules of Vorticella. By John A. Ryder. Pp. 9-12, 1 fig. July 8, 1884.

399. A new geographical race of the mountain sheep (Ovis montana dalli var. nov.) from Alaska. By E. W. Nelson. Pp. 12-13. July 8, 1884.

400. Note on Selasphorus torridus Salvin. By Robert Ridgway. P. 14. July 8, 1884.

401. A review of the species of the genus Calamus. By David S. Jordan and Charles H. Gilbert. Pp. 14-24. July 8, 1884.

402. Descriptions of ten new species of fishes from Key West, Florida. By David S. Jordan and Charles H. Gilbert. Pp. 24-32. July 8, 1884.

403. Note on Caranx ruber and Caranx bartholomaei. By David S. Jordan and Charles H. Gilbert. Pp. 32-33. July 8, 1884.

404. Notes on a collection of fishes from Pensacola, Florida, obtained by Silas Stearns, with descriptions of two species (Exocoetus volador and Gnathypops mystacinus). By David S. Jordan. Pp. 33-40. July 8, 1884.

405. Note on Aelurichthys eydouxii and Porichthys porosissimus. By David S. Jordan. Pp. 40-41. July 8, 1884.

406. Notes on some Florida fishes. By G. Brown Goode and Tarleton H. Bean. Pp. 42-47. July 8, 1884.

407. Description of a new species of whitefish (Coregonus nelsonii), from Alaska. By Tarleton H. Bean. P. 48. July 8, 1884.

408. On the literature and systematic relations of the saccopharyngoid fishes. By Theodore Gill and John A. Ryder. Pp. 48-64, July 8, 1884; p. 65, July 25, 1884.

409. On domesticated hybrid ducks (Anas boschas + obscura). By Elisha Slade. P. 66. July 25, 1884. 
410. On prochlorite from the District of Columbia. By George P. Merrill. P. 67. July $25,1884$.

411. Melanetta fusca (Linn.) in Alaska. By Robert Ridgway. P. 68. July 25, 1884.

412. Description of a new snow bunting from Alaska. By Robert Ridgway. Pp. 68-70. July $25,1884$.

413. On the use of trinominals in American ornithology. By Leonhard Stejneger. Pp. 70-81. July 25, 1884.

414. Descriptions of scaroid fishes from Havana and Key West, including five nerv species. By David S. Jordan and Joseph Swain. Pp. 81-102. July 25, 1884.

415. Description of a new species of Sphaerium. By Temple Prime. Pp. 102-103. July 25, 1884.

416. List of fishes collected at Key West, Florida, with notes and descriptions. By David S. Jordan. Pp. 103-144, July 25, 1884; pp. 145-150, Sept. 1, 1884.

417. Note on Calamus proridens, a new species of Calamus. By David S. Jordan and Charles H. Gilbert. P. 150. Sept. 1, 1884.

418. A catalogue of fishes received from the Public Museum of the Institute of Jamaica, with descriptions of Pomadasys approximans and Tylosurus euryops, two new species. By Tarleton H. Bean and H. G. Dresel. Pp. 151-170. Sept. $1,1884$.

419. On a new muskrat, Neofiber alleni, from Florida. By Frederick W. True. Pp. 170-172. Sept. 1, 1884.

420. On a collection of birds made by Messrs. J. E. Benedict and W. Nye, of the United States Fish Commission steamer Albatross. By Robert Ridgway. Pp. 172-180. Sept. 1, 1884.

421. Contributions to the history of the Commander Islands. No. 2.-Investigations relating to the date of the extermination of Steller's sea-cow. By Leonhard Stejneger. Pp. 181-189. Sept. 1, 1884.

422. An identification of the figures of fishes in Catesby's Natural History of Carolina, Florida, and the Bahama Islands. By David S. Jordan. Pp. 190-199. Sept. 1, 1884.

423. A list of fishes collected in the east fork of White River, Indiana, with descriptions of two new species. By Charles H. Gilbert. Pp. 199-205. Sept. $1,1884$.

424. Notes on the fishes of Switz City Swamp, Greene County, Indiana. By Chas. H. Gilbert. Pp. 206-210. Sept. 1, 1884.

425. Remarks on the species of the genus Cepphus. By Leonhard Stejneger. Pp. 210224, Sept. 1, 1884; pp. 225-229, 6 figs., Sept. 12, 1884.

426. Notes on fishes collected by David S. Jordan at Cedar Keys, Florida. By David S. Jordan and Joseph Swain. Pp. 230-234. Sept. 12, 1884.

427. List of fishes observed in the Saint John's River at Jacksonville, Florida. By David S. Jordan and Seth E. Meek. Pp. 235-237. Sept. 12, 1884.

428. Notes on the pipe-fishes of Key West, Florida, with description of Siphostoma mckayi, a new species. By Joseph Swain and Seth E. Meek. Pp. 237-239. Sept. 12, 1884.

429. Descriptions of Physiculus fulvus and Lotella maxillaris, new species of fishes collected in 1881 by the United States Fish Commission. By Tarleton H. Bean. Pp. 240-242. Sept. 12, 1884.

430. On the occurrence of the striped bass in the lower Mississippi Valley. By Tarleton H. Bean. Pp. 242-244. Sept. 12, 1884.

431. Notes on some Greenland fishes. By H. G. Dresel. Pp. 244-256, Sept. 12, 1884; pp. 257-258, Sept. 19, 1884.

432. Description of a new species of field-sparrow from New Mexico. By Robert Ridgway. P. 259. Sept. 19, 1884.

433. Notes on fishes collected at Guaymas, Mexico, by Mr. H. F. Emeric, with a description of Gobiosoma histrio, a new species. By David S. Jordan. Pp. 260-261. Sept. 19, 1884.

434. A review of the American species of marine Mugilidae. By David S. Jordan and Joseph Swain. Pp. 261-275. Sept. 19, 1884. 
Synopsis of the genera of the superfamily Teuthidoidea (families Teuthididae and Siganidae). By Theodore Gill. Pp. 275-281. Sept. 19, 1884.

436. A review of the species of the genus Haemulon. By David S. Jordan and Joseph Swain. Pp. 281-304, Sept. 19, 1884; pp. 305-317, Sept. 27, 1884.

437. List of fishes collected in the vicinity of New Orleans by Dr. R. W. Shufeldt, U. S. A. By David S. Jordan. Pp. 318-320, Sept. 27, 1884; pp. 321-322, Sept. 29, 1884.

438. List of the fishes collected in Lake Jessup, and Indian River, Florida, by Mr. R. E. Earll, with descriptions of two new species. By David S. Jordan. Pp. 322-324. Sept. 29, 1884.

439. Concerning some of the forms assumed by the patella in birds. By R. W. Shufeldt. Pp. 324-331, 7 figs. Sept. 29, 1884.

440. Observations upon a collection of insects made in the vicinity of New Orleans, Louisiana, during the years 1882 and 1883. By R. W. Shufeldt. Pp. 331336, Sept. 29, 1884; pp. 337-338, 1 fig., Oct. 3, 1884.

441. Hermaphrodite fishes. [Translation from Der Naturforscher.] Pp. 339-340. Oct. 3, 1884.

442. Contributions to the history of the Commander Islands. No. 3.-Report on the Mollusca of the Commander Islands, Bering Sea, collected by Leonhard Stejneger in 1882 and 1883. By W. H. Dall. Pp. 340-349, 1 pl. Oct. 3, 1884.

443. Note on the Sternoptychidae. By Theodore Gill. Pp. 349-351. Oct. 3, 1884.

444. The osteological characteristics of the Lutjaninae. By Theodore Gill. Pp. 351-355. Oct. 3, 1884.

445. A contribution to the terminology of ichthyography. By Theodore Gill. Pp. 356-357. Oct. 3, 1884.

446. Description of a new species of coot from the West Indies. By Robert Ridgway. P. 358. Oct. 3, 1884.

447. A review of the American species of Epinephelus and related genera. By David S. Jordan and Joseph Swain. Pp. 358-384, Oct. 3, 1884; pp. 385-410, Oct. 9, 1884.

448. Synopsis of the plectognath fishes. By Theodore Gill. Pp. 411-416, Oct. 9, 1884 ; pp. 417-427, Oct. 18, 1884.

449. A review of the species of Lutjaninae and Hoplopagrinae found in American waters. By David S. Jordan and Joseph Swain. Pp. 427-432, Oct. 18, 1884; pp. 433-474, Oct. 23, 1884.

450. Description of four new species of Cyprinidae in the United States National Museum. By David S. Jordan and Seth E. Meek. Pp. 474-477. Oct. 23, 1884.

451. Description of four new species of Poecilichthys in the United States National Museum. By David S. Jordan. Pp. 477-480. Oct. 23, 1884.

452. Description of Sciaena sciera, a new species of Sciaena from Mazatlan and Panama. By David S. Jordan and Charles H. Gilbert. P. 480, Oct. 23, 1884; pp. 481-482, Feb. 25, 1885.

453. Description of $Z$ ygonectes zonifer, a new species of $Z$ ygonectes, from Nashville, Georgia. By David S. Jordan and Seth E. Meek. P. 482. Feb. 25, 1885.

454. Annotated list of the described species of parasitic Copepoda (Siphonostoma) from American waters contained in the United States National Museum. By Richard Rathbun. Pp. 483-492. Feb. 25, 1885.

455. On some new or little known decapod Crustacea, from recent Fish Commission dredgings off the east coast of the United States. By Sidney I. Smith. Pp. 493-511. Feb. 25, 1885.

456. Description of three new fishes from Kansas. By Charles H. Gilbert. Pp. 512 514. Feb. 25, 1885.

457. Description of a new race of the red-shouldered hawk from Florida. By Robert Ridgway. Pp. 514-515. Feb. 25, 1885.

458. On two hitherto unnamed sparrows from the coast of California. By Robert Ridgway. Pp. 516-518. Feb. 25, 1885.

459. Description of seven new species of Crustacea and one worm from Arctic Alaska. By John Murdoch. Pp. 518-522. Feb. 25, 1885. 
Proc.

No.

460. New or specially interesting shells of the Point Barrow Expedition. By W. H. Dall. Pp. 523-526. Feb. 25, 1885.

461. Description of a new species of Hybopsis (Hybopsis montanus). By Seth E. Meek. Pp. 526-527. Feb. 25, 1885.

462. Contributions to the history of the Commander Islands. No. 4. A. Notes upon the plants collected on the Commander Islands (Bering and Copper Islands) by Leonhard Stejneger. By Asa Gray. Pp. 527-528, Feb. 25, 1885; p. 529, Mar. 23, 1885.

463. [Contributions to the history of the Commander Islands. No. 4.] B. Additional notes on the plants of the Commander Islands. By Leonhard Stejneger. Pp. 529-538. Mar. 23, 1885.

464. Description of a new species of flounder, Citharichthys macrops, from Pensacola, Florida. By H. G. Dresel. Pp. 539-541. Mar. 23, 1885.

465. Description of three new species of fishes (Prionotus stearnsi, Prionotus ophryas, and Anthias vivanus) collected at Pensacola, Florida, by Mr. Silas Stearns. By David S. Jordan and Joseph Swain. Pp. 541-544, Mar. 23, 1885; p. 545, Mar. 28, 1885.

466. Supplementary notes on North American fishes. By David S. Jordan. Pp. 545-548. Mar. 28, 1885.

467. Description of a new species of Hybognathus (Hybognathus hayi) from Mississippi. By David S. Jordan. Pp. 548-550. Mar. 28, 1885.

468. On the occurrence of Loncheres armatus, (Geoff.) Wagner, in the Island of Martinique, West Indies. By Frederick W. True. Pp. 550-551. Mar. 28, 1885.

469. Notes on fishes collected at San Cristobal Bay, Lower California, by Mr. Charles H. Townsend. By Rosa Smith. Pp. 551-553. Mar. 28, 1885.

\section{Volume 8}

Proceedings of the United States National Museum, vol. 8. Pp. i-viii (title page, advertisement, table of contents, list of illustrations, and list of corrections); pp. 1-636 (Proceedings papers 470-548); pp. 637-686 (Appendix, circulars 32 and 33 ) ; pp. 687-729 (index); 15 figs., 25 pls. 1886.

470. List of fishes collected in Iowa and Missouri in August, 1884, with descriptions of three new species. By David S. Jordan and Seth E. Meek. Pp. 1-17. May 6, 1885.

471. On Oestrelata fisheri and Oe. defilippiana. By Robert Ridgway. Pp. 17-18 May 6, 1885.

472. Icterus cucullatus, Swainson, and its geographical variations. By Robert Ridgway. Pp. 18-19. May 6, 1885.

473. Passer saturatus, a new species of tree-sparrow from the Liu-Kiu Islands, Japan. By Leonhard Stejneger. Pp. 19-20. May 6, 1885.

474. Description of a new species of Contopus from tropical America. By Robert Ridgway. P. 21. May 6, 1885.

475. Note on the Anser leucopareius of Brandt. By Robert Ridgway. Pp. 21-22. May 6, 1885.

476. Description of a new warbler from Yucatan. By Robert Ridgway. P. 23. May 26, 1885.

477. Description of two new birds from Costa Rica. By Robert Ridgway. Pp. 23-24. May 6, 1885.

478. Description of three supposed new honey creepers from the Lesser Antilles, with a synopsis of the species of the genus Certhiola. By Robert Ridgway. Pp. 25-30. May 6, 1885.

479. On hornblende andesites from the new volcano on Bogosloff Island in Bering Sea. By George P. Merrill. Pp. 31-33. May 6, 1885.

480. On Cathartes burrovianus, Cassin, and C. urubitinga, Pelzeln. By Robert Ridgeway. Pp. 34-36. May 6, 1885.

481. On Onychotes gruberi. By Robert Ridgway. Pp. 36-38. May 6, 1885.

482. Notes and descriptions taken from selachians in the U. S. National Museum. By S. Garman. Pp. 39-44. May 6, 1885. 
483. A review of the American species of flying fishes (Exocoetus). By David S. Jordan and Seth E. Meek. Pp. 44-67. May 6, 1885.

484. Notes on skeletons of Etheostomatinae. By David S. Jordan and Carl H. Eigenmann. Pp. 68-72. May 6, 1885.

485. Note on the scientific name of the yellow perch, the striped bass, and other North American fishes. By David S. Jordan. Pp. 72-73. May 6, 1885.

486. Description of a new species of Plectromus (P. crassiceps) taken by the United States Fish Commission. By Tarleton H. Bean. Pp. 73-74. May 6, 1885.

487. Description of a new species of Aspidophoroides (A. gïntherii), from Alaska. By Tarleton H. Bean. Pp. 74-75. May 6, 1885.

488. Remarks on the type specimen of Buteo oxypterus, Cassin. By Robert Ridgway. Pp. 75-77. May 6, 1885.

489. Early iron manufacture in Virginia-1619-1776. By R. Brock. Pp. 77-80. May 6, 1885.

490. Note on Mr. Garman's paper on "The American Salmon and Trout." By David S. Jordan. Pp. 81-83. June 19, 1885.

491. Report upon the Echini collected by the United States Fish Commission steamer Albatross, in the Caribbean Sea and Gulf of Mexico, January to May, 1884. By Richard Rathbun. Pp. 83-89. June 19, 1885.

492. An account of recent captures of the California sea-elephant, and statistics relating to the present abundance of the species. By Charles H. Townsend. Pp. 90-93. June 19, 1885.

493. Description of a new species of boat-billed heron from Central America. By Robert Ridgway. Pp. 93-94. June 19, 1885.

494. Description of a new hawk from Cozumel. By Robert Ridgway. Pp. 94-95. June 19, 1885.

495. On a new species of porpoise, Phocaena dalli, from Alaska. By Frederick W. True. Pp. 95-98, 4 pls. June 19, 1885.

496. On Peucaea mexicana (Lawr.) a sparrow new to the United States. By Robert Ridgway. Pp. 98-99. June 19, 1885.

497. On deposits of volcanic dust and sand in southwestern Nebraska. By George P. Merrill. Pp. 99-100, 1 fig. June 19, 1885.

498. On the influence of atropia on the heart. By H. G. Beyer. Pp. 101-103, 1 pl. June 19, 1885.

499. Catalogue of the birds of Costa Rica, indicating those species of which the United States National Museum possesses specimens from that country. By José C. Zeledon. Pp. 104-118. June 19, 1885.

500. Identification of the species of Cyprinidae and Catostomidae, described by Dr. Charles Girard, in the Proceedings of the Academy of Natural Sciences of Philadelphia for 1856. By David S. Jordan. Pp. 118-127. June 19, 1885.

501. On the development of viviparous osseous fishes. By John A. Ryder. Pp. 128155,6 pls. June 19, 1885 .

502. On certain features of the development of the salmon. By John A. Ryder. Pp. 156-162, 1 pl. June 19, 1885.

503. On the Etheostoma variatum of Kirtland. By David S. Jordan. Pp. 163-165. June 19, 1885.

504. On the occurrence of Hadropterus aurantiacus (Cope), in the French Broad River, North Carolina. By Tarleton H. Bean. Pp. 165-166. June 19, 1885.

505. On the identity of Cottus manulatus, Fischer, with Cottus bubalis, Euphrasen. By Tarleton H. Bean. Pp. 166-167. June 19, 1885.

506. Description of a new crustacean allied to Homarus and Nephrops. By Sidney I. Smith. Pp. 167-170. June 19, 1885.

507. On some genera and species of Penaeidae, mostly from recent dredgings of the United States Fish Commission. By Sidney I. Smith. Pp. 170-176, June 19, 1885; pp. 177-190, June 29, 1885.

508. On Stathmonotus, a new genus of fishes related to Muraenoides, from Florida. By Tarleton H. Bean. Pp. 191-192, 1 pl. June 29, 1885.

509. Note on Stoasodon narinari, Euphrasen. By Tarleton H. Bean. Pp. 192-193. June 29, 1885. 
Proc.

No.

510. On the American fishes in the Linnaean collection. By G. Brown Goode and Tarleton H. Bean. Pp. 193-208. June 29, 1885.

511. Note on Epinephelus nigritus. By David S. Jordan. P. 208, June 29, 1885; p. 209, July 24, 1885.

512. Description of a new species of Amblystoma (Amblystoma copeianum) from Indiana. By O. P. Hay. Pp. 209-213, 1 pl. July 24, 1885.

513. List of plants collected by Mr. Charles L. McKay at Nushagak, Alaska, in 1881, for the United States National Museum. By Frank H. Knowlton. Pp. 213-221. July 24, 1885.

514. The generic name of the pastinacas, or "sting-rays." By S. Garman. Pp. 221224. July 24, 1885 .

515. The influence of variations of temperature upon the rate and the work of the heart of the slider terrapin. (Pseudemys rugosa.) By H. G. Beyer. Pp. 225-229, 2 pls. July 24, 1885.

516. Description of a new species of Pempheris (Pempheris poeyi) from Cuba. By Tarleton H. Bean. Pp. 229-230. July 24, 1885.

517. Notes on Epinephelus nigritus, Caulolatilus microps, and Coryphaena hippurus. By Tarleton H. Bean. Pp. 230-233. July 24, 1885.

518. List of the birds of Labrador, including Ungava, East Main, Moose, and Gulf districts of the Hudson Bay Company, together with the Island of Anticosti. By Lucien M. Turner. Pp. 233-254. July 24, 1885.

519. Notes on some Floridian land and fresh-water shells with a revision of the Auriculacea of the eastern United States. By W. H. Dall. Pp. 255-288, 2 pls., July 24, 1885; p. 289, Aug. 27, 1885.

520. A list of the Mesozoic and Cenozoic types in the collections of the U.S. National Museum. By John Belknap Marcou. Pp. 290-336, Aug. 27, 1885; pp. 337-344, Sept. 17, 1885.

521. On Turbinella pyrum, Lamarck, and its dentition. By W. H. Dall. Pp. 345348,1 pl. Sept. 17, 1885.

522. A review of the American "golden warblers." By Robert Ridgway. Pp. 348350. Sept. 17, 1885.

523. Notes on the mineralogy and lithology of the District of Columbia. By George P. Merrill. Pp. 351-353. Sept. 17, 1885.

524. Some emended names of North American birds. By Robert Ridgway. Pp. 354356. Sept. 17, 1885

525. A list of the Astacidae in the United States National Museum. By Walter Faxon. Pp. 356-361. Sept. 17, 1885.

526. A list of the fishes known from the Pacific coast of tropical America, from the Tropic of Cancer to Panama. By David S. Jordan. Pp. 361-384, Sept. 17, 1885; pp. 385-394, Oct. 3, 1885.

527. Note on some Linnaean names of American fishes. By David S. Jordan. Pp. 394-396. Oct. 3, 1885.

528. On a collection of Medusae made by the United States Fish Commission steamer Albatross in the Caribbean Sea and Gulf of Mexico. By J. Walter Fewkes. Pp. 397-402, 1 pl. Oct. 3, 1885.

529. Description of Hesperomys truci, a new species belonging to the subfamily Murinae. By R. W. Shufeldt. Pp. 403-408, 1 pl. Oct. 3, 1885.

530. Notes on some apparently preoccupied ornithological generic names. By Leonhard Stejneger. Pp. 409-410. Oct. 3, 1885.

531. The Chaclacayo trephined skull. By Otis T. Mason. Pp. 410-412, 1 pl. Oct. 3, 1885.

532. On the parasites of the Hessian fly. By C. V. Riley. Pp. 413-422, 1 pl. Oct. 3, 1885.

533. Description of Leptophidium cervinum and L. marmoratum, new fishes from deep water off the Atlantic and Gulf coasts. By G. Brown Goode and Tarleton H. Bean. Pp. 422-424. Oct. 3, 1885.

534. Notice of recent additions to the marine Invertebrata of the northeastern coast of America, with descriptions of new genera and species and critical 
remarks on others. Part V.-Annelida, Echinodermata, Hydroida, Tunicata. By A. E. Verrill. Pp. 424-448. Oct. 3, 1885.

535. Report on the flora of western and southern Texas. By V. Havard. Pp. 449496, Oct. 3, 1885; pp. 497-533, 1 fig. Oct. 10, 1885.

536. Notes on the mollusks of the vicinity of San Diego, Cal., and Todos Santos Bay, Lower California. By Charles R. Orcutt, with comments by W. H. Dall. Pp. 534-544, Oct. 10, 1885; pp. 545-552, Oct. 26, 1885.

537. Notes on a collection of fishes from Florida, with descriptions of new or little known species. By O. P. Hay. Pp. 552-559. Oct. 26, 1885.

538. Description of an apparently new species of Dromococcyx from British Guiana. By Robert Ridgway. P. 559. Oct. 26, 1885.

539. Catalogue of a collection of birds made on the Island of Cozumel, Yucatan, by the naturalists of the U. S. Fish Commission steamer Albatross, Capt. Z. L. Tanner, Commander. By Robert Ridgway. Pp. 560-576, Oct. 26, 1885; pp. 577-583, Nov. 21, 1885.

540. Contributions to the history of the Commander Islands. No. 5.-Description of a new species of Mesoplodon, $M$. stejnegeri, obtained by Dr. Leonhard Stejneger, in Bering Island. By Frederick W. True. Pp. 584-585, 1 pl. Nov. 21, 1885.

541. A note upon the Hyperoodon semijunctus of Cope. By Frederick W. True. Pp. 585-586. Nov. 21, 1885.

542. Fresh-water sponges from Mexico. By Edward Potts. Pp. 587-589, 1 fig. Nov. 21, 1885.

543. Descriptions of new fishes obtained by the United States Fish Commission mainly from deep water off the Atlantic and Gulf coasts. By G. Brown Goode and Tarleton H. Bean. Pp. 589-605. Nov. 21, 1885.

544. Report upon the Echini collected by the U. S. Fish Commission steamer Albatross in the Gulf of Mexico from January to March, 1885. By Richard Rathbun. Pp. 606-608, Nov. 21, 1885; pp. 609-620, Dec. 28, 1885.

545. List of a few species of birds new to the fauna of Guadeloupe, West Indies, with a description of a new species of Ceryle. By George N. Lawrence. Pp. 621-624, Dec. 28, 1885; p. 625, Jan. 20, 1886.

546. Remarks upon the plumage of Regulus calendula. By Charles Wickliffe Beckham. Pp. 625-628. Jan. 20, 1886.

547. Notice of a collection of stalked crinoids made by the steamer Albatross in the Gulf of Mexico and Caribbean Sea, 1884 and 1885. By Richard Rathbun. Pp. 628-635. Jan. 20, 1886.

548. Notes on the great dolphin, Coryphaena hippurus, Linné. By Silas Stearns. Pp. 635-636. Jan. 20, 1886.

\section{Volume 9}

Proceedings of the United States National Museum, vol. 9: Pp. i-viii (title page, advertisement, table of contents, list of illustrations, dates of publication of signatures, and list of corrections); pp. 1-660 (Proceedings papers 549-598); pp. 661-714 (index); 6 figs., 25 pls. 1887.

549. List of fishes collected in Arkansas, Indian Territory, and Texas, in September, 1884, with notes and descriptions. By David S. Jordan and Charles H. Gilbert. Pp. 1-25. Sept. 17, 1886.

550. Notes on fishes collected at Beaufort, North Carolina, with a revised list of the species known from that locality. By David S. Jordan. Pp. 25-30. Sept. $17,1886$.

551. List of fishes collected at Havana, Cuba, in December, 1883, with notes and descriptions. By David S. Jordan. Pp. 31-55. Sept. 17, 1886.

552. A review of the genera and species of Julidinae found in American waters. By David S. Jordan and Elizabeth G. Hughes. Pp. 56-70. Sept. 17, 1886.

553. On the value of the fin-rays and their characteristics of development in the classification of the fishes, together with remarks on the theory of degeneration. By John A. Ryder. Pp. 71-82, 1 fig. Sept. 17, 1886. 
Proc.

No.

554. On fulgurites. By George P. Merrill. Pp. 83-91, 1 pl. Sept. 17, 1886.

555. Descriptions of some new species of birds, supposed to be from the interior of Venezuela. By Robert Ridgway. Pp. 92-94. Sept. 17, 1886.

556. On Aestrelata sandwichensis Ridgw. By Robert Ridgway. Pp. 95-96. Sept. 17, 1886.

557. Description of a new genus and species of mole, Dymecodon pilirostris, from Japan. By Frederick W. True. Pp. 97-98. Sept. 25, 1886.

558. Review of Japanese birds. By Leonhard Stejneger. I.-The woodpeckers. Pp. 99-124, 1 pl. Sept. 25, 1886.

559. Catalogue of animals collected by the Geographical and Exploring Commission of the Republic of Mexico. By Fernando Ferrari-Perez. Pp. 125-160, Sept. 25, 1886; pp. 161-192, Oct. 2, 1886; pp. 193-199, Oct. 22, 1886.

560. The British marsh-tit. By Leonhard Stejneger. Pp. 200-201. Oct. 22, 1886.

561. Report on the mollusks collected by L. M. Turner at Ungava Bay, North Labrador, and from the adjacent Arctic seas. By W. H. Dall. Pp. 202-208, 1 pl. Oct. 22, 1886.

562. Contributions to the natural history of the Commander Islands. No. 6.-Report on Bering Island Mollusca collected by Mr. Nicholas Grebnitzki. By W. H. Dall. Pp. 209-219. Oct. 22, 1886.

563. On the occurrence of a new species of Rhinoptera ( $R$. encenadae) in Todos Santos Bay, Lower California. By Rosa Smith. P. 220. Oct. 22, 1886.

564. An annotated list of the mammals collected by the late Mr. Charles L. McKay in the vicinity of Bristol Bay, Alaska. By Frederick W. True. Pp. 221224. Oct. 22, 1886.

565. Notes on some fishes collected at Pensacola by Mr. Silas Stearns, with descriptions of one new species (Chaetodon aya). By David S. Jordan. Pp. 225-229. Oct. 22, 1886.

566. A review of the American species of Tetraodontidae. By David S. Jordan and Charles L. Edwards. Pp. 230-247. Oct. 22, 1886.

567. Description of a melanistic specimen of Buteo latissimus (Wils.) By Robert Ridgway. Pp. 248-249. Oct. 22, 1886.

568. Supplement to the list of Mesozoic and Cenozoic invertebrate types in the collections of the National Museum. By John Belknap Marcou. Pp. 250254. Oct. 22, 1886.

569. Catalogue of the collection of recent Echini in the United States National Museum (corrected to July 1, 1886). By Richard Rathbun. Pp. 255-288, Oct. 22, 1886; pp. 289-293, Feb. 10, 1887.

570. Notes on species of the Australian genus Pardalotus. By Leonhard Stejneger. Pp. 294-296. Feb. 10, 1887.

571. Supplementary notes on some species of mollusks of the Bering Sea and vicinity. By W. H. Dall. Pp. 297-309, 1 pl. Feb. 10, 1887.

572. Descriptions of parasitic Copepoda belonging to the genera Pandarus and Chondracanthus (with seven plates). By Richard Rathbun. Pp. 310-324, 1 fig., 7 pls. Feb. 10, 1887.

573. Description of a recently new oyster-catcher (Haematopus galapagensis) from the Galapagos Islands. By Robert Ridgway. Pp. 325-326. Feb. 10, 1887.

574. A review of the species of the genus Prionotus. By David S. Jordan and Elizabeth G. Hughes. Pp. 327-338. Feb. 10, 1887.

575. A review of the American species of Belonidae. By David S. Jordan and Morton W. Fordice. Pp. 339-361. Feb. 10, 1887.

576. Description of Rallus jouyi, with remarks on Rallus striatus and Rallus gularis. By Leonhard Stejneger. Pp. 362-364. Feb. 10, 1887.

577. On Turdus alpestris and Turdus torquatus, two distinct species of European thrushes. By Leonhard Stejneger. Pp. 365-373. Feb. 10, 1887.

578. Review of Japanese birds. II.-Tits and nuthatches. By Leonhard Stejneger. Pp. 374-394, 1 fig. Feb. 10, 1887.

579. Review of Japanese birds. III.-Rails, gallinules, and coots. By Leonhard Stejneger. Pp. 395-408. Feb. 10, 1887. 
580. A new study of the genus Dipodomys. By Frederick W. True. Pp. 409-413. Feb. 10, 1887.

581. A revision of the lepidopterous family Saturniidae. By John B. Smith. Pp. 414-416, Feb. 10, 1887; pp. 417-437, 3 pls., Feb. 14, 1887.

582. Analyses of the cinchona barks on exhibition in the materia medica section, U. S. National Museum. By George E. Doering. Pp. 438-442. Feb. 14, 1887.

583. Norsk naval architecture. By George H. Boehmer. Pp. 443-459, 1 fig., 5 pls. Feb. 4, 1887.

584. A new land shell from California, with note on Selenites duranti, Newcomb. By William G. Mazyck. Pp. 460-461, 2 figs. Feb. 14, 1887.

585. Notes on a collection of fishes from the Escambia River, with description of a new species of Zygonectes (Zygonectes escambiae). By Charles H. Bollman. Pp. 462-465. Feb. 14, 1887.

586. Description of six new species of fishes from the Gulf of Mexico, with notes on other species. By David S. Jordan and Barton W. Evermann. Pp. 466-476. Feb. 14, 1887.

587. A review of the Gobiidae of North America. By David S. Jordan and Carl H. Eigenmann. Pp. 477-518. Feb. 14, 1887.

588. Description of a new subspecies of Cyclorhis from Yucatan. By Robert Ridgway. P. 519. Feb. 14, 1887.

589. Description of a new species of Myiarchus, presumably from the Orinoco district of South America. By Robert Ridgway. P. 520. Feb. 14, 1887.

590. On a probable hybrid between Dryobates nuttallii (Gamb.) and D. pubescens gairdnerii (Aud.): By Robert Ridgway. Pp. 521-522. Feb. 14, 1887.

591. Description of an apparently new species of Picolaptes, from the lower Amazon. By Robert Ridgway. P. 523. Feb. 14, 1887.

592. On the status of Synthliboramphus wumizusume as a North American bird. By Leonhard Stejneger. P. 524. Feb. 14, 1887.

593. Notes on typical specimens of fishes described by Cuvier and Valenciennes and preserved in the Musée d'Histoire Naturelle in Paris. By David Starr Jordan. Pp. 525-528, Feb. 14, 1887; pp. 529-546, Feb. 24, 187.

594. Descriptions of ten species and one new genus of annelids from the dredgings of the U. S. Fish Commission steamer Albatross. By James E. Benedict. Pp. 547-553, 6 pls. Feb. 24, 1887.

595. A preliminary list of the fishes of the West Indies. By David Starr Jordan. Pp. 554-608. Feb. 24, 1887.

596. A catalogue of the birds of Grenada, West Indies, with observations thereon. By John Grant Wells. [Edited by George N. Lawrence.] Pp. 609-624, Feb. 24, 1887; pp. 625-633, Mar. 9, 1887.

597. On a collection of birds made by Mr. M. Namiye, in the Liu Kiu Islands, Japan, with descriptions of new species. By Leonhard Stejneger. Pp. 634651. Mar. 9, 1887.

598. Water-birds of Japan. By T. W. Blakiston. Pp. 652-656, Mar. 9, 1887; pp. $657-660,1887$ (exact date of publication unknown).

\section{Volume 10}

Proceedings of the United States National Museum, vol. 10. Pp. i-viii (title page, advertisement, table of contents, list of illustrations, dates of publication of signatures, and list of corrections); pp. 1-698 (Proceedings papers 599-675; pp. 699-731 (Appendix [circular 37]); pp. 733-771 (index); 11 figs., 39 pls. 1888.

599. Description of a new species of Cotinga from the Pacific coast of Costa Rica. By Robert Ridgway. Pp. 1-2. Apr. 25, 1887.

600. Description of a new form of Spindalis from the Bahamas. By Robert Ridgway. P. 3. Apr. 25, 1887.

601. Review of Japanese birds. IV. Synopsis of the genus Turdus. By Leonhard Stejneger. Pp. 4-5. Apr. 25, 1887.

602. Description of a new species of bat, Vespertilio longicrus, from Puget Sound. By Frederick W. True. Pp. 6-7. Apr. 25, 1887. 
603. Some distinctive cranial characters of the Canada lynx. By Frederick W. True. Pp. 8-9. Apr. 25, 1887.

604. Catalogue of the species of corals belonging to the genus Madrepora, contained in the United States National Museum. By Richard Rathbun. Pp. 10-19. Apr. 25, 1887.

605. Description of the adult female of Carpodectes antoniae Zeledon, with critical remarks, notes on habits, etc., by José C. Zeledón. By Robert Ridgway. P. 20. Apr. 25, 1887.

606. List of recently identified fossil plants belonging to the United States National Museum, with descriptions of several new species. By Leo Lesquereux. Pp. 21-32, Apr. 25, 1887; pp. 33-46, 4 pls., May 17, 1887.

607. Descriptions of new and little known etheostomoids. By Chas. H. Gilbert. Pp. 47-64. May 17, 1887.

608. A review of the North American species of the genera Lagodon, Archosargus, and Diplodus. By Carl H. Eigenmann and Elizabeth G. Hughes. Pp. 6574. May 17, 1887.

609. Birds of Kauai Island, Hawaiian Archipelago, collected by Mr. Valdemar Knudsen, with descriptions of new species. By Leonhard Stejneger. Pp. 75-96, May 17, 1887; pp. 97-102, 1 pl., July 2, 1887.

610. Notes on the northern Palaearctic bullfinches. By Leonhard Stejneger. Pp. 103-110. July 2, 1887.

611. Description of a new species of Porzana from Costa Rica. By Robert Ridgway. P. 111. July 2, 1887.

612. Notes on Ardea querdemanni Baird. By Robert Ridgway. Pp. 112-115. July 2, 1887.

613. Description of a new species of Ophichthys (Ophichthys retropinnis), from Pensacola, Fla. By Carl H. Eigenmann. P. 116. July 2, 1887.

614. Contributions to the natural history of the Commander Islands. No. 7.Revised and annotated catalogue of the birds inhabiting the Commander Islands. By Leonhard Stejneger. Pp. 117-145, 3 pls. July 2, 1887.

615. On a new species of Tropidonotus found in Washington. By E. D. Cope. P. 146. July $2,1887$.

616. Trogon ambiguus breeding in Arizona. By Robert Ridgway. P. 147. July 2, 1887.

617. Description of a new plumed partridge from Sonora. By Robert Ridgway. Pp. 148-150. July 2, 1887.

618. Description of a new genus of dendrocolaptine bird from the lower Amazon. By Robert Ridgway. P. 151. July 2, 1887.

619. Description of a new species of Phacellodomus from Venezuela. By Robert Ridgway. P. 152. July 2, 1887.

620. Contributions to the natural history of the Commander Islands. No. 8.Description of Alopecurus stejnegeri, a new species of grass from the Commander Islands. By Geo. Vasey. P. 153. July 2, 1887.

621. Contributions to the natural history of the Commander Islands. No. 9.-On the Entomostraca collected by Mr. Leonhard Stejneger, on Bering Island, 1882-'83. By W. Lilljeborg. Pp. 154-156. July 2, 1887.

622. Notes on the osteology of the spotted tinamou (Nothura maculosa). By Frederic A. Lucas. Pp. 157-158, 2 figs. July 2, 1887.

623. Field-notes on the mammals, birds and reptiles of northern California. By Charles H. Townsend. Pp. 159-241, 4 figs., 1 pl. July 2, 1887.

624. A contribution to the knowledge of the fishes of Kansas. By O. P. Hay. Pp. 242-253. July 2, 1887.

625. Notes on the North American Lithobiidae and Scutigeridae. By Charles $\mathrm{H}$. Bollman. Pp. 254-256, July 2, 1887; pp. 257-266, Aug. 1, 1887.

626. Description of two new species of Kaup's genus Megascops. By Robert Ridgway. Pp. 267-268. Aug. 1, 1887.

627. Notes on a collection of fishes sent by Mr. Charles C. Leslie from Charleston, South Carolina. By David S. Jordan and Carl H. Eigenmann. Pp. 269-270. Aug. 1, 1887. 
628. Review of Japanese birds. V.-Ibises, storks, and herons. By Leonhard Stejneger. Pp. 271-272, Aug. 1, 1887; pp. 273-319, 1 pl., Aug. 3, 1887.

629. On the systematic name of the Kamtschatkan and Japanese carrion crow. By Leonhard Stejneger. P. 320, Aug. 3, 1887; p. 321, Sept. 16, 1887.

630. Note on Polynemus californiensis of Thominot. By David S. Jordan. P. 322. Sept. 16, 1887.

631. List of the myriapods found in Escambia County, Florida, with descriptions of six new species. By Jerome McNeill. Pp. 323-327, 1 pl. Sept. 16, 1887.

632. Descriptions of twelve new species of Myriapoda, chiefly from Indiana. By Jerome McNeill. Pp. 328-334, 1 pl. Sept. 16, 1887.

633. The species of Euerythra Harv. By John B. Smith. Pp. 335-337, 1 pl. Sept. 16, 1887.

634. The North American species of Callimorpha Latr. By John B. Smith. Pp. 338-352, Sept. 16, 1887; p. 353, 1 pl., Sept. 29, 1887.

635. Annotated catalogue of the species of Porites and Synaraea in the United States National Museum, with a description of a new species of Porites. By Richard Rathbun. Pp. 354-366, 5 pls. Sept. 29, 1887.

636. Notes on a trematode from the white of a newly-laid hen's egg. By Edwin Linton. Pp. 367-369, 1 fig. Sept. 29, 1887.

637. Descriptions of five new species of fishes sent by Prof. A. Dugès from the Province of Guanajuato, Mexico. By Tarleton H. Bean. Pp. 370-375, 1 pl. Sept. 29, 1887.

638. On a collection of birds' sterna and skulls, collected by Dr. Thomas H. Streets, U. S. Navy. By R. W. Shufeldt. Pp. 376-384, Sept. 29, 1887; pp. 385-387, 4 figs., Nov. 3, 1887.

639. Description of a new species of Thalassophryne (Thalassophryne dowi) from Punta Arenas and Panama. By David S. Jordan and Charles H. Gilbert. P. 388. Nov. 3, 1887.

640. Notes on Psittirostra psittacea from Kauai, Hawaiian Islands. By Leonhard Stejneger. Pp. 389-390. Nov. 3, 1887.

641. Further contributions to the avifauna of the Liu Kiu Islands, Japan, with descriptions of new species. By Leonhard Stejneger. Pp. 391-415, 1 pl. Nov. 3, 1887.

642. Review of Japanese birds. VI.-The pigeons. By Leonhard Stejneger. Pp. 416-429, 1 pl. Nov. 3, 1887.

643. Description of a new Muscisaxicola, from Lake Titicaca, Peru. By Robert Ridgway. P. 430. Nov. 3, 1887.

644. On Phrygilus gayi (Eyd. \& Gerv.) and allied species. By Robert Ridgway. Pp. 431-435. Nov. 3, 1887.

645. List of the Batrachia and Reptilia of the Bahama Islands. By E. D. Cope. Pp. 436-439. Nov. 3, 1887.

646. Descriptions of the species of Heliaster (a genus of star-fishes) represented in the U. S. National Museum. By Richard Rathbun. Pp. 440-448, Nov. 3, 1887 ; p. 449,4 pls., Jan. 6, 1888.

647. New genera and species of North American Noctuidae. By John B. Smith. Pp. 450-479. Jan. 6, 1888.

648. Note on the "Analyse de la Nature" of Rafinesque. By David S. Jordan. Pp. 480-481. Jan. 6, 1888.

649. On a collection of birds made by Mr. M. Namiye, in the Islands of Idzu, Japan. By Leonhard Stejneger. Pp. 482-487. Jan. 6, 1888.

650. A review of the genus Dendrocincla Gray. By Robert Ridgway. Pp. 488-496, Jan. 6, 1888; p. 497, Aug. 6, 1888.

651. Descriptions of two new species of the genus Unio, from the Ozark region of Missouri. By R. Ellsworth Call. Pp. 498-500, 2 pls. Aug. 6, 1888.

652. Description of a new species of Callionymus (Callionymus bairdi) from the Gulf of Mexico. By David Starr Jordan. Pp. 501-502. Aug. 6, 1888.

653. Description of a new species of bird of the genus Catharus, from Ecuador. By Geo. N. Lawrence. P. 503. Aug. 6, 1888. 
Proc.

No.

654. Remarks on Catharus berlepschi Lawr. By Robert Ridgway. P. 504. Aug. 6, 1888.

655. Descriptions of some new species and subspecies of birds from Middle America. By Robert Ridgway. Pp. 505-510. Aug. 6, 1888.

656. Note on the generic name Uropsila, Scl. \& Salv. By Robert Ridgway. P. 511. Aug. 6, 1888.

657. Notes on a young red snapper (Lutjanus blackfordi) from Great South Bay, Long Island. By Tarleton H. Bean. P. 512. Aug. 6, 1888.

658. Description of a new species of Thyrsitops ( $T$. violaceus) from the fishingbanks off the New England coast. By Tarleton H. Bean. Pp. 513-514. Aug. 6, 1888.

659. A note on Vesperugo hesperus (Allen). By Frederick W. True. P. 515. Aug. $6,1888$.

660. Descriptions of new species and genera of birds from the lower Amazon. By Robert Ridgway. Pp. 516-528. Aug. 6, 1888.

661. A review of the genus Psittacula of Brisson. By Robert Ridgway. Pp. 529548. Aug. 6, 1888.

662. Description of the nest and eggs of the California black-capped gnat-catcher (Polioptila californica Brewster). By Chas. E. Bendire. Pp. 549-550. Aug. 6,1888 .

663. Notes on a collection of birds' nests and eggs from southeris 'Arizona Territory. By Chas. E. Bendire. Pp. 551-558. Aug. 6, 1888.

664. Descriptions of new species of parasitic copepods, belonging to the genera Trebius, Perissopus, and Lernanthropus. By Richard Rathbun. Pp. 559-571, 7 pls. Aug. 6, 1888.

665. Catalogue of a collection of birds made by Mr. Chas. H. Townsend, on islands in the Caribbean Sea and in Honduras. By Robert Ridgway. Pp. 572-592, Aug. 6, 1888 ; pp. 593-597, Sept. 19, 1888.

666. The meteoric iron which fell in Johnson County, Ark., 3.17 P.M., March 27, 1886. By George F. Kunz. Pp. 598-605, 2 figs., 3 pls. Sept. 19, 1888.

667. Review of Japanese birds. VII.-The creepers. By Leonhard Stejneger. Pp. 606-611. Sept. 19, 1 S88.

668. The characteristics of the elacatids. By Theodore Gill. Pp. 612-614, 1 pl. Sept. 19, 1888.

669. Note on the Gramma loreto of Poey. By Theodore Gill. Pp. 615-616. Sept. $19,1888$.

670. Descriptions of fourteen new species of North American myriapods. By Charles H. Bollman. Pp. 617-627. Sept. 19, 1888.

671. Description of a supposed new species of char (Salvelinus aureolus), from Sunapee Lake, New Hampshire. By Tarleton H. Bean. Pp. 628-630. Sept. $19,1888$.

672. Description of a new genus and species of fish, Acrotus avilloughbyi, from Washington Territory. By Tarleton H. Bean. Pp. 631-632. Sept. 19, 1888.

673. Observations on the birds of southwestern Texas. By Charles Wickliffe Beckham. Pp. 633-688, Sept. 19, 1888; pp. 689-696, Oct. 12, 1888.

674. Description of a new Psaltriparus from southern Arizozna. By Robert Ridgway. P. 697. Oct. 12, 1888.

675. Description of a new species of Xyrichthys (Xyrichthys jessiae) from the Gulf of Mexico. By David Starr Jordan. P. 698. Oct. 12, 1888.

\section{Volume 11}

Proceedings of the United States National Museum, vol. 11. Pp. i-xi (title page, advertisement, table of contents, list of illustrations, dates of publication of signatures, and list of errata); pp. 1-671 (Proceedings papers 676-760); pp. 673703 (index) ; 137 figs., 60 pls. 1889.

676. New species of fossil wood (Araucarioxylon arizonicum) from Arizona and New Mexico. By F. H. Knowlton. Pp. 1-5, 1 pl. Nov. 8, 1888.

677. Description of two new species of fossil coniferous wood from Iowa and Montana. By F. H. Knowiton. Pp. 5-8, 2 pls. Nov. 8, 1888. 
678. Description of Storeria dekayi, var. anomola. By A. Dugès. Pp. 9-10, 1 fig. Nov. 8, 1888.

679. Recent determinations of fossil plants from Kentucky, Louisiana, Oregon, California, Alaska, Greenland, etc., with descriptions of new species. By Leo Lesquereux. Pp. 11-38, 13 pls. Nov. 8, 1888.

680. The paleontologic history of the genus Platanus. By Lester F. Ward. Pp. 3942,6 pls. Nov. $8,1888$.

681. Notes on Indiana fishes. By Barton W. Evermann and Oliver P. Jenkins. Pp. 43-57. Nov. 8, 1888.

682. On the occurrence of the Great Lake trout (Salvelinus namaycush) in the waters of British Columbia. By David S. Jordan. P. 58. Nov. 8, 1888.

683. The Navajo tanner. By R. W. Shufeldt. Pp. 59-66. 6 pls. Nov. 8, 1888.

684. Note on the genus Dipterodon. By Theodore Gill. Pp. 67-68. Nov. 8, 1888.

685. Note on the genus Gobiomorus. By Theodore Gill. Pp. 69-70. Nov. 8, 1888.

686. Notes on European marsh-tits with description of a new subspecies from Norway. By Leonhard Stejneger. Pp. 71-76. Nov. 8, 1888.

687. Hampe's method of determining $\mathrm{Cu}_{2} \mathrm{O}$ in metallic copper. By Fred P. Dewey. Pp. 77-82. Nov. 8, 1888.

688. List of fossil plants collected by Mr. I. C. Russell, at Black Creek, near Gadsden, Ala., with descriptions of several new species. By Leo Lesquereux. Pp. 83-87, 1 pl. Nov. 8, 1888.

689. On a new series of Charina from California. By E. D. Cope. P. 88. [Illustration on plate accompanying No. 729.] Nov. 8, 1888.

690. Description of two species of Palmoxylon-one new-from Louisiana. By F. H. Knowlton. Pp. 89-91, 1 pl. Nov. 8, 1888.

691. Description of a new western subspecies of Accipiter velox (Wils.) and subspecific diagnosis of $A$. cooperi mexicanus (Swains.). By Robert Ridgway. P. 82. Nov. 8, 1888.

692. Further contributions to the Hawaiian avifauna. By Leonhard Stejneger. Pp. 93-103. Nov. 8, 1888.

693. Note on Aestrelata sandwichensis Ridgw. By Robert Ridgway. P. 104. Nov. $8,1888$.

694. On the serpentine of Montville, New Jersey. By George P. Merrill. Pp. 105111, 2 pls. Nov. 6, 1888.

[694a.] [Unnumbered.] Description of a new pigeon from Guayaquil, Ecuador. By Robert Ridgway. P. 112. Nov. 6, 1888.

695. Notes on the European crested titmice. By Leonhard Stejneger. Pp. 113-114. Nov. 8, 1888.

696. On nephrite and jadeite. By F. W. Clarke and G. P. Merrill. Pp. 115-128. Nov. 8, 1888; pp. 129-130, 1 pl., Jan. 5, 1889.

697. The Navajo shoemaker. By Alexander M. Stephen. Pp. 131-136, 7 figs. Jan5, 1889.

698. Description of eighteen new species of fishes from the Gulf of California. By Oliver P. Jenkins and Barton W. Evermann. Pp. 137-158. Jan. 5, 1889.

699. Description of Geomys personatus and Dipodomys compactus, two new species of rodents from Padre Island, Texas. By Frederick W. True. Pp. 159-160. Jan. 5, 1889.

700. On the San Emigdio meteorite. By George P. Merrill. Pp. 161-167, 1 pl. Jan. 5, 1889.

701. Diagnosis of the Kamtschatkan three-toed woodpecker (Picoides albidior). By Leonhard Stejneger. P. 168. Jan. 5, 1889.

702. A remarkable Eskimo harpoon from East Greenland. By John Murdoch. Pp. 169-171, 3 figs. Jan. 5, 1889.

703. The corrugation in African sword blades and other weapons. By Walter Hough. P. 172. Jan. 5, 1889.

704. Notes on the osteology of the thrushes, Miminae, and wrens. By Frederic A. Lucas. Pp. 173-176, Jan. 5, 1889; pp. 177-180, 7 figs., 1 pl., Mar. 12, 1889.

705. An Eskimo strike-a-light from Cape Bathurst. By Walter Hough. Pp. 181184, 6 figs. Mar. 12, 1889. 
Proc.

No.

706. Notes on Cydosia and Cerathosia. By John B. Smith. Pp. 185-190, 2 figs. Mar. 12, 1889.

707. On a peridotite from Little Deer Isle, in Penobscot Bay, Maine. By George P. Merrill. Pp. 191-195, 1 fig., 1 pl. Mar. 12, 1889.

708. Description of the adult male of Acanthidops bairdi. By Robert Ridgway. P. 196. Mar. 12, 1889.

709. The houses of the Kwakiutl Indians, British Columbia. By Franz Boas. Pp. 197-213, 21 figs., 3 pls. Mar. 12, 1889.

710. Description of a new species of Hyalina. By Wm. H. Dall. P. 214, 3 figs. Mar. 12, 1889.

711. Observations upon the osteology of the North American Anseres. By R. W. Shufeldt. Pp. 215-240, Mar. 12, 1889; pp. 241-251, 30 figs., Mar. 26, 1889.

712. On the proper name of the genus Labrax of Cuvier. By Theodore Gill. P. 252. Mar. 26, 1889.

713. Observations upon the osteology of the order Tubinares and Steganopodes. By R. W. Shufeldt. Pp. 253-304, Mar. 26, 1889; pp. 305-315, 43 figs., July 5, 1889.

714. Description of a new species of insect, Fontaria pulchella, from Strawberry Plains, Jefferson County, Tennessee. By Charles H. Bollman. P. 316. July $5,1889$.

715. On a new species of Bufo from Texas. By E. D. Cope. Pp. 317-318. July 5, 1889.

716. On the proper generic name of the tunny and albicore. By Theodore Gill. Pp. 319-320. July 5, 1889.

717. On the Psychrolutidae of Günther. By Theodore Gill. Pp. 321-327, 1 pl. July 5, 1889.

718. Ethnology of the Coast Indian tribes of Alaska. By A. P. Niblack. P. 328. July 5, 1889.

719. List of fishes collected by Alphonse Forrer about Mazatlan, with descriptions of two new species-Heros beani and Poecilia butleri. By David Starr Jordan. Pp. 329-334. July 5, 1889.

720. Notes on a collection of Myriapoda from Cuba. By Charles H. Bollman. Pp. 335-338. July 5, 1889.

721. Notes on a collection of Myriapoda from Mossy Creek, Tenn., with a description of a new species. By Charles H. Bollman. Pp. 339-342. July 5, 1889.

722. Notes upon some myriapods belonging to the U. S. National Museum. By Charles H. Bollman. Pp. 343-350. July 5, 1889.

723. Descriptions of fourteen species of fresh-water fishes collected by the U.S. Fish Commission in the summer of 1888. By David Starr Jordan. Pp. 351362,3 pls. July 5,1889 .

724. A study of the boomerang. By H. Eggers. Pp. 363-367, 3 figs. July 5, 1889.

725. List of plants from Lower California sent to the Smithsonian Institution by Lieut. Charles F. Pond, U. S. Navy. By George Vasey. P. 368. July 5, 1889.

726. A study of the American species of Vertigo contained in the U. S. National Museum, with the description of a new subgenus of Pupidae. By V. Sterki. Pp. 369-380, 6 figs., 1 pl. July 5, 1889.

727. On the snakes of Florida. By E. D. Cope. 381-394. July 5, 1889.

728. Catalogue of Batrachia and Reptilia brought by William Taylor from San Diego, Tex. By E. D. Cope. Pp. 395-398. July 5, 1889.

729. On the Eutaeniae of southeastern Indiana. By E. D. Cope. Pp. 399-401, 1 pl. [Fig. 2 pertains to No. 689.] July 5, 1889.

730. The Stone Age at Mount Vernon. By Otis T. Mason. P. 402 . July 5, 1889.

731. Catalogue of the myriapods of Indiana. By Charles H. Bollman. Pp. 403410. July 5, 1889.

732. List of fishes now in the U. S. National Museum collected in Nicaragua by Dr. Louis F. H. Birt. By David Starr Jordan. Pp. 411-412. July 5, 1889.

733. Notes on some albino birds presented to the U. S. National Museum, with some remarks on albinism. By Wirt Robinson. Pp. 413-416. July 5, 1889. 
734. Description of a new species of deer, Cariacus clavatus, from Central America. By Frederick W. True. Pp. 417-424. July 5, 1889.

735. Review of Japanese birds. VIII.-The nutcracker (Nucifraga caryocatactes macrorhynchos). By Leonhard Stejneger. Pp. 425-432. July 5, 1889.

736. The single-headed drum of the Naskopie (Nagnagnot) Indians, Ungave district, Hudson Bay territory. By Lucien M. Turner. Pp. 433-434. Sept. 3, 1889.

737. Notes on a collection of fishes from the Maumee Valley, Ohio. By Seth E. Meek. Pp. 435-440. Sept. 3, 1889.

138. Description of new genera and species of fossils from the Middle Cambrian. By Charles D. Walcott. Pp. 44i-446, 1 fig. Sept. 3, 1889.

939. A simple method of measuring the thickness of inclined strata. By Charles D. Walcott. Pp. 447-448, 1 fig. Sept. 3, 1889.

740. Notes on some Indian Territory land and fresh-water shells. By Chas. Torrey Simpson. Pp. 449-454. Sept. 3, 1889.

741. Notes on Hydrocotyle americana L. By Theodor Holm. Pp. 455-462, 2 pls. Sept. 3, 1899.

742. Notes on some California fishes, with descriptions of two new species. By Carl H. Eigenmann and Rosa S. Eigenmann. Pp. 463-466. Sept. 3, 1889.

743. On the occurrence of Echinomys semispinosus, Tomes, in Nicaragua. By Frederick W. True. Pp. 467-468. Sept. 3, 1889.

744. On the mammals collected in eastern Honduras in 1887 by Mr. Charles $\mathbf{H}$. Townsend, with a description of a new subspecies of Capromys from Little Swan Island. By Frederick W. True. Pp. 469-472. Sept. 3, 1889.

745. The preparation of Japanese lacquer and the manufacture of Wakasa lacquer ware. By Romyn Hitchcock. Pp. 473-479. Sept. 3, 1889.

746. A fossil Lingula preserving the cast of the peduncle. By Charles D. Walcott. P. 480,3 figs. Sept. 3, 1889.

747. Notes on the species of Lachnosterna of temperate North America, with descriptions of new species. By John B. Smith. Pp. $481-525,13$ pls. Sept. 3, 1889.

748. Description of Coregonus pusillus, a new species of whitefish from Alaska. By Tarleton H. Bean. P. 526. Sept. 3, 1889.

749. List of plants collected by Dr. Edward Palmer in Lower California in 1889. By George Vasey and Joseph N. Rose. Pp. 527-528, Sept. 3, 1889; pp. 529-536, Sept. 20, 1889.

750. Notes on Costa Rican birds, with descriptions of seven new species and subspecies and one new genus. By Robert Ridgway. Pp. 537-546. Sept. 20, 1889.

751. Review of Japanese birds. IX.-The wrens. By Leonhard Stejneger. Pp. 547-548. Sept. 20, 1889.

752. List of fishes collected at Green Turtle Cay, in the Bahamas, by Charles $\mathbf{L}$. Edwards, with descriptions of three new species. By David Starr Jordaв and Charles Harvey Bollman. Pp. 549-553. Sept. 20, 1889.

753. Description of a new species of Bathymaster (B. jordani) from Puget's Sound and Alaska. By Charles H. Gilbert. P. 554. Sept. 20, 1889.

754. Notes on a collection of fishes obtained in the Gila River, at Fort Thomas, Arizona, by Lieut. W. L. Carpenter, U. S. Army. By Philip H. Kirsch. Pp. 555-558. Sept. 20, 1889.

755. Notes on some Neotropical birds belonging to the United States National Museum. By Hans von Berlepsch. Pp. 559-560, Sept. 20, 1889; pp. 561-566, Sept. 25, 1889.

756. On the classification of the mail-cheeked fishes. By Theodore Gill. Pp. 567592. Sept. 25, 1889.

757. Gleanings among the pleuronectids, and observations on the name Pleuronectes. By Theodore Gill. Pp. 593-606. Sept. 25, 1889.

758. Note on the genus $S$ pheroides. By Theodore Gill. Pp. 607-608. Sept. $25,1889$. 
759. A list of fishes from a small tributary of the Poteau River, Scott County, Arkansas. By Charles H. Gilbert. Pp. 609-610. Sept. 25, 1889.

760. Descriptions of new Braconidae in the collection of the U. S. National Museum. By William H. Ashmead. Pp. 611-656, Sept. 25, 1889; pp. 657-671, Sept. 27, 1889.

\section{Volume 12}

Proceedings of the United States National Museum, vol. 12. Pp. i-viii (title page, advertisement, table of contents, list of illustrations, dates of publication of articles, and list of errata); pp. 1-652 (Proceedings papers 761-789); pp. 653686 (index); 14 figs., 23 pls. 1890.

761. A review of the genus Xiphocolaptes of Lesson. By Robert Ridgway. Pp. 1-20. Feb. 5, 1890.

762. A review of the genus Sclerurus of Swainson. By Robert Ridgway. Pp. 21-31. Feb. 5, 1890.

763. Descriptive notes of new genera and species from the Lower Cambrian or Olenellus zone of North America. By Charles D. Walcott. Pp. 33-46. Feb. 5, 1890.

764. New North American Acrididae, found north of the Mexican boundary. By Lawrence Bruner. Pp. 47-82, 1 pl. Feb. 5, 1890.

765. Contributions to the natural history of the Commander Islands. A.-Contributions to the history of Pallas' cormorant. By Leonhard Stejneger. Pp. 83-88. B.-Description of some bones of Pallas' cormorant (Phalacrocorax perspicillatus). By Frederic A. Lucas. Pp. 88-94, 3 pls. Feb. 5, 1890.

766. Description of two new species of snakes from California. By Leonhard Stejneger. Pp. 95-99, 3 figs. Feb. 5, 1890.

767. Scientific results of explorations by the U. S. Fish Commission steamer Albatross. No. I.-Birds collected on the Galapagos Islands in 1888. By Robert Ridgway. Pp. 101-128, 6 figs. Feb. 5, 1890.

768. Scientific results of explorations by the U. S. Fish Commission steamer Albatross. No. II.-Birds collected on the Island of Santa Lucia, West Indies, the Abrolhos Islands, Brazil, and at the Straits of Magellan, in 1887-'88. By Robert Ridgway. Pp. 129-139. Feb. 5, 1890.

769. Scientific results of explorations by the U. S. Fish Commission steamer Albatross. No. III.-Report on the batrachians and reptiles collected in 1887-'88. By E. D. Cope. Pp. 141-147. Feb. 5, 1890.

770. Scientific results of explorations by the U. S. Fish Commission steamer Albatross. No. IV.-Descriptions of new species of fishes collected at the Galapagos Islands and along the coast of the United States of Colombia, 1887-'88. By David Starr Jordan and Charles Harvey Bollman. Pp. 149-183. Feb. 5, 1890.

771. Scientific results of explorations by the U. S. Fish Commission steamer Albatross. No. V.-Annotated catalogue of the insects collected in 1887-'88. By L. O. Howard. Pp. 185-216. Feb. 5, 1890.

772. Scientific results of explorations by the U. S. Fish Commission steamer Albatross. No. VI.-List of the plants collected in Alaska in 1888. By George Vasey. Pp. 217-218. Feb. 5, 1890.

773. Scientific results of explorations by the U. S. Fish Commission steamer Albatross. No. VII.-Preliminary report on the collection of Mollusca and Brachiopoda obtained in 1887-'88. By William Healey Dall. Pp. 219-362, 10 pls. Mar. 7, 1890.

774. Notes on the occurrence of Gillichthys y-cauda at San Diego, California. By Charles H. Gilbert. P. 363. Mar. 4, 1890.

775. Description of a new genus and species of inarticulate brachiopod from the Trenton limestone. By Charles D. Walcott. Pp. 365-366, 4 figs. Mar. 4, 1890. (Advance sheets issued Dec. 10, 1889.)

776. The archaeology of the Potomac tide-water region. By Otis T. Mason. Pp. 367-370, 1 fig., 5 pls. Mar. 7, 1890. 
777. The palaeolithic period in the District of Columbia. By Thomas Wilson. Pp. 371-376, 2 pls. Mar. 7, 1890.

778. Notes on a third collection of birds made in Kauai, Hawaiian Islands, by Valdemar Knudsen. By Leonhard Stejneger. Pp. 377-386. Mar. 8, 1890.

779. Descriptions of new Ichneumonidae in the collection of the U. S. National Museum. By William H. Ashmead. Pp. 387-451. Apr. 21, 1890.

780. Description of the yellow-finned trout of Twin Lakes, Colorado. By David Starr Jordan and Barton Warren Evermann. Pp. 453-454. Apr. 21, 1890. (Advance sheets issued Jan. 20, 1890.)

781. Contributions toward a monograph of the Noctuidae of temperate North America-revision of some taeniocampid genera. By John B. Smith. Pp. 455-496, 2 pls. 1890 (exact date of publication unknown).

782. Catalogue of the described Araneae of temperate North America. By George Marx. Pp. 497-594. May 22, 1890.

783. Notes on the serpentinous rocks of Essex County, New York; from Aqueduct Shaft 26, New York City; and from near Easton, Pennsylvania. By George P. Merrill. Pp. 595-600. May 22, 1890.

784. A revision of the genus Araucarioxylon of Kraus, with compiled descriptions and partial synonymy of the species. By F. H. Knowlton. Pp. 601-617. May 22, 1890.

785. Notes on North American crayfishes-family Astacidae. By Walter Faxon. Pp. 619-634. May 22, 1890.

786. Description of two new species of bats-Nyctinomus europs and N. orthotis. By Harrison Allen. Pp. 635-640. May 22, 1890.

787. Scientific results of explorations by the U. S. Fish Commission steamer Albatross. No. VIII.-Description of a new cottoid fish from British Columbia. By Tarleton H. Bean. Pp. 641-642. June ?, 1890. (Advance sheets issued Mar. 4, 1890.)

788. Description of a new lizard from Lower California. By Leonhard Stejneger. Pp. 643-644. June ?, 1890.

789. Scientific results of explorations by the U. S. Fish Commission steamer Albatross. No IX.-Catalogue of fishes collected at Port Castries, St. Lucia, by the steamer Albatross, November, 1888. By David Starr Jordan. Pp. 645-652. June ?, 1890.

\section{Volume 13}

Proceedings of the United States National Museum, vol. 13. Pp. i-viii (title page, advertisement, table of contents, list of illustrations, dates of publication of articles, and list of errata); pp. 1-643 (Proceedings papers 790-841); pp. 645-665 (index); 12 figs., 38 pls. 1891.

790. Description of a new species of land shell from Cuba-Vertigo cubana. By Wm. H. Dall. Pp. 1-2, 2 figs. July 1, 1890.

791. Description of a new species of fish from Tippecanoe River, Indiana. By David Starr Jordan and Barton Warren Evermann. Pp. 3-4, 1 fig. July 1, 1890.

792. Remarks on some fossil remains considered as peculiar kinds of marine plants. By Leo Lesquereux. Pp. 5-12, 1 pl. July 18, 1890.

793. Scientific results of explorations by the U. S. Fish Commission steamer Albatross. No. X.-On certain Mesozoic fossils from the Islands of St. Paul's and St. Peter's, in the Straits of Magellan. By Charles A. White. Pp. 13-14, 2 pls. July $22,1890$.

794. Notes on the leaves of Liriodendron. By Theodor Holm. Pp. 15-35, 6 pls. Sept. 9, 1890.

795. Scientific results of explorations by the U. S. Fish Commission steamer Albatross. No. XI.-New fishes collected off the coast of Alaska and the adjacent region southward. By Tarleton H. Bean. Pp. 37-45. July 1, 1890.

796. Further notes on the genus Xiphocolaptes of Lesson. By Robert Ridgway. Pp. 47-48. July 1, 1890. 
797. Scientific results of explorations by the U. S. Fish Commission steamer Albatross. No. XII.-A preliminary report on the fishes collected by the steamer Albatross on the Pacific coast of North America during the year 1889, with descriptions of twelve new genera and ninety-two new species. By Charles H. Gilbert. Pp. 49-126. July 1, 1890.

798. Scientific results of explorations by the U. S. Fish Commission steamer Albatross. No. XIII.-Catalogue of skeletons of birds collected at the Abrolhos Islands, Brazil, the Straits of Magellan, and the Galapagos Islands, in 1887-'88. By Frederic A. Lucas. Pp. 127-130. July 1, 1890.

799. Scientific results of explorations by the U. S. Fish Commission steamer Albatross. No. XIV.-Birds from the coasts of western North America and adjacent islands, collected in 1888-'89, with descriptions of new species. By Chas. H. Townsend. Pp. 131-142. Sept. 9, 1890.

800. Scientific results of explorations by the U. S. Fish Commission steamer Albatross. No. XV.-Reptiles from Clarion and Socorro Islands and the Gulf of California, with description of a new species. By Chas. H. Townsend. Pp. 143-144. Sept. 9, 1890.

801. Scientific results of explorations by the U. S. Fish Commission steamer Albatross. No. XVI.-Plants collected in 1889 at Socorro and Clarion Islands, Pacific Ocean. By Geo. Vasey and J. N. Rose. Pp. 145-149. Sept. 9, 1890.

802. On a new genus and species of colubrine snakes from North America. By Leonhard Stejneger. Pp. 151-155, 1 fig. Sept. 9, 1890.

803. The osteological characteristics of the family Anguillidae. By Theodore Gill. Pp. 157-160. Sept. 9, 1890.

804. The osteological characteristics of the family Synaphobranchidae. By Theodore Gill. Pp. 161-164. Sept. 9, 1890.

805. The osteological characteristics of the family Muraenidae. By Theodore Gill. Pp. 165-170. Sept. 9, 1890.

806. On the disappearance of the dick cissel (Spiza americana) from the District of Columbia. By Hugh M. Smith. Pp. 171-172. Sept. 9, 1890.

807. Description of a new species of bat, Atalapha semota. By Harrison Allen. Pp. 173-175. Sept. 9, 1890.

808. On the snakes of the genus Charina. By Leonhard Stejneger. Pp. 177-182. Sept. 9, 1890.

809. On the North American lizards of the genus Barissia of Gray. By Leonhard Stejneger. Pp. 183-185. Sept. 9, 1890.

810. A collection of stone implements from the District of Columbia. By S. V. Proudfit. Pp. 187-194, 5 pls. Sept. 9, 1890.

811. Notes on the occurrence of a young crab-eater (Elacate canada), from the lower Hudson Valley, New York. By A. K. Fisher. P. 195. Sept. 9, 1890.

812. Observations on the life history of the bottlenose porpoise. By Frederick W. True. Pp. 197-203, 1 fig. Sept. 9, 1890.

813. Scientific results of explorations by the U. S. Fish Commission steamer Albatross. No. XVII.-Descriptions of new West American land, fresh-water, and marine shells, with notes and comments. By Robert E. C. Stearns. Pp. 205-225, 3 pls. Sept. 16, 1890.

814. Description of two new species of mammals from Mt. Kilima-Njaro, East Africa. By Frederick W. True. Pp. 227-229. Sept. 16, 1890.

815. Osteological characteristics of the family Muraenesocidae. By Theodore Gill. Pp. 231-234. Sept. 16, 1890.

816. On the family Rancipitidae. By Theodore Gill. Pp. 235-238, 1 pl. Oct. 14, 1890.

817. The osteological characteristics of the family Simenchelyidae. By Theodore Gill. Pp. 239-242. Oct. 14, 1890.

818. The characteristics of the Dactylopteroidea. By Theodore Gill. Pp. 243-248, 1 pl. Oct. 14, 1890.

819. Notes on the birds observed during the cruise of the United States Fish Commission schooner Grampus in the summer of 1887. By William Palmer. Pp. 249-265. Oct. 14, 1890. 
Proc.

No.

820. Description of new forms of Upper Cambrian fossils. By Charles D. Walcott. Pp. 267-279, 2 pls. Oct. 14, 1890.

821. Notes on the Triassic plants from New Mexico. By Wm. M. Fontaine and F. H. Knowlton. Pp. 281-285, 5 pls. Dec. $31,1890$.

822. Notes on fishes of the genera Agosia, Algansea, and Zophendum. By David Starr Jordan. Pp. 287-288. Nov. 15, 1890.

823. Description of a new species of Etheostoma (E. micropterus) from Chihuahua, Mexico. By Charles H. Gilbert. Pp. 289-290. Nov. 15, 1890.

824. Description of a new species of bat of the genus Carollia, and remarks on Carollia brevicauda. By Harrison Allen. Pp. 291-298. Dec. 11, 1890.

825. Osteological characteristics of the family Amphipnoidae. By Theodore Gill. Pp. 299-302. Dec. 11, 1890.

826. Description of a new species of mouse, Phenacomys longicaudus, from Oregon. By Frederick W. True. Pp. 303-304. Nov. 15, 1890.

827. Notes on the habits of the moose in the far north of British America in 1865 . By J. G. Lockhart. Pp. 305-308. Nov. 15, 1890.

828. Observations on the Farallon rail (Porzana jamaicensis coturniculus Baird). By Robert Ridgway. Pp. 309-311. Nov. 15, 1890.

829. Scientific results of explorations by the U. S. Fish Commission steamer Albatross. No. XVIII.-List of fishes obtained in the harbor of Bahia, Brazil, and in adjacent waters. By David Starr Jordan. Pp. 313-336. Apr. 8, 1891.

830. Notes on the osteology of the Paridae, Sitta, and Chamaea. By Frederic A. Lucas. Pp. 337-345, 5 figs., 1 pl. Apr. 8, 1891.

831. Note on the Aspredinidae. By Theodore Gill. Pp. 347-352. Apr. 18, 1891.

832. Note on the genus Felichthys of Swainson. By Theodore Gill. Pp. 353-354. Apr. 8, 1891.

833. The characteristics of the family of scatophagoid fishes. By Theodore Gill. Pp. 355-360, 1 fig. Apr. 8, 1891.

834. On the relations of Cyclopteroidea. By Theodore Gill. Pp. 361-376, 3 pls. May 8, 1891.

835. The osteological characteristics of the family Hemitripteridae. By Theodore Gill. Pp. 377-380, 1 pl. May 8, 1891.

836. Playing cards from Japan. By Mrs. J. King Van Rensselaer. Pp. 381-382, 1 pl. May 29, 1891.

837. Notes on North American Myriapoda of the family Geophilidae, with descriptions of three genera. By O. F. Cook and G. N. Collins. Pp. 383-396, 3 pls. May 6, 1891.

338. Contributions toward a monograph of the Noctuidae of temperate North America. Revision of Homohadena, Grote. By John B. Smith. Pp. 397-405, 1 fig. Apr. 18, 1891.

839. Contributions toward a monograph of the Noctuidae of temperate North America.-Revision of the species of Hadena referable to $X$ ylophasia and Luperina. By John B. Smith. Pp. 407-447, 2 pls. May 8, 1891.

840. Scientific results of explorations by the U. S. Fish Commission steamer Albatross. No. XIX.-A supplementary list of fishes collected at the Galapagos Islands and Panama, with descriptions of one new genus and three new species. By Charles H. Gilbert. Pp. 449-455. May 29, 1891.

341. The birds of Manitoba By Ernest E. Thompson. Pp. 457-643, 1 pl. May 29, 1891.

\section{Volume 14}

Proceedings of the United States National Museum, vol. 14. Pp. i-vi (title page, advertisement, table of contents, list of illustrations, and dates of publication of articles); pp. 1-720 (Proceedings papers 842-886); pp. 721-750 (index); 3 figs., 34 pls. 1892.

842. A catalogue of the fresh-water fishes of South America. By Carl H. Eigenmann and Rosa S. Eigenmann. Pp. 1-81. July 16, 1891. 
Proc.

No.

843. Fishes collected by William P. Seal in Chesapeake Bay, at Cape Charles City, Virginia, September 16 to October 3, 1890. By Barton A. Bean. Pp. 83-94. July $16,1891$.

844. List of North American land and fresh-water shells received from the U. S. Department of Agriculture, with notes and comments thereon. By Robert E. C. Stearns. Pp. 95-106. July 16, 1891.

845. Relations of temperature to vertebrae among fishes. By David Starr Jordan. Pp. 107-120. July 16, 1891.

846. Report upon a collection of fishes made at Guaymas, Sonora, Mexico, with descriptions of new species. By Barton W. Evermann and Oliver P. Jenkins. Pp. 121-165, 2 pls. July 16, 1891.

847. Description of a new genus and species of tailless batrachian from tropical America. By Leonhard Stejneger and Frederick C. Test. Pp. 167-168, 1 pl. July $16,1891$.

848. On the structure of the tongue in humming birds. By Frederic A. Lucas. Pp. 169-172, 2 figs., 1 pl. July 16, 1891.

849. Scientific results of explorations by the U. S. Fish Commission steamer Albatross. No. XX.-On some new or interesting west American shells obtained from the dredgings of the U. S. Fish Commission steamer Albatross in 1888, and from other sources. By Wm. H. Dall. Pp. 173-191, 3 pis. July 24, 1891.

850. Descriptions of two supposed new species of mice from Costa Rica and Mexico, with remarks on Hesperomys melanophrys of Coues. By J. A. Allen. Pp. 193-196. July 24, 1891.

851. Contributions toward a monograph of the Noctuidae of temperate North America. Revision of the species of Mamestra. By John B. Smith. Pp. 197276, 4 pls. Sept. 26, 1891.

852. Report upon the Annelida Polychaeta of Beaufort, North Carolina. By E. A. Andrews. Pp. 277-302, 7 pls. Aug. 20, 1891.

853. On Eleginus of Fischer, otherwise called Tilesia or Pleurogadus. By Theodore Gill. Pp. 303-305. Aug. 27, 1891.

854. List of shells collected on the west coast of South America, principally between latitudes $7^{\circ} 30^{\prime}$ S., and $8^{\circ} 49^{\prime}$ N., by Dr. W. H. Jones, Surgeon, U. S. Navy. By Robert E. C. Stearns. Pp. 307-335. Aug. 29, 1891.

855. Descriptions of new genera, species, and subspecies of birds from Costa Rica. By George K. Cherrie. Pp. 337-346. Sept. 4, 1891.

856. Scientific results of explorations by the U. S. Fish Commission steamer Albatross. No. XXI.-Descriptions of apodal fishes from the tropical Pacific. By Charles H. Gilbert. Pp. 347-352. Sept. 8, 1891.

857. Description of a new species of chamaeleon from Kilima-njaro, eastern Africa. By Leonhard Stejneger. Pp. 353-354. Oct. 12, 1891.

858. The genus Panopeus. By James E. Benedict and Mary J. Rathbun. Pp. 355385,6 pls. Dec. $12,1891$.

859. Some observations on the Havesu-pai Indians. By R. W. Shufeldt. Pp. 387390, 2 pls. Dec. 12, 1891.

860. The Navajo belt-weaver. By R. W. Shufeldt. Pp. 391-393, 1 pl. Dec. 12, 1891.

861. On the genera Labrichthys and Pseudolabrus. By Theodore Gill. Pp. 395404. Sept. 8, 1891.

862. Description of a new scincoid lizard from East Africa. By Leonhard Stejneger. Pp. 405-406. Aug. 31, 1891.

863. Description of a new species of lizard from the Island San Pedro Martir, Gulf of California. By Leonhard Stejneger. Pp. 407-408. Aug. 31, 1891.

864. Description of a new North American lizard of the genus Sauromalus. By Leonhard Stejneger. Pp. 409-411. Oct. 27, 1891.

865. Notes on and list of birds and eggs collected in Arctic America, 1861-1866. By R. MacFarlane. Pp. 413-446. Sept. 26, 1891.

866. On the characters of some Paleozoic fishes. By E. D. Cope. Pp. 447-463, 6 pls. Dec. 12, 1891.

867. Description of a new species of whippoorwill from Costa Rica. By R. Ridgway. Pp. 465-466. Oct. 12, 1891. 
868. Notes on some birds from the interior of Honduras. By Robert Ridgway. Pp. 467-471. Oct. 26, 1891.

869. Notes on some Costa Rican birds. By Robert Ridgway. Pp. 473-478. Oct. 31, 1891.

870. Note on Pachyrhamphus albinucha, Burmeister. By Robert Ridgway. Pp. 479480. Oct. 22, 1891.

871. Description of two supposed new forms of Thamnophilus. By Robert Ridgway. P. 481 . Oct. 22, 1891.

872. Description of a new sharp-tailed sparrow from California. By Robert Ridgway. Pp. 483-484. Oct. 22, 1891.

873. Notes on Scleroporus variabilis and its geographical distribution in the United States. By Leonhard Stejneger. Pp. 485-488. Oct. 27, 1891.

874. Notes on Japanese birds contained in the Science Coliege Museum, Imperial University, Tokyo, Japan. By Leonhard Stejneger. Pp. 489-498. Oct. 26, 1891.

875. Notes on the cubital coverts in the birds of paradise and bower birds. By Leonhard Stejneger. Pp. 499-500. Oct. 27, 1891.

876. Notes on some North American snakes. By Leonhard Stejneger. 501-505. Oct. $31,1891$.

877. Notes on the genus Sittasomus of Swainson. By Robert Ridgway. Pp. 507-510. Oct. $31,1891$.

878. On the snakes of the California genus Lichanura. By Leonhard Stejneger. Pp. 511-515. Nov. 7, 1891.

879. Notes on Costa Rica birds. By George K. Cherrie. Pp. 517-537. Nov. 17, 1891.

880. Scientific results of explorations by the U. S. Fish Commission steamer Albatross. No. XXII.-Descriptions of thirty-four new species of fishes collected in 1888 and 1889, principally among the Santa Barbara Islands and in the Gulf of California. By Charles H. Gilbert. Pp. 539-566. Mar. 28, 1892.

881. The biology of the hymenopterous insects of the family Chalcididae. By L. O. Howard. Pp. 567-588. Mar. 28, 1892.

882. A critical review of the characters and variations of the snakes of North America. By E. D. Cope. Pp. 589-694. Mar. 28, 1892.

883. Note on the genus Hiatula of Lacépède or Tautoga of Mitchill. By Theodore Gill. P. 695. Mar. 25, 1892.

884. Note on the genus Chonerhinus or Xenopterus. By Theodore Gill. Pp. 697699. Apr. 19, 1892.

885. On the genus Gnathanacanthus of Bleeker. By Theodore Gill. Pp. 701-704, 1 fig. Apr. 19, 1892.

886. Notes on the Tetraodontoidea. By Theodore Gill. Pp. 705-720, 1 pl. Apr. 20, 1892.

\section{Volume 15}

Proceedings of the United States National Museum, vol. 15. Pp. i-vi (title page, advertisement, table of contents, list of illustrations, dates of publication of articles); pp. 1-495 (Proceedings papers 887-918); pp. 497-508 (index); 8 figs., 84 pls. 1893.

887. Preliminary descriptions of thirty-seven new species of hermit crabs of the genus Eupagurus in the U. S. National Museum. By James E. Benedict. Pp. 1-26. Mar. 28, 1892.

888. Description of two apparently new flycatchers from Costa Rica. By George K. Cherrie. Pp. 27-28. Mar. 25, 1892.

889. A maid of Wolpai. By R. W. Shufeldt. Pp. 29-31, 1 pl. Aug. 2, 1892.

890. Contributions toward a monograph of the Noctuidae of boreal America.Revision of the genus Cucullia. By John B. Smith. Pp. 35-52, 1 pl. Aug. 5, 1892.

891. Contributions toward a monograph of the Noctuidae of boreal America.Revision of the Dicopinae. By John B. Smith. Pp. 53-64. Aug. 5, 1892.

892. Contributions toward a monograph of the Noctuidae of boreal America.Revision of Xylomiges and Morrisonia. By John B. Smith. Pp. 65-86, 1 pl. Aug. 5, 1892. 
Proc.

No.

893. Notes on avian Entozoa. By Edwin Linton. Pp. 87-113, 5 pls. Aug. 5, 1892.

894. Preliminary description of a new genus and species of blind cave salamander from North America. By Leonhard Stejneger. Pp. 115-117, 1 pl. Aug. 2, 1892.

895. Descriptions of two new forms of Basileuterus rufifrons, from Mexico. By Robert Ridgway. P. 119. July 18, 1892.

896. Description of a new species of star-gazer (Cathetostoma albigutta), from the Gulf of Mexico. By Tarleton H. Bean. Pp. 121-122. July 18, 1892.

897. The fishes of San Diego, California. By Carl H. Eigenmann. Pp. 123-178, 9 pls. Aug. 2, 1892.

898. An annotated list of the shells of San Pedro Bay and vicinity. By Mrs. M. Burton Williamson, with a description of two new species by W. H. Dall. Pp. 179-220, 5 pls. Aug. 2, 1892.

899. Chinese relics in Alaska. By T. Dix Bolles. P. 221, 1 pl. Aug. 2, 1892.

900. Corystoid crabs of the genera Telmessus and Erimacrus. By James E. Benedict. Pp. 223-230, 3 pls. Aug. 2, 1892.

901. Catalogue of the crabs of the family Periceridae in the U. S. National Museum. By Mary J. Rathbun. Pp. 231-277, 13 pls. Aug. 2, 1892.

902. The evolution of house-building among the Navajo Indians. By R. W. Shufeldt. Pp. 279-282, 3 pls. Aug. 2, 1892.

903. Notes on fishes collected in Mexico by Prof. Alfredo Dugès, with descriptions of new species. By Tarleton H. Bean. Pp. 283-287, 1 pl. Aug. 2, 1892.

904. Notes on a collection of birds made by Mr. Harry V. Henson in the Island of Yezo, Japan. By Leonhard Stejneger. Pp. 289-359, 1 pl. Aug. 2, 1892.

905. Insects of the subfamily Encyrtinae with branched antennae. By L. O. Howard. Pp. 361-369, 2 pls. Sept. 19, 1892.

906. Two additions to the Japanese avifauna, including description of a new species. By Leonhard Stejneger. Pp. 371-373. Sept. 19, 1892.

907. On the ejection of blood from the eyes of horned toads. By O. P. Hay. Pp. 375-378. Sept. 19, 1892.

908. Some observations on the turtles of the genus Malaclemys. By O. P. Hay. Pp. 379-383. Sept. 19, 1892.

909. On the breeding habits, eggs, and young of certain snakes. By O. P. Hay. Pp. 385-397. Sept. 19, 1892.

910. Notes on the flowers of Anthoxanthum odoratum L. By Theo. Holm. Pp. 399403, 1 pl. Oct. 5, 1892.

911. Notes on the Unionidae of Florida and the southeastern States. By Charles T. Simpson. Pp. 405-436, 26 pls. Oct. 26, 1892.

912. On a new subfamily of phyllostome bats. By Harrison Allen. Pp. 437-439, 1 fig. Oct. 26, 1892.

913. Description of a new genus of phyllostome bats. By Harrison Allen. Pp. 441442, 2 figs. Oct. 26, 1892.

914. On Temminck's bat, Scotophilus temminckii. By Harrison Allen. Pp. 443-444. Oct. 26, 1892.

915. An annotated catalogue of the mammals collected by Dr. W. L. Abbott in the Kilma-Njaro region, East Africa. By Frederick W. True. Pp. 445-480, 5 figs., 6 pls. Oct. 26, 1892.

916. A description of the golden trout of Kern River, California, Salmo mykiss agua-bonita. By David Starr Jordan. Pp. 481-483. July 24, 1893.

917. On the occurrence of the spiny boxfish (genus Chilomycterus) on the coast of California. By Carl H. Eigenmann. P. 485, 1 pl. July 24, 1893.

918. Description of some fossil plants from the Great Falls coal field of Montana. By William M. Fontaine. Pp. 487-495, 3 pls. July 24, 1893.

711175-47-6 


\section{Volume 16}

Proceedings of the United States National Museum, vol. 16. Pp. 1-x (title page, advertisement, table of contents, list of illustrations, dates of publication of articles, and list of corrections); pp. 1-791 (Proceedings papers 919-975); pp. 793-808 (index); 21 figs., 84 pls. 1894.

Proc.

No.

919. Introduction to a monograph of the North American bats. By Harrison Allen. Pp. 1-28. June 13, 1893.

920. Notes on the genera of Vespertilionidae. By Harrison Allen. Pp. 29-31. June 13, 1893.

921. Notes on a few fossil plants from the Fort Union group of Montana, with a description of one new species. By F. H. Knowlton. Pp. 33-36, 2 pls. July 27, 1893.

922. On a collection of batrachians and reptiles from Mount Orizaba, Mexico, with descriptions of two new species. By W. S. Blatchley. Pp. 37-42. June 13, 1893.

923. Description of two supposed new species of swifts. By Robert Ridgway. Pp. 43-44. June 13, 1893.

924. Notes on American Hemiptera Heteroptera. By A. L. Montandon. Pp. 45-52. June 13, 1893.

925. Catalogue of the fresh-water fishes of Central America and southern Mexico. By Carl H. Eigenmann. Pp. 53-60. June 13, 1893.

926. On the making of gelatin casts. By J. W. Scollick. Pp. 61-62. June 13, 1893.

927. Catalogue of the crabs of the family Maiidae in the U. S. National Museum. By Mary J. Rathbun. Pp. 63-103, 6 pls. July 26, 1893.

928. Notes on Erian (Devonian) plants from New York and Pennsylvania. By D. P. Penhallow. Pp. 105-114, 6 pls. July 26, 1893.

929. Notes on Nematophyton crassum. By D. P. Penhallow. Pp. 115-118, 4 pls. July $26,1893$.

930. Scientific results of explorations by the U. S. Fish Commission steamer Albatross. No. XXIII.-Report on the Actiniae collected by the United States Fish Commission steamer Albatross during the winter of 1887-1888. By J. Playfair McMurrich. Pp. 119-216, 17 pls. July 29, 1893.

931. On the status of the gray shrike, collected by Capt. Blakiston, in Yezo, Japan. By Leonhard Stejneger. Pp. 217-218. June 6, 1893.

932. Throwing-sticks from Mexico and California. By Otis T. Mason. Pp. 219221, 6 figs. July 19, 1893.

933. Scientific results of explorations by the U. S. Fish Commission steamer Albatross. No. XXIV.-Descriptions of new genera and species of crabs from the west coast of North America and the Sandwich Islands. By Mary J. Rathbun. Pp. 223-260. July 12, 1893.

934. Notes on some fossil plants from the Trinity division of the Comanche series of Texas. By William Morris Fontaine. Pp. 261-282, 8 pls. Oct. 6, 1893.

935. Observations on the blind crayfishes of Indiana, with a description of a new subspecies; Cambarus pellucidus testii. By W. P. Hay. Pp. 283-286, 2 pls. Sept. 28, 1893.

936. The shofar-its use and origin. By Cyrus Adler. Pp. 287-301, 4 pls. Oct. 7, 1893.

937. List of Diatomaceae from a deep-sea dredging in the Atlantic Ocean off Delaware Bay by the U. S. Fish Commission steamer Albatross. By Albert Mann. Pp. 303-312. July 19, 1893.

938. Description of a new species of cyprinoid fish, Couesius greeni, from the head waters of Frazer River in British Columbia. By David S. Jordan. Pp. 313 314. July 19, 1893.

939. Note on the wall-eyed pollack (Pollachius chalcogrammus fucensis) of Puget Sound. By David S. Jordan and Charles H. Gilbert. Pp. 315-316. July 19, 1893. 
Proc.

No.

940. Preliminary report on the molluscan species collected by the United States scientific expedition to West Africa, in 1889-'90. By Robert E. C. Stearns. Pp. 317-339. Sept. 28, 1893.

941. On rare or little known mollusks from the west coast of North and South America, with descriptions of new species. By Robert E. C. Stearns. Pp. 341-352, 1 pl. Sept. 28, 1893.

942. Scientific results of explorations by the U. S. Fish Commission steamer Albatross. No. XXV.-Report on the mollusk-fauna of the Galapagos Islands with descriptions of new species. By Robert E. C. Stearns. Pp. 353-450, 2 pls. Sept. 29, 1893.

943. Scientific results of explorations by the U. S. Fish Commission steamer Albatross. No. XXVI.-Report on the pteropods and heteropods collected by the U. S. Fish Commission steamer Albatross during the voyage from Norfolk, Va., to San Francisco, Cal., 1887-'88. By James I. Peck. Pp. 451-466, 3 pls. Sept. 30, 1893.

944. Diagnosis of a new Californian lizard. By Leonhard Stejneger. P. 467. July 21, 1893.

945. Description of a supposed new species of Odontophorus from southern Mexico. By Robert Ridgway. Pp. 469-470. July 21, 1893.

946. A subtropical Miocene fauna in Arctic Siberia. By William Healey Dall. Pp. 471-478, 1 pl. Sept. 30, 1893.

947. Notes on a collection of birds from eastern Nicaragua and the Rio Frio, Costa Rica, with a description of a supposed new Trogon. By Charles W. Richmond. Pp. 479-532. Oct. 4, 1893.

948. Description of a new species of fruit bat, Pteropus aldabrensis, from Aldabra Island. By Frederick W. True. Pp. 533-534. Oct. 21, 1893. (Advance sheets issued July 14, 1893.)

949. Notice of the crustaceans collected by the United States scientific expedition to the west coast of Africa. By James E. Benedict. Pp. 535-541. Oct. 9, 1893.

950. A descriptive catalogue of the harvest-spiders (Phalangiidae) of Ohio. By Clarence M. Weed. Pp. 543-563, 1 fig., 13 pls. Oct. 25, 1893.

951. Scientific results of the U. S. eclipse expedition to West Africa, 1889-'90. Repore upon the Insecta, Arachnida, and Myriopoda. By C. V. Riley. Pp. 565590, 13 figs., 1 pl. Oct. 23, 1893.

952. On some fossil Unios and other fresh-water shells from the drift at Toronto, Canada; with a review of the distribution of the Unionidae of northeastern North America. By Chas. T. Simpson. Pp. 591-595. Oct. 25, 1893.

953. Descriptions of some new birds collected on the islands of Aldabra and Assumption, northwest of Madagascar, by Dr. W. L. Abbott. By Robert Ridgway. Pp. 597-600. Oct. 25, 1893. (Advance sheets issued Aug. 16, 1893.)

954. Notes on a small collection of mammals from the Tana River, East Africa, with descriptions of new species. By Frederick W. True. Pp. 601-603. Oct. 25, 1893.

955. Remarks on the avian genus Myiarchus, with special reference to $M$. $y u c a$ tanensis Lawrence. By Robert Ridgway. Pp. 605-608. Oct. 25, 1893.

956. On a small collection of birds from Costa Rica. By Robert Ridgway. Pp. 609614. Oct. 28, 1893.

957. Notes on a third installment of Japanese birds in the Science College Museum, Tokyo, Japan, with descriptions of new species. By Leonhard Stejneger. Pp. 615-638. Oct. 30, 1893.

958. Land shells of the genus Bulimulus in Lower California, with descriptions of several new species. By William Healey Dall. Pp. 639-647, 2 pls. Nov. 23, 1893.

959. Descriptions of new species of American fresh-water crabs. By Mary J. Rathbun. Pp. 649-661, 5 pls. Nov. 23, 1893. 
960. Scientific results of explorations by the U. S. Fish Commission steamer Albatross. No. XXVII.-Catalogue of a collection of birds made in Alaska by Mr. C. H. Townsend during the cruise of the U. S. Fish Commission steamer Albatross, in the summer and autumn of 1888. By Robert Ridgway. Pp. 663-665. Nov. 24, 1893.

961. A revision of the genus Formicarius Boddaert. By Robert Ridgway. Pp. 667686. Nov. 28, 1893.

962. Description of a new storm petrel from the coast of western Mexico. By Robert Ridgway. Pp. 687-688. Nov. 24, 1893.

963. Description of a new species of mouse (Sitomys decolorus) from Central America. By Frederick W. True. Pp. 689-690. Feb. 5, 1894.

964. Description of a new Geothlypis from Brownsville, Texas. By Robert Ridgway. Pp. 691-692. Feb. 5, 1894.

965. The proper generic name of the tunnies. By Theodore Gill. Pp. 693-694. Feb. 5, 1894.

966. The shell heaps of the east coast of Florida. By DeWitt Webb. Pp. 695-698, 7 pls. Apr. 9, 1894.

967. Description of a new blennioid fish from California. By Tarleton H. Bean. Pp. 699-701, 1 fig. Feb. 10, 1894.

968. Notes on Myriapoda from Loanda, Africa, collected by Mŕ. Heli Chatelaine, including a description of a new genus and species. By O. F. Cook. Pp. 703-708. Feb. 7, 1894.

969. Description of a new species of blind-snakes (Typhlopidae) from the Congo Free State. By Leonhard Stejneger. Pp. 709-710. Feb. 5, 1894.

970. On some collections of reptiles and batrachians from East Africa and the adjacent islands, recently received from Dr. W. L. Abbott and Mr. William Astor Chanler, with descriptions of new species. By Leonhard Stejneger. Pp. 711-741. Feb. 7, 1894.

971. Notes on recent collections of North American land, fresh water, and marine shells received from the U. S. Department of Agriculture. By Robert E. C. Stearns. Pp. 743-755. Feb. 5, 1894.

972. On the relationships of Taylor's mouse, Sitomys taylori. By Frederick W. True. Pp. 757-758. Feb. 7, 1894.

973. Notes on the natural history of Aldabra, Assumption and Glorioso Islands, Indian Ocean. By W. L. Abbott. Pp. 759-764. Feb. 9, 1894.

974. Remarks on Japanese quails. By Leonhard Stejneger. Pp. 765-769. Feb. 13, 1894.

975. Notes on birds of central Mexico, with descriptions of forms believed to be new. By P. L. Jouy. Pp. 771-791. Apr. 18, 1894.

\section{Volume 17}

Proceedings of the United States National Museum, vol. 17. Pp. i-xiii (title page, advertisement, table of contents, and list of plates); pp. 1-733 (Proceedings papers 976-1032); pp. 735-765 (index) ; 83 figs., 32 pls. 1895.

976. Notes on mammals of Baltistan and the Vale of Kashmir, presented to the National Museum by Dr. W. L. Abbott. By Frederick W. True. Pp. 1-16. May 8, 1894.

977. Description of a new lizard (Verticaria beldingi), from California. By Leonhard Stejneger. Pp. 17-18. May 4, 1894.

978. Note on a blue mineral, supposed to be ultramarine, from Silver City, New Mexico. By R. L. Packard. Pp. 19-20. May 4, 1894.

979. Descriptions of two new species of crabs from the western Indian Ocean, presented to the National Museum by Dr. W. L. Abbott. By Mary J. Rathbun. Po. 21-24. May 4. 1894. 
Proc.

No.

980. Descriptions of a new genus and two new species of African fresh-water crabs. By Mary J. Rathbun. Pp. 25-27. May 4, 1894.

981. An analysis of jadeite from Mogoung, Burma. By Oliver C. Farrington. Pp. 29-31. July 29, 1894.

982. Notes on some skeletons and skulls of porpoises of the genus Prodelphinus, collected by Dr. W. L. Abbott in the Indian Ocean. By Frederick W. True. Pp. 33-37. July 19, 1894.

983. Description of nests and eggs of some new birds, collected on the Island of Aldabra, northwest of Madagascar, by Dr. W. L. Abbott. By Charles Bendire. Pp. 39-41. July 19, 1894.

984. Notes on the crabs of the family Inachidae in the United States National Museum. By Mary J. Rathbun. Pp. 43-75, 1 pl. July 21, 1894.

985. On the formation of stalactites and gypsum incrustations in caves. By George P. Merrill. Pp. 77-81, 4 pls. July 28, 1894.

986. Descriptions of a new genus and four new species of crabs from the Antillean region. By Mary J. Rathbun. Pp. 83-86. July 21, 1894. (Advance sheets issued Mar, 30, 1894.)

987. The formation of sandstone concretions. By George P. Merrill. Pp. 87-88, 1 pl. July $23,1894$.

988. Monograph of the genus Gnathodon, Gray (Rangia, Desmoulins). Bv Wm. H. Dall. Pp. 89-106, 1 pl. July 23, 1894.

989. On the nomenclature and characteristics of the lampreys. By Theodore Gill. Pp. 107-110. July 23, 1894.

990. The nomenclature of the Myliobatidae or Aëtobatidae. By Theodore Gill. Pp. 111-114. July 23, 1894.

991. The nomenclature of the family Poeciliidae or Cyprinodontidae. By Theodore Gill. Pp. 115-116. July 19, 1894.

992. The differential characters of the Salmonidae and Thymallidae. By Theodore Gill. Pp. 117-122. July 19, 1894.

993. On the relations and nomenclature of Stizostedion or Lucioperca. By Theodore Gill. Pp. 123-128. July 21, 1894.

994. Description of a new species of cotton rat (Sigmodon minima) from New Mexico. By Edgar A. Mearns. Pp. 129-130. July 19, 1894.

995. Notes on the invertebrate fauna of the Dakota formation, with descriptions of new molluscan forms. By Charles A. White. Pp. 131-138, 1 pl. July 19, 1894.

996. The shells of the Tres Marias and other localities along the shores of Lower California and the Gulf of California. By Robert E. C. Stearns. Pp. 139-204. July 19, 1894.

997. Notes on a Japanese species of reed warbler. By Leonhard Stejneger. Pp. 205-206. July 21, 1894.

998. A review of the fossil flora of Alaska, with descriptions of new species. By F. H. Knowlton. Pp. 207-240, 1 pl. Aug. 2, 1894.

999. Diagnoses of new North American mammals. By Frederick W. True. Pp. 241-243. Nov. 15, 1894. (Advance sheets issued Apr. 26, 1894.)

1000. Descriptions of new species of starfishes and ophiurans, with a revision of certain species formerly described; mostly from the collections made by the United States Commission of Fish and Fisheries. By A. E. Verrill. Pp. 245297. Nov. 15, 1894.

1001. Notes on the anatomy and affinities of the Coerebidae and other American birds. By Frederic A. Lucas. Pp. 299-312, 13 figs. Nov. 15, 1894.

1002. Discovery of the genus Oldhamia in America. By Charles D. Walcott. Pp. 313-315, 1 fig. Nov. 15, 1894.

1003. Notes on reptiles and batrachians collected in Florida in 1892 and 1893. By Einar Loennberg. Pp. 317-339, 3 figs. Nov. 15, 1894.

1004. On the rodents of the genus Sminthus in Kashmir. By Frederick W. True. Pp. 341-343. Nov. 15, 1894. 
Proc.

1005. The relationship of the lacertilian genus Anniella, Gray. By G. Baur. Pp. 345-351. Nov. 15, 1894.

1006. Diagnoses of some undescribed wood rats (genus Neotoma) in the National Museum. By Frederick W. True. Pp. 353-355. Nov. 15, 1894. (Advance sheets issued June 27, 1894.)

1007. Descriptions of twenty-two new species of birds from the Galapagos Islands. By Robert Ridgway. Pp. 357-370. Nov. 15, 1894.

1008. Descriptions of some new birds from Aldabra, Assumption, and Gloriosa Islands, collected by Dr. W. L. Abbott. By Robert Ridgway. Pp. 371-373. Nov. 15, 1894.

1009. A revision of the fishes of the subfamily Sebastinae of the Pacific coast of America. By Carl H. Eigenmann and Charles H. Beeson. Pp. 375-407. Nov. 15, 1894.

1010. Additional notes on the native trees of the lower Wabash Valley. By Robert Ridgway. Pp. 409-421, 6 pls. Jan. 24, 1895.

1011. Distribution of the land and fresh-water mollusks of the West Indian region, and their evidence with regard to past changes of land and sea. By Charles Torrey Simpson. Pp. 423-450, 1 pl. Jan. 26, 1895.

1012. Scientific results of explorations by the U. S. Fish Commission steamer Albatross. No. XXVIII.-On Cetomimidae and Rondeletiidae, two new families of bathybial fishes from the northwestern Atlantic. By G. Brown Goode and Tarleton H. Bean. Pp. 451-454, 1 pl. Jan. 26, 1895.

1013. Scientific results of explorations by the U. S. Fish Commission steamer Alba. tross. No. XXIX.-A revision of the order Heteromi, deep-sea fishes, with a description of the new generic types Macdonaldia and Lipogenys. By G. Brown Goode and Tarleton H. Bean. Pp. 455-470, 1 pl. Jan. 26, 1895.

1014. Scientific results of explorations by the U. S. Fish Commission steamer Albatross. No. XXX.-On Harriotta, a new type of chimaeroid fish from the deeper waters of the northwestern Atlantic. By G. Brown Goode and Tarleton H. Bean. Pp. 471-473, 1 pl. Jan. 26, 1895.

1015. Overlaying with copper by the American aborigines. By Otis T. Mason. Pp. 475-477, 4 figs. Jan. 26, 1895.

1016. Scientific results of explorations by the U. S. Fish Commission steamer Albatross. No. XXXI.-Descriptions of new genera and species of crabs of the family Lithodidae, with notes on the young of Lithodes camtschaticus and Lithodes brevipes. By James E. Benedict. Pp. 479-488. Jan. 29, 1895.

1017. Scientific results of explorations by the U. S. Fish Commission steamer Albatross. No. XXXII.-Report on the Crustacea of the order Stomatopoda collected by the steamer Albatross between 1885 and 1891, and on other specimens in the U. S. National Museum. By Robert Payne Bigelow. Pp. 489-550, 28 figs., 3 pls. Feb. 5, 1895.

1018. The pterylography of certain American goat-suckers and owls. By Hubert Lyman Clark. Pp. 551-572, 11 figs. May 11, 1895.

1019. The box tortoises of North America. By W. E. Taylor. Pp. 573-588, 7 figs. May 11, 1895.

1020. Description of Uta mearnsi, a new lizard from California. By Leonhard Stejneger. Pp. 589-591. May 11, 1895. (Advance sheets issued Nov. 30, 1894.)

1021. Notes on Butler's garter snake. By Leonhard Stejneger. Pp. 593-594. May, $11,1895$.

1022. On the specific name of the coachwhip snake. By Leonhard Stejneger. Pp. 595-596. May 11, 1895.

1023. Description of a new salamander from Arkansas with notes on Ambystoma annulatum. By Leonhard Stejneger. Pp. 597-599. May 11, 1895.

1024. Diagnosis of a new genus of trogons (Heterotrogen), based on Hapaloderma vittatum of Shelley; with a description of the female of that species. By Charles W. Richmond. Pp. 601-603. May 11, 1895.

1025. On the bothriothoracine insects of the United States. By L. O. Howard. Pp. 605-613. May 11, 1895. 
1026. Notes on the geographical distribution of scale insects, By T. D. A. Cockerell. Pp. 615-625. May 11, 1895.

1027. Description of a new species of rockfish, Scbastichthys brevispinis, from Alaska. By Tarleton H. Bean. Pp. 627-628. May 11, 1895,

1028. Description of a new species of fish, Bleekeria gilli. By Tarleton H. Bean. Pp. 629-630. May 11, 1895.

1029. Description of Gobioides broussoneti, a fish new to North America, from the Gulf of Mexico. By Tarleton H. Bean and Barton A. Bean. Pp. 631-632, 1 fig. May 11, 1895.

1030. Scientific results of explorations by the U. S. Fish Commission steamer Albatross. No. XXXIII.-Descriptions of two new flounders, Gastropsetta frontalis and Cyclopsetta chittendeni. By Barton A. Bean. Pp. 633-636, 3 figs. May 11, 1895.

1031. Notes on some eruptive rocks from Gallatin, Jefferson, and Madison Counties, Montana. By George P. Merrill. Pp. 637-673, 10 figs. May 11, 1895.

1032. Scientific results of explorations by the U. S. Fish Commission steamer Albatross. No. XXXIV.-Report on Mollusca and Brachiopoda dredged in deep water, chiefly near the Hawaiian Islands, with illustrations of hitherto unfigured species from northwest America. By William Healey Dall. Pp. 675-733, 3 figs., 10 pls. 1895 (exact date of publication unknown).

\section{Volume 18}

Proceedings of the United States National Museum, vol. 18. Pp. i-xiv (title page, advertisement, table of contents, list of plates, and list of corrections); pp. 1-781 (Proceedings papers 1033-1100); pp. 783-819 (index); 51 figs., 35 pls. 1896.

1033. Diagnoses of new mollusks from the survey of the Mexican boundary. By W. H. Dall. Pp. 1-6. Apr. 28, 1896.

1034. Diagnoses of new species of mollusks from the west coast of America. By W. H. Dall. Pp. 7-20. Apr. 23, 1896.

1035. Diagnoses of new Tertiary fossils from the southern United States. By W. H. Dall. Pp. 21-46. Apr. 23, 1896.

1036. Two new diplopod Myriapoda of the genus Oxydesmus from the Congo. By O. F. Cook. Pp. 47-52. Apr. 23, 1896.

1037. Priadesmus, new genus of Diplopoda from Surinam. By O. F. Cook. Pp. 53-57, 1 pl. Apr. 23, 1896.

1038. On Geophilus attenuatus, Say, of the class Chilopoda. By O. F. Cook. Pp. 59-62. Apr. 23, 1896.

1039. An arrangement of the Geophilidae, a family of Chilopoda. By O. F. Cook. Pp. 63-75. Apr. 23, 1896.

1040. Description of a new species of golden beetle from Costa Rica. By Martin L. Linell. Pp. 77-78. Apr. 23, 1896. (Advance sheets issued Jan. 12, 1895.)

1041. Two new species of beetles of the tenebrionid genus Echocerus. By F. H. Chittenden. Pp. 79-80. Apr. 23, 1896. (Advance sheets issued Jan. 16, 1895.)

1042. East African Diplopoda of the suborder Polydesmoidea, collected by Mr. William Astor Chanler. By O. F. Cook. Pp. 81-111, 5 pls. Apr. 23, 1896.

1043. Description of a new species of pipefish (Siphostoma scovelli) from Corpus Christi, Texas. By Barton W. Evermann and William C. Kendall. Pp. 113115. Apr. 16, 1896.

1044. Description of a new species of snake (Tantilla eiseni) from California. By Leonhard Stejneger. Pp. 117-118. Apr. 16, 1896.

1045. Description of a new species of ground warbler from eastern Mexico. By Robert Ridgway. Pp. 119-120. Apr. 16, 1896.

1046. East African Odonata, collected by Doctor W. L. Abbott. By Philip P. Calvert. Pp. 121-142, 15 figs. Apr. 23, 1896.

1047. Notes on the Odonata from east Africa, collected by the Chanler Expedition. By Philip P. Calvert. Pp. 143-145. Apr. 23, 1896. 
1048. On the proper name of the gunnels or butterfishes. By Theodore Gill. Pp 147-151. Apr. 23, 1896.

1049. The differential characters of the syngnathid and hippocampid fishes. By Theodore Gill. Pp. 153-159. Apr. 23, 1896.

1050. Notes on the synonymy of the Torpedinidae or Narcobatidae. By Theodore Gill. Pp. 161-165. Apr. 23, 1896.

1051. The families of synentognathous fishes and their nomenclature. By Theodor Gill. Pp. 167-178. Apr. 23, 1896.

1052. On the application of the name Teuthis to a genus of fishes. By Theodore Gill. Pp. 179-189. Apr. 23, 1896.

1053. Notes on the nomenclature of Scymnus or Scymnorhinus, a genus of sharks. By Theodore Gill. Pp. 191-193. May 27, 1896.

1054. Notes on the genus Cephaleutherus of Rafinesque, and other rays with aberrant pectoral fins (Propterygia and Hieroptera). By Theodore Gill. Pp. 195198. Apr. 23, 1896.

1055. Notes on characinoid fishes with ctenoid scales, with a description of a new Psectrogaster. By Theodore Gill. Pp. 199-203. May 27, 1896.

1056. The differential characters of characinoid and erythrinoid fishes. By Theodore Gill. Pp. 205-209. Apr. 23, 1896.

1057. Notes on Orectolobus or Crossorhinus, a genus of sharks. By Theodore Gill. Pp. 211-212. Apr. 16, 1896.

1058. Note on the fishes of the genus Characinus. By Theodore Gill. Pp. 213-215. Apr. 16, 1896.

1059. The nomenclature of Rachicentron or Elacate, a genus of acanthopterygian fishes. By Theodore Gill. Pp. 217-219. Apr. 23, 1896.

1060. Note on the nomenclature of the poecilioid fishes. By Theodore Gill. Pp. 221-224. Apr. 23, 1896.

1061. The nomenclature of the fishes of the characinoid genus Tetragonopterus. By Theodore Gill. Pp. 225-227. Apr. 23, 1896.

1062. List of the Lepidoptera collected in eastern Africa by Dr. W. L. Abbott, witb descriptions of some apparently new species. By W. J. Holland. Pp. 229258. May 27, 1896.

1063. List of Lepidoptera collected in Somali-land, East Africa, by Mr. William Astor Chanler and Lieutenant Von Hoehnel. By W. J. Holland. Pp. 259264. May 27, 1896.

1064. List of the Lepidoptera from Aldabra, Seychelles, and other East African islands, collected by Dr. W. L. Abbott. By W. J. Holland. Pp. 265-273. May 27, 1896.

1065. List of the Lepidoptera collected in Kashmir by Dr. W. L. Abbott. By W. J. Holland. Pp. 275-279, 2 pls. May 27, 1896.

1066. Notes on asbestos and asbestiform minerals. By George P. Merrill. Pp. 281292, 5 figs. Apr. 23, 1896.

1067. Preliminary description of some new birds from the Galapagos Archipelago. By Robert Ridgway. Pp. 293-294. 1896 (exact date of publication unknown).

- 1068. The classification and geographical distribution of the pearly fresh-water mussels. By Charles T. Simpson. Pp. 295-343, 1 pl. May 19, 1896.

1069. Note on the occurrence of an armadillo of the genus Xenurus in Honduras. By Frederick W. True. Pp. 345-347, 2 pls. July 8, 1896.

1070. The genus Callinectes. By Mary J. Rathbun. Pp. 349-375, 17 pls. July 8, 1896.

1071. Descriptions of two new species of fresh-water crabs from Costa Rica. By Mary J. Rathbun. Pp. 377-379, 3 figs., 2 pls. July 8, 1896.

- 1072. Description of four new Triassic Unios from the Staked Plains of Texas. By Charles Torrey Simpson. Pp. 381-385, 5 figs. May 19, 1896.

1073. Revision of the North American Empidae-a family of two-winged insects. By D. W. Coquillett. Pp. 387-440. May 25, 1896.

1074. Description of a new subspecies of the genus Peucedramus, Coues. By Robert Ridgway. P. 441. May 21, 1896. 
1075. Preliminary diagnoses of new mammals from the Mexican border of the United States. By Edgar A. Mearns. Pp. 443-447. May 23, 1896. (Advance sheets issued Mar. 25, 1896.)

1076. Characters of a new American family of passerine birds. By Robert Ridgway. Pp. 449-450. June 24, 1896.

1077. Osteological and pterylographical characters of the Procniatidae. By F. A. Lucas. Pp. 505-507, 5 figs. June 24, 1896.

1078. Catalogue of a collection of birds made by Doctor W. L. Abbott in Kashmir, Baltistan and Ladak, with notes on some of the species, and a description of a new species of Cyanecula. By Charles W. Richmond. Pp. 451-503. June 24, 1896.

1079. On birds collected by Doctor W. L. Abbott in the Seychelles, Amirantes, Gloriosa, Assumption, Aldabra, and adjacent islands, with notes on habits, etc., by the collector. By Robert Ridgway. Pp. 509-546. June 24, 1896.

1080. Descriptions of two new subspecies of the downy woodpecker, Dryobates pubescens (Linnaeus). By Harry C. Oberholser. Pp. 547-550. June 24, 1896.

1081. Preliminary description of a new subgenus and six new species and subspecies of hares, from the Mexican border of the United States. By Edgar A. Mearns. Pp. 551-565. June 24, 1896.

1082. Note on Plectroplites and Hypoplectrodes, genera of serranoid fishes. By Theodore Gill. Pp. 567-568. July 24, 1896.

1083. Catalogue of a collection of birds made by Doctor W. L. Abbott in eastern Turkestan, the Thian-Shan Mountains, and Tagdumbash Pamir, central Asia, with notes on some of the species. By Charles W. Richmond. Pp. 569-591. July 25, 1896.

1084. Descriptions of three species of sand fleas (amphipods) collected at Newport, Rhode Island. By Sylvester D. Judd. Pp. 593-603, 11 figs. July 25, 1896.

1085. Remarks on the synonymy of some North American scolytid beetles. By William Eichhoff. (Translated and annotated by E. A. Schwarz.) Pp. 605-610, Aug. 12, 1896.

1086. Fossil jelly fishes from the Middle Cambrian terrane. By Charles D. Walcott. Pp. 611-614, 2 pls. Aug. 12, 1896.

1087. Preliminary descriptions of a new genus and three new species of crustaceans from an artesian well at San Marcos, Texas. By James E. Benedict. Pp. 615-617, Aug. 12, 1896. (Advance sheets issued Apr. 14, 1896.)

1088. Description of a new genus and species of blind tailed batrachians from the subterranean waters of Texas. By Leonhard Stejneger. Pp. 619-621. Aug. 12, 1896. (Advance sheets issued Apr. 15, 1896.)

1089. Description of a new stickleback, Gasterosteus gladiunculus, from the coast of Maine. By W. C. Kendall. Pp. 623-624. Aug. 12, 1896.

1090. Description of a new species of ant thrush from Nicaragua. By Charles W. Richmond. Pp. 625-626. Aug. 12, 1896.

1091. Partial list of birds collected at Alta Mira, Mexico, by Mr. Frank B. Armstrong. By Charles W. Richmond. Pp. 627-632. Aug. 12, 1896.

1092. On some reared parasitic hymenopterous insects from Ceylon. By L. O. Howard and Wm. H. Ashmead. Pp. 633-648. Aug. 12, 1896.

1093. An annotated list of birds observed on the Island of Margarita, and at Guanta and Laguayra, Venezuela. By Wirt Robinson, with critical notes and descriptions of new species by Charles W. Richmond. Pp. 649-685, 1 fig., 1 pl. Aug. 12, 1896.

1094. List of Coleoptera collected on the Tana River, and on the Jombene Range, East Africa, by Mr. William Astor Chanler and Lieutenant Ludwig von Höhnel, with descriptions of new genera and species. By Martin L. Linell. Pp. 687-716. Aug. 12, 1896.

1095. Contributions to the natural history of the Commander Islands. XI.-The cranium of Pallas's cormorant. By Frederic A. Lucas. Pp. 717-719, 2 pls. Oct. $7,1896$.

1096. New species of North American Coleoptera of the family Scarabaeidae. By Martin L. Linell. Pp. 721-731. Oct. 7, 1896. 
Proc.

No.

1097. Observations on the development and migration of the urticating organs of sea nettles, Cnidaria. By Louis Murbach. Pp. 733-740. Oct. 7, 1896.

1098. List of the Lepidoptera collected in East Africa, 1894, by Mr. William Astor Chanler and Lieutenant Ludwig von Höhnel. By W. J. Holland. Pp. 741767. Oct. 7, 1896.

1099. Notes on the vampire bat (Diphylla ecaudata), with special reference to its relationships with Desmodus rufus. By Harrison Allen. Pp. 769-777, 6 figs. Oct. $27,1896$.

1100. Description of a new species of bat of the genus Glossophaga. By Harrison Allen. Pp. 779-781. Oct. 27, 1896.

\section{Volume 19}

Proceedings of the United States National Museum, vol. 19. Pp. i-viii (title page, advertisement, table of contents, and list of plates); pp. 1-824 (Proceedings papers 1101-1123) ; pp. 825-864 (index) ; 53 figs., 5 maps, 48 charts, 68 pls. 1897.

1101. A revision of the American moles. By Frederick W. True. Pp. 1-112, 46 figs., 5 maps, 4 pls, Dec. 21, 1896.

1102. Descriptions of new cynipidous galls and gall-wasps in the United States National Museum. By William H. Ashmead. Pp. 113-136. Dec. 30, 1896.

1103. Preliminary diagnoses of new mammals from the Mexican border of the United States. By Edgar A. Mearns. Pp. 137-140. Dec. 21, 1896. (Advance sheets issued May 25, 1896.)

1104. Description of a new genus and four new species of crabs from the Weat Indies. By Mary J. Rathbun. Pp. 141-144. Dec. 21, 1896.

1105. A revision of the adult tapeworms of hares and rabbits. By Ch. Wardell Stiles. Pp. 145-235, 21 pls. Dec. 30, 1896.

1106. Contributions to the natural history of the Commander Islands. XII.-Fishes collected at Bering and Copper Islands by Nikolai A. Grebnitski and Leonhard Stejneger. By Tarleton H. Bean and Barton A. Bean. Pp. 237-251. Dec. 30, 1896.

1107. Is the Florida box tortoise a distinct species? By Einar Lönnberg. Pp. 253254. Dec. 30, 1896.

1108. Summary of the Hemiptera of Japan, presented to the United States National Museum by Professor Mitzukuri. By Philip R. Uhler. Pp. 255-297. Dec. $30,1896$.

1109. On the genus Remondia, Gabb, a group of Cretaceous bivalve mollusks. By Timothy W. Stanton. Pp. 299-301, 1 pl. Dec. 30, 1896.

- 1110. Descriptions of Tertiary fossils from the Antillean region. By R. J. Lechmere Guppy and William Healey Dall. Pp. 303-331, 4 pls. Dec. 30, 1896.

1111. Report on the mollusks collected by the International Boundary Commission of the United States and Mexico, 1892-1894. By William Healey Dall. Pp. 333-379, 3 pls. Jan. 27, 1897.

1112. Notes on fishes collected in Kamchatka and Japan by Leonhard Stejneger and Nicolai A. Grebnitski, with a description of a new blenny. By Tarleton H. Bean and Barton A. Bean. Pp. 381-392, 2 pls. Jan. 27, 1897.

1113. Descriptions of new species of North Amercan Coleoptera in the families Cerambycidae and Scarabaeidae. By Martin L. Linell. Pp. 393-401. Feb. $5,1897$.

1114. Report on the fishes dredged in deep water near the Hawaiian Islands, with descriptions and figures of twenty-three new species. By Charles Henry Gilbert and Frank Cramer. Pp. 403-435, 13 pls. Feb. 5, 1897.

1115. Descriptions of twenty-two new species of fishes collected by the steamer Albatross, of the United States Fish Commission. By Charles Henry Gilbert. Pp. 437-457, 7 pls. Feb. 5, 1897.

1116. Birds of the Galapagos Archipelago. By Robert Ridgway. Pp. 459-670, 7 figs., 2 pls., 48 charts. Mar. 15, 1897.

1117. On the fossil phyllopod genera, Dipeltis and Protocaris, of the family Apodidae. By Charles Schuchert. Pp. 671-676, 1 pl. May 13, 1897. 
1118. Catalogue of a collection of birds made by Doctor W. L. Abbott in Madagascar, with descriptions of three new species. By Charles W. Richmond. Pp. 677-694. May 13, 1897.

1119. On the insects collected by Doctor Abbott on the Seychelles, Aldabra, Glorioso, and Providence Islands, with descriptions of nine new species of Coleoptera. By Martin L. Linell. Pp. 695-706. May 13, 1897.

1120. Cambrian Brachiopoda: Genera Iphidea and Yorkia, with descriptions of new species of each, and of the genus Acrothele. By Charles D. Walcott. Pp. 707-718, 2 pls. Aug. 27, 1897.

1121. Descriptions of six new mammals from North America. By Edgar A. Mearns. Pd. 719-724. July 30, 1897.

1122. The food plants of scale insects (Coccidae). By T. D. A. Cockerell. Pp. 725-785. Aug. 14, 1897.

1123. Notes on larval cestode parasites of fishes. By Edwin Linton. Pp. 787-824, 8 pls. Oct. 4, 1897.

\section{Volume 20}

Proceedings of the United States National Museum, vol. 20. Pp. i-xii (title page, advertisement, table of contents, list of illustrations, and errata) ; pp. 1-901 (Proceedings papers 1124-1139); pp. 903-932 (index) ; 149 figs., 97 pls. 1898.

1124. Revision of the orthopteran group Melanopli (Acridiidae), with special reference to North American forms. By Samuel Hubbard Scudder. Pp. 1-421, 26 pls. Dec. 28, 1897.

1125. Notes on cestode parasites of fishes. By Edwin Linton. Pp. 423-456, 8 pls. Dec. 24, 1897.

1126. Preliminary diagnoses of new mammals of the genera Lynx, Urocyon, Spilogale, and Mephitis, from the Mexican boundary line. By Edgar A. Mearns. Pp. 457-461. Dec. 24, 1897. (Advance sheets issued Jan. 12, 1897.)

1127. Description of a new blenny-like fish of the genus Opisthocentrus, collected in Vulcano Bay, Port Mororan, Japan, by Nicolai A. Grebnitski. By Tarleton H. Bean and Barton A. Bean. Pp. 463-464, 1 pl. Dec. 24, 1897. (Advance sheets issued Jan. 28, 1897.)

1128. Description of a new crustacean of the genus Sphaeroma from a warm spring in New Mexico. Pp. 465-466. Dec. 24, 1897. (Advance sheets issued Feb. 6, 1897.)

1129. Preliminary diagnoses of new mammals of the genera Mephitis, Dorcelaphus, and Dicotyles, from the Mexican border of the United States. By Edgar A. Mearns. Pp. 467-471. Dec. 24, 1897. (Advance sheets issued Feb. 11, 1897.)

1130. New species of Coleoptera of the family Chrysomelidae, with a short review of the tribe Chlamydini. By Martin L. Linell. Pp. 473-485. Jan. 5, 1898.

1131. Notes on a collection of fishes from the Colorado Basin in Arizona. By Charles Henry Gilbert and Norman Bishop Scofield. Pp. 487-499, 4 pls. Jan. 19, 1898.

1132. Preliminary diagnoses of new mammals of the genera Sciurus, Castor, Neotoma, and Sigmodon, from the Mexican border of the United States. By Edgar A. Mearns. Pp. 501-505. Jan. 19, 1898. (Advance sheets issued Mar. 5, 1897.)

1133. Notes on trematode parasites of fishes. By Edwin Linton. Pp. 507-548, 15 pls. Jan. 20, 1898.

1134. Contributions to Philippine ornithology. Part I.-A list of the birds known to inhabit the Philippine and Palawan Islands, showing their distribution within the limits of the two groups. By Dean C. Worcester and Frank S. Bourns. Part II. - Notes on the distribution of Philippine birds. By Dean C. Worcester. Pp. 549-625, 7 pls. Feb. 17, 1898.

1135. Supplement to the annotated catalogue of the published writings of Charles Abiathar White, 1886-1897. By Timothy W. Stanton. Pp. 627-642. Feb. $12,1898$. 
1136. Observations on the Astacidae in the United States National Museum and in the Museum of Comparative Zoology, with descriptions of new species. By Walter Faxon. Pp. 643-694, 9 pls. Feb. 17, 1898.

1137. A revision of tropical African Diplopoda of the family Strongylosomatidae. By O. F. Cook. Pp. 695-708. Mar. 8, 1898.

1138. American leaf-hoppers of the subfamily Typhlocybinae. By Clarence P. Gillette. Pp. 709-773, 149 figs. Apr. 20, 1898.

1139. Revision of the deep-water Mollusca of the Atlantic coast of North America, with descriptions of new genera and species. Part I.-Bivalvia. By Addison E. Verrill and Katherine J. Bush. Pp. 775-901, 27 pls. June 15, 1898.

\section{Volume 21}

Proceedings of the Unted States National Museum, vol. 21. Pp. i-xiii (title page, advertisement, table of contents, and list of illustrations); pp. 1-901 (Proceedings papers 1140-1178); pp. 903-933 (index); 105 figs., 89 pls. 1899.

1140. Contributions toward a monograph of the lepidopterous family Noctuidae of boreal North America. A revision of the species of Acronycta (Ochsenheimer) and of certain allied genera. By John B. Smith and Harrison G. Dyar. Pp. 1-194, 22 pls. Nov. 17, 1898.

1141. Descriptions of the species of Cycadeoidea, or fossil cycadean trunks, thus far determined from the Lower Cretaceous rim of the Black Hills. By Lester F. Ward. Pp. 195-229. Oct. 29, 1898.

1142. On some new parasitic insects of the subfamily Encyrtinae. By L. O. Howard. Pp. 231-248. Oct. 4, 1898.

1143. On the coleopterous insects of Galapagos Islands. By Martin L. Linell. Pp. 249-268. Oct. 4, 1898.

1144. The birds of the Kuril Islands. By Leonhard Stejneger. Pp. 269-296. Oct. 4, 1898.

1145. Description of a species of Actaeon from the Quaternary bluffs at Spanish Bight, San Diego, California. By Robert E. C. Stearns. Pp. 297-299, 1 fig. Nov. 2, 1898.

1146. Report on a collection of Japanese Diptera, presented to the U. S. National Museum by the Imperial University of Tokyo. By D. W. Coquillett. Pp. 301-340. Nov. 4, 1898.

1147. Notes on the mammals of the Catskill Mountains, New York, with general remarks on the fauna and flora of the region. By Edgar A. Mearns. Pp. 341-360, 6 figs. Nov. 4, 1898.

1148. Topaz crystals in the mineral collection of the U. S. National Museum. By Arthur S. Eakle. Pp. 361-369, 22 figs. Nov. 10, 1898.

1149. Notes on Cytherea (Tivela) crassatelloides Conrad, with descriptions of many varieties. By Robert E. C. Stearns. Pp. 371-378, 3 pls. Nov. 10, 1898.

1150. On the occurrence of Amphiuma, the so-called Congo snake, in Virginia. By Hugh M. Smith. Pp. 379-380. Nov. 10, 1898.

1151. Description of a new species of spiny-tailed iguana from Gautemala. By Leonhard Stejneger. Pp. 381-383. Nov. 10, 1898.

1152. Cambrian Brachiopoda: Obolus and Lingulella, with descriptions of new species. By Charles D. Walcott. Pp. 385-420, 3 pls. Nov. 19, 1898.

1153. A revision of the wrens of the genus Thryomanes Sclater. By Harry C. Oberholser. Pp. 421-450. Nov. 19, 1898.

1154. American oniscoid Diplopoda of the order Merocheta. By O. F. Cook. Pp. 451-468, 4 pls. Nov. 19, 1898.

1155. The osteology and relationships of the family Zeidae. By Edwin Chapin Starks. Pp. 469-476, 6 pls. Nov. 21, 1898.

1156. A contribution to the knowledge of the variations of the tree frog $\mathrm{Hyla}$ regilla. By Frederick Cleveland Test. Pp. 477-492, 1 pl. Nov. 19, 1898.

1157. Japanese Hymenoptera of the family Tenthredinidae. By C. L. Marlatt. Fp. 493-506. Nov. 21, 1898. 
1158. A contribution to a knowledge of the fresh-water crabs of America-the Pseudothelphusinae. By Mary J. Rathbun. Pp. 507-537, 18 figs. Nov. 21, 1898.

1159. Notes on a collection of fishes from Mexico, with description of a new species of Platypoecilus. By Barton A. Bean. Pp. 539-542, 1 fig. Nov. 21, 1898.

1160. The leeches of the U. S. National Museum. By J. Percy Moore. Pp. 543-563, 1 pl. Nov. 21, 1898.

1161. On the occurrence of Caulolepis longidens Gill, on the coast of California. By Charles Henry Gilbert. Pp. 565-566. Nov. 21, 1898.

1162. The Brachyura collected by the U. S. Fish Commission steamer Albatross on the voyage from Norfolk, Virginia, to San Francisco, California, 1887-1888. By Mary J. Rathbun. Pp. 567-616, 4 pls. Nov. 22, 1898.

1163. On the nomenclature of the whalebone whales of the tenth edition of Linnaeus's Systema Naturae. By Frederick W. True. Pp. 617-635. Nov. 4, 1898.

1164. A new snake from the Eocene of Alabama. By F. A. Lucas. Pp. 637-638, 2 pls. Dec. 20, 1898.

1165. Notes on the capture of rare fishes. By Barton A. Bean. Pp. 639-640. Dec. 20, 1898.

1166. The feather-tracts of North American grouse and quail. By Hubert Lyman Clark. Pp. 641-653, 4 figs., 3 pls. Jan. 4, 1899.

1167. Note on Oxycottus acuticeps (Gilbert) from Sitka and Kadiak, Alaska. By Tarleton H. Bean and Barton A. Bean. Pp. 655-656. Dec. 20, 1898.

1168. African Diplopoda of the genus Pachybolus. By O. F. Cook. Pp. 657-666, 3 pls. Mar. 17, 1899.

1169. The diplopod family Striariidae. By O. F. Cook. Pp. 667-676, 2 pls. Mar. 30, 1899.

1170. African Diplopoda of the family Gomphodesmidae. By O. F. Cook. Pp. 677-739, 7 pls. Mar. 30, 1899.

1171. Hydroida from Alaska and Puget Sound. By Charles Cleveland Nutting. Pp. 741-753, 3 pls. Apr. 29, 1899.

1172. The fossil bison of North America. By Frederick A. Lucas. Pp. 755-771, 2 figs., 20 pls. May 13, 1899.

1173. Petrographic report on rocks from the United States-Mexico boundary. By Edwin C. E. Lord. Pp. 773-782, 1 pl. May 22, 1899.

1174. The land reptiles of the Hawaiian Islands. By Leonhard Stejneger. Pp. 783813, 13 figs. June 5, 1899.

1175. Key to the isopods of the Pacific coast of North America, with descriptions of twenty-two new species. By Harriet Richardson. Pp. 815-869, 34 figs. June 5, 1899.

1176. Description of a new species of subterranean isopod. By W. P. Hay. Pp. 871-872, 1 pl. June 1, 1899.

1177. Synopsis of the Recent and Tertiary Leptonacea of North America and the West Indies. By William H. Dall. Pp. 873-897, 2 pls. June 26, 1899.

1178. Description of a new genus and species of discoglossoid toad from North America. By Leonhard Stejneger. Pp. 899-901, 4 figs., 1 pl. June 20, 1899.

\section{Volume 22}

Proceedings of the United States National Museum, vol. 22. Pp. i-xii (title page, advertisement, table of contents, list of illustrations, and errata) ; pp. 1-1044 (Proceedings papers 1179-1205); pp. 1045-1075 (index); 15 figs., 18 pls. 1900.

1179. The osteological characters of the fishes of the suborder Percesoces. By Edwin Chapin Starks. Pp. 1-10, 3 pls. Oct. 7, 1899.

1180. Notes on birds from the Cameroons district, West Africa. By Harry C. Oberholser. Pp. 11-19. Oct. 7, 1899.

1181. Descriptions of two new species of tortoises from the Tertiary of the United States. By O. P. Hay. Pp. 21-24, 3 pls. Oct. 7, 1899.

1182. A list of the birds collected by Mr. R. P. Currie in Liberia. By Harry C. Oberholser Pp. 25-37, 1 pl. Oct. 9, 1899.

1183. A list of the biting lice (Mallophaga) taken from birds and mammals of North America. By Vernon L. Kellogg. Pp. 39-100. Oct. 9, 1899. 
1184. New species of nocturnal moths of the genus Campometra, and notes. By John B. Smith. Pp. 101-105. Oct. 9, 1899.

1185. Synopsis of the Solenidae of North America and the Antilles. By William H. Dall. Pp. 107-112. Oct. 9, 1899.

1186. The osteology and relationship of the percoidean fish, Dinolestes lequini. By Edwin Chapin Starks. Pp. 113-120, 4 pls. Oct. 11, 1899.

1187. Description of two new species of crayfish. By W. P. Hay. Pp. 121-123, 2 figs. Oct. 11, 1899.

1188. Contributions to the natural history of the Commander Islands. No. XIII.-A new species of stalked Medusae, Haliclystus stejnegeri. By K. Kishinouye. Pp. 125-129, 3 figs. Dec. 23, 1899.

1189. Description of a new species of Idotea from Hakodate Bay, Japan. By Harriet Richardson. Pp. 131-134, 6 figs. Feb. 2, 1900.

1190. List of shells collected by Vernon Bailey in Heron and Eagle Lakes, Minnesota. with notes. By Robert E. C. Stearns. Pp. 135-138. Apr. 7, 1900.

1191. Description of a new variety of Haliotis from California, with faunal and geographical notes. By Robert E. C. Stearns. Pp. 139-142. Apr. 7, 1900.

1192. On the lower Silurian (Trenton) fauna of Baffin Land. By Charles Schuchert. Pp. 143-177, 2 figs., 3 pls. Apr. 9, 1900.

1193. Some Neocene corals of the United States. By Henry Stewart Gane. Pp. 179198, 1 pl. Apr. 20, 1900.

1194. A new fossil species of Caryophyllia from California, and a new genus and species of turbinolid coral from Japan. By T. Wayland Vaughan. Pp. 199-203, 1 pl. Apr. 20, 1900.

1195. Notes on birds collected by Doctor W. L. Abbott in central Asia. By Harry C. Oberholser. Pp. 205-228. Apr. 23, 1900.

1196. Notes on some birds from Santa Barbara Islands, California. Pp. 229-234. Apr. 23, 1900.

1197. Catalogue of a collection of birds from Madagascar. By Harry C. Oberholser. Pp. 235-248. Apr. 24, 1900.

1198. Report on a collection of dipterous insects from Puerto Rico. By D. W. Coquillett. Pp. 249-270. May 12, 1900.

1199. The decapod crustaceans of West Africa. By Mary J. Rathbun. Pp. 271-316, 2 figs. May 12, 1900.

1200. Description of a new bird of the genus Dendrornis. By Charles W. Richmond. Pp. 317-318. May 12, 1900.

1201. Descriptions of three new birds from Lower Siam. By Charles W. Richmond. Pp. 319-321. May 12, 1900.

1202. On the genera of the chalcid-flies belonging to the subfamily Encyrtinac. By William H. Ashmead. Pp. 323-412. June 5, 1900.

1203. A hundred new moths of the family Noctuidae. By John B. Smith. Pp. 413 495. July 14, 1900.

1204. A new bird of paradise. By Rolla P. Currie. Pp. 497-499, 1 pl. July 7, 1900. 1205. Synopsis of the naiades, or pearly fresh-water mussels. By Charles Torrey Simpson. Pp. 501-1044, 1 pl. Oct. 8, 1900.

\section{Volume 23}

Proceedings of the United States National Museum, vol. 23. Pp. i-xv (titie page, advertisement, table of contents, list of illustrations, and errata) ; pp. 1-913 (Proceedings papers 1206-1240); pp. 915-952 (index); 82 figs., 42 pls. 1901.

1206. Classification of the ichneumon flies, or the superfamily Ichneumonoidea. By William H. Ashmead. Pp. 1-220. Oct. 13, 1900.

1207. A new rhinoceros, Trigonias osborni, from the Miocene of South Dakota. By Frederic A. Lucas. Pp. 221-224, 2 figs. Oct. 9, 1900.

1208. New species of moths of the superfamily Tineina from Florida. By August Busck. Pp. 225-254, 1 pl. Oct. 15, 1900.

1209. Life histories of some North American moths. By Harrison G. Dyar. Pp. 255-284. Oct. 15, 1900. 
1210. Synopsis of the family Tellinidae and of the North American species. By William Healey Dall. Pp. 285-326, 3 pls. Nov. 14, 1900.

1211. The pelvic girdle of zeuglodon, Basilosaurus cetoides (Owen), with notes on other portions of the skeleton. By Frederic A. Lucas. Pp. 327-331, 3 pls. Nov. 8, 1900.

1212. A new fossil cyprinoid, Leuciscus turneri, from the Miocene of Nevada. By Frederic A. Lucas. Pp. 333-334, 1 pl. Nov. 8, 1900.

1213. A list of fishes collected in Japan by Keinosuke Otaki, and by the United States steamer Albatross, with descriptions of fourteen new species. By David Starr Jordan and John Otterbein Snyder. Pp. 335-380, 12 pls. Dec. 10, 1900.

1214. Synopsis of the family Cardiidae and of the North American species. By William Healey Dall. Pp. 381-392. Jan. 2, 1901.

1215. Revision of the orthopteran genus Trimerotropis. By Jerome McNeill. Pp. 393-449, 1 pl. Jan. 19, 1901.

1216. The hermit crabs of the Pagurus bernhardus type. By James E. Benedict. Pp. 451-466, 6 figs. Jan. 19, 1901.

1217. On a new species of spiny-tailed iguana from Utilla Island, Honduras. By Leonhard Stejneger. Pp. 467-468. Jan. 19, 1901.

1218. A new systematic name for the yellow boa of Jamaica. By Leonhard Stejneger. Pp. 469-470. Jan. 19, 1901.

1219. Diagnosis of a new species of iguanoid lizard from Green Cay, Bahama Islands. By Leonhard Stejneger. P. 471. Jan. 19, 1901.

1220. On the wheatears (Saxicola) occurring in North America. By Leonard Stejneger. Pp. 473-481, 1 fig. Feb. 25, 1901.

1221. List of fishes collected in the River Pei-Ho, at Tien-Tsin, China, by Noah Fields Drake, with descriptions of seven new species. By James Francis Abbott. Pp. 483-491, 7 figs. Feb. 25, 1901.

1222. Key to the isopods of the Atlantic coast of North America with descriptions of new and little known species. By Harriet Richardson. Pp. 493-579, 34 figs. Feb. 28, 1901.

1223. Some spiders and other Arachnida from southern Arizona. By Nathan Banks. Pp. 581-590, 1 pl. Feb. 25, 1901.

1224. A new dinosaur, Stegosaurus marshi, from the Lower Cretaceous of South Dakota. By Frederic Á. Lucas. Pp. 591-592, 2 pls. Feb. 26, 1901.

1225. New Diptera in the U. S. National Museum. By D. W. Coquillett. Pp. 593618. Mar. 27, 1901.

1226. A list of the ferns and fern allies of North America north of Mexico, with principal synonyms and distribution. By William R. Maxon. Pp. 619-651. May 4, 1901.

1227. A systematic arrangement of the families of the Diptera. By D. W. Coquillett. Pp. 653-658. May 2, 1901.

1228. A comparison of the osteology of the jerboas and jumping mice. By Marcus W. Lyon, Jr. Pp. 659-668, 3 pls. May 2, 1901.

1229. Cambrian Brachiopoda: Obolella, subgenus Glyptias; Bicia; Obolus, subgenus Westonia; with descriptions of new species. By Charles D. Walcott. Pp. 669 695. May 22, 1901.

1250. A revision of certain species of plants of the genus Antennaria. By Elias NelBon. Pp. 697-713. June 4, 1901.

1231. Description of a new species of snake from Clarion Island, west coast of Mexico. By Lecnhard Stejneger. Pp. 715-717. June 5, 1901.

1232. On the relationships of the lutianoid fish, Aphareus furcatus. By David Starr Jordan and Edwin Chapin Starks. Pp. 719-723, 2 pls. June 21, 1901.

1233. A review of the lancelets, hag-fishes, and lampreys of Japan, with a description of two new species. By David Starr Jordan and John Otterbein Snyder. Pp. 725-734, 1 pl. July 16, 1901.

1234. The proper names of Bdellostoma or Heptatrema. By Theodore Gill. Pp. 735738. June 6, 1901. 
1235. List of fishes collected in 1883 and 1885 by Pierre Louis Jouy and preserved in the United States National Museum, with descriptions of six new species. By David Starr Jordan and John Otterbein Snyder. Pp. 739-769, 8 pls. July 2, 1901.

1236. Four new symmetrical hermit crabs (pagurids) from the West India region. By James E. Benedict. Pp. 771-778, 7 figs. July 1, 1901.

1237. Synopsis of the Lucinacea and of the American species. By William Healey Dall. Pp. 779-833, 4 pls. Aug. 22, 1901.

1238. On a slug of the genus Veronicella from Tahiti. By T. D. A. Cockerell. Pp. 835836. Aug. 15, 1901.

1239. A review of the apodal fishes or eels of Japan, with descriptions of nineteen new species. By David Starr Jordan and John Otterbein Snyder. Pp. 837890, 22 figs. Aug. 28, 1901.

1240. A review of the cardinal fishes of Japan. By David Starr Jordan and John Otterbein Snyder. Pp. 891-913, 10 figs., 2 pls. Oct. 2, 1901.

\section{Volume 24}

Proceedings of the United States National Museum, vol. 24. Pp. i-xv (title page, advertisement, table of contents, and list of illustrations) ; pp. 1-926 (Proceedings papers 1241-1274) ; pp. 927-971 (index) ; 124 figs., 56 pls. 1902.

1241. A review of the hypostomide and lophobranchiate fishes of Japan. By David Starr Jordan and John Otterbein Snyder. Pp. 1-20, 12 pls. Oct. 27, 1901.

1242. List of the myriapod family Lithobiidae of Salt Lake County, Utah, with descriptions of five new species. By Ralph V. Chamberlin. Pp. 21-25. Sept. 27, 1901.

1243. New Diptera from southern Africa. By D. W. Coquillett. Pp. 27-32. Sept. 27, 1901.

1244. A review of the gobioid fishes of Japan, with descriptions of twenty-one new species. By David Starr Jordan and John Otterbein Snyder. Pp. 33-132, 33 figs. Sept. 25, 1901.

1245. A flightless auk, Mancalla californiensis, from the Miocene of California. By Frederic A. Lucas. Pp. 133-134, 3 figs. Sept. 27, 1901.

1246. An annotated list of mammals collected in the vicinity of La Guaira, Venezuela. By Wirt Robinson and Marcus Ward Lyon, Jr. Pp. 135-162. Oct. 3, 1901.

1247. An annotated list of birds collected in the vicinity of La Guaira, Venezuela. By Wirt Robinson and Charles W. Richmond. Pp. 163-178. Oct. 3, 1901.

1248. An annotated list of batrachians and reptiles collected in the vicinity of La Guaira, Venezuela, with descriptions of two new species of snakes. By Leonhard Stejneger. Pp. 179-192, 33 figs. Oct. 3, 1901.

1249. On a stony meteorite, which fell near Felix, Perry County, Alabama, May 15, 1900. By George P. Merrill. Pp. 193-198, 2 pls. May 15, 1900.

1250. A review of the atherine fishes of Japan. By David Starr Jordan and Edwin Chapin Starks. Pp. 199-206, 4 figs. Oct. 4, 1901.

1251. The cacomitl cat of the Rio Grande Valley. By Edgar A. Mearns. Pp. 207210. Oct. 4, 1901.

1252. A new species of bullfrog from Florida and the Gulf coast. By Leonhard Stejneger. Pp. 211-215, 1 fig. Oct. 4, 1901.

1253. Some spiders and other Arachnida from Porto Rico. By Nathan Banks. Pp. 217-227, 1 pl. Oct. 4, 1901.

1254. A review of the gymnodont fishes of Japan. By David Starr Jordan and John Otterbein Snyder. Pp. 229-264, 8 figs. Nov. 30, 1901.

1255. Two new species of algae of the genus Buthotrephis, from the Upper Silurian of Indiana. By David White. Pp. 265-270, 3 pls. Nov. 30, 1901.

- 1256. The fossil fresh-water shells of the Colorado Desert, their distribution, environment, and variation. By Robert E. C. Stearns. Pp. 271-299, 9 figs., 6 pls. Dec. 28, 1901. 
1257. Chondrodonta, a new genus of ostreiform mollusks from the Cretaceous, with descriptions of the genotype and a new species. By Timothy W. Stanton. Pp. 301-307, 2 pls. Dec. 30, 1901.

1258. Catalogue of a collection of hummingbirds from Ecuador and Colombia. By Harry C. Oberholser. Pp. 309-342. Jan. 19, 1902.

1259. A review of the discobolous fishes of Japan. By David Starr Jordan and John Otterbein Snyder. Pp. 343-351, 2 figs. Feb. 10, 1902.

1260. A review of the Japanese species of surf-fishes or Embiotocidae. By David Starr Jordan (assisted by Michitaro Sindo). Pp. 353-359, 2 figs. Feb. 26, 1902.

1261. A review of the pediculate fishes or anglers of Japan. By David Starr Jordan (assisted by Michitaro Sindo). Pp. 361-381, 7 figs. Feb. 26, 1902.

1262. Descriptions of new American butterflies. By William Schaus. Pp. 383-460. Mar. 1, 1902.

1263. A review of the trachinoid fishes and their supposed allies found in the waters of Japan. By David Starr Jordan and John Otterbein Snyder. Pp. 461497, 7 figs. Mar. 28, 1902.

1264. Illustrations and descriptions of new, unfigured, or imperfectly known shells, chiefly American, in the U. S. National Museum. By William Healey Dall. Pp. 499-566, 14 pls. Mar. 31, 1902.

1265. A review of the salmonoid fishes of Japan. By David Starr Jordan and John Otterbein Snyder. Pp. 567-593, 5 figs. Mar. 25, 1902.

1266. A review of the labroid fishes and related forms found in the waters of Japan. By David Starr Jordan and John Otterbein Snyder. Pp. 595-662, 10 figs. May 2, 1902.

1267. List of generic terms proposed for birds during the years 1890 to 1900 , inclusive, to which are added names omitted by Waterhouse in his "Index Generum Avium." By Charles W. Richmond. Pp. 663-730. May 2, 1902.

1268. A review of the American moths of the genus Depressaria Haworth, with descriptions of new species. By August Busck. Pp. 731-749. May 12, 1902.

1269. The mammals of the Andaman and Nicobar Islands. By Gerrit S. Miller, Jr. Pp. 751-795, 2 pls. May 29, 1902.

1270. Henicops dolichopus, a new chilopod from Utah. By Ralph V. Chamberlin. Pp. 797-800. May 24, 1902.

1271. A review of the larks of the genus Otocoris. By Harry C. Oberholser. Pp. 801-883, 7 pls. June 9, 1902.

1272. Descriptions of new decapod crustaceans from the west coast of North America. By Mary J. Rathbun. Pp. 885-905. May 23, 1902.

1273. A newly found meteorite from Admire, Lyon County, Kansas. By George P. Merrill. Pp. 907-913, 7 pls. May 31, 1902.

1274. Descriptions of three new birds from the southern United States. By Edgar A. Mearns. Pp. 915-926. June 2, 1902.

\section{Volume 25}

Proceedings of the United States National Museum, vol. 25. Pp. i-xiv (title page, advertisement, table of contents, and list of illustrations); pp. 1-959 (Proceedings papers 1275-1305); pp. 961-1021 (index); 144 figs., 32 pls. 1903.

1275. A list of the beetles of the District of Columbia. By Henry Ulke. Pp. 1-57. Sept. 2, 1902.

1276. Some new South American birds. By Harry C. Oberholser. Pp. 59-68. Aug. 30, 1902.

1277. The Casas Grandes meteorite. By Wirt Tassin. Pp. 69-74, 4 pls. Sept. 2, 1902.

1278. A review of the oplegnathoid fishes of Japan. By David Starr Jordan and Henry W. Fowler. Pp. 75-78. Aug. 30, 1902.

1279. Descriptions of two new species of squaloid sharks from Japan. By David Starr Jordan and John Otterbein Snyder. Pp. 79-81, 2 figs. Sept. 2, 1902. 
Proce

No.

1280. New Diptera from North America. By D. W. Coquillett. Pp. 83-126. Sept. $12,1902$.

1281. List of birds collected by William T. Foster in Paraguay. By Harry C. Oberholser. Pp. 127-147. Sept. 8, 1902.

1282. The reptiles of the Huachuca Mountains, Arizona. By Leonhard Stejneger. Pp. 149-158. Sept. 8, 1902.

1283. Contributions toward a monograph of the lepidopterous family Noctuidae of Boreal North America. A revision of the moths referred to the genus Leucania, with descriptions of new species. By John B. Smith. Pp. 159-209, 2 pls. Sept. 3, 1902.

1284. A list of spiders collected in Arizona by Messrs. Schwarz and Barber during the summer of 1901. By Nathan Banks. Pp. 211-221, 1 pl. Sept. 10, 1902.

1285. Observations on the crustacean fauna of the region about Mammoth Cave, Kentucky. By William Perry Hay. Pp. 223-236, 1 pl. Sept. 12, 1902.

1286. The ocelot cats. By Edgar A. Mearns. Pp. 237-249. Sept. 17, 1902.

1287. A review of the trigger-fishes, file-fishes, and trunk-fishes of Japan. By David Starr Jordan and Henry W. Fowler. Pp. 251-286, 6 figs. Sept. 17, 1902.

1288. Birds collected by Dr. W. L. Abbott and Mr. C. B. Kloss in the Andaman and Nicobar Islands. By Charles W. Richmond. Pp. 287-314. Sept. 17, 1902.

1289. Notes on a collection of fishes from the Island of Formosa. By David Starr Jordan and Barton Warren Evermann. Pp. 315-368, 29 figs. Sept. 24, 1902.

1290. Descriptions of the larvae of some moths from Colorado. By Harrison G. Dyar. Pp. 369-412. Sept. 23, 1902.

1291. A review of the cling-fishes (Gobiesocidae) of the waters of Japan. By David Starr Jordan and Henry W. Fowler. Pp. 413-416, 1 fig. Sept. 19, 1902.

1292. Observations on the crustacean fauna of Nickajajck Cave, Tennessee, and vicinity. By William Perry Hay. Pp. 417-439, 11 figs. Sept. 23, 1902.

1293. A review of the blennoid fishes of Japan. By David Starr Jordan and John Otterbein Snyder. Py. 441-504, 28 figs. Sept. 26, 1902.

1294. A new fresh-water isopod of the genus Mancasellus from Indiana. By Harriet Richardson. Pp. 505-507, 4 figs. Sept. 25, 1902.

1295. A new terrestrial isopod of the genus Pseudarmadillo from Cuba. By Harriet Richardson. Pp. 509-511, 4 figs. Sept. 25, 1902.

1296. A review of the Chaetodontidae and related families of fishes found in the waters of Japan. By David Starr Jordan and Henry W. Fowler. Pp. 513563, 6 figs. Sept. 30, 1902.

1297. The relationship and osteology of the caproid fishes or Antigoniidae. By Edwin Chapin Starks. Pp. 565-572, 3 figs. Sept. 25, 1902.

1298. Notes on little-known Japanese fishes with description of a new species of Aboma. By David Starr Jordan and Henry W. Fowler. Pp. 573-576, 1 fig. Oct. 2, 1902.

1299. Cambrian Brachiopoda Acrotreta; Linnarssonella; Obolus; with descriptions of new species. By Charles D. Waicott. Pp. 577-612. Nov. 3, 1902.

1300. On certain species of fishes confused with Bryostemma polyactocephalum. By David Starr Jordan and John Otterbein Snyder. Pp. 613-618, 3 figs. Noy. 4, 1902.

1301. The shoulder girdle and characteristic osteology of the hemibranchiate fishes. Edwin Chapin Starks. Pp. 619-634, 6 figs. Nov. 4, 1902.

1302. North American parasitic copepods of the family Argulidae, with a bibliography of the group and a systematic review of all known species. By Charles Branch Wilson. Pp. 635-742, 23 figs., 20 pls. Nov. 25, 1902.

1303. A review of the ophidioid fishes of Japan. By David Starr Jordan and Henry W. Fowler. Pp. 743-766, 6 figs. Dec. 2, 1902.

1304. A revision of the American moths of the family Gelechiidae, with descriptions of new species. By August Busck. Pp. 767-938, 1 fig., 5 pls. May 9, 1903.

1305. A review of the dragonets (Callionymidae) and related fishes of the watero of Japan. By David Starr Jordan and Henry W. Fowler. Pp. 939-959., figs. May 9, 1903. 


\section{Volume 26}

Proceedings of the United States National Museum, vol. 26. Pp. i-xv (title page, advertisement, table of contents, and list of illustrations); pp. 1-1016 (Proceedings papers 1306-1349); pp. 1017-1058 (index); 193 figs., 69 pls. 1903.

Proc.

No.

1306. A review of the berycoid fishes of Japan. By David Starr Jordan and Heary W. Fowler. Pp. 1-21, 4 figs. Nov. 25, 1902.

1307. Japanese stalk-eyed crustaceans. By Mary J. Rathbun. Pp. 23-55, 24 figs. Nov. $28,1902$.

1308. A review of the hemibranchiate fishes of Japan. By David Starr Jordan and Edwin Chapin Starks. Pp. 57-73, 3 figs. Dec. 2, 1902.

1309. Descriptions of new species of Hawaiian crabs. By Mary J. Rathbun. Pp. 75-77, 4 figs. Nov. 18, 1902.

1310. Contribution to a monograph of the insects of the order Thysanoptera inhabiting North America. By Warren Elmer Hinds. Pp. 79-242, 11 pls. Dec. 20, 1902.

1311. Descriptions of a new genus and forty-six new species of crustaceans of the family Galatheidae, with a list of the known marine species. By James E. Benedict. Pp. 243-334, 47 figs. Dec. 29, 1902.

1312. Synopsis of the family Veneridae and of the North American Recent species. By William Healey Dall. Pp. 335-412, 5 pls. Dec. 29, 1902.

1313. On the lower Devonic and Ontaric formations of Maryland. By Charles Schuchert. Pp. 413-424. Feb. 3, 1903.

1314. Observations on the number of young of the lasiurine bats. By Marcus Ward Lyon, Jr. Pp. 425-426, 1 pl. Jan. 26, 1903.

1315. Note on the sea anemone, Sagartia paguri Verrill. By J. Playfair McMurrich. Pp. 427-428, 2 figs. Jan. 27, 1903.

1316. On a small collection of crustaceans from the Island of Cuba. By William Perry Hay. Pp. 429-435, 3 figs. Feb. 2, 1903.

1317. Mammals collected by Dr. W. L. Abbott on the coast and islands of northwest Sumatra. By Gerrit S. Miller, Jr. Pp. 437-483, 1 fig., 2 pls. Feb. 3, 1903.

1318. Birds collected by Dr. W. L. Abbott on the coast and islands of northwest Sumatra. By Charles W. Richmond. Pp. 485-524, 1 fig. Feb. 4, 1903.

1319. A review of the synentognathous fishes of Japan. By David Starr Jordan and Edwin Chapin Starks. Pp. 525-544, 3 figs. Feb. 4, 1903.

1320. Notes on the osteology and relationship of the fossil birds of the genera Hesperornis, Hargeria, Baptornis, and Diatryma. By Frederic A. Lucas. Pp. 545-556, 8 figs. Feb. 4, 1903.

1321. Rediscovery of one of Holbrook's salamanders. By Leonhard Stejneger. Pp. 557-558. Jan. 29, 1903.

1322. A new Procelsterna from the Leeward Islands, Hawaiian Group. By Walter K. Fisher. Pp. 559-563. Jan. 29, 1903.

1323. The structural features of the bryozoan genus Homotrypa, with descriptions of species from the Cincinnatian group. By Ray S. Bassler. Pp. 565-591, 6 pls. March 28, 1903.

1324. A review of the elasmobranchiate fishes of Japan. By David Starr Jordan and Henry W. Fowler. Pp. 593-674, 10 figs., 2 pls. Mar. 30, 1903.

1325. The cerebral fissures of the Atlantic walrus. By Pierre A. Fish. Pp. 675-688, 2 pls. Apr. 9, 1903.

1326. Description of a new species of sculpin from Japan. By David Starr Jordan and Edwin Chapin Starks. Pp. 689-690, 1 fig. Apr. 11, 1903.

1327. On the identification of a species of Eucalyptus from the Philippines. By Joseph Henry Maiden. Pp. 691-692. Apr. 11, 1903.

1328. Supplementary note on Bleekeria mitsukurii, and on certain Japanese fisheo. By David Starr Jordan. Pp. 693-696, 3 figs., 1 pl. Apr. 9, 1903.

1329. The use of the name torpedo for the electric catfish. By Theodore Gill. Pp. 697-698. Apr. 9, 1903. 
1330. A review of the Cepolidae or band-fishes of Japan. By David Starr Jordan and Henry W. Fowler. Pp. 699-702, 1 fig. Apr. 9, 1903.

1331. A genealogic study of dragon-fly wing venation. By James G. Needham. Pp. 703-764, 44 figs., 24 pls. Apr. 16, 1903.

1332. A review of the Cobitidae, or loaches, of the rivers of Japan. By David Starr Jordan and Henry W. Fowler. Pp. 765-774, 2 figs. Apr. 9, 1903.

1333. Notes on Orthoptera from Colorado, New Mexico, Arizona, and Texas, with descriptions of new species. By Andrew Nelson Caudell. Pp. 775-809, 1 pl. July 6, 1903.

1334. A review of the cyprinoid fishes of Japan. By David Starr Jordan and Henry W. Fowler. Pp. 811-862, 8 figs. July 6, 1903.

1335. The Phasmidae, or walkingsticks, of the United States. By Andrew Nelson Caudell. Pp. 863-885, 4 pls. July 9, 1903.

1336. Description of an extinct mink from the shell-heaps of the Maine coast. By Daniel Webster Prentiss. Pp. 887-888, 1 fig. July 6, 1903.

1337. Revision of the Crustacea of the genus Lepidopa. By James E. Benedict. Pp. 889-895, 8 figs. July 7, 1903.

1338. A review of the siluroid fishes or catfishes of Japan. By David Starr Jordan and Henry W. Fowler. Pp. 897-911, 2 figs. July 7, 1903.

1339. Notice of a collection of fishes made by H. H. Brimley in Cane River and Bollings Creek, North Carolina, with a description of a new species of Notropis (N. brimleyi). By Barton A. Bean. Pp. 913-914. July 6, 1903.

1340. On the relations of the fishes of the family Lamprididae or opahs. By Theodore Gill. Pp. 915-924, 3 figs. July 7, 1903.

1341. Amphipoda from Costa Rica. By Thomas R. R. Stebbing. Pp. 925-931, 2 pls. July 9, 1903.

1342. Synopsis of the family Astartidae, with a review of the American species. By William Healey Dall. Pp. 933-951, 2 pls. July 10, 1903.

1343. An Alaskan Corymorpha-like hydroid. By Samuel Fessenden Clarke. Pp. 953958, 7 figs. July 11, 1903.

1344. On some neglected genera of fishes. By Theodore Gill. Pp. 959-962. July 11, 1903.

1345. Notice of a small collection of fishes, including a rare eel, recently received from H. Maxwell Lefroy, Bridgetown, Barbados, West Indies. By Barton A. Bean. Pp. 963-964, 1 fig. July 10, 1903.

1346. On some fish genera of the first edition of Cuvier's Règne Animal and Oken's names. By Theodore Gill. Pp. 965-967. July 11, 1903.

1347. Report of the fresh-water Ostracoda of the United States National Museum, including a revision of the subfamilies and genera of the family Cyprididae. By Richard W. Sharpe. Pp. 969-1001, 6 pls. July 15, 1903.

1348. A review of the fishes of Japan belonging to the family of Hexagrammidae. By David Starr Jordan and Edwin Chapin Starks. Pp. 1003-1013, 3 figs. July 15, 1903.

1349. Note on the fish genera named Macrodon. By Theodore Gill. Pp. 1015-1016. July 6, 1903.

\section{Volume 27}

Proceedings of the United States National Museum, vol. 27. Pp. i-xvii (title page, advertisement, table of contents, and list of illustrations); pp. 1-961 (Proceedings papers 1350-1381); pp. 963-998 (index); 270 figs., 50 pls. 1904.

1350. Contributions to the natural history of the Isopoda. By Harriet Richardson. Pp. 1-89, 92 figs. Jan. 19, 1904.

1351. A review of the scorpaenoid fishes of Japan. By David Starr Jordan and Edwin Chapin Starks. Pp. 91-175, 21 figs., 2 pls. Jan. 22, 1904.

1352. A revision of the American great horned owls. By Harry C. Oberholser. Pp. 177-192. Jan. 22, 1904.

1353. A new batrachian and a new reptile from the Trias of Arizona. By Frederic A. Lucas. Pp. 193-195, 2 pls. Jan. 22, 1904.

1354. A review of the wrens of the genus Troglodytes. By Harry C. Oberholser. Pp. 197-210, 1 pl. Jan. 23, 1904. 
1355. Report on the fresh-water Bryozoa of the United States. By Charles B. Davenport. Pp. 211-221, 1 pl. Jan. 22, 1904.

1356. On the species of white Chimaera from Japan. By David Starr Jordan and John Otterbein Snyder. Pp. 223-226, 2 figs. Jan. 23, 1904.

1357. Notes on a killer whale (genus Orcinus) from the coast of Maine. By Frederick W. True. Pp. 227-230, 2 pls. Jan. 27, 1904.

1358. A review of the Cottidae or sculpins found in the waters of Japan. By David Starr Jordan and Edwin Chapin Starks. Pp. 231-335, 43 figs. Jan. 28, 1904.

1359. Notes on the bats collected by William Palmer in Cuba. By Gerrit S. Miller, Jr. Pp. 337-348, 1 pl. Jan. 23, 1904.

1360. List of Hemiptera-Heteroptera of Las Vegas Hot Springs, New Mexico, collected by Messrs. E. A. Schwarz and Herbert S. Barber. By Philip R. Uhler. Pp. 349-364. Jan. 27, 1904.

1361. A revision of American Siphonaptera, or fleas, together with a complete list and bibliography of the group. By Carl F. Baker. Pp. 365-469, 17 pls. Feb. 16, 1904.

1362. The aleyrodids, or mealy-winged flies, of California, with references to other American species. By Florence E. Bemis. Pp. 471-537, 11 pls. Feb. 16, 1904.

1363. Studies in Old World forficulids or earwigs, and blattids or cockroaches. By James A. G. Rehn. Pp. 539-560. Feb. 16, 1904.

1364. Studies in American mantids or soothsayers. By James A. G. Rehn. Pp. 561574. Feb. 6, 1904.

1365. A review of the Japanese fishes of the family of Agonidae. By David Starr Jordan and Edwin Chapin Starks. Pp. 575-599, 13 figs. Feb. 23, 1904.

1366. The osteology of some berycoid fishes. By Edwin Chapin Starks. Pp. 601-619, 10 figs. Feb. 18, 1904.

1367. A new genus and two new species of crustaceans of the family Albuneidae from the Pacific Ocean; with remarks on the probable use of the antennulae in Albunea and Lepidopa. By James E. Benedict. Pp. 621-625, 5 figs. Feb. $16,1904$.

1368. A new species of Argulus, with a more complete account of two species already described. By Charles Branch Wilson. Pp. 627-655, 38 figs. Apr. 9, 1904.

1369. Contributions to the natural history of the Isopoda. By Harriet Richardson. Pp. 657-681, 39 figs. Jan. 19, 1904.

1370. Description of a new African weaver-bird. By Harry C. Oberholser. P. 683. Apr. 13, 1904.

1371. New dragon-fly nymphs in the United States National Museum. By James G. Needham. Pp. 685-720, 11 figs., 7 pls. May 20, 1904.

1372. New molluscan genera from the Carboniferous. By George H. Girty. Pp. 721-736, 3 pls. June 1, 1904.

1373. Description of two new birds from Somali Land. By Harry C. Oberholser. Pp. 737-739. May 21, 1904.

1374. Two new ferns of the genus Polypodium, from Jamaica. By William R. Maxon. Pp. 741-744. May 21, 1904.

1375. Tineid moths from British Columbia, with descriptions of new species. By August Busck. Pp. 745-778. May 25, 1904.

1376. The Lepidoptera of the Kootenai District of British Columbia. By Harrison G. Dyar. Pp. 779-938. June 7, 1904.

1377. Notes on collections of fishes from Oahu Island and Laysan Island, Hawaii, with descriptions of four new species. By David Starr Jordan and John Otterbein Snyder. Pp. 939-948. June 2, 1904.

1378. Two Orthoptera hitherto unrecorded from the United States. By Andrew Nelson Caudell. Pp. 949-952, 3 figs. June 2, 1904.

1379. A new fern, Goniophlebium pringlei, from Mexico. By William R. Maxon. Pp. 953-954, 1 fig., 1 pl. June 27, 1904.

1380. The Persimmon Creek meteorite. By Wirt Tassin. Pp. 955-959, 1 fig., 2 pls. June 27, 1904. 
1381. Schmidtina, a genus of Japanese sculpins. By David Starr Jordan and Edwin Chapin Starks. P. 961. June 27, 1904.

\section{Volume 28}

Proceedings of the United States National Museum, vol. 28. Pp. i-xix (title page, advertisement, table of contents, and list of illustrations); pp. 1-987 (Proceedings papers 1382-1414); pp. 989-1027 (index); 380 figs., 35 pls. 1905.

1382. A treatise on the Acarina, or mites. By Nathan Banks. Pp. 1-114, 201 figs. Sept. 24, 1904.

1383. Notes on Hawaiian reptiles from the Island of Maui. By Richard C. McGregor. Pp. 115-118. Sept. 24, 1904.

1384. Labracinus the proper name for the fish genus Cichlops. By Theodore Gill. P. 119. Oct. 5, 1904.

1385. Note on the genus Prionurus or Acanthocaulos. By Theodore Gill. P. 121. Oct. 5, 1904.

1386. Description of a new species of fish (Apogon evermanni) from the Hawaiian Islands, with notes on other species. By David Starr Jordan and John Otterbein Snyder. Pp. 123-126. Oct. 6, 1904.

1387. Descriptions of new genera and species of Hymenoptera from the Philippine Islands. By William H. Ashmead. Pp. 127-158, 2 pls. Nov. 5, 1904.

1388. On the systematic relations of the ammodytoid fishes. By Theodore Gill. Pp. 159-163, 4 figs. Nov. 12, 1904.

1389. The dragonflies (Odonata) of Burma and Lower Siam. I.-Subfamily Calopteryginae. By Edward Bruce Williamson. Pp. 165-187, 18 figs. Apr. 22, 1905.

1390. On the Liparis (Trismegistus) orustoni Jordan and Snyder. By Peter Schmidt. Pp. 189-191, 2 figs. Nov. 29, 1904.

1391. On a collection of fishes made in Korea, by Pierre Louis Jouy, with descriptions of new species. By David Starr Jordan and Edwin Chapin Starks. Pp. 193-212, 11 figs. Feb. 23, 1905.

1392. The Mount Vernon meteorite. By Wirt Tassin. Pp. 213-217, 1 fig., 2 pls. Feb. 23, 1905.

1393. The scorpaenoid fish, Neosebastes entaxis, as the type of a distinct genus. By Theodore Gill. Pp. 219-220, 2 figs. Feb. 15, 1905.

1394. Note on the genera of synanceine and pelorine fishes. By Theodore Gill. Pp. 221-225, 1 fig. Feb. 23, 1905.

1395. Cambrian Brachiopoda with descriptions of new genera and species. By Charles D. Walcott. Pp. 227-337. Feb. 17, 1905.

1396. On the generic characteristics of Prionotus stearnsii. By Theodore Gill. Pp. 339-342, 4 figs. Feb. 15, 1905.

1397. Three new frogs and one new gecko from the Philippine Islands. By Leonhard Stejneger. Pp. 343-348. Feb. 15, 1905.

1398. Descriptions of new species of tortricid moths, from North Carolina, with notes. By William Dunham Kearfott. Pp. 349-364. Apr. 22, 1905.

1399. Note on the salmon and trout of Japan. By David Starr Jordan. Pp. 365-366. May 9, 1905.

1400. Descriptions of a new genus of Isopoda belonging to the family Tanaidae and of a new species of Tanais, both from Monterey Bay, California. By Harriet Richardson. Pp. 367-370, 13 figs. May 9, 1905.

1401. A critical review of the literature on the simple genera of the Madreporaria Fungida, with a tentative classification. By T. Wayland Vaughan. Pp. 371-424. May 10, 1905.

1402. Descriptions of new genera and species of mammals from the Philippíne Islands. By Edgar A. Mearns. Pp. 425-460. May 13, 1905.

1403. On a collection of Orthoptera from southern Arizona, with descriptions of new species. By Andrew Nelson Caudell. Pp. 461-477, 6 figs. June 12, 1905. 
Proc.

No.

1404. North American parasitic copepods belonging to the family Caligidae. Part I.The Caliginae. By Charles Branch Wilson. Pp. 479-672, 51 figs., 25 pls. June 23, 1905.

1405. Notes on mammals collected and observed in the northern Mackenzie River District, Northwest Territories of Canada, with remarks on explorers and explorations of the Far North. By R. MacFarlane. Pp. 673-764, 2 figs., 5 pls. June 22, 1905.

1406. Description of a new toad from Cuba. By Leonhard Stejneger. Pp. 765-767, 6 figs: June 24, 1905.

1407. List of fishes collected by Dr. Bashford Dean on the Island of Negros, Philippines. By David Starr Jordan and Alvin Seale. Pp. 769-803, 20 figs. July 3, 1905.

1408. The life history of the sea-horses (hippocampids). By Theodore Gill. Pp. 805-814, 12 figs. July 6, 1905.

1409. Notes on an adult goblin shark (Mitsukurina oqustoni) of Japan. By Barton A. Bean. Pp. 815-818, 2 figs. July 6, 1905.

1410. Notes on cestode cysts, Taenia chamissonii, new species, from a porpoise. By Edwin Linton. Pp. 819-822, 1 pl. July 14, 1905.

1411. Birds collected by Dr W. L. Abbott in the Kilimanjaro region, East Africa. By Harry C. Oberholser. Pp. 823-936. July 8, 1905.

1412. A descriptive list of a collection of early stages of Japanese Lepicioptera. By Harrison G. Dyar. Pp. 937-956, 23 figs. July 8, 1905.

1413. Additions to the recorded hymenopterous fauna of the Philippine Islands, with descriptions of new species. By William H. Ashmead. Pp. 957-971. July 8, 1905.

1414. Notes on the fishes of Puget Sound. By Charles H. Gilbert and Joseph C. Thompson. Pp. 973-987, 3 figs. Aug. 8, 1905.

\section{Volume 29}

Proceedings of the United States National Museum, vol. 29. Pp. i-xvi (title page, advertisement, table of contents, and list of illustrations); pp. 1-820 (Proceedings papers 1415-1441); pp. 821-840 (index); 143 figs., 44 pls. 1906.

1415. Cambrian faunas of China. By Charles D. Walcott. Pp. 1-106. Sept. 6, 1905.

1416. New Hymenoptera from the Philippines. By William H. Ashmead. Pp. 107119. Oct. 5, 1905.

1417. The classification of the American Siphonaptera. By Carl F. Baker. Pp. 121170. Oct. 3, 1905.

1418. A new subspecies of ground dove from Mona Island, Porto Rico. By J. H. Riley. Pp. 171-172. Sept. 30, 1905.

1419. New genera of South American moths. By Harrison G. Dyar. Pp. 173-178. Oct. 12, 1905.

1420. Descriptions of new South American moths. By William Schaus. Pp. 179345. Oct. 11, 1905.

1421. Some new South American moths. By William Warren. Pp. 347-352. Oct. $6,1905$.

1422. A list of fishes collected in Tahiti by Mr. Henry P. Bowie. By David Starr Jordan and John Otterbein Snyder. Pp. 353-357, 3 figs. Oct. 7, 1905.

1423. List of American cochlidian moths, with descriptions of new genera and species. By Harrison G. Dyar. Pp. 359-396. Oct. 12, 1905.

1424. New genera and species of Hymenoptera from the Philippines. By William H. Ashmead. Pp. 397-413. Oct. 5, 1905.

1425. Thomas Martyn and the Universal Conchologist. By William Healey Dall. Pp. 415-432. Oct. 6, 1905.

1426. The mounted skeleton of Triceratops prorsus. By Charles W. Gilmore. Pp. 433-435, 2 pls. Oct. 4, 1905.

1427. Five new species of Mexican plants. By J. N. Rose. Pp. 437-439. Sept. 30, 1905.

1428. Two new umbelliferous plants from the Coastal Plain of Georgia. By J. N. Rose. Pp. 441-442, 1 pl. Oct. 5, 1905. 
Proc.

No.

1429. Descriptions of three Mexican violets. By J. N. Rose and H. D. House. Pp. 443-444, 1 pl. Oct. 6, 1905.

1430. Description of a new species of Livoneca from the coast of Panama. By Harriet Richardson. Pp. 445-446, 2 figs. Dec. 2, 1905.

1431. The breeding habits and the segmentation of the egg of the pipefish, Siphostoma floridae. By Eugene Willis Gudger. Pp. 447-500, 2 figs., 7 pls. Dec. 6, 1905.

1432. Notes on exotic forficulids or earwigs, with descriptions of new species. By James A. G. Rehn. Pp. 501-515, 9 figs. Dec. 2, 1905.

1433. List of fishes collected in $1882-83$ by Pierre Louis Jouy at Shanghai and Hongkong, China. By David Starr Jordan and Alvin Seale. Pp. 517-529, 6 figs. Dec. 6, 1905.

1434. On the syntomid moths of southern Venezuela collected in 1898-1900. By Edward A. Klages. Pp. 531-552. Jan. 31, 1906.

1435. A fossil raccoon from a California Pleistocene cave deposit. By James Williams Gidley. Pp. 553-554, 1 pl. Feb. 2, 1906.

1436. The monkeys of the Macaca nemestrina group. By Gerrit S. Miller, Jr. Pp. 555-563, 8 pls. Feb. 3, 1906.

1437. A new lizard of the genus Phrynosoma, from Mexico. By Leonhard Stejneger. Pp. 565-567. Feb. 2, 1906.

1438. A study of the wings of the Tenthredinoidea, a superfamily of Hymenoptera. By Alexander Dyer MacGillivray. Pp. 569-654, 20 figs., 24 pls. Feb. 10, 1906.

1439. A new blattoid from the Cretaceous formation of North America. By Anton Handlirsch. Pp. 655-656, 1 fig. Mar. 7, 1906.

1440. On some bats of the genus Rhinolophus, collected by Dr. W. L. Abbott in the Islands of Nias and Engano. By Knud Andersen. Pp. 657-659. Mar. 7, 1906.

1441. Revision of American Paleozoic insects. By Anton Handlirsch. Pp. 661-820, 109 figs. Mar. 7, 1906.

\section{Volume 30}

Proceedings of the United States National Museum, vol. 30. Pp. i-xvi (title page, advertisement, table of contents, and list of illustrations); pp. 1-855 (Proceedings papers 1442-1478); pp. 857-883 (index); 120 figs., 78 pls. 1906.

1442. A study of the James types of Ordovician and Silurian Bryozoa. By Ray S. Bassler. Pp. 1-66, 7 pls. Apr. 2, 1906.

1443. The life history of the cave salamander, Spelerpes maculicaudus (Cope). By Arthur M. Banta and Waldo L. McAtee. Pp. 67-83, 3 figs., 3 pls. Apr. 2, 1906.

1444. Descriptions of new South American moths. By William Schaus. Pp. 85-141. Apr. 2, 1906.

1445. Descriptions of six new species of fishes from Japan. By David Starr Jordan and Alvin Seale. Pp. 143-148, 6 figs. Apr. 4, 1906.

1446. New American Paleozoic Ostracoda. Notes and descriptions of Upper Carboniferous genera and species. By Edward O. Ulrich and Ray S. Bassler. Pp. 149-164, 1 pl. Apr. 4, 1906.

1447. A new ruminant from the Pleistocene of New Mexico. By James Williams Gidley. Pp. 165-167, 3 figs. Apr. 4, 1906.

1448. Descriptions of new Hymenoptera from Japan. By William H. Ashmead. Pp. 169-201, 4 pls. May 11, 1906.

1449. The osteology of Sinopa, a creodont mammal of the Middle Eocene. By William Diller Matthew. Pp. 203-233, 20 figs., 1 pl. May 11, 1906.

1450. The Locustidae and Gryllidae (katydids and crickets) collected by W. T. Foster in Paraguay. By Andrew Nelson Caudell. Pp. 235-244. Apr. 21, 1906.

1451. Brains and brain preservatives. By Aleš Hrdlička. Pp. 245-320b, 27 figs. June 4, 1906.

- 1452. Notes on Japanese, Indopacific, and American Pyramidellidae. By William Healey Dall and Paul Bartsch. Pp. 321-369, 10 pls. May 9, 1906. 
Proc.

No.

1453. Notes on South American grasshoppers of the subfamily Acridinae (Acrididae), with descriptions of new genera and species. By James A. G. Rehn. Pp. 371-391. May 9, 1906.

1454. Descriptions of two new naiads. By Paul Bartsch. Pp. 393-395, 3 pls. May 9, 1906.

1455. A synopsis of the sturgeons (Acipenseridae) of Japan. By David Starr Jordan and John Otterbein Snyder. Pp. 397-398. May 9, 1906.

1456. Descriptions of new genera and species of South American geometrid moths. By William Warren. Pp. 399-557. May 11, 1906.

1457. A new salamander from North Carolina. By Leonhard Stejneger. Pp. 559562, 6 figs. May 22, 1906.

1458. Cambrian faunas of China. By Charles D. Walcott. Pp. 563-595. May 23, 1906.

1459. Descriptions of three new species of katydids and a new genus of crickets from Costa Rica. By James A. G. Rehn. Pp. 597-605, 8 figs. May 24, 1906.

1460. Notes on some recent additions to the exhibition series of vertebrate fossils. By Charles W. Gilmore. Pp. 607-611, 6 pls. May 31, 1906.

1461. Synoptic list of Paraguayan Acrididae, or locusts, with descriptions of new forms. By Lawrence Bruner. Pp. 613-694, 3 pls. June 5, 1906.

1462. List of fishes collected on Tanega and $\mathrm{Yaku}$, offshore islands of southern Japan, by Robert Van Vleck Anderson, with descriptions of seven new species. By David Starr Jordan and Edwin Chapin Starks. Pp. 695-706, 13 figs. June 4, 1906.

1463. A review of the American moths of the genus Cosmopteryx Hübner. By August Busck. Pp. 707-713. June 4, 1906.

1464. A review of the sand lances or Ammodytidae of the waters of Japan. By David Starr Jordan. Pp. 715-719, 2 figs. June 4, 1906.

1465. Tineid moths from southern Texas, with descriptions of new species. By August Busck. Pp. 721-736, 10 figs. June 4, 1906.

1466. Notes on Malayan pigs. By Gerrit S. Miller, Jr. Pp. 737-758, 1 fig., 26 pls. June 13, 1906.

1467. A new American pentremite. By Charles Schuchert. Pp. 759-760, 3 figs. June $11,1906$.

1468. On a collection of fishes made by P. O. Simons in Ecuador and Peru. By Edwin Chapin Starks. Pp. 761-800, 10 figs., 2 pls. June 14, 1906.

1469. Notes on birds from German and British East Africa. By Harry C. Oberholser. Pp. 801-811. June 4, 1906.

1470. Description of a new species of threadfin (family Polynemidae) from Japan. By David Starr Jordan and Richard Crittenden McGregor. Pp. 813-815, 1 fig. June 4, 1906.

1471. A new tree toad from Costa Rica. By Leonhard Stejneger. Pp. 817-818. June 4, 1906.

1472. The mammals of Engano Island, West Sumatra. By Gerrit S. Miller, Jr. Pp. 819-825. June 4, 1906.

1473. Three new Fungiae, with a description of a specimen of Fungia granulosa Klunzinger and a note on a specimen of Fungia concinna Verrill. By T. Wayland Vaughan. Pp. 827-832, 8 pls. June 20, 1906.

1474. On a species of loach; Misgurnus decemcirrosus (Basilewsky) from northern China. By David Starr Jordan and John Otterbein Snyder. Pp. 833-834, 1 fig. June 16, 1906.

1475. Description of a new genus and species of fossil seal from the Miocene of Maryland. By Frederick W. True. Pp. 835-840, 2 pls. June 16, 1906.

1476. The giant bass of Japan. By David Starr Jordan and John Otterbein Snyder. Pp. 841-845, 2 figs. June 16, 1906.

1477. A new species of Coenocyathus from California and the Brazilian astrangid corals. By T. Wayland Vaughan. Pp. 847-850, 2 pls. June 27, 1906.

1478. New fishes from Santo Domingo. By Barton W. Evermann and H. Walton Clark. Pp. 851-855, 3 figs. June 27, 1906. 


\section{Volume 31}

Proceedings of the United States National Museum, vol. 31. Pp. i-xii (title page, advertisement, table of contents, and list of illustrations); pp. 1-720 (Proceedings papers 1479-1504); pp. $721-739$ (index); 139 figs., 20 pls. 1907.

Proe.

1479. Descriptions of new isopod crustaceans of the family Sphaeromidae. By Harriet Richardson. Pp. 1-22, 27 figs. July 23, 1906.

1480. Schizopod crustaceans in the U. S. National Museum. The families Lophogastridae and Eucopiidae. By Arnold E. Ortmann. Pp. 23-54, 2 pls. July 23, 1906.

1481. Mammals collected by Dr. W. L. Abbott in the Karimata Islands, Dutch Eant Indies. By Gerrit S. Miller, Jr. Pp. 55-66, 1 fig. July 23, 1906.

1482. Notes on a collection of fishes from Argentina, South America, with descriptions of three new species. By Barton Warren Evermann and William Converse Kendall. Pp. 67-108, 4 figs. July 25, 1906.

- 1483. The urocoptid mollusks from the mainland of America in the collection of the United States National Museum. By Paul Bartsch. Pp. 109-160, 16 figs., 3 pls. Sept. 10, 1906.

1484. A review of the flounders and soles of Japan. By David Starr Jordan and Edwin Chapin Starks. Pp. 161-246, 27 figs. Sept. 10, 1906.

1485. The mammals collected by Dr. W. L. Abbott in the Rhio-Linga Archipelago. By Gerrit S. Miller, Jr. Pp. 247-286, 1 fig. Sept. 11, 1906.

1486. A review of the Poeciliidae or killifishes of Japan. By David Starr Jordan and John Otterbein Snyder. Pp. 287-290, 1 fig. Sept. 10, 1906.

1487. The digger wasps of North America and the West Indies belonging to the subfamily Chlorioninae. By Henry T. Fernald. Pp. 291-423, 5 pls. Sept. $20,1906$.

1488. On the diurnal Lepidoptera of the Athabaska and MacKenzie Region, British America. By Merritt Cary. Pp. 425-457. Sept. 24, 1906.

1489. List of fishes collected in Japan in 1903, with descriptions of new genera and species. By Hugh M. Smith and Thomas E. B. Pope. Pp. 459-499, 12 figs. Sept. 24, 1906.

1490. A new Costa Rican amphipod. By Thomas R. R. Stebbing. Pp. 501-504, 2 figs., 1 pl. Sept. 24, 1906.

1491. Fishes collected in the Philippine Islands by Maj. Edgar A. Mearns, surgeon, U. S. Army. By Barton W. Evermann. Pp. 505-512, 4 figs. Sept. 24, 1906.

1492. Notes on a newly mounted skeleton of Merycoidodon, a fossil mammal. By Charles W. Gilmore. Pp. 513-514, 1 pl. Oct. 8, 1906.

1493. Notes on a collection of fishes from Port Arthur, Manchuria, obtained by James Francis Abbott. By David Starr Jordan and Edwin Chapin Starks. Pp. 515526, 5 figs. Oct. 8, 1906.

1494. Notes on the slow lemurs. By Marcus Ward Lyon, Jr. Pp. 527-538, 1 pl. Nov. 9, 1906.

1495. Anatomical observations on a collection of orang skulls from western Borneo; with a bibliography. By Aleš Hrdlička. Pp. 539-568, 8 figs. Nov. 17, 1906.

1496. Description of a new species of great ant-eater from Central America. By Marcus Ward Lyon, Jr. Pp. 569-571, 1 pl. Nov. 14, 1906.

1497. Note on an occurrence of graphitic iron in a meteorite. By Wirt Tassin. Pp. 573-574, 1 fig. Nov. 14, 1906.

1498. Mammals of Banka, Mendanau, and Billiton Islands, between Sumatra and Borneo. By Marcus Ward Lyon, Jr. Pp. 575-612, 1 fig. Dec. 18, 1906.

1499. A review of the herring-like fishes of Japan. By David Starr Jordan and Albert Christian Herre. Pp. 613-645, 5 figs. Dec. 18, 1906.

1500. Mammal remains from two prehistoric village sites in New Mexico and Arizona. By Marcus Ward Lyon, Jr. Pp. 647-649. Dec. 18, 1906.

1501. Description of a new rock-fish of the genus Sebastodes from California. By Barton Warren Evermann and Edmund Lee Goldsborough. Pp. 651-652, 1 fig. Jan. 9, 1907. 
Proc.

No.

1502. Mammals of Batam Island, Rhio Archipelago. By Marcus Ward Lyon, Jr. Pp. 653-657. Jan. 16, 1907.

1503. An account of Amazon River fishes collected by J. B. Steere; with a note on Pimelodus clarias. By Carl H. Eigenmann and Barton A. Bean. Pp. $659-$ 668, 5 figs. Jan. 16, 1907.

1504. North American parasitic copepods belonging to the family Caligidae. Part 2.The Trebinae and Euryphorinae. By Charles Branch Wilson. Pp. 669-720, 19 figs., 6 pls. Jan. 17, 1907.

\section{Volume 32}

Proceedings of the United States National Museum, vol. 32. Pp. i-xvi (title page, advertisement, table of contents, and list of illustrations); pp. 1-744 (Proceedings papers $1505-1555$; pp. $745-767$ (index); 190 figs., 82 pls. 1907.

1505. A specimen of typical Burchell's zebra in the United States National Museum. By Marcus Ward Lyon, Jr. Pp. 1-3, 3 pls. Jan. 16, 1907.

1506. Revision of the American moths of the genus Argyresthia. By August Busck. Pp. 5-24, 3 figs., 2 pls. Jan. 16, 1907.

1507. The fresh-water Amphipoda of North America. By Ada L. Weckel. Pp. 2558, 15 figs. Feb. 4, 1907.

1508. On a newly found meteorite from Selma, Dallas County, Alabama. By George P. Merrill. Pp. 59-61, 2 pls. Feb. 6, 1907.

1509. New marine worms of the genus Myzostoma. By J. F. McClendon. Pp. 63-65, 2 figs. Feb. 7, 1907.

1510. Notes on fishes from the Island of Santa Catalina, southern California. By David Starr Jordan and Edwin Chapin Starks. Pp. 67-77, 8 figs. Feb. 7, 1907.

1511. Notes on the composition and structure of the Hendersonville, North Carolina, meteorite. By George P. Merrill. Pp. 79-82, 1 fig., 2 pls. Feb. 6, 1907.

1512. The Philippine mollusks of the genus Planorbis. By Paul Bartsch. Pp. 83-85, 2 figs. Feb. 7, 1907.

1513. A review of the Mullidae, surmullets, or goatfishes of the shores of Japan. By John Otterbein Snyder. Pp. 87-102, 3 figs. Feb. 7, 1907.

1514. A review of the bats of the genus Hemiderma. By Walter L. Hahn. Pp. 103118. Feb. 8, 1907.

1515. Two new land shells from Mexico. By Paul Bartsch. Pp. 119-120, 2 figs. Feb. 8, 1907.

1516. Report on the mosquitoes of the coast region of California, with descriptions of new species. By Harrison G. Dyar. Pp. 121-129. Feb. 8, 1907.

1517. Note on Otohime, a new genus of gurnards. By David Starr Jordan and Edwin Chapin Starks. Pp. 131-133, 1 fig. Feb. 8, 1907.

1518. The Philippine pond snails of the genus Vivipara. By Paul Bartsch. Pp. 135150, 2 pls. Feb. 8, 1907.

1519. The type of the Jurassic reptile Morosaurus agilis redescribed, with a note on Camptosaurus. By Charles W. Gilmore. Pp. 151-165, 9 figs., 2 pls. Feb. 8, 1907.

1520. New mollusks of the family Vitrinellidae from the west coast of America. By Paul Bartsch. Pp. 167-176, 11 figs. Feb. 8, 1907.

1521. Measurements of the cranial fossae. By Aleš Hrdlička. Pp. 177-232, 2 pls. Mar. 12, 1907.

1522. A new mollusk of the genus Macromphalina from the west coast of America. By Paul Bartsch. P. 233, 1 fig. Mar. 12, 1907.

1523. A review of the fishes of the family Histiopteridae, found in the waters of Japan; with a note on Tephritis Günther. By David Starr Jordan. Pp. 235239. Mar. 12, 1907.

1524. On the meteorite from Rich Mountain, Jackson County, North Carolina. By George P. Merrill, with chemical analysis by Wirt Tassin. Pp. 241-244, 1 pl. Apr. 18, 1907. 
1525. A review of the fishes of the family Gerridae found in the waters of Japan. By David Starr Jordan. Pp. 245-248, 2 figs. Apr. 8, 1907.

1526. Some madreporarian corals from French Somaliland, East Africa, collected by Dr. Charles Gravier. By T. Wayland Vaughan. Pp. 249-266, 12 pls. Apr. $18,1907$.

1527. A new brachiopod, Rensselaeria mainensis, from the Devonian of Maine. By Henry Shaler Williams. Pp. 267-269, 2 figs. Apr. 18, 1907.

1528. A new fossil stickleback fish from Nevada. By Oliver P. Hay. Pp. 271-273, 3 figs. May 18, 1907.

1529. Notes on Calyptrobothrium, a cestode genus found in the torpedo. By Edwin Linton. Pp. 275-284, 8 figs. May 18, 1907.

1530. The Decticinae (a group of Orthoptera) of North America. By Andrew Nelson Caudell. Pp. 285-410, 94 figs. May 23, 1907.

1531. Additional notes on the development of the Argulidae, with description of a new species. By Charles Branch Wilson. Pp. 411-424, 4 pls. May 23, 1907.

1532. The poeciliid fishes of Rio Grande do Sul and the La Plata Basin. By Carl H. Eigenmann. Pp. 425-433, 11 figs. May 23, 1907.

1533. A review of the cobitoid fishes of the basin of the Amur. By Leo Berg. Pp. 435-438. May 23, 1907.

1534. Remarks on the giant squirrels of Sumatra, with descriptions of two new species. By Marcus Ward Lyon, Jr. Pp. 439-445, 1 pl. May 23, 1907.

1535. A new terrestrial isopod from Guatemala, the type of a new genus. By Harriet Richardson. Pp. 447-450, 1 fig. May 23, 1907.

1536. A review of the species of the ten-spined sticklebacks or Pygosteus from East Asia. By Leo Berg. Pp. 451-454. May 23, 1907.

1537. Notes on mammals of the Kankakee Valley. By Walter L. Hahn. Pp. 455464. June $15,1907$.

1538. A new salamander from Nicaragua. By Leonhard Stejneger. Pp. 465-466. June 15, 1907.

1539. Eighteen new species and one new genus of birds from eastern Asia and the Aleutian Islands. By Austin H. Clark. Pp. 467-475. June 15, 1907.

1540. The skull of Brachauchenius, with observations on the relationships of the plesiosaurs. By Samuel W. Williston. Pp. 477-489, 4 pls. June 15, 1907.

1541. List of fishes recorded from Okinawa or the Riu Kiu Islands of Japan. By David Starr Jordan and Edwin Chapin Starks. Pp. 491-504, 5 figs. June 15, 1907.

1542. A new gerrhonotine lizard from Costa Rica. By Leonhard Stejneger. Pp. 505-506. June 15, 1907.

1543. Two new crinoids from the North Pacific Ocean. By Austin H. Clark. Pp. 507-512, 2 figs. June 15, 1907.

1544. A review of the lizard-fishes or Synodontidae of the waters of Japan. By David Starr Jordan and Albert Christian Herre. Pp. 513-524, 2 figs. June 15, 1907.

1545. New and characteristic species of fossil mollusks from the oil-bearing Tertiary formations of southern California. By Ralph Arnold. Pp. 525-546, 14 pls. June 15, 1907.

1546. On a peculiar form of metamorphism in siliceous sandstone. By George P. Merrill. Pp. 547-550, 1 pl. June 15, 1907.

1547. A new species of crinoid (Ptilocrinus pinnatus) from the Pacific coast, with a note on Bathycrinus. By Austin H. Clark. Pp. 551-554, 1 fig. June 15, 1907.

1548. A new parasitic mollusk of the genus Eulima. By Paul Bartsch. Pp. 555-556, 1 pl. June 15, 1907.

1549. Descriptions of new species of Ordovician fossils from China. By Stuart Weller. Pp. 557-563. June 15, 1907.

1550. Descriptions of new species of moths of the family Cochlidiidae. By Harrison G. Dyar. Pp. 565-567. June 15, 1907.

1551. On a collection of crinoids of the genus Eudiocrinus from Japan, with description of a new species. By Austin H. Clark. Pp. 569-574. June 15, 1907. 
1552. Notes on the porcupines of the Malay Peninsula and Archipelago. By Marcus Ward Lyon, Jr. Pp. 575-594, 4 pls. June 29, 1907.

1553. A catalogue of the Acarina, or mites, of the United States. By Nathan Banks. Pp. 595-625. June 29, 1907.

1554. A new horned rodent from the Miocene of Kansas. By James Williams Gidley. Pp. 627-636, 1 fig., 8 pls. June 29, 1907.

1555. The holothurians of the Hawaiian Islands. By Walter K. Fisher. Pp. 637-744, 17 pls. June 29, 1907.

\section{Volume 33}

Proceedings of the United States National Museum, vol. 33. Pp. i-xv (title page, advertisement, table of contents. and list of illustrations); pp. 1-729 (Proceedings papers 1556-1590); pp. 731-750 (index); 144 figs., 65 pls. 1908.

1556. An annotated list of characin fishes in the United States National Museum and the Museum of Indiana University, with descriptions of new species. By Carl H. Eigenmann and Fletcher Ogle. Pp. 1-36, 8 figs. Sept. 10, 1907.

1557. Descriptions of new species of Upper Paleozoic fossils from China. By George H. Girty. Pp. 37-48. Sept. 10, 1907.

1558. The holothurians of the North Pacific coast of North America collected by the Albatross in 1903. By Charles Lincoln Edwards. Pp. 49-68, 12 figs. Sept. 14, 1907.

1559. Descriptions of new species of recent unstalked crinoids from the North Pacific Ocean. By Austin Hobart Clark. Pp. 69-84. Sept. 17, 1907.

1560. Notes on parasites of Bermuda fishes. By Edwin Linton. Pp. 85-126, 15 pls. Oct. 14, 1907.

1561. Descriptions of new species of Recent unstalked crinoids from the coasts of northeastern Asia. By Austin Hobart Clark. Pp. 127-156. Sept. 17, 1907.

1562. A review of the cirrhitoid fishes of Japan. By David Starr Jordan and Albert Christian Herre. Pp. 157-167, 2 figs. Oct. 23, 1907.

1563. On some earwigs (Forficulidae) collected in Guatemala by Messrs. Schwarz and Barber. By Andrew Nelson Caudell. Pp. 169-176. Oct. 23, 1907.

1564. New marine mollusks from the west coast of America. By Paul Bartsch. Pp. 177-183. Oct. 23, 1907.

1565. Supplementary notes on Martyn's Universal Conchologist. By William Healey Dall. Pp. 185-192, 1 fig. Oct. 23, 1907.

1566. Basketry bolo case from Basilan Island. By Otis T. Mason. Pp. 193-196, 5 figs. Oct. 25, 1907.

1567. Descriptions of new North American tineid moths, with a generic table of the family Blastobasidae. By Lord Walsingham. Pp. 197-228. Oct. 29, 1907.

1568. On a collection of fishes from the Philippine Islands, made by Maj. Edgar A. Mearns, surgeon, U. S. Army, with descriptions of seven new species. By Alvin Seale and Barton A. Bean. Pp. 229-248, 8 figs. Nov. 21, 1907.

1569. The West American mollusks of the genus Triphoris. By Paul Bartsch. Pp. 249-262, 1 pl. Dec. 12, 1907.

1570. On a collection of fishes from Echigo, Japan. By David Starr Jordan and Robert Earl Richardson. Pp. 263-266, 3 figs. Dec. 12, 1907.

1571. The dragonflies (Odonata) of Burma and Lower Siam.-II. Subfamilies Cordulegasterinae, Chlorogomphinae, and Gomphinae. By Edward Bruce Williamson. Pp. 267-317, 39 figs. Dec. 13, 1907.

1572. Description of a new species of killifish, Lucania browni, from a hot spring in Lower California. By David Starr Jordan and Robert Earl Richardson. Pp. 319-321, 1 fig. Dec. 24, 1907.

1573. North American parasitic copepods belonging to the family Caligidae. Parts 3 and 4.-A revision of the Pandarinae and the Cecropinae. By Charles Branch Wilson. Pp. 223-490, 18 figs., 27 pls. Dec. 31, 1907.

1574. The pyramidellid mollusks of the Oregonian faunal area. By William Healey Dall and Paul Bartsch. Pp. 491-534, 5 pls. Dec. 31, 1907. 
Proc.

No.

1575. List of fishes collected in the river at Buytenzorg, Java, by Dr. Douglas Houghton Campbell. By David Starr Jordan and Alvin Seale. Pp. 535-543, 2 figs. Dec. 24, 1907.

1576. A new geckoid lizard from the Philippine Islands. By Leonhard Stejneger. Pp. 545-546. Dec. 24, 1907.

1577. Mammals collected in western Borneo by Dr. W. L. Abbott. By Marcus Ward Lyon, Jr. Pp. 547-571, 2 figs. Dec. 24, 1907.

1578. Two new species of toads from the Philippines. By Leonhard Stejneger. Pp. 573-576. Feb. 18, 1908.

1579. The pulque of Mexico. By Walter Hough. Pp. 577-592, 19 figs. Feb. 18, 1908.

1580. North American parasitic copepods: New genera and species of Caliginae. By Charles Branch Wilson. Pp. 593-627, 8 pls. Feb. 28, 1908.

1581. A review of the flat-heads, gurnards, and other mail-cheeked fishes of the waters of Japan. By David Starr Jordan and Robert Earl Richardson. Pp. 629-670, 9 figs. Feb. 28, 1908.

1582. Infrabasals in Recent genera of the crinoid family Pentacrinitidae. By Austin Hobart Clark. Pp. 671-676, 8 figs. Feb. 29, 1908.

1583. A new species of flying lizard from the Philippine Islands. By Leonhard Stejneger. Pp. 677-679. Feb. 29, 1908.

1584. A new fresh-water bivalve (Corneocyclas) from the mountains of Ecuador. By Paul Bartsch. Pp. 681-682, 1 fig. Feb. 29, 1908.

1585. The crinoid genus Comatula Lamarck; with a note on the Encrinus parrae of Guerin. By Austin Hobart Clark. Pp. 683-688. Feb. 29, 1908.

1586. On some isopods of the family Dajidae from the northwest Pacific Ocean, with descriptions of a new genus and two new species. By Harriet Richardson. Pp. 689-696, 7 figs. Feb. 29, 1908.

1587. Notes on the fresh-water mollusk Planorbis magnificus and descriptions of two new forms of the same genus from the southern States. By Paul Bartsch. Pp. 697-700, 1 pl. Mar. 4, 1908.

1588. On Ctenolucius Gill, a neglected genus of characin fishes, with notes on the typical species. By Barton A. Bean. Pp. 701-703, 1 fig. Mar. 4, 1908.

1589. Fresh-water Crustacea from Labrador and Newfoundland. By Joseph A. Cushman. Pp. 705-713, 5 pls. Mar. 4, 1908.

1590. On the collection of thysanopterous insects from Barbados and St. Vincent Islands. By Henry James Franklin. Pp. 715-729, 3 pls. Mar. 4, 1908.

\section{Volume 34}

Proceedings of the United States National Museum, vol. 34. Pp. i-xiv (title page, advertisement, table of contents, and list of illustrations); pp. 1-746 (Proceedings papers 1591-1630); pp. 747-777 (index); 78 figs., 105 pls. 1908.

1591. Schizopod crustaceans in the U. S. National Museum: Schizopods from Alaska. By Arnold E. Ortmann. Pp. 1-10, 1 pl. Apr. 6, 1908.

1592. Notes on a collection of fishes from the Gulf of Mexico at Vera Cruz and Tampico. By David Starr Jordan and Mary Cynthia Dickerson. Pp. 11-22, 2 figs. Apr. 6, 1908.

1593. The parasitic isopod Leidya distorta (Leidy) found on a new host. By Harriet Richardson. Pp. 23-26, 5 figs. Apr. 6, 1908.

1594. Descriptions of four new species of amphipodous Crustacea from the Gulf of Mexico. By Arthur S. Pearse. Pp. 27-32, 4 figs. Apr. 6, 1908.

1595. Description of Pantosteus santa-anae, a new species of fish from the Santa Ana River, California. By John Otterbein Snyder. Pp. 33-34. Apr. 6, 1908.

1596. The Dalmanellas of the Chemung formation, and a closely related new brachiopod genus Thiemella. By Henry S. Williams. Pp. 35-64, 3 pls. Apr. 6, 1908.

1597. Descriptions of three new species of saturnian moths. By William Schaus. Pp. 65-66. Apr. 17, 1908.

1598. Description of a new isopod of the genus Eurycope from Marthas Vineyard. By Harriet Richardson. Pp. 67-69, 3 figs. Apr. 17, 1908. 
Proc.

No.

1599. Notes on some western Orthoptera; with the description of one new species. By Andrew Nelson Caudeil. Pp. 71-81. Apr. 17, 1908.

1600. On the revision of the mollusk genus Pterinea Goldfuss. By Henry Shaler Williams. Pp. 83-90. Apr. 17, 1908.

1601. Descriptions of new species of South American geometrid moths. By William Warren. Pp. 91-110. Apr. 25, 1908.

1602. Description of a new species of half-beak (Hemiramphus mioprorus) from Nagasaki, Japan. By David Starr Jordan and Mary C. Dickerson. Pp. 111112, 1 fig. Apr. 25, 1908.

1603. Foraminifera collected near the Hawaiian Islands by the steamer Albatross in 1902. By Rufus Mather Bagg, Jr. Pp. 113-172, 1 pl. Apr. 28, 1908.

1604. Descriptions of new curculionid beetles of the tribe Anthonomini. By W. Dwight Pierce. Pp. 173-181. Apr. 28, 1908.

1605. On three existing species of sea-turtles, one of them (Caretta remivaga) new. By Oliver P. Hay. Pp. 183-198, 6 pls. May 4, 1908.

1606. Three new species of lizards from the Philippine Islands. By Leonhard Stejneger. Pp. 199-204, 6 figs. May 4, 1908.

1607. New stalked crinoids from the eastern coast of North America. By Austin Hobart Clark. Pp. 205-208, 3 figs. May 4, 1908.

1608. Descriptions of new species of crinoids, chiefly from the collections made by the U. S. Fisheries steamer Albatross at the Hawaiian Islands in 1902; with remarks on the classification of the Comatulida. By Austin Hobart Clark. Pp. 209-239. May 14, 1908.

1609. A new amphipod crustacean, Orchestoidea biolleyi, from Costa Rica. By Thomas R. R. Stebbing. Pp. 241-244, 2 figs., 1 pl. May 15, 1908.

1610. Descriptions of new species of mollusks from the Pacific coast of the United States, with notes on other mollusks from the same region. By William Healey Dall. Pp. 245-257. June 16, 1908.

1611. New species of Cretaceous invertebrates from northern Colorado. By Junius Henderson. Pp. 259-264, 1 pl. June 16, 1908.

1612. Some cases of abnormal arm structure in Recent crinoids. By Austin Hobart Clark. Pp. 265-270, 5 figs. June 16, 1908.

1613. The crinoid genus Eudiocrinus, with description of a new species. By Austin H. Clark. Pp. 271-279, 11 figs. June 20, 1908.

1614. On some new and old species of Carboniferous fossils. By George H. Girty. Pp. 281-303, 8 pls. July 14, 1908.

1615. On a collection of feather stars, or comatulids, from Japan. By Austin Hobart Clark. Pp. 305-319. July 15, 1908.

1616. Decorative designs of Alaskan needlecases: a study in the history of conventional designs, based on materials in the U. S. National Museum. By Franz Boas. Pp. 321-344, 16 figs., 9 pls. July 15, 1908.

1617. Descriptions of new Cretaceous and Tertiary fossils from the Santa Cruz Mountains, California. By Ralph Arnold. Pp. 345-389, 7 pls. Aug. 8, 1908.

1618. Description of a new isopod genus of the family Dajidae. By Harriet Richardson. Pp. 391-392, 3 figs. Aug. 10, 1908.

1619. Remarks on the horns and on the systematic position of the American antelope. By Marcus Ward Lyon, Jr. Pp. 393-401, 2 pls. Aug. 11, 1908.

1620. Description of a new brittle star from the Upper Miocene of the Santa Cruz Mountains, California. By Ralph Arnold. Pp. 403-405, 1 pl. Aug. 17, 1908.

1621. The late Niagaran strata of west Tennessee. By William F. Pate and Ray S. Bassler. Pp. 407-432. Aug. 18, 1908.

1622. On the occurrence of calcium sulphide (oldhamite) in the Allegan meteorite. By Wirt Tassin. Pp. 433-434. Aug. 19, 1908.

1623. The nomenclature of the Recent crinoids. By Austin Hobart Clark. Pp. 435542. Aug. 25, 1908.

1624. Descriptions of the Alcyonaria collected by the U. S. Bureau of Fisheries steamer Albatross in the vicinity of the Hawaiian Islands in 1902. By Charles C. Nutting. Pp. 543-601, 11 pls. Sept. 12, 1908. 
1625. On a collection of fishes from Fiji, with notes on certain Hawaiian fishes. By David Starr Jordan and Mary Cynthia Dickerson. Pp. 603-617, 6 figs. Sept. 14, 1908.

1626. Mammals collected in eastern Sumatra by Dr. W. L. Abbott during 1903, 1906, and 1907, with descriptions of new species and subspecies. By Marcus Ward Lyon, Jr. Pp. 619-679, 4 figs., 5 pls. Sept. 14, 1908.

1627. Descriptions of two new species of Pleistocene ruminants of the genera Ovibos and Boötherium, with notes on the latter genus. By James Williams Gidley. Pp. 681-684, 1 fig., 3 pls. Sept. 15, 1908.

1628. On meteoric chromites. By Wirt Tassin. Pp. 685-690. Sept. 15, 1908.

1629. A new rabbit cestode, Cittotaenia mosaica. By Maurice C. Hall. Pp. 691699, 6 figs. Sept. 15, 1908.

1630. The collection of Jewish ceremonial objects in the United States National Museum. By Cyrus Adler and I. M. Casanowicz. Pp. 701-746, 46 pls. Sept. 28, 1908.

\section{Volume 35}

Proceedings of the United States National Museum, vol. 35. Pp. i-xvi (title page, advertisement, table of contents, and list of illustrations) ; pp. 1-727 (Proceedings papers 1631-1658); pp. 729-757 (index); 251 figs., 91 pls. 1909.

1631. Vocabulary of Malaysian basketwork: A study in the W. L. Abbott collections. By Otis T. Mason. Pp. 1-51, 41 figs., 17 pls. Nov. 7, 1908.

1632. Descriptions of some new mosquitoes from tropical America. By Harrison G. Dyar and Frederick Knab. Pp. 53-70. Oct. 30, 1908.

1633. Some new Isopoda of the superfamily Aselloidea from the Atlantic coast of North America. By Harriet Richardson. Pp. 71-86, 21 figs. Oct. 30, 1908.

1634. The axial canals of the Recent Pentacrinitidae. By Austin Hobart Clark. Pp. 87-91, 16 figs. Oct. 30, 1908.

1635. Descriptions of eighteen new species and two new genera of fishes from Japan and the Riu Kiu Islands. By John Otterbein Snyder. Pp. 93-111. Oct. 30, 1908.

1636. The homologies of the arm joints and arm divisions in the Recent crinoids of the families of the Comatulida and the Pentacrinitidae. By Austin Hobart Clark. Pp. 113-131, 28 figs. Oct. 30, 1908.

1637. The formation of geodes with remarks on the silicification of fossils. By Ray S. Bassler. Pp. 133-154, 1 fig., 7 pls. Nov. 7, 1908.

1638. Choerodon in place of Choerops for a labroid genus of fishes. By Theodore Gill. Pp. 155-156. Oct. 31, 1908.

1639. Description of new fossil liverwort from the Fort Union beds of Montana. By Frank Hall Knowlton. Pp. 157-159, 1 pl. Nov. 9, 1908.

1640. Descriptions of five species of North American fossil turtles, four of which are new. By Oliver P. Hay. Pp. 161-169, 3 figs., 2 pls. Nov. 9, 1908.

1641. New examples of American Indian skulls with low forehead. By Aleš Hrdlička. Pp. 171-175, 1 fig., 1 pl. Nov. 9, 1908.

1642. Descriptions and figures of some land and fresh-water shells from Mexico, believed to be new. By William Healey Dall. Pp. 177-182, 2 pls. Nov. $10,1908$.

1643. Notes on two rare California fishes, Rimicola eigenmanni and Plagiogrammus hopkinsi. By John Otterbein Snyder. Pp. 183-186. Oct. 31, 1908.

1644. A generic revision of American moths of the family Oecophoridae, with descriptions of new species. By August Busck. Pp. 187-207. Oct. 31, 1908.

1645. A revision of some species of Noctuidae heretofore referred to the genus Homoptera Boisduval. By John B. Smith. Pp. 209-275, 6 pls. Nov. 10, 1908.

1646. New American Paleozoic Ostracoda. Preliminary revision of the Beyrichiidae, with descriptions of new genera. By Edward O. Ulrich and Ray S. Bassler. Pp. 277-340, 64 figs., 8 pls. Nov. 10, 1908.

1647. Descriptions of fossil crabs from California. By Mary J. Rathbun. Pp. 341349, 5 pls. Nov. 14, 1908. 
Proc.

No.

1648. On certain genera and species of carnivorous dinosaurs, with special reference to Ceratosaurus nasicornis Marsh. By Oliver P. Hay. Pp. 351-366, 4 figs. Oct. 31, 1908.

1649. Descriptions of new species of North American crambid moths. By William Dunham Kearfott. Pp. 367-393, 14 figs. Oct. 31, 1908.

1650. Two new species of Neotropical Orthoptera of the family Acrididae. By James A. G. Rehn. Pp. 395-398, 5 figs. Oct. 30, 1908.

1651. A further report on the Ostracoda of the United States National Museum. By Richard W. Sharpe. Pp. 399-430, 16 pls: Nov. 19, 1908.

1652. North American parasitic copepods: A list of those found upon the fishes of the Pacific coast, with descriptions of new genera and species. By Charles Branch Wilson. Pp. 431-481, 18 pls. Dec. 10, 1908.

1653. Some new isopods of the family Gnathiidae from the Atlantic coast of North America. By Harriet Richardson. Pp. 483-488, 7 figs. Nov. 20, 1908.

1654. The Amphipoda collected by the U. S. Bureau of Fisheries steamer Albatross off the west coast of North America, in 1903 and 1904, with descriptions of a new family and several new genera and species. By Samuel J. Holmes. Pp. 489-543, 46 figs. Nov. 20, 1908.

1655. Notes on the mammals and cold-blooded vertebrates of the Indiana University Farm, Mitchell, Indiana. By Walter L. Hahn. Pp. 545-581. Dec. 7, 1908.

1656. Generic names applied to birds during the years 1901 to 1905 , inclusive, with further additions to Waterhouse's "Index Generum Avium." By Charles W. Richmond. Pp. 583-655. Dec. 16, 1908.

1657. A revision of the kingfisher genus Ramphalcyon (Pelargopsis). By Harry C. Oberholser. Pp. 657-680. Feb. 9, 1909.

1658. Alcyonaria of the California coast. By Charles C. Nutting. Pp. 681-727, 8 pls. Feb. 20, 1909.

\section{Volume 36}

Proceedings of the United States National Museum, vol. 36. Pp. i-xviii (title page, advertisement, table of contents, and list of illustrations); pp. 1-680 (Proceedings papers 1659-1694); pp. 681-697 (index); 205 figs., 70 pls. 1909.

1659. The American species of snapping shrimps of the genus Synalpheus. By Henri Coutière. Pp. 1-93, 54 figs. Jan. 30, 1909.

1660. On the skull and the brain of Triceratops, with notes on the brain-cases of Iguanodon and Megalosaurus. By Oliver P. Hay. Pp. 95-108, 3 pls. Feb. 6, 1909.

1661. On Brazilian grasshoppers of the subfamilies Pyrgomorphinae and Locustinae (Acridinae of authors). By James A. G. Rehn. Pp. 109-163, 39 figs. Mar. 3, 1909.

1662. Descriptions of three new species of cisco, or lake herring (Argyrosomus), from the Great Lakes of America; with a note on the species of whitefish. By David Starr Jordan and Barton Warren Evermann. Pp. 165-172, 3 figs. Mar. 3, 1909.

1663. The isopod crustacean, Ancinus depressus (Say). By Harriet Richardson. Pp. 173-177, 9 figs. Mar. 3, 1909.

1664. A new American Jurassic crinoid. By Frank Springer. Pp. 179-190, 1 pl. Mar. 3, 1909.

1665. Description of two species of fossil turtles, Toxochelys stenopora and Christernon? interpositum, the latter hitherto unknown. By Oliver P. Hay. Pp. 191196, 3 figs., 1 pl. Apr. 8, 1909.

1666. Osteology of the Jurassic reptile Camptosaurus, with a revision of the species of the genus, and descriptions of two new species. By Charles W. Gilmore. Pp. 197-332, 48 figs., 15 pls. Apr. 17, 1909.

1667. The collection of rosaries in the United States National Museum. By Immanuel M. Casanowicz. Pp. 333-359, 10 pls. Apr. 17, 1909.

1668. Comatilla, a remarkable new genus of unstalked crinoids. By Austin Hobart Clark. Pp. 361-367. Apr. 27, 1909. 
1669. Description of a new species of leatherback turtle from the Miocene of Maryland. By William Palmer. Pp. 369-373, 1 pl. Apr. 27, 1909.

1670. Four new species of isopods from the coast of California. By S. J. Holmes and M. E. Gay. Pp. 375-379, 6 figs. Apr. 27, 1909.

1671. Notes on two slugs of the genus Veronicella. By W. W. Robbins and T. D. A. Cockerell. Pp. 381-384, 1 pl. Apr. 27, 1909.

1672. Anyam gila (mad weave): A Malaysian type of basketwork. By Otis T. Mason. Pp. 385-390, 11 figs. May 6, 1909.

1673. On a collection of Recent crinoids from the Philippine Islands. By Austin Hobart Clark. Pp. 391-410, 1 fig. May 13, 1909.

1674. Descriptions of some bees in the U. S. National Museum. By T. D. A. Cockerell. Pp. 411-420. May 13, 1909.

1675. Description of a new isopod of the genus Jaeropsis from Patagonia. By Harriet Richardson. Pp. 421-422, 1 fig. May 13, 1909.

1676. Ammodiscoides, a new genus of arenaceous Foraminifera. By Joseph A. Cushman. Pp. 423-424, 1 pl. May 13, 1909.

1677. Description of a new whitefish (Coregonus oregonius) from McKenzie River, Oregon. By David Starr Jordan and John Otterbein Snyder. Pp. 425-430, 1 fig. May 15, 1909.

1678. The isopod crustacean Acanthoniscus spiniger Kinahan redescribed. By Harriet Richardson. Pp. 431-434, 7 figs. May 15, 1909.

1679. Additions to the list of Philippine birds, with descriptions of new and rare species. Py Edgar Alexander Mearns. Pp. 435-447. May 22, 1909.

1680. Remarks on the insectivores of the genus Gymnura. By Marcus Ward Lyon, Jr. Pp. 449-456, 4 pls. May 27, 1909.

1681. Description of a new snake from Panama. By Leonhard Stejneger. Pp. 457. 458. May 27, 1909.

1682. Description of a new skate (Dactylobatus armatus) from deep water off the southern Atlantic coast of the United States. By Barton A. Bean and Alfred C. Weed. Pp. 459-461, 1 fig., 1 pl. May 27, 1909.

1683. A list of birds collected by Dr. Paul Bartsch in the Philippine Islands, Borneo, Guam, and Midway Island, with descriptions of three new forms. By Edgar Alexander Mearns. Pp. 463-478. May 27, 1909.

1684. Additional notes on mammals of the Rhio-Linga Archipelago, with descriptions of new species and a revised list. By Marcus Ward Lyon, Jr. Pp. 479-491, 1 pl. June 1, 1909.

1685. Revision of the crinoid family Comasteridae, with descriptions of new genera and species. By Austin Hobart Clark. Pp. 493-507. June 7, 1909.

1686. A new squirrel from Direction Island, South China Sea. By Marcus Ward Lyon, Jr. Pp. 509-510. June 7, 1909.

1687. The thorax of insects and the articulation of the wings. By Robert Evans Snodgrass. Pp. 511-595, 6 figs., 30 pls. June 18, 1909.

1688. Descriptions of new genera and species of fishes from Japan and the Riu Kiu Islands. By John Otterbein Snyder. Pp. 597-610. June 18, 1909.

1689. Notes on the fossil mammalian genus Ptilodus, with descriptions of new species. By James Williams Gidley. Pp. 611-626, 9 figs., 1 pl. June 19, 1909.

1690. Fresh-water sponges in the collection of the United States National Museum. -Part I. Specimens from the Philippines and Australia. By Nelson Annandale. Pp. 627-632, 4 figs. June 19, 1909.

1691. Descriptions of seventeen new species of Recent crinoids. By Austin Hobart Clark. Pp. 633-651. June 19, 1909.

1692. Dragonflies of the Mississippi Valley collected during the pearl mussel investigations on the Mississippi River, July and August, 1907. By Charles Branch Wilson. Pp. 653-671. June 19, 1909.

1693. Four new species of the crinoid genus Rhizocrinus. By Austin Hobart Clark. Pp. 673-676. June 19, 1909.

1694. Descriptions of two new species of electric rays, of the family Narcobatidac, from deep water off the southern Atlantic cosst of the United States. By Barton A. Bean and Alfred C. Weed. Pp. 677-680, 1 fig. June 21, 1909. 


\section{Volume 37}

Proceedings of the United States National Museum, vol. 37. Pp. i-xii (title page, advertisement, table of contents, and list of illustrations); pp. 1-666 (Proceedings papers 1695-1724); pp. 667-697 (index); 108 figs., 39 pls. 1910. Proc. No.

1695. The mouse deer of the Rhio-Linga Archipelago: A study of specific differentiation under uniform environment. By Gerrit S. Miller, Jr. Pp. 1-9, 2 figs., 3 pls. Sept. 1, 1909.

1696. Carboniferous air-breathing vertebrates of the United States National Museum. By Roy L. Moodie. Pp. 11-28, 7 pls. Sept. 23, 1909.

1697. Five new species of Recent unstalked crinoids. By Austin Hobart Clark. Pp. 29-34. Aug. 23, 1909.

1698. A new rhynchocephalian reptile from the Jurassic of Wyoming, with notes on the fauna of "Quarry 9." By Charles W. Gilmore. Pp. 35-42, 3 figs., 1 pl. Oct. 15, 1909.

1699. On the nature of Edestus and related genera, with descriptions of one new genus and three new species. By Oliver P. Hay. Pp. 43-61, 7 figs., 4 pls. Oct. 16, 1909.

1700. Report on barnacles of Peru, collected by Dr. R. E. Coker and others. By Henry A. Pilsbry. Pp. 63-74, 2 figs., 4 pls. Oct. 18, 1909.

1701. Isopods collected in the Northwest Pacific by the U. S. Bureau of Fisheries steamer Albatross in 1906. By Harriet Richardson. Pp. 75-129, 50 figs. Oct. 22, 1909.

1702. Fresh-water sponges collected in the Philippines by the Albatross Expedition. By Neison Annandale. Pp. 131-132. Oct. 23, 1909.

1703. The polychaetous annelids dredged in 1908 by Mr. Owen Bryant off the coasts of Labrador, Newfoundland, and Nova Scotia. By J. Percy Moore. Pp. 133-146. Oct. 25, 1909.

1704. Report on a collection of shells from Peru, with a summary of the littoral marine Mollusca of the Peruvian zoological province. By William Healey Dall. Pp. 147-294, 9 pls. Nov. 24, 1909.

1705. Four new land shells from the Philippine Islands. By Paul Bartsch. Pp. 295299, 1 pl. Nov. 26, 1909.

1706. Coelenterates from Labrador and Newfoundland, collected by Mr. Owen Bryant from July to October, 1908. By Henry B. Bigelow. Pp. 301-320, 3 pls. Dec. 14, 1909.

1707. Three new land shells from Mexico and Guatemala. By Paul Bartsch. Pp. 321-323, 1 pl. Dec. 14, 1909.

1708. Studies of North American weevils. By W. Dwight Pierce. Pp. 325-364. Dec. 11, 1909.

1709. Notes on the Philippine pond snails of the genus Vivipara, with descriptions of new species. By Paul Bartsch. Pp. 365-367, 1 pl. Dec. 14, 1909.

1710. The North American dragonflies (Odonata) of the genus Macromia. By Edward Bruce Williamson. Pp. 369-398, 7 figs., 2 pls. Dec. 4, 1909.

1711. A new species of Cerithiopsis from Alaska. By Paul Bartsch. Pp. 399-400, 1 fig. Dec. 11, 1909.

1712. Fresh-water sponges in the collection of the United States National Museum.Part II. Specimens from North and South America. By Nelson Annandale. Pp. 401-406, 3 figs. Dec. 22, 1909.

1713. Diagnoses of new cephalopods from the Hawaiian Islands. By S. Stillman Berry. Pp. 407-419, 9 figs. Dec. 30, 1909.

1714. A review of the Serranidae or sea bass of Japan. By David Starr Jordan and Robert Earl Richardson. Pp. 421-474, 16 figs. Jan. 9, 1910.

1715. On olivine-diabase from Davidson County, North Carolina. By Joseph E. Pogue. Pp. 475-484, 1 fig., 1 pl. Jan. 19, 1910.

1716. The snapping shrimps (Alpheidae) of the Dry Tortugas, Florida. By Henri Coutière. Pp. 485-487, 3 figs. Jan. 20, 1910. 
1717. Some bees of the genus Augochlora from the West Indies. By T. D. A. Cockerell. Pp. 489-494. Feb. 2, 1910.

1718. Description of a new terrestrial isopod from Guatemala. By Harriet Richardson. Pp. 495-497, 1 fig. Feb. 2, 1910.

1719. The type-species of the North American genera of Diptera. By D. W. Coquillett. Pp. 499-647. Aug. 4, 1910.

1720. Description of a new isopod of the genus Notasellus from the east coast of Patagonia. By Harriet Richardson. Pp. 649-650, 1 fig. Aug. 4, 1910.

1721. The paradise flycatchers of Japan and Korea. By Pierre Louis Jouy. Pp. 651655. Aug. 4, 1910.

1722. Some new hymenopterous insects from the Philippine Islands. By S. A. Rohwer. Pp. 657-660. Aug. 4, 1910.

1723. Notes on Anteliochimaera and related genera of chimaeroid fishes. By Barton A. Bean and Alfred C. Weed. Pp. 661-663, 2 pls. Aug. 4, 1910.

1724. A new ophiuran from the West Indies. By Hubert Lyman Clark. Pp. 665666, 2 figs. Aug. 4, 1910.

\section{Volume 38}

Proceedings of the United States National Museum, vol. 38. Pp. i-xv (title page, advertisement, table of contents, and list of illustrations); pp. 1-650 (Proceedings papers 1725-1771) ; pp. 651-677 (index) ; 146 figs., 56 pls. 1911.

1725. The Gustavus Vasa Fox collection of Russian souvenirs in the United States National Museum. By Immanuel M. Casanowicz. Pp. 1-15, 8 pls. Apr. 3, 1910.

1726. On sand-barites from Kharga, Egypt. By Joseph E. Pogue. Pp. 17-24, 1 fig., 1 pl. Apr. 30, 1910.

1727. The birds collected and observed during the cruise of the United States Fisheries steamer Albatross in the North Pacific Ocean, and in the Bering, Okhotsk, Japan, and eastern seas, from April to December, 1906. By Austin Hobart Clark. Pp. 25-74, 1 fig. Apr. 30, 1910.

1728. Description of a new species of deep-water sculpin (Triglopsis ontariensis) from Lake Ontario, with notes on related species. By David Starr Jordan and William Francis Thompson. Pp. 75-78, 3 figs. Apr. 30, 1910.

1729. Report on isopods from Peru, collected by Dr. R. E. Coker. By Harriet Richardson. Pp. 79-85, 6 figs. May 3, 1910.

1730. Three new genera and species of parasitic Hymenoptera. By J. C. Crawford. Pp. 87-90, 5 figs. May 3, 1910.

1731. The batrachians and reptiles of Formosa. By Leonhard Stejneger. Pp. 91-114. May 3, 1910.

1732. The phylogenetic interrelationships of the Recent crinoids. By Austin $\mathbf{H}$. Clark. Pp. 115-118. May 3, 1910.

1733. New Hymenoptera from the Philippine Islands. By J. C. Crawford. Pp. 119-133. May 3, 1910.

1734. Notes on a collection of fishes from Cameron, Louisiana. By Frank Walter Weymouth. Pp. 135-145, 2 figs. May 3, 1910.

1735. Report on a collection of birds made by Pierre Louis Jouy in Korea. By Austin H. Clark. Pp. 147-176. May 9, 1910.

1736. On some land shells collected by Dr. Hiram Bingham in Peru. By William Healey Dall. Pp. 177-182, 4 figs. June 6, 1910.

1737. Fresh-water sponges in the collection of the United States National Museum.Part III. Description of a new species of Spongilla from China. By Nelson Annandale. P. 183. June 6, 1910.

1738. A revision of the fossil plants of the genus Nageiopsis of Fontaine. By Edward W. Berry. Pp. 185-195, 2 figs. June 6, 1910.

1739. On a collection of Tenthredinoidea from eastern Canada. By S. A. Rohwer. Pp. 197-209. June 6, 1910.

1740. On the origin of certain types of crinoid stems. By Austin Hobart Clark. Pp. 211-216. June 6, 1910. 
Proc.

No.

1741. Summary of the shells of the genus Conus from the Pacific coast of America in the U. S. National Museum. By William Healey Dall. Pp. 217-228. June 6, 1910.

1742. Descriptions of some new species and genera of Lepidoptera from Mexico. By Harrison G. Dyar. Pp. 229-273. June 7, 1910.

1743. A new Australian crinoid. By Austin H. Clark. Pp. 275-276. June 7, 1910.

1744. A review of the flounders belonging to the genus Pleuronichthys. By Edwin Chapin Starks and William Francis Thompson. Pp. 277-287, 2 figs. June 14, 1910.

1745. The North American bees of the genus Nomia. By T. D. A. Cockerell. Pp. 289-298. June 14, 1910.

1746. A new fresh-water amphipod from Virginia, with some notes on its biology. By George C. Embody. Pp. 299-305, 17 figs. June 18, 1910.

1747. Descriptions of eight new species of fossil turtles from west of the one hundredth meridian. By Oliver P. Hay. Pp. 307-326, 23 figs., 3 pls. June 29, 1910.

1748. A comparison of the chub-mackerels of the Atlantic and Pacific Oceans. By Barton Warren Evermann and William Converse Kendall. Pp. 327-328. June 18, 1910.

1749. A new European crinoid. By Austin Hobart Clark. Pp. 329-333. June $18,1910$.

1750. On some Ostracoda, mostly new, in the collection of the United States $\mathrm{Na}$ tional Museum. By Richard W. Sharpe. Pp. 335-341, 5 figs. August 6, 1910.

1751. Descriptions of some new species of monkeys of the genera Pithecus and Pygathrix collected by Dr. W. L. Abbott and presented to the United States National Museum. By D. G. Elliot. Pp. 343-352. August 6, 1910.

1752. Note on the gold-eye, Amphiodon alosoides Rafinesque, or Elattonistius chrysopsis (Richardson). By David Starr Jordan and William Francis Thompson. Pp. 353-357, 2 figs. Aug. 6, 1910.

1753. Studies on the North American geometrid moths of the genus Pero. By John A. Grossbeck. Pp. 359-377, 4 pls. Aug. 19, 1910.

1754. Descriptions of new species of ichneumon flies. By H. L. Viereck. Pp. 379384, 3 figs. Aug. 6, 1910.

1755. A new carnivore from China. By Gerrit S. Miller, Jr. Pp. 385-386, 1 pl. Aug. 19, 1910.

1756. [Scientific results of the Philippine cruise of the Fisheries steamer Albatross, 1907-10.-No. 5.] Proisocrinus, a new genus of Recent crinoids. By Austin Hobart Clark. Pp. 387-390, 3 figs. Aug. 6, 1910.

1757. Descriptions of two new genera and sixteen new species of mammals from the Philippine Islands. By Gerrit S. Miller, Jr. Pp. 391-404, 3 pls. Aug. 19, 1910.

1758. Notes on the marine Copepoda and Cladocera of Woods Hole and adjacent regions, including a synopsis of the genera of the Harpacticoida. By Richard W. Sharpe. Pp. 405-436, 20 figs. Aug. 20, 1910.

1759. [Scientific results of the Philippine cruise of the Fisheries steamer Albatross, 1907-10.-No. 6.] New arenaceous Foraminifera from the Philippines. By Joseph Augustine Cushman. Pp. 437-442, 19 figs. Aug. 20, 1910.

1760. The Dermaptera (earwigs) of the United States National Museum. By Malcolm Burr. Pp. 443-467, 8 figs. Aug. 20, 1910.

1761. On a new Labradorean species of Onchidiopsis, a genus of mollusks new to eastern North America; with remarks on its relationships. By Francis N. Balch. Pp. 469-484, 2 pls. Oct. 6, 1910.

1762. Leidyosuchus sternbergii, a new species of crocodile from the Ceratops beds of Wyoming. By Charles W. Gilmore. Pp. 485-502, 2 figs., 7 pls. Oct. $15,1910$.

1763. Report on the fishes collected by Mr. Owen Bryant on a trip to Labrador in the summer of 1908. By William Converse Kendall. Pp. 503-510, 1 pl. Oct. 15, 1910. 
Proc.

No.

1764. A review of the venomous toadfishes. By Barton A. Bean and Alfred C. Weed. Pp. 511-526, 7 figs., 4 pls. Oct. 15, 1910.

1765. New moths of the genus Trichostibas. By August Busck. Pp. 527-530, 1 p!. Oct. $15,1910$.

1766. The stalk-eyed Crustacea of Peru and the adjacent coast. By Mary J. Rathbun. Pp. 351-620, 3 figs., 21 pls. Oct. 20, 1910.

1767. Marine amphipods from Peru. By Alfred O. Walker. Pp. 621-622, 1 fig. Oct. 18, 1910.

1768. Fresh-water amphipods from Peru. By Ada L. Weckel. Pp. 623-624, 1 fig. Oct. 18, 1910.

1769. A revision of the fossil plants of the genera Acrostichopteris, Taeniopteris, Nilsonia, and Sapindopsis from the Potomac group. By Edward W. Berry. Pp. 625-644. Oct. 18, 1910.

1770. Description of a new parasitic isopod from the Hawaiian Islands. By Harriet Richardson. Pp. 645-647, 6 figs. Oct. 18, 1910.

1771. Fresh-water sponges in the collection of the United States National Museum.Part IV. Note on the fresh-water sponge, Ephydatia japonica, and its allies. By Nelson Annandale. Pp. 649-650. Oct. 18, 1910.

\section{Volume 39}

Proceedings of the United States National Museum, vol. 39. Pp. i-xviii (title page, advertisement, table of contents, and list of illustrations); pp. 1-664 (Proceedings papers 1772-1807); pp. 665-968 (index); 189 figs., 71 pls. 1911.

1772. The annelids of the family Arenicolidae of North and South America, including an account of Arenicola glacialis Murdoch. By James Hartley Ashworth. Pp. 1-32, 14 figs. Sept. 23, 1910.

1773. A new genus and species of lizard from Florida. By Leonhard Stejneger. Pp. 33-35, 6 figs. Sept. 23, 1910.

1774. The thorax of the Hymenoptera. By Robert Evans Snodgrass. Pp. 37-91, 91 figs., 16 pls. Oct. 25, 1910.

1775. Terrestrial isopods collected in Costa Rica by J. F. Tristan, with descriptions of a new genus and species. By Harriet Richardson. Pp. 93-95, 4 figs. Oct. 25, 1910.

1776. A new scincid lizard from the Philippine Islands. By Leonhard Stejneger. Pp. 97-98. Oct. 25, 1910.

1777. Japanese sawflies in the collection of the United States National Museum. By S. A. Rohwer. Pp. 99-120. Oct. 25, 1910.

1778. The fishes of the Lake of the Woods and connecting waters. By Barton Warren Evermann and Homer Barker Latimer. Pp. 121-136. Oct. 25, 1910.

1779. Description of a new species of Anilocra from the Atlantic coast of North America. By Harriet Richardson. Pp. 137-138, 1 fig. Oct. 25, 1910.

1780. A new species of cestode parasite (Taenia balaniceps) of the dog and the lynx, with a note on Proteocephalus punicus. By Maurice C. Hall. Pp. 139-151, 9 figs. Oct. 25, 1910.

1781. The west American mollusks of the genus Alaba. By Paul Bartsch. Pp. 153-156, 4 figs. Oct. 25, 1910.

1782. Notes on the structure and habits of the wolffishes. By Theodore Gill. Pp. 157-187, 13 figs., 12 pls. Jan. 9, 1911.

1783. North American parasitic copepods.-Part 9. The Lernaeopodidae. By Charles Branch Wilson. Pp. 189-226, 8 pls. Jan. 9, 1911.

1784. Description of a new rabbit from islands off the coast of Virginia. By Edgar A. Mearns. Pp. 227-228, 2 pls. Jan. 9, 1911.

1785. Descriptions of new mollusks of the family Vitrinellidae from the west coast of America. By Paul Bartsch. Pp. 229-234, 2 pls. Jan. 9, 1911.

1786. New South American parasitic Hymenoptera. By J. C. Crawford. Pp. 235239, 4 figs. Dec. 28, 1910.

1787. A review of the sciaenoid fishes of Japan. By David Starr Jordan and William Francis Thompson. Pp. 241-261, 4 figs. Jan. 30, 1911. 
1788. North American parasitic copepods belonging to the family Ergasilidae. By Charles Branch Wilson. Pp. 263-400, 41 figs., 20 pls. Jan. 11, 1911.

1789. New species of reared ichneumon-flies. By H. L. Viereck. Pp. 401-408. Jan. 11, 1911.

1790. The Recent and fossil mollusks of the genus Alabina from the west coast of America. By Paul Bartsch. Pp. 409-418, 2 pls. Jan. 13, 1911.

1791. Sperm transfer in certain decapods. By E. A. Andrews. Pp. 419-434, 15 figs. Jan. 11, 1911.

1792. A review of the fishes of the families Lobotidae and Lutianidae, found in the waters of Japan. By David Starr Jordan and William Francis Thompson. Pp. 435-471, 8 figs. Jan. 30, 1911.

1793. [Scientific results of the Philippine cruise of the Fisheries steamer Albatross, 1907-10.-No. 7.] Thalassocrinus, a new genus of stalked crinoids from the East Indies. By Austin Hobart Clark. Pp. 473-476. Jan. 11, 1911.

1794. On some hymenopterous insects from the island of Formosa. By S. A. Rohwer. Pp. 477-485. Jan. 11, 1911.

1795. On the inorganic constituents of the skeletons of two Recent crinoids. By Austin Hobart Clark. Pp. 487-488. Jan. 11, 1911.

1796. A new labyrinthodont from the Kansas Coal Measures. By Roy L. Moodie. Pp. 489-495, 4 figs. Jan. 30, 1911.

1797. Corynotrypa, a new genus of tubuliporoid Bryozoa. By Ray S. Bassler. Pp. 497-527, 27 figs. Jan. 30, 1911.

1798. [Scientific results of the Philippine cruise of the Fisheries steamer Albatross, 1907-10.-No. 8.] On a collection of unstalked crinoids made by the United States Fisheries steamer Albatross in the vicinity of the Philippine Islands. By Austin Hobart Clark. Pp. 529-563. Feb. 15, 1911.

1799. The west American mollusks of the genus Eumeta. By Paul Bartsch. Pp. 565-568, 3 figs. Feb. 15, 1911.

1800. Description of a little-known rattlesnake, Crotalus willardi, from Arizona. By Frank A. Hartman. Pp. 569-570, 4 figs. Feb. 15, 1911.

1801. On calamine crystals from Mexico, rutile-mica intergrowth from Canada, and pseudomorphs of marcasite after pyrrhotite from Prussia. By Joseph E. Pogue. Pp. 571-579, 1 fig., 2 pls. Feb. 24, 1911.

1802. The Recent and fossil mollusks of the genus Diastoma from the west coast of America. By Paul Bartsch. Pp. 581-584, 4 figs. Feb. 15, 1911.

1803. A monograph of the flycatcher genera Hypothymis and Cyanonympha. By Harry C. Oberholser. Pp. 585-615. Feb. 25, 1911.

1804. Descriptions of new Hymenoptera. 1. By J. C. Crawford. Pp. 617-623, 3 figs. Feb. 25, 1911.

1805. North American parasitic copepods. Descriptions of new genera and species. By Charles Branch Wilson. Pp. 625-634, 4 pls. March 11, 1911.

1806. Bees in the collection of the U. S. National Museum. 1. By T. D. A. Cockerell. Pp. 635-658, 1 fig. Mar. 3, 1911.

1807. Hyalinothrix, a new genus of starfishes from the Hawaiian Islands. By Walter K. Fisher. Pp. 659-664, 3 pls. Mar. 11, 1911.

\section{Volume 40}

Proceedings of the United States National Museum, vol. 40. Pp. i-xi (title page, advertisement, table of contents, and list of illustrations); pp. 1-654 (Proceedings papers 1808-1845); pp. 655-670 (index); 40 figs., 70 pls. 1911.

1808. The Recent crinoids of the coasts of Africa. By Austin Hobart Clark. Pp. 1-51. March 15, 1911.

1809. Mammals collected by Dr. W. L. Abbott on Borneo and some of the small adjacent islands. By Marcus Ward Lyon, Jr. Pp. 53-146, 2 figs., 7 pls. Apr. 25, 1911.

1810. Notes on the distribution of millipeds in southern Texas, with descriptions of new genera and species from Texas, Arizona, Mexico, and Costa Rica. By O. F. Cook. Pp. 147-167. Apr. 10, 1911. 
Proc.

No.

1811. Descriptions of a new genus and species of isopod crustacean of the family Idotheidae from the mouth of the Rio de la Plata, Argentina, South America. By Harriet Richardson. Pp. 169-171, 5 figs. Apr. 10, 1911.

1812. Descriptions of six new genera and thirty-one new species of ichneumon flies. By H. L. Viereck. Pp. 173-196. Apr. 17, 1911.

1813. Final supplement of the catalogue of the published writings of Charles Abiathar White, 1897-1908. By Timothy W. Stanton. Pp. 197-199. Apr. 10, 1911.

1814. Notes upon two rare flatfishes (Gymnachirus fasciatus Günther and $G$. nudus Kaup). By W. C. Kendall. Pp. 201-203, 2 figs. Apr. 10, 1911.

1815. Descriptions of tineoid moths (Microlepidoptera) from South America. By August Busck. Pp. 205-230, 2 pls. Apr. 13, 1911.

1816. An electric ray and its young from the west coast of Florida. By Barton A. Bean and Alfred C. Weed. Pp. 231-232, 2 pls. Apr. 13, 1911.

1817. A new trematode (Styphlodora bascaniensis) with a blind Laurer's canal. By Joseph Goldberger. Pp. 233-239, 3 figs. Apr. 11, 1911.

1818. Bees in the collection of the United States National Museum. 2. By T. D. A. Cockerell. Pp. 241-264. Apr. 11, 1911.

1819. The Hoffman Philip Abyssinian ethnological collection. By Walter Hough. Pp. 265-276, 23 pls. May 18, 1911.

1820. New species of shells from Bermuda. By William Healey Dall and Paul Bartsch. Pp. 277-288, 1 pl. May 8, 1911.

1821. A revision of several genera of gymnospermous plants from the Potomac group in Maryland and Virginia. By Edward W. Berry. Pp. 289-318. May 8, 1911.

1822. [Scientific results of the Philippine cruise of the Fisheries steamer Albatross, 1907-10.-No. 9.] Descriptions of three new fishes of the family Chaetodontidae from the Philippine Islands. By Hugh M. Smith and Lewis Radcliffe. Pp. 319-326, 3 figs. Apr. 17, 1911.

1823. The Recent and fossil mollusks of the genus Cerithiopsis from the west coast of America. By Paul Bartsch. Pp. 327-367, 6 pls. May 8, 1911.

1824. Notes on the genus Lepomis. By Barton A. Bean and Alfred C. Weed. Pp. 369-376, 9 pls. May 6, 1911.

1825. Remarks on the long-tailed shrews of the eastern United States, with description of a new species. By N. Hollister. Pp. 377-381. Apr. 17, 1911.

1826. The Recent and fossil mollusks of the genus Bittium from the west coast of America. By Paul Bartsch. Pp. 383-414, 8 pls. May 12, 1911.

1827. [Scientific results of the Philippine cruise of the Fisheries steamer Albatross, 1907-10.-No. 10.] New genera of starfishes from the Philippine Islands. By Walter K. Fisher. Pp. 415-427. May 17, 1911.

1828. Two amphibians, one of them new, from the Carboniferous of Illinois. By Roy L. Moodie. Pp. 429-433, 2 figs. May 8, 1911.

1829. New mollusks of the genus Aclis from the North Atlantic. By Paul Bartsch. Pp. 435-438, 1 pl. May 18, 1911.

1830. Descriptions of new Hymenoptera. 2. By J. C. Crawford. Pp. 439-449. May 12, 1911.

1831. New tropical millipeds of the order Merocheta, with an example of kinetic evolution. By O. F. Cook. Pp. 451-473, 10 figs., 1 pl. May 31, 1911.

1832. Descriptions of one new genus and eight new species of ichneumon-flies. By H. L. Viereck. Pp. 475-480. Apr. 17, 1911.

1833. On the supposed origin of the moldavites and like sporadic glasses from various sources. By George P. Merrill. Pp. 481-486, 2 pls. May 31, 1911.

1834. Notes on insects of the order Strepsiptera, with descriptions of new species. By W. Dwight Pierce. Pp. 487-511. May 17, 1911.

1835. The relation of bornite and chalcocite in the copper ores of the Virgilina district of North Carolina and Virginia. By Francis Baker Laney. Pp. 513-524, 1 fig., 7 pls. 
Proc.

No.

1836. Descriptions of new genera and species of fishes from Japan and the Riu Kiu Islands. By John Otterbein Snyder. Pp. 525-549. May 26, 1911.

1837. Descriptions of new species of wasps with notes on described species. By S. A. Rohwer. Pp. 551-587. May 26, 1911.

1838. Preliminary notices of some new Pacific cephalopods. By S. Stillman Berry. Pp. 589-592. May 31, 1911.

1839. Fresh-water sponges in the collection of the United States National Museum.Part V. A new genus proposed, with Heteromeyenia radiospiculata Mills as type. By Nelson Annandale. Pp. 593-594. May 26, 1911.

1840. A revision of the forms of the hairy woodpecker (Dryobates villosus [Linnaeus]). By Harry C. Oberholser. Pp. 595-621, 1 pl. June 3, 1911.

1841. Description of a new species of Aega from the Atlantic coast of the United States. By Harriet Richardson. Pp. 623-624, 4 figs. Apr. 10, 1911.

1842. The hothouse milliped as a new genus. By O. F. Cook. Pp. 625-631. June 11, 1911.

1843. Descriptions of a new genus and species of Janiridae from the Nortliwest Pacific. By Harriet Richardson. Pp. 633-635, 1 fig. June 7, 1911.

1844. A new cestode from an African bustard. By Brayton Howard Ransom. Pp. 637-647, 7 figs. June 24, 1911.

1845. The systematic position of the crinoid genus Marsupites. By Austin Hobart Clark. Pp. 649-654. June 24, 1911.

\section{Volume 41}

Proceedings of the United States National Museum, vol. 41. Pp. i-xiv (title page, advertisement, table of contents, and list of illustrations); pp. 1-705 (Proceedings papers 1846-1879); pp. 707-719 (index); 211 figs., 61 pls. 1912.

1846. The structure and relationships of certain eleutherozoic Pelmatozoa. By Edwin Kirk. Pp. 1-137, 11 pls. June 7, 1911.

1847. A revision of the forms of the ladder-backed woodpecker (Dryobates scalaris [Wagler]). By Harry C. Oberholser. Pp. 139-159, 1 pl. June 30, 1911.

1848. Descriptions of recently discovered Cladocera from New England. By Alfred A. Doolittle. Pp. 161-170, 7 pls. July 15, 1911.

1849. A new unstalked crinoid from the Philippine Islands. By Austin Hobart Clark. Pp. 171-173. June 24, 1911.

1850. The crinoid fauna of the Knobstone formation. By Frank Springer. Pp. 175-208. June 24, 1911.

1851. The Waverlyan period of Tennessee. By Ray S. Bassler. Pp. 209-224. June 24, 1911.

1852. Names applied to bees of the genus Nomada, found in North America. By T. D. A. Cockerell. Pp. 225-243. June 30, 1911.

1853. [Scientific results of the Philippine cruise of the Fisheries steamer Albatross, 1907-10.-No. 12.] Notes on some fishes of the genus Amia, family of Cheilodipteridae, with descriptions of four new species from the Philippine Islands. By Lewis Radclifie. Pp. 245-261, 3 figs., 6 pls. July 15, 1911.

1854. The west American mollusks of the genus Amphithalamus. By Paul Bartsch. Pp. 263-265, 3 figs. June 30, 1911.

1855. Descriptions of new Hymenoptera. No. 3. By J. C. Crawford. Pp. 267-282, 6 figs. June 30, 1911.

1856. Description of a new amphisbaenoid lizard from Peru. By Leonhard Stejneger. Pp. 283-284. July 15, 1911.

1857. Descriptions of three new batrachians from Costa Rica and Panama. By Leonhard Stejneger. Pp. 285-288. Aug. 14, 1911.

1858. The west American mollusks of the genus Nodulus. By Paul Bartsch. Pp. 289-291, 4 figs. Aug. 22, 1911.

1859. Descriptions of one new genus and three new species of ichneumon flies. By H. L. Viereck. Pp. 293-295. Aug. 28, 1911.

1860. A new fossil alligator from the Hell Creek beds of Montana. By Charles W. Gilmore. Pp. 297-302, 1 fig., 2 pls. Sept. 9, 1911. 
Proc.

No.

1861. New marine mollusks from Bermuda. By Paul Bartsch. Pp. 303-306, 1 pl. Oct. 12, 1911.

1862. A revision of the fossil ferns from the Potomac group which have been referred to the genera Cladophlebis and Thyrsopteris. By Edward W. Berry. Pp. 307-332. Oct. 6, 1911.

- 1863. The Recent and fossil mollusks of the genus Alvania from the west coast of America. By Paul Bartsch. Pp. 333-362, 4 pls. Nov. 15, 1911.

1864. Two new species of parasitic nematodes. By Brayton Howard Ransom. Pp. 363-369, 7 figs. Oct. 31, 1911.

1865. The American species of Sphyradium with an inquiry as to their generic relationships. By G. Dallas Hanna. Pp. 371-376, 4 figs. Oct. 14, 1911.

1866. New sawflies in the collections of the United States National Museum. By S. A. Rohwer. Pp. 377-411, 14 figs. Oct. 14, 1911.

1867. Crystallized variscite from Utah. By Waldemar T. Schaller. Pp. 413-430, 2 figs., 1 pl. Jan. 31, 1912.

1868. [Scientific results of the Philippine cruise of the Fisheries steamer Albatross, 1907-10.-No. 13.] Descriptions of fifteen new fishes of the family Cheilodipteridae, from the Philippine Islands and contiguous waters. By Lewis Radcliffe. Pp. 431-446, 5 pls. Jan. 31, 1912.

1869. Descriptions of new species of wasps in the collections of the United States National Museum. By S. A. Rohwer. Pp. 447-478, 24 figs. Jan. 22, 1912.

1870. A new mosasauroid reptile from the Cretaceous of Alabama. By Charles W. Gilmore. Pp. 479-484, 3 figs., 2 pls. Jan. 31, 1912.

1871. The west American mollusks of the genus Cingula. By Paul Bartsch. Pp. 485488, 1 pl. Feb. 8, 1912.

1872. [Scientific results of the Philippine cruise of the Fisheries steamer Albatross, 1907-10.-No. 14.] Description of new notidanoid shark from the Philippine Islands representing a new family. By Hugh M. Smith. Pp. 489-491, 1 fig., 1 pl. Feb. 8, 1912.

1873. The characters of the fossil plant Gigantopteris Schenk and its occurrence in North America. By David White. Pp. 493-516, 7 pls. Feb. 8, 1912.

1874. Description of a new salamander from Iowa. By Alexander G. Ruthven. Pp. 517-519. Jan. 22, 1912.

1875. A review of the Sparidae and related families of perch-like fishes found in the waters of Japan. By David Starr Jordan and William Francis Thompson. Pp. 521-601, 15 figs. Jan. 22, 1912.

1876. The Crustacea of the order Cumacea in the collection of the United States National Museum. By William T. Calman. Pp. 603-676, 112 figs. Apr. 6, 1912.

1877. [Scientific results of the Philippine cruise of the Fisheries steamer Albatross, 1907-10.-No. 15.] The squaloid sharks of the Philippine Archipelago, with descriptions of new genera and species. By Hugh M. Smith. Pp. 677-685, 4 figs., 5 pls. Feb. 8, 1912.

1878. The mounted skeletons of Camptosaurus in the United States National Museum. By Charles W. Gilmore. Pp. 687-696, 4 figs., 7 pls. Feb. 8, 1912.

1879. Preservation of osseous and horny tissue. By F. L. J. Boettcher. Pp. 697-705. Jan. 22, 1912.

\section{Volume 42}

Proceedings of the United States National Museum, vol. 42. Pp. i-xiv (title page, advertisement, table of contents, and list of illustrations); pp. 1-655 (Proceedings papers 1880-1922); pp. 657-675 (index); 101 figs., 76 pls. 1912.

1880. Descriptions of new Hymenoptera, No. 4. By J. C. Crawford. Pp. 1-10, 2 figs. March 6, 1912.

1881. A revision of the forms of the edible-nest swiftlet, Collocalia fuciphaga (Thunberg). By Harry C. Oberholser. Pp. 11-20. Mar. 6, 1912.

1882. A small collection of bats from Panama. By Gerrit S. Miller, Jr. Pp. 21-26. Mar. 6, 1912. 
1883. Description of a new species of isopod of the genus Cleantis from Japan. By Harriet Richardson. Pp. 27-29, 1 fig. Mar. 6, 1912.

1884. On an important specimen of Edestus; with description of a new species, Edestus mirus. By Oliver Perry Hay. Pp. 31-38, 2 pls. Apr. 25, 1912.

1885. Descriptions of new species and genera of Lepidoptera, chiefly from Mexico. By Harrison G. Dyar. Pp. 39-106. Mar. 6, 1912.

1886. Description of a new species of the isopod genus Cassidinidea from Mexico. By Harriet Richardson. Pp. 107-108, 3 figs. Mar. 6, 1912.

1887. Censers and incense of Mexico and Central America. By Walter Hough. Pp. 109-137, 12 figs., 12 pls. Apr. 7, 1912.

1888. Descriptions of five new genera and twenty-six new species of ichneumon-flies. By H. L. Viereck. Pp. 139-153. Mar. 9, 1912.

1889. Systematic notes and descriptions of some weevils of economic or biological importance. By W. Dwight Pierce. Pp. 155-170. Mar. 19, 1912.

1890. Variation of the skull and horns of the Isabella gazelle. By Gerrit S. Miller, Jr. Pp. 171-172, 1 pl. Apr. 13, 1912.

1891. Description of a new isopod crustacean belonging to the genus Livoneca from the Atlantic coast of Panama. By Harriet Richardson. Pp. 173-174, 1 fig. Mar. 19, 1912.

1892. A new nematode, Ostertagia bullosa, parasitic in the alimentary tract of sheep. By Brayton Howard Ransom and Maurice C. Hall. Pp. 175-179, 4 figs. Feb. 28, 1912.

1893. Instructions for collecting and fixing rotifers in bulk. By $P$. de Beauchamp. Pp. 181-185. Mar. 19, 1912.

1894. Marine and terrestrial isopods from Jamaica. By Harriet Richardson. Pp. 187-194, 3 figs. Apr. 5, 1912.

1895. Naumachocrinus, a new genus belonging to the crinoid family Phrynocrinidae. By Austin Hobart Clark. Pp. 195-197. Mar. 19, 1912.

1896. [Scientific results of the Philippine cruise of the Fisheries steamer Albatross, 1907-1910.-No. 16.] New pediculate fishes from the Philippine Islands and contiguous waters. By Lewis Radcliffe. Pp. 199-214, 3 figs., 12 pls. Apr. 30, 1912.

1897. Names applied to bees of the genus Osmia, found in North America. By T. D. A. Cockerell. Pp. 215-225. Apr. 13, 1912.

1898. [Scientific results of the Philippine cruise of the Fisheries steamer Albatross, 1907-1910.-No. 17.] New arenaceous Foraminifera from the Philippine Islands and contiguous waters. By Joseph A. Cushman. Pp. 227-230, 1 pl. Apr. 16, 1912.

1899. [Scientific results of the Philippine cruise of the Fisheries steamer Albatross, 1907-1910.-No. 18.] The chimaeroid fishes of the Philippine Islands, with description of a new species. By Hugh M. Smith. Pp. 231-232, 1 pl. Apr. 13, 1912.

1900. Descriptions of new species of parasitic copepods in the collections of the United States National Museum. By Charles Branch Wilson. Pp. 233-243, 5 pls. Apr. 30, 1912.

1901. Notes on fresh-water Copepoda in the United States National Museum. By C. Dwight Marsh. Pp. 245-255, 14 figs. Apr. 25, 1912.

1902. Descriptions of certain species of wasps of the family Sphecidae. By Henry T. Fernald. Pp. 257-259. Apr. 25, 1912.

1903. Additions to the west American pyramidellid mollusk fauna, with descriptions of new species. By Paul Bartsch. Pp. 261-289, 4 pls. May 17, 1912.

1904. [Scientific results of the Philippine cruise of the Fisheries steamer Albatross, 1907-1910-No. 19.] Diagnoses of new barnacles from the Philippine Archipelago and China Sea. By Henry A. Pilsbry. Pp. 291-294. May 29, 1912.

1905. A second meteoric find from Scott County, Kansas. By George P. Merrill. Pp. 295-296, 1 pl. June 15, 1912. 
1906. A zoogeographic study based on the pyramidellid mollusks of the west coast of America. By Paul Bartsch. Pp. 297-349, 1 pl. June 15, 1912.

1907. New cyclogasterid fishes from Japan. By C. H. Gilbert and C. V. Burke. Pp. 351-380, 18 figs., 8 pls. July 3, 1912.

1908. Some new Mollusca from the Silurian formations of Washington County, Maine. By Henry Shaler Williams. Pp. 381-398, 2 pls. July 3, 1912.

1909. Japanese shore fishes collected by the United States Bureau of Fisheries steamer Albatross Expedition of 1906. By John Otterbein Snyder. Pp. 399-450, 1 fig., 11 pls. Aug. 30, 1912.

1910. Notes on African Orthoptera of the families Mantidae and Phasmidae in the United States National Museum, with descriptions of new species. By James A. G. Rehn. Pp. 451-475, 17 figs. Aug. 29, 1912.

1911. Description of a new terrestrial isopod belonging to the genus Cubaris from Panama. By Harriet Richardson. Pp. 477-479, 2 figs. Aug. 29, 1912.

1912. A new discodrilid worm from Colorado. By Max M. Ellis. Pp. 481-486, 5 figs. Aug. 29, 1912.

1913. The fishes of Okinawa, one of the Riu Kiu Islands. By John Otterbein Snyder. Pp. 487-519, 9 pls. Aug. 30, 1912.

1914. Descriptions of two new parasitic isopods belonging to the genera Palaegyge and Probopyrus from Panama. By Harriet Richardson. Pp. 521-524, 8 figs. Aug. 29, 1912.

1915. Descriptions of two new species of fishes, from Honolulu, Hawaii. By David Starr Jordan and Charles William Metz. Pp. 525-527, 1 pl. Aug. 30, 1912.

1916. A revision of the subspecies of the green heron (Butorides virescens [Linnaeus]). By Harry C. Oberholser. Pp. 529-577. Aug. 29, 1912.

1917. [Scientific results of the Philippine cruise of the Fisheries steamer Albatross, 1907-1910.-No. 20.] Description of a new family of pediculate fishes from Celebes. By Hugh M. Smith and Lewis Radcliffe. Pp. 579-581, 1 pl. Aug. 30, 1912.

1918. Description of a new species of isopod belonging to the genus $A$ pseudes from Ecuador. By Harriet Richardson. Pp. 583-585, 1 fig. Aug. 29, 1912.

1919. Notes on a collection of fishes from Java, made by Owen Bryant and William Palmer in 1909, with description of a new species. By Barton A. Bean and Alfred C. Weed. Pp. 587-611, 3 figs., 3 pls. Aug. 30, 1912.

1920. Contributions to our knowledge of bees and ichneumon-flies, including the descriptions of twenty-one new genera and fifty-seven new species of ichneumon-flies. By H. L. Viereck. Pp. 613-648, 2 figs. Aug. 29, 1912.

1921. Model of a Brahmin temple. By Immanuel M. Casanowicz. Pp. 649-653, 1 pl. Aug. 30, 1912.

1922. Note on the generic name Safole, replacing Boulengerina, for a genus of kuhliid fishes. By David Starr Jordan. P. 655. Aug. 29, 1912.

\section{Volume 43}

Proceedings of the United States National Museum, vol. 43. Pp. i-xi (title page, advertisement, table of contents, and list of illustrations); pp. 1-658 (Proceedings papers 1923-1945); pp. 659-669 (index); 49 figs., 46 pls. 1913.

1923. Descriptions of the Alcyonaria collected by the U. S. Fisheries steamer Albatross, mainly in Japanese waters, during 1906. By Charles C. Nutting. Pp. 1-104, 21 pls. Nov. 23, 1912.

1924. [Scientific results of the Philippine cruise of the Fisheries steamer Albatross, 1907-1910.-No. 21.] Descriptions of a new family, two new genera, and twenty-nine new species of anacanthine fishes from the Philippine Islands and contiguous waters. By Lewis Radcliffe. Pp. 105-140, 11 figs., 10 pls. Sept. 27, 1912.

1925. Studies in the woodwasp superfamily Oryssoidea, with descriptions of new species. By S. A. Rohwer. Pp. 141-158, 6 figs., 2 pls. Sept. 27, 1912. 
1926. Descriptions of two new isopods, an Apseudes and a Munnopsis, both from the Galapagos Islands. By Harriet Richardson. Pp. 159-162, 4 figs. Sept. 7, 1912.

1927. Descriptions of new Hymenoptera, No. 5. By J. C. Crawford. Pp. 163-188, 2 figs. Sept. 7, 1912.

1928. Dragon flies of the Cumberland Valley in Kentucky and Tennessee. By Charles Branch Wilson. Pp. 189-200. Sept. 7, 1912.

1929. Descriptions of a new genus of isopod crustaceans, and of two new species from South America. By Harriet Richardson. Pp. 201-204, 2 figs. Sept. $27,1912$.

1930. Notes on sawflies, with descriptions of new species. By S. A. Rohwer. Pp. 205-251, 6 figs. Sept. 30, 1912.

1931. [Scientific results of the Philippine cruise of the Fisheries steamer Albatross, 1907-1910.-No. 22.] Preliminary account of one new genus and three new species of Medusae from the Philippines. By Henry B. Bigelow. Pp. 253-260. Nov. 20, 1912.

1932. Names applied to the eucerine bees of North America. By T. D. A. Cockerell. Pp. 261-273. Oct. 19, 1912.

1933. Bryozoa from Labrador, Newfoundland, and Nova Scotia, collected by Dr. Owen Bryant. By Raymond C. Osburn. Pp. 275-289, 1 pl. Nov. 20, 1912.

1934. New American dipterous insects of the family Pipunculidae. By J. R. Malloch. Pp. 291-299, 9 figs. Oct. 9, 1912.

1935. Descriptions of new genera and species of muscoid flies from the Andean and Pacific coast regions of South America. By Charles H. T. Townsend. Pp. 301-367. Nov. 22, 1912.

1936. Notes on certain amphipods from the Gulf of Mexico, with descriptions of new genera and new species. By Arthur S. Pearse. Pp. 369-379, 8 figs. Nov. 20, 1912.

1937. The crinoids of the Museum fuer Naturkunde, Berlin. By Austin Hobart Clark. Pp. 381-410. Nov. 20, 1912.

1938. The insects of the dipterous family Phoridae in the United States National Museum. By J. R. Malloch. Pp. 411-529, 7 pls. Dec. 14, 1912.

1939. A revision of the forms of the great blue heron (Ardea herodias Linnaeus). By Harry C. Oberholser. Pp. 531-559. Dec. 12, 1912.

1940. Notes on the occurrence of the crustacean Alonopsis in America, with description of a new species. By Alfred A. Doolittle. Pp. 561-565, 2 pls. Dec. 31, 1912.

1941. A new genus and six new species of fishes of the family Cyclogasteridae. By Charles Victor Burke. Pp. 567-574. Dec. 12, 1912.

1942. Descriptions of one new family, eight new genera, and thirty-three new species of ichneumon-flies. By H. L. Viereck. Pp. 575-593. Dec. 31, 1912.

1943. A newly found meteroric iron from Perryville, Perry County, Missouri. By George P. Merrill. Pp. 595-597, 2 pls. Dec. 31, 1912.

1944. [Scientific results of the Philippine cruise of the Fisheries steamer Albatross, 1907-1910.-No. 23.] Four new genera and fifty-eight new species of starfishes from the Philippine Islands, Celebes, and the Moluccas. By Walter K. Fisher. Pp. 599-648. Feb. 5, 1913.

1945. One new genus and eight new species of dipterous insects in the United States National Museum collection. By J. R. Malloch. Pp. 649-658, 1 pl. Dec. 31, 1912.

\section{Volume 44}

Proceedings of the United States National Museum, vol. 44. Pp. i-xii (title page, advertisement, table of contents, and list of illustrations); pp. 1-654 (Proceedings papers 1946-1975); pp. 655-666 (index) ; 92 figs., 82 pls. 1913.

1946. Medusae and siphonophorae collected by the U. S. Fisheries steamer Albatross in the northwestern Pacific, 1906. By Henry B. Bigelow. Pp. 1-119, 2 figs.,

6 pls. Mar. 26, 1913. 
Proc.

No.

1947. Descriptions of new species of saturnian moths in the collection of the United States National Museum. By Harrison G. Dyar. Pp. 121-134. Feb. 11, 1913.

1948. [Scientific results of the Philippine cruise of the Fisheries steamer Albatross, 1907-1910.-No. 24.] Descriptions of seven new genera and thirty-one new species of fishes of the families Brotulidae and Carapidae from the Philippine Islands and the Dutch East Indies. By Lewis Radcliffe. Pp. 135-176, 11 pls. Apr. 3, 1913.

1949. Results of the Yale Peruvian Expedition of 1911. Orthoptera (Acridiidaeshort-horned locusts). By Lawrence Bruner. Pp. 177-187. Feb. 11, 1913.

1950. Crustacean parasites of West Indian fishes and land crabs, with descriptions of new genera and species. By Charles Branch Wilson. Pp. 189-277, 36 pls. Apr. 3, 1913.

1951. Descriptions of new Lepidoptera, chiefly from Mexico. By Harrison G. Dyar. Pp. 279-324. Feb. 11, 1913.

1952. A newly found meteorite from near Cullison, Pratt County, Kansas. By George P. Merrill. Pp. 325-330, 2 pls. Apr. 12, 1913.

1953. A revision of the South American dipterous insects of the family Ptychopteridae. By Charles P. Alexander. Pp. 331-335, 3 figs. Feb. 20, 1913.

1954. Terrestrial isopods collected in Costa Rica by Mr. Picado, with the description of a new genus and species. By Harriet Richardson. Pp. 337-340, 5 figs. Feb. 20, 1913.

1955. Some fossil insects from Florissant, Colorado. By T. D. A. Cockerell. Pp. 341-346, 3 figs., 1 pl. Apr. 30, 1913.

1956. Results of the Yale Peruvian Expedition of 1911. Orthoptera (exclusive of Acridiidae). By A. N. Caudell. Pp. 347-357. Apr. 20, 1913.

1957. Description of Anguilla manabei, a new eel from Japan. By David Starr Jordan. Pp. 359-360, 1 pl. Apr. 3, 1913.

1958. Descriptions of new species of American flies of the family Borboridae. By J. R. Malloch. Pp. 361-372. Feb. 20, 1913.

1959. The sipunculids of the eastern coast of North America. By John Hiram Gerould. Pp. 373-437, 18 figs., 5 pls. Apr. 12, 1913.

1960. Results of the Yale Peruvian Expedition of 1911. Hymenoptera, superfamilies Vespoidea and Sphecoidea. By S. A. Rohwer. Pp. 439-454, 1 fig. Feb. 10, 1913.

1961. Notes on Ranzania makua Jenkins and other species of fishes of rare occurrence on the California coast. By John Otterbein Snyder. Pp. 455-460, 1 pl. Apr. 12, 1913.

1962. Two new species of Diptera in the United States National Museum collection. By J. R. Malloch. Pp. 461-463. Feb. 20, 1913.

1963. Descriptions of two new fishes of the genus Triglops from the Atlantic coast of North America. By Charles H. Gilbert. Pp. 465-468, 1 pl. Apr. 30, 1913.

1964. Results of the Yale Peruvian Expedition of 1911. Hymenoptera-Ichneumonoidea. By H. L. Viereck. Pp. 469-470. Feb. 10, 1913.

1965. A synopsis of the American minks. By N. Hollister. Pp. 471-480. Apr. 18, 1913.

1966. A synopsis of part of the Neotropical crane-flies of the subfamily Limnobinae. By Charles P. Alexander. Pp. 481-549, 4 pls. Apr. 30, 1913.

1967. Description of a new species of actinian of the genus Edwardsiella from southern California. By J. Playfair McMurrich. Pp. 551-553, 1 fig. Apr. 18, 1913.

1968. Descriptions of ten new genera and twenty-three new species of ichneumonflies. By H. L. Viereck. Pp. 555-568. Apr. 18, 1913.

1969. Notes on some fossil horses, with descriptions of four new species. By Oliver P. Hay. Pp. 569-594, 28 figs., 5 pls. Apr. 30, 1913.

1970. Notes on Nearctic orthopterous insects. I. Non-saltatorial forms. By A. N. Caudell. Pp. 595-614, 27 figs. Apr. 18, 1913.

1971. Descriptions of new species of crabs of the family Ocypodidae. By Mary J. Rathbun. Pp. 615-620, 3 pls. Apr. 30, 1913. 
1972. Notes on some American Diptera of the genus Fannia, with descriptions of new species. By J. R. Malloch. Pp. 621-631, 1 pl. Apr. 30, 1913.

1973. [Scientific results of the Philippine cruise of the Fisheries steamer Albatross, 1907-1910.-No. 25.] New Textulariidae and other arenaceous Foraminifera from the Philippine Islands and contiguous waters. By Joseph A. Cushman. Pp. 633-638, 3 pls. Apr. 30, 1913.

1974. Descriptions of six new genera and twelve new species of ichneumon-flies. By H. L. Viereck. Pp. 639-648. Apr. 18, 1913.

1975. A recently mounted zeuglodon skeleton in the United States Museum. By James W. Gidley. Pp. 649-654, 3 figs., 2 pls. Apr. 30, 1913.

\section{Volume 45}

Proceedings of the United States National Museum, vol. 45. Pp. i-xi (title page, advertisement, table of contents, and list of illustrations); pp. 1-657 (Proceedings papers 1976-2007) ; pp. 659-669 (index) ; 43 figs., 57 pls. 1913.

1976. Treeshrews: An account of the mammalian family Tupaiidae. By Marcus Ward Lyon, Jr. Pp. 1-188, 29 figs., 11 pls. Nov. 29, 1913.

1977. A systematic monograph of the chalcinoid Hymenoptera of the subfamily Signiphorinae. By A. Arsène Girault. Pp. 189-233. May 22, 1913.

1978. [Scientific results of the Philippine cruise of the Fisheries steamer Albatross, 1907-1910.-No. 26.] The giant species of the molluscan genus Lima obtained in Philippine and adjacent waters. By Paul Bartsch. Pp. 235-240, 9 pls. June 13, 1913.

1979. Descriptions of new Hymenoptera, No. 6. By J. C. Crawford. Pp. 241-260, 2 figs. May 22, 1913.

1980. A fossil flower from the Eocene. By Edward W. Berry. Pp. 261-263, 1 fig., 1 pl. June 13, 1913.

1981. A synopsis, and descriptions of the Nearctic species of sawflies of the genug $X y e l a$, with descriptions of other new species of sawflies. By S. A. Rohwer. Pp. 265-281, 1 fig. May 22, 1913.

1982. Fossil Coleoptera from Florissant in the United States National Museum. By H. F. Wickham. Pp. 283-303, 5 pls. June 13, 1913.

1983. [Scientific results of the Philippine cruise of the Fisheries steamer Albatross, 1907-1910.-No. 27.] The Philippine mollusks of the genus Dimya. By Paul Bartsch. Pp. 305-307, 2 pls. June 13, 1913.

1984. Descriptions of new Hymenoptera, No. 7. By J. C. Crawford. Pp. 309-317, 1 fig. May 22, 1913.

1985. New species of Silurian fossils from the Edmunds and Pembroke formations of Washington County, Maine. By Henry Shaler Williams. Pp. 319-352, 3 pls. July 22, 1913.

1986. New parasitic Hymenoptera belonging to the trible Xoridini. By S. A. Rohwer. Pp. 353-361. May 22, 1913.

1987. Three interesting butterflies from eastern Massachusetts. By Austin Hobart Clark. Pp. 363-364, 1 pl. June 13, 1913.

1988. Miscellaneous contributions to the knowledge of the weevils of the families Attelabidae and Brachyrhinidae. By W. Dwight Pierce. Pp. 365-426. May 23, 1913.

1989. The simple ascidians from the northeastern Pacific in the collection of the United States National Museum. By William E. Ritter. Pp. 427-505, 4 pls. June 25, 1913.

1990. Mammals collected by the Smithsonian-Harvard Expedition to the Altai Mountains, 1912. By N. Hollister. Pp. 507-532, 6 pls. June 21, 1913.

1991. Descriptions of thirteen new species of parasitic Hymenoptera and a table to certain species of the genus Ecphylus. By S. A. Rohwer. Pp. 533-540. June 21, 1913.

1992. Results of the Yale Peruvian Expedition of 1911.-Batrachians and reptiles. By Leonhard Stejneger. Pp. 541-547. June 4, 1913. 
Proc.

No.

1993. New land shells from the Philippine Islands. By Paul Bartsch. Pp. 549-553, 1 pl. June 21, 1913.

1994. Description of a new fossil fern of the genus Gleichenia from the Upper Cretaceous of Wyoming. By Frank H. Knowlton. Pp. 555-558, 1 pl. June 21, 1913.

1995. The isopod genus Ichthyoxenus Herklots, with description of a new species from Japan. By Harriet Richardson. Pp. 559-562, 6 figs. June 4, 1913.

1996. Some new Hawaiian cephalopods. By S. Stillman Berry. Pp. 563-566. June 4, 1913.

1997. [Scientific results of the Philippine cruise of the Fisheries steamer Albatross, 1907-1910.-No. 28.] The hemiscylliid sharks of the Philippine Archipelago, with description of a new genus from the China Sea. By Hugh M. Smith. Pp. 567-569, 2 figs., 1 pl. June 21, 1913.

1998. Notes on a small collection of amphipods from the Pribilof Islands, with descriptions of new species. By A. S. Pearse. Pp. 571-573, 2 figs. June 4, 1913.

1999. Description of the Yachats "smelt," a new species of atherinoid fish from Oregon. By David Starr Jordan and John Otterbein Snyder. Pp. 575-576, 1 pl. June 21, 1913.

2000. Two fossil insects from Florissant, Colorado, with a discussion of the venation of the aeshnine dragon-flies. By T. D. A. Cockerell. Pp. 577-583, 3 figs. June 21, 1913.

2001. Results of the Yale Peruvian Expedition of 1911. Orthoptera (Addenda to the Acridiidae-short-horned locusts). By Lawrence Bruner. Pp. 585-586. June 11, 1913.

2002. Diagnoses of new shells from the Pacific Ocean. By William Healey Dall. Pp. 587-597. June 11, 1913.

2003. [Scientific results of the Philippine cruise of the Fisheries steamer Albatross, 1907-1910.-No. 29.] Description of a new carcharioid shark from the Sulu Archipelago. By Hugh M. Smith. Pp. 599-601, 3 figs., 1 pl. June 21, 1913.

2004. Three new species of Anthomyidae (Diptera) in the United States National Museum collection. By J. R. Malloch. Pp. 603-607. June 11, 1913.

2005. The Mount Lyell copper district of Tasmania. By Chester G. Gilbert and Joseph E. Pogue. Pp. 609-625, 1 fig., 4 pls. July 22, 1913.

2006. Results of the Yale Peruvian Expedition of 1911. Lepidoptera. By Harrison G. Dyar. Pp. 627-649. July 22, 1913.

2007. Description of Mesoplodon mirum, a beaked whale recently discovered on the coast of North America. By Frederick W. True. Pp. 651-657, 1 fig., 6 pls. Nov. 29, 1913.

\section{Volume 46}

Proceedings of the United States National Museum, vol. 46. Pp. i-xiii (title page, advertisement, table of contents, and list of illustrations); pp. 1-668 (Proceedings papers 2008-2042); pp. 669-681 (index); 202 figs., 57 pls. 1914.

2008. New genera and species of Thysanoptera, with notes on distribution and food plants. By A. C. Morgan. Pp. 1-55, 79 figs. Aug. 23, 1913.

2009. Notes on an unusually fine slab of fossil crinoids. By R. S. Bassler. Pp. 57-59, 2 pls. Nov. 29, 1913.

2010. New parasitic Hymenoptera of the genus Eiphosoma. By T. D. A. Cockerell. Pp. 61-64. Aug. 23, 1913.

2011. Notes on a collection of fishes from the Island of Shikoku in Japan, with a description of a new species, Gnathypops iyonis. By David Starr Jordan and William Francis Thompson. Pp. 65-72, 5 figs. Aug. 23, 1913.

2012. A new nematode, Rictularia splendida, from the coyote, with notes on other coyote parasites. By Maurice C. Hall. Pp. 73-84, 6 figs. Aug. 23, 1913.

2013. Notes on the bats of the genus Molossus. By Gerrit S. Miller, Jr. Pp. 85-92. Aug. 23, 1913. 
Proc.

No.

2014. Preliminary report on a recently discovered Pleistocene cave deposit near Cumberland, Maryland. By James Williams Gidley. Pp. 93-102, 8 figs. Aug. 23, 1913.

2015. New moth-flies (Psychodidae) bred from Bromeliaceae and other plants. By Frederick Knab. Pp. 103-106. Aug. 23, 1913.

2016. New mollusks from the Bahama Islands. By Paul Bartsch. Pp. 107-109, 1 pl. Nov. 29, 1913.

2017. Notes on the Odonata, or dragonflies, of Bumping Lake, Washington. By Clarence Hamilton Kennedy. Pp. 111-126, 57 figs. Sept. 30, 1913.

2018. A synopsie of the genera of Agromyzidae, with descriptions of new genera and species. By J. R. Malloch. Pp. 127-154, 3 pls. Dec. 6, 1913.

2019. A new sponge from the New Jersey Cretaceous. By Hervey W. Shimer and Sidney Powers. Pp. 155-156, 1 pl. Dec. 6, 1913.

2020. The variation exhibited by mainland and island specimens of the Hibakari snake, Natrix vibakari (Boie). By J. C. Thompson. Pp. 157-160. Sept. 30, 1913.

2021. The extinct bisons of North America, with description of one new species, Bison regius. By Oliver P. Hay. Pp. 161-200, 10 figs., 12 pls. Dec. 6, 1913.

2022. [Scientific results of the Philippine cruise of the Fisheries steamer Albatross, 1907-1910.-No. 30.] New starfishes from the Philippine Islands, Celebes, and the Moluccas. By Walter K. Fisher. Pp. 201-224. Sept. 30, 1913.

2023. On a brackish water Pliocene fauna of the southern Coastal Plain. By William Healey Dall. Pp. 225-237, 3 pls. Dec. 6, 1913.

2024. The genera of flies in the subfamily Botanobiinae with hind tibial spur. By J. R. Malloch. Pp. 239-266, 2 pls. Dec. 6, 1913.

2025. Camels of the fossil genus Camelops. By Oliver P. Hay. Pp. 267-277, 1 fig., 2 pls. Dec. 6, 1913.

2026. Revision of the crinoid genus Himerometra. By Austin Hobart Clark. Pp. 279289. Nov. 25, 1913.

2027. A review of the fishes of the genus Osmerus of the California coast. By Mary Fisk. Pp. 291-297, 1 fig. Nov. 25, 1913.

2028. A review of the Philippine land mammals in the United States National Museum. By N. Hollister. Pp. 299-341, 3 pls. Dec. 31, 1913.

2029. Descriptions of new Hymenoptera, No. 8. By J. C. Crawford. Pp. 343-352, 8 figs. Dec. 23, 1913.

2030. Descriptions of new species of crabs of the families Grapsidae and Ocypodidae. By Mary J. Rathbun. Pp. 353-358, 4 pls. Dec. 31, 1913.

2031. Descriptions of twenty-three new genera and thirty-one new species of ichneumon-flies. By Henry L. Viereck. Pp. 359-386. Dec. 31, 1913.

2032. A list of the Rotatoria of Washington and vicinity, with descriptions of a new genus and ten new species. By Harry K. Harring. Pp. 387-405, 5 pls. Dec. 31, 1913.

2033. Gad-flies ('Tabanidae) of the genus Stibasoma. By Frederick Knab. Pp. 407412. Dec. 23, 1913.

2034. Revision of the bats of the genus Glossophaga. By Gerrit S. Miller, Jr. Pp. 413-429, 1 fig. Dec. 31, 1913.

2035. New Hymenoptera from North America. By A. B. Gahan. Pp. 431443, 1 pl. Dec. 30, 1913.

2036. Some new American pycnodont fishes. By James Williams Gidley. Pp. 445449, 6 figs. Dec. 31, 1913.

2037. North American spring-tails of the subfamily Tomocerinae. By Justus W. Folsom. Pp. 451-472, 10 figs., 2 pls. Dec. 30, 1913.

2038. Notes on the fossil crinoid genus Homocrinus Hall. By Edwin Kirk. Pp. 473483, 1 pl. Feb. 14, 1914.

2039. New species of noctuid moths from tropical America. By William Schaus. Pp. 485-549. Jan. 29, 1914.

2040. Notes on a viviparous distome. By Edwin Linton. Pp. 551-555, 1 pl. Feb. 24, 1914.

$711175-47-9$ 
Proc.

No.

2041. A contribution toward a monograph of the homopterous insects of the family Delphacidae of North and South America. By David L. Crawford. Pp. 557-640, 6 pls. Mar. 4, 1914.

2042. Archeological investigations in Ste. Genevieve County, Missouri. By David I. Bushnell, Jr. Pp. 641-668, 8 figs., 8 pls. Mar. 4, 1914.

\section{Volume 47}

Proceedings of the United States National Museum, vol. 47. Pp. i-xii (title page, advertisement, table of contents, and list of illustrations); pp. 1-729 (Proceedings papers 2043-2063) ; pp. 731-755 (index); 23 figs., 56 pls. 1915.

2043. New genera and species of Microlepidoptera from Panama. By August Busck. Pp. 1-67. Apr. 30, 1914.

2044. [Scientific results of the Philippine cruise of the Fisheries steamer Albatross, 1907-1910.-No. 31.] New species of crabs of the families Grapsidae and Ocypodidae. By Mary J. Rathbun. Pp. 69-85. May 7, 1914.

2045. Names applied to the North American bees of the genera Lithurgus, Anthidium, and allies. By T. D. A. Cockerell. Pp. 87-94. May 7, 1914.

2046. The noctuid moths of the genera Palindia and Dyomyx. By Harrison G. Dyar. Pp. 95-116. May 7, 1914.

2047. New genera and species of American brachyrhynchous crabs. By Mary J. Rathbun. Pp. 117-129, 5 figs., 10 pls. May 20, 1914.

2048. Hymenoptera, superfamilies Apoidea and Chalcidoidea, of the Yale Dominican Expedition of 1913. By J. C. Crawford. Pp. 131-134. Apr. 30, 1914.

2049. Two cottoid fishes from Monterey Bay, California. By Charles H. Gilbert. Pp. 135-137, 1 pl. May 20, 1914.

2050. Report on the Lepidoptera of the Smithsonian biological survey of the Panama Canal Zone. By Harrison G. Dyar. Pp. 139-350. May 20, 1914.

2051. The variations exhibited by Thamnophis ordinoides (Baird and Girard), a garter-snake inhabiting the Sausalito Peninsula, California. By Joseph C. Thompson. Pp. 351-360. May 16, 1914.

2052. Results of the Yale-Peruvian Expedition of 1911. Addendum to the Hymenoptera Ichneumonoidea. By P. R. Myers. Pp. 361-362. Oct. 24, 1914.

2053. A new pearly freshwater mussel of the genus Hyria from Brazil. By L. S. Frierson. P. 363, 1 pl. Oct. 29, 1914.

2054. Descriptions of new species and genera of Lepidoptera from Mexico. By Harrison G. Dyar. Pp. 365-409. Oct. 24, 1914.

2055. Littoral marine mollusks of Chincoteague Island, Virginia. By John B. Henderson and Paul Bartsch. Pp. 411-421, 2 pls. Oct. 29, 1914.

2056. Lepidoptera of the Yale-Dominican Expedition of 1913. By Harrison G. Dyar. Pp. 423-426. Oct. 24, 1914.

2057. A systematic account of the grasshopper mice. By N. Hollister. Pp. 427-489, 3 figs., 1 pl. Oct. 29, 1914.

2058. Orthoptera of the Yale-Dominican Expedition of 1913. By A. N. Caudell. Pp. 491-495. Oct. 24, 1914.

2059. A peculiarity in the growth of the tail feathers of the giant hornbill (Rhinoplax vigil). By Alex Wetmore. Pp. 497-500. Oct. 24, 1914.

2060. Notes on wolframite, beraunite, and axinite. By Edgar T. Wherry. Pp. 501-511. Oct. 24, 1914.

2061. Vespoid and sphecoid Hymenoptera collected in Guatemala by W. P. Cockerell. By S. A. Rohwer. Pp. 513-523. Oct. 24, 1914.

2062. Report on Rotatoria from Panama with descriptions of new species. By Harry K. Harring. Pp. 525-564, 9 pls. Dec. 15, 1914.

2063. North American parasitic copepods belonging to the Lernaeopodidae, with a revision of the entire family. By Charles Branch Wilson. Pp. 565-729, 15 fgso, 32 pls. Mar. 6, 1915. 


\section{Volume 48}

Proceedings of the United States National Museum, vol. 48. Pp. i-x (title page, advertisement, table of contents, and list of illustrations); pp. 1-661 (Proceedings papers 2064-2091) ; pp. 663-672 (index) ; 40 figs., 46 pls. 1915.

Proc.

No.

2064. New North American bees of the genus Andrena. By Henry L. Viereck and T. D. A. Cockerell. Pp. 1-58. Nov. 28, 1914.

2065. The Crustacea Euphausiacea of the United States National Museum. By H. J. Hansen. Pp. 59-114, 4 pls. Jan. 19, 1915.

2066. List of generic names and their type-species in the coleopterous superfamily Scolytoidea. By A. D. Hopkins. Pp. 115-136. Dec. 16, 1914.

2067. [Scientific results of the Philippine cruise of the Fisheries steamer Albatross, 1907-1910.-No. 32.] A new genus and some new species of crabs of the family Goneplacidae. By Mary J. Rathbun. Pp. 137-154. Dec. 16, 1914.

2068. Descriptions of new genera and species, with notes on parasitic Hymenoptera. By A. B. Gahan. Pp. 155-168. Dec. 16, 1914.

2069. Two new South American jaguars. By N. Hollister. Pp. 169-170, 1 pl. Dec. 16, 1914.

2070. Report on the parasitic and predaceous Diptera from northeastern New Mexico. By W. R. Walton. Pp. 171-186, 2 pls. Dec. 16, 1914.

2071. Descriptions of a new genus and species of the discodrilid worms. By Maurice C. Hall. Pp. 187-193, 3 figs. Dec. 16, 1914.

2072. New genera and species of gall midges. By E. Porter Felt. Pp. 195-211, 15 figs. Jan. 19, 1915.

2073. Report on the holothurians collected by the United States Fisheries steamer Albatross in the northwestern Pacific during the summer of 1906. By Hiroshi Ohshima. Pp. 213-291, 1 fig., 4 pls. Feb. 11, 1915.

2074. The Mississippi River bluffs at Columbus and Hickman, Kentucky, and their fossil flora. By Edward W. Berry. Pp. 293-303, 2 pls. Jan. 28, 1915.

2075. Fishes collected by the United States Fisheries steamer Albatross in southern California in 1904. By Charles Henry Gilbert. Pp. 305-380, 9 pls. Jan. 28, 1915.

2076. Descriptions of new African birds of the genera Francolinus, Chalcopelia, Cinnyris, Chalcomitra, Anthreptes, Estrilda, Halcyon, Melittophagus, and Colius. By Edgar A. Mearns. Pp. 381-394. Jan. 19, 1915.

2077. An extinct marsupial from the Fort Union with notes on the Myrmecobidae and other families of this group. By James Williams Gidley. Pp. 395-402, 1 pl. Jan. 28, 1915.

2078. Reptiles of northwestern Nevada and adjacent territory. By C. H. Richardson. Pp. 403-435. Jan. 19, 1915.

2079. On some generic names first mentioned in the "Conchological Illustrations." By William Healey Dall. Pp. 437-440. Jan. 10, 1915.

2080. Description of new species of crane-flies from Central America. By Charles P. Alexander. Pp. 441-444, 1 pl. Feb. 11, 1915.

2081. Synopsis of the species of sawflies belonging to the genus Dimorphopteryx. By S. A. Rohwer. Pp. 445-448. Feb. 11, 1915.

2082. Flounders and soles from Japan collected by the United States Bureau of Fisheries steamer Albatross in 1906. By Carl L. Hubbs. Pp. 449-496, 3 pls. Mar. 20, 1915.

2083. Notes on some sawfly larvae belonging to the genus Dimorphopteryx. By William Middleton. Pp. 497-501, 4 figs., 1 pl. Mar. 18, 1915.

2084. The Fisher, Polk County, Minnesota, meteorite. By George P. Merrill. Pp. 503-506, 1 pl. May 3, 1915.

2085. Descriptions of six new species of ichneumon-flies. By R. A. Cushman. Pp. 507-513. Mar. 8, 1915.

2086. Contributions to the knowledge of the mammals of the Pleistocene of North America. By Oliver P. Hay. Pp. 515-575, 5 figs., 8 pls. Apr. 8, 1915. 
Proc.

No.

2087. Descriptions of new Hymenoptera, No. 9. By J. C. Crawford. Pp. 577-586, 11 figs. May 3, 1915.

2088. A synopsis of the races of the long-tailed goatsucker, Caprimulgus macrurus Horsfield. By Harry C. Oberholser. Pp. 587-599. May 3, 1915.

2089. Notes on Neotropical dragonflies, or Odonata. By Edward Bruce Williamson. Pp. 601-638, 1 fig., 7 pls. May 12, 1915.

2090. A review of the subspecies of the ruddy kingfisher, Entomothera coromanda (Linnaeus). By Harry C. Oberholser. Pp. 639-657. May 18, 1915.

2091. Rediscovery of Pourtales' Haliotis. By John B. Henderson. Pp. 659-661, 2 pls. May 22, 1915.

\section{Volume 49}

Proceedings of the United States National Museum, vol. 49. Pp. i-xiv (title page, advertisement, table of contents, and list of illustrations) ; pp. 1-690 (Proceedings papers 2092-2130); pp. $691-702$ (index); 296 figs., 83 pls. 1916.

2092. Descriptive catalogue of the Washington relics in the United States National Museum. By Theodore T. Belote. Pp. 1-24, 27 pls. Oct. 19, 1915.

2093. Notes on some United States grasshoppers of the family Acrididae. By A. N. Caudell. Pp. 25-31. June 21, 1915.

2094. The Recent and fossil mollusks of the genus Rissoina from the west coast of America. By Paul Bartsch. Pp. 33-62, 6 pls. July 24, 1915.

2095. A revision of the North American ichneumon-flies of the subfamily Opiinae. By A. B. Gahan. Pp. 63-95, 2 pls. Aug. 23, 1915.

2096. Descriptions of two new species of Entomostraca from Colorado, with notes on other species. By G. S. Dodds. Pp. 97-102, 10 figs. Aug. 13, 1915.

2097. Flies of the genus Agromyza, related to Agromyza virens. By J. R. Malloch. Pp. 103-108, 1 fig., 1 pl. July 24, 1915.

2098. Notes on the composition and structure of the Indarch, Russia, meteoric stone. By George P. Merrill. Pp. 109-112, 1 pl. July 24, 1915.

2099. The dipterous genus Symphoromyia in North America. By John Merton Aldrich. Pp. 113-142, 11 figs. July 16, 1915.

2100. The genera and subgenera of raccoons and their allies. By N. Hollister. Pp. 143-150, 2 pls. Aug. 13, 1915.

2101. Notes on the flies of the genus Pseudodinia, with description of a new species. By J. R. Malloch. Pp. 151-152. July 16, 1915.

2102. A peculiar oolite from Bethlehem, Pennsylvania. By Edgar T. Wherry. Pp. 153-156, 2 pls. Aug. 13, 1915.

2103. On a collection of Javanese crane-flies (Tipulidae, Diptera) in the United States National Museum. By Charles Paul Alexander. Pp. 157-193, 9 pls. Aug. 13, 1915.

2104. The Philippine land shells of the genus Schistoloma. By Paul Bartsch. Pp. 195-204, 1 pl. July 24, 1915.

2105. Descriptions of new species of Hymenoptera. By S. A. Rohwer. Pp. 205-249. July 16, 1915.

2106. Critical notes on the subspecies of the spotted owl, Strix occidentalis (Xantus). By Harry C. Oberholser. Pp. 251-257. July 26, 1915.

2107. Notes on the life history and ecology of the dragonflies (Odonata) of Washington and Oregon. By Clarence Hamilton Kennedy. Pp. 259-345, 201 figs. July 28, 1915.

2108. Report on some carbonic acid tests on the weathering of marbles and limestones. By George P. Merrill. Pp. 347-349. July 26, 1915.

2109. A collection of amphibians and reptiles from Gogebic County, Michigan. By Arthur T. Evans. Pp. 351-354. July 26, 1915.

2110. A new restoration of Stegosaurus. By Charles W. Gilmore. Pp. 355-357, 1 fig., 1 pl. Aug. 23, 1915.

2111. A colored drawing of the Medeba mosaic map of Palestine in the United States National Museum. By I. M. Casanowicz. Pp. 359-376, 1 pl. Aug. 23, 1915. 
2112. An albino salamander, Spelerpes bilineatus. By Arthur M. Banta and Ross Aiken Gortner. Pp. 377-379, 2 pls. Aug. 31, 1915.

2113. A contribution to the knowledge of the extinct sirenian Desmostylus hesperus Marsh. By Oliver P. Hay. Pp. 381-397, 3 pls. Aug. 31, 1915.

2114. Eperetmus, a new genus of Trachomedusae. By Henry B. Bigelow. Pp. 399404, 1 pl. Aug. 31, 1915.

2115. New Neotropical muscoid flies. By Charles H. T. Townsend. Pp. 405-440. Nov. 27, 1915.

2116. A review of some bivalve shells of the group Anatinacea from the west coast of America. By William Healey Dall. Pp. 441-456. Nov. 27, 1915.

2117. A new crustacean, Diaptomus virginiensis, and a description of Diaptomus tyrelli Poppe. By C. Dwight Marsh. Pp. 457-462, 7 figs. Dec. 11, 1915.

2118. Notes on allophanite, fuchsite, and triphylite. By Edgar T. Wherry. Pp. 463467. Nov. 27, 1915.

2119. British fossil insects. By T. D. A. Cockerell. Pp. 469-499, 6 pls. Dec. 11, 1915.

2120. On the fore limb of Allosaurus fragilis. By Charles W. Gilmore. Pp. 501-513, 7 figs. Nov. 27, 1915.

2121. A synopsis of the races of the crested tern, Thalasseus bergii (Lichtenstein). By Harry C. Oberholser. Pp. 515-526, 1 pl. Dec. 23, 1915.

2122. Three new species of Anodontites from Brazil. By William B. Marshall. Pp. 527-529, 3 pls. Dec. 11, 1915.

2123. An account of the Crustacea collected by the Walker Expedition to Santa Marta, Colombia. By A. S. Pearse. Pp. 531-556, 9 figs., 4 pls. Dec. 23, 1915.

2124. Notes on the species of the molluscan subgenus Nucella inhabiting the northwest coast of America and adjacent regions. By William Healey Dall. Pp. 557-572, 2 pls. Dec. 11, 1915.

2125. Notes on a collection of fishes made by Dr. Edgar A. Mearns from rivers tributary to the Gulf of California. By John Otterbein Snyder. Pp. 573586, 1 fig., 2 pls. Dec. 23, 1915.

2126. New fresh-water shells from the Ozark Mountains. By Anson A. Hinkley. Pp. 587-589, 1 pl. Dec. 23, 1915.

2127. Osteology of Thescelosaurus, an orthopodous dinosaur from the Lance formation of Wyoming. By Charles W. Gilmore. Pp. 591-616, 20 figs., 4 pls. Dec. 23, 1915.

2128. Diagnoses of new genera of muscoid flies founded on old species. By Charles H. T. Townsend. Pp. 617-633. Jan. 14, 1916.

2129. [Scientific results of the Philippine cruise of the Fisheries steamer Albatross, 1907-1910.-No. 33.] The euphausiacean crustaceans of the Albatross expedition to the Philippines. By H. J. Hansen. Pp. 635-654, 1 pl. Jan. $14,1916$.

2130. The genera of the tettiginiid insects of the subfamily Rhaphidophorinae found in America north of Mexico. By A. N. Caudell. Pp. 655-690, 28 figs. Jan. 7, 1916.

\section{Volume 50}

Proceedings of the United States National Museum, vol. 50. Pp. i-xiv (title page, advertisement, table of contents, and list of illustrations); pp. 1-652 (Proceedings papers 2131-2138) ; pp. 653-663 (index); 290 figs., 36 pls. 1916.

2131. Nematode parasites of mammals of the orders Rodentia, Lagomorpha, and Hyracoidea. By Maurice C. Hall. Pp. 1-258, 290 figs., 1 pl. May 13, 1916.

2132. A generic revision of the American moths of the subfamily Hypeninae, with descriptions of new genera and species. By William Schaus. Pp. 259-399. May 20, 1916.

2133. Fishes collected by the United States Bureau of Fisheries steamer Albatross during 1888, between Montevideo, Uruguay, and Tome, Chile, on the voyage through the Straits of Magellan. By Will F. Thompson. Pp. 401-476, 5 pls. May 20, 1916. 
Proc.

No.

2134. North American collembolous insects of the subfamilies Achorutinae, Neanurinae, and Podurinae. By Justus W. Folsom. Pp. 477-525, 19 pls. May $31,1916$.

2135. [Scientific results of the Philippine cruise of the Fisheries steamer Albatross, 1907-1910.-No. 34.] New species of crabs of the families Inachidae and Parthenopidae. By Mary J. Rathbun. Pp. 527-559. May 31, 1916.

2136. Revision of the parasitic hymenopterous insects of the genus Aphycus Mayr, with notice of some related genera. By P. H. Timberlake. Pp. 561-640, 6 pls. May 31, 1916.

2137. Description of two new species of fossil turtles, from the Lance formation of Wyoming. By Charles W. Gilmore. Pp. 641-646, 4 pls. May 31, 1916.

2138. Description of three species of crabs (Osachila) from the eastern coast of North America. By Mary J. Rathbun. Pp. 647-652, 1 pl. May 31, 1916.

\section{Volume 51}

Proceedings of the United States National Museum, vol. 51. Pp. i-xii (title page, advertisement, table of contents, and list of illustrations); pp. 1-662 (Proceedings papers 2139-2172); pp. 663-676 (index); 25 figs., 121 pls. 1917.

2139. Descriptions of new Lepidoptera from Mexico. By Harrison G. Dyar. Pp. 1-37. Oct. 16, 1916.

2140. Descriptions of miscellaneous North American chalcidoid Hymenoptera of the family Eulophidae. By A. A. Girault. Pp. 39-52. Oct. 16, 1916.

2141. Some Diptera (Microdon) from nests of ants. By T. D. A. Cockerell and Hazel Andrews. Pp. 53-56, 2 figs. Oct. 16, 1916.

2142. On the geographical forms of the Philippine elegant titmouse, Pardaliparus elegans (Lesson), with descriptions of three new subspecies. By Edgar Alexander Mearns. Pp. 57-65. Oct. 16, 1916.

2143. Report on Arachnida collected by Messrs. Curie, Caudell, and Dyar in British Columbia. By Nathan Banks. Pp. 67-72. Oct. 16, 1916.

2144. New brachiopods of the genus Spirifer from the Silurian of Maine. By Henry Shaler Williams. Pp. 73-80, 1 pl. Dec. 16, 1916.

2145. Notes on alunite, psilomelanite, and titanite. By Edgar T. Wherry. Pp. 81-88. Oct. 16, 1916.

2146. Some American fossil insects. By T. D. A. Cockerell. Pp. 89-106, 9 figs., 1 pl. Oct. 16, 1916.

2147. Descriptions of two extinct mammals of the order Xenarthra from the Pleistocene of Texas. By Oliver P. Hay. Pp. 107-123, 5 pls. Oct. 28, 1916.

2148. New North American Hymenoptera of the family Eulophidae. By A. A. Girault. Pp. 125-133. Oct. 28, 1916.

2149. Report on the Japanese macrouroid fishes collected by the United States Fisheries steamer Albatross in 1906, with a synopsis of the genera. By Charles Henry Gilbert and Carl L. Hubbs. Pp. 135-214, 4 pls. Oct. 28, 1916.

2150. New and little-known heteropterous Hemiptera in the United States National Museum. By E. Bergroth. Pp. 215-239. Oct. 28, 1916.

2151. A review of the fossil plants in the United States National Museum from the Florissant lake beds at Florissant, Colorado, with descriptions of new species and list of type-specimens. By F. H. Knowlton. Pp. 241-297, 16 pls. Nov. 24, 1916.

2152. New genera and species of muscoid flies. By Charles H. T. Townsend. Pp. 299-323. Oct. 28, 1916.

2153. A recently-found iron meteorite from Cookeville, Putnam County, Tennessee. By George P. Merrill. Fp. 325-326, 1 pl. Nov. 24, 1916.

2154. Two new fossil plants from the Triassic of Pennsylvania. By Edgar T. Wherry. Pp. 327-329, 2 pis. Nov. 24, 1916.

2155. Two new land shells from the western States. By Paul Bartsch. Pp. 331333, 1 pl. Nov. 24, 1916. 
Proc.

No.

2156. A contribution to our knowledge of the white flies of the subfamily Aleyrodinae (Aleyrodidae). By A. L. Quaintance and A. C. Baker. Pp. 335-445, 10 figs., 46 pls. Jan. 20, 1917.

2157. Notes on the Whitfield County, Georgia, meteoric irons, with new analyses. By George P. Merrill. Pp. 447-449, 1 pl. Dec. 16, 1916.

2158. A Lower Jurassic flora from the upper Matanuska Valley, Alaska. By F. H. Knowlton. Pp. 451-460, 4 pls. Dec. 16, 1916.

2159. Studies of weevils (Rhynchophora) with descriptions of new genera and species. By W. Dwight Pierce. Pp. 461-473, 2 figs. Dec. 16, 1916.

2160. A new mollusk of the genus Pisidium from Alaska, with field notes by $G$. Dallas Hanna. By Victor Sterki. Pp. 475-477, 2 figs. Dec. 16, 1916.

2161. New Javanese chalcidoid Hymenoptera. By A. A. Girault. Pp. 479-485. Dec. $16,1916$.

2162. A contribution to the invertebrate fauna of the Oligocene beds of Flint River, Georgia. By William Healey Dall. Pp. 487-524, 6 pls. Dec. 21, 1916.

2163. A newly found meteoric stone from Lake Okechobee, Florida. By George p. Merrill. Pp. 525-526. Dec. 21, 1916.

2164. A revision of the rotatorian genera Lepadella and Lophocharis with descriptions of five new species. By Harry K. Harring. Pp. 527-568, 9 pls. Dec. 21, 1916.

2165. A new genus and three new species of parasitic isopod crustaceans. By W. P. Hay. Pp. 569-574, 3 pls. Jan. 15, 1917.

2166. Summary of the mollusks of the family Alectrionidae of the west coast of America. By William Healey Dall. Pp. 575-579. Jan. 15, 1917.

2167. Descriptions of seven new species of red spiders. By E. A. McGregor. Pp. 581-590, 7 pls. Jan. 15, 1917.

2168. Paraphernalia of a Korean sorceress in United States National Museum. By I. M. Casanowicz. Pp. 591-597, 5 pls. Dec. 21, 1916.

2169. Mollusks from the type locality of the Choctawhatchee marl. By Wendell C. Mansfield. Pp. 599-607, 1 pl. Dec. 21, 1916.

2170. The Californian land shelis of the Epiphragmophora traskii group. By Paul Bartsch. Pp. 609-619, 4 pls. Dec. 21, 1916.

2171. A generic synopsis of the coccinellid larvae in the United States National Museum, with a description of the larva of Hyperaspis binotata Say. By Adam Böving. Pp. 621-650, 4 pls. Jan. 15, 1917.

2172. [Scientific results of the Philippine cruise of the Fisheries steamer Albatross, 1907-1910.-No. 35.] New species and varieties of Forminifera from the Philippines and adjacent waters. By Joseph A. Cushman. Pp. 651-662. Jan. 15, 1917.

\section{Volume 52}

Proceedings of the United States National Museum, vol. 52. Pp. i-xiii (title page, advertisement, table of contents, and list of illustrations); pp. 1-693 (Proceedings papers 2173-2193); pp. 683-693 (index); 652 figs., 47 pls. 1917.

2173. A revision of the bembicine wasps of America north of Mexico. By John Bernard Parker. Pp. 1-155, 230 figs. Feb. 10, 1917.

2174. North American earthworms of the family Lumbricidae in the collections of the United States National Museum. By Frank Smith. Pp. 157-182. Feb. 8, 1917.

2175. The birds of Bawean Island, Java Sea. By Harry C. Oberholser. Pp. 183198. Feb. 8, 1917.

2176. Field notes on Virginia Orthoptera. By Henry Fox. Pp. 199-234. Mar. 16, 1917.

2177. Fossil fishes in the collection of the United States National Museum. By Charles R. Eastman. Pp. 235-304, 9 figs., 23 pls. Feb. 24, 1917.

2178. Monograph of the Nearctic Hymenoptera of the genus Bracon Fabricitis. By Harold Morrison. Pp. 305-343, 4 pls. Max. 7, 1917. 
Proc.

No.

2179. The variation exhibited by Thamnophis ordinoides (Baird and Girard), a garter snake inhabiting the San Francisco Peninsula. By Joseph C. Thompson. Pp. 345-366. Mar. 7, 1917.

2180. Trophodiscus, a new sea star from Kamchatka. By Walter K. Fisher. Pp. 367-371, 3 pls. Mar. 7, 1917.

2181. New Tertiary insects. By T. D. A. Cockerell. Pp. 373-384, 1 pl. Feb. 23, 1917.

2182. New species of South Dakota Cretaceous crabs. By Mary J. Rathbun. Pp. 385-391, 2 pls. Feb. 23, 1917.

2183. Diagnoses of new species of marine bivalve mollusks from the northwest coast of America in the collection of the United States National Museum. By William Healey Dall. Pp. 393-417. Dec. 27, 1916.

2184. A new find of meteoric stones near Plainview, Hale County, Texas. By George P. Merrill. Pp. 419-422, 2 pls. Mar. 7, 1917.

2185. Description of a new goby, Garmannia spongicola, from North Carolina. By Lewis Radcliffe. Pp. 423-425, 1 fig. Feb. 8, 1917.

2186. A new species of polychaetous annelid from Panama, with notes on an Hawaiian form. By Aaron L. Treadwell. Pp. 427-430, 5 figs. Feb. 8, 1917.

2187. Notice of a new Paleocene mammal, a possible relative of the titanotheres. By James Williams Gidley. Pp. 431-435, 1 fig., 1 pl. Feb. 23, 1917.

2188. Mammals collected by Dr. W. L. Abbott on the chain of islands lying off the western coast of Sumatra, with descriptions of twenty-eight new species and subspecies. By Marcus Ward Lyon, Jr. Pp. 437-462. Dec. 30, 1916.

2189. New species of fossil beetles from Florissant, Colorado. By H. F. Wickham. Pp. 463-472, 3 pls. Feb. 23, 1917.

2190. Rotatoria of Los Angeles, California, and vicinity, with descriptions of a new species. By Frank J. Myers. Pp. 473-478, 2 pls. Feb. 23, 1917.

2191. On certain secondary sexual characters in the male ruddy duck, Erismatura jamaicensis (Gmelin). By Alexander Wetmore. Pp. 479-482, 1 fig. Feb. 8, 1917.

2192. Notes on the life history and ecology of the dragonflies (Odonata) of central California and Nevada. By Clarence Hamilton Kennedy. Pp. 483-635, 404 figs. May 12, 1917.

2193. Descriptions of new west American marine mollusks and notes on previously described forms. By Paul Bartsch. Pp. 637-681, 6 pls. May 29, 1917.

\section{Volume 53}

Proceedings of the United States National Museum, vol. 53. Pp. i-xi (title page, advertisement, table of contents, and list of illustrations); Pp. 1-659 (Proceedings papers 2194-2222) ; pp. 661-669 (index); 154 figs., 79 pls. 1917.

2194. North American parasitic copepods belonging to the Lernaeidae with a revision of the entire family. By Charles Branch Wilson. Pp. 1-150, 4 figs., 21 pls. June 13, 1917.

2195. Descriptions of thirty-one new species of Hymenoptera. By S. A. Rohwer. Pp. 151-176, 1 fig. June 5, 1917.

2196. Some effects of environment and habit on captive lions. By N. Hollister. Pp. 177-193, 2 figs., 4 pls. June 1, 1917.

2197. Descriptions of some new parasitic Hymenoptera. By A. B. Gahan. Pp. 195217. May 26, 1917.

2198. Description of a new species of mastodon, Gomphotherium elegans, from the Pleistocene of Kansas. By Oliver P. Hay. Pp. 219-221, 1 pl. June 1, 1917.

2199. Gomphus parvidens, a new species of dragonfly from Maryland. By Bertha P. Currie. Pp. 223-226, 2 pls. June 1, 1917.

2200. A remarkable occurrence of calcite in silicified wood. By Edgar $T$. Wherry. Pp. 227-230, 3 pls. June 1, 1917.

2201. An asymmetrical bird-louse found on three different species of troupials. By John Howard Paine. Pp. 231-232, 1 pl. June 1, 1917. 
2202. A report on a collection of Hymenoptera (mostly from California) made by W. M. Giffard. By S. A. Rohwer. Pp. 233-249. May 28, 1917.

2203. A new species of bear-animalcule from the coast of North Carolina. By W. P. Hay. Pp. 251-254, 1 pl. June 1, 1917.

2204. A new American parasite of the Hessian fly (Mayetiola destructor Say). By P. R. Myers. Pp. 255-257. May 28, 1917.

2205. Cuban amphibians and reptiles collected for the United States National Museum from 1899 to 1902. By Leonhard Stejneger. Pp. 259-291, 128 figs. May 31, 1917.

2206. An American species of the hymenopterous genus Wesmaelia of Foerster. By P. R. Myers. Pp. 293-294. May 24, 1917.

2207. A monograph of West American melanellid mollusks. By Paul Bartsch. Pp. 295-356, 16 pls. Aug. 13, 1917.

2208. The type-species of the genera of the Cynipoidea, or the gall wasps and parasitic cynipoids. By S. A. Rohwer and Margaret M. Fagan. Pp. 357380. June 6, 1917.

2209. New and little-known species of South American fresh-water mussels of the genus Diplodon. By William B. Marshall. Pp. 381-388, 6 pls. Aug. 15, 1917.

2210. Some fossil insects from Florissant, Colorado. By T. D. A. Cockerell. Pp. 389-392. June 2, 1917.

2211. The salamanders of the genera Desmognathus and Leurognathus. By Emmett R. Dunn. Pp. 393-433, 15 figs. June 4, 1917.

2212. Description of a new species of extinct horse, Equus lambei, from the Pleistocene of Yukon Territory. By Oliver P. Hay. Pp. 435-443, 3 pls. June 5, 1917.

2213. Notes and descriptions of miscellaneous chalcid-flies (Hymenoptera). By A. A. Girault. Pp. 445-450. Aug. 10, 1917.

2214. Description of a new species of crab from the California Pliocene. By Mary J. Rathbun. Pp. 451-452, 1 pl. Aug. 15, 1917.

2215. Fossil remains of what appears to be a passerine bird from the Florissant shales of Colorado. By R. W. Shufeldt. Pp. 453-455, 2 pls. Aug. 15, 1917.

2216. Eight new species of reared ichneumon-flies with notes on some other species. By R. A. Cushman. Pp. 457-469. Aug. 9, 1917.

2217. Notes on the shells of the genus Epitonium and its allies of the Pacific coast of America. By William Healey Dall. Pp. 471-488. Aug. 10, 1917.

2218. Fossil Echini of the Panama Canal Zone and Costa Rica. By Robert Tracy Jackson. Pp. 489-501, 4 figs., 7 pls. Sept. 24, 1917.

2219. A revision of hymenopterous insects of the tribe Cremastini of American north of Mexico. By R. A. Cushman. Pp. 503-551. Aug. 22, 1917.

2220. The color of amethyst, rose, and blue varieties of quartz. By' Thomas $\mathrm{L}$. Watson and R. E. Beard. Pp. 553-563. Aug. 11, 1917.

2221. Generic names applied to birds during the years 1906 to 1915 , inclusive, with additions and corrections to Waterhouse's "Index Generum Avium." By Charles W. Richmond. Pp. 565-636. Aug. 16, 1917.

2222. North American collembolous insects of the subfamily Onychiurinae. By Justus W. Folsom. Pp. 637-659, 12 pls. Aug. 22, 1917.

\section{Volume 54}

Proceedings of the United States National Museum, vol. 54. Pp. i-xv (title page, advertisement, table of contents, and list of illustrations); pp. 1-640 (Proceedings papers 2223-2257) pp. 641-653 (index) ; 95 figs., 96 pls. 1919.

2223. Chitons taken by the United States Fisheries steamer Albatross in the northwest Pacific in 1906. By S. Stillman Berry. Pp. 1-18, 1 fig., 10 pls. Dec. 5, 1917.

2224. Notes on Hawaiian lizards. By John Otterbein Snyder. Pp. 19-25. Oct. 7, 1917.

2225. Nuculites from the Silurian formations of Washington County, Maine. By Henry Shaler Williams. Pp. 27-58, 1 fig., 2 pls. Oct. 20, 1917.

2226. Altitudinal distribution of Entomostraca in Colorado. By Gideon S. Dodds. Pp. 59-87, 9 figs., 2 pls. Oct. 27, 1917. 
Proc.

No.

2227. New flies of the genus Sarcophaga from Guam and the Philippines. By R. R. Parker. Pp. 89-97, 5 figs. Oct. 17, 1917.

2228. On two species of fishes from the Yalu River, China. By Isaac Ginsburg. Pp. 99-101. Oct. 18, 1917.

2229. Fossil plants from Bolivia and their bearing upon the age of uplift of the eastern Andes. By Edward W. Berry. Pp. 103-164, 2 figs., 4 pls. Oct. 27, 1917.

2230. A review of the subspecies of the Leach petrel, Oceanodroma leucorhoa (Vieillot). By Harry C. Oberholser. Pp. 165-172. Oct. 19, 1917.

2231. Description of Hymenocephalus tenuis, a new macruroid fish from the Hawaiian Islands. By Charles H. Gilbert and Carl L. Hubbs. Pp. 173-175. Dec. $14,1917$.

2232. Birds collected by Dr. W. L. Abbott on various islands in the Java Sea. By Harry C. Oberholser. Pp. 177-200. Nov. 2, 1917.

2233. An account of some fishes from Owens River, California. By John Otterbein Snyder. Pp. 201-205. Dec. 13, 1917.

2234. Notes on Chrysodomus and other mollusks from the north Pacific Ocean. By William Healey Dall. Pp. 207-234. Apr. 5, 1918.

2235. The Hopi Indian collection in the United States National Museum. By Walter Hough. Pp. 235-296, 48 figs., 35 pls. Apr. 6, 1918.

2236. The fishes of Mohave River, California. By John Otterbein Snyder. Pp. 297299, 1 fig. Mar. 5, 1918.

2237. New species of North American fossil beetles, cockroaches, and tsetse flies. By T. D. A. Cockerell. Pp. 301-311, 5 figs., 2 pls. July 5, 1918.

2238. Notes on the nomenclature of the mollusks of the family Turritidae. By William Healey Dall. Pp. 313-333. Apr. 5, 1918.

2239. Descriptions of new Lepidoptera from Mexico. By Harrison G. Dyar. Pp. 335-372. Apr. 5, 1918.

2240. Notes on mimetite, thaumasite, and wavellite. By Edgar T. Wherry. Pp. 373-381, 1 pl. Dec. 23, 1918.

2241. A newly mounted skeleton of the armored dinosaur, Stegosaurus stenops, in the United States National Museum. By Charles W. Gilmore. Pp. 383390, 7 pls. Dec. 26, 1918.

2242. The comparative morphology of the order Strepsiptera together with records and descriptions of insects. By W. Dwight Pierce. Pp. 391-501, 5 figs., 1 map, 15 pls. Sept. 12, 1918.

2243. Further notes on the Plainview, Texas, meteorite. By George P. Merrill. Pp. 503-505, 2 pls. Oct. 7, 1918.

2244. Mammals and reptiles collected by Theodoor de Booy in the Virgin Islands. By Gerrit S. Miller, Jr. Pp. 507-511, 1 pl. Oct. 15, 1918.

2245. Bones of birds collected by Theodoor de Booy from kitchen midden deposits in the islands of St. Thomas and St. Croix. By Alexander Wetmore. Pp. 513522,1 pl. Nov. 21, 1918.

2246. Two new land shells of the Epiphragmophora traskii group. By Paul Bartsch. Pp. 523-524, 1 pl. Dec. 23, 1918.

2247. Report on the calcareous sponges collected during 1906 by the United States Fisheries steamer Albatross in the northwestern Pacific. By Sanji Hōzawa. Pp. 525-556, 11 figs., 2 pls. Oct. 16, 1918.

2248. On the Fayette County, Texas, meteorite finds of 1878 and 1900 and the probability of their representing two distinct falls. By George P. Merrill. Pp. 557-561, 1 fig., 1 map, 2 pls. Nov. 25, 1918.

2249. Descriptions and notes on some ichneumon-flies from Java. By S. A. Rohwer. Pp. 563-570. Nov. 25, 1918.

2250. New marine shells from Panama. By Paul Bartsch. Pp. 571-575, 1 pl. Dec. 23, 1918.

2251. On the anatomy of Nyctibius with notes on allied birds. By Alexander Wetmore. Pp. 577-586, 7 figs. Oct. 15, 1918. 
2252. Four new African parasitic Hymenoptera belonging to the subfamily Microgasterinae. By A. B. Gahan. Pp. 587-590. Nov. 15, 1918.

2253. Descriptions of ten new isopods. By Pearl L. Boone. Pp. 591-604, 4 pls. Oct. $16,1918$.

2254. A new West Indian fossil land shell. By Paul Bartsch. Pp. 605-606, 1 pl. Dec. 26, 1918.

2255. Annotated catalogue of a collection of birds made by Mr. Copley Amory, Jr., in northeastern Siberia. By J. H. Riley. Pp. 607-626. Oct. 28, 1918.

2256. Fossil plants from the late Tertiary of Oklahoma. By Edward W. Berry. Pp. 627-636, 2 pls. Nov. 19, 1918.

2257. A new genus and species of multibrachiate ophiuran of the family Gorgonocephalidae from the Caribbean Sea. By Austin H. Clark. Pp. 637-640, 1 pl. Nov. 1, 1918.

\section{Volume 55}

Proceedings of the United States National Museum, vol. 55. Pp. i-vi (title page, advertisement, table of contents, and list of illustrations); pp. 1-649 (Proceedings papers 2258-2287) ; pp. 651-660 (index) ; 183 figs., 97 pls. 1920.

2258. The adult taenioid cestodes of dogs and cats, and of related carnivores in North America. By Maurice C. Hall. Pp. 1-94, 80 figs. Apr. 11, 1919.

2259. A heretofore undescribed meteoric stone from Kansas City, Missouri. By George P. Merrill. Pp. 95-96, 2 pls. Apr. 12, 1919.

2260. A new restoration of Triceratops, with notes on the osteology of the genus. By Charles W. Gilmore. Pp. 97-112, 6 figs., 7 pls. Apr. 9, 1919.

2261. New reared parasitic Hymenoptera with some notes on synonymy. By A. B. Gahan. Pp. 113-128, 2 figs. Apr. 26, 1919.

2262. The birds of the Tambelan Islands, South China Sea. By Harry C. Oberholser. Pp. 129-143. Apr. 26, 1919.

2263. Descriptions of new African earthworms, including a new genus of Moniligastridae. By Frank Smith and Bessie R. Green. Pp. 145-166, 18 figs. May 19, 1919.

2264. Bees in the collection of the United States National Museum.-3. By T. D. A. Cockerell. Pp. 167-221. May 7, 1919.

2265. Notes on the wrens of the genus Nannus Billberg. By Harry C. Oberholser. Pp. 223-236. Apr. 28, 1919.

2266. Additions and corrections to "The Type-species of the Genera of the Cynipoidea or the Gall Wasps and Parasitic Cynipoids." By S. A. Rohwer and Margaret M. Fagan. Pp. 237-240. Apr. 26, 1919.

2267. The branchiobdellid worms in the collections of the United States National Museum, with descriptions of new genera and new species. By Max M. Ellis. Pp. 241-265, 19 figs., 4 pls. May 2, 1919.

2268. Notes on birds collected by Dr. W. L. Abbott on Pulo Taya, Berhala Strait, southeastern Sumatra. By Harry C. Oberholser. Pp. 267-274. Apr. 28, 1919.

2269. Hemiptera collected by the Yale-Dominican Expedition of 1913. By Edmund H. Gibson. Pp. 275-277. Apr. 26, 1919.

2270. Miocene fossil plants from northern Peru. By Edward W. Berry. Pp. 279294, 4 pls. Apr. 28, 1919.

2271. Five new species of ptinid beetles. By W. S. Fisher. Pp. 295-299. Apr. 26, 1919.

2272. New land shells from the Philippine Islands. By Paul Bartsch. Pp. 301-307, 3 pls. Apr. 28, 1919.

2273. On certain genera of atherine fishes. By David Starr Jordan. Pp. 309-311, 2 figs. Apr. 26, 1919.

2274. A new species of parasitic copepod, with notes on species already described. By Charles Branch Wilson. Pp. 313-316, 1 pl. May 2, 1919.

2275. Distribution and use of slings in pre-Columbian America, with descriptive catalogue of ancient Peruvian slings in the United States National Museum. By Philip Ainsworth Means. Pp. 317-349, 3 figs., 6 pls. May 7, 1919. 
Proc.

No.

2276. A revision of the subspecies of the white-collared kingfisher, Sauropatis chloris (Boddaert). By Harry C. Oberholser. Pp. 351-395. May 2, 1919.

2277. On a rare species of half-beak, Hemiramphus balao, from Cuba. By David Starr Jordan. Pp. 397-398, 1 fig. May 2, 1919.

2278. The races of the Nicobar megapode, Megapodius nicobariensis Blyth. By Harry C. Oberholser. Pp. 399-402. May 7, 1919.

2279. Notes on some genera and species of chalcid-flies belonging to the Aphelininae with description of a new species. By A. B. Gahan. Pp. 403-407, 5 figs. May 22, 1919.

2280. Exploration of a pit house village at Luna, New Mexico. By Walter Hough. Pp. 409-431, 44 figs., 11 pls. June 14, 1919.

2281. A revision of the chalcid-flies of the genus Harmolita of America north of Mexico. By W. J. Phillips and W. T. Emery. Pp. 433-471, 10 pls. Aug. 6, 1919.

2282. Notes on Dr. W. L. Abbott's second collection of birds from Simalur Island, western Sumatra. By Harry C. Oberholser. Pp. 473-498, 1 fig. June 5, 1919.

2283. Descriptions of new species of chitons from the Pacific coast of America. By William Healey Dall. Pp. 499-516. June 7, 1919.

2284. Descriptions of new North American ichneumon-flies. By R. A. Cushman. Pp. 517-543, 1 fig. June 7, 1919.

2285. Report on a collection of Copepoda made in Honduras by F. J. Dyer. By C. Dwight Marsh. Pp. 545-548, 1 pl. June 5, 1919.

2286. North American parasitic copepods belonging to the new family Sphyriidae. By Charles Branch Wilson. Pp. 549-604, 10 pls. June 18, 1919.

2287. Descriptive catalogue of the collection of ecclesiastical art in the United States National Museum. By I. M. Casanowicz. Pp. 605-649, 38 pls. June 18, 1919.

\section{Volume 56}

Proceedings of the United States National Museum, vol. 56. Pp. i-xi (title page, advertisement, table of contents, and list of illustrations); pp. 1-679 (Proceedings papers 2288-2303); pp. $681-692$ (index); 43 figs., 81 pls. 1920.

2288. Descriptions of new species of mollusks of the family Turritidae from the west coast of America and adjacent regions. By William Healey Dall. Pp. 1-86, 24 pls. Aug. 8. 1919.

2289. A review of the leafhoppers of the genus Gypona north of Mexico. By Edmund H. Gibson. Pp. 87-100, Aug. 6, 1919.

2290. A new foraminifer commensal on Cyclammina. By Joseph A. Cushman. Pp. 101-102, 1 pl. July 31, 1919.

2291. Descriptions of some mammalian and fish remains from Florida of probably Pleistocene age. By Oliver P. Hay. Pp. 103-112, 3 pls. July 31, 1919.

2292. New fossil turtles, with notes on two described species. By Charles W. Gilmore. Pp. 113-132, 8 figs., 9 pls. July 30, 1919.

2293. Revision of the parasitic chalcidoid flies of the genera Homalotylus Mayr and Isodromus Howard, with descriptions of two closely related genera. By P. H. Timberlake. Pp. 133-194, 4 pls. Aug. 29, 1919.

2294. The fishes of the United States Eclipse Expedition to West Africa. By Henry W. Fowler. Pp. 195-292, 13 figs. Aug. 8, 1919.

2295. Descriptions of new species of Mollusca from the North Pacific Ocean in the collection of the United States National Museum. By William Healey Dall. Pp. 293-371. Aug. 30, 1919.

2296. Notes on certain genera of ichneumon-flies with descriptions of a new genus and four new species. By R. A. Cushman. Pp. 373-382, 2 figs. Aug. 27, 1919.

2297. A study of the brachiopod genus Platystrophia. By Eula Davis McEwan. Pp. 383-448, 11 pls. Sept. 2, 1919.

2298. Habits and economic relations of the guano birds of Peru. By Robert E. Coker. Pp. 449-511, 1 fig., 17 pls. Sept. 11, 1919. 
Proc.

No.

2299. Report on a small collection of Indian parasitic Hymenoptera. By A. B. Gahan. Pp. 513-524. Oct. 20, 1919.

2300. A mounted skeleton of Dimetrodon gigas in the United States National Museum, with notes on the skeletal anatomy. By Charles W. Gilmore. Pp. 525-539, 8 figs., 4 pls. Dec. 15, 1919.

2301. New genera and species of muscoid flies. By Charles H. T. Townsend. Pp. 541-592. Dec. 15, 1919.

2302. Recent Foraminifera from off New Zealand. By Joseph C. Cushman. Pp. 593-640, 2 pls. Dec. 16, 1919.

2303. The red spiders of America and a few European species likely to be introduced. By E. A. McGregor. Pp. 641-679, 11 figs., 6 pls. Jan. 8, 1920.

\section{Volume 57}

Proceedings of the United States National Museum, vol. 57. Pp. i-x (title page, advertisement, table of contents, and list of illustrations); pp. 1-678 (Proceedings papers 2304-2324); pp. 679-689 (index); 99 figs., 55 pls. 1921.

2304. On some hitherto unrecognized reptilian characters in the skull of the Insectivora and other mammals. By Jacob L. Wortman. Pp. 1-52, 16 figs. Apr. 5, 1920.

2305. On some forest Lepidoptera with descriptions of new species, larvae, and pupae. By Carl Heinrich. Pp. 53-96, 13 pls. June 17, 1920.

2306. The Cumberland Falls, Whitley County, Kentucky, meteorite. By George P. Merrill. Pp. 97-105, 1 fig., 5 pls. June 15, 1920.

2307. New species of Lepidoptera in the United States National Museum. By William Schaus. Ppp. 107-152. June 15, 1920.

2308. Observation on living specimens of Iridia diaphana, a species of Foraminifera. By Joseph Augustine Cushman. Pp. 153-158, 3 pls. June 16, 1920.

2309. Three new species of Indian drynnid parasites of rice leaf-hoppers. By S. A. Rohwer. Pp. 159-161, 1 pl. June 16, 1920.

2310. Report on cephalopods collected during 1906 by the United States Bureau of Fisheries steamer Albatross in the northwestern Pacific. By Madoka Sasaki. Pp. 163-203, 4 pls. Sept. 3, 1920.

2311. American records of whales of the genus Pseudorca. By Gerrit S. Miller, Jr. Pp. 205-207, 5 pls. June 15, 1920.

2312. Descriptions of twenty-five new species of North American Hymenoptera. By S. A. Rohwer. Pp. 209-231. June 16, 1920.

2313. Eocene insects from the Rocky Mountains. By T. D. A. Cockerell. Pp. 233-260, 11 figs., 5 pls. June 15, 1920.

2314. Annotated list of the Recent Brachiopoda in the collection of the United States National Museum, with descriptions of thirty-three new forms. By William Healey Dall. Pp. 261-377. June 24, 1920.

2315. Holarctic tribes of the ichneumon-flies of the subfamily Ichneumoninae (Pimplinae). By R. A. Cushman and S. A. Rohwer. Pp. 379-396, 14 figs. June 18, 1920.

2316. Diabantite, stilpnomelane, and chalcodite of the trap quarries of Westfield, Massachusetts. By Earl V. Shannon. Pp. 397-403. June 15, 1920.

2317. The North American ichneumon-flies of the tribes Labenini, Rhyssini, Xoridini, Odontomerini, and Phytodietini. By S. A. Rohwer. Pp. 405-474, 13 figs. June 19, 1920.

2318. Petrography of some lamprophyric dike rocks of the Coeur d'Alene mining district, Idaho. By Earl V. Shannon. Pp. 475-495, 4 figs., 3 pls. Sept. $2,1920$.

2319. A new Chinese isopod, Ichthyoxenus geei. By Pearl L. Boone. Pp. 497-502, 2 pis. July $27,1920$.

2320. The North American ichneumon-flies of the tribe Acoenitini. By R. A. Cushman and S. A. Rohwer. Pp. 503-523, 3 figs. June 21, 1920.

2321. A new fresh-water mollusk from Indiana. By Bryant Walker. P. 525, 1 fig. Sept. 9, 1920. 
Proc.

No.

2322. Synopsis of the trematode family Heterophyidae with descriptions of a new genus and five new species. By Brayton Howard Ransom. Pp. 527-573, 33 figs. June 16, 1920.

2323. Larvae of North American beetles of the family Cleridae. By Adam G. Böving and A. B. Champlain. Pp. 575-649, 12 pls. Aug. 31, 1920.

2324. Pleistocene peccaries from the Cumberland Cave deposit. By James Williams Gidley. Pp. 651-678, 13 figs., 2 pls. June 18, 1920.

\section{Volume 58}

Proceedings of the United States National Museum, vol. 58. Pp. i-viii, title page, advertisement, table of contents, and list of illustrations); pp. 1-680 (Proceedings papers 2325-2353); pp. 681-692 (index); 32 figs., 35 pls. 1921.

2325. Notes on a collection of shells from Trinidad, California. By Eric Knight Jordan. Pp. 1-5, 1 pl. Sept. 8, 1920.

2326. The North American ichneumon-flies of the tribes Lycorini, Polysphinctini, and Theroniini. By R. A. Cushman. Pp. 7-48, 5 figs., 1 pl. Sept. 3, 1920.

2327. A classification of the American operculate land mollusks of the family Annulariidae. By John B. Henderson and Paul Bartsch. Pp. 49-82. July $8,1920$.

2328. Descriptions of some Pleistocene vertebrates found in the United States. By Oliver P. Hay. Pp. 83-146, 4 figs., 9 pls. Oct. 12, 1920.

2329. The chemical composition of hydrotalcite and the hydrotalcite group of minerals. By William F. Foshag. Pp. 147-153. Sept. 9, 1920.

2330. The dipterous genus Zygothrica of Wiedemann. By A. H. Sturtevant. Pp. 155-158, 1 fig. Sept. 9, 1920.

2331. The west American mollusks of the families Rissoellidae and Synceratidae, and the rissoid genus Barlecia. By Paul Bartsch. Pp. 159-176, 2 pls. Nov. 9, 1920.

2332. New serphidoid, cynipoid, and chalcidoid Hymenoptera. By A. A. Girault. Pp. 177-216. Sept. 9, 1920.

2333. Report on the Mammalia collected by Mr. Edmund Heller during the Peruvian Expedition of 1915 under the auspices of Yale University and the National Geographic Society. By Oldfield Thomas. Pp. 217-249, 2 pls. Nov. 10, 1920.

2334. North American ichneumon-flies, new and described, with taxonomic and nomenclatorial notes. By R. A. Cushman. Pp. 251-292, 1 fig. Nov. 8, 1920.

2335. Preliminary diagnoses of new cephalopods from the western Atlantic. By S. Stillman Berry. Pp. 293-300, 1 pl. Nov. 10, 1920.

2336. New fresh-water shells from Guatemala. By William B. Marshall. Pp. 301-302, 1 pl. Nov. 13, 1920.

2337. Some recent accessions to the mineral collections of the United States National Museum. By William F. Foshag. Pp. 303-305, 3 pls. Nov. 13, 1920.

2338. A small collection of fishes from Soochow, China, with descriptions of two new species. By Henry W. Fowler. Pp. 307-321, 2 figs. Nov. 3, 1920.

2339. Recent accessions in the Division of Applied Geology. By Earl V. Shannon. Pp. 323-326. Nov. 10, 1920.

2340. The North American ichneumon-flies of the tribe Ephialtini. By R. A. Cushman. Pp. 327-362, 1 fig., 1 pl. Nov. 10, 1920.

2341. Notes on the meteorite of Estherville, Iowa, with especial reference to its included "peckhamite" and probable metamorphic nature. By George P. Merrill. Pp. 363-370, 3 pls. Nov. 11, 1920.

2342. Analyses and optical properties of amesite and corundophilite from Chester, Massachusetts, and of chromium-bearing chlorites from California and Wyoming. By Earl V. Shannon. Pp. 371-379. Nov. 10, 1920.

2343. Additions to West Indian Tertiary decapod crustaceans. By Mary J. Rathbun. Pp. 381-384, 1 pl. Nov. 11, 1920.

2344. Diptera of the superfamily Tipuloidea found in the District of Columbia. By C. P. Alexander and W. L. McAtee. Pp. 385-435, 1 pl. Dec. 7, 1920. 
2345. Notes on anglesite, anthophyllite, calcite, datolite, sillimanite, stilpnomelane, tetrahedrite and triplite. By Earl V. Shannon. Pp. 437-453, 13 figs. Dec. 18, 1920.

2346. Two new genera and species of acanthocephalous worms from Venezuelan fishes. By H. J. Van Cleave. Pp. 455-466, 2 pls. Dec. 21, 1920.

2347. A new polychaetous annelid of the genus Nereis from Brazil. By Aaron L. Treadwell. Pp. 467-468, 4 figs. Nov. 8, 1920.

2348. Some minerals from the old tungsten mine at Long Hill in Trumbull, Connecticut. By Earl V. Shannon. Pp. 469-482, 1 fig. Nov. 9, 1920.

2349. A revision of the North American species of ichneumon-flies belonging to the genus Apanteles. By C. F. W. Muesebeck. Pp. 483-576. Jan. 4, 1921.

2350. Observations on the nematode genus Nematodirus, with descriptions of new species. By Henry G. May. Pp. 577-588, 7 pls. Nov. 30, 1920.

2351. Boulangerite, bismutoplagionite, naumannite and a silver-bearing variety of jamesonite. By Earl V. Shannon. Pp. 589-607. Nov. 3, 1920.

2352. Amphibians and reptiles from southern Peru collected by the Peruvian Expedition of 1914-1915 under the auspices of Yale University and the National Geographic Society. By Thomas Barbour and G. K. Noble. Pp. 609-620. Jan. 6, 1921.

2353. Genotypes of the elaterid bettles of the world. By J. A. Hyslop. Pp. 621-680. Apr. 9, 1921.

\section{Volume 59}

Proceedings of the United States National Museum, vol. 59. Pp. i-xiii (title page, advertisement, table of contents, and list of illustrations); pp. 1-676 (Proceedings papers 2354-2395) ; pp. 677-685 (index) ; 97 figs., 125 pls. 1922.

2354. New species and a new genus of parasitic copepods. By Charles Branch Wilson. Pp. 1-17, 7 pls. June 10, 1921.

2355. Some fossil fish scales from Peru. By T. D. A. Cockerell. Pp. 19-20, 7 figs. June 10, 1921.

2356. A palm nut from the Miocene of the Canal Zone. By Edward W. Berry. Pp. 21-22, 3 figs. June 10, 1921.

2357. Notes on some western fluvial fishes described by Charles Girard in 1856. By John Otterbein Snyder. Pp. 23-28. June 16, 1921.

2358. Some Eocene insects from Colorado and Wyoming. By T. D. A. Cockerell. Pp. 29-39, 9 figs., 1 pl. June 27, 1921.

2359. The fossil annelid genus Hamulus Morton, an operculate Serpula. By Bruce Wade. Pp. 41-46, 2 pls. June 10, 1921.

2360. Foraminifera from the north coast of Jamaica. By Joseph A. Cushman. Pp. 47-82, 16 figs., 9 pls. June 10, 1921.

2361. Notes on sawflies, with descriptions of new genera and species. By S. A. Rohwer. Pp. 83-109. June 28, 1921.

2362. Barnacles of the San Juan Islands, Washington. By Henry A. Pilsbry. Pp. 111-115, 2 figs., 1 pl. June 27, 1921.

2363. Tertiary fossil plants from the Dominican Republic. By Edward W. Berry. Pp. 117-127, 1 pl. June 28, 1921.

2364. First supplement to "Type Species of the Genera of Ichneumon-flies." By Henry L. Viereck. Pp. 129-150. June 11, 1921.

2365. New species of North American clerid beetles of the genus Aulicus. By Charles Schaeffer. Pp. 151-159. June 28, 1921.

2366. Notes and descriptions of Neotropical sawflies of the subfamily Perreyiinac. By S. A. Rohwer. Pp. 161-167. June 20, 1921.

2367. Tertiary fossil plants from Costa Rica. By Edward W. Berry. Pp. 169-185, 6 pls. June 14, 1921.

2368. American gallflies of the family Cynipidae producing subterranean galls on oak. By Lewis H. Weld. Pp. 187-246, 10 pls. June 27, 1921.

2369. New mollusks from Camaguey and Santa Clara Provinces, Cuba. By Carlos de la Torre and John B. Henderson. Pp. 247-267, 5 pls. July 12, 1921. 
2370. North American predaceous beetles of the tribe Tillini in the United States National Museum. By A. B. Wolcott. Pp. 269-290, 1 pl. June 24, 1921.

2371. Descriptive catalogue of the collection of Buddhist art in the United States National Museum. By I. M. Casanowicz. Pp. 291-347, 49 pls. June 18, 1921.

2372. New species of Lepidoptera in the United States National Museum. By William Schaus. Pp. 349-396. Aug. 13, 1921.

2373. Description of ferroanthophyllite, an orthorhombic iron amphibole from Idaho, with a note on the nomenclature of the anthophyllite group. By Earl V. Shannon. Pp. 397-401. Aug. 3, 1921.

2374. Some notes on wasps of the subfamily Nyssoninae, with descriptions of new species. By S. A. Rohwer. Pp. 403-413. Aug. 11, 1921.

2375. Description of vivianite encrusting a fossil tusk from gold placers of Clearwater County, Idaho. By Earl V. Shannon. Pp. 415-417, 1 fig., 1 pl. Aug. 6, 1921.

2376. The crystallography and chemical composition of creedite. By William F. Foshag. Pp. 419-424, 3 figs. Aug. 4, 1921.

2377. The North American semiparasitic copepods of the genus Clausidium. By Charles Branch Wilson. Pp. 425-431, 2 pls. Aug. 11, 1921.

2378. Notes on certain genera of parasitic Cynipidae proposed by Ashmead with descriptions of genotypes. By Lewis H. Weld. Pp. 433-451, 9 figs. Aug. 18, 1921.

2379. A new Cretaceous rudistid from the San Felipe formation of Mexico. By Timothy W. Stanton. Pp. 453-454, 2 pls. Sept. 14, 1921.

2380. Some Eocene insects of the family Fulgoridae. By T. D. A. Cockerell and Grace Sandhouse. Pp. 455-457, 1 pl. Sept. 15, 1921.

2381. Crustacea from Lake Valencia, Venezuela. By A. S. Pearse. Pp. 459-462, 2 figs. Aug. 11, 1921.

2382. Sexual differences in coloration in the spotted turtle, Clemmys guttata. By S. F. Blake. Pp. 463-469, 1 pl. Sept. 13, 1921.

2383. The Troup, Texas, meteorite. By J. A. Udden. Pp. 471-476, 2 figs., 3 pls. Sept. 15, 1921.

2384. On the mineral composition and structure of the Troup meteorite. By George P. Merrill. Pp. 477-478. Sept. 15, 1921.

2385. A crystallographic study of the datolite from Westfield, Massachusetts. By Earl V. Shannon. Pp. 479-539, 24 figs., 4 pls. Oct. 10, 1921.

2386. Two new genera of nematodes, with a note on a neglected nematode structure. By Maurice C. Hall. Pp. 541-546, 2 figs. Oct. 5, 1921.

2387. Three new myrmecophilous beetles. By William M. Mann. Pp. 547-552, 6 figs. Oct. 5, 1921.

2388. Tertiary fossil plants from Venezuela. By Edward W. Berry. Pp. 553-579, 4 figs., 3 pls. Oct. 14, 1921.

2389. The fauna of the Arundel formation of Maryland. By Charles W. Gilmore. Pp. 581-594, 5 pls. Oct. 7, 1921.

2390. Some interesting dragon-fly naiads from Texas. By Clarence Hamilton Kennedy. Pp. 595-598, 1 pl. Oct. 10, 1921.

2391. Descriptions of species of Pleistocene Vertebrata, types or specimens of most of which are preserved in the United States National Musum. By Oliver P. Hay. Pp. 599-642, 9 pls. Oct. 13, 1921.

2392. Description of deep-sea fishes from the coast of Hawaii, killed by a lava flow from Mauna Loa. By David Starr Jordan. Pp. 643-656, 8 figs. Oct. 14, 1921.

2393. A new species of ray from the Texas coast, and report of the occurrence of a top minnow new to the fauna of eastern Texas. By Asa C. Chandler. Pp. 657-658. Oct. 5, 1921.

2394. New Nearctic spider mites of the family Tetranychidae. By H. E. Ewing. Pp. 659-666, 1 pl. Oct. 7, 1921.

2395. Ludwigites from Idaho and Korea. By Earl V. Shannon. Pp. 667-676. Oct. 5. 1921. 


\section{Volume 60}

Proceedings of the United States National Museum, vol. 60. Pp. i-xviii (title page, advertisement, table of contents, and list of illustrations); arts. 1-26; (Proceedings papers 2396-2421, paged separately). 1922.

Proc.

No.

2396. North American sawflies of the subfamily Cladiinae. By S. A. Rohwer, with notes on habits and descriptions of larvae by William Middleton. Art. 1 , pp. $1-45,7$ pls. Jan. $26,1922$.

2397. Nereis (Ceratonereis) alaskensis, a new polychaetous annelid from Alaska. By A. L. Treadwell. Art. 2, pp. 1-3, 4 figs. Jan. 3, 1922.

2398. Mineralogy of some black sands from Idaho, with a description of the methods used for their study. By Earl V. Shannon. Art. 3, pp. 1-33, 28 figs. Jan. 10, 1922.

2399. North American ichneumon-flies of the genera Clistopyga and Schizopyga. By R. A. Cushman. Art. 4, pp. 1-14, 14 figs. Jan. 4, 1922.

2400. North American parasitic copepods belonging to the family Dichelesthiidae. By Charles Branch Wilson. Art. 5, pp. 1-100, 13 pls. Mar. 22, 1922.

2401. A contribution to the anatomy of Dinobothrium, a genus of selachian tapeworms; with descriptions of two new species. By Edwin Linton. Art. 6, pp. 1-13, 4 pls. Jan. 23, 1922.

2402. The centipeds of Central America. By Ralph V. Chamberlin. Art. 7, pp. 1-17, 4 pls. Jan. 7, 1922.

2403. The millipeds of Central America. By Ralph V. Chamberlin. Art. 8, pp. 1-75, 25 pls. Mar. 14, 1922.

2404. Synoptic series of obects in the United States National Museum illustrating the history of inventions. By Walter Hough. Art. 9, pp. 1-47, 56 pls. Feb. 13, 1922.

2405. An illustrated synopsis of the puparia of 100 muscoid flies (Diptera). By Charles T. Greene. Art. 10, pp. 1-39, 20 pls. Jan. 13, 1922.

2406. Notes on Nearctic bibionid flies. By W. L. McAtee. Art. 11, pp. 1-27. Jan. 12, 1922.

2407. A redescription of the type species of the genera of Coccidae based on species originally described by Maskell. By Harold Morrison and Emily Morrison. Art. 12, pp. 1-120, 37 figs., 6 pls. May 12, 1922.

2408. On a new silurid fish from the Yalu River, South Manchuria. By Arthur de Carle Sowerby. Art. 13, pp. 1-2. Dec. 28, 1921.

2409. The jade of the Tuxtla statuette. By Henry S. Washington. Art. 14, pp. 1-12, 2 pls. Feb. 23, 1922.

2410. Suggestions for collecting and preparing diatoms. By Albert Mann. Art. 15, pp. 1-8. Feb. 13, 1922.

2411. Notes on an andorite-bearing silver ore from Nevada. By Earl V. Shannon. Art. 16, pp. 1-5. May 25, 1922.

2412. Synopsis of the North American flies of the genus Tachytrechus. By Charles T. Greene. Art. 17, pp. 1-21, 1 pl. May 5, 1922.

2413. Bees in the collection of the United States National Museum.-4. By T. D. A. Cockerell. Art. 18, pp. 1-20. Apr. 27, 1922.

2414. Brooksina, a new pentameroid genus from the Upper Silurian of southeastern Alaska. By Edwin Kirk. Art. 19, pp. 1-8, 1 pl. May 5, 1922.

2415. Two new intestinal trematodes from the dog in China. By Marcos A. Tubangui. Art. 20, pp. 1-12, 4 pls. May 3, 1922.

2416. New species of ichneumon-flies with taxonomic notes. By R. A. Cushman. Art. 21, pp. 1-28, 1 fig. Apr. 28, 1922.

2417. Velardeñite from a new locality in Tulare County, California. By Earl V. Shannon. Art. 22, pp. 1-4. May 4, 1922.

2418. A new description of Saniwa ensidens Leidy, an extinct varanid lizard from Wyoming. By Charles W. Gilmore. Art. 23, pp. 1-28, 22 figs., 3 pls. June 8, 1922. 
Proc.

No.

2419. Terrestrial Isopoda collected in Java by Dr. Edward Jacobson with descriptions of five new species. By Harriet Richardson Searle. Art. 24, pp. 1-7, 2 pls. May 5, 1922.

2420. Undescribed species of Costa Rican flies belonging to the family Tipulidae in the United States National Museum. By Charles P. Alexander. Art. 25, pp. 1-7. Apr. 25, 1922.

2421. Description of a new species of agamid lizard from the Malay Peninsula. By Doris M. Cochran. Art. 26, pp. 1-3. March 13, 1922.

\section{Volume 61}

Proceedings of the United States National Museum, vol. 61. Pp. i-xii (title page, advertisement, table of contents, and list of illustrations); arts. 1-25 (Proceedings papers 2422-2446, paged separately). 1922.

2422. Some Upper Cretaceous shells of the rudistid group from Tamaulipas, Mexico. By L. W. Stephenson. Art. 1, pp. 1-28, 15 pls. June 13, 1922.

2423. A revision of the chalcid-flies of the cyrtid genus Chrysoplatycerus. By P. H. Timberlake. Art. 2, pp. 1-10, 2 figs., 1 pl. Apr. 25, 1922.

2424. The smallest known horned dinosaur, Brachyceratops. By Charles W. Gilmore. Art. 3, pp. 1-4, 4 pls. Apr. 24, 1922.

2425. On meteoric irons from Alpine, Brewster County, Texas, and Signal Mountain, Lower California, and a pallasite from Cold Bay, Alaska. By George P. Merrill. Art. 4, pp. 1-4, 2 pls. Apr. 25, 1922.

2426. Crinoids from the Upper Cretaceous of Tamaulipas, Mexico. By Frank Springer. Art. 5, pp. 1-4, 1 pl. Apr. 25, 1922.

2427. Studies on chalcid-flies of the subfamily Leucospidinae, with descriptions of new species. By Clara Jamieson Weld. Art. 6, pp. 1-43, 2 figs., 4 pls. June 28, 1922.

2428. New buprestid beetles from Borneo and the Philippine Islands. By W. S. Fisher. Art. 7, pp. 1-18. Apr. 28, 1922.

2429. On the Ashmead manuscript species of Ichneumonidae of Mrs. Slosson's Mount Washington lists. By R. A. Cushman. Art. 8, pp. 1-30. May 22, 1922.

2430. A new genus of trematodes from the white bass. By H. J. Van Cleave. Art. 9, pp. 1-8, 1 pl. May 24, 1922.

2431. Notes on West Indian millipeds. By Ralph V. Chamberlin. Art 10, pp. $1-19,6$ pls. July $6,1922$.

2432. Parsee religious ceremonial objects in the United States National Museum. By I. M. Casanowicz. Art. 11, pp. 1-16, 7 pls. May 3, 1922.

2433. A new cestode from the maneater and mackerel sharks. By Edwin Linton. Art. 12, pp. 1-16, 3 pls. May 25, 1922.

2434. Ants from Honduras and Guatemala. By William M. Mann. Art. 13, pp. 1-54, 22 figs. June 14, 1922.

2435. Description of the skull of Megaptera miocaena, a fossil humpback whale from the Miocene diatomaceous earth of Lompoc, California. By Remington Kellogg. Art. 14, pp. 1-18, 10 figs., 4 pls. July 3, 1922.

2436. A revision of the North American inchneumon-flies, belonging to the subfamilies Neoneurinae and Microgasterinae. By C. F. W. Muesebeck. Art. 15, pp. 1-76, 1 pl. Aug. 5, 1922.

2437. New pearly fresh water mussels from South America. By William B. Marshall. Art. 16, pp. 1-9, 3 pls. Apr. 28, 1922.

2438. Description of a new fossil sea cow from Florida, Metaxytherium floridanum. By Oliver P. Hay. Art. 17, pp. 1-4, 1 pl. May 3, 1922.

2439. Notes on cynipid wasps, with descriptions of new North American species. By Lewis H. Weld. Art. 18, pp. 1-29, 3 figs., 1 pl. June 28, 1922.

2440. Notes on American gallflies of the family Cynipidae producing galls on acorns, with descriptions of new species. By Lewis H. Weld. Art. 19, pp. 1-32, 3 figs., 5 pls. June $28,1922$. 
2441. New termites from Hawaii, Central and South America, and the Antilles. By Thomas E. Snyder. Art. 20, pp. 1-32, 6 figs., 5 pls. May 25, 1922.

2442. Descriptions of some North American sawfly larvae. By William Middleton. Art 21, pp. 1-31, 8 figs. May 12, 1922.

2443. Studies on the cyclostomatous Bryozoa. By Ferdinand Canu and Ray S. Bassler. Art. 22, pp. 1-160, 40 figs., 28 pls. Oct. 6, 1922.

2444. A new cecidomyiid parasite of the white fly. By E. P. Felt. Art. 23, pp. 1-2. Nov. 2, 1922.

2445. Descriptions of miscellaneous new reared parasitic Hymenoptera. By A. B. Gahan. Art. 24, pp. 1-24, 1 pl. May 25, 1922.

2446. Two-winged flies of the genera Dolichopus and Hydrophorus collected in Alaska in 1921, with new species of Dolichopus from North America and Hawaii. By J. M. Aldrich. Art. 25, pp. 1-18. May 3, 1922.

\section{Volume 62}

Proceedings of the United States National Museum, vol. 62. Pp. i-xvi (title page, advertisement, table of contents, and list of illustrations); arts. 1-22 (Proceedings papers 2447-2468, paged seperately). 1923.

2447. The mosquitoes of the United States. By Harrison G. Dyar. Art. 1, pp. 1-119. June 28, 1922.

2448. Fishes from Formosa and the Philippine Islands. By Henry W. Fowler and Barton A. Bean. Art. 2, pp. 1-73, 4 figs. July 28, 1922.

2449. Seven new species of fish of the order Malacopterygii. By W. W. Welsh. Art. 3, pp. 1-11, 10 figs. Feb. 10, 1923.

2450. A revision of the North American two-winged flies of the family Therevidae. By Frank R. Cole. Art. 4, pp. 1-140, 3 figs., 13 pls. May 10, 1923.

2451. A new fossil turtle, Kinosternon arizonense, from Arizona. By Charles W. Gilmore. Art. 5, pp. 1-8, 7 figs., 5 pls. Feb. 6, 1923.

2452. Rehabilitation of a hitherto overlooked species of musk turtle of the southern States. By Leonhard Stejneger. Art. 6, pp. 1-3. Feb. 10, 1923.

2453. Two new Lithothamnieae, calcareous algae, from the Lower Miocene of Trinidad, British West Indies. By Marshall A. Howe. Art. 7, pp. 1-3, 4 pls. Dec. 22, 1922.

2454. The leaf and twig mining buprestid beetles of Mexico and Central America. By Warren S. Fisher. Art. 8, pp. 1-95. Dec. 22, 1922.

2455. Mineralogic notes on pucherite, pyrite, trichalcite, and wavellite. By Earl V. Shannon. Art. 9, pp. 1-10, 10 figs. Jan. 5, 1923.

2456. Species of round worm (Gongylonema) from domestic swine in the United States. By Edward A. Chapin. Art. 10, pp. 1-3, 3 figs. Dec. 8, 1922.

2457. The Neotropical muscoid genus Mesembrinella Giglio-Tos and other testaceous muscoid flies. By J. M. Aldrich. Art. 11, pp. 1-24. Dec. 19, 1922.

2458. On siderite and associated minerals from the Columbia River basalt at Spokane, Washington. By Earl V. Shannon. Art. 12, pp. 1-19, 14 figs., 3 pls. Mar. 29, 1923.

2459. The dermanyssid mites of North America. By H. E. Ewing. Art. 13, pp. 1-26, 7 figs., 2 pls. Jan. 27, 1923.

2460. Tertiary fossil plants from the Republic of Haiti. By Edward W. Berry. Art 14, pp, 1-10, 2 figs., 1 pl. Dec. 28, 1922.

2461. Notes on the mineralogy of three gouge clays from precious metal veins. By Earl V. Shannon. Art. 15, pp. 1-11. Nov. 22, 1924.

2462. Description of two squalodonts recently discovered in the Calvert Cliffs, Maryland; and notes on the shark-toothed cetaceans. By Remington Kellogg. Art. 16, pp. 1-69, 3 figs., 20 pls. Apr. 24, 1923.

2463. The scale insects of the subfamilies Monophlebinae and Margarodinae treated by Maskell. By Harold Morrison and Emily Morrison. Art. 17, pp. 1-47, 19 figs., 3 pls. June 9, 1923. 
Proc.

No.

2464. A meteoric metabolite from Dungannon, Virginia. By George P. Merrill. Art. 18, pp. 1-2, 2 pls. Mar. 19, 1923.

2465. Miocene plants from southern Mexico. By Edward W. Berry. Art. 19, pp. 1-27, 1 fig., 7 pls. June 2, 1923.

2466. New genera of two-winged flies of the subfamily Leptogastrinae of the family Asilidae. By J. M. Aldrich. Art. 20, pp. 1-6, 3 figs. Feb. 13, 1923.

2467. The dragonflies (Odonata) of Burma and Lower Siam-III. Subfamily Aeschninae. By Frank Fortescue Laidlaw. Art. 21, pp. 1-29, 1 pl. June 21, 1923.

2468. Steiroxys hendersoni, a new katydid from Utah. By A. N. Caudell. Art. 22, pp. 1-2, 1 fig. Feb. 13, 1923.

\section{Volume 63}

Proceedings of the United States National Museum, vol. 63. Pp. i-xiii (title page, advertisement, table of contents, and list of illustrations); arts. 1-21 (Proceedings papers $2469-2490$, paged separately). 1924.

2469. Paleocene primates of the Fort Union, with discussion of relationships of Eocene primates. By James Williams Gidley. Art. 1, pp. 1-38, 4 figs., 5 pls. Apr. 28, 1923.

2470. A revision of the North American species of ichneumon-flies belonging to the genus Meteorus Haliday. By C. F. W. Muesebeck. Art. 2, pp. 1-44, 2 figs. June 28, 1923.

2471. Three new trematodes from Amphiuma means. By Asa C. Chandler. Art. 3, pp. 1-7, 2 pls. Apr. 28, 1923.

2472. Note on Icichthys lockingtoni Jordan and Gilbert, a pelagic fish from California. By David Starr Jordan. Art. 4, pp. 1-3, 1 pl. June 2, 1923.

2473. Description of remains of Bison occidentalis from central Minnesota. By Oliver P. Hay. Art. 5, pp. 1-8, 2 pls. May 9, 1923.

2474. Two Asiatic muscoid flies parasitic upon the so-called Japanese beetle. By J. M. Aldrich. Art. 6, pp. 1-4. Apr. 13, 1923.

2475. A fossil cichlid fish from the Republic of Haiti. By T. D. A. Cockerell. Art. 7, pp. 1-2, 1 pl. Apr. 27, 1923.

2476. Some bees from Victoria, Mexico. By T. D. A. Cockerell. Art. 8, pp. 1-5. Apr. 16, 1923.

2477. Fossil crabs from the Republic of Haiti. By Mary J. Rathbun. Art. 9, pp. 1-6, 2 pls. Apr. 28, 1923.

2478. Additions and emendations to United States National Museum Bulletin No. 112. By William H. Dall. Art. 10, pp. 1-4. Apr. 12, 1923.

2479. Crystallographic notes on stephanite in a silver ore from Mexico. By Earl V. Shannon. Art. 11, pp. 1-6, 4 figs. Apr. 12, 1923.

2480. Catalogue of human crania in the United States National Museum collections: The Eskimo, Alaska and related Indians, Northeastern Asiatics. By Aleš Hrdlička. Art. 12, pp. 1-51. Mar. 14, 1924.

2481. Descriptions of new American and Chinese spiders, with notes on other Chinese species. By Ralph V. Chamberlin. Art. 13, pp. 1-38, 7 pls. Feb. 8, 1924.

2482. A fossil porpoise from the Calvert formation of Maryland. By Remington Kellogg. Art. 14, pp. 1-39, 18 pls. Mar. 26, 1924.

2483. Description of a new genus and species of whalebone whale from the Calvert Cliffs, Maryland. By Remington Kellogg. Art. 15, pp. 1-14, 6 pls. Feb. 5, 1924.

2484. Revision of the North American wasps of the subfamily Platygasterinae. By Robert M. Fouts. Art. 15a, pp. 1-145, 10 figs, 1 pl. June 30, 1924.

2485. New pearly fresh-water mussels from Mexico and Uruguay. By William B. Marshall. Art. 16, pp. 1-4, 3 pls. Jan. 8, 1924.

2486. The North American species of parasitic two-winged flies belonging to the genus Phorocera and allied genera. By J. M. Aldrich and Ray T. Webber. Art. 17, pp. 1-90, 1 fig. Feb. 29, 1924. 
2487. Recently found meteoric irons from Mesa Verde Park, Colo., and Savannah, Tenn. By George P. Merrill. Art. 18, pp. 1-4, 3 pls. Mar. 4, 1924.

2488. Descriptions of eighteen new species of fishes from the Wilkes Exploring Expedition, preserved in the United States National Museum. By Henry W. Fowler and Barton A. Bean. Art. 19, pp. 1-27. Dec. 22, 1923.

2489. On the taxonomy, biology, and distribution of the biting lice of the family Gyropidae. By H. E. Ewing. Art. 20, pp. 1-42, 18 figs., 1 pl. Mar. 4, 1924.

2490. Notes and descriptions of two-winged flies of the family Dolichopodidae from Alaska. By M. C. Van Duzee. Art. 21, pp. 1-16, 1 pl. Jan. 4, 1924.

\section{Volume 64}

Proceedings of the United States National Museum, vol. 64. Pp. i-xiii (title page, advertisement, table of contents, and list of illustrations); arts. 1-23 (Proceedings papers 2491-2513, paged separately). 1925.

2491. Tertiary mollusks of the genus Orthaulax from the Republic of Haiti, Porto Rico, and Cuba. By Wendell P. Woodring. Art. 1, pp. 1-12, 2 pls. Dec. 22, 1923.

2492. The Sharps meteorite, Richmond County, Virginia. By Thomas L. Watson. Art. 2, pp. 1-4, 2 pls. Dec. 22, 1923.

2493. A remarkable new sea star from Japan. By W. K. Fisher. Art. 3, pp. 1-6, 6 figs., 2 pls. Mar. 18, 1924.

2494. New genera and species of ichneumon-flies. By R. A. Cushman. Art. 4, pp. 1-16, 2 figs. Jan, 12, 1924.

2495. Fossil birds from southeastern Arizona. By Alexander Wetmore. Art. 5, pp. 1-18, 9 figs. Jan. 15, 1924.

2496. Descriptions of new species and hitherto unknown castes of termites from America and Hawaii. By Thomas E. Snyder. Art 6, pp. 1-40, 5 pls. May 10, 1924.

2497. Studies of larvae of crabs of the family Pinnotheridae. By O. W. Hyman. Art. 7, pp. 1-9, 6 pls. Mar. 5, 1924.

2498. A synopsis of the species of Boeckella and Pseudoboeckella with a key to the genera of the fresh-water Centropagidae. By C. Dwight Marsh. Art. 8, pp. 1-28, 35 figs. Mar. 19, 1924.

2499. The heteronereis phase of a new species of a polychaetous annelid from Uruguay. By Aaron L. Treadwell. Art. 9, pp. 1-3, 1 pl. Dec. 22, 1923.

2500. New species of two-winged flies from western North America belonging to the family Tipulidae. By Charles P. Alexander. Art. 10, pp. 1-16. Mar. 11, 1924.

2501. Revision of the two-winged flies of the family Clusiidae. By A. L. Melander and Naomi George Argo. Art. 11, pp. 1-54, 4 pls. May 16, 1924.

2502. Notes and descriptions of naiads belonging to the dragonfly genus Helocordulia. By Clarence Hamilton Kennedy. Art. 12, pp. 1-4, 1 pl. Mar. 5, 1924.

2503. Fossil insects in the United States National Museum. By T. D. A. Cockerell. Art. 13, pp. 1-15, 2 figs., 2 pls. Feb. 2, 1924.

2504. New species and subspecies of spider crabs. By Mary J. Rathbun. Art. 15, pp. 1-5. Jan. 2, 1924.

2505. A revision of the mutillid wasps of the genera Myrmilloides and Pseudomethoca occurring in America north of Mexico. By Clarence E. Mickel. Art. 15, pp. 1-52, 4 pls. June 17, 1924.

2506. A collection of birds from north and north-central Celebes. By J. H. Riley. Art. 16, pp. 1-118. Oct. 28, 1924.

2507. New North American parasitic copepods, new hosts, and notes on copepod nomenclature. By Charles Branch Wilson. Art. 17, pp. 1-22, 3 pls. July 7, 1924.

2508. Notes on certain catostomids of the Bonneville system of Utah, including the type of Pantosteus virescens Cope. By John Otterbein Snyder. Art. 18, pp. 1-6. Mar. 5, 1924. 
Proc.

No.

2509. Mordenite and associated minerals from near Challis, Custer County, Idaho. By Clarence S. Ross and Earl V. Shannon. Art. 19, pp. 1-19, 6 figs., 3 pls. Mar. 22, 1924.

2510. On the genera of the ichneumon-fies of the tribe Paniscini Ashmead, with descriptions and discussion of related genera and species. By R. A. Cushman. Art. 20, pp. 1-48, 7 figs. Jan. 12, 1924.

2511. Notes on cestode parasites of sharks and skates. By Edwin Linton. Art. 21, pp. $1-114,13$ pls. Oct. 27, 1924.

2512. Notes on birds collected by Dr. W. L. Abbott on the Karimata Islands, off west Borneo. By Harry C. Oberholser. Art. 22, pp. 1-4. Mar. 28, 1924.

2513. The blister beetle Tricrania sanguinipennis-biology, descriptions of different stages, and systematic relationship. By J. B. Parker and Adam G. Böving. Art. 23, pp. 1-40, 1 fig., 5 pls. July 30, 1924.

\section{Volume 65}

Proceedings of the United States National Museum, vol. 65. Pp. i-xii (title page, advertisement, table of contents, and list of illustrations; arts. 1-24 (Proceedings papers 2514-2537, paged separately). 1925.

2514. Studies on the larvae of North American beetles of the subfamily Tenebrioninae with a description of the larva and pupa of Merinus laevis (Olivier). By R. A. St. George. Art. 1, pp. 1-22, 4 pls. July 19, 1924.

2515. Miocene and Pleistocene Cirripedia from Haiti. By Henry A. Pilsbry. Art. 2, pp. 1-3, 1 pl. May 10, 1924.

2516. A Tertiary crinoid from the West Indies. By Frank Springer. Art. 3, pp. 1-8, 1 pl. May 12, 1924.

2517. Some parasitic Hymenoptera with notes on several described forms. By A. B. Gahan. Art. 4, pp. 1-23. July 19, 1924.

2518. A new nautiloid cephalopod, Eutrephoceras sloani, from the Eocene of South Carolina. By John B. Reeside, Jr. Art. 5, pp. 1-4, 1 fig., 3 pls. May 10, 1924.

2519. Description of a recently discovered fossil sculpin from Nevada regarded as Cottus beldingi. By David Starr Jordan. Art. 6, pp. 1-2, 1 pl. Sept. 12, 1924.

2520. New species of moths in the United States National Museum. By William Schaus. Art. 7, pp. 1-74. June 2, 1924.

2521. Notes on the osteology and dentition of the genera Desmostylus and Cornquallius. By Oliver P. Hay. Art. 8, pp. 1-8, 2 figs., 2 pls. July 19, 1924.

2522. A revision of the West Indian Coleoptera of the family Buprestidae. By Warren S. Fisher. Art. 9, pp. 1-207. Mar. 27, 1925.

2523. Studies on larvae of crabs of the family Grapsidae. By O. W. Hyman. Art. 10 , pp. $1-8,3$ pls. Oct. $6,1924$.

2524. Amastridium, a neglected genus of snakes. By E. R. Dunn. Art. 11, pp. 1-3. Apr. 1, 1924.

2525. Keys to flies of the families Lonchaeidae, Pallopteridae, and Sapromyzidae of the eastern United States, with a list of the species of the District of Columbia region. By J. R. Malloch and W. L. McAtee. Art. 12, pp. 1-26, 2 pls. Sept. 9, 1924.

2526. Nematode parasites of the Brazilian land-tortoise, Testudo denticulata. Results of the Mulford Biological Exploration.-Helminthology. By Edward A. Chapin. Art. 13, pp. 1-6, 2 pls. Sept. 9, 1924.

2527. A remarkable new genus and species of mermithid worms from Jamaica. By G. Steiner. Art. 14, pp. 1-4, 2 pls. Apr. 25, 1924.

2528. The magic, psychic, ancient Egyptian, Greek, and Roman medical collections of the Division of Medicine in the United States National Museum. By Charles Whitebread. Art. 15, pp. 1-44, 24 figs., 5 pls. Nov. 24, 1924.

2529. Synopsis of the North American flies of the genus Scellus. By Charles T. Greene. Art. 16, pp. 1-18, 3 pls. Sept. 9, 1924.

2530. Studies on the morphology, taxonomy, and ecology of the larvae of Holarctic tiger-beetles (family Cicindelidae). By Clyde C. Hamilton. Art. 17, pp. 1-87, 12 pls. Apr. 24, 1925. 
Proc.

No.

2531. Notes on Entomostraca from Colorado. The Shantz collections from the Pikes Peak region. By G. S. Dodds. Art. 18, pp. 1-7, 1 fig. May 12, 1924.

2532. New American species of bees belonging to the genus Halictus (Chloralictus). By Grace Adelbert Sandhouse. Art. 19, pp. 1-43. Sept. 9, 1924.

2533. Hookworms of the genus Uncinaria of the dog, fox, and badger. By B. H. Ransom. Art. 20, pp. 1-5, 1 pl. July 8, 1924.

2534. A new genus and species of two-winged flies of the family Chloropidae injuring Manihot in Brazil. By J. M. Aldrich. Art. 21, pp. 1-2. June $7,1924$.

2535. The fossils of the Lower San Pedro fauna of the Nob Hill cut, San Pedro, California. By T. S. Oldroyd. Art. 22, pp. 1-39, 2 pls. June 16, 1925.

2536. A new marine annelid from Chile. By A. L. Treadwell. Art. 23, pp. 1-3, 4 figs. Aug. 9, 1924.

2537. Benjaminite, a new sulphosalt mineral of the klaprotholite group. By Earl V. Shannon. Art. 24, pp. 1-9, 3 figs. June 17, 1924.

\section{Volume 66}

Proceedings of the United States National Museum, vol. 66. Pp. xviii (title page, advertisement, table of contents, and list of illustrations); arts. 1-35 (Proceedings papers 2538-2572, paged separately). 1926.

2538. Parasitic nematodes from Tonkin, Indo-China, including a new species of Ascaridia. By Benjamin Schwartz. Art. 1, pp. 1-9, 1 fig. May 14, 1925.

2539. The mineralogy and petrology of intrusive Triassic diabase at Goose Creek, Loudoun County, Virginia. By Earl V. Shannon. Art. 2, pp. 1-86, 32 figs., 9 pls. Dec. 13, 1924.

2540. Descriptions of Neotropical two-winged flies of the family Drosophilidae. By J. R. Malloch. Art. 3, pp. 1-11. Oct. 13, 1924.

2541. Senecella calanoides, a recently described fresh-water copepod. By Chancey Juday. Art. 4, pp. 1-6, 3 pls. May 23, 1925.

2542. A contribution toward the classification of the weevil larvae of the subfamily Calendrinae, occurring in North America. By Richard T. Cotton. Art. 5, pp. 1-11, 10 pls. Oct. 11, 1924.

2543. Notes on the herpetological collections made by Dr. W. L. Abbott on the island of Haiti. By Doris M. Cochran. Art. 6, pp. 1-15. Oct. 15, 1924.

2544. Some hitherto unpublished photographs and measurements of the blue whale. By Gerrit S. Miller, Jr. Art. 7, pp. 1-4, 9 pls. Nov. 3, 1924.

2545. A second instance of the development of rodent-like incisors in an artiodactyl. By Gerrit S. Miller, Jr. Art. 8, pp. 1-3, 1 pl. Oct. 13, 1924.

2546. A pollack whale from Florida presented to the National Museum by the Miami Aquarium Association. By Gerrit S. Miller, Jr. Art. 9, pp. 1-15, 22 pls. Dec. 11, 1924.

2547. Notes on Oriental dragonflies of the genus Aciagrion. By Frank Fortescue Laidlaw. Art. 10, pp. 1-9, I pl. Oct. 13, 1924.

2548. A new species of round worm of the genus Trichostrongylus from the rabbit. By H. W. Craybill. Art. 11, pp. 1-2, 1 pl. Oct. 8, 1924.

2549. A new earthworm from Texas belonging to the genus Diplocardia. By Frank Smith. Art. 12, pp. 1-6. Oct. 6, 1924.

2550. New species of mollusks of the genus Chilina. By William B. Marshall. Art. 13, pp. 1-5, 1 pl. Oct. 8, 1924.

2551. New mollusks from Santa Elena Bay, Ecuador. By Paul Bartsch. Art. 14, pp. 1-9, 2 pls. Oct. 17, 1924.

2552. New Uruguayan mollusks of the genus Corbicula. By William B. Marshall. Art. 15, pp. 1-12, 2 pls. Nov. 3, 1924.

2553. Some parasitic round worms of the rabbit with descriptions of two new species. By Asa C. Chandler. Art. 16, pp. 1-6, 2 pls. Nov. 3, 1924.

2554. Illustrations of unfigured types of shells in the collection of the United States National Museum. By William Healey Dall. Art. 17, pp. 1-41, 36 pls. Sept. 22, 1925. 
2555. New Diptera or two-winged fies in the United States National Museum. By J. M. Aldrich. Art. 18, pp. 1-36, 1 fig. Jan. 24, 1925.

2556. Plant and insect fossils from the Green River Eocene of Colorado. By T. D. A. Cockerell. Art. 19, pp. 1-13, 2 pls. Feb. 16, 1925.

2557. A rare Cretaceous sea urchin, Scutellaster cretaceus Cragin. By John B. Reeside, Jr. Art. 20, pp. 1-4, 2 figs., 1 pl. Dec. 9, 1924.

2558. A Pleistocene flora from the Island of Trinidad. By Edward W. Berry. Art. 21, pp. 1-9, 4 pls. May 23, 1925.

2559. Miocene gastropods and scaphopods from Trinidad, British West Indies. By Wendell C. Mansfield. Art. 22, pp. 1-65, 10 pls. Sept. 18, 1925.

2560. A revision of the North American species of the genus Argyra Macquart, two-winged flies of the family Dolichopodidae. By M. C. Van Duzee. Art. 23, pp. 1-43, 1 pl. May 5, 1925.

2561. A new proliferating larval tapeworm from a porcupine. By Benjamin Schwartz. Art. 24, pp. 1-4, 1 pl. Dec. 26, 1924.

2562. Chinese amphibians and reptiles in the United States National Museum. By Leonhard Stejneger. Art. 25, pp. 1-115, 6 figs. July 15, 1925.

2563. On the occurrence of remains of fossil porpoises of the genus Eurhinodelphis in North America. By Remington Kellogg. Art. 26, pp. 1-40, 4 figs., 17 pls. May 23, 1925.

2564. A fossil physeteroid cetacean from Santa Barbara County, California. By Remington Kellogg. Art. 27, pp. 1-8, 2 pls. Feb. 28, 1925.

2565. Mineralogy and petrography of Triassic limestone conglomerate metamorphosed by intrusive diabase at Leesburg, Virginia. By Earl V. Shannon. Art. 28, pp. 1-31, 8 figs., 3 pls. May 22, 1925.

2566. The puparia and larvae of sarcophagid fies. By Charles T. Greene. Art. 29, pp. 1-26, 9 pls. Feb. 10, 1925.

2567. A new genus of Eocene Foraminifera. By Joseph A. Cushman. Art. 30, pp. 1-4, 1 fig., 2 pls. Jan. 23, 1925.

2568. Buprestid beetles collected by the Mulford Biological Exploration in Bolivia. By Warren S. Fisher. Art. 31, pp. 1-46. Feb. 13, 1925.

2569. Harpidium, a new pentameroid brachiopod genus from southeastern Alaska. By Edwin Kirk. Art. 32, pp. 1-7, 2 pls. Apr. 11, 1925.

2570. Notes on the fishes of Hawaii, with descriptions of six new species By Eric Knight Jordan. Art. 33, pp. 1-43, 2 pls. Sept. 22, 1925.

2571. A further and detailed description of the type of Elephas roosevelti Hay and descriptions of three referred specimens. By Oliver P. Hay. Art. 34, pp. 1-6, 1 fig., 4 pls. May 22, 1925.

2572. On remains of mastodons found in Texas, Anancus brazosius and Gomphotherium cimarronis. By Oliver P. Hay. Art. 35, pp. 1-15, 9 figs., 4 pls. Apr. $25,1925$.

\section{Volume 67}

Proceedings of the United States National Museum, vol. 67. Pp. i-xix (title page, advertisement, table of contents, and list of illustrations); arts. 1-29 (Proceedings papers 2573-2601, paged separately). 1926.

2573. Revision of the American bugs of the reduviid subfamily Ploiariinae. By W. L. McAtee and J. R. Malloch. Art. 1, pp. 1-152, 9 pls. Apr. 16, 1925.

2574. Notes on the meteoric stone of Colby, Wisconsin. By George P. Merrill. Art 2, pp. 1-3, 1 pl. May 23, 1925.

2575. Studies on the larvae of crabs of the family Xanthidae. By O. W. Hyman. Art. 3, pp. 1-22, 14 pls. June 1, 1925.

2576. Microscopic sculpture of pearly fresh-water mussel shells. By William B. Marshall. Art. 4, pp. 1-14, 4 pls. Mar. 23, 1925.

2577. The genus Pentacrinus in Alaska. By Frank Springer. Art. 5, pp. 1-7, 1 pl. May 22, 1925.

2578. A new meteoric stone from Baldwyn, Mississippi. By George P. Merrill. Art. 1, pp. 1-2, 1 pl. May 22, 1925. 
Proc.

No.

2579. The origin, occurrence, composition, and physical properties of the mineral iddingsite. By Clarence S. Ross and Earl V. Shannon. Art. 7, pp. 1-19, 2 pls. May $15,1925$.

2580. A revision of the parasitic wasps of the genus Microbracon occurring in America north of Mexico. By C. F. W. Muesebeck. Art. 8, pp. 1-85, 2 pls. May 25, 1925.

2581. Unusual forms of fossil crinoids. By Frank Springer. Art. 9, pp. 1-137, 10 figs., 26 pls. Feb. 15, 1926.

2582. The Indian medical exhibit of the Division of Medicine in the United States National Museum. By Charles Whitebread. Art. 10, pp. 1-26, 20 figs., 2 pls. July 22, 1925.

2583. A synoptic review of the beetles of the tribe Osoriini from the Western Hemisphere. By Howard Notman. Art. 11, pp. 1-26. Apr. 30, 1925.

2584. A new species of polychaetous annelid from Uruguay, Aphrodita magna. By A. L. Treadwell. Art. 12, pp. 1-3, 2 figs. Apr. 11, 1925.

2585. Revision of bugs of the family Cryptostemmatidae in the collection of the United States National Museum. By W. L. McAtee and J. R. Malloch. Art. 13, pp. 1-42, 4 pls. Apr. 16, 1925.

2586. A review of the beetle family Pseudomorphidae, and a suggestion for a rearrangement of the Adephaga, with descriptions of a new genus and new species. By Howard Notman. Art. 14, pp. 1-34. May 25, 1925.

2587. The dragon god (Dai-Ja) in Idzumo, Japan. A Japanese tale. By I. M. Casanowicz. Art. 15, pp. 1-4, 1 pl. May 23, 1925.

2588. Eggs of a new species of nematoid worm from a shark. By G. A. MacCallum. Art. 16, pp. 1-2, 1 pl. May 9, 1925.

2589. Two new larval nematodes belonging to the genus Porrocaecum from mammals of the order Insectivora. By Benjamin Schwartz. Art. 17, pp. 1-8, 1 pl. May 23, 1925.

2590. 'Occurrence of the crinoid genus Apiocrinus in America. By Frank Springer. Art. 18, pp. 1-5, 1 pl. April 8, 1925.

2591. The adaptive modifications and the taxonomic value of the tongue in birds. By Leon L. Gardner. Art. 19, pp. 1-49, 16 pls. Sept. 25, 1925.

2592. A revision of the insects of the aphid genus Amphorophora. By Preston W. Mason. Art. 20, pp. 1-92, 18 pls. Sept. 23, 1925.

2593. Studies on the cyclostomatous Bryozoa. By Ferdinand Canu and Ray S. Bassler. Art. 21, pp. 1-124, 46 figs., 31 pls. Mar. 29, 1926.

2594. Three new land shells from Mexico. By Paul Bartsch. Art. 22, pp. 1-5, 1 pl. Dec. 14, 1925.

2595. Ten new North American ichneumon-flies. By R. A. Cushman. Art. 23, pp. 1-13. Feb. 2, 1926.

2596. South American snakes in the collection of the United States National Museum. By Afranio do Amaral. Art. 24, pp. 1-30. Dec. 23, 1925.

2597. Foraminifera of the genera Siphogenerina and Pavonina. By Joseph A. Cushman. Art. 25, pp. 1-24, 6 pls. Mar. 9, 1926.

2598. A new species of hookworm from a North American raccoon. By Benjamin Schwartz. Art. 26, pp. 1-4, 4 figs. Dec. 2, 1925.

2599. Asymmetry in the skulls of mammals. By A. Brazier Howell. Art. 27, pp. 1-18, 8 pls. Dec. 31, 1925.

2600. Supplementary observations on the skull of the fossil porpoise Zarhachis flagellator Cope. By Remington Kellogg. Art. 28, pp. 1-18, 5 pls. Feb. 24, 1926.

2601. A list of the annelids collected by Captain R. A. Bartlett in Alaska, 1924, with a description of a new species. By A. L. Treadwell. Art. 29, pp. 1-3, 4 figs. Nov. 18, 1925. 


\section{Volume 68}

Proceedings of the United States National Museum, vol. 68. Pp. i-xvii (title page, advertisement, table of contents, and list of illustrations); arts. 1-25 (Proceedings papers 2602-2626, paged separately). 1927.

Proc.

No.

2602. Tertiary insects from Argentina. By T. D. A. Cockerell. Art. 1, pp. 1-5, 1 fig., 1 pl. Dec. 11, 1925.

2603. Descriptions of new internal parasites. By Edward A. Chapin. Art. 2, pp. 1-4, 4 figs. Nov. 14, 1925.

2604. Systematic notes on and descriptions of North American wasps of the subfamily Brachycistiinae. By J. R. Malloch. Art. 3, pp. 1-28, 4 pls. Feb. 17, 1926.

2605. Crane flies from the Maritime Province of Siberia. By Charles P. Alexander. Art. 4, pp. 1-21, 1 pl. Dec. 11, 1925.

2606. Tertiary insects from Kudia River, Maritime Province, Siberia. By T. D. A. Cockerell. Art. 5, pp. 1-16, 5 figs., 2 pls. Dec. 11, 1925.

2607. Some halictine bees from the Maritime Province of Siberia. By T. D. A. Cockerell. Art. 6, pp. 1-12. Dec. 23, 1925.

2608. Buprestid beetles from the Maritime Province of Siberia. By W. S. Fisher. Art. 7, pp. 1-8. Nov. 28, 1925.

2609. Sawflies from the Maritime Province of Siberia. By S. A. Rohwer. Art. 8, pp. 1-12. Dec. 28, 1925.

2610. North American species of two-winged flies belonging to the tribe Miltogrammini. By Harry W. Allen. Art. 9, pp. 1-106, 2 figs., 5 pls. May 27, 1926.

2611. Field notes on gall-inhabiting cynipid wasps with descriptions of new species. By Lewis H. Weld. Art. 10, pp. 1-131, 8 pls. May 27, 1926.

2612. New fossil fresh-water mollusks from Florida. By William B. Marshall. Art. 11, pp. 1-4, 1 pl. Feb. 19, 1926.

2613. A classification of the toothlike fossils, conodonts, with descriptions of American Devonian and Mississippian species. By E. O. Ulrich and Ray S. Bassler. Art. 12, pp. 1-63, 5 figs., 11 pls. Mar. 13, 1926.

2614. Parasitic nematodes from China. By Benjamin Schwartz. Art. 13, pp. 1-10, 3 figs. Feb. 12, 1926.

2615. Termites collected on the Mulford Biological Exploration to the Amazon Basin, 1921-1922. By Thomas E. Snyder. Art. 14, pp. 1-76, 3 figs., 3 pls. Apr. 26, 1926.

2616. A new nematode from the rat, and its life history. By Eloise B. Cram. Art. 15, pp. 1-7, 2 pls. Feb. 19, 1926.

2617. The Nearctic budworms of the lepidopterous genus Heliothis. By S. E. Crumb. Art. 16, pp. 1-8, 1 pl. Feb. 12, 1926.

2618. The minerals of Obsidian Cliff, Yellowstone National Park, and their origin. By William F. Foshag. Art. 17, pp. 1-18, 5 figs., 4 pls. June 14, 1926.

2619. Revision of the American leaf hoppers of the jassid genus Typhlocyba. By W. L. McAtee. Art. 18, pp. 1-47, 6 pls. June 10, 1926.

2620. A revision of the American lice of the genus Pediculus, together with a consideration of the significance of their geographical and host distribution. By H. E. Ewing. Art. 19, pp. 1-30, 8 figs., 3 pls. June 10, 1926.

2621. A new genus and species of borborid flies from South America. By Mario Bezzi. Art. 20, pp. 1-6, 2 figs. May 13, 1926.

2622. New genera and species of acalyptrate flies in the United States National Museum. By J. R. Malloch. Art. 21, pp. 1-35, 2 pls. May 29, 1926.

2623. Descriptions of new West Indian longicorn beetles of the subfamily Lamiinae. By Warren S. Fisher. Art. 22, pp. 1-40. June 10, 1926.

2624. North American two-winged flies of the genus Cylindromyia Meigen (Ocyptera of authors). By J. M. Aldrich. Art. 23, pp. 1-27, 1 pl. May 29, 1926.

2625. A collection of Pleistocene vertebrates from southwestern Texas. By Oliver P. Hay. Art. 24, pp. 1-18, 2 figs., 8 pls. June 7, 1926. 
2626. Amphipods of the family Bateidae in the collection of the United States National Museum. By Clarence R. Shoemaker. Art. 25, pp. 1-26, 16 figs. June 7, 1926.

\section{Volume 69}

Proceedings of the United States National Museum, vol. 69. Pp. i-xii (title page, advertisement, table of contents, and list of illustrations); arts. 1-23 (Proceedings papers 2627-26́49, paged separately). 1927.

2627. A new species of fluke, Parametorchis noveboracensis, from the cat in the United States. By See-Lü Hung. Art. 1, pp. 1-2, 1 fig. June 5, 1926.

2628. The optical properties and chemical composition of glauconite. By Clarence S. Ross. Art. 2, pp. 1-15, 2 figs. May 29, 1926.

2629. Miscellaneous new chalcid-flies of the hymenopterous family Encyrtidae. By P. H. Timberlake. Art. 3, pp. 1-34, 1 fig., 2 pls. June 12, 1926.

2630. The collection of ancient Oriental seals in the United States National Museum. By I. M. Casanowicz. Art. 4, pp. 1-23, 20 pls. Sept. 23, 1926.

2631. Catalogue of human crania in the United States National Museum collections: The Algonkin and related Iroquois; Siouan, Caddoan, Salish and Sahaptin, Shoshonean, and Californian Indians. By Aleš Hrdlička. Art. 5, pp. 1-127. May 4, 1927.

2632. A new sea star of the genus Evasterias. By W. K. Fisher. Art. 6, pp. 1-5, 2 pls. Dec. 16, 1926.

2633. Descriptions of new reared parasitic Hymenoptera and some notes on synonymy. By C. F. W. Muesebeck. Art. 7, pp. 1-18. Oct. 15, 1926.

2634. Crustaceans of the orders Euphausiacea and Mysidacea from the western Atlantic. By Walter M. Tattersall. Art. 8, pp. 1-31, 2 pls. Nov. 20, 1926.

2635. Review of the American xylotine syrphid-flies. By Raymond C. Shannon. Art. 9, pp. 1-52. Dec. 1, 1926.

2636. The North American two-winged fies of the family Simuliidae. By Harrison G. Dyar and Raymond C. Shannon. Art. 10, pp. 1-54, 7 pls. Feb. 25, 1927.

2637. The chrysotoxine syrphid-flies. By Raymond C. Shannon. Art. 11, pp. 1-20, 3 figs. Nov. 26, 1926.

2638. New land and fresh-water mollusks from Central and South America. By William B. Marshall. Art. 12, pp. 1-12, 3 pls. Nov. 6, 1926.

2639. American two-winged flies of the genus Microphthalma Macquart, with notes on related forms. By J. M. Aldrich. Art. 13, pp. 1-8. Oct. 15, 1926.

2640. Classification of the cheilostomatous Bryozoa. By Ferdinand Canu and Ray S. Bassler. Art. 14, pp. 1-42, 1 pl. Apr. 9, 1927.

2641. Polychaetous annelids from Fiji, Samoa, China, and Japan. By A. L. Treadwell. Art. 15, pp. 1-20, 2 pls. Oct. 14, 1926.

2642. A revision of the parasitic wasps of the subfamily Braconinae occurring in America north of Mexico. By C. F. W. Muesebeck. Art. 16, pp. 1-73, 1 fig., 2 pls. Mar. 17, 1927.

2643. Identity of Hallowell's snake genera Megalops and Aepidea. By Leonhard Stejneger. Art. 17, pp. 1-3. Oct. 16, 1926.

2644. Notes on the age of the continental Triassic beds in North America, with remarks on some fossil vertebrates. By F. R. von Huene. Art. 18, pp. 1-10, 8 figs. Oct. 15, 1926.

2645. Kentriodon pernix, a Miocene porpoise from Maryland. By Remington Kellogg. Art. 19, pp. 1-55, 20 figs., 14 pls. Feb. 5, 1927.

2646. Additional new mollusks from Santa Elena Bay, Ecuador. By Paul Bartsch. Art. 20, pp. 1-20, 3 pls. Dec. 16, 1926.

2647. Distributional notes on some Neotropical bugs of the family Nabidae, with description of a new species. By Halbert M. Harris. Art. 21, pp. 1-4. Nov. 10, 1926.

2648. Descriptions of new and little known Diptera or two-winged flies. By J. M. Aldrich. Art. 22, pp. 1-26. Dec. 27, 1926. 
2649. Cymbidium, a new genus of Silurian pentameroid brachiopods from Alaska. By Edwin Kirk. Art. 23, pp. 1-5, 1 pl. Nov. 23, 1926.

\section{Volume 70}

Proceedings of the United States National Museum, vol. 70. Pp. i-xiii (title page, advertisement, table of contents, and list of illustrations); arts. 1-23 (Proceedings papers 2650-2672, paged separately). 1927.

2650. American wasps of the genus Sceliphron Klug. By Bennett A. Porter. Art. 1, pp. 1-22, 4 pls. Dec. 1, 1926.

2651. Descriptions of larvae and pupae of two-winged flies belonging to the family Leptidae. By Charles T. Greene. Art. 2, pp. 1-20, 3 pls. Nov. $12,1926$.

2652. A fossil palm fruit from the middle Eocene of northwestern Peru. By Edward W. Berry. Art. 3, pp. 1-4, 1 pl. Oct. 5, 1926.

2653. New urocoptid land shells from Mexico. By Paul Bartsch. Art. 4, pp. 1-13, 1 pl. Nov. 29, 1926.

2654. A collection of birds from the Provinces of Yunnan and Szechwan, China, made for the National Geographic Society by Dr. Joseph F. Rock. By J. H. Riley. Art. 5, pp. 1-70. Oct. 23, 1926.

2655. Nematode eggs from the gill region of a shark, Carcharhinus milberti. By G. A. MacCallum. Art. 6, pp. 1-2, 1 fig. Oct. 15, 1926.

2656. Notes on cestode parasites of birds. By Edwin Linton. Art. 7, pp. 1-73, 15 pls. Feb. 8, 1927.

2657. Some braconid and chalcid flies from Formosa parasitic on aphids. By A. B. Gahan. Art. 8, pp. 1-7. Jan. 7, 1927.

2658. A review of the South American two-winged flies of the family Syrphidae. By Raymond C. Shannon. Art. 9, pp. 1-33, 1 pl. Apr. 29, 1927.

2659. On a collection of Copepoda from Florida, with a description of Diaptomus floridanus, new species. By C. Dwight Marsh. Art. 10, pp. 1-4, 6 figs. Dec. 16, 1926.

2660. New west American marine mollusks. By Paul Bartsch. Art. 11, pp. 1-36, 6 pls. Apr. 8, 1927.

2661. Tanaodon, a new molluscan genus from the Middle Devonian of China. By Edwin Kirk. Art. 12, pp. 1-4, 1 pl. Feb. 25, 1927.

2662. Contribution to the anatomy of the Chinese finless porpoise, Neomeris phocaenoides. By A. Brazier Howell. Art. 13, pp. 1-43, 14 figs., 1 pl. Mar. 11, 1927.

2663. A taxonomic and ecological review of the North American chalcid-flies of the genus Callimome. By L. L. Huber. Art. 14, pp. 1-114, 4 pls. May $25,1927$.

2664. Generic names applied to birds during the years 1916 to 1922 , inclusive, with additions to Waterhouse's "Index Generum Avium." By Charles W. Richmond. Art. 15, pp. 1-44. Apr. 6, 1927.

2665. Foraminifera of the genus Ehrenbergina and its species. By Joseph A. Cushman. Art. 16, pp. 1-8, 2 pls. Feb. 25, 1927.

2666. Description of a new dragon fly from Lower Siam belonging to the genus Urothemis. By F. F. Laidlaw. Art. 17, 1-3, 1 pl. Feb. 25, 1927.

2667. Small shells from dredgings off the southeast coast of the United States by the United States Fisheries steamer Albatross in 1885 and 1886. By William H. Dall. Art. 18, pp. 1-134. Apr. 20, 1927.

2668. Diagnoses of undescribed new species of mollusks in the collection of the United States National Museum. By William Healey Dall. Art. 19, pp. 1-11. Feb. 9, 1927.

2669. The occurrence and properties of chlorophoenicite, a new arsenate from Franklin, New Jersey. By William F. Foshag, Harry Berman, and Robert B. Gage. Art. 20, pp. 1-6, 2 figs. Mar. 17, 1927. 
2670. A stony meteorite from Forksville, Mecklenburg County, Virginia. By George P. Merrill. Art. 21, pp. 1-4, 3 pls. Feb. 23, 1927.

2671. Richmond faunal zones in Warren and Clinton Counties, Ohio. By George M. Austin. Art. 22, pp. 1-18. May 4, 1927.

2672. A revision of the beetles of the genus Oedionychis occurring in America north of Mexico. By Doris Holmes Blake. Art. 23, pp. 1-44, 1 fig., 2 pls. Apr. 25, 1927.

\section{Volume 71}

Proceedings of the United States National Museum, vol. 71. Pp. i-xiii (title page, advertisement, table of contents, and list of illustrations); arts. 1-24 (Proceedings papers 2673-2696, paged separately). 1928.

2673. Description of a new species of fresh-water copepod of the genus Moraria from Canada. By Arthur Willey. Art. 1, pp. 1-12, 30 figs. Apr. 6, 1927.

2674. The beetles of the family Cleridae collected on the Mulford Biological Exploration of the Amazon Basin, 1921-1922. By Edward A. Chapin. Art. 2, pp. 1-10, 1 fig. Mar. 17, 1927.

2675. On a collection of orthopteroid insects from Java made by Owen Bryant and William Palmer in 1909. By A. N. Caudell. Art. 3, pp. 1-42, 4 figs. Apr. 23, 1927.

2676. Miscellaneous descriptions of new parasitic Hymenoptera with some synonymical notes. By A. B. Gahan. Art. 4, pp. 1-39, 3 figs., 1 pl. Apr. 18, 1927.

2677. A new parasitic nematode from an unknown species of bat. By Benjamin Schwartz. Art. 5, pp. 1-4, 4 figs. Apr. 6, 1927.

2678. A new genus and two new species of South American fresh-water mussers. By William B. Marshall. Art. 6, pp. 1-4, 2 pls. Apr. 9, 1927.

2679. Orthopteroid insects from the Maritime Provine of Siberia. By A. N. Cauden. Art. 7, pp. 1-7, 2 figs. May 21, 1927.

2680. Larger Foraminifera of the genus Lepidocyclina related to Lepidocycunta mantelli. By T. Wayland Vaughan. Art. 8, pp. 1-5, 4 pls. May 23, 1927.

2681. The digger wasps of North America of the genus Podalonia (Psammophila). By H. T. Fernald. Art. 9, pp. 1-42, 4 figs., 2 pls. May 2, 1927.

2682. Notes on fishes obtained in Sumatra, Java, and Tahiti. By Henry W. Fowici and Barton A. Bean. Art. 10, pp. 1-15, 2 figs. May 4, 1927.

2683. Notes on the melitaeid butterfly Euphydryas phaëton (Drury), with descriptions of a new subspecies and a new variety. By Austin H. Clark. Art. 11, pp. 1-22, 5 pls. Apr. 22, 1927.

2684. Megachilid bees from Bolivia collected by the Mulford Biological Expedition, 1921-22. By T. D. A. Cockerell. Art. 12, pp. 1-22. June 3, 1927.

2685. A revision of the cottoid fishes of the genus Artediellus. By Peter Schmidt. Art. 13, pp. 1-10. July 12, 1927.

2686. A new type of caddis case from the lower Eocene of Tennessee. By Edward W. Berry. Art. 14, pp. 1-4, 1 pl. July 1, 1927.

2687. On fossil turtles from the Pleistocene of Florida. By Charles W. Gilmore. Art. 15, pp. 1-10, 4 figs., 5 pls. Aug. 30, 1927.

2688. Some peculiar fossil forms from Maryland. By Wendell C. Mansfield. Art. 16, pp. 1-9, 5 pls. July 13, 1927.

2689. The Maskell species of scale insects of the subfamily Asterolecaniinae. By Harold Morrison and Emily Morrison. Art. 17, pp. 1-67, 29 pls. Aug. 29, 1927.

2690. The geology, petrography, and mineralogy of the vicinity of Italian Mountain, Gunnison County, Colorado. By Whitman Cross and Earl V. Shannon. Art. 18, pp. 1-42, 17 figs., 2 pls. Sept. 26, 1927.

2691. The American moths of the genus Diatraea and allies. By Harrison G. Dyar and Carl Heinrich. Art. 19, pp. 1-48, 20 pls. Aug. 23, 1927.

2692. Pycnodesma, a new molluscan genus from the Silurian of Alaska. By Edwin Kirk. Art. 20, pp. 1-9, 2 pls. Aug. 4, 1927. 
Proc.

No.

2693. A recently found iron meteorite from Oakley, Idaho. By George P. Merrill. Art. 21, pp. 1-3, 2 pls. Sept. 12, 1927.

2694. A new nematode, Nematodirus antilocaprae, from the prong-horn antelope, with a key to the species of Nematodirus. By Emmett W. Price. Art. 22, pp. 1-4, 1 pl. July 7, 1927.

2695. A fossil insect from the lower Permian of the Grand Canyon. By Frank M. Carpenter. Art. 23, pp. 1-4, 1 pl. July 1, 1927.

2696. Catalogue of human crania in the United States National Museum collections: Australians, Tasmanians, South African Bushmen, Hottentots, and Negroes. By Aleš Hrdlička. Art. 24, pp. 1-140. Mar. 5, 1928.

\section{Volume 72}

Proceedings of the United States National Museum, vol. 72. Pp. i-xv (title page, advertisement, table of contents, and list of illustrations); arts. 1-25 (Proceedings papers 2697-2721, paged separately). 1928.

2697. Description of Ancylostoma pluridentatum, a hookworm of carnivores, and a review of the genus Ancylostoma. By Benjamin Schwartz. Art. 1, pp. 1-9, 6 figs. Oct. 27, 1927.

2698. Undescribed crane flies from the Holarctic region in the United States National Museum. By Charles P. Alexander. Art. 2, pp. 1-17, 1 pl. Nov. 2, 1927.

2699. New species of mollusks of the genus Corbicula from Uruguay and Brazil. By William B. Marshall. Art. 3, pp. 1-7, 1 pl. Sept. 30, 1927.

2700. Heretofore undescribed meteoric irons from [1] Bolivia, South America, [2] western Arkansas, and [3] Seneca Township, Michigan. By George P. Merrill. Art. 4, pp. 1-4, 2 pls. Sept. 29, 1927.

2701. A bibliography of the conodonts with descriptions of early Mississippian species. By Grace B. Holmes. Art. 5, pp. 1-38, 11 pls. Feb. 7, 1928.

2702. Insects of the subclass Apterygota from Central America and the West Indies. By J. W. Folsom. Art. 6, pp. 1-16, 8 pls. Dec. 10, 1927.

2703. Redescription of types of American muscoid flies in the collection of the Vienna Natural History Museum, with incidental notes. By J. M. Aldrich. Art. 7, pp. 1-35, 3 figs. Dec. 31, 1927.

2704. New parasitic Hymenoptera of the subfamily Anteoninae from the Americas. By F. A. Fenton. Art. 8, pp. 1-16, 2 pls. Oct. 29, 1927.

2705. New species of two-winged flies of the family Cyrtidae, with a new genus from the Philippines. By J. M. Aldrich. Art. 9, pp. 1-4, 2 figs. Oct. 13, 1927.

2706. Additions to the Upper Cretaceous invertebrate faunas of the Carolinas. By Lloyd W. Stephenson. Art. 10, pp. 1-25, 9 pls. Oct. 29, 1927.

2707. Rossite and metarossite; two new vanadates from Colorado. By William F. Foshag and Frank L. Hess. Art. 11, pp. 1-12, 2 figs. Dec. 31, 1927.

2708. Crystalline carnotite from Utah. By Frank L. Hess and William F. Foshag. Art. 12, pp. 1-6. Nov. 29, 1927.

2709. Miscellaneous notes and descriptions of ichneumon-flies. By R. A. Cushman. Art. 13, pp. 1-22, 2 figs. Oct. 29, 1927.

2710. Fossil and Recent Bryozoa of the Gulf of Mexico region. By Ferdinand Canu and Ray S. Bassler. Art. 14, pp. 1-199, 35 figs., 34 pls. Mar. 9, 1928.

2711. The Australian land shell, Thersites bipartita, and its allies. By William B. Marshall. Art. 15, pp. 1-16, 3 pls. Oct. 25, 1927.

2712. The rodents of the genus Plagiodontia. By Gerrit S. Miller, Jr. Art. 16, 1-8, 1 pl. Sept. 30, 1927.

2713. On some terrestrial isopods in the United States National Museum. By Hans Lohmander. Art. 17, pp. 1-18, 6 figs. Oct. 13, 1927.

2714. Millipeds of the order Colobognatha, with descriptions of six new genera and type species, from Arizona and California. By O. F. Cook and H. F. Loomis. Art. 18, pp. 1-26, 6 figs., 2 pls. Mar. 16, 1928.

2715. The green pit viper, Trimeresurus gramineus, in China. By Leonhard Stejneger. Art. 19, pp. 1-10, 2 figs. Dec. 15, 1927. 
2716. Foraminifera of the genus Siphonina and related genera. By Joseph A. Cushman. Art. 20, pp. 1-15, 4 pls. Dec. 14, 1927.

2717. The oxidation of meteoric irons with comparative descriptions of two new examples of magnetic iron oxides from terrestrial sources. By Earl V. Shannon. Art. 21, pp. 1-15. Oct. 13, 1927.

2718. On newly discovered meteoric irons from the Wallapai (Hualapai) Indian Reservation, Arizona. By George P. Merrill. Art. 22, pp. 1-4, 3 pls. Dec. 27, 1927.

2719. The flora of the Esmeralda formation in western Nevada. By Edward W. Berry. Art. 23, pp. 1-15, 2 pls. Dec. 19, 1927.

2720. Description of a new species of gecko from Tanganyika Territory, Africa. By Arthur Loveridge. Art. 24, pp. 1-2, 1 pl. Mar. 14, 1928.

2721. Synopsis of pentatomid bugs of the subfamilies Megaridinae and Canopinae. By W. L. McAtee and J. R. Malloch. Art. 25, pp. 1-25, 2 pls. Feb. 14, 1928.

\section{Volume 73}

Proceedings of the United States National Museum, vol. 73. Pp. i-xv (title page, advertisement, table of contents, and list of illustrations); arts. 1-24 (Proceedings papers 2722-2745, paged separately). 1929.

2722. Notes on trematode parasites of birds. By Edwin Linton. Art. 1, pp. 1-36, 11 pls. Mar. 17, 1928.

2723. Two new nematodes of the family Strongylidae, parasitic in the intestines of mammals. By Benjamin Schwartz. Art. 2, pp. 1-5, 2 pls. Mar. 21, 1928.

2724. Further consideration of the shell of Chelys and of the constitution of the armor of turtles in general. By Oliver P. Hay. Art. 3, pp. 1-12, 2 pls. Mar. 21, 1928.

2725. New helminth parasites from Central American mammals. By Emmett W. Price. Art. 4, pp. 1-7, 2 pls. Mar. 30, 1928.

2726. Two common species of parasitic Crustacea (Sacculinidae) of the West Indies. By H. Boschma. Art. 5, pp. 1-10, 6 figs. May 19, 1928.

2727. Two new crabs from the Eocene of Texas. By Mary J. Rathbun. Art. 6, pp. 1-6, 3 pls. Apr. 3, 1928.

2728. A new fossil reptile from the Triassic of New Jersey. By Charles W. Gilmore. Art. 7, pp. 1-8, 3 figs., 3 pls. Mar. 30, 1928.

2729. A revision of the American parasitic flies belonging to the genus Belvosia. By J. M. Aldrich. Art. 8, pp. 1-45. May 17, 1928.

2730. The scorpions of the western part of the United States, with notes on those occurring in northern Mexico. By H. E. Ewing. Art. 9, pp. 1-24, 1 fig., 2 ple. May 24, 1928.

2731. New Vicksburg (Oligocene) mollusks from Mexico. By C. Wythe Cooke. Art. 10, pp. 1-11, 2 pls. Apr. 24, 1928.

2732. A prehistoric pit house village site on the Columbia River at Wahluke, Grant County, Wash. By Herbert W. Krieger. Art. 11, pp. 1-29, 7 pls. May 17, 1928.

2733. A revision of the lizards of the genus Ctenosaura. By John Wendell Bailey. Art. 12, pp. 1-58, 30 pls. Sept. 26, 1928.

2734. Fossil nutlets of the genus Lithospermum. By Edward W. Berry. Art. 13, pp. 1-3, 1 pl. May 1, 1928.

2735. Fire-making apparatus in the United States National Museum. By Walter Hough. Art. 14, pp. 1-72, 56 figs., 11 pls. June 22, 1928.

2736. Contribution to the comparative anatomy of the eared and earless seals (genera Zalophus and Phoca). By A. Brazier Howell. Art. 15, pp. 1-142, 30 figs., 1 pl. Jan. 26, 1929.

2737. Zeolites from Ritter Hot Spring, Grant County, Oregon. By D. F. Hewett, Earl V. Shannon, and Forest A. Gonyer. Art. 16, pp. 1-18, 1 fig., 2 plo. June 12, 1928. 
Proc.

No.

2738. Field notes on vertebrates collected by the Smithsonian-Chrysler East African Expedition of 1926. By Arthur Loveridge. Art. 17, pp. 1-69, 4 pls. June $20,1928$.

2739. Two new species of commensal copepods from the Woods Hole region. By H. R. Seiwell. Art. 18, pp. 1-5, 2 pls. June 4, 1928.

2740. New moths of the family Ceruridae (Notodontidae) in the United States National Museum. By William Schaus. Art. 19, pp. 1-90. June 27, 1928.

2741. The Florida tree snails of the genus Liguus. By Charles Torrey Simpson. Art. 20, pp. 1-44, 1 fig., 4 pls. May 11, 1929.

2742. Concerning the origin of the metal in meteorites. By George P. Merrill. Art. 21 , pp. $1-7,3$ pls. June 20, 1928.

2743. Tertiary fossil plants from the Argentine Republic. By Edward W. Berry. Art. 22, pp. 1-27, 1 fig., 5 pls. Oct. 17, 1828.

2744. Notes on American two-winged flies of the family Sapromyzidae. By J. R. Malloch. Art. 23, pp. 1-18, 5 figs. June 23, 1928.

2745. A new pterosaurian reptile from the marine Cretaceous of Oregon. By Charles W. Gilmore. Art. 24, pp. 1-5, 2 figs. June 25, 1928.

\section{Volume 74}

Proceedings of the United States National Museum, vol. 74. Pp. i-xii (title page, advertisement, table of contents, and list of illustrations); arts. 1-26 (Proceedings papers 2746-2771, paged separately). 1929.

2746. New Diptera or two-winged flies from South America. By J. M. Aldrich. Art. 1, pp. 1-25, 2 figs. Dec. 1, 1928.

2747. Three new species of two-winged flies of the family Bombyliidae from India. By J. M. Aldrich. Art. 2, pp. 1-3. Oct. 26, 1928.

2748. New fossil pearly fresh-water mussels from deposits on the upper Amazon of Peru. By William B. Marshall. Art. 3, pp. 1-7, 1 pl. Oct. 31, 1928.

2749. Two new nematode worms from rodents. By Emmett W. Price. Art. 4, pp. 1-5, 2 pls. Nov. 10, 1928.

2750. Fossil footprints from the Fort Union (Paleocene) of Montana. By Charles W. Gilmore. Art. 5, pp. 1-4, 1 fig., 3 pls. Oct. 6, 1928.

2751. Notes on some Oriental sapromyzid flies (Diptera), with particular reference to the Philippine species. By J. R. Malloch. Art. 6, pp. 1-97, 6 pls. Apr. 24, 1929.

2752. A revision of the wood-warbler genus Basileuterus and its allies. By W. E. Clyde Todd. Art. 7, pp. 1-95, 1 fig. Apr. 26, 1929.

2753. Five new parasitic flies reared from beetles in China and India. By J. M. Aldrich. Art. 8, pp. 1-7. Oct. 19, 1928.

2754. Moniezia, a genus of cestode worms and the proposed reduction of its species to three. By E. Leonard Taylor. Art. 9, pp. 1-9, 5 pls. Nov. 24, 1928.

2755. Tropical American Diptera or two-winged flies of the family Dolichopodidae from Central and South America. By M. C. Van Duzee. Art. 10, pp. 1-64, 2 pls. Feb. 9, 1929.

2756. Synopsis and description of North American tadpoles. By A. H. Wright. Art. 11, pp. 1-70, 9 pls. June 4, 1929.

2757. A new polychaetous annelid of the genus Phyllodoce from the west coast of Costa Rica. By Aaron L. Treadwell. Art. 12, pp. 1-3, 3 figs. Nov. 10, 1928.

2758. Tschermigite, ammoniojarosite, epsomite, celestite, and paligorskite from southern Utah. By Earl V. Shannon. Art. 13, pp. 1-12, 1 fig. Jan. 31, 1929.

2759. New fossil mollusks from the Miocene of Virginia and North Carolina, with a brief outline of the divisions of the Chesapeake group. By Wendell C. Mansfield. Art. 14, pp. 1-11, 5 pls. Jan. 14, 1929.

2760. The fossil crinoid genus Vasocrinus Lyon. By Edwin Kirk. Art. 15, pp. 1-16, 2 pls. Jan. 29, 1929.

2761. A revision of the North American ichneumon-flies of the genus Mesostenus and related genera. By R. A. Cushman. Art. 16, pp. 1-58, 8 figs. Feb. 20, 1929. 
2762. New fresh-water and marine bivalve shells from Brazil and Uruguay. By William B. Marshall. Art. 17, pp. 1-7, 4 pls. Oct. 26, 1928.

2763. Bathmopterus, a new fossil gasteropod genus from the Silurian of Alaska. By Edwin Kirk. Art. 18, pp. 1-4, 1 pl. Dec. 13, 1928.

2764. Further studies of types of American muscoid flies in the collection of the Vienna Natural History Museum. By J. M. Aldrich. Art. 19, pp. 1-34, 2 figs. Feb. 25, 1929.

2765. A new species of trichostrongylid worm of the genus Cooperia from the Carabao in the Philippine Islands, with a review of the genus. By Benjamin Schwartz. Art. 20, pp. 1-5, 1 fig., 1 pl. Nov. 27, 1928.

2766. Miargyrite silver ore from the Randsburg district, California. By Earl V. Shannon. Art. 21, pp. 1-10, 3 figs. Jan. 31, 1929.

2767. Two new frogs from Jamaica. By Emmett Reid Dunn. Art. 22, pp. 1-2. Dec. $18,1928$.

2768. Mineralogy and geology of Cerro Mercado, Durango, Mexico. By William F. Foshag. Art. 23, pp. 1-27, 3 figs., 4 pls. Feb. $20,1929$.

2769. Notes and new species of American moths of the genus Scoparia Haworth. By Harrison G. Dyar. Art. 24, pp. 1-9. Jan. 31, 1929.

2770. A new salamander from southern California. By Emmett Reid Dunn. Art. 25, pp. 1-3. Jan. 31, 1929.

2771. The gums of the porpoise Phocoenoides dalli (True). By Gerrit S. Miller, Jr. Art. 26, pp. 1-4, 4 pls. Jan. 26, 1929.

\section{Volume 75}

Proceedings of the United States National Museum, vol. 75. Pp. i-xiii (title page, advertisement, table of contents, and list of illustrations); arts. 1-26 (Proceedings papers 2772-2797, paged separately). 1929.

2772. Mammals from China in the collections of the United States National Museum. By A. Brazier Howell. Art. 1, pp. 1-82, 10 pls. June 7, 1929.

2773. Beetle larvae of the subfamily Galerucinae. By Adam G. Böving. Art. 2, pp. 1-48, 3 figs., 5 pls. Apr. 13, 1929.

2774. On some new and interesting species of water beetles of the family Gyrinidae in the United States National Museum. By Georg Ochs. Art. 3, pp. 1-6. Jan. 31, 1929.

2775. A review of the birds of the islands of Siberut and Sipora, Mentawi group (Spolia Mentawiensia). By J. H. Riley. Art. 4, pp. 1-45, 1 pl. Apr. 6, 1929.

2776. A generic revision of the fossorial wasps of the tribes Stizini and Bembicini, with notes and descriptions of new species. By John Bernard Parker. Art. 5, pp. 1-203, 15 pls. June 7, 1929.

2777. Some new genera and species of nematode worms, Filarioidea, from animals dying in the Calcutta Zoological Garden. By Asa C. Chandler. Art. 6, pp. 1-10, 3 pls. Apr. 6, 1929.

2778. A revision of the American two-winged flies of the psychodid subfamily Bruchomyinae. By Charles P. Alexander. Art. 7, pp. 1-9, 2 figs. Mar. 21, 1929.

2779. Notes on some North American moths of the subfamily Eucosminae. By Carl Heinrich. Art. 8, pp. 1-23, 5 pls. Apr. 5, 1929.

2780. Recent Foraminifera from off Juan Fernandez Islands. By Joseph A. Cushman and R. T. D. Wickenden. Art. 9, pp. 1-16, 6 pls. Apr. 16, 1929.

2781. A summary of the earthworm fauna of Burma with descriptions of fourteen new species. By G. E. Gates. Art. 10, pp. 1-41, 24 figs. June 28, 1929.

2782. A contribution to our knowledge of the anatomy of the fresh-water mussels of the District of Columbia. By Lucy Reardon. Art. 11, pp. 1-12, 5 pls. Apr. 22, 1929.

2783. A new liver fluke from a monkey and new parasitic roundworms from various African animals. By J. H. Sandground. Art. 12, pp. 1-11, 2 pls. June $10,1929$. 
2784. Bugs of the family Miridae of the District of Columbia and vicinity. By H. H. Knight and W. L. McAtee. Art. 13, pp. 1-27. June 8, 1929.

2785. Distribution and key of the North American copepods of the genus Diaptomus, with the description of a new species. By C. Dwight Marsh. Art. 14, pp. 1-27, 16 figs. June 28, 1929.

2786. A new crab from the Eocene of Florida. By Mary J. Rathbun. Art. 15, pp. 1-4, 3 pls. May 6, 1929.

2787. A newly found meteoric stone reported by W. B. Lang from Peck's Spring, Midland County, Tex. By George P. Merrill. Art. 16, pp. 1-2, 1 pl. May 6, 1929.

2788. A new nematode, Sincosta aberrans, new genus and new species from a rodent. By Glenwood C. Roe. Art. 17, pp. 1-3, 1 pl. May 11, 1929.

2789. A 8ynopsis of the trematode family Schistosomidae, with descriptions of new genera and species. By Emmett W. Price. Art. 18, pp. 1-39, 15 pls. June $28,1929$.

2790. A revision of the beetles of the tenebrionid tribe Usechini, with descriptions of a new genus and new species. By Frank E. Blaisdell, Sr. Art. 19, pp. 1-14, 2 figs., 1 pl. Sept. 25, 1929.

2791. Tapeworms of the genera Rhabdometra and Paruterina found in the quail and yellow-billed cuckoo. By Myrna F. Jones. Art. 20, pp. 1-8, 1 pl. June 13, 1929.

2792. A new species of the trematode worms belonging to the genus Hasstilesia from rabbits in Texas. By Asa C. Chandler. Art. 21, pp. 1-5, 4 figs. June 7, 1929.

2793. Pagecrinus, a new crinoid genus from the American Devonian. By Edwin Kirk. Art. 23, pp. 1-4, 1 pl. June 7, 1929.

2794. A new species of mosquito from Montana, with annotated list of the species known from the State. By Harrison G. Dyar. Art. 23, pp. 1-8. June 7, 1929.

2795. Tertiary fossil plants from Colombia, South America. By Edward W. Berry. Art. 24, pp. 1-12, 5 pls. June 14, 1929.

2796. Recent Foraminifera from the west coast of South America. By Joseph A. Cushman and Betty Kellett. Art. 25, pp. 1-16, 5 pls. June 19, 1929.

2797. Two new species of polychaetous annelids from the Argentine coast. By A. L. Treadwell. Art. 26, pp. 1-5, 6 figs. June 7, 1929.

\section{Volume 76}

Proceedings of the United States National Museum, vol. 76. Pp. i-xiv (title page, advertisement, table of contents, and list of illustrations); arts. 1-26 (Proceedings papers 2798-2823, paged separately). 1930.

-2798. New fossil land and fresh-water mollusks from the Reynosa formation of Texas. By William B. Marshall. Art. 1, pp. 1-6, 1 pl. June 10, 1929.

2799. A revision of the two-winged flies of the genus Procecidochares in North America, with an allied new genus. By J. M. Aldrich. Art. 2, pp. 1-13. June 7, 1929.

2800. Descriptions of new species of Foraminifera of the genus Discocyclina from the Eocene of Mexico. By Thomas Wayland Vaughan. Art. 3, pp. 1-18, 7 pls. June 10, 1929.

2801. North American species of the weevils of the otiorhynchid genus Mesagroicus. By L. L. Buchanan. Art. 4, pp. 1-14, 1 fig., 2 pls. June 27, 1929.

2802. Three new land shells of the genus Oreohelix from Arizona. By William B. Marshall. Art. 5, pp. 1-3, 1 pl. Oct. 10, 1929.

2803. New species of buprestid beetles from Costa Rica. By W. S. Fisher. Art. 6, pp. 1-20. Oct. 22, 1929.

2804. Briarosaccus callosus, a new genus and new species of a rhizocephalan parasite of Lithodes agassizii Smith. By H. Boschma. Art. 7, pp. 1-8, 8 figs. Mar. 13, 1930.

2805. A new variety of the hexactinellid sponge, Rhabdocalyptus darosoni (Lambe) and the species of Rhabdocalyptus. By H. V. Wilson and J. T. Penney. Art. 8, pp. $1-9,2$ pls. Feb. 5, 1930. 
2806. New Lower and Middle Cambrian Crustacea. By Charles E. Resser. Art. 9, pp. 1-18, 7 pls. Dec. 27, 1929.

2807. Notes on the species of myctophine fishes represented by type specimens in the United States National Museum. By Albert Eide Parr. Art. 10, pp. 1-47, 21 figs. Dec. 27, 1929.

2808. Revision of the two-winged flies of the genus Coelopa Meigen in North America. By J. M. Aldrich. Art. 11, pp. 1-6. Nov. 16, 1929.

2809. Two new species of trematodes of the genus Parametorchis from fur-bearing animals. By Emmett W. Price. Art. 12, pp. 1-5, 2 figs. Nov. 19, 1929.

2810. The bryozoan fauna of the Galapagos Islands. By Ferdinand Canu and R. S. Bassler. Art. 13, pp. 1-78, 13 figs., 14 pls. Jan. 20, 1930.

2811. The Middle Devonian Traverse group of rocks in Michigan, a summary of existing knowledge. By Erwin R. Pohl. Art. 4, pp. 1-34, 2 pls. Jan. 10, 1930.

2812. New genera and species of muscoid flies. By J. M. Aldrich. Art. 15, pp. 1-13. Nov. 16, 1929.

2813. Oölites or cave pearls in the Carlsbad Caverns. By Frank L. Hess. Art. 16, pp. $1-5,8$ pls. Oct. $28,1929$.

2814. Contribution to the taxonomy of Asiatic wasps of the genus Tiphia (Scoliidae). By H. W. Allen and H. A. Jaynes. Art. 17, pp. 1-105, 1 fig., 4 pls. Mar. 5, 1930.

2815. Two new mollusks of the genera Ostrea and Exogyra from the Austin chalk, Texas. By Lloyd W. Stephenson. Art. 18, pp. 1-6, 3 pls. Dec. 23, 1929.

2816. The Foraminifera of the Ripley formation on Coon Creek, Tennessee. By Willard Berry and Louis Kelley. Art. 19, pp. 1-20, 3 pls. Dec. 19, 1929.

2817. Notes on the muscoid flies of the genera Opelousia and Opsodexia with the description of three new species. By H. J. Reinhard. Art. 20, pp. 1-9. Nov. $27,1929$.

2818. Ordovician trilobites of the family Telephidae and concerned stratigraphic correlations. By E. O. Ulrich. Art. 21, pp. 1-101, 8 pls. Feb. 4, 1930.

2819. Mitrospira, a new Ordovician gasteropod genus. By Edwin Kirk. Art. 22, pp. 1-6, 3 pls. Jan. 8, 1930.

2820. A new fossil coral from the Cretaceous of Texas. By J. Edward Hoffmeister. Art. 23, pp. 1-3, 2 pls. Dec. 21, 1929.

2821. A systematic classification for the birds of the world. By Alexander Wetmore. Art. 24, pp. 1-8. Jan. 8, 1930.

2822. New species of ichneumon-flies and taxonomic notes. By R. A. Cushman. Art. 25, pp. 1-18. Jan. 6, 1930.

2823. A nearly complete carapace of a fossil turtle, Amyda virginiana (Clark). By W. Gardner Lynn. Art. 26, pp. 1-4, 2 pls. Dec. 23, 1929.

\section{Volume 77}

Proceedings of the United States National Museum, vol. 77. Pp. i-xvi (title page, advertisement, table of contents, and list of illustrations); arts. 1-20 (Proceedings papers 2824-2843, paged separately). 1931.

2824. Two new species of trematode worms of the genus Eucotyle from North American birds. By Emmett W. Price. Art. 1, pp. 1-4, 2 figs. Jan. 18, 1930.

2825. New land and fresh-water mollusks from South America. By William B. Marshall. Art. 2, pp. 1-7, 2 pls. Jan. 25, 1930.

2826. A revision of the North American species of ichneumon-flies of the genus Odontomerus. By R. A. Cushman. Art. 3, pp. 1-15, 4 figs. Feb. 4, 1930.

2827. The lysianassid amphipod crustaceans of Newfoundland, Nova Scotia, and New Brunswick in the United States National Museum. By Clarence R. Shoemaker. Art. 4, pp. 1-19, 10 figs. Mar. 3, 1930.

2828. The excavation and repair of Betatakin. By Neil Merton Judd. Art. 5, pp. 1-77, 28 figs., 46 pls. Sept. 2, 1930.

2829. A monograph of the foraminiferal family Polymorphinidae, Recent and fossil. By Joseph A. Cushman and Yoshiaki Ozawa. Art. 6, pp. 1-195, 2 figs., 40 pls. Aug. 29, 1930. 
2830. The caudal molt of certain coraciiform, coliiform, and piciform birds. By Herbert Friedmann. Art. 7, pp. 1-6. Mar. 13, 1930.

2831. Synonymical and descriptive notes on parasitic Hymenoptera. By A. B. Gahan. Art. 8, pp. 1-12. Apr. 9, 1930.

2832. Three new genera and five new species of parasitic Crustacea. By H. F. Nierstrasz and G. A. Brender à Brandis. Art. 9, pp. 1-9, 20 figs. Apr. 8, 1930.

2833. A nearly complete shell of the extinct turtle, Trachemys sculpta. By Charles W. Gilmore. Art. 10, pp. 1-8, 2 figs., 3 pls. Apr. 8, 1930.

2834. The herpetological collections made by Dr. Hugh M. Smith in Siam from 1923 to 1929. By Doris M. Cochran. Art. 11, pp. 1-39, 6 figs. Apr. 30, 1930.

2835. Birds from the small islands off the northeast coast of Dutch Borneo. By J. H. Riley. Art. 12, pp. 1-23, 1 pl. Oct. 21, 1930.

2836. Some peculiar spiral fossil forms from California and Mexico. By Wendell C. Mansfield. Art. 13, pp. 1-3, 2 pls. Oct. 22, 1930.

2937. New forms of sphecoid wasps of the genus Didineis Wesmael. By J. R. Malloch and S. A. Rohwer. Art. 14, pp. 1-7, 8 figs. Oct. 22, 1930.

2838. Birds collected in Inner Mongolia, Kansu, and Chihli by the National Geographic Society's Central-China Expedition under the direction of F. R. Wulsin. By J. H. Riley. Art. 15, pp. 1-39. Oct. 29, 1930.

2839. On dinosaurian reptiles from the Two Medicine formaton of Montana. By Charles W. Gilmore. Art. 16, pp. 1-39, 18 figs., 10 pls. Nov. 20, 1930.

2840. Studies of the North American weevils belonging to the superfamily Platystomoidea. By W. Dwight Pierce. Art. 17, pp. 1-34, 5 pls. Dec. 10, 1930.

2841. New species of North American weevils of the genus Lixus. By F. H. Chittenden. Art. 18, pp. 1-25, 1 pl. Nov. 15, 1930.

2842. Notes on the rhinotragine beetles of the family Cerambycidae, with descriptions of new species. By W. S. Fisher. Art. 19, pp. 1-20. Oct. 15, 1930.

2843. The taxonomy and host relationships of the biting lice of the genera Dennyus and Eureum, including the descriptions of a new genus, subgenus, and four new species. By H. E. Ewing. Art. 20, pp. 1-16, 7 figs. Oct. 15, 1930.

\section{Volume 78}

Proceedings of the United States National Museum, vol. 78. Pp. i-xii (title page, advertisement, table of contents, and list of illustrations); arts. 1-23 (Proceedings papers 2844-2866, paged separately). 1931.

2844. New two-winged flies of the family Calliphoridae from China. By J. M. Aldrich. Art. 1, pp. 1-5, 3 figs. Sept. 25, 1930.

2845. Catalogue of human crania in the United States National Museum collections: Pueblos, southern Utah Basket-makers, Navaho. By Aleš Hrdlička. Art. 2, pp. 1-95. Apr. 9, 1931.

2846. A new species of trematode worm of the genus Ornithobilharzia from a Canadian goose. By Rudolf Wetzel. Art. 3, pp. 1-4, 1 pl. Oct. 25, 1930.

2847. Cambrian bivalved Crustacea of the order Conchostraca. By E. O. Ulrich and R. S. Bassler. Art. 4, pp. 1-130, 10 pls. Apr. 13, 1931.

2848. New and old land shells from the island of Luzon, Philippines. By Paul Bartsch. Art. 5, pp. 1-20, 9 pls. Nov. 25, 1930.

2849. The South American lizards in the collection of the United States National Museum. By Charles E. Burt and May Danheim Burt. Art. 6, pp. 1-52. Nov. 25, 1930.

2850. A revision of the species of Coccophagus, a genus of hymenopterous, coccidinhabiting parasites. By Harold Compere. Art. 7, pp. 1-132, 14 pls. Mar. $12,1931$.

2851. Fossil decapod crustaceans from Mexico. By Mary J. Rathbun. Art. 8, pp. 1-10, 6 pls. Nov. 1, 1930.

2852. American two-winged flies of the genus Stylogaster Macquart. By J. M. Aldrich. Art. 9, pp. 1-27. Oct. 15, 1930.

2853. A revision of the North American tachinid flies of the genus Achaetoneura. By R. T. Webber. Art. 10, pp. 1-37, 14 figs. Dec. 10, 1930. 
Proc.

No.

2854. Restudy of some Burgess shale fossils. By George Evelyn Hutchinson. Art. 11, pp. 1-24, 5 figs., 1 pl. Nov. 4, 1930.

2855. Notes on the types of American two-winged flies of the genus Sarcophaga and a few related forms, described by the early authors. By J. M. Aldrich. Art. 12 , pp. $1-39,3$ pls. Nov. $5,1930$.

2856. Exploration of ruins in the White Mountain Apache Indian Reservation, Arizona. By Walter Hough. Art. 13, pp. 1-21, 9 figs., 10 pls. Oct. 25, 1930.

2857. Notes on ichneumon-flies of the genus Polycyrtus with descriptions of new species. By R. A. Cushman. Art. 14, pp. 1-62. Mar. 31, 1931.

2858. Notes on some acalyptrate flies in the United States National Museum. By John R. Malloch. Art. 15, pp. 1-32, 10 figs. Jan. 10, 1931.

2859. Report on the South American sea stars collected by Waldo L. Schmitt. By W. K. Fisher. Art. 16, pp. 1-10, 2 figs., 8 pls. Apr. 7, 1931.

2860. Mollusks from the Aspen shale (Cretaceous) of southwestern Wyoming. By John B. Reeside, Jr., and A. Allen Weymouth. Art. 17, pp. 1-24, 4 pls. Feb. 26, 1931.

2861. A new species of amphipod crustacean (Acanthonotozomatidae) from California, and notes on Eurystheus tenuicornis. By Clarence R. Shoemaker. Art. 18, pp. 1-8, 4 figs. Mar. 11, 1931.

2862. Notes on the American bats of the genus Tadarida. By H. Harold Shamel. Art. 19, pp. 1-27. May 6, 1931.

2863. A new parasitic fly of the genus Chaetophlepsis. By R. T. Webber. Art. 20, pp. 1-4. Mar. 26, 1931.

2864. Description of a new species of amidostomine worm of the genus Epomidiostomum from the gizzard of anserine birds. By Rudolf Wetzel. Art. 21, pp. 1-10, 2 pls. Mar. 19, 1931.

2865. Redescription of two species of trematode worms from the MacCallum collection, with a note on the family Pronocephalidae. By Emmett W. Price. Art. 22, pp. 1-10, 2 figs. Mar. 11, 1931.

2866. New genera and species of nematode worms. By Asa C. Chandler. Art. 23, pp. 1-11, 2 pls. Mar. 11, 1931.

\section{Volume 79}

Proceedings of the United States National Museum, vol. 79. Pp. i-xvi (title page, advertisement, table of contents, and list of illustrations); arts. 1-34 (Proceedings papers 2867-2900, paged separately). 1932.

2867. Three new species of polychaetous annelids from Chesapeake Bay. By Aaron L. Treadwell. Art. 1, pp. 1-5, 3 figs. July 21, 1931.

2868. Revision of the species of beetles of the genus Trirhabda north of Mexico. By Doris Holmes Blake. Art. 2, pp. 1-36, 2 pls. July 24, 1931.

2869. A new species of nematode worm from the sage grouse. By Everett E. Wehr. Art. 3, pp. 1-3, 3 figs. June 24, 1931.

2870. Four new species of trematode worms from the muskrat, Ondatra zibethica, with a key to the trematode parasites of the muskrat. By Emmett W. Price. Art. 4, pp. 1-13, 4 figs. July 10, 1931.

2871. Description of a new genus and species of nematode worm occurring in the northwestern belted kingfisher, with a key to the genera of the subfamily Acuariinae. By Everett E. Wehr. Art. 5, pp. 1-4, 5 figs. June 20, 1931.

2872. Two new species of nematode worms of the genus Ostertagia from the Virginia deer, with a note on Ostertagia lyrata. By G. Dikmans. Art. 6, pp. 1-6, 1 fig., 2 pls. July 25, 1931.

2873. Descriptions of new genera and species of Siamese fishes. By Hugh M. Smith. Art. 7, pp. 1-48, 22 figs., 1 pl. Mar. 26, 1931.

2874. A new shipworm from Venezuela. By Paul Bartsch. Art. 8, pp. 1-3, 1 pl. Apr. 7, 1931.

2875. A new species of troödont dinosaur from the Lance formation of Wyoming. By Charles W. Gilmore. Art. 9, pp. 1-6, 5 pls. June 1, 1931. 
2876. Report on birds recorded by the Pinchot Expedition of 1929 to the Caribbean and Pacific. By Albert K. Fisher and Alexander Wetmore. Art. 10, pp. 1-66, 10 pls. Aug. 29, 1931.

2877. The two-winged flies belonging to Siphosturmia and allied genera, with descriptions of two new species. By H. J. Reinhard. Art. 11, pp. 1-11. July $30,1931$.

2878. A new pearl oyster from the Hawaiian Islands. By Paul Bartsch. Art. 12, pp. 1-2, 2 pls. June 2, 1931.

2879. Notes on and descriptions of some American moths. By Carl Heinrich. Art. 13, pp. 1-16, 1 fig., 7 pls. Aug. 10, 1931.

2880. Descriptions of thirteen new American and Asiatic ichneumon-flies, with taxonomic notes. By R. A. Cushman. Art. 14, pp. 1-16. Aug. 1, 1931.

2881. Descriptions of new marine mollusks from Panama, with a figure of the genotype of Engina. By Paul Bartsch. Art. 15, pp. 1-10, 1 pl. Aug. 1, 1931.

2882. Descriptions of a new genus and eight new species of ichneumon-flies, with taxonomic notes. By C. F. W. Muesebeck. Art. 16, pp. 1-16, 1 fig. Aug. $14,1931$.

2883. A new species of trematode of the family Heterophyidae, with a note on the genus Apophallus and related genera. By Emmett W. Price. Art. 17, pp. 1-6, 1 fig. Sept. 21, 1931.

2884. Two new lungworms from North America ruminants and a note on the lungworms of sheep in the United States. By G. Dikmans. Art. 18, pp. 1-4, 2 pls. Aug. 29, 1931.

2885. A new genus and new species of trematode worms of the family Plagiorchiidae. By John T. Lucker. Art. 19, pp. 1-8, 1 pl. Aug. 29, 1931.

2886. Revision of the American parasitic flies belonging to the genus Winthemia. By H. J. Reinhard. Art. 20, pp. 1-54, 1 pl. Nov. 24, 1931.

2887. Some Tertiary mollusks from southern Florida. By W. C. Mansfield. Art. 21, pp. 1-12, 4 pls. Oct. 9, 1931.

2888. The stegocephalid and ampeliscid amphipod crustaceans of Newfoundland, Nova Scotia, and New Brunswick in the United States National Museum. By Clarence R. Shoemaker. Art. 22, pp. 1-18, 6 figs. Oct. 16, 1931.

2889. Anodontites: A genus of South and Central American and Mexican pearly fresh-water mussels. By William B. Marshall. Art. 23, pp. 1-16, 2 pls. Oct. 8, 1931.

2890. Three new parasitic nematode worms. By Mary Scott Skinker. Art. 24, pp. 1-9, 19 figs. Nov. 10, 1931.

2891. Report on a collection of insects of the order Trichoptera from Siam and China. By A. B. Martynov. Art. 25, pp. 1-20, 4 pls. Nov. 5, 1931.

2892. Four new species of trematode worms of the subfamily Onchocotylinae. By G. A. MacCallum. Art. 26, pp. 1-8, 1 fig., 1 pl. Dec. 5, 1931.

2893. Some new Middle Cambrian fossils from British Columbia. By Rudolf Ruedemann. Art. 27, pp. 1-18, 6 figs., 7 pls. Nov. 27, 1931.

2894. Revision of the chalcid flies of the tribe Decatomini (Eurytomidae) in America north of Mexico. By W. V. Balduf. Art. 28, pp. 1-95, 4 pls. May 19, 1932.

2895. The buffalo motive in Middle Celebes decorative design. By Walter Hough. Art. 29, pp. 1-8, 9 pls. Feb. 11, 1932.

2896. Design areas in Oceania based on specimens in the United States National Museum. By Herbert W. Krieger. Art. 30, pp. 1-53, 33 pls. Apr. 21, 1932.

2897. A new nematode worm, Viannaia bursobscura, from the opossum, with a note on other parasites of the opossum. By G. Dikmans. Art. 31, pp. 1-4, 2 pls. Nov. 30, 1931.

2898. Excavations at a prehistoric Indian village site in Mississippi. By Henry B. Collins, Jr. Art. 32, pp. 1-22, 3 figs., 13 pls. Feb. 25, 1931.

2899. A new Middle Cambrian merostome crustacean. By Charles Elmer Resser. Art. 33, pp. 1-4, 1 pl. Dec. 30, 1931.

2900. Flies of the genus Pseudotephritis Johnson (Diptera: Ortalidae). By John R. Malloch. Art. 34, pp. 1-6. Oct. 21, 1931. 


\section{Volume 80}

Proceedings of the United States National Museum, vol. 80. Pp. i-xii (title page, advertisement, table of contents, and list of illustrations); arts. 1-23 (ProceedProc. ings papers 2901-2923, paged separately). 1932.

No.

2901. Observations on the growth rate of the foot in the mound birds of the genus Megapodius. By Herbert Friedmann. Art. 1, pp. 1-4. Oct. 28, 1931.

2902. Three new species of polychaetous annelids in the collections of the United State National Museum. By Aaron L. Treadwell. Art. 2, pp. 1-5, 3 figs. Nov. 10, 1931.

2903. Recent Foraminifera from the Atlantic coast of South America. By Joseph A. Cushman and Frances L. Parker. Art. 3, pp. 1-24, 4 pls. Nov. 19, 1931.

2904. The North American beetles of the genus Coccinella. By Th. Dobzhansky. Art. 4, pp. 1-32, 30 figs. Nov. 10, 1930.

2905. Echinoderms from the islands of Niuafoou and Nukualofa, Tonga Archipelago, with the description of a new genus and two new species. By Austin $\mathrm{H}$. Clark. Art. 5, pp. 1-12, 8 pls. Jan. 30, 1932.

2906. The fishes obtained by the Pinchot South Seas Expedition of 1929, with description of one new genus and three new species. By Henry W. Fowler. Art. 6, pp. 1-16, 4 figs. Feb. 16, 1932.

2907. A second collection of birds from the provinces of Yunnan and Szechwan, China, made for the National Geographic Society by Dr. Joseph F. Rock. By J. H. Riley. Art. 7, pp. 1-91. Dec. 31, 1931.

2908. A catalogue of the Trombiculinae, or chigger mites, of the New World, with new genera and species and a key to the genera. By H. E. Ewing. Art. 8, pp. $1-19,3$ pls. Nov. 19, 1931.

2909. The west American mollusks of the genus Acar. By Paul Bartsch. Art. 9, pp. 1-4, 1 pl. Nov. 23, 1931.

2910. Notes on Francis Walker's types of North American flies of the family Tachinidae. By J. M. Aldrich. Art. 10, pp. 1-16. Nov. 10, 1931.

2911. North American two-winged flies of the genus Spathimeigenia, with descriptions of five new species. By J. M. Aldrich. Art. 11, pp. 1-10. Dec. 31, 1931.

2912. The birds of St. Lawrence Island, Bering Sea. By Herbert Friedmann. Art. 12, pp. 1-31, 2 figs., 6 pls. Feb. 13, 1932.

2913. The brachial flexor muscles in primates. By A. Brazier Howell and William L. Straus, Jr. Art. 13, pp. 1-31, 2 pls. Nov. 21, 1931.

2914. Upper Cretaceous Foraminifera from Trinidad. By Joseph A. Cushman and P. W. Jarvis. Art. 14, pp. 1-60, 16 pls. Mar. 10, 1932.

2915. The copepod crustaceans of Chesapeake Bay. By Charles Branch Wilson. Art. 15, pp. 1-54, 1 fig., 5 pls. Mar. 31, 1932.

2916. The ancient caves of Szechwan Province, China. By David Crockett Graham. Art. 16, pp. 1-13, 14 figs., 16 pls. Mar. 23, 1932.

2917. A new marine shell of the genus Xenophora from Florida. By Paul Bartsch. Art. 17, pp. 1-2, 1 pl. Dec. 31, 1931.

2918. The parasitic habit in the ducks, a theoretical consideration. By Herbert Friedmann. Art. 18, pp. 1-7. Mar. 4, 1932.

2919. A review of the nematodes of the genus Hastospiculum, with descriptions of two new species. By B. G. Chitwood. Art. 9, pp. 1-9, 3 pls. Apr. 28, 1932.

2920. Records of dipterous insects of the family Tachinidae reared by the late George Dimmock, with description of one new species and notes on the genus Anetia Robineau-Desvoidy. By J. M. Aldrich. Art. 20, pp. 1-8. Mar. 31, 1932.

2921. Insects of the order Orthoptera of the Pinchot Expedition of 1929. By A. N. Caudell. Art. 21, pp. 1-7. Aug. 10, 1932.

2922. New West Indian cerambycid beetles. By W. S. Fisher. Art. 22, pp. 1-93. June 7, 1932.

2923. Revision of the Nearctic ichneumon-flies belonging to the genus Macrocentrus. By C. F. W. Muesebeck. Art. 23, pp. 1-55. Aug. 3, 1932. 


\section{Volume 81}

Proceedings of the United States National Museum, vol. 81. Pp. i-xii (title page, advertisement, table of contents, and list of illustrations); arts. 1-18 (ProProc. ceedings papers 2924-2941, paged separately). 1933.

No.

2924. New bopyrid isopod crustaceans from Dry Tortugas, Florida. By A. S. Pearse. Art. 1, pp. 1-6, 26 figs. June 1, 1932.

2925. Birds collected in Cuba and Haiti by the Parish-Smithsonian Expedition of 1930. By Alexander Wetmore. Art. 2, pp. 1-40, 7 pls. July 22, 1932.

2926. A new species of cestode, Crepidobothrium amphiumae, from Amphiuma tridactylum. By Clarke Courson Zeliff. Art. 3, pp. 1-3, 1 pl. June 18, 1932.

2927. The marine and fresh-water sponges of California. By M. W. de Laubenfels. Art. 4, pp. 1-140, 79 figs. Dec. 2, 1932.

2928. A new trematode of the genus Urotrema from bats. By Joseph E. Alicata. Art. 5, pp. 1-4, 1 fig. Aug. 11, 1932.

2929. A newly discovered West Indian mollusk faunula. By Paul Bartsch. Art. 6, pp. 1-12, 3 pls. July 6, 1932.

2930. Decorative designs on Elden Pueblo pottery, Flagstaff, Ariz. By Walter Hough. Art. 7, pp. 1-11, 1 fig., 10 pls. July 20, 1932.

2931. The fishes obtained by Lieut. H. C. Kellers, of the United States Naval Eclipse Expedition of 1930, at Niuafoou Island, Tonga Group, in Oceania. By Henry W. Fowler. Art. 8, pp. 1-9, 3 figs. Aug. 15, 1932.

2932. New Diptera, or two-winged flies, from America, Asia, and Java, with additional notes. By J. M. Aldrich. Art. 9, pp. 1-28, 2 figs., 1 pl. June $30,1932$.

2933. A cache of Basket Maker baskets from New Mexico. By Walter Hough. Art. 10, pp. 1-3, 3 pls. June 25, 1932.

2934. The forms of the common Old World swallowtail butterfly (Papilio machaon) in North America, with descriptions of two new subspecies. By Austin H. Clark. Art. 11, pp. 1-15, 8 pls. July 12, 1932.

2935. Report on the hexactinellid sponges collected by the United States Fisheries steamer Albatross in the northwestern Pacific during the summer of 1906. By Yaichiro Okada. Art. 12, pp. 1-118, 16 figs., 6 pls. Oct. 19, 1932.

2936. The trematode parasites of marine mammals. By Emmett W. Price. Art. 13, pp. 1-68, 12 pls. Oct. 1, 1932.

2937. Two new land shells of the genus Bulimulus from Bolivia. By William B. Marshall. Art. 14, pp. 1-3, 1 pl. July 28, 1932.

2938. A Miocene mollusk of the genus Haliotis from the Tremblor Range, California. By W. P. Woodring. Art. 15, pp. 1-4, 1 pl. Aug. 30, 1932.

2939. Notes on the helminth paraistes of the opossum (Didelphis virginiana) in southeast Texas, with descriptions of four new species. By Asa C. Chandler. Art. 16, pp. 1-15, 5 figs. Aug. 15, 1932.

2940. The helminths parasitic in the Amphibia and Reptilia of Houston, Texas, and vicinity. By Paul D. Harwood. Art. 17, pp. 1-71, 5 pls. Dec. 21, 1932.

2941. On a newly mounted skeleton of Diplodocus in the United States National Museum. By Charles W. Gilmore. Art. 18, pp. 1-21, 3 figs., 6 pls. Nov. 18,1932 .

\section{Volume 82}

Proceedings of the United States National Museum, vol. 82. Pp. i-xii (title page, advertisement, table of contents, and list of illustrations); arts. 1-30 (Proceedings papers 2942-2971, paged separately). 1934.

2942. A remarkable new genus and species of two-winged flies related to the Oestridae. By Charles H. T. Townsend. Art. 1, pp. 1-4, 2 figs. Oct. $11,1932$.

2943. A new Paleocene mammal from a deep well in Louisiana. By George Gay. lord Simpson. Art. 2, pp. 1-4, 1 fig. Nov. 5, 1932.

2944. The Chinese lizards of the genus Gekko. By Leonhard Stejneger. Art. 3, pp. 1-8. Nov. 7, 1932. 
2945. Description of a tick, Dermacentor halli, from the Texas peccary, with a key to the North American species of Dermacentor. By Allen McIntosh. Art. 4, pp. 1-6, 1 fig., 1 pl. Oct. 26, 1932.

- 2946. New fossil fresh-water mollusks from Ecuador. By William B. Marshall and Edgar U. Bowles. Art. 5, pp. 1-7, 1 pl. Dec. 2, 1932.

2947. Two new nematodes, and notes on new findings of nematodes parasitic in Amphibia. By A. C. Waiton. Art. 6, pp. 1-5, 1 fig. Mar. 1, 1933.

2948. A fossil rhinoceros (Diceratherium armatum Marsh) from Gallatin County, Montana. By Horace Elmer Wood, 2d. Art. 7, pp. 1-4, 3 pls. Mar. 13, 1933.

2949. New fresh-water gastropod mollusks of the genus Chilina of South America. By William B. Marshali. Art. 8, pp. 1-6, 1 pl. Mar. 1, 1933.

2950. A new species of extinct turtle from the Upper Pliocene of Idaho. By Charles W. Gilmore. Art. 9, pp. 1-7, 5 figs., 3 pls. Mar. 1, 1933.

2951. A collection of birds from Great Namaqualand, Southwest Africa. By Herbert Friedmann. Art. 10, pp. 1-12, 1 pl. Feb. 17, 1933.

2952. Five new species of North American ichneumon-flies. By Frank D. DeGant. Art. 11, pp. 1-6. Feb. 3, 1933.

2953. Fossil plants from the Aspen shale of southwestern Wyoming. By Roland W. Brown. Art. 12, pp. 1-10, 2 figs., 2 pls. Mar. 1, 1933.

2954. Camptostroma, a Lower Cambrian floating hydrozoan. By Rudolf Ruedemann. Art. 13, pp. 1-8, 2 figs., 4 pls. Mar. 1, 1933.

2955. Descriptions of new ichneumon-files, with taxonomic notes. By R. A. Cushman. Art. 14, pp. 1-16. Mar. 1, 1933.

2956. Description of two parasitic nematodes from the Texas peccary. By Benjamin Schwartz and Joseph E. Alicata. Art. 15, pp. 1-6, 4 figs. Mar. 29, 1933.

2957. New termites from India. By Thomas E. Snyder. Art. 16, pp. 1-15, 8 figs., 1 pl. Apr. 28, 1933.

2958. A new nematode from the rhea. By Everett E. Wehr. Art. 17, pp. 1-5, 3 figs. Mar. 29, 1933.

2959. Synopsis of the calanoid crustaceans, exclusive of the Diaptomidae, found in fresh and brackish waters, chiefly of North America. By C. Dwight Marsh. Art. 18, pp. 1-58, 24 pls. June 30, 1933.

-2960. West African snails of the family Achatinidae in the United States National Museum. By Henry A. Pilsbry. Art. 19, pp. 1-6, 2 pls. Apr. 28, 1933.

2961. Descriptions of new and imperfectly known species of genera of gobioid and pleuronectid fishes in the United States National Museum. By Isaac Ginsburg. Art. 20, pp. 1-23, 3 figs. May 19, 1933.

2962. Crossochir koelzi: A new Californian surf-fish of the family Embiotocidae. By Carl L. Hubbs. Art. 21, pp. 1-9, 1 pl. June 7, 1933.

2963. Pottery of the Hopewell type from Louisiana. By Frank M. Setzler. Art. 22, pp. 1-22, 6 figs., 7 pls. June 16, 1933.

2964. A new protozoan from the larva of the beetle Osmoderma scabra. By Clarke Courson Zeliff. Art. 23, pp. 1-3, 2 pls. July 19, 1933.

2965. A new fresh-water sponge from South Carolina. By James T. Penney. Art. 24, pp. 1-5, 9 figs. Sept. 8, 1933.

2966. Additional notes on the birds of Haiti and the Dominican Republic. By Alexander Wetmore and Frederick C. Lincoln. Art. 25, pp. 1-68, 6 pls. Dec. 4, 1933.

2967. Review of the wasps of the subfamily Pseninae of North America (Hymenoptera: Aculeata). By J. R. Malloch. Art. 26, pp. 1-60, 2 pls. Oct. 25, 1933.

2968. New species of buprestid beetles from Mexico and Central America. By W. S. Fisher. Art. 27, pp. 1-47. Dec. 4, 1933.

2969. Revision of the beetles of the genus Disonycha occurring in America north of Mexico. By Doris Holmes Blake. Art. 28, pp. 1-66, 8 pls. Dec. 4, 1933. 
Proc.

No.

2970. Three new chigger mites of the genus Trombicula from Panama, with a key to the known adults of Trombicula of the New World. By H. E. Ewing. Art. 29, pp. 1-6, 3 figs. Sept. 20, 1933.

2971. New genera and species of parasitic mites of the superfamily Parasitoidea. By H. E. Ewing. Art. 30, pp. 1-14, 4 pls. Sept. 25, 1933.

\section{Volume 83}

Proceedings of the United States National Museum, vol. 83. Pp. i-viii (title page, advertisement, table of contents, and list of illustrations); pp. 1-594 (Proceedings papers 2972-2997); pp. 595-617 (index); 71 figs., 38 pls. 1937.

2972. Corynecrinus, a new Devonian crinoid genus. By Edwin Kirk. Pp. 1-7, 1 pl. Oct. 8, 1934.

2973. American muscoid flies of the genera Ceratomyiella and Paradidyma. By H. J. Reinhard. Pp. 9-43. Dec. 28, 1934.

2974. Revision of the American two-winged flies belonging to the genus Cuphocera. By H. J. Reinhard. Pp. 45-70. Oct. 25, 1934.

2975. Some fossil corals from the West Indies. By John W. Wells. Pp. 71-110, 4 pls. Dec. 20, 1934.

2976. Fossil hares from the late Pliocene of southern Idaho. By C. Lewis Gazin. Pp. 111-121, 5 figs. Nov. 14, 1934.

2977. Parasites of fishes in Galveston Bay. By Asa C. Chandler. Pp. 123-157, 7 pls. June 13, 1935.

2978. On the Reptilia of the Kirtland formation of New Mexico, with descriptions of new species of fossil turtles. By Charles W. Gilmore. Pp. 159-188, 12 figs., 6 pls. June 27, 1935.

2979. New West Indian cerambycid beetles. By W. S. Fisher. Pp. 189-210. Sept. 9, 1935.

2980. Two new species of tapeworms from carnivores and a redescription of Taenia laticollis Rudolphi, 1819. By Mary Scott Skinker. Pp. 211-220, 3 pls. Oct. 25, 1935.

2981. New Paleocene mammals from the Fort Union of Montana. By George Gaylord Simpson. Pp. 221-244. Oct. 18, 1935.

2982. Five new genera and two new species of unstalked crinoids. By Austin $\mathbf{H}$. Clark. Pp. 245-250. Mar. 14, 1936.

2983. Notes on the butterflies of the genus Enodia and description of a new fritillary from Peru. By Austin H. Clark. Pp. 251-259, 1 pl. Apr. 11, 1936.

2984. Polychaetous annelids from Amoy, China. By Aaron L. Treadwell. Pp. 261-279, 3 figs. June 10, 1936.

2985. A study of the fossil horse remains from the Upper Pliocene of Idaho. By C. Lewis Gazin. Pp. 281-320, 4 figs., 11 pls. June 1, 1936.

2986. A new genus and species of trematode from the little brown bat and a key to the genera of Pleurogenetinae. By Ralph W. Macy. Pp. 321-324, 1 fig. May 19, 1936.

2987. Two new cottid fishes from the western Pacific, with a revision of the genus Stlengis Jordan and Starks. By Rolf L. Bolin. Pp. 325-334, 2 figs., 1 pl. June 15, 1936.

2988. Tertiary plants from Venezuela. By Edward W. Berry. Pp. 335-360, 4 figs. June 12, 1936.

2989. Three new millipeds of the order Colobognatha from Tennessee, Texas, and Lower California, with records of previously known species. By H. F. Loomis. Pp. 361-368, 1 fig. May 11, 1936.

2990. A revision of the chalcid flies of the genus Perilampus Latreille occurring in America north of Mexico. By M. T. Smulyan. Pp. 369-412. Oct. 16, 1936

2991. Pycnogonids from Puget Sound. By Harriet I. Exline. Pp. 413-422, I fig July 9, 1936.

2992. California Crustacea of the order Cumacea. By Carl Zimmer. Pp. 423-439. 6 figs. Aug. 27, 1936. 
Proc.

No.

2993. A comparison of the shallow-water sponges near the Pacific end of the Panama Canal with those at the Caribbean end. By M. W. deLaubenfels. Pp. 441-466, 6 figs. July 31, 1936.

2994. New species of polychaetous annelids of the family Nereidae from California. By Olga Hartman. Pp. 467-480, 8 figs. July 11, 1936.

2995. Four new species of Chalcidoidea parasitic on cactus insects. By A. B. Gahan. Pp. 481-486. Aug. 7, 1936.

2996. New Tertiary Foraminifera of the genera Operculina and Operculinoides from North America and the West Indies. By Thomas Wayland Vaughan and W. Storrs Cole. Pp. 487-496, 4 pls. Oct. 8, 1936.

2997. Review of the seahorses (Hippocampus) found on the coasts of the American continents and of Europe. By Isaac Ginsburg. Pp. 497-594, 18 figs. Jan. 18, 1937.

\section{Volume 84}

Proceedings of the United States National Museum, vol. 84. Pp. i-viii (title page, advertisement of contents, and list of illustrations); pp. 1-584 (Proceedings papers 2998-3026); pp. 585-606 (index); 34 figs., 20 pls. 1938.

2998. Report on the fishes collected by H. C. Raven in Lake Tanganyika in 1920. By George S. Myers. Pp. 1-15, 1 pi. Sept. 24, 1936.

2999. The ichneumon-flies of the genus Brachycyrtus Kriechbaumer. By R. A. Cushman. Pp. 17-24, 4 figs. Sept. 26, 1936.

3000. New cottid fishes from Japan and Bering Sea. By Rolf L. Bolin. Pp. 25-38, 4 figs. Oct. 10, 1936.

3001. Revision of the North American beetles of the staphylinid subfamily Tachyporinae-Part 1: Genus Tachyporus Gravenhorst. By Richard E. Blackwelder. Pp. 39-54. Nov. 17, 1936.

3002. Revision of the fishes of the family Microdesmidae, with description of a new species. By Earl D. Reid. Pp. 55-72, 4 figs., 1 pl. Dec. 10, 1936.

3003. Two new species of hawks from the Miocene of Nebraska. By Alexander Wetmore. Pp. 73-78, 2 figs. Nov. 3, 1936.

3004. A new North American mason-wasp from Virginia, with notes on some allied forms. By Joseph Bequaert. Pp. 79-87, 1 fig. Nov. 24, 1936.

3005. The nest of Odynerus tempiferus var. macio Bequaert, with notes on the habits of the wasps. By Austin H. Clark and Grace A. Sandhouse. Pp. 89-95. Nov. 24, 1936.

3006. Crested millipeds of the family Lysiopetalidae in North America, with descriptions of new genera and species. By H. F. Loomis. Pp. 97-135, 3 figs., 2 pls. May 15, 1937.

3007. Notes on phallostethid fishes. By George S. Myers. Pp. 137-143. Jan. 6, 1937.

3008. The deep-sea zeomorph fishes of the family Grammicolepidae. By George S. Myers. Pp. 145-156, 3 pls. Jan. 18, 1937.

3009. New North American species of earthworms of the family Megascolecidae. By Frank Smith. Pp. 157-181. Jan. 8, 1937.

3010. Observations on the trematode genus Brachycoelium Dujardin. By Elon E. Byrd. Pp. 183-199, 2 pls. Apr. 7, 1937.

3011. New muscoid flies (Diptera) in the United States National Museum. By David G. Hall. Pp. 201-216, 8 figs. Apr. 6, 1937.

3012. The pupa of Myocera tabanivora Hall (Diptera). By Charles T. Greene. Pp. 217-218, 1 fig. Apr. 6, 1937.

3013. A new subspecies of the nymphalid butterfly Polygonia faunus. By Austin H. Clark. Pp. 219-222, 1 pl. Apr. 9, 1937.

3014. A new species of trematode from the mud-eel (Siren lacertina). By C. Courson Zeliff. Pp. 223-226, 1 pl. May 4, 1937.

3015. Mexican fossil Echini. By Robert Tracy Jackson. Pp. 227-237, 4 pls. June 12, 1937.

3016. Two new beetles of the family Mordellidae from orchids. By Eugene Ray. Pp. 239-241. Apr. 21, 1937. 
Proc.

No.

3017. Revision of the North American species of ichneumon-flies of the genus Exetastes Gravenhorst. By R. A. Cushman. Pp. 243-312, 6 pls. July 3, 1937.

3018. A revision of the clapper rails (Rallus longirostris Boddaert). By Harry C. Oberholser. Pp. 313-354. June 30, 1937.

3019. Moths of the genus Rupela (Pyralididae: Schoenobiinae). By Carl Heinrich. Pp. 355-388, 12 pls. July 3, 1937.

3020. Synopsis of the Puerto Rican beetles of the genus Mordellistena, with descriptions of new species. By Eugene Ray. Pp. 389-399, 1 fig. June 26, 1937.

3021. Observations on the birds of West Virginia. By Alexander Wetmore. Pp. 401-441. Aug. 24, 1937.

3022. Annotated list of West Virginia mammals. By Remington Kellogg. Pp. 443-479. Oct. 7, 1937.

3023. On the detailed skull structure of a crested hadrosaurian dinosaur. By Charles W. Gilmore. Pp. 481-491, 6 figs. Oct. 12, 1937.

3024. Hydrocorals of the north Pacific Ocean. By Walter Kenrick Fisher. Pp. 493-554, 43 pls. Mar. 8, 1938.

3025. A giant new species of fairy shrimp of the genus Branchinecta from the State of Washington. By James E. Lynch. Pp. 555-562, 4 pls. Dec. 3, 1937.

3026. New species of moths of the family Notodontidae in the United States National Museum. By William Schaus. Pp. 563-584. Dec. 29, 1937.

\section{Volume 85}

Proceedings of the United States National Museum, vol. 84. Pp. i- $x$ (title page, advertisement, table of contents, and list of illustrations); pp. 1-507 (Proceedings papers 3027-3040); pp. 509-530 (index); 39 figs., 101 pls. 1940.

3027. On some onychophores from the West Indies and Central America. By Austin H. Clark. Pp. 1-3. Nov. 5, 1937.

3028. Synopsis of the beetles of the Chilean genus Phytholaema (Scarabaeidae: Melolonthinae). By Lawrence W. Saylor. Pp. 5-11, 1 fig. Dec. 3, 1937.

3029. Redescription of the capelin Mallotus catervarius (Pennant) of the North Pacific. By Leonard P. Schultz. Pp. 13-20. Dec. 2, 1937.

3030. A Miocene booby and other records from the Calvert formation of Maryland. By Alexander Wetmore. Pp. 21-25, 2 figs. Jan. 14, 1938.

3031. Another fossil owl from the Eocene of Wyoming. By Alexander Wetmore. Pp. 27-29, 2 figs. Jan. 17, 1938.

3032. Descriptions of new fishes obtained by the United States Bureau of Fisheries steamer Albatross, chiefly in Philippine seas and adjacent waters. By Henry W. Fowler. Pp. 31-135, 56 figs. May 23, 1938.

3033. Evidence of Triassic insects in the Petrified Forest National Monument, Arizona. By M. V. Walker. Pp. 137-141, 4 pls. June 14, 1938.

3034. Review of the annelid worms of the family Nephtyidae from the northeast Pacific, with descriptions of five new species. By Olga Hartman. Pp. 143-158, 6 figs. June 8, 1938.

3035. A Miocene dog from Maryland. By Charles T. Berry. Pp. 159-161, 1 fig. Aug. 10, 1938.

3036. Revision of the Nearctic leafhoppers of the tribe Errhomenellini (Homoptera: Cicadellidae). By P. W. Oman. Pp. 163-180, 2 pls. May 27, 1938.

3037. A new genus and two new species of the dipterous family Phoridae. By Charles T. Greene. Pp. 181-185, 1 fig. June 27, 1938.

3038. A new genus and two new species of cottoid fishes from the Aleutian Islands. By Leonard P. Schultz. Pp. 187-191, 1 fig. May 12, 1938.

3039. The Cuban operculate land shells of the subfamily Chondropominae. By Carlos de la Torre and Paul Bartsch. Pp. 193-403, 31 figs., 33 pls. July 27, 1938.

3040. On some species of Chinese earthworms, with special reference to specimens collected in Szechwan by Dr. D. C. Graham. By G. E. Gates. Pp. 405-507. Mar. 20. 1939. 


\section{Volume 86}

Proceedings of the United States National Museum, vol. 86. Pp. i-ix (title page, advertisement, table of contents, and list of illustrations); pp. 1-607 (ProceedProc. ings papers 3041-3065); pp. 595-626 (index); 71 figs., 71 pls. 1940.

No.

3041. Revision of the North American beetles of the staphylinid subfamily Tachyporinae-Part 2: Genus Coproporus Kraatz. By'Richard E. Blackwelder. Pp. 1-10. Oct. 8, 1938.

3042. Descriptions of new and little-known fossil lizards from North America. By Charles W. Gilmore. Pp. 11-26, 9 figs., 1 pl. Dec. 16, 1938.

3043. The cambaloid millipeds of the United States, including a family new to the fauna and new genera and species. By H. F. Loomis. Pp. 27-66, 12 figs., 1 pl. Dec. $17,1938$.

3044. Polyclads of the east coast of North America. By A. S. Pearse. Pp. 67-98, 13 figs. Dec. 17, 1938.

3045. Hopewellian remains near Kansas City, Missouri. By Waldo R. Wedel. Pp. 99-106, 6 pls. Dec. 16, 1938.

3046. The types of the polychaete worms of the families Polynoidae and Polyodontidae in the United States National Museum and the description of a new genus. By Olga Hartman. Pp. 107-134, 7 figs. Dec. 7, 1938.

3047. Review of the fishes of the genera Polyipnus and Argyropelecus (family Sternoptichidae), with descriptions of three new species. By Leonard P. Schultz. Pp. 135-155, 4 figs. Dec. 27, 1938.

3048. Revision of the beetles of the melolonthine subgenus Phytalus of the United States. By Lawrence W. Saylor. Pp. 157-167, 2 pls. Feb. 15, 1939.

3049. New species of polychaete worms of the genus Euphrosyne, with notes on Euphrosyne borealis Orsted. By Aaron L. Treadwell. Pp. 169-173, 1 fig. Jan. 20, 1939.

3050. Notes on the birds of Tennessee. By Alexander Wetmore. Pp. 175-243. Jan. 31, 1939.

3051. Annotated list of Tennessee mammals. By Remington Kellogg. Pp. 245-303. Feb. 14, 1939.

3052. Species of the foraminiferal family Camerinidae in the Tertiary and Cretaceous of Mexico. By R. Wright Barker. Pp. 305-330, 12 pls. May 16, 1939.

3053. The cactus-feeding Phycitinae: A contribution toward a revision of the American pyralidoid moths of the family Phycitidae. By Carl Heinrich. Pp. 331-413, 29 pls. Mar. 16, 1939.

3054. Two new ophiurans from the Smithsonian-Hartford Expedition, 1937. By Hubert Lyman Clark. Pp. 415-418, 1 pl. Apr. 4, 1939.

3055. New species of flatworms from North, Central, and South America. By Libbie H. Hyman. Pp. 419-439, 5 figs. Apr. 14, 1939.

3056. Echinoderms of the Smithsonian-Hartford Expedition, 1937, with other West Indian records. By Austin H. Clark. Pp. 441-456, 2 pls. Apr. 5, 1939.

3057. A new cave isopod from Florida. By James O. Maloney. Pp. 457-459, 1 fig. May 26, 1939.

3058. Two new Atlantic species of dog sharks, with a key to the species of Mustelus. By Stewart Springer. Pp. 461-468, 3 figs. Apr. 27, 1939.

3059. A new sea star of the genus Poraniopsis from Japan. By Walter K. Fisher. Pp. 469-472, 1 fig., 2 pls. Apr. 4, 1939.

3060. A revision of the toadfishes referred to Porichthys and related genera. By Carl L. Hubbs and Leonard P. Schultz. Pp. 473-496, 1 fig. Apr. 29, 1939.

3061. A new genus of starfishes from the Aleutian Islands. By Austin H. Clark. Pp. 497-500, 1 pl. May 17, 1939.

3062. Eleven new species and three new genera of oceanic fishes collected by the International Fisheries Commission from the northeastern Pacific. By Wilbert McLeod Chapman. Pp. 501-542, 13 figs. Apr. 28, 1939. 
Proc.

3063. New species of moths of the families Notodontidae and Bombycidae in the United States National Museum. By William Schaus. Pp. 543-561. May 18, 1939.

3064. Restriction of the genus Gelechia (Lepidoptera: Gelechiidae), with descriptions of new genera. By August Busck. Pp. 563-593, 14 pls. May 23, 1939.

3065. Neotropical flies of the family Stratiomyidae in the United States National Museum. By Maurice T. James. Pp. 595-607, 1 fig. Aug. 3, 1939.

\section{Volume 87}

Proceedings of the United States National Museum, vol. 87. Pp. i-viii (title page, advertisement, table of contents, and list of illustrations); pp. 1-634 (Proceedings papers 3066-3077); pp. 635-672 (index); 157 figs., 19 pls. 1941.

3066. Ceratopsian dinosaurs from the Two Medicine formation, Upper Cretaceous of Montana. By Charles W. Gilmore. Pp. 1-18, 11 figs. Aug. 3, 1939.

3067. Two new parasitic isopods from the eastern coast of North America. By A. S. Pearse and Henry A Walker. Pp. 19-23, 2 figs. Aug. 1, 1939.

3068. The Hederelloidea, a suborder of Paleozoic cyclostomatous Bryozoa. By Ray S. Bassler. Pp. 25-91, 1 fig., 16 pls. Sept. 12, 1939.

3069. A generic revision of the staphylinid beetles of the tribe Paederini. By Richard E. Blackwelder. Pp. 93-125. Sept. 15, 1939.

3070. New turritid mollusks from Florida. By Paul Bartsch and Harald A. Rehder. Pp. 127-138, 1 pl. Scpt. 15, 1939.

3071. A new trematode from the lcon, Gavia immer, and its relationship to Haematotrephus fodiens Linton, 1928. By W. Carl Gower. Pp. 139-143, 1 fig. Sept. 1, 1939.

3072. A study of LeConte's types of the beetles in the genus Monoxia, with descriptions of new species. By Doris Holmes Blake. Pp. 145-171, 2 pls. Oct. 5, 1939.

3073. Observations on the birds of northern Venezuela. By Alexander Wetmore. Pp. 173-260. Nov. 3, 1939.

3074. A revision of the soapfishes of the genus Rypticus. By Leonard P. Schultz and Earl D. Reid. Pp. 261-270. Oct. 24, 1939.

3075. A taxonomic study of Neotropical beetles of the family Mordellidae, with descriptions of new species. By Eugene Ray. Pp. 271-314, 4 figs. Dec. $15,1939$.

3076. Catalog of human crania in the United States National Museum collections: Indians of the Gulf States. By Aleš Hrdlička. Pp. 315-464, 1 fig. May $18,1940$.

3077. Further studies on the opalinid ciliate infusorians and their hosts. By Maynard M. Metcalf. Pp. 465-634, 137 figs. Oct. 29, 1940.

\section{Volume 88}

Proceedings of the United States National Museum, vol. 88. Pp. i-viii (title page, advertisement, table of contents, and list of illustrations); pp. 1-586 (Proceedings papers 3078-3091); pp. 587-615 (index); 50 figs., 33 pls. 1942.

3078. Trematodes from fishes mainly from the Woods Hole region, Massachusetts. By Edwin Linton. Pp. 1-172, 26 pls. May 16, 1940.

3079. Report on certain groups of neuropteroid insects from Szechwan, China. By Nathan Banks. Pp. 173-220, 4 pls. Apr. 13, 1940.

3080. Cestocrinus, a new fossil inadunate crinoid genus. By Edwin Kirk. Pp. 221-224, 1 pl. Mar. 14, 1940.

3081. Notes on some pedunculate barnacles from the North Pacific. By Dora Priaulx Henry. Pp. 225-236, 5 figs. Apr. 20, 1940.

3082. Revision of the chalcid-flies of the tribe Chalcidini in America north of Mexico. By B. D. Burks. Pp. 237-354, 9 figs. June 11, 1940. 
No.

3083. New genera and species of ichneumon-flies, with taxonomic notes. By R. A. Cushman. Pp. 355-372, 2 figs. Mar. 13, 1940.

3084. The scolytid beetles of the genus Renocis Casey, with descriptions of nine new species. By M. W. Blackman. Pp. 373-401, 2 figs. June 22, 1940.

3085. Two new genera and three new species of cheilodipterid fishes, with notes on the other genera of the family. By Leonard P. Schultz. Pp. 403-423, 2 figs. Apr. 26, 1940.

3086. A contribution to the knowledge of the Eucharidae (Hymenoptera: Chalcidoidea). By A. B. Gahan. Pp. 425-458. Apr. 25, 1940.

3087. A review of the parasitic Crustacea of the genus Argulus in the collections of the United States National Museum. By O. Lloyd Meehan. Pp. 459-522, 27 figs. June 22, 1940.

3088. The ichneumon-flies of the subfamily Neorhacodinae, with descriptions of a new genus and three new species. By R. A. Cushman. Pp. 523-527, 1 fig. Apr. 13, 1940.

3089. Notes on the birds of Kentucky. By Alexander Wetmore. Pp. 529-574. Apr. 23, 1940.

3090. Seven new species and one new genus of hydroids, mostly from the Atlantic Ocean. By C. McLean Fraser. Pp. 575-580, 2 pls. Sept. 13, 1940.

3091. A prehistoric roulette from Wyandotte County, Kansas. By Waldo R. Wedel and Harry M. Trowbridge. Pp. 581-586, 2 figs. June 5, 1940.

\section{Volume 89}

Proceedings of the United States National Museum, vol. 89. Pp. i-ix (title page, advertisement, table of contents, and list of illustrations); pp. 1-581 (Proceedings papers 3092-3105); pp. 583-620 (index); 31 figs., 62 pls. 1942.

3092. A revision of the West Indian beetles of the scarabaeid subfamily Aphodiinae. By Edward A. Chapin. Pp. 1-41. May 23, 1940.

3093. Two new anuran amphibians from Mexico. By Edward H. Taylor. Pp. 43-47, 3 pls. Aug. 13, 1940.

3094. The west American Haliotis. By Paul Bartsch. Pp. 49-58, 3 pls. Aug. $15,1940$.

3095. Revision of the scarabaeid beetles of the phyllophagan subgenus Listrochelus of the United States, with discussion of related subgenera. By Lawrence W. Saylor. Pp. 59-130, 13 figs. Nov. 15, 1940.

3096. The Cuban operculate land mollusks of the family Annulariidae, exclusive of the subfamily Chondropominae. By Carlos de la Torre and Paul Bartsch. Pp. 131-385, 49 pls. Pp. i-x (index). Apr. 2, 1941.

3097. Seven new crayfishes of the genus Cambarus from Florida, with notes on other species. By Horton H. Hobbs, Jr. Pp. 387-423, 9 figs. Nov. 23, 1940.

3098. Echinoderms from Greenland collected by Capt. Robert A. Bartlett. Pp. 425-433, 2 pls. Feb. 27, 1941.

3099. A revision of the keyhole urchins (Mellita). By Hubert Lyman Clark. Pp. 435-444, 3 pls. Dec. 12, 1940.

3100. Eurhoptodes, a remarkable new genus of Philippine cryptorhynchine weevils. By Elwood C. Zimmerman. Pp. 445-448, 1 fig. Nov. 1, 1940.

3101. The polyclad flatworms of the Atlantic coast of the United States and Canada. By Libbie H. Hyman. Pp. 449-495, 8 figs. Feb. 27, 1941.

3102. New species of heterocerous moths in the United States National Museum. By William Schaus. Pp. 497-511. Mar. 6, 1941.

3103. Dinotocrinus, a new fossil inadunate crinoid genus. By Edwin Kirk. Pp. 513-517, 1 pl. Feb. 28, 1941.

3104. A supposed jellyfish from the pre-Cambrian of the Grand Canyon. By R. S. Bassler. Pp. 519-522, 1 pl. Feb. 27, 1941.

3105. Notes on birds of the Guatemalan Highlands. By Alexander Wetmore. Pp. 523-581. Mar. 26, 1941. 


\section{Volume 90}

Proceedings of the United States National Museum, vol. 90. Pp. i-vii (title page, advertisement, table of contents, and list of illustrations); pp. 1-551 (ProceedProc. ings papers 3106-3120); pp. 553-581 (index); 24 figs., 74 pls. 1942.

No.

3106. New fishes of the family Callionymidae, mostly Philippine, obtained by the United States Bureau of Fisheries steamer Albatross. By Henry W. Fowler. Pp. 1-31, 16 figs. Apr. 8, 1941.

3107. Revision of the North American moths of the family Oecophoridae, with descriptions of new genera and species. By J. F. Gates Clarke. Pp. 33-286, 48 pls. Pp. i-viii (index). Nov. 6, 1941.

3108. Synopsis of the tachinid flies of the genus Tachinomyia, with descriptions of new species. By Ray T. Webber. Pp. 287-304, 1 fig. June 30, 1941.

3109. A history of the Division of Vertebrate Paleontology in the United States National Museum. By Charles W. Gilmore. Pp. 305-377, 5 pls. Aug. 5, 1941.

3110. A new harpacticoid copepod from the gill chambers of a marsh crab. By Arthur G. Humes. Pp. 379-386, 1 fig. Aug. 5, 1941.

3111. The Chicora (Butler County, Pa.) meteorite. By F. W. Preston, E. P. Henderson, and James R. Randolph. Pp. 387-416, 1 fig., 6 pls. June 17, 1941.

3112. Cestode parasites of teleost fishes of the Woods Hole region, Massachusetts. By Edwin Linton. Pp. 417-442, 3 pls. July 15, 1941.

3113. Pamlico fossil echinoids. By Willard Berry. Pp. 443-445, 3 pls. July 5, 1941.

3114. A new genus of sea stars (Plazaster) from Japan, with a note on the genus Parasterina. By Walter K. Fisher. Pp. 447-456, 3 figs., 5 pls. June 18, 1941.

3115. Notes on Mexican turtles of the genus Kinosternon. By Leonhard Stejneger. Pp. 457-459. July 25, 1941.

3116. A revision of the chalcid-flies of the genus Monodontomerus in the United States National Museum. By A. B. Gahan. Pp. 461-482. Aug. 19, 1941.

3117. Notes on the birds of North Carolina. By Alexander Wetmore. Pp. 483-530. Oct. 31, 1941.

3118. Notes on some North and Middle American danaid butterflies. By Austin H. Clark. Pp. 531-542, 4 pls. Nov. 4, 1941.

3119. A new genus of psammocharid wasp from China. By P. P. Babiy. Pp. 543-546, 1 fig. Oct. 24, 1941.

3120. Two new species of cecidomyiid flies from phlox. By Charles T. Greene. Pp. 547-551, 1 fig. Oct. 30, 1941.

\section{Volume 91}

Proceedings of the United States National Museum, vol. 91. Pp. i-viii (title page, advertisement, table of contents, and list of illustrations); pp. 1-520 (Proceedings papers 3121-3132); pp. 521-529 (index); 64 figs., 28 pls. 1943.

3121. The mammalian faunas of the Paleocene of central Utah, with notes on the geology. By C. Lewis Gazin. Pp. 1-53, 29 figs., 3 pls. Oct. 2, 1941.

3122. A new fossil crocodilian from Colombia. By Charles C. Mook. Pp. 55-58, 6 pls. Jan. 17, 1942.

3123. The North American moths of the genus Arachnis, with one new species. By J. F. Gates Clarke. Pp. 59-70, 3 pls. Nov. 14, 1941.

3124. Some little-known fossil lizards from the Oligocene of Wyoming. By Charles W. Gilmore. Pp. 71-76, 3 figs. Nov. 13, 1941.

3125. New species of hydroids, mostly from the Atlantic Ocean, in the United States National Museum. By C. McLean Fraser. Pp. 77-89, 6 pls. Nov. 14, 1941.

3126. The Nevada early Ordovician (Pogonip) sponge fauna. By R. S. Bassler. Pp. 91-102, 6 pls. Nov. 1, 1941.

3127. The Mexican subspecies of the snake Coniophanes fissidens. By Hobart $\mathbf{M}$. Smith. Pr. 103-111, 1 fig. Nov. 13, 1941. 
3128. Report on the Smithsonian-Firestone Expedition's collection of reptiles and amphibians from Liberia. By Arthur Loveridge. Pp. 113-140, 1 fig. Nov. 14, 1941.

3129. Notes on some crayfishes from Alabama caves, with the description of a new species and a new subspecies. By Rendell Rhoades. Pp. 141-148, 2 figs. Nov. 6, 1941.

3130. Notes on the snake genus Trimorphodon. By Hobart M. Smith. Pp. 149-168, 2 figs. Nov. 10, 1941.

3131. Catalog of human crania in the United States National Museum collections: Eskimo in general. By Aleš Hrdlička. Pp. 169-429, 1 fig. Aug. 1, 1942.

3132. The species of Aegla, endemic South American fresh-water crustaceans. By Waldo L. Schmitt. Pp. 431-520, 25 figs., 4 pls. Aug. 18, 1942.

\section{Volume 92}

Proceedings of the United States National Museum, vol. 92. Pp. i-viii (title page, advertisement, table of contents, and list of illustrations); pp. 1-619 (Proceedings papers 3133-3156); pp. 621-668 (index); 47 figs., 43 pls. 1943.

3133. Notes on two genera of American flies of the family Trypetidae. By John R. Malloch. Pp. 1-20, 1 fig. Jan. 7, 1942.

3134. The Freda, N. Dak., meteorite: a nickel-rich ataxite. By E. P. Henderson and Stuart H. Perry. Pp. 20-23, 4 pls. Mar. 23, 1942.

3135. Some cestodes from Florida sharks. By Asa C. Chandler. Pp. 25-31, 2 figs. Feb. 9, 1942.

3136. A new species of phyllopod crustacean from the southwestern short-grass prairies. By J. G. Mackin. Pp. 33-39, 3 figs. Apr. 15, 1942.

3137. Descriptions of five new species of Chalcidoidea, with notes on a few described species (Hymenoptera.) By A. B. Gahan. Pp. 41-51. Mar. 4, 1942.

3138. A new stomatopod crustacean from the west coast of Mexico. By Steve A. Glassell. Pp. 53-56, 1 fig. Mar. 26, 1942.

3139. The chrysomelid beetles Luperodes bivittatus (LeConte) and varicornis (LeConte) and some allied species. By Doris H. Blake. Pp. 57-74, 2 pls. Apr. 7, 1942.

3140. Notes on the classification of the staphylinid beetles of the groups Lispini and Osoriinae. By Richard E. Blackwelder. Pp. 75-90. Apr. 7, 1942.

3141. Scored bone artifacts of the central Great Plains. By W. R. Wedel and A. T. Hill. Pp. 91-100, 7 pls. Apr. 28, 1942.

3142. The identity of some marine annelid worms in the United States National Museum. By Olga Hartman. Pp. 101-140, 8 figs. June 10, 1942.

3143. The Sardis (Georgia) meteorite. By E. P. Henderson and C. Wythe Cooke. Pp. 141-150, 2 pls. Apr. 30, 1942.

3144. Rhopocrinus, a new fossil inadunate crinoid genus. By Edwin Kirk. Pp. 151-155, 1 pl. Apr. 24, 1942.

3145. Notes on beetles related to Phyllophaga Harris, with descriptions of new genera and subgenera. By Lawrence W. Saylor. Pp. 157-165, 1 pl. June 11, 1942.

3146. Descriptions of the larvae of some West Indian melolonthine beetles and a key to the known larvae of the tribe. By Adam G. Böving. Pp. 167-176, 2 pls. June 13, 1942.

3147. New species of bark beetles (Pityophthorini) from Mexico and tropical America (Coleoptera, Scolytidae). By M. W. Blackman. Pp. 177-228, 4 pls. Nov. 25, 1942.

3148. Osteology of Polyglyphanodon, an Upper Cretaceous lizard from Utah. By Charles W. Gilmore. Pp. 229-265, 21 figs., 3 pls. Oct. 13, 1942.

3149. Notes and new species of Microlepidoptera from Washington State. By J. F. Gates Clarke. Pp. 267-276, 6 pls. Oct. 13, 1942.

3150. The genotypes of some of Ashmead's genera of ichneumon-flies. By R. A. Cushman. Pp. 277-289. Oct. 8, 1942. 
Proc.

No.

3151. New Neotropical insects of the apterygotan family Japygidae. By H. E. Ewing and Irving Fox. Pp. 291-299, 2 pls. Oct. 1, 1942.

3152. The fresh-water fishes of Liberia. By Leonard P. Schultz. Pp. 301-348, 1 fig., 2 pls. Nov. 13, 1942.

3153. Mexican herpetological miscellany. By Hobart M. Smith. Pp. 349-395, 1 fig., 1 pl. Nov. 5, 1942.

3154. Revision of the genus Phloeosinus Chapuis in North America (Coleoptera, Scolytidae). By M. W. Blackman. Pp. 397-474, 4 pls. Dec. 21, 1942.

3155. The late Cenozoic vertebrate faunas from the San Pedro Valley, Ariz. By C. Lewis Gazin. Pp. 475-518, 9 figs., 2 pls. Dec. 10, 1942.

3156. The type species of the genera and subgenera of bees. By Grace A. Sandhouse. Pp. 519-619. Mar. 5, 1943.

\section{Volume 93}

Proceedings of the United States National Museum, vol. 93. Pp. i-viii (title page, advertisement, table of contents, and list of illustrations); pp. 1-608 (Proceedings papers 3157-3170); pp. 609-647 (index); 21 figs., 32 pls. 1944.

3157. The Nearctic species of parasitic flies belonging to Zenillia and allied genera. By Wendell F. Sellers. Pp. 1-108. Jan. 19, 1943.

3158. A new fossil reptile from the Upper Cretaceous of Utah. By Charles W. Gilmore. Pp. 109-114, 5 figs. Dec. 12, 1942.

3159. Some American geometrid moths of the subfamily Ennominae heretofore associated with or closely related to Ellopia Treitschke. By $\mathrm{Hahn} \mathrm{W.}$ Capps. Pp. 115-151, 10 pls. Feb. 24, 1943.

3160. Skeletal remains with cultural associations from the Chicama, Moche, and Virú Valleys, Peru. By T. D. Stewart. Pp. 153-185, 8 pls. Jan. 23, 1943.

3161. New marine mollusks from the Antillean region. By Harald A. Rehder. Pp. 187-203, 2 pls. Jan. 20, 1943.

3162. A new pest of Albizzia in the District of Columbia (Lepidoptera: Glyphipterygidae). By J. F. Gates Clarke. Pp. 205-208, 5 pls. Mar. 9, 1943.

3163. Osteology of Upper Cretaceous lizards from Utah, with a description of a new species. By Charles W. Gilmore. Pp. 209-214, 5 figs. Jan. 19, 1943.

3164. The birds of southern Veracruz, Mexico. By Alexander Wetmore. Pp. 215340, 1 fig., 3 pls. May 25, 1943.

3165. New genera and species of bark beetles of the subfamily Micracinae (Scolytidae, Coleoptera). By M. W. Blackman. Pp. 341-365, 2 pls. Mar. 22, 1943.

3166. Notes on some barnacles from the Gulf of California. By Dora Priaulx Henry. Pp. 367-373, 1 pl. May 3, 1943.

3167. New species of buprestid beetles of the genus Agrilus from Trinidad. By W. S. Fisher. Pp. 375-380. July 26, 1943.

3168. Some fungus beetles of the family Endomychidae in the United States $\mathrm{Na}$ tional Museum, mostly from Latin America and the Philippine Islands. By H. F. Strohecker. Pp. 381-392, 1 fig. Aug. 5, 1943.

3169 Summary of the collections of snakes and crocodilians made in Mexico under the Walter Rathbone Bacon Traveling Scholarship. By Hobart M. Smith. Pp. 393-504, 3 figs., 1 pl. Oct. 29, 1943.

3170. The North American parasitic wasps of the genus Tetrastichus-a contribution to biological control of insect pests. By B. D. Burks. Pp. 505-608, 6 figs. Oct. 26, 1943. 


\section{Volume 94}

Proceedings of the United States National Museum, vol. 94. Pp. i-vi (title page, advertisement, table of contents, and list of illustrations); pp. 1-582 (Proceedings papers 3171-3177) ; pp. 583-598 (index); 34 pls., 157 figs. 1944.

Proc.

No.

3171. Catalog of human crania in the United States National Museum collections: Non-Eskimo people of the Northwest coast, Alaska, and Siberia. By Aleš Hrdlička. Pp. 1-172. Apr. 6, 1944.

3172. The catfishes of Venezuela, with descriptions of thirty-eight new forms. By Leonard P. Schultz. Pp. 173-338, 5 figs., 14 pls. Feb. 11, 1944.

3173. Revisions of two genera of chalcid-flies belonging to the family Eupelmidae from North and South America. By A. B. Gahan. Pp. 339-369. Nov. 26, 1943.

3174. New species of American scolytoid beetles, mostly Neotropical. By M. W. Blackman. Pp. 371-399, 3 pls. Nov. 22, 1943.

3175. A revision of the Embioptera, or web-spinners, of the New World. By Edward S. Ross. Pp. 401-504, 151 figs., 2 pls. Jan. 19, 1944.

3176. Twelve new species of Chinese leaf-katydids of the genus Xiphidiopsis. By Ernest R. Tinkham. Pp. 505-527, 1 fig. Apr. 29, 1944.

3177. Parasitic copepods in the United States National Museum. By Charles Branch Wilson. Pp. 529-582, 15 pls. July 10, 1944.

\section{Volume 95}

Proceedings of the United States National Museum, vol. 95. Pp. i-viii (title page, advertisement, table of contents, and list of illustrations); pp. 1-613 (Proceedings papers 3178-3185); pp. 615-647 (index); 61 figs., 32 pls. 1947.

3178. New American cynipids from galls.' By Lewis H. Weld. Pp. 1-24, 2 pls. Apr. 15, 1944.

3179. A collection of birds from northern Guanacaste, Costa Rica. By Alexander Wetmore. Pp. 25-80, 4 pls. July 7, 1944.

3180. Studies in Neotropical Mallophaga (III): Tinamidae No. 2. By M. A. Carriker, Jr. Pp. 81-233, 29 figs. Oct. 10, 1944.

3181. The fishes of the family Characinidae from Venezuela, with descriptions of seventeen new forms. By Leonard P. Schultz. Pp. 235-367, 27 figs. Sept. 6, 1944.

3182. New genera and species of Oriental and Australian plant bugs in the United States National Museum. By Tsai-Yu Hsiao. Pp. 369-396, 1 fig. Aug. 5, 1944.

3183. New species of buprestid beetles from Trinidad. By W. S. Fisher. Pp. 397-409. July 22, 1944.

3184. The Fulgoroidea, or lanternflies, of Trinidad and adjacent parts of South America. By R. G. Fennah. Pp. 411-520, 11 pls. May 24, 1945.

3185. Summary of the collections of amphibians made in Mexico under the Walter Rathbone Bacon Traveling Scholarship. By Edward $H$. Taylor and Hobart M. Smith. Pp. 521-613, 4 figs., 15 pls. Jan. 30, 1945.

\section{Volume 96}

Proceedings of the United States National Museum, vol. 96 [not yet completed]. 3186. Review of the spider monkeys. By Remington Kellogg and E. A. Goldman. Pp. 1-45, 2 figs. Nov. 2, 1944.

3187. A revision of the American clingfishes, family Gobiesocidae, with descriptions of new genera and forms. By Leonard P. Schultz. Pp. 47-77, 1 pl. Dec. $30,1944$.

3188. New beetles of the family Eucnemididae from Central America and the West Indies. By W. S. Fisher. Pp. 79-93. May 8, 1945. 
Proc.

No.

3189. New lanternflies (Fulgoroidea) from South America. By R. G. Fennah. Pp. 95-104, 2 pls. May 9, 1945.

3190. The genus Fundella Zeller: A contribution toward a revision of the American pyralidoid moths of the family Phycitidae. By Carl Heinrich. Pp. 105-114, 3 pls. May 18, 1945.

3191. A new genus and two new species of percoid fishes from New Guinea, family Centropomidae. By Leonard P. Schultz. Pp. 115-121, 2 figs. Mar. 6, 1945.

3192. Three new sciaenid fishes of the genus Ophioscion from the Atlantic coasts of Central and South America. By Leonard P. Schultz. Pp. 123-137, 4 figs. Apr. 25, 1945.

3193. The ichneumon-flies of the genus Cryptanura Brullé, mainly tropical American. By R. A. Cushman. Pp. 139-176. May 23, 1945.

3194. Neotropical lanternflies of the genus Phrictus in the United States National Museum, with descriptions of four new species. By John S. Caldwell. Pp. 177-184, 4 pls. May 16, 1945.

3195. Hyporhamphus patris, a new species of hemiramphid fish from Sinaloa, Mexico, with an analysis of the generic characters of Hyporhamphus and Hemiramphus. By Robert R. Miller. Pp. 185-193, 1 fig., 1 pl. July 27, 1945.

3196. Notes on recently mounted reptile fossil skeletons in the United States National Museum. By Charles W. Gilmore. Pp. 195-203, 8 pls. Feb. 5, 1946.

3197. The onychophores of Panama and the Canal Zone. By Austin H. Clark and James Zetek. Pp. 205-213. Feb. 21, 1946.

3198. Echiuroid worms of the North Pacific Ocean. By Walter Kenrick Fisher. Pp. 215-292, 10 figs., 18 pls. Apr. 11, 1946.

3199. The osteology of the fossil turtle Testudo praeextans Lambe, with notes on other species of Testudo from the Oligocene of Wyoming. By Charles W. Gilmore. Pp. 293-310, 8 figs., 7 pls. Mar. 28, 1946.

3200. Eight new species of chalcid-flies of the genus Pseudaphycus Clausen, with a key to the species. By A. B. Gahan. Pp. 311-327. Nov. 22, 1946.

3201. New cerambycid beetles belonging to the tribe Disteniini from Central and South America. By W. S. Fisher. Pp. 329-333. Nov. 26, 1946.

3202. Machaeroides eothen Matthew, the sabertooth creodont of the Bridger Eocene. By C. Lewis Gazin. Pp. 335-347, 2 pls. Dec. 16, 1946.

3203. Review of some chalcidoid genera related to Cerocephala Westwood. By A. B. Gahan. Pp. 349-376, 2 pls. Dec. 31, 1946.

3204. A revision of the genera of mullets, fishes of the family Mugilidae, with descriptions of three new genera. By Leonard P. Schultz. Pp. 377-395, 5 figs. Dec. 5, 1946. 


\section{CIRCULARS ${ }^{1}$}

Circ.

1. Plan of organization and regulations. By G. Brown Goode. Pp. 1-58. 1881.

2. Circular addressed to friends of the Museum. By Spencer F. Baird. Pp. 1-2. 1881.

3. Circular in reference to petroleum collections. By S. F. Baird. Pp. 1-2. 1881.

4. Circular concerning the department of insects. By Spencer F. Baird. 1 p. 1881.

5. Establishment and officers. Pp. 1-2. 1881.

6. Classification and arrangement of the materia medica collection. By James M. Flint. Pp. 1-2. 1881.

7. A classification of the forms in which drugs and medicines appear, and are administered. By James M. Flint. Pp. 1-7. 1881.

8. Memoranda for collectors of drugs for the materia medica section of the National Museum. By James M. Flint. Pp. 1-2. 1881.

9. Circular in reference to the building-stone collection. By Spencer F. Baird. Pp. 1-6. 1881.

10. Two letters on the work of the National Museum. By Barnet Phillips. Pp. 1-10. 1881.

11. A provisional classification of the food collections. By G. Brown Goode. Pp. 1-22. 1881.

12. Classification of the collection to illustrate the art of taxidermy. By William $T$. Hornaday. Pp. 1-2. 1881.

13. Outline of a scheme of Museum classification. By G. Brown Goode. Pp. 1-4. 1881.

14. Circular requesting material for the library. By Spencer F. Baird. Pp. 1-3. 1881.

15. The organization and objects of the National Museum. Pp. 1-4. 1881.

16. Plans for the installation of collections. Pp. 1-2. 1881.

17. Contributions and their acknowledgment. 1 p. 1881.

18. List of publications of the United States National Museum. Pp. 1-12. 1881.

19. Classification of the materia medica collection of the U. S. National Museum, and catalogue of specimens. By James M. Flint. Pp. 1-45. 1883.

20. Request for specimens of drugs and information concerning them. By Spencer F. Baird. 1 p. 1883.

21. Circular relative to contributions of aboriginal antiquities to the United States National Museum. By Charles Rau. 5 pp. 1883.

22. Brief directions for removing and preserving the skins of mammals. By Wm. T. Hornaday. 7 pp., 4 figs. 1883.

23. Instructions for taking paper molds of inscriptions in stone, wood, bronze, etc. Prepared by A. P. Niblack. 5 pp. 1883.

24. Plan of a collection to illustrate the textile industries of the United States, to be exhibited at the World's Industrial and Cotton Centennial Exposition of 1884-1885, at New Orleans. By Romyn Hitchcock. Pp. 1-16. 1884.

25. Preliminary plan for a collection of the building and ornamental stones and rocks of the United States, to be exhibited at the World's Industrial and Cotton Centennial Exposition of 1884-1885, at New Orleans. By George P. Merrill. Pp. 1-2. 1884.

26. Plan for a collection of gems and precious stones, to be exhibited at the Cincinnati Industrial Exposition and the World's Industrial and Cotton Centennial Exposition of 1884-1885, at New Orleans. By F. W. Clarke. Pp. 1-2. 1884.

27. Directions for collecting, preserving, and transporting tortricids and other small moths. By C. H. Fernald. Pp. 1-3. 1884.

28. Directions for mound exploration. By Cyrus Thomas. Pp. 1-3. 1884.

29. Provisional plan for a collection of mammals to be exhibited at the World's Industrial and Cotton Centennial Exposition of 1884-'85, at New Orleans. By Frederick W. True. Pp. 1-27. 1884.

1 Circulars 1-18 reprinted in Proc. U. S. Nat. Mus., vol. 4; 19-23, vol. 6; 24-31, vol. 7; 32 and 33, vol. 8; 35, Rep. U. S. Nat. Mus. for 1886; 37, Proc. U. S. Nat. Mus., vol. 10. 
Circ.

30. A list of birds the eggs of which are wanted to complete the series in the National Museum, with instructions for collecting eggs. By Charles E. Bendire. Pp. 1-4. 1884.

31. Plan to illustrate the mineral resources of the United States and their utilization, at the World's Industrial and Cotton Centennial Exposition of 1884-1885, at New Orleans. By Fred. P. Dewey. Pp. 1-8. 1884.

32. Classification of the materia medica collection of the U. S. National Museum, and catalogue of specimens. By James M. Flint. (Revised and extended by Henry G. Beyer). Pp. 1-39. 1885.

33. Notes on the preparation of rough skeletons. By Frederic A. Lucas. Pp. 1-8, 12 figs.

34. Circular for the guidance of persons desiring to make exchanges of birds or birds' eggs with the National Museum. 1 p. 1886.

35. Concerning the lending of type specimens. By Spencer F. Baird. 1 p. 1886.

36. Circular concerning the department of antiquities. By S. P. Langley. 1 p., 5 pls. 1887.

37. Catalogue of the contributions of the section of graphic arts to the Ohio Valley Centennial Exposition, Cincinnati, 1888. By S. R. Koehler. 31 pp. 1887.

38. Contributions of the department of transportation and engineering to the Ohio Valley Centennial Exhibition, 1888. By J. Elfreth Watkins. Pp. 1-18. 1888.

39. The contribution of the section of Oriental antiquities to the Ohio Valley Centennial Exhibition. By Cyrus Adler. Pp. 1-7. 1888.

40. Description of exhibit made by the department of prehistoric anthropology in the National Museum at the Ohio Valley and Central States Exposition in Cincinnati, Ohio, 1888. By Thomas Wilson. Pp. 1-33, 50 figs. 1888.

41. Guide to a collection illustrating the families of mammals, exhibited in the Ohio Valley Centennial Exposition in 1888 by the U. S. National Museum. By Frederick W. True. Pp. 1-26. 1888.

42. Circular relating to prehistoric anthropology. By Thomas Wilson. Pp. 1-16, 4 figs. 1888.

43. To the correspondents of the U. S. National Museum. [With a view to securing accessions for the library.] By G. Brown Goode. 1 p. 1894.

44. To the correspondents of the U. S. National Museum. [With a view to securing publications for the library in exchange.] By G. Brown Goode. Pp. 1-8. 1894.

45. To the correspondents of the U. S. National Museum. [With a view to securing authors' separates and reprints for the library.] By G. Brown Goode. 1 p. 1894.

46. [On the proposed revision of Bulletin 22, relating to the flora of the District of Columbia.] By G. Brown Goode. 2 pp. 1895.

47. Circular in regard to the identification of specimens of mollusks by the National Museum. By G. Brown Goode. 2 pp. 1895.

48. Circular in regard to bones and teeth of the mastodon and mammoth. By Frederic A. Lucas. Pp. 1-4, 2 figs. 1897.

49. [Relating to the North American Violaceae.] By Frederick W. True. 1 p. 1899.

50. [Transmitting questions relating to birds and birds' eggs.] By Richard Rathbun. 3 pp. 1901.

51. Circular to accompany collections illustrating rock-weathering and soil-formation which have been prepared by the department of geology, U. S. National Museum, under direction of Dr. George P. Merrill, head curator. Pp. 1-3. Dec. 1, 1901.

52. Circular to accompany collections illustrating rock-weathering and soil-formation which have been prepared by the department of geology, U. S. National Museum. Pp. 1-2. 1928.

53. Mammoths and mastodons. By James W. Gidley. Pp. 1-5, 2 figs. Jan. 28, 1929. 


\section{Prepared by Gladys O. Visel}

The index that follows is intended as a finding-index to the titles and authors of the publicatons listed in the foregoing pages. It does not attempt to go beyond the titles to index the detailed contents of the papers, as this would require a work of many times this size. ${ }^{1}$ For example, under the locality California a user of the index would not be referred to every Museum publication that might include California in its scope. Localities are included only when they appear in the titles. The large categories America and North America have usually not been indexed even when they appear in the titles, as they are too numerous and general to make their indexing of any value. Countries of South America, Africa, Asia, Australia, etc., generally have not been included under the continent except where the latter appears in the title; these countries appear in their alphabetical place in the Index. In general, subjects are broken down into the main divisions of curatorial and research work with which the National Museum is concerned and which is reflected in its publications. Here again the user should not expect to find under any one subject a complete catalog of information. A general paper on insects, for example, might contain information on many families and groups, but since the names of these would not appear in the title of the paper as listed they would not appear in the index (except perhaps in other connections). A paper entitled "The Birds of Ecuador" would be indexed under Birds and under Ecuador, but not under $W$ arblers although this group might occupy a large portion of the paper; whereas a paper on "The Warblers of Ecuador" would be indexed under Birds, Warblers, under Warblers (see Birds), and under Ecuador, Warblers, but not under Ecuador, Birds. In other words, although this is a classified Index, the user must remember that in the natural-history sections entries have not been reassembled under the geographic groups for the sake of systematic completeness; he will find, for example, under South America, entries under Hymenoptera, Diptera, moths, etc., but these have not been assembled under Insects. The reader will find also that absolute uniformity of treatment has occasionally been sacrificed for the sake of brevity and expediency. An instance of this will be found in the class Insecta, which because of its size has been subdivided into its various orders; in other classes of animals this has not been done. Cross-references have been freely used to avoid duplication and to reduce the size of the index.

1 A comprehensive, detailed index of National Museum publications has been in preparation in the Editorial Office of the Museuin for several years and is completed to the year 1900. It is in the form of a 3-by-5 card file and comprises to date about 235,000 cards. It may be consulted in the Editor's Office, Smithsonian Building, by anyone interested. 


\title{
Key to Abbreviations of Series
}

\author{
B: Bulletin \\ C: Circular \\ CNH: Contributions from the National Herbarium \\ P: Proceedings \\ R: Annual Report \\ SB: Special Bulletin
}




\section{A}

Abbott, James Francis, P1221.

fishes collected in Manchuria, P1493.

Abbott, William Louis, R1891, pt. 3, No. 2; P973.

Abbott, W. L., collections: basketwork, Malaysian, P1631.

birds, Africa, east, Kilimanjaro region, P1411.

Aldabra and Assumption Islands, P953.

Aldabra, Assumption, and Gloriosa Islands, $\mathrm{P} 1008$.

Andaman and Nicobar Islands, P1288.

Asia, central, P1083, 1195.

Java Sea Islands, P2232.

Karimata Islands, P2512.

Kashmir, Baltistan, and L. dak, P1078.

Madagascar, P1118.

Seychelles, Amirantes, Gloriosa, Assumption, Aldabra, and adjacent islands, P1079.

Siam and Malay Peninsula, B172.

Sumatra, P1318, 2268, 2282.

birds' nests and eggs, Aldabra, P983.

crabs, Indian Ocean, P979.

herpetological collections, Haiti, P2543.

insects, Seychelles, Aldabra, Glorioso, and Providence Islands, P1119.

Lepidoptera, Africa, east, P1062.

Aldabra, Seychelles, and other east African islands, P1064.

Kashmir, P1065.

mammals, Africa, east, Kilimanjaro region, $\mathrm{P} 915$.

Baltistan and vale of Kashmir, P976.

Borneo, P1577, 1809.

Dutch East Indies, Karimata Islands, P1481.

Rhio-Linga Archipelago, P1485.

Sumatra, P1317, 1626, 2188.

Odonata, east Africa, P1046.

porpoises, Prodelphinus, skeletons and skulls, Indian Ocean, P982. reptiles and batrachians, East Africa, P970.

Aborigines, American. (See under Anthropology, Indians.)

Abrolhos Islands, birds collected by $\mathrm{Al}$ batross, P768, 798.

Abyssinia, Hoffman Philip ethnological collections, P1819.

Acanthocephalans, parasites of birds, P893; of fishes, P1560, 2346, 2977.

Acarina. (See under Arachnids.)

Acorns, gallflies producing galls on, P2440.
Actinians. (See under Sea anemones.)

Adler, Cyrus, R1892, pt. 3, No. 4; 1893, pt. 2, Nos. 8, 9; C39; P936.

Adler, Cyrus, and Casanowicz, Immanuel Moses, R1896, pt. 2, Nos. 4, 5 ; P1630.

Africa, batrachians from W. L. Abbott and W. A. Chanler, P970.

birds, Cameroons District, P1180.

Ethiopia and Kenya Colony, Frick Expedition, B153.

Francolinus, Chalcopelia, Cinnyris, Chalcomitra, Anthreptes, Estrilda, $H$ a l c y o $n$, Melittophagus, Colius, P2076.

German and British East, P1469. Kilimanjaro region, P1411.

Liberia, P1182.

Smithsonian-Chrysler Expedition, P2738.

blindsnakes, Congo Free State, P969. cestode from bustard, P1844.

chameleon, new, Kilimanjaro, P857.

Coleoptera, Tana River and Jobene

Range, P1094.

corals, French Somaliland, P1526.

crabs, fresh-water, new, P980.

crinoids of coasts, P1808.

crustaceans, P949, 1199.

Diplopoda, Gomphodesmidae, P1170

Polydesmoidea collected by W. A. Chanler, P1042; Oxydesmus from Congo, P1036; Strongylosomatidae, P1137.

Diptera, new, P1243.

earthworms, new, P2263.

ethnological collections from Kilimanjaro, R1891, pt. 3, No. 2.

fishes, collected by H. C. Raven in Lake Tanganyika, P2998; Liberia, P3152; U. S. Eclipse Expedition, P2294.

fluke from monkey and roundworms from animals, P2783.

gecko, Tanganyika Territory, P2720.

Hymenoptera, parasitic, Microgasterinae, P2252.

implements, flint, Fayum, Egypt, R1904, pt. 2, No. 3.

Insecta, Arachnida, and Myriapoda of U. S. Eclipse Expedition, P951.

Lepidoptera, P1062, 1098.

lizard, scincoid, new, P862.

mammals, Kilimanjaro, P814, 915;

Smithsonian-Chrysler Expedition, P2738; Tana River, P954.

mammals in National Museum, B99: Insectivora, Chiroptera, Carnivora, pt. 1; Rodentia, Lagomorpha, Tubulidentata, pt. 2; Primates, Artiodactyla, Perissodactyla, Proboscidea, Hyracoidea, pt. 3.

mancala, national game, R1894, pt. 2 , No. 2 . 
Africa (continued).

mollusks, Achatinidae, P2960; U. S. Scientific Expedition, P940.

Myriapoda, collected bv H. Chaetelaine in Loanda, P968, 969; Oxydesmus, Congo, P1036.

Odonata, P1046, 1047.

Orthoptera, Mantidae and Phasmidae, P1910.

reptiles and amphibians in National Museum, B151; Smithsonian-Firestone Liberian collection, P3125.

reptiles from W. L. Abbott and W. A. Chanler, P970.

sand-barites, Kharga, P1726.

sword blades and other weapons, corrugation in, P703.

vertebrates collected by SmithsonianChrysler Expedition, P2738.

weaverbird, new, P1370.

(See also under South Africa and Southwest Africa.)

African islands, east, Lepidoptera, P1064.

Ainos, Japan, R1890, pt. 3, No. 6.

Alabama, crayfishes from caves, P312?. meteorites from, P1249, 1508.

plant life, CNH6.

plants, fossil, collected by I. C. Russell at Black Creek, near Gadsden, P688.

reptile, mosasauroid, Cretaceous, P1870.

snake, Eocene, new, P1164.

Alaska, Alepidosaurus aesculapius, P342. amphipods, Pribilof Islands, P1998.

annelids, collected by R. A. Bartlett, P2601; Nereis (Ceratonereis) alaskenis, P2397.

Aspidophoroides güntheri, $\mathrm{P} 487$.

Bathymaster jordani, P753.

birds, collected by C. H. Townsend, P960; notes on, P274.

botany, Yakutat Bay, CNH3, No. 6. brachiopod, Cymbidium, Silurian, P2649; Harpidium, fossil, P2569.

Brooksina, Upper Silurian, P2414.

Cerithiopsis, new, P1711.

Chinese relics, P899.

Coast Indians, R1888, pt. 3, No. 1; P718.

crania, non-Eskimo, P3171.

Crustacea and one worm, P459.

crustaceans, schizopod, in National Museum, P1591.

ethnological specimens from Ugashagmut tribe, Ugashak River, Bristol Bay, P364.

fishes, Anarrhichas lepturus, witl notes on other Anarrhiches, P80; catalog, P225.

collected by Nichols, P255, 387 .

genera and species, P100.

new, collected by Yukon, P210; collected by Albatross, P795.

Uranidea microstoma, P121.
Alaska (continued).

flies, two-winged, Colichopodidae, P2446, 2490.

flora, fossil, review, p998.

Lower Jurassic, Matanuska Valley, P2158.

Miocene, P300.

gasteropod, Bathmopterus, Silurian, P2763.

grasses, CNH13, pt. 3.

Hippoglossus vulgaris, Unalaska and St. Michaels, P70.

hydroid, corymorphalike, P1343.

Hydroida, P1171.

Indians, crania, P2480.

jadeite implements of Innuits, P395.

lichens collected by T. H. Bean, P397.

Lycodes turneri, P59.

mammals, collected by C. L. McKay at Bristol Bay, P564.

Melanetta fusca in, P411.

mollusks, new, P1.

Pisidium, with field notes by G. D. Hanna, P2160.

Pycnodesma, Silurian, P2692.

mountain sheep, Ovis montana dalli, P399.

needlecases, decorative designs of, study in history of conventional designs, P1616.

pallasite, Cold Bay, P2425.

Pentacrinus, fossil, P2577.

petrel, new, P339.

plants, collected by Albatross, P772;

by L. McKay, Nushagak, P513; fossil, P679.

porpoise, Phocaena dalli, P495.

rockfish, Sebastichthys brevispinis,

P1027.

snow bunting, new, P412.

Stichaeus punctatus, St. Michaels, P47.

whitefish, Coregonus nelsonii, P407. Coregonus pusillus, P748.

Alaskan region, limpets and chitons, report on, P48.

Albatross collections: actinians, $\mathrm{P} 930$.

Alcyonaria, Hawaiian Islands, P1624. Japanese waters, P1923.

Amphipoda, west coast, North America, P1654.

annelids, including one new genus, P594.

Philippine Islands, B100, vol. 1, pts. 8,9 ; vol. 6 , pts. 2,5 .

ascidians, Philippine Islands, B100, vol. 1, pt. 2.

barnacles, China Sea and Philippine Islands, P1904.

batrachians, cruise of 1887-88, P769. birds, Alaska, collected by C. $\mathbf{H}$. Townsend, P960; by J. E. Benedict and $W$. Nye, P420. 
Albatross collections, birds (continued). Cozumel Island, Yucatán, P539. Galápagos Islands, P767.

North America, western coasts and adjacent islands, P799.

north Pacific Ocean, Bering, Okhotsk, Japan, and eastern seas, P1727.

West Indies, Santa Lucia; Brazil, Abrolhos Islands; Straits of Magellan, P768.

bird skeletons, Abrolhos Islands, Brazil, Straits of Magellan, and Galápagos Islands, P798.

Brachiopoda, 1887-88 cruise, P773.

Hawaiian Islands and northwest America, P1032.

Brachyura, Norfolk, Va., to San Francisco, Calif., P1162.

bryozoans, Philippine Islands, B100, vol. 9.

cephalopods, northwestern Pacific, P2310.

chaetognaths, Philippine Islands, B100, vol. 1, pt. 4.

chitons, northwest Pacific, P2223.

coelenterates, Philippine Islands, B100, vol. 1 , pts. 3 , 5 ; vol. 6 , pt. 3 . crabs, Lithodidae, P1016.

Philippine Islands, P2044, 2067, 2135.

west coast of America and Sandwich Islands, P933.

crinoids, Hawaiian Islands, P1608.

Philippine Islands, P1756, 1798.

stalked, Gulf of Mexico and Caribbean Sea, P547; Philippine Islands, P1793.

crust aceans, Philippine Islands, P2129; Stomatopoda, P1017.

Diatomaceae, Atlantic Ocean off Delaware Bay, P937.

diatoms, Pacific Ocean, CNH10, pt. 5; Philippine Islands, B100, vol. 6 , pt. 1.

Echini, Caribbean Sea and Gulf of Mexico, P491; Gulf of Mexico, P544.

echinoderms, Philippine Islands, B100, vols. 3 , 5 ; vol. 6 , pt. 4 ; vol. 14 , pt. 1 .

fishes, Alaska, P795.

apodal, tropical Pacific, P856.

Atlantic SB2; northwestern, P1012-1014.

Bahia, Brazil, P829.

British Columbia, P787.

California, southern, P2075.

Celebes, P1917.

Chile to Uruguay, P2133.

East Indies, B100, vol. 1, pt. 7.

Galápagos Islands and Colombia, P770.

Galápagos Islands and Panama, P840.

Heteromi, P1013.

Japan, P1213, 1909, 2149.
Albatross collections, fishes (continued). new, from list of aberrant, P1115. North America, Pacific coast, P797.

Philippine Islands, B100, vol. 1, pt. 7 , vols. $7,8,10-14$, pt. 2 ; P1822, 1853, 1868, 1872, 1877, $1896,1899,1924,1948,1997$, 3032, 3106.

Santa Barbara Islands and Gulf of California, P880.

St. Lucia, Port Castries, P789.

Straits of Magellan, P2133.

Sulu Archipelago, P2003.

Uruguay to Chile, P2133.

flounders, Gastropsetta frontalis and Cyclopsetta chittendeni, P1030.

flounders and soles, Japan, P2082.

Foraminifera, Hawaiian Islands, P1603.

Pacific, tropical, B161.

Philippine Islands, B100, vol. 1, pt. 6, vol. 4; P1759, 1898, 1973, 2172.

Recent, R1897, pt. 2, No. 1.

fossils, Mesozoic, St. Pauls and St. Peters Islands, P793.

holothurians, north Pacific coast of North America, P1558; northwestern Pacific, P2073.

Hydroida, B100, vol. 6 , pt. 3 .

hydromedusae, siphonophores, and ctenophores, B100, vol. 1, pt. 5. insects, 1887-88 cruise, P771.

isopods, northwestern Pacific, P1701. medusae, Caribbean Sea and Gulf of Mexico, P528; Philippines, P1931.

medusae and siphonophorae, northwestern Pacific, P1946.

mollusks, 1887-88 cruise, P773, 813, 849.

Galápagos Islands, P942.

Hawaiian Islands and northwest America, P1032.

Philippine Islands, B100, vol. 1, pt. 1, vol. 2 , pt. 5, vol. 6, pts. 6-9; P1978, 1983.

southeast coast of U. S., P2667.

ophiurans, Philippine seas, B100, vol. 5.

plants, Alaska, P772.

America, western coast, CNH1, No. 5 (2d art.).

Philippine Islands, B100, vol. 6, pt. 1.

Socorro and Clarion Islands, P801. pteropods and heteropods, Norfolk, Va., to San Francisco, Calif., P943. reptiles, $1887-88$ cruise, P769; Clarion and Socorro Islands and Gulf of California, P800.

Salpidae, B100, vol. 2 , pt. 1.

Scyphomedusae, Philippine Islands, and Malay Archipelago, B100, vol. 1 , pt. 3.

shells, west America, P849. 
Albatross collections (continued).

sponges, northwestern Pacific, P2247, 2935.

Philippine Islands, B100, vol. 2, pt. 4; P1702.

starfishes, Philippine Islands, B100, vol. 3; P1827, 1944, 2022.

tunicates, Philippine Islands, B100, vol. 1 , pt. 2 ; vol. 2 , pts. 1-3.

turbellarians, Philippine Islands, B100, vol. 1, pt. 10.

Albicore. (See under Fishes.)

albinism in birds, P733.

Alcyonarians:

California, P1658.

Hawaiian Islands, P1624.

Japan, P1923.

Aldabra, birds collected by W. L. Abbott, P953, 973, 1008, 1079.

birds' nests and eggs collected by W. L. Abbott, P983.

fruit bat, Pteropus aldabrensis, P948. insects collected by W. L. Abbott, P1119.

Lepidoptera collected by W. L. Abbott, P1064.

natural history of, $\mathrm{P} 973$.

Aldrich, John Merton, P2099, 2446, 2457, 2466, 2474, 2534, 2555, 2624, 2639, 2648, $2703,2705,2729,2746,2747,2753,2764$, $2799,2808,2812,2844,2852,2855,2910$, 2911, 2920, 2932.

Aldrich, J. M.; Van Duzee, Millard Carr; and Cole, Frank Raymond, B116.

Aldrich, J. M., and Webber, Ray Trask, P2486.

Aleutian Islands, birds, new genus and species, P1539.

fishes, cottoid, new genus and species, P3038.

starfishes, new genus, P3061.

Alexander, Charles Paul, P1953, 1966, 2080, 2103, 2420, 2500, 2605, 2698, 2778.

Alexander, C. P., and McAtee, Waldo Lee, P2344.

Algae. (See under Plants and Fossils, plants.)

Alicata, Joseph Everett, P2928.

Alicata, J. E., and Schwartz, Benjamin, P2956.

Allen, Glover Morrill, and Miller, Gerrit S., Jr., B144.

Allen, H. N., Korean collection, R1891, pt. 3, No. 3 .

Allen, Harrison, B43; P786, 807, 824, 912-914, 919, 920, 1099, 1100.

Allen, Harry Willis, P2610.

Allen, H. W., and Jaynes, Harold Andrus, P2814.

Allen, Joel Asaph, P850.

Alligator, fossil, Hell Creek beds, Montana, P1860.

Allophanite, P2118.

Altai Mountains, mammals of Smithsonian-Harvard Expedition, P1990.

Alunite, P2145.

Amaral, Afranio do, P2596.
Amazon Basin, Mulford Biological Exploration, beetles, Cleridae, P2674; nematodes, P2526; termites, P2615.

Amazon River, birds, dendrocolaptine, new genus, P618; new species and genera, P660.

fishes collected by J. B. Steere, with note on Pimelodus clarias, P1503. mussels, new, fossil, Peru, P2748.

Picolaptes, new species, P591.

Amberfishes. (See under Fishes.)

Amesite, from Chester, Mass., P2342.

Amirantes, birds collected by W. L. Abbott, P1079.

Ammoniojarosite, from Utah, P2758.

Amory, Copley, Jr., birds collected by in northeastern Siberia, P2255.

Amphibians:

Africa, east, B151; P970, 2738.

Amblystoma copeianum, Indiana, P512.

Amblystoma mexicanum, habits and rearing, P276.

Ambystoma annulatum, Arkansas, P1023.

Amphiuma in Virginia, P1150.

A mphiuma tridactylum, cestode from, P2926.

anuran, Mexican, P3093.

Arkansas, P1023.

axolotl, P276.

Bahama Islands, P645.

Bufo, new, Texas, P715.

bullfrog, new, Florida and Gulf coast, P1252.

California, southern, P2770.

cestode, Crepidobothrium amphiumae from, P2926.

China, P2562.

Costa Rica, P1471.

Cuba, P1406, 2205.

Desmognathus, P2211.

Fanning Islands, B7.

Florida, P1252.

frogs, P1156, 1397, 2767.

Gulf coast, United States, P1252.

Haiti, P2543.

Hawaiian Islands, B7.

helminths parasitic in, P2940.

Hispaniola, B177.

Hyla regilla, variations, $\mathrm{P} 1156$.

Indiana, P512.

Iowa, P1874.

Jamaica, P2767.

Japan and adjacent territory, B58.

Labrador, P353.

Leurognathus, P2211.

Liberia, P3128.

Lower California, B7.

Mexico, B160; P559, 3093, 3185.

Michigan, Gogebic County, P2109. nematodes parasitic in, P2947.

new species in National Museum, P299.

Nicaragua, P1538.

North Carolina, P1457.

Peru, P2352. 
Amphibians (continued).

Philippine Islands, P1397, 1578.

Puerto Rico, R1902, pt. 2, No. 2.

salamanders, P1023, 1457, 1538, 1874, 2112, 2211, 2770.

cave, P894, 1443.

Holbrook's, rediscovery, P1321.

Siredon lichenoides, observations on, P199.

Spelerpes bilineatus, P2112.

Spelerpes maculicaudus, life history, P1443.

tadpoles, synopsis and description, P2756.

tailless, Mexican, B160.

Texas, B17; P715.

toads, P1406, 1578.

discoglossid, North American, P1178.

horned, ejection of blood from eyes, P907.

toads, tree, Costa Rican, P1471.

(See also under Batrachians and under Fossils.)

Amphibole, from Idaho, P2373.

Amphipods. (See under Crustaceans.)

Amur, pointed bark canoes, R1899, pt. 2, No. 4.

Amur River Basin, fishes, cobitoid, review, P1533.

Anamba Islands, birds, B98.

Anatomical preparations, arsenic acid used for protection, P12.

Andaman Islands, birds collected by W. L. Abbott and C. B. Kloss, P1288; mammals, P1269.

Andersen, Knud, P1440.

Anderson, Robert Van Vleck, fishes collected on Tanega and Yaku, southern Japan, P1462.

Andes, fossil plants, bearing on age of uplift, P2229; Pilea, CNH26, pts. 8, 10.

Andesites, hornblende, from Bogosloff Island, P479.

Andorite-bearing silver ore, P2411.

Andrews, Ethan Allen, P852, 1791.

Andrews, Hazel, and Cockerell, Theodore Dru Alison, P2141.

Anglers. (See under Fishes.)

Anglesite, notes on, P2345.

Animal products, United States, commercial statistics, June 30,1877, B14, pt. 3.

Animal resources, classification of collection at International Exhibition of 1876, B6, 14.

Annandale, Nelson, P1690, 1702, 1712, 1737, 1771, 1839.

ANNELIDS:

Alaska, P2601.

Albatross collections. (See under Albatross.)

America, Arctic, B15; northeast coast, P76, 168, 534.

Bermudas, B25, pt. 7 .

Brazil, P2347.

exhibit of, sent to International Fisheries Exhibition at London, B27, pt. B.
AnNelids (continued).

gephyreans, northeast coast, P76.

Kerguelen Island, B3.

leeches in National Museum, P1160. marine, in National Museum, P3142.

$\mathrm{P}$ a c if i c Ocean, north, echiuroid worms, P3198.

Philippine, B100, vol. 1, pts. 8, 9; vol. 6 , pts. 2,5 .

sipunculids, eastern coast of North America, P1959.

(See also Oligochaetes, Polychaetes; also under Fossils.)

Anoplura. (See under Insects.)

Antbirds. (See under Birds.)

Anteater. (See under Mammals.)

Antelopes. (See under Mammals.)

Anthophyllite. (See under Mineralogy.)

Anthozoans, American, northeast coast,

P76; Kerguelen Island, B3.

Anthropology, Abyssinia, P1819.

Africa, R1891, pt. 3, No. 2; 1894, pt. 2, No. 2; P703.

Ainos of Yezo, Japan, R1890, pt. 3, No. 6.

Alaska, R1888, pt. 3, No. 1; P364, $395,718,899,1616,3171$.

Amur pointed bark canoes, R1899, pt. 2, No. 4.

antiquities, aboriginal American, in National Museum, C21; concerning the department of anthropology, C36.

Arizona, R1901, pt. 2, No. 4; B87; P2856, 2930.

armor, primitive American, R1893, pt. 2, No. 5 ; Philippine, B137.

arrowpoints, prehistoric, R1897, pt. 2, No. 7.

art, Buddhist collection in the $\mathrm{Na}$ tional Museum, catalog, P2371.

Catlin Indian paintings, R1885, pt. $5 ; 1890$, pt. 3 , No. 8.

ecclesiastical, in National Museum, P2287.

Eskimo, R1895, pt. 2, No. 2.

Oceania, design areas, P2896.

origin of art as manifested in works of prehistoric man, R1896, pt. 2, No. 2.

Roman mosaic in National Museum, P393.

artifacts, scored bone, central Great

Plains, P3141.

Asiatics, crania, P2480.

Australians, crania, P2696.

Basilan Island, P1566.

basketry, aboriginal American, R1884, pt. 3, No. 2; 1902, pt. 2, No. 1 .

Anyam Gila (mad weave), P1672. Basket Maker, New Mexico, P2933. bolo case from Basilan Island, P1516.

directions for collectors of American, B39p. 
AnTHROPOLOGY, basketry (continued). Malaysian, P1631, 1672.

Bathurst, Cape, P705.

Betatakin, excavation and repair, P2828.

beverages, pulque of Mexico, P1579.

bolo case, basketry, Basilan Island, P1566.

boomerang, study of, P724.

bows, Eskimo, in National Museum, R1884, pt. 3, No. 3 .

brains and brain preservatives, P1451.

Brazil, Purus River, R1901, pt. 2, No. 5.

British Columbia, R1888, pt. 3, No. 1; P709.

buffalo motive in decorative design, Middle Celebes, P2895.

Burial caves, Crump Cave (Blount County, Ala.), R1892, pt. 3, No. 5; Szechwan, China, P2916.

Bushmen, crania, P2696.

California, R1900, pt. 2, No. 1; P932.

canoes, Kutenai and Amur, R1899, pt. 2, No. 4.

Carthage, P393.

casts of heads of Indian children, Hampton Institute, Va., P79; of Indian prisoners at Fort Marion, St. Augustine, Fla., P29.

Celebes, Middle, P2895.

Central America, P1887.

Chaclacayo trephined skull, P531.

China, R1893, pt. 2, No. 2; Szechwan (ancient caves), P2916.

Chinese relics in Alaska, P899.

cloth fragment from mound in Ohio, P347.

collectors, instructions to, B39p, 39q.

Columbia River, P244, 2732.

copper, overlaying by American aborigines, P1015.

Costa Rica, P11.

cradles of American aborigines, R1887, pt. 3, No. 1.

crania, human, in National Museum, P2480, 2631, 2696, 2845, 3076, $3131,3171$.

cranial fossae, measurements, P1521. Cumberland Sound, B15.

deformation, artificial, of children, R1887, pt. 3, No. 2 .

department, exhibit at Pan American Exposition, Buffalo, R1901, pt. 2, No. 1.

designs, buffalo motive, Middle Celebes, P2895; design areas in Oceania, P2896; history of conventional designs, P1616.

District of Columbia, P777.

divination, implements, R1896, pt. 2 , No. 3.

Dominican Republic, B147, 156.

drilling, primitive methods, R1894, pt. 2, No. 5.
ANTHROPOLOGY (continued).

drum, Naskopie Indians, Hudson Bay Territory, P736.

Easter Island, R1889, pt. 3, No. 2; 1897 , pt. 2 , No. 4.

Egypt, R1904, pt. 2, No. 3; P2528.

Elden Pueblo pottery, P2930.

Eskimo collection, catalog, R1887, pt. 3, No. 5.

Eskimos, bows in National Museum, R1884, pt. 3, No. 3.

crania, P2480, 3131.

Cumberland Sound, B15.

graphic art, R1895, pt. 2, No. 2.

harpoon, east Greenland, P702.

lamp, R1896, pt. 2, No. 5.

strike-a-light, P705.

Ugashagmut tribe, ethnological specimens, P364.

ulu, R1890, pt. 3, No. 4.

ethno-conchology, R1887, pt. 3, No. 4.

ethnological collections, Kilimanjaro, east Africa, R1891, pt. 3, No. 2.

ethnology of Coast Indian tribes, P718.

Europe, north, R1891, pt. 3, No. 7.

fire, strike-a-light, Eskimo, P705.

fire as agent in human culture, B139.

fire-making apparatus in National Museum, R1888, pt. 3, No. 4; P2735.

Florida, P966; casts of heads of Indian prisoners held at Fort Marion, St. Augustine, Fla., P29.

food of Klamath Indians, R1892, pt. 2, No. 3.

games, cards, Japanese, P836.

chess and playing cards, R1896, pt. 2, No. 3.

Chinese, R1893, pt. 2, No. 2.

dice and dominoes, $\mathrm{Ch}$ in es $\epsilon$, R1893, pt. 2, No. 2.

mancala, Africa, R1894, pt. 2, No. 2.

Great Plains (central), P3141.

Greek medical collections in $\mathrm{Na}$ tional Museum, P2528.

Greenland, east, P702.

Gulf States (Indian crania), P3076. harpoons, American, R1900, pt. 2, No. 2; Eskimo, east Greenland, P702.

heads, casts of Indian, P29, 79.

heating utensils in National Museum, B141.

Hopewell pottery, P2963.

Hopewellian remains near Kansas City, Mo., P3045.

Hottentots, crania, P2696.

house-building, evolution of among Navajo Indians, P902.

houses, Kwakiutl Indians, P709. pit, Luna, N. Mex., P2280; village site on Columbia River, Wash., P2732. 
AntHROPOLOGY (continued).

Hudson Bay Territory, P736.

implements, flint, Fayum, Egypt, R1904, pt. 2, No. 3 ; Indian Territory, R1901, pt. 2, No. 2.

jadeite, Innuit, P395.

stone, from District of Columbia, P810; from India, R1892, pt. 3, No. 6.

India, R1892, pt. 3, No. 6.

Indian medical exhibit in National Museum, P2582.

Indians, Alaska, crania, P2480; Coast tribes, R1888, pt. 3, No. 1; P718.

Algonkin, crania, P2631.

American, skulls, P1641.

Amur, canoes, R1899, pt. 2, No. 4.

antiquity in America, R1865, pt. 2, No. 8.

Apache, White Mountain, ruins, P2856.

Basket Maker, baskets from New Mexico, P2933; crania, P2845.

British Columbia, Coast tribes, R1888, pt. 3, No. 1.

Caddoan and Californian, crania, P2631.

casts of heads, P29, 79.

Catlin Indian paintings, R1885, pt. $5 ; 1890$, pt. 3 , No. 8 .

Chinnook names of salmon, P244.

Dominican Republic, B156.

Gulf States, crania, P3076.

Havesu-pai, P859.

Hopi, R1900, pt. 2, No. 5 ; P2235.

Innuits, jadeite implements, P395.

Iroquois, crania, P2631.

Klamath, food, R1892, pt. 2, No. 3 ; plants used by, CNH5, pt. 2.

knives, R1897, pt. 2, No. 5.

Kutenai canoes, R1899, pt. 2, No. 4. Kwakiutl, R1895, pt. 2, No. 1 ; P709. matting from Louisiana, R1888, pt. 3, No. 7.

Mendocino County, Calif., plants used by, $\mathrm{CNH} 7$, pt. 3.

Mississippi, excavations, P2898.

Naskopi (Nagnagnot), drum, P736.

Navajo, belt-weaver, P860; crania, P2845; house-building, P902; shoemaker, P697; tanner, P683.

Pueblos, crania, P2845; culture, B87.

Purus River, Brazil, R1901, pt. 2, No. 5.

Quillehute, taking surf-smelt, P112.

Sahaptin, Salish, Shoshonean, and Siouan, crania, P2631.

Wolpai, maid of, P889.

Indian Territory, Afton, R1901, pt. 2, No. 2.

inscriptions, instructions for taking paper molds, C23.

inventions, history of, synoptic series of objects in National Museum, P2404.
Anthropology (continued).

Japan, R1890, pt. 3, No. 5; R1891, pt. 3, Nos. 4-6.

Kansas, Wyandotte County, P3091.

kitchen middens, Costa Rica, P11; St. Thomas and St. Croix, P2248; Westchester, N. Y., P351.

Klamath Indians, plants used by, CNH5, No. 2.

knives, man's, among I n di a $\mathrm{n}$, R1897, pt. 2, No. 5; prehistoric, R1897, pt. 2, No. 7 ; woman's ulu, R1890, pt. 3, No. 4.

Korea, R1888, pt. 3, No. 5; 1891, pt. 3, No. 3; P2168.

lighting utensils, lamp of the Eskimo, R1896, pt. 2, No. 5 ; in National Museum, B141; strike-alight, P705.

Louisiana, R1888, pt. 3, No. 7 ; P2963.

Malaysia, P1631, 1672.

Medeba mosaic map of Palestine, drawing in National Museum, P2111.

medicine, ancient Egyptian, Greek, and Roman collections in $\mathrm{Na}$ tional Museum, P2528.

Indian, exhibit in National Museum, P2582.

magic, collection in National $\mathrm{Mu}$ seum, P2528.

psychic, collection in National Museum, P2528.

Mexico, P932, 1579, 1887, 2409.

Mississippi, excavations at prehistoric Indian village site, P2898.

Missouri, Kansas City, P3045; Platte and Clay Counties, B183; Ste. Genevieve County, P2042.

molds, paper, instructions for taking, C23.

money, primitive, R1887, pt. 3, No. 4. mosaic from Carthage, Roman, in National Museum, P393.

mound exploration, directions, C28. mounds, burial, Japan, R1891, pt. 3, No. 5.

Ohio, fragment of cloth, P347.

shell, Florida, P966; New Brunswick and New England, P2229; Westchester, N. Y., P351.

Mount Vernon, stone age at, P730.

museum, classifications and arrangement of exhibits, R1901, pt. 2, No. 3.

mythology, Shinto, Japan, R1891, pt. 3, No. 4.

naval architecture, European, R1891, pt. 3, No. 7.

needlecases, decorative designs, study in history of conventional designs, P1616.

Negroes, crania, P2696.

New Mexico, B87; R2280, 2933.

New York, Westchester, shell beds, P351.

non-Eskimo crania, P3171.

Oceania, P2896. 
AnTHRopology (continued).

Ohio, P347.

onyx marbles, ancient uses, R1893, pt. 2, No. 3 .

Paleolithic period in District of Columbia, P777; in North America, R1888, pt. 3 , No. 8 .

Palestine, P2111.

Panama, southeastern, B134.

Paris Exposition, R1890, pt. 3, No. 10. patera of Rennes, R1894, pt. 2, No. 3. Peru, P2275, 3160.

Philip Abyssinian ethnological collection, P1819.

Philippine Islands, B137.

physical anthropology, directions for collecting information and specimens, B39r.

pipes and smoking customs among American aborigines, R1897, pt. 2, No. 2.

plants, aboriginal uses, B39j; CNH5, pts. 2, 3; CNH7, pt. 3.

Potomac tidewater region, P776.

pottery, Dominican Republic, B156. Elden Pueblo, P2930.

Hopewell type, P2963.

mortuary, Korean, R1888, pt. 3, No. 5.

roulette for decorating, P3091.

pre-Columbian anthropology, P2275.

prehistoric anthropology, circular relating to, C42; exhibit of at Ohio Valley Centennial Exposition, Cincinnati, C40; study of, R1888, pt. 3 , No. 6.

prehistoric man, origin of art, R1896, pt. 2 , No. 2 .

publications of Charles Rau, list, P253.

Pueblos, Upper Gila River region, N. Mex. and Ariz., P87.

religion, Biblical antiquities, R1896, pt. 2, No. 4.

Brahmin temple, model, P1921.

Budda, bronze, R1889, pt. 3, No. 8.

Buddhist art, R1904, pt. 2, No. 2; P2371.

censers and incense of Mexico and Central America, P1887.

ceremonial objects in the National Museum, B148; R1899, pt. 2, No. 5; P1630, 2432.

ecclesiastical art in the National Museum, P2287.

Japan, dragon-god, P2587.

Jewish ceremonial objects, R1899, pt. 2, No. 5 ; P1630.

Korean sorceress, paraphernalia in National Museum, P2168.

museum collections to illustrate history and ceremonials, R1893, pt. 2, No. 9.

Parsee ceremonial objects in $\mathrm{Na}$ tional Museum, P2432.

rosaries in National Museum, P1667.
Anthropology, religion (continued). Shinto, Japan, R1891, pt. 3, No. 4. shofar, R1892, pt. 3, No. 4; P936.

Rennes, R1894, pt. 2, No. 3.

Roman medical collections in $\mathrm{Na}$ tional Museum, P2528.

roulette, prehistoric, W y a n d o t t e County, Kans., P3091.

St. Croix, P2245.

St. Thomas, P2245.

seals, Oriental, in National Museum, P2630.

Siberia, P3171.

skeletal remains, Peru, P3160; Platte and Clay Counties, Mo., B183.

skin-dressing, R1889, pt. 3, No. 3.

skulls, American Indian, with low forehead, P1641; Chaclacayo trephined, P531.

slings, pre-Columbian America, Peru, P2275.

sorceress, Korean, paraphernalia in National Museum, P2168.

spearheads, prehistoric, R1897, pt. 2 , No. 7.

stone age, at Mount Vernon, P730; man in America, R1888, pt. 3, No.8. strike-a-light, Eskimo, P705.

swastika, R1894, pt. 2, No. 6.

swords, corrugation in Af rican blades, P703.

Tasmanians, crania, P2696.

throwing-sticks, Mexican and Californian, P932; in National Museum, R1884, pt. 3, No. 1.

Tibet, R1893, pt. 2, No. 7.

transportation, primitive, R1887, pt. 3, No. $3 ; 1894$, pt. 2 , No. 1 .

Tuxtla statuette, jade of, P2409.

Utah, Basketmakers, crania, P2845.

Virginia, P79, 730.

weapons, primitive, Philippine, B137.

weaving, Navajo belt-weaver, P860; primitive frame, R1899, pt. 2, No. 2.

White Mountain Apache Indian ruins, exploration, P2856.

Antigua, birds collected by Fred A. Ober, P35.

Antillean region, crabs, new, P986.

mollusks, new marine, P3161.

Tertiary fossils, P1110.

Antilles, Lesser, birds collected by F. A. Ober, P61; new honey-creepers, with synopsis of Certhiola, P478.

Antilles, Solenidae, synopsis, P1185. termites, new, P2441.

Antiquities. (See under Anthropology.)

Ants. (See under Insects, Hymenoptera.)

Apaches, White Mountain ruins, P2856.

Aphaniptera. (See under Insects.)

Aphids. (See under Insects, Hemiptera.)

Apterygota. (See under Insects.)

ARACHNIDS:

Acarina, P1382, 1553.

Africa, west, P951. 
ARAchnids (continued).

America, Arctic, Howgate Polar Expedition, B15.

Araneae, temperate North American, P782:

Arizona, P1223, 1284.

British Columbia, collected by Currie, Caudell, and Dyar, P2143.

China, P2481.

Dermacentor, key to North American species, P2945.

Dermacentor halli from Texas peccary, P2945.

Mexico, P2730.

mites, P1382, 1553, 2394, 2971; chigger mites, P2908, 2970; dermanyssid, P2459.

Nearctic, B72; P2394.

Ohio, P950.

Panama, P2970.

Parasitoidea, new, P2971.

Phalangiidae, Ohio, P950.

Puerto Rico, P1253.

scorpions, United States and Mexican, P2730.

spiders, B72; P950, 1223, 1253, 1284, 2481.

red, American and European species likely to be introduced, P2303; new species, P2167.

Tetranychidae, Nearctic, P2394.

tick from Texas peccary, P2945.

Trombicula, Panama, with key to New World adults, P2970.

Trombiculinae, New World, P2980. Archeology. (Papers on archeology are included with those on anthropology, but they are not listed separately under Archeology.)

Arctic Alaska, crustacean and worm, P459.

Arctic America, birds and eggs, P865; Howgate Polar Expedition, natural history, B15.

Arctic region, limpets and chitons, P48.

Arctic seas, mollusks collected by L. M. Turner, P561.

Argentina, annelids, polychaetous, P2797. birds, B133.

fishes, P1482.

insects, Tertiary, P2602.

isopod, Idotheidae, Rio de la Plata, P1811.

plants, Tertiary, P2743.

Argo, Naomi George, and Melander, Axel Leonard, P2501.

Arizona, archeological field work, Museum-Gates Expedition, R1901, pt. 2, No. 4 ; B87.

batrachian and reptile from Trias, P1353.

birds, fossil, P2495.

birds' nests and eggs, P663.

fishes, Colorado Basin, P1131. obtained by W. L. Carpenter, Gila River, P754.

fossil wood, Araucarioxylon arizonicum, P676.

711175-17-13
Arizona (continued).

insects, lower Permian, Grand Canyon, P2695; Triassic, Petrified Forest National Monument, P3033.

jellyfish, pre-Cambrian, P3104.

mammal remains from prehistoric village sites, P1500.

meteoric irons, Wallapai (Hualapai) Indian Reservation, P2718.

millipeds, Colobognatha, P2714; new genera and species, P1810.

Opuntia, new species, CNH12, pt. 9 (6th art.).

Orthoptera, P1333, 1403.

plants collected by E. Palmer, CNH1, No. 4 (1st and $2 \mathrm{~d}$ arts.).

pottery, Elden Pueblo, Flagstaff, P2930.

Psaltriparus, P674.

rattlesnake, Crotalus willardi, P1800.

reptiles, Huachuca Mountains, P1282. shells, land, Oreohelix, P2802.

spiders and other Arachnida, P1223. spiders collected by E. A. Schwarz and H. Barber, P1284.

Trogon ambiguus breeding in, $\mathrm{P} 616$. turtle, Kinosternon arizonense, fossil, P2451.

Upper Gila River region, culture of ancient Pueblos, Museum-Gates Expedition, B87.

vertebrate fauna, late Cenozoic, San Pedro Valley, P3155.

White Mountain Apache Indian Reservation, exploration of ruins, P2856.

Arkansas, fishes, P549; Scott County, Poteau River, P759.

fossils, Cretaceous, P207; invertebrate, Mesozoic and Cenozoic, P137.

meteoric irons, P666, 2700.

salamander, with notes on $A$ mbystoma annulatum, P1023.

Scott County, Poteau River, fishes from tributary, P759.

Armadillo. (See under Mammals.)

Armor. (See under Anthropology.)

Armstrong, Frank B., birds collected at Alta Mira, Mexico, P1091.

Arnold, Ralph, P1545, 1617, 1620.

Arrowpoints, prehistoric, R1897, pt. 2, No. 7.

arsenic acid for protecting anatomical preparations, P12.

Art, Buddhist religious, R1904, pt. 2, No. 2; P2371.

casts, Persepolitan, in the National Museum, R1893, pt. 2, No. 8.

ecclesiastical, in National Museum, P2287.

Freer collection, catalog of objects exhibited in National Museum, B78.

Ii, Baron Kamon-no-Kami Naosuke, statue, R1894, pt. 2, No. 4. 
ART (continued).

National Gallery (now National Collection of Fine Arts), history, B70.

Persepolis, R1893, pt. 2, No. 8.

(See also under Anthropology, Ceramics, and Graphic arts.)

Arthropods:

Africa, west, P951.

Arctic America, Howgate Polar Expedition, B15.

(See also Arachnids, Myriapods, Crustaceans, Insects, Onychophores, Pycnogonids, Trilobites.)

Artifacts, scored bone, central Great Plains, P3141.

Artiodactyls. (See under Mammals.)

Arundel formation, Md., fossil fauna, P2389.

Asbestos and asbestiform minerals, P1066.

Ascidians. (See under Tunicates.)

Ashmead, William Harris, B45; P760, $779,1102,1202,1206,1387,1413,1416$, $1424,1448$.

Ashmead, W. H., and Howard, Leland Ossian, P1092.

Ashmead manuscript species of Ichneumonidae of Mrs. Slosson's lists, P2429.

Ashworth, James Hartley, P1772.

Asia, birds, collected by W. L. Abbott, P1195; collected by W. L. Abbott in eastern Turkestan, Thian-Shan Mountains, and Tagdumbash $\mathrm{Pa}$ mir, P1083; new species and genus from eastern Asia, P1539.

crinoids, unstalked, new, P1561.

flies, Diptera, new, P2932; muscoid, parasitic on Japanese beetle, P2474.

ichneumon-flies, new, P2880.

Pteridophyta collected by J. F. Rock, CNH26, pt. 6.

stickleback, 10-spined, Pygosteus, review, P1536.

wasps, Tiphia, taxonomy, P2814.

(See also under China, India, etc.)

Asiatics, crania, P2480.

Aspen shale, Wyoming, fossils, P2860, 2953.

Assumption Island, birds collected by W. L. Abbott, P953, 1008, 1079; natural history, P973.

Atlanta, Ga., Cotton States International Exposition: Biblical antiquities exhibited, R1896, pt. 2, No. 4; games and implements for divination exhibited, R1896, pt. 2, No. 3; cotton presented to National Museum, P333.

Atlantic Ocean, cephalopods, new, from western, P2335.

chub-mackerels, comparison with those of Pacific, P1748.

crustaceans, Euphausiacea and Mysidacea from western, P2634.

Diatomaceae dredged by Albatross, off Delaware Bay, P937.

dog sharks, with key to Mustelus, P3058.
Atlantic Ocean (continued).

fishes, Alepocephalus bairdii, from western, P68.

Cetomimidae and Rondeletiidae collected by Albatross in north. western, P1012.

chimaeroid, Harriotta, collected by Albatross, P1014.

gadoid, Phycis chesteri and Haloporphyrus viola, $\mathrm{P} 40$.

Foraminifera, B104.

hydroids, new, P3090, 3125.

walrus, cerebral fissures, P1325.

Atropia, influence on the heart, P498.

Atwood, Alice Cary, CNH12, pt. 1.

Auks. (See under Birds; Fossils, birds.)

Austin, George M., P2671.

Austin chalk mollusks, P2815.

Australia, crinoid, new, P1743.

Pardalotus, notes on species, P570.

plant bugs, new, P3182.

shell, land, Thersites bipartita, and allies, P2711.

sponges, fresh-water, in National Museum, P1690.

Australians, crania, P2696.

Avocets. (See under Birds.)

Axinite, notes on, P2060.

Axolotl. (See under Amphibians.)

Ayres, W. Q., note on paper by, and its bearing on nomenclature of cyprinoid fishes of San Francisco markets, P159.

\section{B}

Babiy, Paul Peter, P3119.

Bacon, Walter Rathbone, Traveling Scholarship, amphibians collected in Mexico, P3185; snakes and crocodilians collected in Mexico, P3169.

Bacteria, putrefactive, action of dry heat and sulphurous acid, P218.

Badgers. (See under Mammals.)

Baffinland, Lower Silurian (Trenton) fauna, P1192.

Bagg, Rufus Mather, Jr., P1603.

Bahama Islands, Batrachia and Reptilia, P645.

fishes collected by C. L. Edwards, Green Turtle Cay, P752.

lizard, iguanoid, new, Green Cay, P1219.

mollusks, Annulariidae, B192; new, P2016.

Spindalis, new, P600.

Bailey, John Wendell, P2733.

Bailey, Vernon, shells collected in Heron and Eagle Lakes, Minn., P1190.

Baird, Spencer Fullerton, C2, 3, 4, 9, 14, 20, 35; P229.

published writings of, B20.

Baja California. (See under Lower California.)

Baker, Arthur Challen, and Quaintance, Altus Lacy, P2156.

Baker, Carl Fuller, P1361, 1417.

Balch, Francis Noyes, P1761. 
Balduf, Walter Valentine, P2894.

Baltic Provinces, Early Paleozoic Bryozoa, B77.

Baltistan, birds collected by W. L. Abbott, P1078.

mammals presented by W. L. Abbott, P976.

Bandfishes. (See under Fishes.)

Banka Island, mammals, P1498.

Banks, Nathan, B67, 72, P951, 1223, 1253, 1284, 1382, 1553, 2143, 3079.

Banks, N., and Snyder, Thomas Elliot, B108.

Banta, Arthur Mangum, and Gortner, Ross Aiken, P2112.

Banta, A. M., and McAtee, Waldo Lee, P1443.

Barbados, fishes, including rare eel, from H. Maxwell Lefroy, P1345. thysanopterous insects, P1590.

Barber, Herbert Spencer, earwigs collected in Guatemala, P1563.

Herniptera-Heteroptera collected at Las Vegas Hot Springs, N. Mex., P1360.

spiders collected in Arizona, P1284.

Barbets. (See under Birds.)

Barbour, Thomas, and Noble, Gladwyn Kingsley, P2352.

Barbuda, birds collected by Fred A. Cher, P35.

Barker, Reginald Wright, P3052.

Barnacles. (See under Crustaceans; also under Fossils: Crustaceans, Cirripedia.)

Bartlett, Robert A., annelids collected in Alaska, P2601.

echinoderms collected in Greenland, P3098.

Bartram, Edwin Bunting, CNH26, pt. 3.

Bartsch, Paul, B91; B100, vol. 1, pt. 1; vol. 2 , pt. 5 ; vol. 6 , pts. $6-9$; B122, 192.

P1454, 1483, 1512, 1515, 1520, 1522, $15+8,1564,1569,1584,1587,1705$, $1707,1709,1711,1781,1785,1790$, $1799,1802,1823,1826,1854,1858$, $1861,1863,1871,1903,1906,1978$, 1983, 1993, 2016, 2094, 2104, 2155, $2170,2193,2207,2246,2250,2254$, $2272,2331,2551,2594,2646,2653$, $2660,2848,2874,2878,2881,2909$, 2917, 2929, 3094.

birds collected in the Philippines, Borneo, Guam, and Midway, P1683.

Bartsch, Paul, and Dall, William Healey, B68; P1452, 1574, 1820.

Bartsch, Paul, and Henderson, John Brooks, P2055, 2327.

Bartsch, Paul, and Rehder, Harald Alfred, P3070.

Bartsch, Paul, and Torre, Carlos de la, P3039, 3096.

Bartsch, Paul; Torre, Carlos de la; and Morrison, Joseph P. E., B181.

Basalt, Columbia River, siderite from, P2458.
Basilan Island, basketry bolo case from, P1566.

Basket Maker baskets, New Mexico, P2933.

Basketry. (See under Anthropology.)

Bass. (See under Fishes.)

Bassler, Ray Smith, [B53, pt. 1, sect. 1], $65,77,92$.

P1323, 1442, 1637, 1797, 1851, 2009, 3068, 3104, 3126.

(See also under Canu and Bassler; Pate and Bassler; Ulrich and Bassler.)

Batam Island, mammals, P1502.

Bathurst, Cape, Eskimo strike-a-light, P705.

Batrachians:

Africa, east, P970.

Albatross collections, $1887-88$ cruise, P769.

Arizona, Triassic, P1353.

Bahama Islands, P645.

Central America, B32.

collecting, directions, B39e.

Costa Rica, P1857.

Florida, P1003.

Formosa, P1731.

Mexico, B32; P922.

North America, B1, 24, 34.

Panama, P1857.

Peru, P1992.

tailless, new, tropical American, P847.

Texas, P728, 1088.

Venezuela, La Guaira, P1248.

(See also under Amphibians and under Fossils.)

Bats. (Ste under Mammals.)

Baur, Georg, P1005.

Bawean Island, Java Sea, birds, P2175.

Bean, Barton Appler, P843, 1030, 1159, 1165, 1339, 1345, 1409, 1588.

(See also under Tarleton $\mathrm{H}$. and Barton A. Bean; Eigenmann and Bean; Fowler and Bean; Seale and Bean.)

Bean, Barton A., and Weed, Alfred Cleveland, P1682, 1694, 1723, 1764, 1816, 1824, 1919.

Bean, Tarlton Hoffman, B15, 27, pt. F. P28, 47, 49, 59, 63, 69-71, 80, 89, 90, $95,100,124,127,190,204,210$, $224,225,233,255,265,271,274$, $340,342,357,387-389,407,429$, $430,486,487,504,505,508,509$, $516,517,637,657,658,671,672$, $748,787,795,896,903,967,1027$, 1028.

Bean, Tarleton H. and Bean, Barton A., P1029, 1106, 1112, 1127.

Bean, Tarleton H., and Dresel, H. G., P418.

(See also under Goode and Bean.)

Bear-animalcule, North Carolina, P2203.

Beard, Robert Edmund, and Watson, Thomas Leonard, P2220.

Bears. (See under Mammals.)

Beauchamp, Paul Marais de, P1893. 
Beauvois' Agrostographie, bibliographic study of, CNH24, pt. 6 .

Beckham, Charles Wickliffe, P546, 673.

Bees. (See under Insects, Hymenoptera.)

Beeson, Charles Henry, and Eigenmann, Carl H., P1009.

Beetles. (See under Insects, Coleoptera; alsn under Fossils, insects.)

Belding, Lyman, P56, 313, 314, 385, 386. birds collected in Lower California, P360.

fishes collected at Cape San Lucas, Lower California, P293.

Bell, Mary M., and Metcalf, Maynard Mayo, B100, vol. 2, pt. 2.

Belote, Theodore T., B163; P2092.

Bemis, Florence Eugenie, P1362.

Bendire, Charles Emil.

Birds: R1893, pt. 2, No. 4; SB1, 3 ; B39d; C30; P662, 663, 983.

Fishes: P196; collected in Washington and Oregon, P265.

Mammals: P287.

Benedict, James Everard, P594, 887, 900 , $949,1016,1087,1216,1236,1311$, $1337,1367$.

birds collected by, P420.

Benedict, J. E., and Rathbun, Mary Jane, P858.

Benguiat, Hadji Ephraim, Jewish ceremonial objects, R1899, pt. 2, No. 5.

Benjaminite from klaprotholite group, P2537.

Bent, Arthur Cleveland, B107, 113, 121, $126,130,135,142,146,162,167,170$, $174,176,179,191$.

Bequaert, Joseph, P3004.

Beraunite, notes on, P2060.

Berg, Leo, P1533, 1536.

Bergroth, Evald, P2150.

Bering Island, Entomostraca collected by L. Stejneger, P621.

fishes collected by N. A. Grebnitski and L. Stejneger, P1106.

Mesoplodon stejnegeri collected by L. Stejneger, P540.

Mollusca collected by N. Grebnitzki, P562.

plants collected by $L$. Stejneger, P462.

Bering Sea, andesites, hornblende, from Bogosloff Island, P479.

birds collected by Albatross, P1727; from St. Lawrence Island, P2912. fishes, P3000.

mollusks, collected by L. Stejneger, P442; new, P571.

(See also under Commander Islands and Cumberland Sound.)

Berlepsch, Hans von, P755.

Berlin, International Fishery Exhibition, exhibit of fisheries and fish culture of the United States, B18.

Berman, Harry; Foshag, William Frederick; and Gage, Robert Burns, P2669.

Bermuda, fishes, catalog, B5; mistakenly described as new by Günther,
BERMUDA (continued).

P58; serranoid, Epinephelus drummond-hayi, P23.

marine mollusks, P1861.

natural history, contributions to, B25; geology, pt. 1; botany, pt. 2 ; mammals, pt. 3 ; birds, pts. 4 , 5 ; reptiles, pt. 6 ; annelids, pt. 7 . new shells, P1820.

parasites of fishes, P1560.

Bernadou, J. B., Korean collection, R1891, pt. 3, No. 3.

Berry, Charles Thompson, P3035.

Berry, Edward Willard, B103, pt. 2.

P1738, 1769, 1821, 1862, 1980, 2074, 2229, 2256, 2270, 2356, 2363, 2367, $2388,2460,2465,2558,2652,2686$, 2719, 2734, 2743, 2795, 2988.

Berry, Samuel Stillman, P1713, 1838, 1996, 2223, 2335.

Berry, Willard, P3113.

Berry, Willard, and Kelley, Louis, P2816. Betatakin, excavation and repair of, P2828.

Beverages, pulque of Mexico, P1579.

Beyer, Henry Gustav, C32; P498, 515.

Bezzi, Mario, P2621.

Bianco, Salvatore Lo, B39m.

Biblical antiquities. (See under Anthropology, religion.)

Bigelow, Henry Bryant, B100, vol. 1, pt. 5; P1706, 1931, 1946, 2114.

Bigelow, Robert Payne, P1017.

Billiton Island, mammals, P1498.

Bingham, Hiram, land shells collected in Peru, P1736.

Binney, William Greene, B28.

Biology. (See under Birds, Mammals, Plants, etc.)

Biology, department of, exhibit at PanAmerican Exposition, Buffalo, R1901, pt. 2, No. 1.

BIRDs:

Acanthidops bairdi, adult male, P708.

Accipiter cooperi mexicanus, diagnosis, P691.

Accipiter velox, new western subspecies of, P691.

Aestrelata sandwichensis, P556, 693.

Africa, P1370, 2076, 2738.

Cameroons District, P1180.

Ethiopia and Kenya Colony, Frick Expedition, B153.

German and British East Africa, P1469.

Kilimanjaro region, P1411.

Liberia, P1182.

Alaska, P339, 411, 412, 960.

Alaudidae, North American, life histories, B179; North and Middle American, B50, pt. 4.

Albatross collections. (See under $\mathrm{Al}$ batross, birds.)

albino, with remarks on albinism, P733.

Alcedinidae, North and Middle American, B50, pt. 6.

Alcidae, North American, B50, pt. 8. 
BiRDs (continued).

Aldabra Island, P953, 973, 983, 1008, 1079.

Aleutian Islands, P1539.

Amazilia yucatanensis and $A$. cerviniventris, P189.

Amazon, lower, P591, 618, 660.

Amirantes Island, P1079.

Ampelidae, North and Middle American, B50, pt. 3.

Anamba Islands, B98.

Anas boschas $\times$ obscura, P409.

Andaman Islands, P1288.

Anser leucopareius, note on, P475.

Anseres, life histories, B126, 130; osteology, P711.

antbirds, Middle American, B50, pt. 5.

Anthreptes, new African, P2076.

Anthus cervinus in Lower California, P361.

Antigua, P35.

Aphrizidae, North and Middle American, B50, pt. 8.

Arctic American, B15; P865.

Ardea herodias, revision, P1939.

Ardea querdemanni, notes on, P612.

Arenariidae, North and Middle American, B50, pt. 8.

Argentina, B133.

Arizona, P616, 663, 674.

Asia, central, P1195; eastern, P1539; eastern Turkestan, Thian-Shan Mountains, and Tagdumbash $\mathrm{Pa}_{\mathbf{2}}$ mir, P1083.

Assumption Island, P953, 973, 1008, 1079.

Atthis ellioti, Guatemala, P7.

auks, great, Funk Island, R1888, pt. 3, No. 3; North American, B50, pt. 8.

Australia, P570.

avocets, North and Middle American, B50, pt. 8.

Bahamas, P 600 .

Baltistan, P1078.

barbets. North and Middle Ameriican, B50, pt. 6 .

Barbuda, P35.

Basileuterus and allies, P2752.

Basileuterus rufifrons, Mexico, P895.

Bawean Island, Java Sea, P2175.

Benedict, J. E., collected by, P420.

Bering Sea, P1727; St. Lawrence Island, P2912.

Bermudas, B25, pts. 4, 5.

birds-of-paradise, P875, 1204.

bones collected by Theodoor de Booy in St. Thomas and St. Croix, P2245.

Boobies. (See under Fossils, birds.)

Borneo, P1683, 2835.

bowerbirds, cubital coverts, P875.

Brazil, Abrolhos Islands, P768, 798.

British Guiana, P538.

Bubonidae, North and Middle American, B50, pt. 6.
Birds (continued).

Bucconidae, North and Middle American, B50, pt. 6.

bullfinches, Palearctic, P610.

bunting, snow, Alaskan, P412.

bustard, African, cestode from, P1844.

Buteo latissimus, melanistic, P567.

Buteo oxypterus, remarks on type, P488.

Butorides virescens, revision, P1916.

California, P56, 458, 623, 662, 872; Santa Barbara Islands, P1196.

Capitonidae, Middle American, B50, pt. 6.

Caprimulgidae, North and Middle American, B50, pt. 6.

Caprimulgiformes, life histories, B176.

Caprimulgus macrurus, races, P2088.

Caribbean Sea, P665, 2876.

Carpodectes antoniae, remarks on by Zeledón, P605.

Cathartes burrovianus and $C$. urubitinga, P480.

Catharus, Ecuador, P653.

Catharus berlepschi, remarks on, P654.

caudal molt, P2830.

Celebes, P2506.

Central America, P493.

Centurus, review, P198.

Cepphus, remarks on, P425.

Certhia, European and North American, P270.

Certhiidae, North American, B50, pt. 3.

Certhiola, synopsis, P478.

cestode parasites from, B69; P2656.

Chachalacas, North and Middle American, B50, pt. 10.

Chalcomitra, new African, P2076.

Chalcopelia, new African, P2076.

Chamnea, osteology, P830.

Chamaeidae, North American, B50, pt. 3.

Charadriidae, North and Middle American, B50, pt. 8.

chats, palm, North American, B50, pt. 3 .

chatterers, North and Middle American, B50, pt. 4.

Chile, B133; P312.

China, Chihli and Kansu, P2838; Yunnan and Szechwan, P2654, 2907.

China Sea, Tambelan Islands, P2262.

Chionis minor, structure and systematic position, B3.

Chordeiles, monograph, B86.

Chrysotis, new Dominican, P142.

Cinclidae, North and Middle American, B50, pt. 3.

Cinnyris, new African, P2076.

classification for birds of world, P2821. 
BIRDS (continued).

Coerebidae, anatomy and affinities, P1001; North and Middle American, B50, pt. 2.

coliiform, caudal molt, P2830.

Colius, new African, P2076.

collecting, directions for, B39a.

Collocalia fuciphaga, revision, P1881.

Colombia, P1258.

Columbidae, $\mathrm{N}$ or th and Middle American, B50, pt. 7.

Columbiformes, life histories, B162.

Commander Islands, B29; P345, 614, $765,1095$.

Contopus, new tropical American, P474.

coots, Japanese, review, P579; North and Middle American, B50, pt. 9; West Indian, P446.

Coraciiformes, caudal molt, P2830; life histories, B176.

cormorant, Pallas's, P765, 1095.

Corvidae, North American, life histories, B191; North and Middle American, B50, pt. 3.

Costa Rica, birds, P3179; Cotinga, P599; whippoorwill, P867.

Cotingidae, North American, life histories, B179; North and Middle American, B50, pt. 4.

cowbirds, R1893, pt. 2, No. 4.

Cozumel, P494.

Cracidae, North and Middle American, B50, pt. 10.

cranes, North and Middle American, B50, pt. 9.

creepers, Japanese, P667; North American, B50, pt. 3 ; tree, P270. crows, carrion, Kamchatkan and Japanese, P629; North American, life histories, B191; North and Middle American, B50, pt. 3.

Cuba, P2925.

cuckoos, North American, life histories, B176; North and Middle American, B50, pt. 7; yellowbilled, tapeworms from, P2791.

Cuculidae, North and Middle American, B50, pt. 7 .

Cuculiformes, life histories, B176.

curassows, North and Middle American, B50, pt. 10.

Cyanecula, new, P1078.

Cyanonympha, monograph, P1803.

Cyclorhis, new subspecies, Yucatan, P588.

Cygninae, outlines of monograph, P275.

Dendrocincla, review, P650.

Dendrocolaptidae, North and Middle American, B50, pt. 5 .

Dendrornis, new, P1200.

dickcissel, disappearance from District of Columbia, P806.

dippers, North and Middle American, B50, pt. 3.
BIRDS (continued).

District of Columbia, B26; P806.

diving, life histories of North American, B107.

Dominican, P19, 142.

Dominican Republic, B155; P2966. dove, ground, Mona Island, Puerto Rico, P1418.

Dromococcyx, British Guiana, P538.

Dryobates nuttallii, hybrid with $D$. pubescens gairdnerii, P590.

Dryobates pubescens, new subspecies of, P1080.

Dryobates pubescens gairdnerii, hybrid with $D$. nuttallii, P590.

Dryobates scalaris, revision, P1847.

Dryobates villosus, revision, P1840.

Ducks, domesticated hybrid, P409; form (rufous-crested) new to North American fauna, P188; parasitic habit, P2918; ruddy, P2191.

Dulidae, North American, B50, pt. 3.

Ecuador, P653, 694a, 1258.

Empidonaces, nests and eggs, P62.

Entomothera coromanda, review, P2090.

Entozra, notes on avian, P893.

Erismatura jamaicensis, secondary sexual characters in male, P2191.

Estrilda, new African, P2076.

Ethiopia, B153.

Europe, Certhia, P270; marshtits, P686; thrushes, P577; titmice, P695; generic and specific appellations, P261.

Eurypygidae, Midd le American, B50, pt. 9.

exchanges with National Museum, directions, C34.

exhibit sent to International Fisheries Exhibition at London, B27, pt. C.

extinct, represented in National Museum, R1889, pt. 3, No. 5.

Falconiformes, life histories, B167, 170.

Fanning Islands, B7.

finches, North and Middle American, B50, pt. 1.

Florida, P457.

flycatchers, life histories, B50, pts. 3,$4 ; \mathrm{B} 179$.

Formicariidae, Middle American, B50, pt. 5.

Formicarius, revision, P961.

Francolinus, new African, P2076.

Fringillidae, North and Middle American, B50, pt. 1.

Funk Islands, R1888, pt. 3, No. 3 .

Furnariidae, North and Middle American, B50, pt. 5.

Galäpagos Islands, P573, 767, 798, $1007,1067,1116$.

Galbulidae, North and Middle American, B50, pt. 6. 
BIRDS (continued).

Galliformes, life histories, B162.

gallinaceous, life histories of North American, B162.

gallinules, Japanese, review, P579; North and Middle American, B50, pt. 9.

Gavia immer, trematode from, P3071.

generic names, preoccupied, P530; with additions to Waterhouse's "Index Generum Avium": 18901900, P1267; 1901-1905, P1656; 1906-1915, P2221; 1916-1922, incl., P2664.

Geothlypis, Brownsville, Tex., P964.

Gloriosa Island, P973, 1008, 1079.

gnatcatcher, black-capped, California, nest and eggs, P662.

goatsuckers, monograph of Chordeiles, B86; long-tailed, P2088; North American, life histories, B176; North and Middle American, B50, pt. 6 ; pterylography, P1018.

goose, Canada, trematode from, P2846.

Grampus cruise, birds collected on, P819.

Great Britain, P101, 560.

Grenada, P45.

grouse, feather-tracts, P1166; North American, B50, pt. 10 ; sage, nematode from, P2869.

Gruidae, North and Middle American, B50, pt. 9.

Guadeloupe, P57.

Guam, P1683.

guano, of Peruvian birds, P2298.

guans, North and Middle American, B50, pt. 10.

Guatemala, P7, 3105.

guineafowls, West Indian, B50, pt. 10.

gulls, North American, life histories, B113; North and Middle American, B50, pt. 8 .

Haematopodidae, North and Middle American, B50, pt. 8.

Haematopus galapagensis, P573.

Haiti, B155; P2925, 2966.

Halcyon, new African, P2076.

Hapaloderma vittatum, basis for new genus, P1024.

Harporhynchus, P262.

Hawaiian Islands, B7; P236, 692. Kauai, P609, 640, 778.

hawk, Cozumel, P494; red-shouldered, Florida, P457.

Heligoland, P67.

Heliornithidae, Middle American, B50, pt. 9.

Herodiones, life histories, B135.

herons, boat-billed, Central American, P493; great blue, P1939; green, P1939; Japanese, review, P628.
BIRDS (continued).

Heterotrogon, new genus, P1024.

Hirundinidae, North American, life histories, B179. North and Middle American, B50, pt. 3.

Honduras, P665, 868.

honey-creepers, L e s s e $r$ Antilles, P478; North and Middle American, B50, pt. 2.

hornbill, giant, peculiarity of growth in tail feathers, P2059.

Hudson's Bay Company districts in Labrador, P518.

hummingbirds, R1890, pt. 3, No. 1; Ecuadorean and Colombian, P1258; Guatemalan, P7; North American, life histories, B176; North and Middle American, B50, pt. 5; structure of tongue, P848.

Hypothymis, monograph, P1803.

ibises, Japanese, review, P628.

Icteridae, North and Middle American, B50, pt. 2.

Icterus, West Indian, P166.

Icterus cucullatus, variations, P472.

"Index Generum Avium," additions to, P1267, 1656, 2221, 2664.

jacamars, North and Middle American, B50, pt. 6 .

Jacanidae, North and Middle American, B50, pt. 8.

Japan, P383, 390, 558, 578, 579, 598, $601,628,629,642,667,735,751$, 874, 906, 957, 974, 997, 1721; Idzu, P649; Liu-Kiu Islands, P473, 597, 641; Sea of Japan, P904, 931, 1727; Yezo, P904, 931.

Java Sea islands, P2232.

jays, North American, life histories, B191; North and Middle American, B50, pt. 3 .

Kamchatka, B29; P345, 629, 701.

Karimata Islands, P2512.

Kashmir, P1078.

Kentucky, P3089.

Kenya Colony, B153.

Kerguelen Island, B2, 3.

kingfisher(s), North and Middle American, B50, pt. 6; northwestern belted, nematode from, P2871; Ramphalcyon, P1657; r u d d y, P2090; white-collared, P2276.

Korea, P1721, 1735.

Kuril Islands, P1144.

Labrador, P353, 518.

Ladak, P1078.

Lagopus mutus and allies, P279.

Laniidae, North American, B50, pt. 3.

Laridae, North and Middle American, B50, pt. 8 .

larks, North American, life histories, B179; North and Middle American, B50, pt. 4 ; Otocoris, P1271.

Lesser Antilles, P61, 478.

Liberia, P1182. 
BIRDs (continued).

lice, taken from North American birds, P1183; from Tinamidae, P3180; found on troupials, P2201.

life histories of North American, $\mathrm{B} 107,113,121,126,130,135,142$, $146,162,167,170,174,176,179$, 191.

Limicolae, North American, life histories, B142, 146.

loon, Gavia immer, trematode from, P3071.

Lower California, B7 ; P313, 314, $360,361,386$.

Loxigilla, new, St. Christopher, P210.

Madagascar, P1118, 1197.

Malay Peninsula, B172.

manakins, Middle American, B50, pt. 4.

Manitoba, P841.

marsh birds, life histories of North American, B135.

marshtits, British, P560; European, P686.

Martinique, P51.

Megapodius, growth rate of foot, P2901.

Megapodius nicobariensis, P2278.

Megascops, new species of, P626.

Melanetta fusca in Alaska, P411.

Meleagrididae, North and Middle American, B50, pt. 10.

Meluttophagus, new African, P2076.

Mentawi Island group, P2775.

Merula confinis, note on, P362.

Methriopterus, P262.

Mexico, B4; P559, 895, 945, 962, 975, 1045; Alta Mira, P1091; Sonora, P385, 617; Veracruz, P3164.

Micropodiiformes, North American, life histories, B176.

Middle America, catalog, B50, pts. 1-10; P655; list of forms not represented in National Museum, P215.

Midway Island, P1683.

Mimidae, North and Middle American, B50, pt. 4.

Miminae, P262, 704.

Mniotiltidae, North and Middle American, B50, pt. 2.

mockingbirds, North and Middle American, B50, pt. 4.

Momotidae, North and $\mathrm{Middle}$ American, B50, pt. 6.

Mongolia, Inner, P2838.

Motacilla amurensis, $M$. blakistoni, and $M$. ocularis, identity, P356.

Motacillidae, North and Middle American, B50, pt. 3.

motmots, North and Middle American, B50, pt. 6 .

moundbirds, Megapodius, growth rate of foot, P2901.
BIRDs (continued).

Muscisaxicola, Lake Titicaca, P643.

Myadestes, West Indian, P260.

Myadestes obscurus, new races, P239.

Myiarchus, Orinoco district, South America, P589; remarks on genus, and on M. yucatanensis, P955.

Nannus, notes on wrens, P2265.

Natuna Islands, B159.

nematode parasites of, Strongylata,

Ascaridata, Spirurata, B140.

Neotropical, P755.

new American races, P259.

New Mexico, P432.

new species and geographical races in National Museum, P38.

Nicaragua, P391, 947, 1090.

Nicobar Islands, P1288, 2278.

North America, additions to av8fauna, P247.

catalog; B50, pts. 1-10; P138.

descriptions of some new, P285.

desiderata among, P219.

emended names, P524.

life histories: B107, diving birds; 113, gulls, terns; 121, petrels, pelicans; 126, 130, wildfowl; 135, marsh birds; 142, 146, shorebirds; 162, gallinaceous birds; 167,170 , birds of prey; 174 , woodpeckers; 176 , cuckoos, goatsuckers, hummingbirds; 179 , flycatchers, larks, swallows; 191, jays, crows, titmice.

life histories, breeding habits, and eggs, SB1, 3.

nomenclature, B21; P102.

some generic and specific appellations, P261.

taenicid cestodes of, B69.

western coasts and adjacent islands, collected by Albatross, P799.

North Carolina, P3117.

Norway, P686.

Nothura maculosa, osteology, P622.

Nucifraga caryocatactes macrorhynchos, Japan, P735.

Numididae, West Indian, B50, pt. 10.

nutcracker, Japanese review, P735.

nuthatches, Japanese, review, P578;

North and Middle American, B50, pt. 3 .

Nycitibiidae, North and Middle American, B50, pt. 6 .

Nyctibius, anatomy of, with notes on allied birds, P2251.

Nye, W., collected by, P420.

Oceanodroma leucorhoa, review of subspecies, P2230.

Odontoglossae, life histories, B135.

Odontophorus, Mexican, P945.

Oedicnemidae, North and Middle American, B50, pt. 8. 
BIRDS (continued).

Oestrelata fisheri and $O$. defilippiana, P471.

Okhotsk Sea, P1727.

Old World, in National Museum, P234.

Onychotes gruberi, P481.

Otocoris, review, $\mathrm{P} 1271$.

ovenbirds, North and Middle American, B50, pt. 5.

owl(s), great horned, revis i o n, P1352; North and Middle American, B50, pt. 6 ; pterylography of American, P1018; Puerto Rican, P238; spotted, P2106.

Oxyruncidae, Middle American, B50, pt. 4.

oystercatchers, Galápagos, P573; North and Middle American, B50, pt. 8.

Pachyrhamphus albinucha, P870.

Pacific Ocean, north, Albatross 1906 cruise, P1727; Pinchot Expedition, P2876.

Palawan Island, P1134.

Paludicolae, North American, life histories, B135.

Paraguay, B133; P1281.

Pardaliparus elegans, Philippine, geographical forms, P2142.

Pardalotus, Australian, P570.

Paridae, North American, life higtories, B191; North and Middle American, B50, pt. 3 ; osteology, P830.

parrots, Dominican, P142; North and Middle American, B50, pt. 7.

parrots to grackles, North American, life histories, SB3.

partridges, North and Middle American, B50, pt. 10 ; plumed, Sonora, P617.

Passeriformes, North American, life histories, B179.

passerine, new American, P1076.

patella in birds, forms assumed by, P439.

Pelargopsis, revision, P1657.

pelicans, North American, life histories, B121.

Peru, B117; P643, 2298.

Peucaea mexicana, new to U. S, P496.

petrels, Alaskan, P339; Hawaiian, P236; Leach's, P2230; North American, life histories, B121; storm, P962.

Petropaulovski, P345.

Peucedramus, new subspecies of, P1074.

Phacellodomus, Venezuelan, P619.

phalaropes, North and $\mathrm{M}$ iddle American, B50, pt. 8.

Phalaropodidae, North and Middle American, B50, pt. 8.
Birds (continued).

Phasianidae, North and Middle American, B50, pt. 10.

Pheasants, North American, B50, pt. 10.

Philippine Islands, P1134, 1679, 1693, 2142.

Phrygilus gayi and allied species, P644.

Picidae, North and Middle American, B50, pt. 6 .

Piciformes, caudal molt, P2830; North American, life histories, B174.

Picoides albidior, Kamchatka, P701.

Picolaptes, lower Amazon, P591.

pigeons, Guayaquil, Ecuador, P694a ; Japanese, P642; North and Middle American, B50, pt. 7.

pipits, North and Middle American, B50, pt. 3.

Pipridae, Middle American, B50, pt. 4.

Ploceidae, North American, B50, pt. 4.

plovers, Chilean, P312; North and Middle American, B50, pt. 8.

Polioptila californica, nest and eggs, P662.

Porzana, new Costa Rican, P611.

Porzana jamaicensis coturniculus, P828.

potoos, North and Middle American, B50, pt. 6.

Procelsterna, Hawaiian group, P1322.

Procniatidae, osteological and pterylographical characters, P1077.

Psaltriparus, Arizona, P674.

Psittacidae, North and Middle American, B50, pt. 7.

Psittaciformes, North American, life histories, B176.

Psittacula, review, P661.

Psittirostra psittacea, Hawaiian, P640.

ptarmigans, North and Middle American, B50, pt. 10.

Pteroptochidae, Middle American, B50, pt. 5.

Ptilogonatidae, North and Middle American, B50, pt. 3.

Puerto Rico, P238, 1418.

puffbirds, North and Middle American, B50, pt. 6 .

Pygopodes, North American, life histories, B107.

quail, feather-tracts, P1166; Japanese, P974; North and Middle American, B50, pt. 10; tapeworms from, P2791.

questions relating to, transmitting, C50. 
BIRDS (continued).

rails, clapper, $\mathrm{r}$ ev is i o $\mathrm{n}, \mathrm{P} 3018$; Farallon, P828; Japanese, review, P579; North and Middle American, B50, pt, 9.

Rallidae, North and Middle American, B50, pt. 9.

Rallus gularis, remarks on, P576.

Rallus jouyi, description of, P576.

Rallus longirostris, revision, P3018.

Rallus striatus, remarks on, P576.

Ramphalcyon, revision, P1657.

Ramphastidae, North and Middle American, L50, pt. 6 .

Recurvirostridae, North and Middle American, B50, pt. 8.

Regulus calendula, plumage, P546. rhea, nematode from, P2958.

Rhinoplax vigil, growth of tail feathers, P2059.

Rynchopidae, North and Middle American, B50, pt. 8.

St. Croix, bones, P2245.

St. Thomas, bones, P2245.

St. Vincent, P27.

Santa Barbara Islands, Calif., P1196. Sauropatis chloris, revision, $\mathrm{P} 2276$.

Saxicola, North American, P1220.

Sclerurus, review, P762.

Scolopacidae, North and Middle American, B50, pt. 8.

Scops, American, review, P21.

Selasphorus torridus, note on, P400. Seychelles, P1079.

sharpbills, Middle American, B50, pt. 4.

shore birds, life histories of North American, B142, 146.

shrikes, gray, Japanese, P931; North American, B50, pt. 3.

Siam, B172, 186; P1201.

Siberia, northeastern, collected by Copley Amory, Jr., P2255.

Sitta, osteology, P830.

Sittasomus, notes on, P877.

Sittidae, North and Middle American, B50, pt. 3.

skeletons, Albatross collections, Abrolhos Islands, Brazil, Straits of Magellan, and Galápagos Islands, P798; preparation, B39c.

skimmers, North and Middle American, B50, pt. 8 .

skuas, North and Middle American, B50, pt. 8.

snipes, North and Middle American, B50, pt. 8.

Somaliland, P1373.

Sonora, P385, 617.

South America, new, P1276; list of forms not represented in National Museum, P215; Orinoco district, P589.

Southwest Africa, Great Namaqualand, P2951.

sparrow(s), California, P458; field,
BIRDS, sparrows (continued).

New Mexico, P432; new to U.S., P496; sharp-tailed, California, P872; tree, Liu-Kiu, Japan, P473. Spindalis, Bahaman, P600.

$S p$ iza americana, disappearance from District of Columbia, P806.

Spolia Mentawiensia, P2775.

starlings, North American, B50, pt. 4.

Steganopodes, osteology, P713.

Stercorariidae, North and Middle American, B50, pt. 8.

sterna and skulls collected by T. H. Streets, P638.

Sternidae, North and Middle American, B50, pt. 8.

stilts, North and Middle American, B50, pt. 8 .

storks, Japanese, review, P628.

Straits of Magellan, P768, 798.

Strigiformes, North American, life histories, B170.

Strix occidentalis, critical notes, P2106.

Sturnidae, North American, B50, pt. 4.

Sumatra, P1318, 2268, 2282.

sun-bitterns, Middle American, B50, pt. 9.

sun-grebes, Middle American, B50, pt. 9.

surf-birds, North and Middle American, B50, pt. 8 .

swallows, North American, life histories, B179; North and Middle American, B50, pt. 3.

swiftlet, edible-nest, Collocalia fuciphaga, P1881.

swifts, North and Middle American, B50, pt. 5 ; supposed new species, P923.

Sylviidae, North and Middle American, B50, pt. 3.

Synthliboramphus wumizusume, status in North America, P592.

Tambelan Islands, China Sea, P2262.

tanagers, North and Middle American, B50, pt. 2.

Tanagridae, North and Middle American, B50, pt. 2.

Tantalus and allies, P315.

tapaculos, Middle American, B50, pt. 5.

Tennessee, P3050.

terns, crested, P2121; North American, life histories, B113; North and Middle American, B50, pt. 8.

Tetraonidae, North American, B50, pt. 10.

Texas, B17; P22, 673, 964.

Thailand, northern, B186.

Thalasseus bergii, synopsis, P2121.

Thamnophilus, supposed new forms, P871. 
BIRDS (continued).

thick-knees, North and $\mathrm{Middle}$ American, B50, pt. 8.

thrushes, ant, Nicaraguan, P1090; North and Middle American, B50, pt. 4; osteology, P704; United States, new, P240.

Thryomanes, revision, $\mathrm{P} 1153$.

Tinamidae, Mallophaga from, P3180. tinamou, spotted, osteology, P622.

titmice, elegant, Philippine, P2142; European, P695; North American, life histories, B191; North and Middle American, B50, pt. 3. tits, Japanese, review, P578.

Todidae, North American, B50, pt. 6. todies, North American, B50, pt. 6 . tongues, R1895, pt. 2, No. 5; adaptive modifications and taxonomic value, P2591; hummingbird, P848. toucans, North and Middle American, B50, pt. 6 .

trematodes from, P2722, 2824.

trinominals in American ornithology, P413.

Trochilidae, in National Museum, P155; North and Middle American, B50, pt. 5 .

Troglodytes, review, P1354.

Troglodytidae, North and Middle American, B50, pt. 3.

Trogon ambiguus, breeding in Arizona, P616.

Trogonidae, North and Middle American, B50, pt. 5.

Trogoniformes, N o r t h American, life histories, B176.

trogons, Heterotrogon, new genus, P1024; Nicaragua, P947; North and Middle American, B50, pt. 5. troupials, bird louse from, P2201.

Tubinares, osteology, P713.

Turdidae, Dominican, P103; North and Middle American, B50, pt. 4; systematic arrangement, P301.

Turdus, Japanese, review, P601.

Turdus alpestris and $T$. torquatus, distinct species, P577.

turkeys, North and Middle American, B50, pt. 10.

turnstones, North and Middle American, B50, pt. 8 .

Tyrannidae, North American, life histories, B179; North and Middle American, B50, pt. 4.

Tyrannus, synopsis, P60.

Tytonidae, North and Middle American, B50, pt. 6 .

United States, southern, new forms from, P1274; west coast, migrations and nesting habits, P85.

Uropsila, note on name, P656.

Uruguay, B133.

Venezuela, P555, 619, 1093, 1247, 3073.
BIRDS (continued).

Vireonidae, North and Middle American, B50, pt. 3.

vireos, North and Middle American, B50, pt. 3.

wagtails, North and Middle American, B50, pt. 3.

warbler(s), golden, review, P522; ground, Mexican, P1045; reed, Japanese, P997; Santa Lucia, W. I., P311; wood, Basileuterus and allies, P2752; wood, North and Middle American, B50, pts. 2, 3; Yucatán, P476.

Waterhouse's "Index Generum Avium," P1267, 1656, 2221, 2664.

waxwings, North and $\mathrm{Middle}$ American, B50, pt. 3.

weapons and wings, R1893, pt. 2, No. 6.

weaverbird, African, P1370; North and Middle American, B50, pt. 4.

West Indies, B50, pt. 10; P166, 260, 446; Dominica, P103; Grenada, P596; Guadeloupe, P545; St. Christopher, P216; Santa Lucia, P311, 768.

West Virginia, P3021.

wheatears, North American, P1220. whippoorwill, Costa Rican, P867. wild fowl, life histories of North American, B126, 130.

woodhewers, North and Middle American, B50, pt. 5.

woodpeckers, downy, P1080; hairy, P1840; Japanese, P558; Kamtschatkan three-toed, P701; ladderbacked, P1847; North American, life histories, B174; North and Middle American, B50, pt. 6. world, systematic classification for birds of, P2821.

worm, amidostomine, from anserine, P2864.

wrens, Japanese, review, P751; Nannus, P2265; North and Middle American, B50, pt. 3; osteology, P704; Thryomanes, P1153; Troglodytes, P1354.

wren-thrushes, North American, B50, pt. 4.

wrentits, North American, B50, pt. 3. Xiphocolaptes, review, P761, 796.

Yucatán, P476, 539, 588.

Zeledoniidae, M id d le American, B50, pt. 4.

(See also under Fossils.)

Birds' eggs, Aldabra, P983.

Arctic America, P865.

Arizona, P663.

Empidonaces, North American, P62.

exchange with National Museum, directions, C34.

Kerguelen Island, B3.

North American, SB1, 3.

North American oology, R1892, pe. 3. No. 7. 
Birds' Eggs (continued).

Polioptila californica, P662.

questions relating to transmitting, C50.

trematode from, P636.

wanted for National Museum, with collecting directions, C30.

Birds' eggs and nests, collecting, preparing, and preserving, directions, B39d.

Birds' nests, Aldabra, P983.

Arizona, P663.

Birds-of-paradise. (See under Birds.)

Birds of prey, life histories of North American, B167, 170.

Birt, Louis F. H., fishes collected in Nicaragua, P732.

Bison. (See under Mammals; also under Fossils, mammals.)

Black Hills, Cycadeoidea, or fossil cycadean trunks, from Lower Cretaceous rim, P1141.

Blackman, Maulsby Willett, P3084, 3147, $3154,3165,3174$.

Blackwelder, Richard Eliot, B182, 185; P3001, 3041, 3069, 3140.

Blaisdell, Frank Ellsworth, Sr., B63; P2790.

Blake, Doris Holmes, P2672, 2868, 2969, $3072,3139$.

Blake, Sidney Fay, CNH20, pt. 7 (1st and $2 \mathrm{~d}$ arts.), pt. 10 (1st through 4th arts.), pt. 13 (1st through $3 \mathrm{~d}$ arts.); CNH22, pt. 8 ; $\mathrm{CNH}_{24}$ (1st, 3d, and 4th pts.) ; CNH26, pt. 5 ; CNH29, pt. 2 (2d art.); P2382.

Blakiston, Thomas Wright, P598. gray shrike collected in Yezo, Japan, P931.

Blanchard, Frank Nelson, B114.

Blatchley, Willis Stanley, P922.

Blattids. (See under Insects, Orthoptera.)

Blattoids. (See under Fossils.)

Blennies. (See under Fishes.)

Bluefishes. (See under Fishes.)

Boas. (See under Reptiles.)

Boas, Franz, R1895, pt. 2, No. 1; P709, 1616.

Boats. (See under Transportation.)

Boehmer, George Hans, R1891, pt. 3, No. 7; P583.

Boettcher, Frederick Louis John, P1879.

Böving, Adam Glede, P2171, 2773, 3146.

Böving, A. G., and Champlain, Alfred B., P2323.

Böving, A. G., and Parker, John Bernard, P2513.

Bogosloff Island, Bering Sea, hornblende andesites, P479.

Bolin, Rolf Ling, P2987, 3000.

Bolivia, grasses, $\mathrm{CNH} 24$, pt. 8.

land shells, Bulimulus, P2937.

meteoric irons, P2700.

Mulford Biological Expedition collections: Bees, P2684; beetles, P2568.
Bolivia (continued).

plants, fossil, bearing on age of uplift of eastern Andes, P2229.

Bolles, Timothy Dix, R1887, pt. 3, No. 5; P899.

Bollman, Charles Harvey, B46; P585, $625,670,714,720-722,731$.

(See also under Jordan and Bollman.)

Bolo case, basketry, Basilan Island, P1566.

Bones. (See under Birds.)

Bonito. (See under Fishes.)

Boobies. (See under Fossils, birds.)

Boomerang, study of, P724.

Boone, Pearl Lee, P2253, 2319.

Borneo, beetles, new buprestid, P2428.

birds collected by Paul Bartsch, P1683; by W. L. Abbott on Karimata Islands, P2512; from islands off northeastern coast, P2835.

mammals collected by W. L. Abbott, P1577, 1809.

orang skulls, anatomical observations on, P1495.

Bornite, North Carolina and Virginia, P1835.

Boschma, Heinrich, P2726, 2804.

Botany. (See under Plants.)

Boulangerite, P2351.

Bourns, Frank Swift, and Worcester, Dean Conant, P1134.

Bowerbirds. (See under Birds.)

Bowie, Henry P., fishes collected in Tahiti, P1422.

Bowles, Edgar Oliver, and Marshall, William Blanchard, P2946.

Bows, Eskimo, in National Museum, R1884, pt. 3, No. 3.

Boxfishes. (See under Fishes.)

Boyd, Charles H., P223.

BRACHIOPODS:

Albatross, P773, 1032.

Hawaiian Islands, P1032.

index to names, B8.

Platystrophia, study of genus, P2297.

Recent, in National Museum, P2314.

United States, southeastern coast, B37.

(See also under Fossils.)

Brachyurans. (See under Crustaceans.)

Braconid-flies. (See under Insects, $\mathrm{Hy}$ menoptera.)

Bradley, Frank H., fishes collected in Panama, P329.

Brahmin temple, model, P1921.

Brains and brain preservatives, P1451.

Branchiopods. (See under Fossils, crustaceans.)

Bransford, Dr., shells collected in kitchen midden in Costa Rica, P11.

Brayton, Alembert Winthrop, and Jordan, David Starr, B12. 
Brazil, annelid, new Nereis, P2347.

Anodontites, new species, P2122.

birds collected by Albatross on Abrolhos Islands, P768.

corals, astrangid, P1477.

fishes obtained by Albatross at $\mathrm{Ba}$ hia, P829.

flies, new Chloropidae injuring manihot, P2534.

grasshoppers, Pyrgomorphinae and Locustinae, P1661.

Indian tribes of Purus River, R1901, pt. 2 , No. 5.

mollusks, new Corbicula, P2699.

mussel, pearly fresh-water, Hyric, P2053.

nematode parasites of land-tortoise, Testudo denticulata, P2526.

shells, new bivalve, P2762.

skeletons, bird, Abrolhos Islands, P798.

Brender à Brandis, Gerard Abraham, and Nierstrasz, Hugo Frederick, P2832.

Brewer, Thomas Mayo, P62.

Bristol Bay, Alaska, ethnological specimens from Ugashagmut tribe, Ugashak River, P364.

mammals collected by C. L. McK.ay, P564.

British Columbia, Arachnida collected by Currie, Caudell, and Dyar, P2143.

Coast Indians, R1888, pt. 3, No. 1.

fishes, collected by Henry E. Nichols, P255, 387; cottoid, collected by Albatross, P787; cyprinoid, new spccies from Frazer River, P938.

fossils, Middle Cambrian, P2893.

Kwakiutl Indians, houses, P709.

Lepidoptera, Kootenai District, P1376.

moths, tineid, P1375.

trout, Great Lake, Salvelinus namaycush, P682.

(See also under Canada.)

British Guiana, Dromococcyx, new species, P538.

grasses, $\mathrm{CNH} 22$, pt. 6.

British Museum, American fishes in collection, P81.

British West Indies. (See under West Indies; also under Trinidad.)

Brittle-stars. (See under Fossils, echinoderms.)

Britton, Nathaniel Lord, and Rose, Joseph Nelson, CNH12, pt. 9 (1st art.), pt. 10 (1st art.) ; CNH16, pts. 7, 9.

Brock, Robert Alonzo, P489.

Brown, James Temple, B27, pt. E.

Brown, Roiand Wilbur, P2953.

Brown, William Henry, CNH13, pt. 10 (2d art.).

Bruner, Lawrence, P764, 1461, 1949, 2001.

Bryant, Owen, collections, annelids, Labrador, Newfoundland, Nova Scotia, P1703.

Bryozoa, Labrador, Newfoundland, Nova Scotia, P1933.
BRYANT, OWEN (continued).

fishes, Java, P1919; L a b r a dor, P1763.

insects, Java, P2675.

BRYOZOANS:

America, Arctic, B15.

Gulf of Mexico region, P2710.

Kerguelen Island, B3.

Labrador, Newfoundland, and Nova Scotia, P1933.

Philippines, B100, vol. 9.

polyzoans, A m e ri c a n, northeast coast, P76.

United States, fresh-water, P1355.

(See also under Fossils.)

Buchanan, Lee L, P2801.

Buddha, bronze, R1889, pt. 3, No. 8.

Buddhist religious art, R1904, pt. 2, No. 2; P2371.

Budworms. (See under Insects, Lepidoptera.)

Buffalo. (See under Anthropology; also under Mammals, bison.)

Buffalo, N. Y., Pan American Exposition, National Museum exhibit, R1901, pt. 2. No. 1.

Building stones:

building and ornamental stones in National Museum, R1886, pt. 3, No. 3.

circular in reference to collection, C9.

exhibition at World's Industrial and Cotton Centennial, plan for, C25.

Maine, in National Museum, P365.

Bullfinches. (See under Birds.)

Bullfrogs. (See under Amphibians.)

Bunting, snow. (See under Birds.)

Burgess, Edward, B15.

Burgess shale, restudy of, P2854.

Burke, [Charles] Victor, B150; P1941.

Burke, C. V., and Gilbert, Charles Henry, P1907.

Burks, Bernard DeWitt, P3082, 3170.

Burma, dragonflies, Aeschinae, P2467; Calopteryginae, P1389; Cordulegasterinae, Chlorogomphinae, and Gomphinae, P1571.

earthworm fauna, summary, P2781.

jadeite of Mogoung, analysis, P981.

Burns, Frank, R1892, pt. 3, No, 5.

Burr, Malcolm, P1760.

Burt, Charles Earle, B154.

Burt, C. E., and Burt, May Danheim, P2849.

Busck, August, P1208, 1268, 1304, 1375, $1463,1465,1506,1644,1765,1815$, 2043, 3064.

Bush, Katharine Jeannette, P377.

Bush, Katharine J., and Verrill, Addison Emory, P1139.

Bushmen, crania, P2696.

Bushnell, David Ives, Jr., P2042.

Bushnell, Expedition to Phoenix and Samoan Islands, fishes, B180.

Bustards. (See under Birds.)

Butterfishes. (See under Fishes.) 
Butterflies. (See under Insects, Lepidoptera.)

Byrd, Elon Eugene, P3010.

Cacao. (See under Plants.)

Cactus. (See under Plants.)

Caddis case. (See under Fossils, insects.)

Calamine crystals from Mexico, P1801.

Calcite. (See under Mineralogy.)

Calcium sulphide (oldhamite) in Allegan meteorite, P1622.

Calcutta, nematodes from animals dying in zoological garden, P2777.

Caldwell, John Stein, P3194.

California, Actaeon species from Quaternary bluffs, Spanish Bight, San Diego, P1145.

actinian, new species of Edwardsiella, P1967.

Agonidae, new species, Brachyopsis verrucosus, $\mathrm{P} 122$.

Agonus vulsus, $\mathrm{P} 162$.

Alcyonaria of coast, P1658.

aleyrodids, P1362.

amphipod, new, Acanthonotozomatidae, and notes on Eurystheus tenuicornis, P2861.

annelids, new polychaetous, Nereidae, P2994.

anthropological studies, R1900, pt. 2, No. 1.

Apodichthys, Monterey, P130.

auk, flightless, Mancalla californiensis, Miocene, P1245.

birds, field notes on, P623; Santa Barbara, P1196; central California, P56.

blenny, Isesthes gilberti, Santa Barbara, P288.

boxfish, spiny, Chilomycterus, P917.

Brachyura collected by Albatross, San Francisco to Norfolk, P1162.

brittle-star, upper Miocene, Santa Cruz Mountains, P1620.

Caryophyllia, new fossil species, P1194.

Caulolepis longidens, P1161.

Cephaloscyllium laticeps, P110.

cetacean, fossil physeteroid, Santa Barbara County, P2564.

Charina, new species, P689.

Chirus of San Francisco markets, P120.

chlorites, analyses and optical properties, P2342.

Coenocyathus, new species, P1477.

crabs, fossil, P1647, 2214.

Cremnobates sp., San Diego, P133.

Crustacea of order Cumacea, P2992.

dragonflies, life history and ecology, P2192.

fishes, Abeona aurora, Monterey, P151.
California, fishes (continued).

Albatross collections, P2075.

blennioid, new, P967.

Brachyopsis xyosternus, Monterey Bay, P135.

cottoid, Monterey Bay, P2049.

Cymatogaster rosaceus, P153.

cyprinoid, of San Francisco mar-

kets, note on paper of Dr. Ayres, P159.

Ditrema atripes, P156.

flatfish, Lepidopsetta isolepis from San Francisco markets, P158.

flounder, Hippoglossoides exilis, P136; Platysomatichthys stomias, P152; Pleuronectes verticalis, P117; Xystreurys liolepis, Santa Catalina lsland, P107.

Gasterosteus williamsoni, San Bernardino, P373.

Gillichthys $y$-cauda, San Diego, P774.

Gobiesox rhessodon, San Diego, P208.

Hemirhamphus rosae, new species, P164.

Icichthys lockingtoni, P154, 2472.

Icosteus aenigmaticus and Osmerus attenuatus, P123.

Mohave River, P2236.

Myriolepis zonifer, Monterey Bay, P140.

new genera and species, P97.

notes on, P742.

Osmerus, review, P2027.

Othonops eos, San Diego, P187.

Owens River, P2333.

Pantosteus santa-anae, Santa Ana River, P1595.

Pleuronectidae of San Francisco, review, P72.

Prionotus stephanophrys, P182.

Ranzania makua and others, P1961.

ray, Platyrhina triseriata, P108; Raia rhina, P141; Raia stellulata, Monterey, P129.

Rimicola eigenmanni and Plagiogrammus hopkinsi, P1643.

"rock cod," Sebastichthys serriceps, P109.

rockfish Sebastichthys carnatus, P126; Sebastichthys chrysomelas, P176; Sebastodes, new, P1501.

San Diego, P106, 897.

Santa Catalina Island, P1510.

Sebastichthys, Monterey Bay, P125, 132, 161.

Sebastichthys maliger, P157.

Sebastichthys umbrosus and Citharichthys stigmaeus, collected by Andrea Larco at Santa Barbara, P296.

sebastoid, new species, P150. 
California, fishes (continued).

Sudis ringens and Myctophum crenulare, Santa Barbara Channel, P146.

surf-fish, Crossochir koelzi, P2962.

trout, golden, Salmo mykiss aguabonita, from Kern River, P916. fossil form, spiral, P2836.

fossils, Cretaceous and Tertiary, Santa Cruz Mountains, P1617; post-Pliocene of coast range, P2; San Pedro fauna, Nob Hill Cut, P2535; Tertiary, distribution, P14. gnatcatcher, black-capped, Polioptila californica, nest and eggs, P662.

Gyrophoraceae, CNH13, pt. 10 (1st art.).

Haliotis, new variety, P1191.

Hymenoptera collected by W. M. Giffard, P2202.

Indians, crania, P2631.

isopods, new genus of Tanaidae and new species of Tanais, Monterey Bay, P1400; new species, P1670.

lichen flora, CNH17, pt. 1; lichens collected by Edward Palmer, CNH1, No. 8 (7th art.).

lizard, new, P944; Uta mearnsi, P1080; Verticaria beldingi, P977. mammals, field notes on, P623. millipeds, Colobognatha, P2714.

mollusks, Epiphragmophora traskii group, P2170; later Tertiary, P8; Miocene Haliotis, Temblor Range, P2938; new shells in National Museum, P18; new, with note on Selenites duranti, P584; oil-bearing Tertiary, P1545; San Diego, P536; San Pedro Bay, P898; Trinidad, P2325.

mosquitoes of coast region, P1516.

plants, fossil, P679; southern California, CNH1, No. 1 (1st art.); used by Indians, $\mathrm{M}$ e $\mathrm{n} \mathrm{d}$ o $\mathrm{c}$ i $\mathrm{n}$ o County, CNH7, No. 3.

Productus giganteus, fossil, P113.

raccoon from Pleistocene cave deposit, P1435.

reptiles, field notes on, $\mathrm{P} 623$.

Rotatoria, new, Los Angeles, P2190. salamander, new, P2770.

sharks, Carcharias lamiella, San Diego, P269; notes on, P118; oil from Galeorhinus galeus, P111.

silver ore, miargyrite, from Randsburg District, P2766.

snakes, garter, Thamnophis ordinoides, variation, P2051, 2179; Lichanura, P878; new species, P766; Tantilla eiseni, P1044.

sparrows, new sharp-tailed, P872; unnamed, P458.

sponges, marine and fresh-water, P2927.

throwing-sticks, P932.
California (continued).

velardeñite from Tulare County, P2417.

whale, humpback, skull of Megaptera miocaena from Miocene of Lompoc, P2435.

Xiphister, Monterey, P130.

(See also Gulf of California.)

Call, Richard Ellsworth, P651.

Calman, William Thomas, P1876.

Calvert, Philip Powell, P951, 1046, 1047.

Calvert Cliffs, Md. (See under Fossils, Maryland.)

Cambrian. (See under Fossils.)

Camels. (See under Fossils, mammals.)

Campbell, Douglas Houghton, fishes collected at Buytenzorg, Java, P1575.

Canada, birds, Manitoba, P841.

copepod, Moraria, new, P2673.

flatworms, polyclad, Atlantic coast, P3101.

Lepidoptera, diurnal, Athabaska and Mackenzie region, P1488.

mammals from northern Mackenzie River district, with remarks on explorers and explorations of the Far North, P1405.

rutile-mica intergrowth, $\mathrm{P} 1801$.

Tenthredinoidea from eastern, P1739.

Unins and other shells, Toronto, P952.

Canal Zone, Bryozoa, fossil, B103, pt. 6. Cirripedia, fossil, B103, pt. 8.

Echini, fossil, B103, pt. 5; P2218.

flora, CNH27.

Foraminifera, fossil, B103, pts. 3, 4. geology and paleontology, contributions to, B103, pts. 1-11.

Lepidoptera, Smithsonian Biologica! Survey, P2050.

Lithothamnieae, fossil and recent, B103, pt. 1.

onychophores, P3197.

palm nut, Miocene, P2356.

plants, higher, fossil, B103, pt. 2.

sedimentary formations, B103, pt. 10.

Candlefish. (See under Fishes.)

Canoes, Kutenai and Amur, R1899, pt. 2, No. 4.

Canu, Ferdinand, and Bassler, Ray Smith, B96, 100, vol. 9; 103, pt. 6; $106,125,165$; P2443, 2593, 2640, 2710, 2810.

Cape San Lucas, fishes collected by John Xantus, P290; by L. Belding, P293.

Capelins. (See under Fishes.)

Capps, Hahn William, P3159.

Carabao. (See under Mammals.)

Carboniferous. (See under Fossils.)

Carbonnier, M. [Charbonnier, Henry F.], P276.

Cardinalfishes. (See under Fishes.)

Cards, playing, Japanese, P836. 
Caribbean Sea, birds, collected by Charles H. Townsend, P665; recorded by Pinchot Expedition, P2876.

crinoids collected by Albatross, P547. Echini collected by Albatross, P491. medusae collected by Albatross, P528. multibrachiate ophiuran of family

Gorgonocephalidae, P2257.

Carleton, Mark Alfred, CNH1, No. 6 (2d art.).

plants collected in Indian Territory, CNH1, No. 6 (1st art.).

Carlin, William Edward, P199.

Carlsbad Caverns, oolites or cave pearls, P2813.

Carmen Island, plants collected by Edward Palmer, CNH1, No. 5 (1st art.).

Carpenter, Frank Morton, P2695.

Carpenter, W. L., fishes obtained at Fort Thomas, Gila River, Ariz., P754.

Carriker, Melbourne Armstrong, Jr., P3180.

Carthage, Roman mosaic in National Museum, P393.

Cary, Merritt, P1488.

Casanowicz, Immanuel Moses, R1904, pt. 2, No. 2; B148; P1667, 1725, 1921, 2111, 2168, 2287, 2371, 2432, 2587, 2630.

(See also under Adler and Casanowicz.)

Casts, gelatine, making, P926.

metallic castings of natural objects, P212.

plaster, making and preserving, P226.

(See also under Anthropology.)

Catesby's Natural History of Carolina, Florida, and the Bahama Islands, identification of figures, $\mathrm{P} 422$.

Catfishes. (See under Fishes.)

Catlin, George, Indian paintings, R1885, pt. 5 ; 1890, pt. 3 , No. 8.

Cats. (See under Mammals.)

Cattie, S. Th., P148.

Caudell, Andrew Nelson, P1333, 1335, $1378,1403,1450,1530,1563,1599$, 1956, 1970, 2058, 2093, 2130, 2468, 2675, 2679, 2921.

Arachnida collected by in British Columbia, P2143.

Cave deposit near Cumberland, Md, Pleistocene, P2014.

Cave pearls in Carlsbad Caverns, P2813. Caves, burial. (See under Anthropology.)

Celebes, birds from north and northcentral parts, P2506.

buffalo motive in decorative design, P2895.

fishes, pediculate, new family collected by Albatross, P1917.

starfishes from Albatross Philippine cruise, P1944, 2022.

Cenozoic. (See under Fossils.)
Censers, Mexico and Central America, P1887.

Centipedes. (See under Myriapods.)

Central America, Allioniaceae, $\mathrm{CNH} 13$, pt. 11.

anteater, great, new species, P1496. batrachians and reptiles, catalog, B32.

beetles, buprestid, leaf and twig mining, P2454; buprestid, new, P2968; checklist, B185; Eucnemididae, new species of, P3188.

censers and incense, P1887.

centipedes, P2402.

corals, fossil, B103, pt. 9.

craneflies, new, P2080.

deer, Cariacus clavatus, P734.

Diptera of family Dolichopodidae, P2755.

Ficus, species of, CNH20, pt. 1.

fishes, fresh-water, catalog, P925; Ophioscion, new Atlantic coast species, P3192.

flatworms, new species, P3055.

geology and paleontology, B103, pts. 1-11.

grasses, CNH24, pt. 9.

belminth parasites from mammals, P2725.

heron, new boat-billed, P493.

insects, Apterygota, P2702; coleopterous, checklist, B185; Hymenoptera, Anteoninae, P2704.

Lecythidaceae, CNH26, pt. 1. millipeds, P2403.

mollusks, land and fresh-water, P2638.

mouse, Sitomys decolorus, P963.

mussels, Anodontites, P2889.

onychophores, P3027.

plants, new or noteworthy, CNH12, pt. $5 ; 13$, pts. 4,$12 ; 18$, pts. 2,4 , 6 ; 20, pts. 3,12 ; studies, CNH5, No. 3 , No. 4 (1st art.) ; 8, pts. 1 , $4 ; 10$, pt. $3 ; 12$, pt. $7 ; 13$, pt. 9 .

sedimentary formations of Panama, relation to geologic history, B103, pt. 11.

Sapium, species of, CNH12, pt. 4.

termites, new, P2441.

Tonduzia, new genus of Apocynaceae, CNH12, pt. 2 (2d art.).

Viburnum, species of, CNH26, pt. 7.

Xenichthys xenurus, P252.

(See also under Middle America.)

Cephalochordata, leptocardians, note on, P307.

Cephalopods. (See under Mollusks.)

Ceramics, Japanese, P745.

lacquerware, Wakasa, P745.

porcelains, Hippisley Chinese, with history of Chinese ceramic art, R1888, pt. 3, No. 2; R1900, pt. 2, No. 3.

pottery, early West Virginia, R1899, pt. 2 , No. 3. 
Ceremonial objects. (See under Anthropology, religion.)

Cestodes:

Calyptrobothrium from torpedo, P1529.

Cittotaenia mosaica from rabbit, P1629.

Crepidobothrium amphiumae from Amphiuma tridactylum, P2926.

Dinobothrium, anatomy, P2401.

from African bustard, P1844.

from Amphiuma tridactylum, P2926.

from birds, B69; P893, 2656.

from dogs and cats, P2258.

from fishes, P1123, 1125, 1560, 2977, 3112.

from sharks, P2433, 2511, 3135.

from skates, P2511.

Moniezia and proposed reduction of species, P2754.

parasites, new internal, P2603.

$P$ aruterina from yellow-billed cuckoo, P2791.

Proteocephalus punicus, note on, P1780.

Rhabdometra from quail, P2791.

Taenia balaniceps, parasite of dog and lynx, with note on Proteocephalus punicus, P1780.

Taenia chamissonii, cysts, from porpoise, P1410.

Taenia laticollis, redescription, P2980.

tapeworms, adult, of hares and rabbits, P1105; from carnivores, P2980; from quail and yellowbilled cuckoo, P.2791; proliferating larvae of from porcupine, P2561; Belachian, anatomy of Dinobothrium, P2401.

Cetaceans. (See under Mammals; also under Fossils, mammals.)

Ceylon, reared parasitic hymenopterous insects, P1092.

Chachalacas. (See under Birds.)

Chaclacayo trephined skull, P531.

Chaetognaths, Philippine, B100, vol. 1, pt. 4.

Chalcid-flies. (See under Insects, $\mathrm{Hy}$ menoptera.)

Chalcocite, relation in copper ores, P1835.

Chalcodite, Westfield, Mass., P2316.

Chamberlin, Ralph Vary, P1242, 1270, 2402, 2403, 2431, 2481.

Chameleons. (See under Reptiles.)

Champlain, Alfred B., and Böving, Adam Glede, P2323.

Chandler, Asa Crawford, P2393, 2471, 2553, 2777, 2792, 2866, 2939, 2977, 3135.

Chanler, William Astor, east African collection, Coleoptera, P1094; Diplo. poda, P1042; Lepidoptera, P1063, 1098 ; Odonata, P1047; reptiles and batrachians, P970.
Chapin, Edward Albert, P2456, 2526, 2603, 2674, 3092.

Chapman, Frank Michler, B117.

Chapman, Wilbert McLeod, P3062.

Characins. (See under Fishes.)

Chars. (See under Fishes.)

Chase, Agnes, CNH22, pt. 1 (3d and 4th arts.), pt. $4 ; 24$, pt. $6 ; 28$, pt. 1.

(See also under Hitchcock and Chase.)

Chatelaine, Heli, Myriapoda collected at Loanda, Africa, P968.

Chats, palm. (See under Birds.)

Chatterers. (See under Birds.)

Chemistry:

arsenic acid for protecting anatomical preparations, P12.

calcium sulphide (oldhamite) in Allegan meteorite, P1622.

sulphurous acid, action of on putrefactive bacteria, compared with that of dry heat, P218.

water destructive to fishes, analysis, P201.

water from Gulf of Mexico, P222.

Chemung formation, Dalmanellas and a new brachiopod genus, Thiemella, P1596.

Cherrie, George Kruck, P855, 879, 888.

Chesapeake Bay, annelids, new, P2867. copepod crustaceans from, P2915.

fishes, Apogon pandionis, P211; notes on, P389.

Chesapeake Group, outline of divisions, P2759.

Chesnut, Victor King, CNH7, No. 3.

Chess, R1896, pt. 2, No. 3.

Chicago, study of museums and kindred institutions, R1903, pt. 2, No. 2; World's Columbian Exposition, system of classification, R1891, pt. 3, No. 8 .

Chigger mites. (See under Arachnids, mites.)

Childs Frick Expedition, Ethiopia and Kenya Colony, birds, B153.

Chile, annelid, new marine, P2536. beetles, Phytholaema, P3028.

birds, observations on, B133.

fishes collected by Albatross between Tome and Montevideo, Uruguay, P2133.

plover, new, P312.

Chilopods. (See under Myriapods.)

Chimaeras. (See under Fishes.)

China, annelids, polychaetous, P2641, 2984.

amphibians in National Museum, P2562.

birds, collected by National Geographic Society's expendition, Chihli and Kansu, P2838; collected for National Geographic Society by Joseph R. Rock, Yunnan and Szechwan, P2654, 2907.

Cambrian faunas, P1415, 1458.

carnivore, new, P1755. 
China (eontinued).

caves, Szechwan, P2916.

earthworms, collected by D. C. Graham, Szechwan, P3040.

fishes, collected by N. F. Drake, River Pei-Ho, Tien-Tsin, P1221; collected by P. L. Jouv, Shanghai and Hongkong, P1433; Soochow, P2338; Yalu River, P2228.

flies, Calliphoridae, P2844; new parasitic species from beetles, P2753.

fossils, new species of Ordovician, P1549; upper Paleozoic, P1557.

games with dice and dominoes, R1893, pt. 2, No. 2.

Hippisley collection of porcelains, with sketch of history of ceramic art, R1888, pt. 3, No. 2; R1900, pt. 2, No. 3.

insects, neuropteroid, Szechwan, P3079; Trichoptera, P2891.

isopod, Ichthyoxenus geei, P2319.

leaf-katydids, Xiphidiopsis, P3176.

lizards, Gekko, P2944.

loach, Misgurnus decemcirrosus, P1474.

mammals, in National Museum, P2772.

molluscan genus Tanaodon, new Middle Devonian, P2661.

nematodes, parasitic, P2614.

plants, collected by R. C. Ching, Kansu Province, CNH28, pt. 4.

porpoise, finless, Neomeris phocaenoides, anatomy, P2662.

reptiles, in National Museum, P2562. spiders, new, P2481.

spleenwort, new, CNH12, pt. 9 (11th art.).

Spongilla, new species of, P1737.

trematodes from dog, P2415.

viper, green pit, Trimeresurus gramineus, P2715.

wasp, psammocharid, new genus, P3119.

China Sea, barnacles collected by Albatross, P1904.

birds of Tambelan Islands, P2262.

hemiscylliid shark, new genus, P1997.

new squirrel, Direction Is land, P1686.

Ching, R. C., plants collected by in southern Mongolia and Kansu Province, China, CNH28, pt. 4.

Chinnook names of salmon, P244.

Chitons. (See under Mollusks.)

Chittenden, Frank Hurlbut, P1041, 2841.

Chitwood, Benjamin Goodwin, P2919.

Chlorites, California and Wyoming, P2342.

Chlorophoenicite, Franklin, N. J., P2669.

Choctawhatchee marl, mollusks, P2169.

Chriatensen. Carl. CNH26, pt. 6.
Chromites, meteoric, P1628.

Cinchona barks, in National Museum, P582.

Cincinnati, Ohio Valley Centennial Exposition, exhibits, graphic arts, C37; mammals, C41; Oriental antiquities, C39; prehistoric anthropology, C40; transportation and engineering, C38.

Cincinnatian group, structural features of Homotrypa, P1323.

Cirripedia. (See under Crustaceans, barnacles, rhizocephalans; also under Fossils, crustaceans. )

Ciscos. (See under Fishes.)

Cladocerans. (See under Crustaceans.)

Clarion Island, plants, P801.

Clark, Alonzo Howard, B27, pt. K.

Clark, Austin Hobart, Birds, P1539, 1727, 1735.

Echinoderms, B82; 100, vol. 5.

P15+3, 1547, 1551, 1559, 1561, 1582, $1585,1607,1608,1612,1613$, $1615,1623,1634,1636,1668$, $1673,1685,1691,1693,1697$, $1732,1740,1743,1749,1756$, $1793,1795,1798,1808,1845$, $1849,1895,1937,2026,2257$, 2905, 2982, 3056, 3061, 3098.

Lepidoptera, B157.

P1987, 2683, 2934, 3013, 3118.

Onychophores, P3027.

Clark, Austin H., and Sandhouse, Grace Adelhert, P3005.

Clark, Austin H., and Zetek, James, P3197.

Clark, Howard Walton, and Evermann, Barton Warren, P1478.

Clark, Hubert Lyman, B75; P1018, 1166, 1724, 3054, 3099.

Clark, Josephine Adelaide, CNH1, No. 5 (4th art.), No. 7.

Clarke, Charles Baron, CNH10, pt. 6.

Clarke, Frank Wigglesworth, R1886, pt. 3, No. 1 ; C26.

Clarke, F. W., and Merrill, George Perkins, P696.

Clarke, John Frederick Gates, P3107, 3123, 3149, 3162.

Clarke, Samuel Fessenden, P1343.

Clays, gouge, from precious metal veins, P2461.

Clingfishes. (See under Fishes.)

Cloth fragment, from mound in Ohio, P347.

Coal. (See under Mineral industries.)

Coast Indians of Alaska. (See under Anthropology, Indians.)

Cochran, Doris Mable, B177; P2421, 2543, 2834.

Cockerell, Theodore Dru Alison, fossils, P1955, 2000, 2119, 2146, 2181, 2210, $2237,2313,2355,2358,2475,2503$, 2556, 2602, 2606.

Homoptera, B391; P1026. 
Cockerkll. (continued).

Hymenoptera, P1674, 1717, 1745, $1806,1818,1852,1897,1932,2010$, $2045,2264,2413,2476,2607,2684$. mollusks, P1238.

plants, P1122.

Cockerell, T. D. A., and Andrews, Hazel, P2141.

Cockerell, T. D. A., and Robbins, Wilfred William, P1671.

Cockerell, T. D. A., and Sandhouse, Grace, P2380.

Cockerell, T. D. A., and Viereck, Henry L., P2064.

Cockerell, W. P., Hymenoptera collected in Guatemala, P2061.

Cockroaches. (See Insects, Orthoptera; also under Fossils, insects.)

Cocos Island, plants, CNH1, No. 5 (2d art.-1).

Cod. (See under Fishes.)

Coelenterates, Labrador and Newfoundland, P1706.

(See also under Anthozoans, Corals, Ctenophores, Hydrozoans, Medusae, Polyps, Sea anemones.)

Cogniaux, Alfred, $\mathrm{CNH}_{3}$, No. 9 (5th art.).

Coker, Robert Ervin, P2298.

barnacles collected by in Peru, P1700.

Cold Bay, Alaska, pallasite, P2425.

Cole, Frank Raymond, P2450.

Cole, F. R.; Van Duzee, Millard Carr; and Aldrich, John Merton, B116.

Cole, William Storrs, and Vaughan, Thomas Wayland, P2996.

Coleoptera. (See under Insects; also under Fossils, insects.)

Collembola. (See under Insects.)

Collins, Frank S., B39b.

Collins, Guy N, CNH12, pt. 10 (4th art.).

Collins, G. N, and Cook, Orator Fuller, CNH8, pt. 2; P837.

Collins, Henry Bascom, Jr., P2898.

Collins, Joseph William, B27, pt. I.

Colombia, crocodilian, fossil, P3122.

Crustacea collected at Santa Marta by Walker Expedition, P2123.

fishes collected by Albatross, P770.

hummingbirds, catalog, P1258.

palms, stilt, new genera of, with review of family Irarteaceae, CNH16, pt. 6 .

plants, new or noteworthy, CNH12, pt. $5 ; 13$, pts. 4,$12 ; 18$, pts. 2,4 , $6 ; 20$, pts. 3, 12; Tertiary, P2795.

Raimondia, new genus of Annonaceae, CNH16, pt. 5 (6th art.).

Colorado, beetles, Florissant, P2189.

bird, Florissant, P2215.

Coleoptera, Florissant, P1982.

Entomostraca, altitudinal distribution, P2226; new species, with notes on others, P2096; Shantz
Colorado, Entomostraca (continued). collections, Pikes Peak region, P2531.

fossils, Cretaceous, P207.

geology, petrography, mineralogy, Italian Mountain, Gunnison County, P2690.

insects, Eocene, P2358; Florissant, P1955, 2000, 2210.

invertebrates, Cretaceous, P1611; new Mesozoic and Cenozoic, P137. moths, larvae, P1290.

Orthoptera, notes on, P1333.

plant and insect fossils, Green River Eocene, P2556.

plants, F1 o ris s a n t, P2151; new, CNH1, No. 8 (4th art.).

rossite and metarossite, new vanadates, P2707.

trout, yellow-finned, Twin Lakes, P780.

worm, new discodrilid, P1912.

Colorado Basin, Ariz., fishes, P1131.

Colorado Desert, fossil fresh-water shells, distribution, environment, and variation, P1256.

Columbia River, Chinnook names of salmon, P244.

pit-house village site, Wahluke, Grant County, Wash., P2732.

Salmonidae, notes on, P196.

Columbia River region, Leibergia, new genus of Umbelliferae, $\mathrm{CNH} 3$, No. 9 (4th art.).

Columbian Institute for Promotion of Arts and Sciences, history of, B101.

Comanche series, Trinity division, Tex. plants, P934.

Comatulids. (See Echinoderms.)

Commander Islands, birds, P345, 614.

cetaceans, new, P344.

cormorant, Pallas's, P765, 1095.

Entomostraca collected by L. Stejneger, P621.

fishes collected by N. A. Grebnitski and L. Stejneger, P1106.

grass, Alopecurus stejnegeri, P620.

medusa e, Haliclystus stejnegeri, P1188.

Mesoplodon stejnegeri collected by L. Stejneger, P540.

Mollusca, P442, 562.

ornithological explorations, B29.

plants, P462, 463, 620.

sea-cow, Steller's, extermination, P421.

Compere, Harold, P2850.

Conchostraca. (See under Fossils, crustaceans.)

Congo, diplopod Myriapoda, Oxydesmus, P1036.

Congo Free State, new species of blindsnakes (Typhlopidae), P969.

Conodonts. (See under Fossils.)

Connecticut, Long Hill in Trumbull, minerals from tungsten mine, P2348.

Cook, Caleb, P9. 
Cook, Orator Fuller, myriapods, P968, 1036-1039, 1042, 1137, 1154, 1169, $1170,1810,1831,1842$.

plants, CNH7, No. $2 ; 13$, pt. $5 ; 14$, pt. $2 ; 16$, pts. 8,$11 ; 17$, pt. 8 .

Cook, O. F., and Collins, G. N, CNH8, pt. 2 ; P837.

Cook, O. F., and Doyle, Conrad Bartling, CNH16, pt. 6.

Cook, O. F., and Loomis, Harold Frederick, P2714.

Cooke, Charles Wythe, P2731.

Cooke, C. Wythe, and Henderson, Edward Porter, P3143.

Cooke, George Henry, R1897, pt. 2, No. 4.

Cooper, James Graham, P85.

Coots. (See under Birds.)

Cope, Edward Drinker, R1898, pt. 2; B1, 17, 32, 34; P615, 645, 689, 715, 727, 728, 729, 769, 866, 882.

Copepods. (See under Crustaceans.)

Copper. (See under Anthropology, Metallography, Mineralogy.)

Copper Island, fishes collected by N. A. Grebnitski and L. Stejneger, P1106; plants collected by L. Stejneger, P462.

Coquillett, Daniel William, P1073, 1146, $1198,1225,1227,1243,1280,1719$.

Corals:

Africa, French Somaliland, P1526. Brazil, P1477.

Coenocyathus, new, California, P1477. fossil, Central America, Cuba, and Puerto Rico, and American Tertiary, Pleistocene, and recent coral reefs, B103, pt. 9.

Fungia concinna and $F$. granulosa, P1473.

Madrepora in National Museum, P604.

Madreporaria, Recent, Hawaiian Islands and Laysan, B59.

Madreporaria Fungida, review, P1401.

Synaraea in National Museum, P635.

(See also under Fossils.)

Cormorants. (See under Birds.)

Corrodentia. (See under Insects.)

Corundophilite, Chester, Mass., P2342.

Costa Rica, amphipods, P1341, 1490, 1609.

annelid, Phyllodoce, P2757.

batrachians, P1857.

beetle(s), buprestid, P2803; golden, new species of, P1040.

birds, collected by C. C. Nutting, P305; from northern Guanacaste, P3179; Gulf of Nicoya, Hacienda "La Palma," P295; new forms, P39, 392, 477, 750, 855; notes on, P235, 499, 869, 879, 956; Rio Frio, P947.

Cotinga, new species, P599. crabs, fresh-water, P1071.

crickets, new species, P1459.
Costa Rica (continued).

Cyperaceae, CNH10, pt. 6.

Echini, fossil, B103, pt. 5; P2218.

flies, Tipulidae, P2420.

flycatcher, new, P888.

isopods, P1775, 1954.

katydids, new species, P1459.

Lecythidaceae, CNH12, pt. 2 (1st art.).

lizard, new gerrhonotine, P1542.

mice, supposed new species, with remarks on Hesperomys melanophrys, P850.

millipeds, new genera and species, P1810.

mosses collected by P. C. Standley, CNH26, pt. 3.

Orchestoidea biolleyi, P1609.

Piperaceae, CNH26, pt. 4.

plants, Tertiary, P2367.

Porzana, new species, P611.

shells from kitchen midden, P11.

Thalassophryne dowi, Punta Arenas, P639.

tree toad, P1471.

whippoorwill, new species, P867.

Cotton. (See under Plants; Textiles.)

Cotion, Richard Thomas, P2542.

Cotton States International Exposition. (See under Atlanta, Ga.).

Coues, Elliott, P101.

Coues, Elliott, and Kidder, Jerome Henry, B3.

Coues, Elliott, and Prentiss, Daniel Webster, B26.

Coulter, John Merle, CNH1, No. 2; 2, Nos. 1.3 ; 3, Nos. $2,7$.

Coulter, John M., and Rose, Joseph Nelson, CNH3, No. 5 (1st art.), No. 9 (4th art.) ; 5, No. 4 (3d art.); 7, No. 1 ; 12 , pt. 10 (3d art.).

Coutière, Henri, P1659, 1716.

Coville, Frederick Vernon, R1892, pt. 2, No. 3; B39j; $\mathrm{CNH} 3$, No. 6, No. 9 (2d art.) ; 4; 5, Nos. 1, 2.

Cowbirds. (See under Birds.)

Coyotes. (See under Mammals.)

Cozumel Island, Yucatán, birds collected by Albatross, P539; new hawk from, P494.

Crabeater. (See under Fishes.)

Crabs. (See under Crustaceans; also under Fossils, crustaceans.)

Cradles, of American aborigines, R1887, pt. 3, No. 1.

Cram, Eloise Blaine, B140; P2616.

Cramer, Frank, and Gilbert, Charles Henry, P1114.

Cranes. (See under Birds.)

Crania. (See under Anthropology; also under Heads.)

Crawford, David Livingston, B85.

Crawford, James Chamberlain, P1730, $1733,1786,1804,1830,1855,1880,1927$, 1979, 1984, 2029, 2041, 2048, 2087.

Crayfishes. (See under Crustaceans.) 
Creedite, crystallography, and chemical composition, P2376.

Creepers. (See under Birds.)

Creodont. (See under Fossils, mammals.)

Cresson, Ezra Townsend, B15.

Cretaceous, Upper and Lower. (See under Fossils.)

Crickets. (See under Insects, Orthoptera.)

Crinoids. (See under Echinoderms; also under Fossils, echinoderms.)

Crocodiles. (See under Fossils, reptiles.)

Crocodilians. (See under Reptiles; also under Fossils, reptiles.)

Cross, Whitman, and Shannon, Earl Victor, P2690.

Crows. (See under Birds.)

Crumb, Samuel Ebb, P2617.

Crustaceans:

Acanthoniscus spiniger redescribed, P1678.

Acanthonotozomatidae, new species, California, P2861.

Aega, Atlantic coast United States, P1841.

Aegla, South American, P3132.

Africa, P949, 980, 1199.

Alabama, P3129.

Alaska, P459, 1591.

Albatross collections. (See under $\mathrm{Al}$ batross.)

Albunea, use of antennulae, P1367.

Albuneidae, Pacific, P1367.

Aldabra Island, P973.

Alonopsis, American, P1940.

Alpheidae, Dry Tortugas, Fla., P1716.

amphipods, Albatross, west coast of North America collection, P1654. ampeliscid, Newfoundland, Nova Scotia, and New Brunswick, P2888.

Baterdae in National Museum, P2626.

California, P2861.

Costa Rican, P1341, 1490.

fresh-water, North American, P1507.

Gulf of Mexico, P1594, 1936.

Newfoundland, Nova Scotia, and New Brunswick, P2827, 2888.

Newport, R. I., P1084.

Peruvian, P1767, 1768.

Pribilof Islands, P1998.

sand fleas, Rhode Island, P1084.

Virginia, P1746.

Ancinus depressus, P1663.

Anilocra, Atlantic coast of North America, P1779.

Anomura, New England, P343.

Antillean region, P986.

Apseudes, Ecuador, P1918; Galápagos Islands, P1926.

Arctic America, Howgate Polar Expedition, B15.

Argentina, Rio de la Plata, P1811.
Crustaceans (continued).

Argulidae, development, P1531; North America, P1302.

Argulus, P1368, 3087.

Aselloidea, Atlantic coast of North America, P1633.

Assumption Island, P173.

Astacidae, P525, 785, 1136.

Atelecyclidae, American, B152.

barnacles, Gulf of California, P3166.

in National Museum, B60.

pedunculate, north Pacific, P3081.

Peruvian, P1700.

Philippine and China Sea, Albctross collection, P1904.

San Juan Islands, Wash., P2362. sessile, American, B93.

Bateidae in National Museum, P2626.

Boeckella, synopsis of species, P2498.

brachyurans, collected by Albatross, from Virginia to California, P1162; New England, P343.

Branchinecta, Washington, P3025.

Briarosaccus callosus, P2804.

calanoid, exclusive of Diaptomidae, P2959.

California, P1400, 1670, 2861, 2992.

Caligidae, North American, P1404; Caliginae, new North American, P1580; Pandarinae and Cecropinae, revision, P1573; Trebinae and Euryphorinae, P1504.

Callinectes, P1070.

Cambarus, Florida, P3097.

Cambarus pellucidus testii, Indiana, P935.

Canada, P2673.

Cancridae, American, B152.

Cassidinidea, Mexican, P1886.

Cecropinae, revision, P1573.

Centropagidae, fresh-water, key to genera, P2498.

Chelura terebrans destructive to submarine structures, P83.

Chesapeake Bay, P2915.

China, isopods, P2319.

China Sea, P1904.

Chondracanthus, P572.

cladocerans, New England, P1758, 1848.

Clausidium, North American, P2377.

Cleantis, Japanese, P1883.

Colombia, collected by Walker Expedition at Santa Marta, P2123.

Colorado, P2226, 2531.

Commander Islands, Bering Island, P621.

copepods, Argulidae, P1302.

Caligidae, P1404; Caliginae, P1580; Pandarinae and Cercopinae, P1573; Trebinae and Euryphorinae, P1504.

Chesapeake Bay, P2915.

Clausidium, P2377. 
Crustaceans, copepods (continued).

Diaptomus, distribution and key, P2795.

Dichelesthiidae, P2400.

Ergasilidae, North American, P1788.

Florida, Diaptomus floridanus, P2659.

fresh-water, in National Museum, P1901.

harpacticoid, from marsh crab, P3110.

Harpacticoida, P1758.

Honduras, P2285.

Lernaeidae, North American, P2194.

Lernaeopodidae, P1783, 2063.

Moraria, Canadian, P2673.

Pandarus and Chondracanthus, P572.

parasites of fishes, P1560, 1652.

parasitic, in National Museum, P1900, 3177; new, P1805, 2274, 2354, 2507.

Senecella calanoides, P2541.

Siphonostoma, in National Museum, P454.

Sphyriidae, P2286.

Trebius, Perissopus, and Lernanthropus, P664.

Woods Hole region, Mass., B158; P2739.

Costa Rica, P1071, 1341, 1490, 1609, 1775, 1954.

crabs, African, new, P980.

Albatross collections. (See under Albatross.)

Antillean, P986.

brachyrhynchous, American, P2047.

cancroid, American, B152.

corystoid, Telmessus and Erimacrus, P900.

Costa Rican, new, P1071.

fresh-water, new, American, P959.

Goneplacidae, Philippine, P2067.

Grapsidae and Ocypodidae, P2030, 2044.

Grapsidae larvae, P2523.

grapsoid, American, B97.

Hawaiian, P1309.

hermit, Eupagurus, in National Museum, P887; pagurids, West Indian region, P1236; Pagurus bernhardus type, P1216.

In achidae and Parthenopidae, Philippine, P2135.

Inachidae in National Museum, P984.

Indian Ocean, western, new, P979.

land, crustacean parasites of West Indian, P1950.

Lithodidae, P1016.

Maiidae, in National Museum, P927.

marsh, copepod from gills, P3110.

Ocypodidae, P1971, 2030, 2044.
Crustaceans, crabs (continued).

Osachila, P2138.

oxystomatous and allied, American, B166.

Periceridae, catalog, P901. Philippine, P2044, 2067, 2135.

Pinnotheridae, larvae, P2497.

Pseudothelphusinae, P1158.

spider, American, B129; new, P2504.

West Indian, new, P1104.

Xanthidae, larvae, P2575.

crayfishes, Alabama caves, P3129.

Astacidae, P525, 785, 1136.

Cambarus, new, P1187, 3097.

Cambarus pellucidus testii, Indiana, P935.

Cuba, P1295, 1316.

Cubaris, Panama, new, P1911.

cumaceans, California, P2992; in National Museum, P1876.

Cyprididae, revision of subfamilies and genera, P1347.

Dajidae, new isopod genus of, P1618; Northwest Pacific, P1586. decapod, Africa, west, P1199; North America, west coast, new, P1272; sperm transfer in, P1791; United States, east coast, P455. (See also under Fossils, crustaceans.)

Diaptomus, distribution and key, P2785.

Diapfomus floridanus, Florida, P2659.

Diaptomus virginiensis and $D$. $t y$ relli, P2117.

Dichelesthiidae, P2400.

Ecuador, P1918.

entomostracans, Alonopsis, P1940; Bering Sea, P621; Colorado, P2096, 2226, 2531. (See also under Crustaceans: Barnacles, Cladocerans, Copepods, Ostracods, Phyllopods, Rhizocephalans.)

Ergasilidae, P1788.

Erimacrus, corystoid crabs, P900.

Eryontidae, new species of Willemoesia group, P99.

Europhiidae in National Museum, P1480.

Eupagurus, in National Museum, P887.

euphausiaceans, Atlantic, western, P2634; in National Museum, P2055; Philippine, P2129.

Euryalidae, American, B152.

Eurycope, Marthas Vineyard, P1598.

Euryphorinae, P1504.

Eurystheus tenuicornis, notes on, P2861.

exhibit sent to International Fisheries Exhibition at London, B27, pt. B.

fairy shrimp, Washington, P3025.

Fanning Islands, B7.

Florida, P2659, 3057, 3097; Dry

Tortugas, P1716, 2924. 
Crustaceans (continued).

Galápagos Islands, P1926.

Galatheidae, marine species, P1311.

Glorioso Island, P973.

Gnathiidae, Atlantic coast of North America, P1653.

Goneplacidae, new, Philippine, P2067.

Grapsidae, new, P2030, 2044.

Grapsidae larvae, P2523.

Guatemala, P1535, 1718.

Gulf of California, P3166.

Gulf of Mexico, P1594, 1936.

Harpacticoida, synopsis of genera, P1758.

Hawaiian Islands, B7; P933, 1309, 1770.

Homarus, new crustacean allied to, P506.

Honduras, P2285.

Ichthyoxenus, discussion of, P1995.

Ichthyoxenus geei, China, P2319.

Idotea, Hakodate Bay, Japan, P1189.

Idotheidae, Argentina, new, P1811.

Inachidae, P984, 2135.

Indian Ocean, western, P979.

Indiana, P935, 1294.

isopods, Acanthoniscus spiniger redescribed, P1678.

Albatross northwest Pacific collection, P1701.

Ancinus depressus, P1663.

Apseudes, P1918, 1926.

Aselloidea, Atlantic coast of North America, P1633.

California, P1670.

Cassidinidea, Mexican, P1886.

Cleantis, Japanese, P1883.

Costa Rican, P1775, 1954.

Cubaris, Panama, new, P1911.

Dajidae, P1586, 1618.

Eurycope, Marthas Vineyard, P1598.

Florida, P2924.

Gnathiidae, Atlantic coast of North America, P1653.

Guatemalan, P1535, 1718.

Hawaiian, P1770.

Ichthyoxenus, discussion of, P1995. Ichthyoxenus geei, China, P2319.

Idotheidae, Argentina, P1811.

Jaeropsis, Patagonia, P1675.

Jamaican, P1894.

Japanese, P1995.

Java, P2419.

Leidya distorta, on new host, P1593.

Livoneca, Panama, new, P1430, 1891.

Mancasellus, Indiana, P1294.

$M u n n o p s i s$, Galápagos Islands, P1926.

natural history, contributions to, P1350, 1369.

New England, P75.
Crustaceans, isopods (continued).

North America, Atlantic coast, key, P1222; eastern coast, P3067; monograph, B54; Pacific coast, key, P1175.

North Carolina, P2165.

Notasellus, Patagonia, P1720.

Palaegyge, Panama, P1914.

parasites of fishes, Bermuda, P1560; Pacific coast, P1652.

Peruvian, P1729.

Probopyrus, Panama, P1914.

Pseudarmadillo, Cuba, P1295.

Pterisopodidae and other new forms, P2253.

Sphaeromidae, P1479.

subterranean, new, P1176.

terrestrial, in National Museum, P2713.

Jaeropsis, Patagonia, new, P1675.

Jamaica, P1894.

Janiridae, northwest Pacific, P1843.

Japan, P1189, 1307, 1883, 1995.

Java, P2419.

Kentucky, Mammoth Cave, P1285.

Kerguelen Island, B3.

Labrador, P374, 375, 1589.

Leidya distorta on new host, P1593.

Lepidopa, revision, P1337; use of antennulae, P1367.

Lernaeidae, P2194.

Lernaeopodidae, P1783, 2063.

Lernanthropus, new species of, P664.

Lithodes agassizii, rhizocephalan parasite of, P2804.

Lithodes brevipes, notes on young, P1016.

Lithodes camtschaticus, P1016.

Lithodidae, new, P1016.

Livoneca, Panama, new, P1430, 1891.

Lophogastridae in National Museum, P1480.

Lower California, B7.

Maiidae, catalog, P927.

Mancasellus, Indiana, P1294.

Massachusetts, B158; P1598, 1758, 2739.

Mexico, P1886, 3138.

Moraria, Canadian, new, P2673.

Munnopsis, Galápagos Islands, P1926.

Mysidacea, western Atlantic, P2634.

Nephrops, new crustacean allied to, P506.

New England, P75, 172, 343, 1848.

Newfoundland, P1589.

Newfoundland, Nova Scotia, and New Brunswick, P2827, 2888.

New Mexico, P1128.

North Carolina, P2165.

Notasellus, Patagonia, P1720.

Ocypodidae, P1971, 2030, 2044.

Orchestoidea biolleyi, Costa Rica, P1609.

Osachila, eastern coast North America, P2138. 


\section{Crustaceans (continued).}

ostracods, fresh-water, with revision of Cyprididae, P1347; in National Museum, P1651, 1750.

Pagurus bernhardus, hermit crabs of the type, P1216.

Palaegyge, Panama, new, P1914.

Panama, P1430, 1891, 1911, 1914.

Pandarinae, revision, P1573.

Pandarus, P572.

Panopeus, P858.

parasitic, new genera and species, P2832; on West Indian fishes and land crabs, P1950.

Parthenopidae, Philippine, P2135.

Patagonia, P1675, 1720.

Penaeidae, P507.

Periceridae, in National Museum, P901.

Perissopus, new species, P664.

Peru, P1700, 1729, 1767, 1768.

Peru and adjacent coast, P1766.

Philippine Islands, P1904, 2044, 2067, 2129, 2135.

Phronimidae, North Pacific, P258.

phyllopods, southwestern shortgrass prairies (U.S.), P2136.

Pinnotheridae, larvae, P2497.

Portunidae, American, B152.

Pribilof Islands, P1998.

Probopyrus, Panama, new, P1914.

Pseudarmadillo, new, Cuba, P1295.

Pseudoboeckella, synopsis of species, P2498.

Pseud othelphusinae, American, P1158.

Pterisopodidae and other new forms, P2253.

rhizocephalan, Briarosaccus callosus, P2804.

Rhode Island, Newport, P1084.

Sacculinidae, West Indian, P2726.

sand fleas (amphipods), Rhode Island, P1084.

schizopods, Alaskan, P1591; Lophogastridae and Eucophiidae, P1480.

Senecella calanoides, fresh-water copepod, P2541.

shrimps, snapping, Alpheidae, Florida, P1716; Synalpheus, P1659.

Siphonostoma, American, P454.

South America, P1929, 3132.

sperm transfer in decapods, P1791.

Sphaeromidae, new, P1479.

Sphyriidae, copepods belonging to, P2286.

Spilaeroma, New Mexico, P1128.

stalk-eyed, Japanese, P1307; Peru and adjacent coast, P1766.

stomatopods, P1017, 3138.

Synalpheus, P1659.

Tanaidae, California, P1400.

Tanais, California, P1400.

Telmessus, corystoid crabs, P900.

Tennessee, Nickajack Cave, P1292.

Texas, San Marcos, P1087.

Trebinae, P1504.
Crustaceans (continued).

Trebius, new species of, P 664.

Venezuela, Lake Valencia, P2381.

Virginia, P1746.

voices of, P6.

Washington, P3025; San Juan Islands, P2362.

West Indies, P1104, 1236, 1950, 2726.

Willemoesia group, P99.

Xanthidae, American, B152; larvae, P2575.

(See also under Fossils.)

Ctenophores, Philippine, B100, vol. 1, pt. 5.

Cuba, amphibians collected for Museum, P2205.

bats collected by William Palmer, P1359.

birds collected by Parish-Smithsonian Expedition, P2925.

corals, fossil, B103, pt. 9.

crustaceans, P1316.

fishes, Havana, P414, 551.

grasses, catalog, CNH12, pt. 6.

halfbeak, Hemiramphus balao, P2277.

isopod, Pseudarmadillo, P1295.

mollusks, Annulariidae exclusive of Chondropominae, P3096; Camaguey and Santa Clara Provinces, P2369; Chondropominae, P3039; Orthaulax, Tertiary, P2491; Vertigo cubana, P790.

Myriapoda, P720.

Pempheris poeyi, P516.

reptiles collected for Museum, P2205. toad, new, P1406.

Cuckoos. (See under Birds.)

Culin, Stewart, R1893, pt. 2, No. 2; 1894 , pt. 2, No. 2 ; 1896, pt. 2, No. 3.

Cumaceans. (See under Crustaceans.)

Cumberland Cave deposit. (See under Fossils, Maryland.)

Cumberland Gulf, fishes, B15.

Cumberland Sound, algae, Eskimos, lichens of Annanactook Harbor, Mammalia, mollusks, plants, B15.

Cumberland Valley of Kentucky and Tennessee, dragonflies, P1928.

Curassows. (See under Birds.)

Curran, H. M., spermatophytes collected in South America, CNH20, pt. 7 (2d art.).

Currie, Bertha Pauline, P2199.

Currie, Rolla Patteson, P1204.

Arachnida collected by in British Columbia, P2143.

birds collected by in Liberia, P1182.

Curtiss, A. H., fishes collected by in St. Johns River, Fla., P105.

Cushrnan, Joseph Augustine, B71; 100, vol. 1 , pt. 6 ; vol. 4 ; B103, pts. 3 , 4; B104, 161.

P1589, 1676, 1759, 1898, 1973, 2172, $2290,2302,2308,2360,2567,2597$, $2665,2716$. 
Cushman, J. A., and Jarvis, P. W., P2914.

Cushman, J. A., and Kellett, Betty, P2796.

Cushman, J. A., and Ozawa, Yoshiaki, P2829.

Cushman, J. A., and Parker, Frances Lawrence, P2903.

Cushman, J. A., and Wickenden, Robert Thomas Daubigny, P2780.

Cushman, Robert Asa, P2085, 2216, 2219, $2284,2296,2326,2334,2340,2399$, $2416,2429,2494,2510,2595,2709$, $2761,2822,2826,2857,2880,2955$, 2999, 3017, 3083, 3088, 3150, 3193.

Cushman, R. A., and Rohwer, Sievert Allen, P2315, 2320.

Cuvier and Valenciennes, typical fishes described by, P593.

Cuvier's "Règne Animal," genera of first edition, P1346.

\section{D}

Dakota formation, invertebrate fauna, P995.

Dall, William Healey, R1897, vol. 2.

Brachiopods, B8, 37; P773, 1032, 2314.

Diptera, P331.

Fossil fauna, [B53, pt. 1, sect. 1], B90; P2, 8, 14, 946, 1035, 1177, 2023, 2162.

Invertebrates, B14, pt. 2.

Mollusks, B3, 15, 37, 39g, 112; P1, $11,18,48,228,246,384,442,460$, $519,521,561,562,571,710,773$, $790,849,898,958,988,1032-1034$, $1111,1177,1185,1210,1214,1237$. $1264,1312,1342,1425,1565,1610$, $1642,1704,1736,1741,2002,2079$, 2116, 2124, 2166, 2183, 2217, 2234, $2238,2283,2288,2295,2478,2554$, $2667,2668$.

Dall, W. H., and Bartsch, Paul, B68; P1452, 1574, 1820.

Dall, W. H., and Guppy, Robert John Lechmere, P1110.

Dall, W. H., and Orcutt, Charles Russell, P536.

Datolite. (See under Mineralogy.)

Davenport, Charles Benedict, P1355.

Dean, Bashford, fishes collected on Negros, Philippine Islands, P1407.

Death Valley Expedition, botany of, CNH4.

de Booy, Theodoor, bones of birds collected by from kitchen midden deposits in St. Thomas and St. Croix, P2245; mammals and reptiles collected by in Virgin Islands, P2244.

Decapods. (See under Crustaceans.)

Deer. (See under Mammals.)

Deformation, artificial, of children, R1887, pt. 3, No. 2.

DeGant, Frank Dean, P2952.

Deignan, Herbert Girton, B186.

DeKay, Charles, R1889, pt. 3, No. 8.

de Laubenfels, Max Walker, P2927, 2993.
Densmore, Frances, B136.

Dermaptera. (See under Insects.)

Designs. (See under Anthropology.)

Devonian. (See under Fossils.)

Dewey, Frederic Perkins, B42; C31; P687.

Diabantite, Westfield, Mass., P2316.

Diabase, Mesozoic, of Atlantic border, composition, P205.

Diatoms. (See under Plants.)

Dice, Chinese, R1893, pt. 2, No. 2.

Dickcissel. (See under Birds.)

Dickerson, Mary Cynthia, and Jordan, David Starr, P1592, 1602, 1625.

Dikmans, Gerard, P2872, 2884, 2897.

Dimmock, George, Tachinidae reared by, P2920.

Dinosaurs. (See under Fossils, Reptiles.)

Diplopods. (See under Myriapods.)

Dippers. (See under Birds.)

Diptera. (See under Insects.)

Direction Island, South China Sea, new squirrel, P1686.

Disko Bay, fishes, B15.

Disko Island, Greenland, plants, B15.

Dismal Swamp region, botanical survey of, CNH5, No. 6.

District of Columbia, avifauna, B26.

beetles, P1275.

butterflies, B157.

crystalline schists, P363.

dickcissel, Spiza americana, disappearance, $\mathrm{P} 806$.

Diptera, Tipuloidea, P2344.

flora, B22; CNH21.

Glyphipterygidae, new pest of $A l$ bizzia, P3162.

Lonchaeidae, Pallopteridae, and Sapromyzidae, P2525.

mineralogy and lithology, P523.

Miridae, P2784.

mussels, fresh-water, anatomy of, P2782.

Paleolithic period, P777.

plants, revision of Bulletin 22, C46. prochlorite from, P410.

Rotatoria, P2032.

stone implements, P810.

Tropidonotus, new species of, P615.

Divination, implements, R1896, pt. 2, No. 3.

Dobzhansky, Theodosius, P2904.

Dodàs, Gideon Stanhope, P2096, 2226, 2531.

Doering, George E., P582.

Dogs. (See under Mammals; also under Fossils, mammals.)

Dolphins. (See under Fishes; also under Mammals.)

Dominica, birds, collected by F. A. Ober, P19; Turdidae, new species of, P103; parrot, new species of Chrysotis, P142.

Dominican Republic, archeological and historical investigations at Samana, B147. 
Dominican Republic (contiaued).

birds, B155; P2966.

insects of Yale Expedition, P2048, 2056, 2058, 2269.

plants, Tertiary, P2363.

pottcry, aboriginal Indian, B156.

Dominoes, Chinese, R1893, pt. 2, No. 2.

Donaldson, Thomas, R1885, pt. 5.

Doolittle, Alfred Abel, P1848, 1940.

Doves. (See under Birds.)

Dow, John M., fishes from Panama, P292.

Doyle, Conrad Bartling, and Cook, Orator Fuller, CNH16, pt. 6.

Dragonets. (See under Fishes.)

Dragonflies. (See under Insects, Odonata; also under Fossils, insects.)

Drake, Noah Fields, fishes collected in China, P1221.

Dresel, Herman George, P431, 464.

Dresel, H. G., and Bean, Tarleton Hoffman, P418.

Drilling, primitive methods, R1894, pt. 2, No. 5.

Drugs. (See under Medicine.)

Drum, Naskopie Indians, Hudson Bay Territory, P736.

Dry preparations, Semper's method, P220.

Ducks. (See under Birds.)

Dugès, Alfred, P278, 678.

fishes collected by in Mexico, P94, 95, 637, 903.

Dunn, Emmett Reid, P2211, 2524, 2767, 2770.

Dutch East Indies, birds collected by W. L. Abbott, Karimata Islands, P2512.

fishes, Brotulidae and Carapidae, collected by Albatross, P1948.

mammals, collected by W. L. Abbott, Karimata Islands, P1481.

(See also under Java.)

Dyar, Harrison Gray, B52; P1209, 1290, $1376,1412,1419,1423,1516,1550$, 1742, 1885, 1947, 1951, 2006, 2046, $2050,2054,2056,2139,2239,2447$, $2769,2794$.

Arachnida collected by in British Columbia, P2143.

Dyar, H. G., and Heinrich, Carl, P2691.

Dyar, H. G., and Knab, Frederick, P1632.

Dyar, H. G., and Shannon, Raymond Corbett, P2636.

Dyar, H. G., and Smith, John Bernhard, P1140.

Dyer, F. J., copepods collected in Honduras, P2285.

\section{E}

Eakle, Arthur Starr, P1148.

Earll, Robert Edward, B27, pt. J.

Earll, R. E., fishes collected in Lake Jessup and Indian River, Fla., P438.

Earthworms. (See under Oligochaetes.)
Earwigs. (See under Insects, Dermaptera.)

East Indies, macrouroid fishes, B100, vol. 1 , pt. 7.

Thalassocrinus, new crinoid genus, P1793.

East Main district of Hudson Bay Company, birds of, P518.

Easter Island ( $\mathrm{Te}$ Pito te Henua, or Rapa Nui), R1889, pt. 3, No. 2; 1897, pt. 2, No. 4.

Eastman, Charles Rochester, P2177.

Eaton, Daniel Cady, CNH1, No. 5 (2d art.-3, 4).

\section{ECHINODERMS:}

Africa, P1808.

Aleutian Islands, P3061.

America, Arctic, B15; northeast coast, P76, 168, 534.

Arbaciidae, Philippine, B100, vol. 14 , pt. 1.

Asia, northeastern, P1561.

Aspidodiadematidae, Philippine, B100, vol. 14, pt. 1 .

Asteroidea, north Pacific and adja. cent waters, B76: Phanerozonia, Spinulosa, pt. 1; Forcipulata, pts. $2,3$.

Australia, P1743.

Bathycrinus, note on, P1547.

Caribbean Sea, P491, 2257.

Celebes, P1944, 2022.

Cidaridae, Philippine region, $\mathrm{B} 100$, vol. 6 , pt. 4.

Comasterida, monograph, B82, pt. 3.

Comasteridae, revision, P1685.

Comatilia, new genus, P1668.

Comatula, P1585, 1608.

comatulids, arm joints and divisions, P1636; Japanese, P1615.

crinoids, African coasts, P1808. arm structure, abnormal, P1612. Asia, northeastern, P1561.

Australia, P1743.

Comasteridae, revision, P1685.

Comatilia, new genus, P1668.

Comatula, P1585, 1608.

Comatulida, arm joints and divisions, P1636; remarks on classification, P1608.

Encrinus parrae, P1585.

Eudiocrinus, P1551, 1613.

European, P1749.

Gulf of Mexico and Caribbean Sea, P547.

Hawaiian, P1608.

Himerometra, revision, P2026.

Marsupites, systematic position, P1845.

monograph of existing, B82: general, pts. 1, 2; Comasterida, pt. 3; Mariametrida, pt. 4a.

Museum für Naturkunde, Berlin, crinoids in, P1937.

Naumachocrinus, new genus, P1895. 
ECHINODERMS, crinoids (continued).

new, Recent, P1691; Recent unstalked, P1697; un st a lked, P2982.

nomenclature of Recent, P1623.

Pacific, north, new species from, P1543, 1559.

Pentacrinitidae, arm joints and divisions, P1636; infrabasals in Recent genera, P1582; axial canals, P1634.

Philippine, P1673, 1756, 1798, 1849.

Phrynocrinidae, Naumachocrinus, new genus, P1895.

phylogenetic interrelationships, P1732.

Proisocrinus, new Philippine genus, P1756.

Ptilocrinus pinnatus, with note on Bathycrinus, P1547.

Rhizocrinus, P1693.

skeletons, inorganic constituents, P1795.

stalked, eastern North America, P1607.

stems, origin, P1740.

Tennessee, B64.

Thalassocrinus, East Indian, P1793.

Troost's unpublished manuscript on, summary, B64.

West Indies, B74.

Diadematidae, Philippine, B100, vol. 14 , pt. 1.

East Indies, P1793.

echinoids, in National Museum, P568; Philippine region, B100, vol. 6 , pt. 4 ; vol. 14 , pt. 1 ; West Indian, B74.

Echinometridae, Philippine, B100, vol. 14 , pt. 1 .

Echinothuridae, Philippine, B100, vol. 14 , pt. 1.

Encrinus parrae, note on, P1585.

Eudiocrinus, P1551, 1613.

Europe, P1749.

Evasterias, new sea-star, P2632.

exhibit sent to International Fisheries Exhibition at London, B27, pt. B.

featherstars, Japanese, P1615.

Forcipulata, north Pacific, B76, pts. $2,3$.

Gorgonocephalidae, $\mathrm{C}$ a ribbe a n, P2257.

Greenland, P3098.

Gulf of Mexico, P491, 544.

Hawaiian Islands, P1555, 1608, 1807.

Heliaster, in National Museum, P646.

Himerometra, revision. P2026.

holothurians, Hawaiian, P1555; North American, north Pacific coast, P1558; northwestern Pacific, P2073.

Hyalinothrix, Hawaiian, P1807.
Echinoderms (continued).

Japan, P1551, 1615, 2493, 3059, 3114.

Kamchatka, P2180.

Kerguelen Island, B3.

keyhole urchins, Melitta, P3099.

Labrador, P377.

Mariametrida, monograph, B82, pt. $4 a$.

Marsupites, systematic position, P1845.

Melitta, revision, P3099.

Micropygidae, Philippine, B100, vol. 14 , pt. 1.

Moluccas, P1944, 2022.

Naumachocrinus, new genus of Phrynocrinidae, P1895.

North America, northeastern coast, P534.

ophiurans, collected by U. S. Commission of Fish and Fisheries, P1000.

Gorgonocephalidae, Caribbean Sea, P2257.

in National Museum, B84.

north Pacific, B75.

Philippine, B100, vol. 5.

Smithsonian-Hartford Expedition, P3054.

West Indian, P1724.

Parasterina, Japanese, P3114.

Pedinidae, Philippine, B100, vol. 14, pt. 1.

Pelmatozoa, structure and relationships, P1846.

Pentacrinitidae, arm joints and divisions, P1636; axial canals of Recent, P1634; infrabasals in Recent genera, P1582.

Phanerozonia, north Pacific, B76, pt. 1.

Philippine Islands, B100, vol. 3 ; vol. 5 ; vol. 6 , pt. 4 ; vol. 14 , pt. 1 ; P1673, 1756, 1798, 1827, 1849, 1944, 2022.

Phrynocrinidae, new genus belonging to, P1895.

Plazaster, Japanese, P3114.

Poraniopsis, Japanese, P3059.

Proisocrinus, new Philippine genus, P1756.

Ptilocrinus pinnatus, P1547.

Rhizocrinus, new species of, P1693.

Saleniidae, Philippine, B100, vol. 14, pt. 1.

sea-stars, Evasterias, P2632; Japanese, P2493; Plazaster, Japanese, with note on Parasterina, P3114; South American, P2859; Trophodiscus, Kamchatkan, P2180.

Spinulosa, north Pacific, B76, pt. 1. starfishes, Aleutian Islands, P3061.

Celebes and the Moluccas, P1944, 2022.

collected by U. S. Commission of Fish and Fisheries, P1000.

Heliaster, in National Museum,. P646. 
Echinoderms, starfishes (continued). Hyalinothrix, Hawaiian, P1807.

Philippine, B100, vol. 3; P1827, 1944, 2022.

Temnopleuridae, Philippine, B100, vol. 14 , pt. 1.

Tennessee, B64.

Thalassocrinus, East Indian, P1793.

Tonga Archipelago, P2905.

Toxopneustidae, Philippine, B100, vol. 14 , pt. 1.

Trophodiscus, Kamchatkan, P2180.

Vorticella, chlorophylloid granules of, P398.

West Indies, B74; P1724, 3056.

(See also under Fossils.)

Echinoids. (See under Echinoderms; also under Fossils, echinoderms.)

Eckfeldt, John W., CNH1, No. 5 (2d art.-6), No. 8 (7th art.).

Eclipse Expedition. (See under United States Naval Eclipse Expedition.)

Ecuador, birds, Catharus, a new species of, P653; Guayaquil, P694a.

Corneocyclas from mountains, P1584. fishes collected by P. O. Simong, P1468.

grasses, $\mathrm{CNH} 24$, pt. 8.

hummingbirds, catalog, P1258.

isopod, Apseudes, P1918.

mollusks, fossil fresh-water, P2946.

Santa Elena Bay, P2551, 2646.

plants, economic fruit-bearing, $\mathrm{CNH} 24$, pt. 5.

Edmunds formation, Washington County, Maine, Silurian fossils, P1985.

Edwards, Charles Lincoln, P1558.

fishes collected by at Green Turtle Cay, Bahamas, P752.

Edwards, C. L., and Jordan, David Starr, P566.

Edwards, Henry, B35.

Edwards, Vinal N, P42.

Edwards, William Henry, B15.

Eels. (See under Fishes.)

Eggers, Heinrich Franz Alexander, B13; P724.

Eggs. (See Birds' eggs; Reptiles' eggs.)

Egleston, Thomas, B33.

Egypt, Fayum, flint implements, R1904, pt. 2, No. 3; Kharga, sand-barites, P1726.

Eichhoff, William, P1085.

Eigenmann, Carl H., P613, 897, 917, 925, 1532.

Eigenmann, C. H., and Bean, Barton Appler, P1503.

Eigenmann, C. H., and Beeson, Charles Henry, P1009.

Eigenmann, C. H., and Eigenmann, Rosa Smith, P742, 842.

Eigenmann, C. H., and Hughes, Elizabeth G., P608.

Eigenmann, C. H., and Jordan, David Starr, P484, 587, 627.
Eigenmann, C. H., and Ogle, Fletcher, P1556.

Eigenmann, Rosa Smith, and Eigenmann, Carl H., P742, 842.

Elden Pueblo pottery, P2930.

Elliot, Daniel Giraud, P1751.

Ellis, Max Mapes, P1912, 2267.

Embioptera, New World, P3175.

Embody, George Charles, P1746.

Emeric, H. F., fishes collected at Guaymas, Mexico, P433.

Emerton, J. H., B15.

Emery, Walter Titus, and Phillips, William Jeter, P2281.

Endlich, Frederick Miller, [B3], B15; P163, 201.

Endo, Riuji, B164.

Energy resources, United States, B102.

Engano, bats, Rhinolophus, collected by W. L. Abbott, P1440; mammals, P1472.

Engelhardt, George Paul, B190.

Engineering, contributions of department to Ohio Valley Centennial Exposition, C38.

mechanical, catalog of National Museum collection, B119, 173.

Engraving, white-line, for relief printing, R1890, pt. 3, No. 2.

Entomostracans. (See under Crustaceans.)

Entozoa, notes on avian, P893.

Eocene. (See under Fossils.)

Ephemerida. (See under Insects.)

Epsomite from Utah, P2758.

Erian. (See under Fossils, Devonian.)

Escambia River, note on fishes, describing new species, Zygonectes escambiae, P585.

Eskimos. (See under Anthropology.)

Esmeralda formation, Nev., flora, P2719.

Ethiopia, birds of the Childs Frick Expedition, B153.

Ethno-conchology, R1887, pt. 3, No. 4.

Ethnology. (Papers on ethnology are included with those on anthropology, but they are not listed separately under Ethnology.)

Eulachon. (See under Fishes.)

Euphausiaceans. (See under Crustaceans.)

Europe, crinoid, new, P1749.

fishes, in National Museum, P63.

marsh-tits, notes on, P686.

museums, notes on, R1903, pt. 2, No. 2.

naval architecture, prehistoric, R1891, pt. 3, No. 7.

seahorses, Hippocampus, review, P2997.

spiders, red, species likely to be introduced into America, P2303.

swords, in National Museum, B163. titmice, notes on crested, P695.

tree-creepers, Certhia, remarks on, P270.

Turdus alpestris and $T$. torquatus, distinct species, P577. 
Evans, Alexander William, CNH1, No. 5 (2d art.-5); 20, pt. 8.

Evans, Arthur Thompson, P2109.

Evermann, Barton Warren, and Clark, Howard Walton, P1478.

Evermann, B. W., and Goldsborough, Edmund I.ee, P1501.

Evermann, B. W., and Jenkins, Oliver Peebles, P681, 698, 846.

Evermann, B. W., and Jordan, David Starr. (See under Jordan and Evermann.)

Evermann, B. W., and Kendall, William Converse, P1043, 1482, 1748.

Evermann, B. W., and Latimer, Homer Barker, P1778.

Evermann, B. W., and Radcliffe, Lewis, B95.

Evermann, B. W., and Seale, Alvin, P1491.

Ewing, Henry Ellsworth, P2394, 2459, $2489,2620,2730,2843,2908,2970$, 2971.

Ewing, H. E., and Fox, Irving, P3151.

Exline, Harriet Idola, P2991.

F

Fábreba, H. Pittier de. (See under Pittier, Henri.)

Fagan, Margaret Mary, and Gahan, Arthur Burton, B124.

Fagan, Margaret M., and Rohwer, Sievert Allen, P2208, 2266.

Fairy shrimps. (See under Crustaceans.)

Fanning Islands, contributions to natural history of, U. S. North Pacific Surveying Expedition, B7.

Farlow, William Gilson, [B3], B15; P222.

Farrington, Oliver Cummings, P981.

Faxon, Walter, P525, 785, 1136.

Fayum, Egypt, flint implements, R1904, pt. 2, No. 3.

Featherstars. (See under Echinoderms.)

Feldspar in sections of rocks, P206.

Felt, Ephraim Porter, P2072, 2444.

Fennah, Ronald Gordon, P3184, 3189.

Fenton, Frederick Azel, P2704.

Fernald, Charles Henry, C27.

Fernald, Henry Torsey, P1487, 1902, 2681.

Ferns. (See under Plants; also under Fossils, plants.)

Ferrari-Perez, Fernando, P559.

Ferroanthophyllite, orthorhombic iron amphibole, P2373.

Fertilizers, situation in United States, B102, pt. 2.

Fewkes, Jesse Walter, P528.

Fiji, annelids, polychaetous, P2641.

fishes, with notes on Hawaiian fishes, P1625.

(See also under South Seas, Oceania, etc.)

Filefishes. (See under Fishes.)

Finches. (See under Birds.)

Fink, Bruce, CNH14, pt. 1.
Fire. (See under Anthropology.)

Firestone Expedition, Liberia, reptiles and amphibians, P3128.

Fish, Pierre Augustine, P1325.

Fish culture, exhibits sent to International Fisheries Exhibit at London, B27, pt. L.

Fisher, Albert Kenrick, P811.

Fisher, A. K., and Wetmore, Alexander, P2876.

Fisher, Elmon M., CNH1, No. 5 (3d art.).

Fisher, Walter Kenrick, B76, 100, vol. 3 ; P1322, 1555, 1807, 1827, 1944, 2022, $2180,2493,2632,2859,3024,3059$, 3114, 3198.

Fisher, Warren Samuel, B145; P2271, $2428,2454,2522,2568,2608,2623$, $2803,2842,2922,2968,2979,3167$, $3183,3188$.

Fisher, William J., P364.

Fisheries, classification of collection at International Exhibition of 1876, B14.

Fisheries and fish culture, exhibit at International Fishery Exhibition, Berlin, B18.

Fishery products, catalog of exhibits sent to International Fisheries Exhibition at London, B27, pt. J.

Fishes:

Abeona aurora, California, P151.

Aboma, Japanese, P1298.

Acanthocaulos, note on, P1385.

Acipenseridae, Japanese, P1455.

Acrotus willoughbyi, Washington, P672.

Aelurichthys eydouxii, note on, P405.

Aëtobatidae, nomenclature, P990.

Africa, west, P2294.

Agonidae, P122, 1365.

Agonus vulsus, California, P162.

A gosia, notes on, P822.

Alaska, P47, 59, 70, 80, 100, 121, $225,255,342,387,407,487,748$, $753,795,1027$.

Albatross collections. (See under $\mathrm{Al}$ batross.)

albicore, proper generic name, P716.

Aldabra Island, P973.

Alepidosaurus aesculapius, Alaska, P342.

Alepocephalus bairdii, western Atlantic, P68.

Aleutian Islands, P3038.

Algansea, notes on, P822.

Amazon River, P1503.

amberfish, Seriola stearnsii, Florida, P66.

American, in British Museum and the Muséum d'Histoire Naturelle, P81; in Linnaean collection, P510; Linnaean names, P527; Pacific coast from Tropic of Cancer to Panama, P526.

Amia, Philippine Islands, P1853.

Amiidae, Philippine, B100, vol. 10.

$A$ mitra, name replaced, P350. 
Fishes (continued).

Amiurus ponderosus, Mississippi River, P90.

Ammodytidae, Japanese, P1464.

ammodytoid, systematic relations, P1388.

Amphiodon alosoides, note on, P1752.

Amphipnoidae, osteological characteristics, P825.

Amur River Basin, P1533.

anacanthine, new, Philippine Islands, P1924.

Anarrhichas lepturus, Alaska, P80.

anglers, Japanese, review of, P1261.

Anguilla manabei, Japan, P1957.

Anguillidae, osteological characteristics, P803.

animal heat of, experiments on, P96.

Anteliochimaera and related genera, P1723.

Antennariidae, note on, P31.

Anthias vivanus, Florida, P465.

Antigoniidae, relationship and osteology, P1297.

Aphareus furcatus, relationships, P1232.

Aphododeridae, North American, B10. apodal, Albatross tropical Pacific collections, P856; Japanese, review of, P1239.

Apodichthys, new, California, P130. Apogon evermanni, Hawaiian Islands, P1386.

Apogon pandionis, Chesapeake Bay, P211.

apparatus for capture, catalog of exhibits sent to International Fisheries Exhibition, London, B27, pt. I.

Aprion ariommus, Florida, P355.

Archosargus, review of North American, P608.

Argentina, P1482.

Argentina syrtensium, Sable Island Bank, P41.

Argyropelecus, review of, P3047.

Argyrosomus, Great Lakes, P1662.

Ariopsis milberti, breeding habits, P46.

Arizona, P754, 1131.

Arkansas, P549, 759.

Arripidae, Philippine, B100, vol. 12.

Artediellus, revision, P2685.

Artedius fenestralis, Puget Sound, P326.

Ascelichthys rhodorus, Washington, P144.

Asia, east, P1536.

Aspidophoroides gïntherii, Alaska, P487.

Aspredinidae, note on, P831.

Assumption Island, P973.

Astroscopus, eastern United States, P69.

atherine, certain genera of, P2273 ; Japanese, review of, P1250.
Fishes (continued).

Auxis rochei, New England, P183.

Ayres' paper on cyprinoid, P159.

Bahamas, Green Turtle Cay, P752.

bandfishes, Japanese, review of, P1330.

Banjosidae, Philippine, B100, vol. 12.

Barbados, P1345.

bass, giant, Japanese, P1476.

sea, Japanese, review of, P1714. striped, P430, 485.

white, trematodes from, P2430.

Bathymaster, Puget Sound and Alaska, P753.

Bdellostoma, proper name of, P1234.

Bdellostomidae, note on, P309.

Belone exilis, generic relations, P174.

Belone latimanus, in Massachusetts, P5

Belonidae, review of American, P575.

Benthodesmus, allied to Lepidopus, P241.

Bering Island, P1106.

Bermuda, B5; P23, 58; fish parasites, P1560.

berycoid, Japanese, review of, P1306; osteology, P1366.

Bleekeria gilli, P1028.

Bleekeria mitsukurii, note on, P1328.

blenny, California, P288; Japanese, P1127.

bluefish, proper name of, P322.

bonito, oceanic, United States, P13, 42.

Bothus, synonymy, P325.

Boulengerina, generic name replaced by Safole, P1922.

boxfish, spiny, in California, P917.

Brachyopsis verrucosus, California, P122.

Brachyopsis xyosternus, California, P135.

Brazil, Bahia, P829.

Brevoortia, revision of American, P15.

Brevoortia patronus, note on, P25.

British Columbia, P255, 387, 682, 787, 938.

Brosmius americanus, identity with B. brosme, P53.

Brotulidae, Philippines and Dutch East Indies, P1948.

Bryostemma polyactocephalum, species confused with, P1300.

butterfishes, proper name of, P1048.

Calamus, review, P401.

Calamus providens, note on, P417.

California, B7; P97, 108-111, 117, $118,122,123,126,136,141,150$, $152-154,156,157,162,164,176$, $182,269,742,917,967,1161$, $1501,1643,1961,2027,2075$, 2472, 2962.

Kern River, P916.

Mohave River, P2236. 
Fisheg, California (continued).

Monterey, P129, 130, 151.

Monterey Bay, P125, 132, 135, 140, 151, 161, 2049.

Owens River, P2333.

San Bernardino, P373.

San Diego, P106, 133, 187, 208, $269,774,897$.

San Francisco, P72.

San Francisco markets, P120, 158, 159.

Santa Ana River, P1595.

Santa Barbara, P146, 288, 296.

Santa Barbara Islands, P880.

Santa Catalina Island, P107, 1510.

Callionymidae, Japanese, review, P1305; Philippine, P3106.

Callionymus bairdi, Gulf of Mexico, P652.

Callyodontidae, Philippine, B100, vol. 7.

candlefish, Northwest coast, P143.

Cape San Lucas, P290, 293.

capelin, redescription of, P3029.

Capriformes, Philippine, B100, vol. 8. capture of rare, P1165.

Carangidae, family and subfamilies, P304.

Caranginae, American, review of, P367.

Caranx bartholomaei, P403.

Caranx beani, North Carolina, P178.

Caranx ruber, note on, P403.

Carapidae, Philippines and Dutch East Indies, P1948.

Carcharhinus milberti, nematode eggs from, P2655.

Carcharias lamiella, California, P269.

cardinalfishes, review of Japanese, P1240.

Catesby's Natural IIistory of Carolina, Florida, and the Bahama Islands, identification of figures, $\mathrm{P} 422$.

catfishes, electric, use of name Torpedo for, P1329; Japanese, review of, P1338; sea, breeding habits, P46; Venezuela, P3172.

Cathetostoma albigutta, Gulf of Mexico, P896.

Catostomidae, described by Girard, P500; North American, synopsis of, B12.

Caulolatilus microps, P16, 517.

Caulolepis longidens, in California, P1161.

Celebes, P1917.

Central America, P252, 925, 3192.

Centrarchidae, B10; P197.

Centropomidae, P302, 3191.

Cephaleutherus and other rays, P1054.

Cephaloscyllium laticeps, California, P110.
Fishes (continued).

Cepolidae, Japanese, review of, P1330.

Ceratiidae, note on, P33.

Cetomimidae, Albatross northwestern Atlantic collections, P1012.

Chaetodon aya, Pensacola, P565.

Chaetodontidae, Philippine, P1822.

Chaetodontidae and related families, Japanese, P1296.

Chandidae, Philippine, B100, vol. 10. char, supposed new species from New Hampshire, P671.

characin, neglected genus of, P1588. Characinidae, Venezuela, P3181.

characinoid, differential characters, P1056; forms with ctenoid scales, with description of a new Psectrogaster, P1055.

Characinus, note on, P1058.

Cheilodipteridae, new genera and species, P3085; Philippine, P1853, 1868.

Chesapeake Bay, P211, 389, 843.

Chile, Tome, to Montevideo, Uruguay, P2133.

Chilomycterus, in California, P917.

Chimaera, white, Japanese, P1356.

chimaeroid, Philippine, P1899.

China, northern, P1474; Shanghai and Hongkong, P1433; Soochow, P2338; Tien Tsin, P1221; Yalu River, P2228.

China Sea, P1997.

Chirus, species found in San Francisco market, P120.

Chloroscombrus orqueta, Panama, P334.

Choerodon, in place of Choerops, P1638.

Chonerhinus, note on, P884.

Chriodorus, new genus, southern United States, P297.

Cichlops, Labracinus proper name for, P1384.

cisco, new species of from Great Lakes, P1662.

Citharichthys macrops, Florida, P46t.

Citharichthys stigmaeus, California, P296.

clingfishes, P1291, 3187.

Clupea tyrannus, P4.

Cobitidae, review of Japanese, P1332.

cod, rock, California, P109.

collecting and preserving, P224.

Colorado, Twin Lakes, P780.

Columbia River, upper, P196.

Commander Islands, Bering and Copper Islands, P1106.

Conodon serrifer, Lower California, P289.

copepods parasitic on, P1560, 1652.

Coregonus hoyi, P340.

Coregonus nelsonii, Alaska, P407.

Coregonus oregonius, Oregon, P1677. 
Fishes (continued).

Coregonus pusillus, Alaska, P748.

Coryphaena hippurus, P517, 548.

Costa Rica, Punta Arenas, P639.

Cottidae, Japanese, review, P1358; North American, B10, P209; western Pacific, P2987.

Cottus maculatus, identity with $C$. bubalis, P505.

Couesius greeni, Frazer River, British Columbia, P938.

crabeater, Hudson Valley, N. Y, P811.

Cremnobates, in California, P133.

Cremnobates integripinnis, life colors, P372.

Crossochir koelzi, California, P2962.

Crossorhinus, notes on, P1057.

crustacean parasites of West Indian, P1950.

Ctenolucius, neglected genus, P1588.

Cuba, P414, 516, 551, 2277.

Cumberland Gulf, B15.

Cuvier and Valenciennes typical specimens, in Musée d'Histoire Naturelle, P593.

Cuvier's "Règne Animal," genera of first edition, P1346.

Cybium, notes on American, P3.

Cyclogasteridae, new, P1941.

Cyclopsetta chittendeni, P1030.

Cyclopteroidea, relations of, P834.

Cymatogaster rosaceus, California, P153.

Cyprinidae, North American, B10; P450, 500.

Cyprinodontidae, nomenclature, P991.

Dacentrus, note on, P160.

Dactylobatus armatus, Atlantic coast, P1682.

Dactylopteroidea, characteristics, P818.

degeneration theory, P553.

Dinolestes lequini, osteology and relationship, P1186.

Diplodus, review of North American, P608.

Dipterodon, note on, P684.

Disko Bay, B15.

Ditrema atripes, California, P156.

dolphin, great, Coryphaena hippurus, $\mathrm{P} 548$.

Dorosoma cepedianum heterurum, notes on, P43.

Dorysomatidac, North American, B10.

dragonets, Japanese, review of, P1305.

Duleidae, Philippine, B100, vol. 10.

duplicates distributed by National Museum, P127, 185.

Dutch East Indies, P1575, 1919, 1948, 2682.

East Indies, B100, vol. 1, pt. 7. echeneidids, relationships, P320.

Ecuador, P1468.

Edestus mirus, P1884.
Frshes (continued).

eels, Barbados, P1345; Galápago Islands, P369; genitalia and sexual characters, P148; Japanese, P1239, 1957; Mexico, P335; ne michthyoid, new genera, P381.

Elacate, nomenclature, P1059.

Elacate canada, in lower Hudson Valley, N. Y., P811.

elacatids, characteristics, P668.

Elasmobranchii, Philippine, B100, vol. 13.

Eleginus, P853.

Ellatonistius chrysopsis, note on, P1752.

Embiotoridae, California, P2962; Japanese, P1260.

Emmelichthyidae, Philippine, B100, vol. 12.

Enoplosidae, Philippine, B100, vol. 12.

Ephippiformes, Philippine, B100, vol. 8.

ephippiids, affinities, P318.

Epinephelus, review of American and related genera, P447.

Epinephelus drummond-hayi, Bermudas and Florida, P23.

Epinephelus nigritus, P26, 511, 517.

erythrinoid, differential characters, P1056.

Escambia River, P585.

Etheostoma micropterus, Mexico, P823.

Etheostoma variatum, P503.

Etheostomatidae, North American, B10.

Etheostomatinae, notes on skeletons, P484.

etheostomoids, new and little-known, P607.

Euchalarodus putnami, identity with Pleuronectes glaber, P49.

eulachon, Northwest coast, P143.

Europe, seahorses, P2997; European fishes in National Museum, P63.

Eurypharyngidae, anatomy and relations, P382.

exhibit sent to International Fisheries Exhibition at London, B27, pt. F.

Exocoetus, review of American, P483.

extinct, represented in National Museum, R1889, pt. 3, No. 5.

Fanning Islands, B7.

Felichthys, note on, P832.

Fiji, P1625.

filefishes, Japanese, review of, P1287.

fin-rays, value in classification of fishes, P553.

flatfishes, from San Francisco markets, P158; Gymnachirus fasciatus and G. nudus, P1814.

flatheads, review of, Japanese. P1581. 
Frigres (continued).

Florida, P16, 23, 24, 73, 104, 406, $508,537,1816$.

Cedar Keys, P426.

cestodes from sharks, P3135.

Jacksonville, St. Johns River, P427.

Key West, P402, 414, 416, 428.

Lake Jessup and Indian River, P438.

Pensacola, P66, 74, 282, 355, 404, 464, 465, 565, 613.

St. Johns River, P73, 105, 427.

Tortugas, P37.

flounders, California, P107, 117, 136, 152.

craig, in America, P10.

Florida, P464.

Gastropsetta frontalis and Cyclopsetta chittendeni, P1030.

Japanese, P1484, 2082.

New England, P165.

Pleuronichthys, review, P1744.

Puget Sound, P147.

fluvial, western, notes on, P2357.

flyingfishes, review of American, P483.

Formosa, P1289, 2448.

Gadus cimbrius, identity with $R$ hinonemus caudacuta, P50.

Galápagos Islands, P369, 840.

Galeorhinus galeus, California, P111.

Galveston Bay, parasites of, P2977.

Garmannia spongicola, North Carolina, P2185.

Garman's paper on salmon and trout, P490.

Gasterosteus atkinsii, Maine, P71.

Gasterosteus gladiunculus, Maine, P1089.

Gasterosteus quilliamsoni in California, P373.

Gastropsetta frontalis, P1030.

Georgia, B12; P89, 453.

Gerridae, Japanese, review, P1525; Philippine, B100, vol. 12.

Gillichthys $y$-cauda, California, P774.

Girellidae, Philippine, B100, vol. 12.

Glyptocephalus cynoglossus in Amer. ica, P10.

Gnathanacanthus, P885.

Gnathypops iyonis, Japan, P2011.

goatfishes, Japanese, P1513.

Gobiesocidae, P1291, 3187.

Gobiesox rhesodon, California, P208.

Gobiidae, North American, P587.

gobioid, in National Museum, P2961.

Gobioides broussoneti, new to North America, P1029.

Gobiomorus, note on, P685.

Gobiosoma histrio, Guaymas, Mexico, P433.

Gobiosoma ios, Vancouver Island, P298.

$711175-47-15$
Fishes (continued).

goby, North Carolina, P2185; Van-

couver Island, P298.

gold-eye, note on, P1752.

Gramma loreto, note on, P669.

Grammicolepidae, P3008.

Grand Bank, P78.

Great Lakes, P1662.

Greenland, B15; P431.

grouper, black, Epinephelus nigritus, P26.

Gulf coast, P533.

Gulf of California, P227, 698, 880, 2125.

Gulf of Mexico, P15, 54, 98, 217, 281 . $349,586,652,675,896,1029,1592$; analysis of water destructive to fish in, P201; destruction of fish in, P200, 203; mortality of fish in, P195, 202.

gunnels, proper name of, P1048.

gurnards, Japanese, review of, P1581; Otohime, new genus, P1517.

Gymnachirus fasciatus and G. nudus, notes on, P1814.

Habana, P414.

Hadropterus aurantiacus in North Carolina, P504.

Hadropterus scierus, Indiana, P379.

Haemulon, review of species, P436.

hagfishes, review of Japanese, P1233.

hake, South Carolina, P124.

halfbeak, Cuban, P2277; Japanese, P1602.

Haloporphyrus viola, Atlantic, P40. Harriotta, Albatross northwestern Atlantic collections, P1014.

Hawaiian Islands, B7; P1114, 1386, 1625, 2231, 2570; Honolulu, P1915; Mauna Loa, P2392; Oahu and Laysan, P1377.

hemibranchiate, shoulder girdle and characteristic osteology, P1201.

Hemiramphus, analysis, P3195.

Hemiramphus balao, Cuba, P2277.

Hemiramphus mioprorus, Nagasaki, Japan, P1602.

Hemirhamphus rosae, California, P164.

Hemitripteridae, osteological characteristics, P835.

Heptatrema, proper names of, P1234.

"Hermaphrodite Fishes," translation from Naturforscher, P441.

Heros beani, Mazatlán, P719.

herring, lake, Great Lakes, P1662.

herringlike fishes, Japanese, review of, P1499.

Heteromi, revision, P1013.

Hexagrammidae, Japanese, review of, P1348.

Hexanchus corinus, P167.

Hiatula, note on, P883.

Hieroptera, notes on, P1054.

hippocampid and syngnathid, differential characters, P1049. 
Fishes (continued).

Hippocampus, American and European, P2997.

Hippocampus antiquorum, St. Georges Banks, P17.

Hippoglossoides elassoden, Puget Sound, P147.

Hippoglossoides exilis, California, P136.

Hippoglossus vulgaris, Alaska, P70.

Histiopteridae, Japanese, review of, P1523.

Holocephali, Philippine, B100, vol. 13.

Hoplopagrinae, review of species, P449.

Hudson Bay, P204.

Hybognathus hayi, Mississippi, P467.

Hybopsis montanus, P461.

Hymenocephalus tenuis, Hawaiian Islands, P2231.

Hypoplectrodes, note on, P1082.

Hyporhamphus, analysis, P3195.

Hyporhamphus patris, Mexico, P3195.

Hypostomidae, review of Japanese, P1241.

ichthyography, terminology, P445.

Ichthyoinyzon castaneus, Louisiana, P271.

Icichthys lockingtoni, Cali fornia, P154, 2472.

Icosteus aenigmaticus, California, P123.

Illinois, southern, P273.

Indian Territory, P549.

Indiana, P379, 423, 424, 681, 791.

International Fisheries Commission collection in northeastern Pacific, P3062.

Ioglossus, new genus, P297.

Iowa, P470.

Isesthes gilberti, California, P288.

Isospondyli, Philippine, B100, vol. 13. Jamaica, P418.

Japan, P1112, 1213, 1233, 1239-1241, $1244,1250,1254,1259-1261$, $1263,1265,1266,1278,1279$, $1287,1291,1293,1296,1298$, $1303,1305,1306,1308,1319$, $1324,1326,1328,1330,1332$, $1334,1338,1348,1351,1356$, $1358,1365,1381,1399,1409$, $1445,1455,1464,1470,1476$, $1484,1486,1489,1499,1513$, $1523,1525,1544,1562,1581$, $1635,1688,1714,1787,1792$, $1836,1875,1907,1909,1957$, 2082, 2149, 3000.

Echigo, P1570.

Nagasaki, P1602.

Shikoku, P2011.

Tanega and Yaki, P1462.

Vulcano Bay, Port Mororan, P1127.

Java, P1575, 1919, 2682.
Fishes (continued).

Johnstons Island, P272.

Juan de Fuca, Straits of, P171.

Julidinae, American, review of, P552.

Kamchatka, P1112.

Kansas, P456, 624.

Kentucky, Whitley County, P378.

Kerguelen Island, B3.

killifishes, Japanese, review of, P1486; Lower California, P1572. Korea, P1391.

Kyphosidae, Philippine, B100, vol. 12.

Labracinus, proper name for $\mathrm{Ci}$ chlops, P1384.

Labrador, P353, 1763.

Labrax, proper name of, P712.

Labrichthys, P861.

Labridae, Philippine, B100, vol. 7.

Lagodon, review of North American, P608.

Lake Michigan, P277.

Lake-of-the-Woods and connecting waters, P1778.

Lake Ontario, P1728.

Lake Tanganyika, P2998.

lampreys, Japanese, review of, P1233; silver, Louisiana, P271; nomenclature and characteristics, P989.

Lamprididae, relations of family, P1340.

lancelets, review of Japanese, P1233.

lances, sand, Japanese, P1464.

La Plata Basin, P1532.

latiloid genera, note on, P214.

Le Have Bank, P78.

Lepidopsetta isolepis, from San Francisco markets, P158.

Lepidopus, allied to Benthodesmus, P241.

Lepomis, notes on, P1824.

Leptophidium cervinum and L. marmoratum, P533.

Letharcus, new genus, southern United States, P297.

Lethrinidae, Philippine, B100, vol. 12.

Leurynnis, identity with Lycodopsis, P139.

Liberia, P3152.

Linnaean collection, American, P510.

Linnaean names, P527.

Liparidae, revision, B150.

Liparis (Trismegistus) orwstoni, P1390.

Liparis ranula, Nova Scotia, P65.

Lipogenys, new generic type, P1013.

lizardfishes, Japanese, P1544.

loaches, Chinese, P1474; Japanese, review of, $\mathrm{P} 1332$.

Lobotidae, Japanese, review of, P1792; Philippine, B100, vol. 11; relations of family, $\mathrm{P} 319$.

Long Island, Great South Bay, P657. 
Fishes (continued).

Lopholatilus chamaeleonticeps, New England, P77.

Lotella maxillaris, P429.

Louisiana, P271, 1734.

Lower California, B7; P149, 227, 1572; Boca Soledad, P289; Cape San Lucas, P290, 293; San Cristobal Bay, P469; Todos Santos Bay, P376, 563.

Lucania browni, Lower California, P1572.

Lucioperca, relations and nomenclature, P993.

Lutianidae, Japanese, review of, P1792.

Lutjanidae, Philippine, B100, vol. 11.

Lutjaninae, osteological characteristics, P444; review of species, $\mathrm{P} 449$.

Lutjanus blackfordi(i), P24, 657.

Lutjanus stearnsii, Florida, P24.

Lycodes paxillus, P64.

Lycodes turneri, Alaska, P59.

Lycodes vahlii, La Have and Grand Banks, P78.

Lycodopsis, identity with Leurynnis, P139.

Macdonaldia, new generic type, P1013.

mackerels, chub, comparison of Atlantic with Pacific, P1748; frigate, New England, P183.

Macrodon, note on, P1349.

Macrurus, Washington, P388.

mail-cheeked, classification, P756, 1581.

Maine, P71, 1089.

Malacopterygii, new species, P2449.

Mallotus catervarius, redescription, P3029.

Maltheidae, note on, P34.

Manchuria, P1493, 2408.

Massachusetts, Buzzards Bay, P5; Provincetown, P96; Vineyard Suund, P42; Woods Hole region, trematodes from fishes of, $\mathrm{P} 3078$. menhaden, note on, P25.

Merlucius, genus related to, P165.

Mexico, P95, 221, 903, 925, 1159.

Chapala Lake, P94.

Chihuahua, P823.

Colima, P291.

Guanajuato, P94, 637.

Guaymas, P433, 846.

Mazatlán, P237, 242, 254, 268, $327,335,370,452,719$.

Sinaloa, P3195.

Sonora, Guaymas, P433, 846 .

Veracruz and Tampico, P1592.

Micredeamidae, revision, P3002.

Middle America, B47.

minnow, top, Texas, P2393.

Misgurnus decemcirrosus, China, P1474.

Mississippi, P179, 467.

Mississippi River, P90.

Mississippi Valley, lower, P430.
Fishes (continued).

Missouri, P470.

Mitsukurina owstoni, Japan, P1409.

mud-eel, trematode from, P3014.

Mugilidae, review of American marine, P434; revision, P3204.

Mullets, revision of genera, P3204.

Mullidae, Philippine, B100, vol. 12.

Muraenesocidae, osteological characteristics, P815.

Muraenidae, osteological characteristics, P805.

Muraenoides, related to Stathmonotu.s, P508.

Mustelus, key, P3058.

myctophine, type specimens in $\mathrm{Na}$ tional Museum, P2807.

Myctophum crenulare, P146, 190.

Myliobatidae, nomenclature, P990.

Myriolepis zonifer, California, P140.

Myrophis vafer, Panama, P334.

Myxinidae, note on, P309.

Natcobatidae, P1050, 1694.

neglected genera, P1344.

Nemichthys avocetta, Puget Sound, P170.

Neosebastes entaxis, as type of genus, P1393.

New England, P77, 165, 177, 183, 658.

Newfoundland, Grand Banks, P184.

New Guinea, P3191.

New Hampshire, Sunapee Lake, P671.

New Orleans, P437.

New York, lower Hudson Valley, P811.

Nicaragua, P732.

North America, catalog, B47, pts. 1-4; new species, P84; nomenclature, P352; notes on, P466; synopsis, B16.

North American ichthyology: Cottidae, Etheostomatidae, Percidae, Centrarchidae, Aphododeridae, Dorysomatidae, Cyprinidae, Siluridae, B10; review of Rafinesque's memoirs, B9.

North Carolina, P124, 178, 2185; Beaufort, P55, 550; Cane River and Bollings Creek, P1339; French Broad River, P504.

Notacanthus phasganorus, Newfoundland. P184.

Notropis brimleyi, North Carolina, P1339.

Noturus, review of, P332.

Nova Scotia, Halifax, P65.

Oceania, Tonga Group, Niuafoou Island, P2931.

oceanic ichthyology, SB2.

Ohio, Maumee Valley, P737.

Oken's names of fish genera, P1346.

Okinawa, P1541, 1913.

opahs, relations of fishes of family Lamprididae, P1340. 
Fishes (continued).

Ophichthys, nomenclature of genus, P336.

Ophichthys retropinnis, Florida, P613.

Ophidium beani, Florida, P355.

Ophioscion, Central and South America, P3192.

Opisthocentrus, Japanese, new, P1127.

Oplegnathidae, Philippine, B100, vol. 12.

Orcynus pelamys, Vineyard Sound, Mass., P42.

Orectolobus, notes on, P1057.

Oregon, P20, 265, 1677, 1999.

Osmerus, California, P2027.

Osmerus attenuatus, California, P123.

Ostarophysi, Philippine, B100, vol. 13.

Ostraciontidae, P87, 1287.

Othonops eos, California, P187.

Otohime, new genus, P1517.

Pacific coast, U. S., bibliography, B11; note on, P191.

Panama, P292, 294, 327, 329, 334, $452,526,639,840$.

Pantosteus santa-anae, California, P1595.

Pantosteus virescens, Utah, P2508.

Paralepis coruscans, Juan de Fuca Straits, P171.

parasites of, Bermuda, P1560; cestode, P1123, 1125, 1529, 2433, $2511,3112,3135$; trematode, P1133, 3014, 3078; Galveston Bay, P2977; Venezuela, P2346.

Parophrys ischyrus, from Puget Sound, P147.

Pastinacas, generic name, P514.

pediculate, extratropical North American, synopsis, P30.

Pediculati, note on, P316.

pelorine, note on genera, P1394.

Pempheridae, Philippine, B100, vol. 11.

Pempheris poeyi, Cuba, P516.

Perca flavescens, note on, P36.

Percesoces, osteology, P1179.

perch, yellow, name of, P485.

perchlike, Japanese, P1875.

Percidae, North America, B10.

Peru, B95, 189; P1468.

Petromyzontidae, note on, P310, 368. phallostethid, notes on, P3007.

Philippine Islands, B100, vol. 1, pt. 7 ; vol. 7 ; vol. 8 ; vols. $10-13$; vol. 14 , pt. 2.

P1407, 1491, 1568, 1822, 1853, $1868,1872,1877,1896,1899$, 1924, 1948, 1997, 2448, 3032, 3106.

Phoenix Islands, B180.

Phycis chesteri, Atlantic, P40.

Phycis earllii, South Carolina, P24.
Fishes (continued).

Phycis regius, in North Carolina, P124.

Physiculus fulvus, P429.

Pimelodus clarias, note on, P1503.

pipefishes, breeding habits and segmentation of egg, P1431; Florida, P428; Texas, P1043.

Plagiogrammus hopkinsi, California, P1643.

Platessa ferruginea, note on, P52.

Platessa rostrata, note on, P52.

Platypoecilus, Mexican, P1159.

Platyrhina exasperata, generic relations, P119.

Platyrhina triseriata, California, P108.

Platysomatichthys stomias, California, P152.

plectognath, synopsis, P448.

Plectromus crassiceps, P4866.

Plectroplites, note on, P1082.

Pleurogadus, P853.

Pleuronectes, observations on name, P757.

Pleuronectes glaber, identity with Euchalarodus putnami, P49.

pleuronectid, gleanings among, P757; in National Museum, P2961; San Francisco, P72.

Pleuronichthys, review, P1744.

Pleuronichthys verticalis, California, P117.

Poecilia butleri, Mazatlán, P719.

Poecilichthys, new species of, P451.

Poeciliidae, P991, 1486.

poecilioid, nomenclature, P1060.

pollack, wall-eyed, Pollachius chalcogrammus fucensis, Puget Sound, P939.

Polyipnus, review of, P3047.

Polynemidae, Japanese, P1470.

Polynemus californiensis, P630.

Pomacentridae, Philippine, B100, vol. 7.

Pomacentrus, life coloration of young, P337.

Pomadasyidae, Philippine, B100, vol. 11.

Pomadasys, Mazatlán, with key to species of Pacific coasts of tropical America, P242.

Pomadasys approximans, Jamaica, P418.

Pomatomidae, note on, P317.

Porichthys and related genera, P3060.

Porichthys porosissimus, note on, P405.

Potamocottus bendirei, P190.

Priacanthidae, Philippine, B100, vol. 11.

Prionistius macellus, British Columbia, P387.

Prionotus, review of, P574.

Prionotus ophryas, Florida, P465. 
Fushes (continued).

Prionotus stearnsii, generic characteristics, P1396; Pensacola, Fla., P465.

Prionotus stephanophrys, California, P182.

Prionurus, note on, P1385.

Propterygia, notes on, P1054.

Psectrogaster, new species of, P1055.

Pseudochromidae, Philippine, B100, vol. 11.

Pseudolabrus, P861.

Pseudotriacis microdon, P357.

Psychrolutidae, P717.

Pterophryne, proper specific name of, P32.

Ptychochilus harfordi, Sacramento River, P193.

Puget Sound, P147, 170, 326, 753, 939, 1414.

Punta Arenas, P639.

Pygosteus, east Asia, P1536.

Rachicentron, nomenclature, P1059.

Rafinesque's "Analyse de la Nature," names, P648.

Rafinesque's Memoirs, review of, B9.

Raia inornata, notes on, P194.

Raia rhina, California, P141.

Raia stellulata, California, P129.

Ranicipitidae, P816.

Ranzania makua and others rare on California coast, P1961.

rays, California, P108, 129, 141 ; electric, P1050, 1694, 1816; Cephaleutherus, Propterygia, and Hieroptera, P1054; sting, generic name, P514; Texas, P2393.

Rhinobatidae, synopsis, P180.

Rhinobatus glaucostigma, Mexico, P370.

Rhinonemus caudacuta, identity with Gadus cimbrius, P50.

Rhinoptera encenadae, Lower California, P563.

Rimicola eigenmanni, California, P1643.

Rio Grande do Sul, P1532.

Riu Kiu Islands, P1541, 1635, 1688, 1836, 1913.

rockfishes, Alaska, P1027; California, P126, 176, 1501.

Rondeletiidae, Albatross northwestern Atlantic collections, P1012.

Rypticus, revision, P3074.

Sable Island Bank, P41.

saccopharyngoid, literature and systematic relations, $\mathrm{P} 408$.

Sacramento River, P193.

Safole, name replacing Boulengerina, P1922.

St. Georges Banks, P17.

St. Johns River, fishes collected by A. H. Curtiss, P105.

St. Lucia, Port Castries, P789.

Salmo mykiss agua-bonita, Kern River, Calif., P916.
Fishes (continued).

salmon, Chinnook names of, P244; development, P502; Garman's paper, note on, P490; Japanese, note on, P1399.

Salmonidae, differential characters, P992; upper Columbia River, P196.

Salvelinus aureolus, New Hampshire, P671.

Salvelinus namaycush, in British Columbia, P682.

Samoan Islands, B7, 180.

Santo Domingo, P1478.

Sargus holbrookii, Savannah Bank, P28.

scatophagoid, characteristics, P833.

Schmidtina, Japanese, P1381.

Sciaena sciera, Mazatlán and Panama, P452.

Sciaenidae, Philippine, B100, vol. 12.

sculpins, deep-water, Lake Ontario, P1728; Japanese, P1326, 1358, 1381.

Scymnus or Scymnorhinus, nomenclature, P1053.

Scytalina cerdale, Washington, P144. seahorses, hippocampids, life history, P1408; review of American and European, P2997.

Sebastichthys brevispinis, Alaska, P1027.

Sebastichthys carnatus, California, P126.

Sebastichthys chrysomelas, California, P176.

Sebastichthys entomelas, California, P132.

Sebastichthys maliger, California, P157.

Sebastichthys miniatus, California, P125.

Sebastichthys mystinus, P192.

Sebastichthys proriger, California, P161.

Sebastichthys rhodochloris, California, P132.

Sebastichthys serriceps, California, P109.

Sebastichthys umbrosus, California, P296.

Sebastinae, review of Pacific coast, P1009.

Sebastodes, California, P1501.

selachians, notes on, P482.

Sema, note on, P160.

Seriola stearnsii, Florida, P66.

Serranidae, Japanese, review of, P1714; Philippine, B100, vol. 10. shad, western gizzard, notes on, P43. sharks, California, notes on, P118.

Carcharhinus milberti, nematode eggs from, P2655.

Carcharias lamiella, California, P269. 
Fishes, sharks (continued). cestode parasites from, P2433, 2511, 3135.

China Sea, P1997.

dog, Atlantic, with key to Mustelus, P3058.

goblin, Japanese, P1409.

Mexican, P268.

nematode eggs from, P2588, 2655.

notidanoid, west coast United States, P167.

oil, California, P111.

Orectolobus or Crossorhinus, notes on, P1057.

Philippine, P1872, 1877, 1997.

Scymnus or Scymnorhinus, nomenclature, P1053.

Sulu Archipelago, P2003.

Siam, B188; P2873.

Sidera castanea, Mexico, P335.

Sidera chlevastes, Galápagos Islands, P369.

Siganidae, synopsis, P435.

Sillaginidae, Philippine, B100, vol. 12.

Siluridae, North American, B10.

Simenchelyidae, osteological characteristics, P817.

Siphostoma floridae, breeding habits and segmentation of egg, P1431.

Siphostoma mckayi, Florida, P428.

Siphostoma scovelli, Texas, P1043.

Siren lacertina, trematode from, P3014.

skates, cestode parasites from, P2511; southern United States, P1682.

skeletons, preparation of, B39c.

smelt, Coregonus hoyi, P340; surf, Northwest coast, P112; Yachats

River, Oreg., P1199.

snapper, red, P24, 457.

soapfishes, revision of, P3074.

soles, Japanese, P1484, 2082.

South America, Atlantic coast, $O p h$ ioscion, P3192; fresh-water, P842.

South Carolina, B12; P124, 328, 627.

South Seas, P1422, 2682, 2906.

Sparidae, Philippine, B100, vol. 12.

Sparidae and related perchlike, Japanese, P1875.

Sparus, note on, P321.

Sparus brachysomus, Lower California, P149.

Spheroides, note on, P758.

Squalius alicieae, Utah Lake, P186.

Squamipennes, Philippine, B100, vol. 8.

star-gazers, Gulf of Mexico, P896.

Stathmonotus, related to Muracnoides, P508.

Sternoptychidae, P443, 3047.

Stichaeus punctatus, Alaska, P47.

sticklebacks, Maine, P1089. ten-spined, east Asia, P1536.
Fishes (continued).

Stizostedion, relations and nomenclature, P993.

Stlengis, revision, P2987.

Stoasodon narinari, note on, P509.

sturgeons, Japanese, P1455.

Sudis ringens, California, P146.

Sulu Archipelago, P2003.

Sumatra, P2682.

surf-fishes, P1260, 2962.

surmullets, Japanese, P1513.

swordfish family, taxonomic relations and distribution, P248.

synanceine, note on genera, P1394.

Synaphobranchidae, osteological characteristics, P804.

synentognathous, families and nom. enclature, P1051.

syngnathid and hippocampid, differential characters, P1049.

Syngnathinae, United States, P283.

Synodontidae, Japanese, P1544.

Tahiti, P1422, 2682.

Tautoga, note on, P883.

teleost, cestode parasites from, P3112.

Tennessee, Alleghany region, B12.

Tephritis, Japanese, P1523.

Teraponidae, Philippine, B100, vol. 11.

Tetragonopterus, nomenclature, P1061.

Tetraodontidae, review of American, P566.

Tetraodontoidea, notes on, P886.

Teuthididae, synopsis, P435.

Teuthidoidea, svnopsis, P435.

Teuthis, application of name, P1052.

Texas, B17; P549, 2393; Corpus Christi, P1043; Galveston, P282.

Thailand, B188; P2873.

Thalassophryne dowi, Punta Arenas and Panama, P639.

threadfins, Japanese, P1470.

Thymallidae, differential characters, P992.

Thyris, name replaced, P350.

Thyrsitops violaceus, New England coast, P658.

Tilesia, P853.

toadfishes, Porichthys and related genera, P3060; venomous, P1764.

Torpedinidae, notes on synonymy, P1050.

torpedo, cestode (Calyptrobothrium) found in, P1529; use of name for electric catfish, P1329.

Tortugas, P37.

triggerfishes, Japanese, review of, P1287.

Triglops, Atlantic coast, P1963.

Triglopsis ontariensis, Lake Ontario, P1728.

Tropic of Cancer to Panama, Pacific coast, P526.

trout, Garman's paper on salmon and trout, note on, P490; golden, 
Fishes, trout (continued).

Kern River, Calif., P916; Great

Lake, in British Columbia, P682;

Japanese, P1399; yellow-finned,

Colnrado, P780.

trunkfishes, P87, 1287.

tuninies, proper generic name of, P716, 965.

Tylnsurus euryops, Jamaica, P418.

United States, Pacific coast, bibliography, B11; note on, P191.

U. S. Fish Commission collection, P723.

Uranidea marginata, P190.

Uranidea microstoma, Alaska, P121.

Uranidea policharis, Lake Michigan, P277.

Uranidea rhothea, Washington, P286.

Urolophus asterias, Mazatlán and Panama, P327.

Uruguay, Montevideo, to Tome, Chile, P2133.

Utah, Bonneville system, P2508.

Utah Lake, P175, 186.

Vancouver Island, P298.

Venezuela, P3172, 3181; parasites of, P2346.

vertebrae, relations of temperature to, P845.

Virginia, Chesapeake Bay, at Cape Charles City, P843.

viviparous osseous, development of, P501.

Washington, $\mathrm{P} 112,265,388,672$; Neah Bay, P144; Spokane River, P286.

West Indies, P595; Santo Domingo, P1478; Jamaica, P418; Port Castries, St. Lucia, P789.

whitefish, Alaska, P407, 748; Coregonus hoyi, P340; Great Lakes, P1662; Oregon, P1677.

wolffishes, notes on structure and habits, P1782.

Xenopterus, note on, P884.

Xiphiidae, nomenclature, P303; taxonomic relations and distribution, P248.

Xiphister, California, P130.

Xyrichthys jessiae, Gulf of Mexico, P675.

$X y$ streurys liolepis, California, P107.

Zeidae, osteology and relationships, P1155.

Zophendum, notes on, P822.

Zygonectes escambiae, P585.

Zygonectes inurus, Illinois, P273.

$2 y$ gonectes zonifer, Georgia, P453.

(See also under Fossils.)

Fishing vessels and equipment, catalog of collection sent to International

Fisheries Exhibition at London, B27.

Fisk, Mary, P2027.

Flatfishes. (See under Fishes.)

Flatheads. (See under Fishes.)
Flatworms, North, Central, and South American, P3055.

(See also under Polyclads.)

Fleas. (See under Insects, Aphaniptera.)

Flint, Dr., shells collected in kitchen midden in Costa Rica, P11.

Flies. (See under Insects: Diptera, Ephemerida, Hemiptera, Hymenoptera, Odonata, Plecoptera, Strepsiptera, Trichoptera.)

Flint, James Milton, R1897, pt. 2, No. 1; B39s, 55; C6-8, 19, 32.

Flora. (See Plants.)

Florida, amberfish, Seriola stearnsii, Pensacola, P66.

bones, fossil, Tise's Ford, P396.

box tortoise, a distinct species?,P1107.

bullfrog, new species of, P1252.

casts of heads of Indian prisoners,

Fort Marion, St. Augustine, P29.

cestodes, from sharks, P3135.

Copepoda, with description of Diaptomus floridanus, P2659.

crab, Eocene, P2786.

crayfishes, P3097.

electric ray and young, P1816.

fishes, Anthias vivanus, Pensacola, P465.

Aprion ariommus, Pensacola, P355.

Caulolatilus microps, new species from Gulf coast, P16.

Cedar Keys, P426.

collected by J. A. Henshall, P104.

Epinephelus drummond-hayi, P23.

flounder, Citharichthys macrops, Pensacola, P464.

Jacksonville, St. Johns River, P427.

Key West, P402, 414, 416, 428.

Lake Jessup and Indian River, P438.

Lut janus blackfordii and L. stearnsii, P24.

notes on, P406, 537.

Ophichthys retropinnis, Pensacola, P613.

Ophidium beani, Pensacola, P355.

Pensacola, P66, 74, 282, 355, 404, $464,465,565,613$.

pipefishes, Key West, notes on, describing Siphostoma mckayi, P428.

Prionotus ophryas and $P$. stearnsi, Pensacola, P465.

St. Johns River, P73, 105, 427.

Stathmonotus, new genus related to Muraenoides, P508.

hawk, red-shouldered, new race, P457.

isopods, cave, P3057; Dry Tortugas, P2924.

lizard, new genus and species, P1773. mammalian and fish remains, probably Pleistocene, P2291. 
Frorida (continued).

meteoric stone, Lake Okechobee, P2163.

mollusks, fossil fresh-water, P2612.

land and fresh-water, notes on, P519.

Liguus, P2741.

Oligocene, Tampa, B90.

shells, sent by Henry Hemphill, P384.

Tertiary, P2887.

turritid, P3070.

Xenophora, new species of, P2917. moths, Tineina, P1208.

muskrat, Neofiber alleni, R1884, pt. 3, No. 5; P419.

myriapods, Escambia County, P631.

phosphatic sandstone, Hawthorne, P263.

plants new to, CNH1, No. 8 (5th art.).

reptiles and batrachians, notes on, P1003.

sea-cow, Metaxytherium floridanum, fossil, P2438.

shell heaps, P966.

shrimps, snapping, Dry Tortugas, P1716.

snakes, P727.

turtles, Pleistocene, P2687.

whale, pollack, from Miami Aquarium Association, P2546.

Florida and the Southeastern States, Unionidae, P911.

Florida Keys, relationships of false date palms, CNH16, pt. 8.

Florissant. (See under Fossils, Colorado.)

Flounders. (See under Fishes.)

Flukes. (See under Trematodes.)

Flycatchers. (See under Birds.)

Flyingfishes. (See under Fishes.)

Folsom, Justus Watson, B168; P2037, 2134, 2222, 2702.

Fontaine, William Morris, P918, 934.

Fontaine, W. M., and Knowlton, Frank Hall, P821.

Food, classification of collections, C11; Klamath Indians, R1892, pt. 2, No. 3.

Footprints, Fort Union, Montana, fossil, P2750.

FORAMINIFERA :

Albatross collections. (See under $\mathrm{Al}$ batross.)

Alveolinellidae, Atlantic, B104, pt. 7.

Ammodiscoides, P1676.

Amphisteginidae, Atlantic, B104, pt. 8.

Anomalinidae, Atlantic Ocean, B104, pt. 8.

Astrorhizidae, B71, pt. 1; 104, pt. 1.

Astrorhizidae to Trochamminidae, tropical Pacific, B161, pt. 1; Lagenidae to Alveolinellidae, B161, pt. 2; Heterohelicidae and Buliminidae, B161, pt. 3 .
Foraminifera (continued).

Atlantic Ocean, B104: Astrorhizidae, pt. 1 ; Lituolidae, pt. 2; Textulariidae, pt. 3 ; Lagenidae, pt. 4 ; Chilostomellidae, Globigerinidae, pt. 5 ; Miliolidae, Ophthalmiidae, Fischerinidae, pt. 6; Nonionidae, Camerinidae, Peneroplidae, Alveolinellidae, pt. 7; Rotaliidae, Amphisteginidae, Calcarinidae, Cymbaloporettidae, Globorotaliidae, Anomalinidae, Planorbulinidae, Rupertiidae, Homotremidae, pt. 8.

Calcarina, relationships with Tinoporus and Baculogypsina, B100, vol. 1, pt. 6 .

Calcarinidae, Atlantic, B104, pt. 8.

Camerinidae, Atlantic, B104, pt. 7.

Chilostomelidae, B71, pts. 3, 4; 104, pt. 5.

commensal on Cyclammina, P2290.

Cymbaloporettidae, Atlantic, B104, pt. 8.

Fischerinidae, Atlantic, B104, pt. 6. Globigerinidae, B71, pt. 4 ; 104, pt. 5. Globorotaliidae, Atlantic, B104, pt. 8. Hawaiian Islands, P1603.

Homotremidae, Atlantic, B104, pt. 8.

Iridia diaphana, observation on living specimens, P2308.

Jamaica, P2360.

Juan Fernández Islands, P2780.

Lagenidae, B71, pt. 3; 104, pt. 4.

Lituolidae, B71, pt. 1; 104, pt. 2.

Miliolidae, B71, pt. $6 ; 104$, pt. 6 .

New Zealand, Recent, P2302.

Nonionidae, Atlantic, B104, pt. 7.

Nummulitidae, north Pacific, B71, pt. 4.

Ophthalmidiidae, Atlantic, B104, pt. 6.

Pacific Ocean, north, B71; Astrorhizidae, Lituolidae, pt. 1; Textlariidae, pt. 2; Lagenidae, pt. 3 ; Chilostomellidae, Globigerinidae, Nummulitidae, pt. 4; Rotaliidae, pt. 5; Miliolidae, pt. 6; tropical Pacific, B161.

Pavonina, P2597.

Peneroplidae, Atlantic, B104, pt. 7.

Philippine Islands, B100, vol. 1, pt. 6; vol. 4; P1759, 1898, 1973, 2172.

Planorbulinidae, Atlantic, B104, pe. 8.

Polymorphinidae, monograph, P2829.

Recent, Albatross collection, R1897, pt. 2, No. 1.

Rotaliidae, B71, pt. 5; 104, pt. 8.

Rupertiidae, Atlantic, B104, pt. 8.

Siphogenerina, P2597.

Siphonina and related genera, P2716.

South America, Atlantic coast P2903 ; west coast, P2796.

Textulariidae, B71, pt. 2; 104, pt. 3. 
Foraminifers (continued).

Textulariidae and other arenaceous, P1973.

Tinnporus, relationships with Calcarina and Baculogypsina, B100, vol. 1 , pt. 6 .

(See also under Fossils.)

Fordice, Morton W., and Jordan, David S., P575.

Forficulids. (See under Insects, Dermaptera.)

Formosa, batrachians and reptiles, P1731.

braconid and chalcid-flies parasitic on aphids, P2657.

fishes, P1289, 2448.

hymenopterous insects, P1794.

Forrer, Alphonse, fishes collected about Mazatlán, P719.

Fort Union, Mont., fossil mammals, B169; P2469, 2981.

Foshag, William Frederick, P2329, 2337, 2376, 2618, 2768.

Foshag, W. F.; Berman, Harry; and Gage, Robert Burns, P2669.

Foshag, W. F., and Hess, Frank L., P2707.

Fossils:

Acrostichopteris, revision, P1769.

Acrothele, P114, 1120.

Acrotreta, Cambrian, P1299.

Actaeon, Quaternary bluffs, California, P1145.

Alabama, plants, Black Creek, near Gadsden, P688; reptiles, P1164, 1870.

Alabina, west coast of America, P1790.

Alaska, brachiopods, P2569, 2649; flora, P300, 679, 998, 2158; branchiopods, P2569; Brooksina, P2414; Pentacrinus, P2577; mollusks, P2692, 2763.

Alligators. (See under Fossils, reptiles.)

Allosaurus fragilis, forelimb, P2120.

Alvania, west coast of America, P1863.

Amazon, mussels from Peru, P2748. amphibians, Illinois, Carboniferous, P1828; labyrinthodont, Kansas Coal Measures, P1796.

Amyda virginiana, carapace, P2823. Anancus brazosius, Texas, P2572. annelids, Serpula (Hamulus), P2359.

Antillean region, Tertiary, P1110.

Antrodemus (Allosaurus), osteology, B110.

Apiocrinus, in America, P2590.

Apodidae, P1117.

Araucarioxylon, revision, P784.

Araucarioxylon arizonicum, Arizosa and New Mexico, P676.

Argentina, Tertiary insects, P2602; Tertiary plants, P2743.
Fossils (continued).

Arizona, batrachian and reptile, P1353; birds, P2495; Cenozoie vertebrate faunas, San Pedro Valley, P3155; insects, Petrified Forest National Monument, P3033; turtle, P2451; wood, Araucarioxylon arixonicum, P676.

Arkansas, P137, 207.

Arundel formation, Md, fauan, P2389.

Aspen shale, Wyoming, P2860, 2953.

Asteroidez, revision, B88.

Austin chalk mollusks, P2815.

Baffin Island, P1192.

Baptornis, osteology and relationship, P1320.

Basilosaurus cetoides, pelvic girdle, P1211.

Bothmopterus, Alaska, P2763.

batrachian, Arizona, Trias, P1353.

Beyrichiidae, revision, P1646.

bibliography of publications, including writings of Meek, White, and Walcott, B30.

Bicia, P1229.

biology, relation of to geological investigation, R1892, pt. 3, No. 2.

birds, Arizona, P2495. auk, flightless, California, P1245.

Baptornis, osteology and relationship, P1320.

booby, Maryland, P3030.

Diatryma, Hargeria, Hesperornis, osteology and relationship, P1320.

hawks, Nebraska, P3003.

Mancalla califormiensis, California, P1245.

owl, Wyoming, P3031.

remains of passerine, Florissant, Colo., P2215.

Bison occidentalis, Minnesota, P2473.

Bison regius, P2021.

Bittium, west coast of America, P1826.

Black Hills, cycadean trunks, P1141.

blattoid, Cretaceous, P1439.

Bolivia, plants, P2229.

bones from Tise's Ford, Fla., P396.

Boötherium, Pleistocene, P1627.

Brachauchenius, skull, P1540.

brachiopods, Acrothele, P114, 1120.

Acrotreta, Cambrian, P1299.

Brooksina, Alaska, P2414.

Cambrian, P1120, 1152, 1229, 1299, 1395.

Cymbidium, Alaska, P2649.

Dalmanellas, Chemung formation, P1596.

Georgia, P116.

Harpidium, Alaska, P2569.

inarticulate, Trenton limestone, P775.

Iphidea, Cambrian, P1120. 
Fossils, brachiopods (continued).

Lingula, preserving cast of peduncle, P746.

Lingulella, Cambrian, P1152.

Linnarssonella, Cambrian, P1299.

Obolella, subgenus Glyptias; Bicia; Obolus, subgenus Westonia, P1229.

Obolus and Lingulella, P1152.

Oldhamia in America, P1002.

Productus giganteus in California, P113.

Rensselaeria mainensis, Maine, P1527.

Spirifer, Maine, P2144.

Stricklandinia salteri and $S$. davidsoni, Georgia, P116.

Triemella related to Dalmanellas, Chemung formation, P1596.

Yorkia, Cambrian, P1120.

Brachyceratops, P2424.

Branchiopods. (See under Fossils, crustaceans.)

British Columbia, new, Middle Cambrian, P2893.

British West Indies. (See under Fossils, Trinidad.)

Brittle-stars. (See under Fossils, echinoderms.)

Brooksina, Alaska, P2414.

bryozoans, Baltic Provinces, early Paleozoic, B77.

Canal Zone and related areas, B103, pt. 6.

cheilostomatous, P2640.

Corynotrypa, new genus, B1797.

cyclostomatous, P2443, 2593.

Galápagos Islands, P2810.

Gult of Mexico region, P2710.

Hederelloidea, Paleozoic, P3068.

Ho motrypa, structural features, with descriptions of species from Cincinnatian group, P1323.

Ordovician and Silurian, study of James types, P1442.

Tertiary, B96, 106.

Tertiary and Quaternary, North America, B125.

tubuliporoid, new genus (Corynotrypa), P1797.

Vincentown limesand, B165.

Burgess shale, restudy of, P2854.

$B$ uthotrephis, Indiana, Silurian, P1255.

California, auk, P1245.

brittle-star, Santa Cruz Mountains, P1620.

Caryophyllia, P1194.

cetacean, Santa Barbara County, P2564.

crabs, P1647, 2214.

Cretaceous and Tertiary, Santa Cruz Mountains, P1617.

mollusks, P8, 1545, 2938.

plants, P679.

post-Pliocene, coast range, $\mathbf{P 2}$.
Fossıls, California (continued). Productus giganteus, P113. raccoon, P1435.

San Pedro fauna, P2535.

spiral forms from, P2836.

Tertiary, distribution of fossils, P14.

whale skull, Miocene, from Lompoc, P2435.

Calvert Cliffs, Md., P2462, 2483.

Calvert formation, Md., booby, P3030; porpoise, P2482.

Cambrian, Brachiopoda, Acrotreta, Linnarssonella, Obolus, P1299; Iphidea, Yorkia, and Acrothele, P1120; new genera and species, P1395; Obolus and Lingulella, P1152; Obolella (subgenus Glyptias), Bicia, Obolus (subgenus Westonia), P1229.

Crustacea, Conchostraca, P2847.

faunas, China, P1415, 1458.

Lower, hydrozoan, P2954; new genera and species, P763.

Lower and Middle, Crustacea, P2806.

Middle, British Columbia, P2893; crustaceans, P2899; jellyfishes, P1086; new genera and species, P738.

Upper, new forms, P820.

Camelops, P2025.

Camerinidae, Mexican, P3052.

Camptosaurus, P1519, 1666, 1878.

Camptostroma, Lower Cambrian, P2954.

Canada, Toronto, Unios, P952.

Canadian formations and fossils of south Manchuria, B164.

Canal Zone, algae, B103, pt. 1.

Bryozoa, B103, pt. 6.

Cirripedia, B103, pt. 8 .

Echini, B103, pt. 5; P2218.

Foraminifera, B103, pts. 3, 4 .

palm nut, P2356.

plants, B103, pt. 2.

sedimentary formations, B103, pt. 10.

Carboniferous, air-breathing vertebrates in National Museum, P1696; amphibians, Illinois, P1828; invertebrate, P86; new and old species, P1614; new molluscan genera, P1372.

cave deposit near Cumberland, Md., Pleistocene, P2014.

Cenozoic, invertebrate types in $\mathrm{Na}$ tional Museum, P568; invertebrates, Arkansas, Wyoming, Colorado, and Utah, P137; late, vertebrate faunas, San Pedro Valley, Ariz., P3155; types in National Museum, P520.

Central America, B103, pts. 9, 11.

Ceratops beds of Wyoming, crocodile, P1762. 
Fossils (continued).

Ceratosaurus, osteology, B110.

Ceratosnurus nasicornis, P1648.

Cerithropsis, west coast of America, P1823.

Cestocrinus, P3080.

Chemung formation, Dalmanellas and a new brachiopod genus, Thiemella, P1596.

Chesapeake group, outline of divisions, P2759.

China, P1415, 1458, 1549, 1557, 2661.

Chisternon? interpositum, P1665.

Choct awhatchee marl, mollusks, P2169.

Chondrodonta, new Cretaceous mollusk, P1257.

Cincinnatian group, structural features of Homotrypa, P1323.

Cirripedia. (See under Fossils, crustaceans.)

Cladophlebis, Potomac group, P1862.

collecting and preparing, directions for, B39k.

Colombia, crocodilian, P3122; Tertiarv plants, P2795.

Colorado, Cretaceous, P207, 1611.

Florissant, beetles, P2189; bird, P2215; insects, P1955, 1982, 2000, 2189, 2210.

insects, Eocene, P2358, 2556.

invertebrates, Cretaceous, P1611; Mesozoic and Cenozoic, P137. plants, P2151, 2556.

Colorado Desert, mollusks, P1256.

Comanche series, Trinity division, Tex., plants, P934.

Conchostraca, Cambrian bivalved Crustacea, P2847.

conodonts, bibliography of early Mississippian species, P2701; Devonian and Mississippian species, P2613.

corals, Caryophyllia, California, P1194.

Central America, Cuba, and Puerto Rico, with account of American Tertiary, Pleistocene, and Recent coral reefs, B103, pt. 9.

Japanese, P1194.

Neocene, United States, P1193.

Texas, P2820.

West Indian, P2975.

Cornwallius, osteology and dentition, P2521.

Corynecrinus, Devonian crinoid genus, P2972.

Corynotrypa, new bryozoan genus, P1797.

Costa Rica, B103, pt. 5; P2218, 2367.

Crabs. (See under Fossils, crustaceans.)

Crendonts. (See under Fossils, mammals.)

Cretacenus, Arkansas and Colorado, P207.

blattoid, P1439.
Fossils, Cretaceous (continued).

California, Santa Cruz Mountains, P1617.

Camerinidae, Mexican, P3052.

coral, Texas, P2820.

crabs, South Dakota, P2182.

invertebrates, Colorado, P1611;

Kansas and Texas, P93.

Lower, Cycadeoidea, Black Hills, P1141; dinosaur, South Dakota, P1224.

mollusks, P1109, 1257, 2860.

Pinna, New Mexico, P115.

reptile, $\mathrm{P} 1870,2745$.

rudistid, Mexico, P2379.

Santa Cruz Mountains, Calif., P1617.

sea-urchin, P2557.

sponge, New Jersey, P2019.

Upper, crinoids from Mexico, P2426; dinosaurs, Two Medicine formation, P3066; fern, Wyoming, P1994; Foraminifera, Trinidad, P2914; invertebrate faunas, Carolinas, P2706; lizards, Utah, P3148, 3158, 3163; shells, Tamaulipas, P2422.

Crinoids. (See under Fossils, echinoderms.)

crustaceans, Apodidae, P1117.

branchiopods, Harpidium, Alaska, P2569.

Cambrian, Lower and Middle, P2806.

Cirripedia, B103, pt. 8; P2515.

Conchostraca, Cambrian, P2847.

crabs, California, P1647, 2214; Florida, P2786; Haiti, P2477; South Dakota, P2182; Texas, P2727.

decapods, Mexico, P2851; Panama, B103, pt. 7; West Indies, P2343.

Dipeltis, P1117.

merostome, Middle Cambrian, P2899.

North America, Pacific slope, B138.

ostracods, Beyrichiidae, revision, P1646: Paleozoic, upper Carboniferous, P1446.

Panama region, B103, pt. 7 .

Protocaris, P1117.

Cuba, B103, pt. 9; P2491.

Cumberland Cave deposit. (See under Fossils, Maryland.)

Cycadeoidea, or cycadean trunks, Black Hills, P1141.

Cymbidium, Alaska, P2649.

Dakota formation, invertebrate fauna, P995.

Dalmanellas, Chemung formation, P1596.

Decapods. (See under Fossils, Crustaceans.)

Desmostylus, osteology and dentition, P2521. 
Fossils (continued).

Desmostylus hesperus, extinct sirenian, P2113.

Devonian, brachiopod, Rensselaeria mainensis, Maine, P1527.

conodonts, American, P2613.

crinoids, P2793, 2972.

Lower, formations of Maryland, P1313.

Middle, molluscan genus from China, P2661; Traverse group, P2811.

plants, New York and Pennaylvania, P928.

Diastoma, west coast of America, P1802.

Diatryma, osteology and relationship, P1320.

Diceratherium armatum, Montana, P2948.

Dimetrodon gigas, skeletal anatomy, P2300.

Dinosaurs. (See under Fossils, reptiles.)

Dinotocrinus, crinoid genus, P3103.

Dipeltis, P1117.

Diplodocus, skeleton in National Museum, P2941.

Discocyclina, Eocene, P2800.

Dolatocrinus and allies, B115.

Dominican Republic, plants, P2363. echinoderms, Asteroidea, revision, B88.

brittle-star, Santa Cruz Mountains, Calif., P1620.

Canal Zone and Costa Rica, B103, pt. 5 ; P2218.

crinoids, Apiocrinus, P2590; Cestocrinus, P3080; Corynecrinus, Devonian, P2972; Dinotocrinus, P3103; Dolatocrinus, B115; Homocrinus, notes on, P2038; Jurassic, P1664; Knobstone formation, P1850; notes on unusually fine slab, P2009; Page. crinus, P2793; Pentacrinus, Alaska, P2577; Rhopocrinus, P3144; unusual forms, P2581; Vasocrinus, P2760; West Indies, P2516.

echinoids, Mexican, P3015; Pamlico, P3113.

pentremite, P1467.

sea-urchin, Scutellaster cretaceus, P2557.

Stelleroidea, revision with reference to Asteroidea, B88.

Ecuador, mollusks, P2946.

Edestus and related genera, P1699.

Edmunds formation, Washington County, Maine, P1985.

Ehrenbergina, P2665.

Elephas roosevelti, description of type, P2571.

Endothyra ornata, P91.
Fossils (continued).

Eocene, Bridger, Machaeroides eothen, sabertooth creodont from, P3202.

crabs, P2727, 2786.

flower, P1980.

Foraminifera, P2567, 2800.

Fulgoridae, P2380.

insects, P2313, 2358.

lower, caddis case, Tennessse, P2686.

middle, palm fruit, Peru, P2652; Sinopa, osteology, P1449.

mollusks, P134, 2518.

owl, Wyoming, P3031.

plants and insects, Green River, Colo., P2556.

primates, relationship with Paleocene, P2469.

snake, Alabama, P1164.

Equus lambei, Pleistocene, Yukon, P2212.

Esmeralda formation, Nev., flora, P2719.

Eurhinodelphis, North American, P2563.

Eutrephoceras sloani, Eocene, South Carolina, P2518.

Exogyra, Texas, Austin Chalk, P2815.

Ferns. (See under Fossils, plants.)

fishes, Cottus beldingif, Nevada, P2519.

Edestus and related genera, P1699.

Haiti, P2475.

in National Museum, P2177.

Leuciscus turneri, Miocene, Nevada, P1212.

Macrocheilus, Plectostylus, and Soleniscus, P366.

Paleozoic, characters, P866.

Pleistocene, Florida, P2291.

pycnodont, American, P2036.

scales from Peru, P2355.

sculpin, Nevada, P2519.

stickleback, Nevada, P1528.

Florida, bones, Tise's Ford, P396. crab. P2786.

mammalian and fish remains, P2291.

mollusks, B90; P2612, 2887.

sea-cow, P2438.

turtie, P2687.

Florissant. (See under Fossils, Colorado.)

footprints, Fort Union, Montana, P2750.

Foraminifera, Camerinidac, Mexican, P3032.

Canal Zone, B103, pts. 3, 4.

Cretaceous, Upper, Trinidad, P2914.

Discocyclina, Eocene, P2800.

Ehrenbergina, P2665.

Endothyra ornata, note on, P9L.

Eocene genus, new, P2567.

Lspidocyclina related to $L$. mantelli, P2680. 
Fossuss, Foraminifera (continued).

Operculina and Operculinoides, Tertiary, P2996.

Polymorphinidae, monograph, P2829.

Ripley formation, Tenn., P2816.

Fort Union, Montana, footprints, P2750.

liverwort, P1639.

mammalian fauna of Crazy Mountain field, B169.

mammals, Paleocene, P2981.

marsupial, with notes on Myrmecobidae and other families of group, P2077.

plants, P921.

primates, P2469.

Galápagos Islands, bryozoans, P2810.

gasteropods. (See under Fossils, mollusks.)

Georgia, brachiopods, P116; Flint River, invertebrate fauna, P2162.

Gigantopteris, in North America, P1873.

Gleichenia, Wyoming, P1994.

Glyptias, subgenus of Obolella, P1229.

Gomphotherium cimarronis, Texas, P2572.

Gomphotherium elegans, Pleistocene, Kansas, P2198.

Grand Canyon, insect, P2695; supposed jellyfish, P3104.

graptolites, Hamilton, Ontario, B65.

Great Britain, insects, P2119.

Greenland, plants, P679.

Green River group, P266.

Gulf of Mexico region, Bryozoa, P2710.

Haiti, Cirripedia, P2515; crabs, P2477; fish, P2475; mollusks, P2491; plants, P2460.

Haliotis, California Miocene, P2938.

Hamulus, operculate Serpula, P2359.

Hargeria, osteology and relationship, P1320.

Harpidium, Alaska, P2569.

Hederelloidea, Paleozoic, P3068.

Hell Creek beds, Montana, alligator, P1860.

Hesperornis, osteology and relationship, P1320.

Homocrinus, notes on, P2038.

Ho motrypa, structural features, P1323.

Hydrozoans, Camplostroma, Lower Cambrian, P2954.

Idaho, P2375, 2950, 2976, 2985.

Iguanodon, notes on brain-case, P1660.

Illinois, P1828.

inclined strata, measuring thicknese of, P739.

Indian Territory, Afton, R1901, ph. 2, No. 2.

Indiana, algae, P1255.
Fossils (continued).

insects, American, P2146.

Argentina, Tertiary, P2602.

Arizona, Petrified Forest, Triassic, P3033.

beetles, cockroaches, and tsetse flies, P2237.

beetles, Florissant, Colo., P2189.

blattoid, North American, P1439.

British, P2119.

caddis case, Lower Eocene, Tennessee, P2686.

Coleoptera, Florissant in National Museum, P1982.

Colorado, Florissant, P1955, 1982, 2000, 2189, 2210; Florissant, dragonflies, P2000; Green River, Eocene, P2556.

dragonflies, Colorado, P2000.

Fulgoridae, Eocene, P2380.

Grand Canyon, lower Permian, P2695.

in National Museum, P2503.

Paleozoic, revision, P1441.

Rocky Mountains, P2313.

Siberia, Tertiary, P2606.

Tertiary, P2181, 2602, 2606.

invertebrate faunas, Carolinas, Upper Cretaceous, P2706.

invertebrates, type and figured specimens in National Museum, B53, pt. 1 , sect. 1 .

Iowa, wood, P677.

Iphidea, Cambrian, P1120.

Japan, coral, P1194.

Jurassic, crinoids, P1664; Lower Jurassic flora, Alaska, P2158; reptiles, P1519, 1666, 1698.

Kansas, P93, 1554, 1796, 2198.

Kentriodon pernix, Maryland, P2645.

Kentucky, Columbus and Hickman, Mississippi River bluffs at, flora, P2074; plants, P679.

Kinosternon arizonense, Arizona, P2451.

Kirtland formation, New Mexica, reptiles, P2978.

Knobstone formation, crinoid fauna, P1850.

labyrinthodont, Kansas Coal Measures, P1796.

Lance formation, Wyoming, P2127, $2137,2875$.

Laramie group, molluscan forms, P266.

Leidyosuchus sternbergii, Wyoming. P1762.

Lepidocyclina related to $L$. mantelli, P2680.

Leptonacea, North America and West Indies, P1177.

Leuciscus turneri, Miocene, Nevada, P1212.

Lingula, preserving cast of peduscle, P746.

Lingulella, Cambrian, P1152. 
Fossils (continued).

Linnarssonella, Cambrian, P1299.

Lithothamnieae, B103, pt. 1; P2453.

Lizards. (See under Fossils, reptiles.)

Louisiana, P679, 690, 2943.

Lower California, R1895, pt. 2, No. 3.

Lucinacea, synopsis, P1237.

Machaeroides eothen, Bridger Eocene, P3202.

Macrocheilus, P366.

Maine, P223, 1527, 2144; Washing. ton County, P1908, 1985, 2225.

mammalian faunas, central Utah, Paleocene, P3121.

mammals, Anancus brazosius, Texas, P2572.

Arizona, P1500.

Basilosaurus cetoides, pelvic girdle, P1211.

Bison occidentalis, Minnesota, P2473.

Bison regius, $\mathrm{P} 2021$.

bisons, North American, P1172, 2021, 2473.

Boötherium, Pleistocene, P1627.

camels, Camelops, P2025.

cetaceans, California, P2564; Calvert Cliffs, Md., P2462.

Cornwallius, osteology and dentition, P2521.

creodont, osteologv of middle Eocene Sinopa, P1449.

sabertooth, Machaeroides eothen, Bridger Eocene, P3202.

Desmostylus, osteology and dentition, P2521.

dog, Miocene, Maryland, P3035.

Elephas roosevelti, description of type, P2571.

Fort Union, Montana, B169; P2077, 2469, 2981.

Gomphotherium cimarronis, Texas, P2572.

Gomphotherium elegans, Pleistocene, Kansas, P2198.

hares, Idaho, late Pliocene. P2976.

horses, Equus lambei, Pleistocene, Yukon, P2212; Idaho, upper Pliocene, P2985; notes on, with descriptions of new species, P1969.

Machaeroides eothen, Bridger Eocene, P3202.

mammoths, circulars regarding, C48, 53.

marsupial, Fort Union, P2077.

mastodons, circulars regarding, C+8, 53; Kansas, P2198; Texas, P2572.

Megaptera miocaena, California, P2435.

Merycoidodon, mounted skeleton, P1492.
Fossils, marnmals (continued).

Myrmecobidae and other families of Fort Union, P2077.

Ovibos, Pleistocene, P1627.

Paleocene, Louisiana, P2943.

peccaries, Cumberland Cave deposit, Pleistocene, P2324.

Pleistocene, North America, P2086.

porpoise, Calvert formation, Md., P2482; Eurhinodelphis, North American, P2563; Kentriodon pernix, P2645; skull of Zarhachis flagellator, P2600.

primates, Paleocene, Fort Union, P2469.

Ptilodus, notes on, P1689.

raccoon, California, Pleistocene, P1435.

remains from Pleistocene of Florida, P2291.

rhinoceros, Diceratherium armatum, Montana, P2948; Trigonias osborni, South Dakota. P1207.

rodent, horned, Kansas, P1554.

ruminant, Pleistocene, New Mexico, P1447; notes on, P1627.

sea-cow, Metaxytherium floridanum, Florida, P2438.

seal, Miocene of Maryland, P1475. Sinopa, osteology, P1449.

sirenian, Desmostylus hesperus, P2113.

squalodonts, Calvert Cliffs, Md., P2462.

Titanotheres, possible Paleocene relative, $\mathrm{P} 2187$.

tusk from Clearwater County, Idaho, encrusted with vivianite, P2375.

walrus (?) from Maine, P223.

whales, P2435, 2483.

Xenarthra, Pleistocene, Texas, P2147.

zeuglodons, P1211, 1975.

Mancalla californiensis, California, P1245.

Manchuria, south, B164.

Maryland, Arundel formation, P2389.

Calvert Cliffs, P2462, 2482, 2483, 3030.

Cumberland Cave, fauna, B171; P2014, 2324.

dog, Miocene, P3035.

Lower Devonian and Ontaric formations, P1313.

peculiar forms, P2688.

plants, P1821.

porpoise, P2645.

seal, P1475.

turtle, P1669. 
Fossils (continuea).

medusae, jellyfishes, Middle Cambrian, P1086; pre-Cambrian of Grand Canyon, P3104.

Megalosaurus, notes on brain case, P1660.

Megaptera miocaena, California, P2435.

Merycoidodon, mounted skeleton, P1492.

Mesozoic, Arkansas, Wyoming, Colorado, and Utah, P137; St. Pauls and St. Peters Islands, Straits of Magellan, P793; types in National Museum, P520, 568.

Metaxytherium fioridanum, P2438.

Mexico, Camerinidae, Tertiary, P3052.

crinoids, P2426.

crustaceans, P2851.

Echini, P3015.

Foraminifera, P2800.

mammals, P1500.

mollusks, P2379, 2731; Tamaulipas, P2422.

plants, Miocene, P2465.

Puebla, gastropod from, P131.

spiral forms from, P2836.

Michigan, Middle Devonian Traverse group of rocks, P2811.

Minnesota, bison, P2473.

Miocene, auk. Mancalla californiensis, California, P1245.

booby, Maryland, P3030.

Cirripedia, Haiti, P2515.

dog, Marvland, P3035.

fauna, subtropical, Arctic Siberia, P946.

fish, Nevada, P1212.

flora, Alaska, P300.

hawks, Nebraska, P3003.

lower, algae, P2453.

mollusks, P2559, 2759, 2938.

palm nut, Canal Zone, P2356.

plants, P2270, 2465.

porpoise, Maryland, P2645.

rhinoceros, South Dakota, P1207.

rodent, Kansas, $\mathrm{P} 1554$.

seal, Marvland, P1475.

turtle, Maryland, P1669.

upper, brittle-star, P1620.

Mississippian conodonts, P2613, 2701.

Mitrospira, Ordovician gasteropod genus, P2819.

molluscan forms, Laramie and Green

River groups, P266.

mollusks, Actaeon, Quaternary bluffs, California, P1145.

Alabina, west coast of America, P1790.

Alvania, west coast of America, P1863.

Aspen shale, Wvoming, P2860.

Austin chalk, P2815.

Bathmopterus, gasteropod, Alaoka, P2763.
Fossils, mollusks (continued).

Bittium, west coast of America, P1826.

Carboniferous, P1372.

Cerithiopsis, west coast of America, P1823.

Choctawhatchee marl, P2169.

Chondrodonta, Cretaceous, P1257.

Colorado Desert, P1256.

Cretaceous, Mexico, P2379; southwestern Wyoming, P2860.

Dakota formation, P995.

Devonian, Middle, China, P2661.

Diastoma, west coast of America, P1802.

Ecuador, P2946.

Eocene, southern United States, P134.

Eutrephoceras sloani, Eocene, South Carolina, P2518.

Exogyra, Texas, P2815.

Florida, P2612.

gasteropods, P131, 2763, 2819.

Green River group, P266.

Haliotis, California Miocene, P2938.

Leptonacea, North America and West Indies, P1177.

Lucinacea, synopsis, P1237.

Macrocheilus, Plectostylus, and Soleniscus, P366.

Mexico, Puebla, P131; Tamaulipas, P2422.

Miocene, California, P2938; Trinidad, P2559; Virginia, and North Carolina, P2759.

Mitrospira, Ordovician gasteropod genus, P2819.

nuculites, Washington County, Maine, Silurian, P2225.

Oligocene, Tampa, Fla., B90.

Ordovician gasteropod genus, P2819.

Orthaulax, Haiti, Puerto Rico, and Cuba, Tertiary, P2491.

Orthaulax pugnax zone, Oligocene, Tampa, B90.

Ostrea, Texas, P2815.

Peru, upper Amazon, P2748.

Pinna, New Mexico, P115.

Pterinea, revision, P1600.

Pycnodesma, Alaska, P2692.

Remondia, Cretaceous, P1109.

Rissoina, west coast of America, P2094.

Silurian, Alaska, P2692, 2763; Washington County, Maine, P1908.

Tertiary, southern California, P1545; southern Florida, P2887.

Texas, Austin Chalk, P2815; Reynosa formation, P2798.

Truckee group, P267.

Unionidae, distribution of northeastern North American, P952.

Unios, Toronto, Canada, P952; Triassic, Staked Plains, Tex.; P1072. 
Fossils, mollusks (continued).

Vicksburg (Oligocene), Mexico, P2731.

West Indian, P2254.

Montana, alligator, P1860; dinosaurs, P3066; footprints, P2750; liverwort, P1639; mammals, B169, P2981; plants, P918. 921 ; reptiles, P2839; rhinoceros, P2948; wood, P677.

(See also under Fossils, Fort Union.)

Morosaurus agilis, with note on Camptosaurus, P1519.

Myrmecobidae and other families of Fort Union, P2077.

Nageiopsis, revision, P1738.

Nebraska, hawks, P3003.

Nematophyton crassum, notes on, P929.

Neocene corals, United States, P1193.

Nevada, fishes, P1212, 1528, 2519; flora, P2719; sculpin, P2519; sponge fauna, early Ordovician (Pogonip), P3126.

New Jersey, reptile, P2728; sponge, P2019.

New Mexico, mollusks, P115; plants, P821; reptiles, P2978; ruminant, P1447; wood, Araucarioxylon arizonicum, P676.

New York, plants, P928.

Niagaran dolomites, Hamilton, Ontario, B65.

Niagaran strata, late, Tennessee, P1621.

North Carolina, Miocene mollusks, P2759; Upper Cretaceous invertebrate faunas, P2706.

Obolella, subgenus Glyptias, P1229.

Obolus, Cambrian, P1152, 1229, 1299.

Ohio, Warren and Clinton Counties, P2671.

Oklahoma, plants, P2256; remains from sulphur spring, R1901, pt. 2, No. 2.

Oldhamia in America, P1002.

Olenellus zone, North American, P763.

Oligocene, invertebrate fauna, Flint River, Ga., P2162; lizards, Wyoming, P3124; mollusks, B90, P2731.

One-hundredth Meridian, west of, turtles, P1747.

Ontaric formations, Maryland, P1313.

Ontario, Hamilton, graptolites, B65.

Operculina and Operculinoides, Tertiary, P2996.

Ordovician, bibliographic index of American, B92.

Bryozoa, James types, P1442.

China, P1549.

early, Pogonip, sponge fauna, P3126.
Fossils, Ordovician (continued). formations and fossils, south Ma*churia, B164.

gasteropod genus, P2819.

trilobites, Telephidae, P2818.

Oregon, plants, P679; reptile, P2745.

Orthaulax, Haiti, Puerto Rico, Cuba, Tertiary, P2491.

Orthaulax pugnax zone, Oligocene, Tampa, B90.

Ostracods. (See under Fossils, crustaceans.)

Ostrea, Texas, Austin Chalk, P2815.

Ovibos, Pleistocene, P1627.

Pagecrinus, Devonian crinoid genus, P2793.

Paleocene, footprints, P2750.

mammals, Louisiana, P2943; Montana, Fort Union, P2981; titanotheres, possible relative of, P2187; primates, Fort Union, P2469; Utah, P3121.

Paleolithic. (See under Anthropology.)

Paleontology, division of vertebrate, history, P3109.

Paleozoic, bryozoans, Hederelloidea, P3068.

early, Baltic Provinces, B77.

fishes, characters, P866.

insects, P1441.

ostracods, P1446, 1646.

Stelleroidea, revision, B88.

upper, China, P1557.

Palmoxylon, Louisiana, P690.

Pamlico, echinoids, P3113.

Panama, B103, pt. 7.

Pembroke formation, Washington County, Maine, P1985.

Pennsylvania, plants, P928, 2154.

Pentacrinus, in Alaska, P2577.

pentremites. (See under Fossils, echinoderms.)

Permian, lower, insect, Grand Canyon, P2695.

Peru, fish scales, P2355; mussels from upper Amazon, P2748; palm fruit, P2652; plants, P2270.

Pinna, Cretaceous, New Mexico, P115. plants, Acrostichopteris, revision, P1769.

Alabama, P688.

Alaskan, P300, 679. 998, 2158.

Igae, $B$ uthotrephis, Indiana, P1255; Lithothamniae, P103, pt. 1; P2453.

Argentina, P2743.

Aspen shale, Wyoming, P2953.

California, P679.

Canal Zone, B103.

Cladophlebis, Potomac group, P1862.

collecting, directions for, B39b.

Colombia, Tertiary, P2795.

Columbus and Hickman, Ky. P2074. 
Fossiss, plants (continued).

Costa Rica, P2367.

Cycadeoidea, or cycadean trunts, Black Hills, P1141.

Dominican Republic, P2363.

Esmeralda formation, Nevada, P2719.

fern, Cladophlebis and Thyrsopteris, P1862; Gleichenia, Wyoming, P1994.

Florissant Lake beds, P2151.

flower, Eocene, P1980.

Fort Union, Montana, P921.

Gigantopteris, in North America, P1873.

Great Falls coal field, Montana, P918.

Green River Eocene, Colo., P2556.

Greenland, P679.

gymnospermous, Potomac group in Maryland and Virginia, P1821. Haiti, P2460.

identified by Prof. Lesquereux, P606.

Indiana, P1255.

Kentucky, P679.

Lithospermum, nutlets of genus, P2734.

liverwort, Fort Union, Mont., P1639.

Louisiana, P679, 690.

marine, P792.

Mexico, P2465.

Nageiopsis, P1738.

Nematophyton crassum, notes on, P929.

New Mexico, P821.

New York and Pennsylvania, Devonian, P928.

Nilsonia, revision, P1769.

nutlets of genus Lithospermum, P2734.

Oklahoma, P2256.

Oldhamia, P1002.

Oregon, P679.

palm fruit, Peru, P2652.

palm nut, Canal Zone, P2356.

Palmoxylon, Louisiana, P690.

Pennsylvania, P2154.

Peru, P2270.

Platanus, pale ontologic history, P680.

Potomac group, P1769, 1821, 1862. remains considered marine, P792. Sapindopsis, revision, P1769.

Taeniopteris, revision, $\mathrm{P} 1769$.

Tertiary, western North American, P306.

Texas, Trinity division, Comanche series, P934.

Thyrsopteris, Potomac group, P1862.

trees in National Museum, P257.

Trinidad, P2558.

type and figured specimens in National Museum, catalog of, B53, pt. 2 , sect. 3 .
FossiLs, plants (continued).

Venezuela, P2388, 2988.

(See also under Fossils, wood.)

Platanus, paleontologic history, P680. Plectostylus, P366.

Pleistocene, cave deposit near Cumberland, Md., F 2014.

Cirripedia, Haiti, P2515.

coral reefs, B103, pt. 9.

flora, Trinidad, P2558.

horse, Yukon Territory, P2212.

mammalian and fish remains, Florida, P2291.

mammals, North America, P2086;

Texas, P2147.

mastodon, Kansas, P2198.

peccaries, Cumberland Cave deposit, P2324.

raccoon, California, P1435.

ruminants, New Mexico, P1447;

Ovibos and Boötherium, P1627.

turtles, Florida, P2687.

vertebrates, P2391; Cumberland

Cave, Md., B171; southwestern

Texas, P2625; United States, P2328.

plesiosaurs, relationships, P1540.

Pliocene, brackish-water fauna, southern Coastal Plain, P2023; crab, California, P2214; late Pliocene hares, Idaho, P2976; upper Pliocene horse remains, Idaho, P2985; turtle, Idaho, P2950.

Pogonip sponges, P3126.

Polyglyphanodon, osteology, P3148.

Polymorphinidae, monograph, P2829. post-Pliocene, California, P2.

Potomac group, plants, P1769, 1821, 1862.

pre-Cambrian supposed jellyfish, P3104.

Productus giganteus in California, P113.

Protocaris, P1117.

Pterinea, revision, P1600.

Ptilodus, notes on, P1689.

Puerto Rico, corals, B103, pt. 9; mollusks, P2491.

Pycnodesma, Alaska, P2692.

Quaternary bluffs, California, P1145.

Quaternary Bryozoa, B125.

Remondia, Cretaceous, P1109.

Rensselaeria mainensis, Maine, P1527.

reptiles, Alabama, P1870.

alligator, Hell Creek beds, Montana, P1860.

Arizona, Trias, P1353.

Brachauchenius, skull, P1540.

Camptosaurus, P1519, 1666, 1878.

Ceratosaurus, osteology, B110.

Ceratosaurus nasicornis, P1648.

crocodile, Wyoming, P1762.

crocodilian, Colombia, P3122.

Dimetrodon gigas, skeletal anatomy, P2300. 
Fossils, reptiles (continued).

Dinosauria, armored, osteology, B89. dinosaurs, Allosaurus fragilis, fore limb, P2120.

Brachyceratops, P2424.

Camptosaurus, mounted skeletons in National Museum, P1878.

carnivorous, osteology, with special reference to Antrodemus (Allosaurus) and Ceratosaurus, B110; with reference to Ceratosaurus nasicornis, P1648.

crested, skull structure, P3023.

Diplodocus skeleton in National Museum, P2941.

Montana, P2839, 3066.

Stegosaurus, osteology, B89.

Stegosaurus marshi, South $\mathrm{Da}$ kota, P1224.

Stegosaurus stenops, in National Museum, P2241.

Wyoming, P2127, 2875.

Iguanodon, notes on brain case, P1660.

Jurassic, Wyoming, P1698.

Leidyosuchus sternbergii, Wyoming, P1762.

lizards, North American, P3042; Oligocene, Wyoming, P3124; Saniwa ensidens, Wyoming, P2418; Utah, P3148, 3163.

Megalosaurus, notes on brain case, P1660.

Morosaurus agilis, with note on Camptosaurus, P1519.

mosasauroid, Alabama, P1870.

New Jersey, Triassic, P2728.

Oregon, P2745.

skeletons in National Museum, P3196.

snake, Alabama, P1164.

Stegosaurus, restoration, P2110.

Thescelosaurus, Wyoming, P2127.

tortoises, United States, P1181.

Triceratops, restoration, with notes on osteology, P2260; skull and brain, with notes on brain cases of Iguanodon and Megalosaurus, P1660.

Triceratops prorsus, mounted skeleton, P1426.

turtles, Amyda virginiana, P2823.

Florida, P2687.

Idaho, P2950.

Kinosternon arizonense, Arizona, P2451.

Maryland, P1669.

new, P2292.

New Mexico, P2978.

North American, P1640.

Testudo, Oligocene, Wyoming, P3199.

Toxochelys stenopora and Chis. ternon? interpositum, P1665.

Trachemys sculpta, shell, P2833.
Fossils, reptiles (continued).

Utah, P3158.

west of One-hundredth Meridian, P1747.

Wyoming, P2137.

Revnosa formation, Texas, mollusks, P2798.

Rhopocrinus, crinoid genus, $\mathrm{P} 3144$.

Richmond faunal zones, Warren and Clinton Counties, Ohio, P2671.

Ripley formation, Foraminifera, P2816.

Rissoina, west coast of America, P2094.

Rocky Mountains, insects, P2313.

St. Pauls and St. Peters Islands, Straits of Magellan, P793.

San Felipe formation, Mexico, rudistid, P2379.

Sanizua ensidens, Wyoming, P2418.

Sapindopsis, revision, P1769.

Scutellaster cretaceus, Cretaceous sea-urchin, P2557.

Sea-urchins. (See under Fossils, echinoderms.)

Serpula, annelid genus, P2359.

Shells. (See under Fossils, mollusks.)

Siberia, insects, P2606; Miocene fauna, Arctic, P946.

silicification of, P1637.

Silurian, bibliographic index of American, B92.

brachiopods, Alaska, P2649.

Brvozoa, study of James types, P1442.

Edmunds and Pembroke formations, Washington County, Maine, P1985.

gasteropod genus, Bathmopterus, Alaska, P2763.

Indiana, algae, Buthotrephis, P1255.

lower, fauna of Baffin Land, P1192. mollusks, Pycnodesma, Alaska, P2692; Washington County, Maine, P1908.

nuculites, Washington County, Maine, P2225.

Spirifer, Maine, P2144.

upper, Brooksina, Alaska, P2414.

Sinopa, osteology, P1449.

skull of Zarliachis flagellator, P2600.

Snakes. (See under Fossils, reptiles.)

Soleniscus, P366.

South Carolina, invertebrate faunas, Upper Cretaceous, P2706; mollusks, P2518.

South Dakota, crabs, P2182; dinosaur, P1224; rhinoceros, P1207.

spiral forms, California and Mexico, P2836.

Spirifer, Maine, P2144.

sponges, Nevada, P3126; New Jersey, P2019.

Stegosaurus, osteology, B89; restoration, P2110. 
Fossils (continued).

Stegosaurus marshi, South Dakota, P1224.

Stegosaurus stenops, mounted skeleton in National Museum, P2241.

Stellcroidea, revision, B88.

Stricklandinia salteri and $S$. davidsoni, Georgia, P116.

Taeniopteris, revision, P1769.

Telephidae, P2818.

Tennessee, P1851; caddis case from, P2686; Foraminifera, P2816; Late Niagaran strata, P1621.

Tertiary, Antillean region, P1110. Bryozoa, B96, 106, 125.

California, P14, 1617.

Camerinidae, Mexican, P3052.

coral reefs, B103, pt. 9.

crinoid, West Indies, P2516.

crustaceans, West Indies, P2343.

Foraminifera, Operculina and $O p$ erculinoides, P2996.

insects, P2181; Argentina, P2602; Siberia, P2606.

Leptonacea, North America and West Indies, P1177.

mollusks, California, P8; Florida, P2887; Haiti, Puerto Rico, and Cuba, P2491; southern California, P1545.

plants, Argentina, P2743 ; Colombia, P2795; Costa Rica, P2367; Dominican Republic, P2363; Haiti, P2+60; North America, wectern, P306; Oklahoma, P2256; Venezuela, P2388, 2988. tortoises, United States, P1181. United States, southern, P1035.

Testudo, Wyoming, P3199.

Texas, coral, P2820.

crabs, P2727.

invertebrates, $\mathrm{P} 93$.

mammals, P2147.

mastodon remains, P2572.

mollusks, Austin Chalk, P2815;

Reynosa formation, P2798; Staked Plains, P1072.

plants, Trinity division, Comanche series, P934.

vertebrates, Pleistocene, P2625.

Thescelosaurus, Wyoming, P2127.

Thiemella related to Dalmanellas, Chemung formation, P1596.

Thyrsopteris, Potomac group, P1862.

Titanotheres, possible Paleocene relative, P2187.

Tortoises. (See under Fossils, reptiles.)

Toxochelys stenopora, P1665.

Trachemys sculpta, shell, P2833.

Traverse group of rocks, P2811.

Trenton fauna of Baffin Land, P1192.

Trenton limestone, inarticulate brachiopod, P775.

Triassic, batrachian and reptile, Arizona, P1353.
Fossils, Triassic (continued). beds in North America, P2644.

insects, Petrified Forest National Monument, Arizona, P3033.

plants, New Mexico, P821; Pennsylvania, P2154.

reptile, New Jersey, P2728.

Unios, Staked Plains, Tex., P1072.

Triceratops, restoration, with notes on osteology, P2260; skull and brain, with notes on brain cases of Iguanodon and Megalosaurus, P1660.

Triceratops prorsus, mounted skeleton, P1426.

Trigonias osborni, South Dakota, P1207.

trilobites, Telephidae, P2818.

Tricidad, algae, P2453; flora, Pleistocene, P2558; Foraminifera, P2914; mollusks, P2559.

Truckee group, mollusks, P267.

Turtles. (See under Fossils, reptiles.)

Two Medicine formation, Montana, dinosaurian reptiles, P2839.

type and figured specimens in the National Museum, B53.

Unionidae, distribution of northeastern North American, P952.

Unios, Toronto, Canada, P952; Triassic, Texas, P1072.

Utah, invertebrates, P137; lizard, P3148, 3163; mammalian faunas, P3121; reptile, P3158.

Vasocrinus, crinoid genus, P2760.

Venezuela, plants, P2388, 2988.

vertebrates, additions to exhibition series, P1460.

air-breathing, Carboniferous, P1696.

Arizona, San Pedro Valley, P3155. exhibition series, notes on additions, P1460.

Pleistocene, southwestern Texas, P2625; types in National Museum, P2391; United States, P2328.

Triassic beds, continental, age of, P2644.

type and figured specimens in $\mathrm{Na}$ tional Museum, B53, pt. 2.

Vicksburg (Oligocene) mollusks, Mexico, P2731.

Vincentown limesand, bryozoans, B165.

Virginia, mollusks, P2759; plants, P1821.

Waverlyan period of Tennessee, P1851.

West Indies, corals, B103, pt. 9; P2975; crinoid, P2516; crustaceans, P2343; Foraminifera, P2996; Leptonacea, P1177; sedimentary formations, B103, pt. 11.

Westonia, subgenus of Obolus, P1229. 


\section{Fossils (continued).}

wood, Araucarioxylon revigion, P784; Araucarioxylon arizonicum, Arizona and New Mexico, P676; coniferous, Iowa and Montana, P677.

Wyoming, crocodile, P1762.

dinosaurs, P2127, 2875.

fern, P1994.

insects, P2358.

invertebrates, P137.

lizards, P2418, 3124.

mollusks, P2860.

owl, P3031.

plants, P2953.

reptiles, P1698, 3199.

turtles, P2137.

Xenarthra, Texas Pleistocene, P2147.

Yorkia, Cambrian, P1120.

Yukon Territory, horse, P2212.

Zarhachis flagellator, skull, P2600.

Foster, Lyman Spalding, B40.

Foster, William $T$., birds collected in

Paraguay, P1281; Locustidae and

Gryllidae collected in Paraguay, P1450.

Fouts, Robert Mann, P2484.

Fowler, Henry Weed, B100, vols. 11-13, 14, pt. 2; P2294, 2906, 2931, 3032, 3106.

(See also under Jordan and Fowler.)

Fowler, H. W., and Bean, Barton Appler, B100, vols. 7, 8, 10; P2338, 2448, 2488, 2682.

Fox, Gustavus Vasa, Russian souvenirs in National Museum, P1725.

Fox, Henry, P2176.

Fox, Irving, and Ewing, Henry Ellsworth, P3151.

Foxes. (See under Mammals.)

Franklin, Henry James, P1590.

Fraser, Charles McLean, P3090, 3125.

Frazer River, British Columbia, new fish, Couesia greeni, P938.

Freer collection of art, catalog of objects exhibited in National Museum, B78.

French Somaliland, East Africa, corals collected by Charles Gravier, P1526.

Frick Expedition, Ethiopia and Kenya Colony, birds, B153.

Friedmann, Herbert, B153 ; P2830, 2901, 2912, 2918, 2951.

Friedmann, Herbert, and Ridgway, Robert, B50, pts. 9, 10.

Frierson, Lorraine Screven, P2053.

Frogs. (See under Amphibians.)

Fuchsite, notes on, P2118.

Fuegia, mosses, CNH1, No. 5 (2d art.-4).

Fulgurites, P554.

Fungiae. (See under Corals.)

Funk Island Expedition, auk, R1888, pt. 3, No. 3.

Funston, Frederick, $\mathrm{CNH} 3$, No. 6 .

\section{G}

Gadflies. (See under Insects, Diptera.)

Gätke, Heinrich, P67.

Gage, Robert Burns; Foshag, William Frederick; and Berman, Harry, P2669.
Gahan, Arthur Burton, P2035, 2068, 2093, 2197, 2252, 2261, 2279, 2299, 2445, $2517,2657,2676,2831,2995,3086,3116$, $3137,3173,3200,3203$.

Gahan, A. B., and Fagan, Margaret Mary, B124.

Galápagos Islands, birds, P767, 1007, 1067, 1116; bird skeletons, P798.

bryozoan fauna, fossil, P2810.

eel, Sidera chlevastes, P369.

fishes, P770, 840.

insects, P1143.

isopods, Apseudes and Murnopsis, new, P1926.

mollusks, P942.

oystercatcher, Haematopus galapagensis, P573.

plants, CNH1. No. 5 (2d art.-2).

Gallflies. (See under Insects, Hymenoptera.

Gallinules. (See under Birds.)

Galveston Bay, parasites of fishes, P2977.

Games. (See under Anthropology.)

Gane, Henry Stewart, P1193.

Gardner, Leon Lloyd, P2591.

Garman, Samuel, B25, pt. 6; P180, 482, 514.

Garman's paper on "The American Salmon and Trout," note on, P490.

Gartersnakes. (See under Reptiles.)

Gas. (See under Mineral Industries.)

Gasteropods. (See under Fossils, mollusks.)

Gates, Gordon Enoch, P2781, 3040.

Gay, Mary Elizabeth, and Holmes, Samuel Jackson, P1670.

Gazelles. (See under Mammals.)

Gazin, Charles Lewis, P2976, 2985, 3121, $3155,3202$.

Gazin, C. L., and Gidley, James Williams, B171.

Geare, Randolph Iltyd, R1897, pt. 2; B51.

Geckos. (See under Reptiles.)

Geese. (See under Birds, goose.)

Gems. (See under Mineralogy.)

Geodes. (See under Geology.)

Geognosy. (See under Geology.)

Geographical and Exploring Commission, animals from Mexico, P559.

GEOLOGY :

American, history of, R1904, pt. 2, No. 1.

applied, guide to study of National Museum collectons, R1899, pt. 2,

Bermudas, B25, pt. 1.

Canal Zone, B103.

Central America, B103.

collecting rocks and preparing thin sections, directions, B39i.

Colorado, Italian Mountain, P2690.

department of, catalog of types, B53; circulars to accompany collections illustrating rock weathering and soil formation, C51, 52; division of applied geology, accessions, 
Geology, department of (continued). P2339; exhibit at Pan American Exposition, Buffalo, R1901, pt. 2, No. 1; handbook, R1889, App. E; 1890 , pt. 3, No. 7.

economic, catalog of collections, B42. fulgurites, P554.

geodes, formation, with remarks on silicification of fossils, P1637.

geognosy, handbook of National Museum collection, R1890, pt. 3, No. 7.

Kentucky, Columbus and Hickman, Mississippi River bluffs, P2074.

Kerguelen Island, B3.

Lower California, R1895, pt. 2, No. 3.

Mexico, Cerro Mercado, Durango, P2768.

Nebraska, southwestern, P497.

Panama, B103.

relation of biology to geological investigation, R1892, pt. 3, No. 2.

rocks and ores subject of special investigation, in National Museum, B53, pt. 2, sect. 4 .

State geological surveys, B109.

Tasmania, Mount Lyell, P2005.

volcanic dust and sand, southwestern Nebraska, P497.

West Indies, B103.

(See also under Building stones, Fossils, Lithology, Metallography, Metallurgy, Mineral industries, Mineral resources, Mineralogy, Paleontology, Petrography, Petrology.)

Georgia, Cotton States International Exposition. (See under Atlanta.)

fishes, B12; P89.

invertebrate fauna, Oligocene beds, Flint River, P2162.

meteoric irons, Whitfield County, P2157.

meteorite, Sardis, P3143.

plants, umbelliferous, P1428.

Stricklandinia salteri and $S$. davidsoni, occurrence, P116.

Zygonectes zonifer, Nashville, P453.

Gephyreans. (See under Annelids.)

Germany, Prussia, pseudomorphs of marcasite after pyrrhotite from, P1801.

Gerould, John Hiram, P1959.

Gibson, Edmund Harrison, P2269, 2289.

Gidley, James Williams, B53, pt. 2, sect. 2; C53.

P1435, 1447, 1554, 1627, 1689, 1975, 2014, 2036, 2077, 2187, 2324, 2469.

Gidley, J. W., and Gazin, Charles Lewis, B171.

Giffard, W. M., Hymenoptera collected mostly in California, P2202.

Gilbert, Charles Henry, P423, 424, 456, $607,753,759,774,797,823,840$, $856,880,1115,1161,1963,2049$, 2075.

(See also under Jordan and Gilbert.)
Gilbert, C. H., and Burke, Charles Victor, P1907.

Gilbert, C. H., and Cramer, Frank, P1114.

Gilbert, C. H., and Hubbs, Carl Leavitt, B100, vol. 1, pt. 7; P2149, 2231.

Gilbert, C. H., and Scofield, Norman Bishop, P1131.

Gilbert, C. H., and Thompson, Joseph Cheesman, P1414.

Gilbert, Chester Garfield, B102, pt. 1.

Gilbert, C. G., and Pogue, Joseph Ezekiel, B102, vol. 1, pts. 4-6; P2005.

Gill, Theodore Nicholas [B3], B11.

P $30-34,139,214,302-304,307-310$, $316-322,380,435,443-445,448$, $668,669,684,685,712,716,717$, $756-758,803-805,815-818,825$, $831-835,853,861,883-886,965$, 989-993, 1048-1061, 1082, 1234, $1329,1340,1344,1346,1349,1384$, $1385,1388,1393,1394,1396,1408$, $1638,1782$.

Gill, Theodore N., and Ryder, John Adam, P381, 382, 408.

Gillette, Clarence P, P1138.

Gilmore, Charles Whitney, B53, pt. 2, sect. $2 ; 89,110$.

P1426, 1460, 1492, 1519, 1666, 1698, $1762,1860,1870,1878,2110,2120$, $2127,2137,2241,2260,2292,2300$, $2389,2418,2424,2451,2687,2728$, $2745,2750,2833,2839,2875,2941$, $2950,2978,3023,3042,3066,3109$, $3124,3148,3158,3163,3196,3199$.

Ginsburg, Isaac, P2228, 2961, 2997.

Girard, Charles, Cyprinidae and Catostomidae described by, P500.

notes on western fluvial fishes described by, P2357.

published writings of, B41.

Girault, Alexandre Arsène, P1977, 2140, 2148, 2161, 2213, 2332.

Girty, George Herbert, P1372, 1557, 1614.

Glassell, Steve Andrew, P3138.

Glasses, sporadic, supposed origin, P1833.

Glauconite, optical properties and chemical composition, P2628.

Glazier, W. C. W., P203.

Gloriosa Isiand, birds collected by W. L. Abbott, P1008, 1079.

insects collected by W. L. Abbott, P1119.

natural history of, P973.

Gnatcatcher. (See under Birds.)

Goatfishes. (See under Fishes.)

Goats. (See under Mammals.)

Goatsuckers. (See under Birds.)

Gobies. (See under Fishes.)

Goldberger, Joseph, P1817.

Goldenrod. (See under Plants.)

Gold-eye. (See under Fishes.)

Goldman, Edward Alphonso, CNH16, pt. 14.

Goldman, E. A., and Kellogg, Remington, P3186. 
Goldman, E. A., and Standley, Paul Carpenter, CNH13, pt. 10 (6th art.).

Goldsborough, Edmund Lee, and Evermann, Barton Warren, P1501.

[Gonyer, Forest A., P2787.]

Gonyer, F. A.; Hewett, Donnell Foster; and Shannon, Earl Victor, P2737.

Goode, George Brown, R1881 through $1896 ; 1889$, pt. 3 , No. 1 ; 1891 , pt. 3, Nos. $1,8$.

B5; $6 ; 14$, pts. 1,$3 ; 18 ; 20 ; 27 ; 41$; 49.

C1, 11, 13, 43-47.

P4-6, 15, 17, 44, 58, 73, 87, 165, 177 , 183, 184, 241, 248, 350.

memorial service, R1897, vol. 2.

Goode, G. Brown, and Bean, Tarleton Hoffman, SB2; P10, 13, 16, 23, 24, 26, $40,41,50,52,53,64-66,68,74,77,78$, $98,211,281,297,406,510,533,543$, 1012-1014.

Goode, G. Brown, and Jones, John Matthew, B25.

Goose. (See under Birds.)

Gortner, Ross Aiken, and Banta, Artbur Mangum, P2112.

Gower, William Carl, P3071.

Graham, David Crockett, P2916.

earthworms collected by in Szechwan, China, P3040.

Grampus, birds observed during cruise, P819.

explorations in Newfoundland and Labrador, R1889, Dt. 3, No. 7.

Grand Bank, Lycodes vahlii, P78.

Grand Canyon, insect, lower Permian, P2695.

pre-Cambrian supposed jellyfish, P3104.

Granites, black nodules in, P354.

Graphic arts, Eskimo, R1895, pt. 2, No. 2. printing, Japanese wood-cut, R1892, pt. 3, No. 1; white-line engraving for, R1890, pt. 3, No. 2.

section of, contributions to Ohio Valley Centennial Exposition, Cincinnati, C37.

Graptolites. (See under Fossils.)

Grasses. (See under Plants.)

Grasshoppers. (See under Insects, Orthoptera.)

[Graves, Lucy M., B53, pt. 2, sect. 3.]

Gravier, Charles, corals collected in French Somaliland, East Africa, P1526.

Gray, Asa, B3, 15; P462.

Graybill, Harry Webster, P2548.

Great Britain, bibliography of birds, P101.

fossil insects, P2119.

marsh-tit, P560.

Great Lakes, cisco, or lake herring ( $A r$ gyrosomus), with note on species of whitefish, P1662.

Great Plains, central (U. S.), bone artifacts, P3141.
Grebnitski, Nikolai A., collections, P562, $1106,1112,1127$.

Green, Bessie Rose, and Smith, Frank, P2263.

Green Cay, new lizard from, P1219.

Green River. (See under Fossils.)

Green Turtle Cay, Bahamas, fishes collected by Charles L. Edwards, P752.

Greene, Charles Tull, P2405, 2412, 2529, 2566, 2651, 3012, 3037, 3120.

Greene, Edward Lee, CNH10, pt. 2.

Greenland, echinoderms collected by Robert A. Bartlett, P3098.

Eskimo harpoon, P702.

fishes, Disko Bay, B15; notes on, P431.

plants, Disko Island, B15; fossil, P679.

Grenada, birds, P45, 596.

Griffiths, David, CNH14, pt. 3.

Gronovius, types of American grasses described by, CNH12, pt. 3.

Grossbeck, John Arthur, P1753.

Grote, Augustus Radcliffe, B15.

Groupers. (See under Fishes.)

Grouse. (See under Birds.)

Guadeloupe, birds, P57, 545.

Guam, birds collected by Paul Bartsch, P1683.

flies, Sarcophaga, P2227.

useful plants; physical features and natural history; character and history of people; agriculture, CNH9.

Guano, of Peruvian birds, P2298.

Guans. (See under Birds.)

Guatemala, ants, P2434.

bircis of highlands, P3105.

cactus, Nopalea lutea, $\mathrm{CNH} 12$, pt. 9 (8th art.).

Crassulaceae, new species of, $\mathrm{CNH} 12$, pt. 9 ( $3 \mathrm{~d}$ art.).

earwigs, Forficulidae, collected by Schwarz and Barber, P1563.

hummingbird, Atthis ellioti, P7.

Hymenoptera collected by W. P. Cockerell, P2061.

iguana, new spiny-tailed, P1151.

isopods, terrestrial, rew, P1535, 1718.

Pereskia, species of, CNH12, pt. 9 (5th art.).

plants, native names and uses, CNH24, pt. 4 ; new, CNH24, pt. 1. Polypodium, study of, CNH8, pt. 3.

shells, new fresh-water, P2336; new land, P1707.

Gudger, Eugene Willis, P1431.

Gïnther, Albert, fishes from the Bermudas mistakenly described as new, P58.

Guineafowl. (See under Birds.)

Gulf of California, barnacles, P3166. fishes, P227, 698, 880, 2125.

lizard, San Pedro Martir, P863.

reptiles collected by Albatross, $\mathrm{P} 800$. shells of, P996.

Gulf of Mexico, amphipods, P1936. Brevoortia, new species, P15. 
Gulf of Mexico (continued).

Callionymus bairdi, P652.

crinoids collected by Albatross, P547. crustaceans, amphipodous, P1594.

Echini collected by Albatross, P491, $5+4$.

fishes, collected by J. W. Velie, P98; Gobioides broussoneti, new to North America, P1029; mortality among, P5t, 195, 200, 202, 203, 217, 349; new species, P586; notes on, P1592; recorded from, P281; star-gazer, Cathetostoma albigutta, P896; Xyrichthys jessiae, P675.

medusae collected by Albatross, P528.

water destructive to fish, analysis, P201, 222.

Gulf of Mexico region, fossil and recent Bryozoa, P2710.

Gulf States, crania of Indians, P3076.

Gulls. (See under Birds.)

Gunnels. (See under Fishes.)

Guppy, Robert John Lechmere, and Dall, William Healey, P1110.

Gurnards. (See under Fishes.)

Gypsum, incrustations and stalactites in caves, P985.

\section{H}

Hagen, Hermann August, B3, 15.

Hagfishes. (See under Fishes.)

Hahn, Walter Louis, P1514, 1537, 1655.

Haiti, birds, B155; P2925, 2966.

Cirripedia, Miocene and Pleistocene, P2515.

crabs, fossil, P2477.

fish. fossil cichlid, P2475.

herpetological collections made by W. L. Abbott, P2543.

mollusks, Orthaulax, Tertiary, P2491.

plants, Tertiary, P2460.

(See also under Hispaniola.)

Hake. (See under Fishes.)

Halfbeak. (See under Fishes.)

Halifax, Nova Scotia, Liparis ranula, P65.

Hall, David G, P3011.

Hall, Maurice Crowther, P1629, 1780, 2012, 2071, 2131, 2258, 2386.

Hall, M. C., and Ransom, Brayton Howard, P1892.

Hamilton, Clyde Carney, P2530.

Hampe's method of determining $\mathrm{Cu}_{2} \mathrm{O}$ in metallic copper, P687.

Hampton Normal and Agricultural Institute, Va., Indian children, plaster casts of heads taken by Clark Mills, P79.

Handlirsch, Anton, P1439, 1441.

Hanna, G Dallas, P1865.

field notes on Pisidium from Alaska, P2160.
Hansen, H. J., P2065, 2129.

Hares. (See under Mammals; also under Fossils, mammals.)

Harger, Oscar, P75.

Harpoons. (See under Anthropology.)

Harring, Harry Kreuger, B81; [P1893], P2032, 2062, 2164.

Harris, Halbert Marion, P2647.

Hartman, Frank Alexander, P1800.

Hartman, Olga, P2994, 3034, 3046, 3142.

Harwood, Paul Duane, P2940.

Hasse, Hermann Edward, CNH17, pt. 1.

Havana, Cuba, fishes, P414, 551.

Havard, Valery, P535.

Havesu-pai. (See under Anthropology, Indians.)

Hawaiian Islands, Alcyonaria collected by Albatross, P1624.

annelid, polychaetous, P2186.

avifauna, contributions to, P692.

birds collected by Valdemar Knudsen, Kauai, P609, 778.

cephalopods, new, P1713, 1996.

crabs, P933, 1309.

crinoids collected by Albatross, with remarks on Comatulida, P1608.

Dolichopus, new species of, P2446.

fishes, Apogon evermanni, P1386; deep-water, P1114; Honolulu, P1915; Hymenocephalus tenuis, P2231; killed by lava from Mauna Loa, P2392; new species, P2570; notes on, P1625; Oahu and Laysan, P1377.

flycatcher and petrel, new, P236.

Foraminifera collected by Albatross, P1603.

holothurians of, P1555.

isoped, parasitic, P1770.

lizards, notes on, P2224.

Madreporaria, B59.

Mollusca and Brachiopoda collected by Albatross, P1032.

natural history, U. S. North Pacific Surveying Expedition, B7.

pearl oyster, P2878.

Procelsterna, leeward islands, P1322.

Psittirostra psittacea, Kauai, P640.

reptiles, P1174, 1383.

starfishes, Hyalinothrix, new genus, P1807.

termites, P2441, 2496.

Hawes, George Wesson, P205, 206, 263.

Hawks. (See under Birds; also under Fossils, birds.)

Hay, Oliver Perry, Amphibians, P512, 907.

Fishes, P179, 537, 624, 1884.

Fossils, P1181, 1528, 1640, 1648, 1660, $1665,1699,1747,1969,2021,2025$, 2086, 2113, 2147, 2198, 2212, 2291, 2328, 2391, 2438, 2473, 2521, 2571, 2572,2625 .

Reptiles, P908, 909, 1605, 2724.

Hay, William Perry, P935, 1176, 1187, 1285, 1292, 1316, 2165, 2203. 
Heads, casts of Indian, P29, 79.

(See also under Anthropology, crania.)

Heap, Gwynn Harris, P393.

Heating utensils, in National Museum, B141.

Hegewald, John Frederick Charles, and Swaine, Peter Tyler, P257.

Heilprin, Angelo, P134.

Heinrich, Carl, B123, 132; P2305, 2779, 2879, 3019, 3053, 3190.

Heinrich, Carl, and Dyar, Harrison Gray, P2691.

Heligoland, birds, P67.

Heller, Edmund, mammals collected on Yale University-National Geographic Peruvian expedition, P2333.

Helminths:

parasites of amphibians and reptiles, Houston, Tex., P2940.

parasites of mammals, Central America, P2725.

parasites of opossum, Texas, P2939.

(See also under Cestodes, Nematodes, Trematodes, etc.)

Hemiptera. (See under Insects.)

Hemphill, Henry, mollusks sent from Florida, P384.

Henderson, Edward Porter, and Cooke, Charles Wythe, P3143.

Henderson, E. P., and Perry, Stuart Hoffman, P3134.

Henderson, E. P., Preston, Francis William, and Randolph, James Robbins, P3111.

Henderson, John Brooks, B111; P2091.

Henderson, J. B., and Bartsch, Paul, P2055, 2327.

Henderson, J. B., and Torre, Carlos de la, P2369.

Henderson, Junius, P1611.

Henderson, Louis Fourniquet, CNH5, No. 4 (2d art.).

Henry, Dora Priaulx, P3081, 3166.

Henshall, J. A., fishes collected in east Florida, P104.

Henson, Harry V., bird, collected in Yezo, Japan, P904.

Herons. (See under Birds.)

Herpetology. (See under Reptiles.)

Herre, Albert Christian, and Jordan, David Starr, P1499, 1544, 1562.

Herre, Albert William Christian Theodore, $\mathrm{CNH} 13$, pt. 10 (1st art.).

Herring. (See under Fishes.)

Hess, Frank L, P2813.

Hess, Frank L, and Foshag, William Frederick, P2707.

Heteropods. (See under Mollusks.)

Heteroptera. (See under Insects, Hemiptera.)

Hewett, Donnell Foster; Shannon, Earl Victor ; and Gonyer, Forest A., P2737.

Hildebrand, Samuel Frederick, B189.

Hill, Asa Thomas, and Wedel, Waldo Rudolph, P3141.
[Hill, Meriden S., R1899, pt. 2, No. 4.]

Hinds, Warren Elmer, P1310.

Hinkley, Anson A., P2126.

Hippisley, Alfred Edward, R1888, pt. 3, No. 2; R1900, pt. 2, No. 3.

Hispaniola, herpetology, B177.

mollusks, Annulariidae, B192.

(See also under Haiti and under Dominican Republic.)

History, instructions to collectors of specimens, B39q.

investigations in Samaná, Dominican Republic, B147.

iron manufacture in Virginia, P489. swords, American and European in National Museum, B163.

Washington relics in National Museum, P2092.

Hitchcock, Albert Spear, $\mathrm{CNH}_{3}$, No. 9 (1st art.) ; 12, pts. 3, 6; 17, pt. 3; 22, pt. 1 (1st and $2 \mathrm{~d}$ arts.), pt. 3 (1st through 4 th arts.), pts. 6,$7 ; 24$, pt. 7 (1st and $2 \mathrm{~d}$ arts.), pts. 8, 9.

Hitchcock, A. S., and Chase, Agnes, CNH $15 ; 17$, pt. $6 ; 18$, pt. 7.

Hitchcock, A. S., and Standley, Paul Carpenter, CNH21.

Hitchcock, Romyn, R1886, pt. 3, Nos. 4, $5 ; 1890$, pt. 3 , Nos. 5,$6 ; 1891$, pt. 3 , Nos. 4-6; C24; P745.

Hoagland, Ruth Agnes, B100, vol. 1, pt. 9.

Hobbs, Horton Holcombe, Jr., P3097.

Höhnel, Ludwig von, east African collections, P1063, 1094, 1098.

Hoffman, Walter James, R1895, pt. 2, No. 2.

Hoffmeister, John Edward, P2820.

Holarctic, crane-flies in National Museum, P2698.

Ichneumoninae (Pimplinae), P2315. tiger-beetles (Cicindelidae), morphology, taxonomy, ecology, P2530.

Holland, William Jacob, P1062-1065, 1098.

Hollister, Ned, B99, pts. 1-3 ; P1825, $1965,1990,2028,2057,2069,2100$, 2196.

Holm, Theodor, P741, 791, 910.

Holmes, Grace Bruce, P2701.

Holmes, Samuel Jackson, P1654.

Holmes, S. J., and Gay, M. E., P1670.

Holmes, William Henry, R1900, pt. 2, No. 1 ; 1901 , pt. 2 , Nos. $1-3$; B39q.

Holmes, William H., and Mason, O. T., B39q.

Holothurians. (See under Echinoderms.)

Holzinger, John Michael, CNH1, No. 6 (1st art.), No. 8 (4th and 5th arts.); CNH3, No. 4.

Homoptera. (See under Insects.)

Honduras, ants, P2434.

armadillo, Xenurus, P1069.

birds, collected by C. H. Townsend,

P665; from the interior, P868.

Capromys, Little Swan Island, P744. 
Hondura3 (continued).

C'pepoda collected by F. J. Dyer, P2885.

iguana, spiny-tailed, Utilla Island, P1217.

mammals collected by C. H. Townsend, P744.

plants, native names and uses, CNH24, pt. 4 ; new, CNH24, pt. 1.

Honey-creepers. (See under Birds.)

Hookworms. (See under Nematodes.)

Hopi. (See under Anthropology, Indians.)

Hopkins, Andrew Delmar, P2066.

Hopkins, Hoyt Stilson, and Metcalf, Maynard Mayo, B100, vol. 2, pt. 3.

Hornaday, William Temple, R1886, pt. 3, No. 6; 1887, pt. 3, No. 6; C12, 22.

Hornbills. (See under Birds.)

Hornblende. (See under Mineralogy.)

Horses. (See under Fossils, mammals.)

Hottentots, crania, P2696.

Hough, Walter, R1887, pt. 3, No. 7; 1888 , pt. 3, No. 4 ; 1891 , pt. 3 , No. 3 ; 1893, pt. 2 , No. 5 ; 1896, pt. 2 , No. $5 ; 1899$, pt. 2 , No. 3 ; 1900 , pt. 2 , No. 5 ; 1901 , pt. 2 , No. 4.

B87, 139, 141.

P703, 705, 1579, 1819, 1887, 2235, $2280,2404,2735,2856,2895,2930$, 2933.

House, Homer Doliver, and Rose, Josepb Nelson, P1429.

Houses. (See under Anthropology.)

[Hovey, Edmund Otis, B39m.]

Howard, Leland Ossian, P771, 881, 905, $1025,1142$.

Howard, L. O., and Ashmead, William Harris, P1092.

Howe, Marshall Avery, B103, pt. 1; P2453.

Howell, Alfred Brazier, P2599, 2662, 2736, 2772.

Howell, A. B., and Straus, William Louis, Jr., P2913.

Howgate Polar Expedition, natural history of Arctic America, B15.

Howland, S. S., collection of Buddist religious art, R1904, pt. 2, No. 2.

Hozawa, Sanji, P2247.

Hrdlička, Aleš, B39r; P1451, 1495, 1521, 1641, 2480, 2631, 2696, 2845, 3076, 3131, 3171.

Hsiao, Tsai-Yu, P3182.

Huachuca Mountains, Ariz., reptiles, P1282.

Hualapai Indian Reservation, meteoric irons, P2718.

Hubbard, Gardiner Greene, R1897, vol. 2.

Hubbs, Carl Leavitt, P2082, 2962.

Hubbs, C. L., and Gilbert, Charles Henry, B100, vol. 1, pt. 7; P2149, 2231.
Hubbs, C. L., and Schultz, Leonard Peter, P3060.

Huber, Lawrence Lester, P2663.

Hudson Bay, notes on fishes, P204.

Hudson Bay Territory, Ungava District, drum of Naskopie (Nagnagnot) Indians, P736.

Hudson's Bay Co., Hudson Bay districts, birds of, P518.

Huene, Friedrich von, P2644.

Hughes, Elizabeth G., and Eigenmann, Carl H., P608.

Hughes, Elizabeth G., and Jordan, David S., P552, 574.

Humbert, Fred., P348.

Humes, Arthur Grover, P3110.

Hummingbirds. (See under Birds.)

Hung, See-Lü, P2627.

Hunt, George, observations on Kwakiutl Indians, R1895, pt. 2, No. 1.

Hunt, James Gibbons, P347,

Hutchinson, George Evelyn, P2854.

Hydrocorals. (See under Hydrozoans.)

Hydroids. (See under Hydrozoans.)

Hydromedusae. (See under Medusae.)

Hydrotalcite group, chemical composition, P2329.

HYDROZOANS:

Alaska, P1171, 1343.

America, P534; SB4.

Atlantic Ocean, P3090, 3125.

hydrocorals, north Pacific, P3024.

hydroids, Alaskan, P1171, 1343.

Atlantic Ocean, P3090, 3125.

Bonneviellidae, SB4, pt. 3.

Campanularidae, SB4, pt. 3.

North American, P534.

Philippine, B100, vol. 6, pt. 3.

Puget Sound, P1171.

Sertularidae, SB4, pt. 2.

Philippine Islands, B100, vol. 1, pt. 5 ; vol. 6, pt. 3.

Puget Sound, P1171.

siphonophores, northwestern Pacific Ocean, P1946; Philippine, B100, vol. 1 , pt. 5 .

(See also under Fossils.)

Hyman, Libbie Henrietta, P3055, 3101.

Hyman, Orren Williams, P2497, 2523, 2575.

Hymenoptera. (See under Insects.)

Hyslop, James Augustus, P2353.

Ibises. (See under Birds.)

Ichneumon-flies. (See under Insect, $\mathrm{Hy}$ menoptera.)

Ichthyography, terminology, P445.

Ichthyology. (See under Fishes.)

Idaho, botanical survey, Coeur d'Alese Mountains, CNH5, No. 1.

ferroanthophyllite, orthorhombic iros amphibole, and nomenclature of anthophyllite group, P2373. 
IDAHo (continued).

hares, late Pliocene, P2976.

horse remains, upper Pliocene, P2985.

iron meteorite, Oakley, P2693.

ludwigites, P2395.

mineralogy of black sands, and methods used for their study, P2398.

minerals, B131.

mordenite and associated minerals, Challis, Custer County, P2509.

petrography, Coeur d'Alene mining district, P2318.

plants collected by J. H. Sandberg, CNH3, vol. 4.

turtle, extinct, upper Pliocene, P2950.

vivianite encrusting fossil tusk, Clearwater County, P2375.

Iddingsite, origin, occurrence, composition, and physical properties, P2579.

Iguana. (See under Reptiles.)

Ii, Naosuke, Kamon-no-Kami, statue of, R1894, pt. 2, No. 4.

Illinois, amphibians, Carboniferous, P1828.

Chicago, studies of museums, R1903, pt. 2, No. 2.

cyprinodont, Zygonectes inurus, P273.

trees of Lower Wabash and White River Valleys, P264.

Imperial University, Tokio, birds in collection of Science College Museum, P874, 957.

Implements. (See under Anthropology.)

Incense, Mexico and Central America, P1887.

Index Generum Avium. (See under Birds.)

India, Bombyliidae, new species, P2747. drynnid parasites of rice leafhoppers, P2309.

flies. new parasitic, from beetles, P2753.

Hymenoptera, parasitic, P2299.

stone implements, minute, R1892, pt. 3, No. 6.

termites, P2957.

Indian Ocean, new crabs presented by W. L. Abbott, P979.

skeletons and skulls of porpoises (Prodelphinus) collected by W. L. Abbott, P982.

(See also under Aldabra, Amirantes, Assumption, Gloriosa, Providence, Seychelles.)

Indian Territory, fishes collected in, P549.

flint implements and fossil remains, Afton, R1901, pt. 2, No. 2.

plants collected by C. S. Sheldon and M. A. Carleton, CNH1, No. 6 (1st art.).

shells, land and fresh-water, P740.

(See also under Oklahonia.)
Indiana, algae, Buthotrephis, upper Silurian, P1255.

Amblystoma copeianum, P512.

crayfishes, blind, with description of Cambarus pellucidus testii, P935.

Eutaeniae, P729.

fishes, Green County, Switz City Swamp, P424; Hadropterus scierus, P379; new species, Tippecanoe River, P791; notes on, P681; White River, P423.

isopod, Mancasellus, P1294.

mammals, Kankakee Valley, P1537. mammals and cold-blooded vertebrates, Indiana University farm, P1655.

mollusk, fresh-water, P2321.

myriapods, P632, 731.

trees, Lower Wabash and White River Valleys, P2664.

University Museum, characin fishes in, and in the National Museum, P1556.

Indians. (See under Anthropology.)

Indo-China, Tonkin, nematodes, with new species of Ascaridia, P2538.

Indopacific, notes on Pyramidellidae, P1452.

Infusorians, opalinid ciliate, B120; P3077.

Ingersoll, Ernest, P195.

Inman, Samuel Martin, P333.

Innuit Indians, jadeite implements, P395.

Inscriptions, instructions for taking paper molds, C23.

Insectivores. (See under Mammals.)

INSECTS .

Africa, west, P951.

Albatross, 1887-88 cruise, P771.

Aldabra Islands, P1119.

Anoplura, lice, Pediculus, P2620.

Aphaniptera, fleas, revision of American, P1361; Siphonaptera, American, classification of, P1417.

Apterygota, Central American and West Indian, P2702.

Coleoptera, Adephaga, suggested rearrangement, P2586.

Africa, east, Tana River and Jombene Range, P1094.

Agrilus, North American, B145; Trinidad, P3167.

Aldabra Island, P973, 1119.

Amazon Basin, P2674.

Anthonomini, P1604.

Aphodiinae, West Indian, revision of, P3092.

Arctic America, B15.

Assumption Island, P973.

Attelabidae, P1988.

Aulicus, North American, P2365.

Bolivia, buprestid beetles, P2568.

Borneo and the Philippine Islands, buprestid beetles, P2428. 
INSECTs, Colenptera (continued).

Brarhyrhinidae, P1988.

Buprestidae, Bolivia, P2568; Borneo and Philippines, P2428; West Indies, P2522.

Calendrinae, larvae, P2542.

Central America, B185; P2454, 2968, 3188, 3201.

Cerambycidae, P1113, 2842.

Chile, P3028.

Chrysomelidae, with review of the Chlamydini, P1130.

Cicindelidae, larvae, Holarctic, P2530.

Cleridae, Amazon Basin, P2674; larvae, North American, P2323.

Cocinella, North American, P2904.

coccinellid larvae in National Museum, with description of larva of Hyperaspis binotata, P2171.

Coproporus, revision of, P3041.

Costa Rica, P1040, 2803.

Disonycha, America north of Mexico, P2969.

Disteniini, Central and South American, P3201.

District of Columbia, P1275.

Echocerus, new species of the genus, P1041.

elaterid beetles, genotypes, P2353.

Eleodiini, United States and Lower California, B63.

Endomychidae, Latin American, and Philippine, P3168.

Eucnemididae, Central American and West Indian, P3188.

Eurhoptodes, Philippine, P3100.

Galápagos Islands, P1143.

Galerucinae, larvae, P2773.

Glorioso, P1119.

Gyrinidae in National Museum, P2774.

Hyperaspis binotata larva, P2171.

Japanese beetles, flies parasitic on, P2474.

Kerguelen Island, B3.

Lachnosterna, North American, P747.

Lamiinae, West Indian, P2623.

Latin America, fungus beetles, P3168.

Lispini, classification, P3140.

Listrochelus, United States, P3095.

Lixus, North American, P2841.

Lower California, Eleodiini, B63.

Luperodes bivittatus and $L$. varicornis, P3139.

Melolonthinae (Phytholaema), Chile, P3028.

melolonthine beetles, West Indian, larvae, P3146.

Merinus laevis, larva and pupa, P2514.

Mesagroicus, North American, P2801.
INSECTs, Coleoptera (continued).

Mexico, bark beetles, P3147; checklist, B185.

Mexico and Central America, P2454, 2968.

Micracinae, new genera and species, P3165.

Monoxia, study of LeConte's types, P3072.

Mordellidae, P3016, 3075.

Mordellistena, Puerto Rican, P3020.

myrmecophilous beetles, P2387.

Neotropical, P3016, 3075, 3174.

Oedionychis, revision of, P2672.

Osmoderma scabra, protozoan from larva, P2964.

Osoriinae, classification, P3140.

Osoriini, Western Hemisphere, P2583.

Paederini, generic revision, P3069.

Philippine Islands, P2428, 3100, 3168.

Phloeosinus, North American, P3154.

Phyllophaga, beetles related to, P3145.

Phytalus, United States, P3048.

Phytholaema, Chilean, P3028.

Pityophthorini, Mexican and Tropical American, P3147.

Platystomoidea, North American, P2s40.

protozoan from beetle larva, P2964.

Providence, P1119.

Pseudomorphidae, rearrangement of Aedephaga, P2586.

ptinid beetles, new, P2271.

Puerto Rico, Mordellistena, P3020.

Renocis, new species of, P3084.

Rhynchophora, studies, P2159.

Scarabaeidae, Chilean, P3028; North American, P1096, 1113.

Scolytidae, new Micracinae, P3165. scolytoid beetles, mostly Neotropical American, P3174; North American, synonym of, P1085.

Scolytoidea, list of generic names and their type species, P2066.

Seychelles, P1119.

Siberia, P2608.

South America, B185; P3201.

Staphylinidae, West Indian, B182.

Tachyporinae, North American, P3001; revision of Coproporus, P3041.

Tachyporus, North American, P3001.

Tenebrioninae, larvae, P2514.

tiger-beetles, Cicindelidae larvae, Holarctic, P2530.

Tillini, North American, P2370.

Tricrania sanguinipennis, biology, P2513.

Trinidad, P3167, 3183. 
INSECTS, Coleoptera (continued).

Trirhabda, American, north of Mexico, P2868.

Tropical America, P3147.

Usechini, revision, P2790.

weevil larvae, Calendrinae, P2542.

weevils, Attelabidae and Brachyrhinidae, P1988; Eurhoptodes, Philippine, P3100; Lixus, North American, P2841; Mesagroicus, North American, P2801; North American, P1708; Platystomoidea, P2840; species of economic or biological importance, P1889; studies on Rhynchophora, P2159.

West Indies, B182, 185; P2522, 2623, 2922, 2979, 3092, 3146, 3188 .

Western Hemisphere, Osoriini, P2583.

world, elaterid beetles, P2353.

collecting and preserving, directions for, B39f, 67.

Collembola, Achorutinae, North American, P2134.

Central America and West Indies, P2702.

Neanurinae, North American, P2134.

Nearctic Collembola, or springtails, Isotomidae, B168.

Onychiurinae, North American, P2222.

Podurinae, North American, P2134.

springtails, Tomocerinae, P2037.

Corrodentia, Kerguelen Island, B3.

department of, circular concerning, C4.

Dermaptera, earwigs or forficulids,

P1363, 1432, 1563; Guatemala,

P1563; in National Museum,

P1760.

Diptera, acalyptrate flies in National Museum, P2858, 2622.

Achaetoneura, North American, P2853.

Africa, southern, P1243.

Agromyza, related to $A$. virens, P2097.

Agromyzidae, synopsis of genera, P2018.

Alaska, P2446, 2490.

Aldabra Island, P973.

American, new, P2932.

Anetia, notes on, P2920.

Anthomyidae in National Museum, P2004.

Arctic America, Howgate Polar Expedition, B15.

Argyra, revision, P2560.

Asia, P2474, 2932.

Asilidae, new genera of Leptogastrinae, P2466.

Assumption Island, P973.

Belvosia, revision, P2729.

bibionid flies, Nearctic, P2406.
INSECTs, Diptera (continued).

Bombyliidae, Indian, P2747.

borborid flies, South American, P2621.

Borboridae, new American, P1958.

Botanobiinae with hind tibial spur, P2024.

Brazil, Chloropidae, P2534.

Bruchomyinae, revision, P2778.

California, P1516.

Calliphoridae, Chinese, P2844.

cecidomyiid flies from Phlox, P3120.

cecidomyiid parasite of white flies, P2444.

Central America, P2080, 2755.

Ceratomyiella, P2973.

Chaetophlepsis, new, P2863.

China, P2753, 2844.

Chloropidae injuring Manihot in Brazil, P2534.

Clusiidae, revision, P2501.

cluster flies, note on, P331.

Coelopa, revision, $\mathrm{P} 2808$.

collections in National Museum, P1225, 1945, 1962, 2103, 2555.

Costa Rica, P2420, 2803.

crane flies, Central American, P2080; Costa Rican Tipulidae, P2420; Holarctic, P2698; Javan Tipulidae, P2103; Neotropical Limnobinae, P1966; Siberian. P2605; Tipulidae in National Museum, P2103.

Cylindromyia, P2624.

Cyrtidae, Philippine, P2705.

District of Columbia, Tipuloidea, P2344.

District of Columbia region, Lonchaidae, Pallopteridae, and Sapromyzidae, P2525.

Dolichopodidae, Alaskan, P2490; Central and South American, P2755.

Dolichopus, Alaskan and $\mathrm{Ha}-$ waiian, P2446; North American, B116.

Drosophilidae, P2540.

Empidae, revision, P1073.

Fannia, notes on, P1972.

Formosa, P2657.

gadflies, Stibasoma, P2033.

gall midges, new genera and species, P2072.

Guam, Sarcophaga, P2227.

Hawaii, Dolichopus, P2446.

Hessian fly, parasites of, P532, 2204.

Holarctic region, crane flies, P2698.

Hydrophorus, Alaskan, P2446.

India, P2747, 2753.

Japan, P1146.

Java, P2103, 2932.

Kerguelen Island, B3.

Leptidae, larvae and pupae, P2651.

Leptogastrinae, new genera, P2466. 
InsBCts, Diptera (continued).

Limnobinae, Neotropical, P1966.

Lonchaeidae, eastern United States, P2525.

Lucilia macellaria, infesting man, P348.

Mayetiola destructor, parasite of, P2204.

Mesembrinella, Neotropical, P2457.

Microdon from nests of ants, P2141.

Microphthalma, American, P2639.

Miltogrammini, North American, P2610.

Montana, mosquito from, P2794.

mosquitoes, California, P1516; Montana, P2794; Tropical American, P1632; United States, P2447.

muscoid flies, Andean and Pacific coast regions, South America, P1935; Ceratomyiella and Paradidyma, P2973; Neotropical, P2115, 2457; new genera and species, P2128, 2152, 2301, 2812, 3011 ; parasitic on Japanese beetle, P2474; synopsis of puparia, P2405; types in Vienna Natural History Museum, P2703, 2764.

Myocera tabanivora, pupa, P3012.

Nearctic, bibionid flies, P2406; parasitic flies, P3157.

Neotropical, Drosophilidae, P2540; Limnobinae, P1966; Mesembrinella, P2457; muscoid flies, P2115; Stratiomyidae, P3065.

new and little known, P2648.

New Mexico, P2070.

North American, new, P1280; type species, P1719.

Ocyptera, North American, P2624.

Oestridae, two-winged flies related to, P2942.

Opelousia, notes on, P2817.

Opsodexia, notes on, P2817.

Ortalidae, Pseudotephritis, P2900.

Pallopteridae, eastern United States, P2525.

Paradidyma, American, P2973.

parasitic and predaceous, New Mexican, P2070.

Philippine Islands, P2227, 2705, 2751.

Phoridae, P1938, 3037.

Phorocera and allied genera, P2486.

Pipunculidae, American, P1934.

Procecidochares, revision, P2799.

Pseudodinia, P2101.

Pseudotephritis, P2900.

Psychodidae from Bromeliaceae and other plants, P2015.

Ptychopteridae, South American. revision of, P1953.

Puerto Rico, P1198.

Sapromyzidae, American, P2525, 2744; Oriental and Philippine,
INSECT, Diptera (continued). P2751.

Sarcophaga, American types, P2855; Guam and Philippines, P2227.

sarcophagid flies, puparia and larvae, P2566.

Scellus, synopsis, P2529.

Siberia, crane flies, P2605.

Simuliidae, North Ameriean, P2636.

Siphosturmia, P2877.

South America, Andean and $\mathrm{Pa}$ cific coast regions, P1935; borborid flies, P2621; Dolichopodidae, P2755; new P2746; Ptychopteridae, P1953; Syrphidae, P2658.

Spathimeigenia, P2911.

Stibasoma, P2033.

Stratiomyidae, Neotropical, P3065.

Stylogaster, American, P2852.

Symphoromyia, North American, P2099.

syrphid flies, review, P2635; chrysotoxine, P2637; North American, synopsis, B31; South American, P2658; xylotine, P2635.

systematic arrangement of families, P1227.

Tabanidae, Stibasoma, P2033.

Tachinidae, reared by George Dimmock, with notes on Anetia, P2920; Walker's types, P2910.

Tachinomyia, synopsis, P3108.

Tachytrechus, synopsis, P2412.

Therevidae, revision, P2450.

Tipulidae, Costa Rican, P2420; Javanese, P2103; western North American, P2500.

Tipuloidea, District of Columbia, P2344.

Trypetidae, notes on, P3133.

type species, P1719.

University of Tokyo, P1146.

Winthemia, revision, P2886.

Zenillia and allied genera, P3157.

Zygothrica, P2330.

Embioptera, New World, P3175.

Ephemerida, mayflies, collecting and rearing, directions for, B39o.

Glorioso Island, P1119.

Hemiptera, aleyrodids, California, P1362.

Aleyrodinae, P2156.

A mphorophora, aphid genus, P2592.

Asterolecaniinae, Maskell species, P2689.

Australia, P3182.

California, P1362.

Canopinae, synopsis, P2721.

Cicadellidae, Nearctic, P3036.

Coccidae, collecting and preserving, directions for, B381; food plants, P1122; Maskell redescriptions, P2407. 
INSECTs, Hemiptera (continued).

Cryptostemmatidae in National Museum, P2585.

Delphacidae, North and South American, P2041.

District of Columbia, P2784.

Dominican Republic, P2269.

Errhomenellini, Nearctic, P3036.

Fulgoroidea, South American, P3184, 3189; Trinidad, P3184.

Gypona, review, P2289.

Heteroptera, collections in $\mathrm{Na}$ tional Museum, P2150; New Mexico, Las Vegas Hot Springs, P1360; notes on American species, P924.

Homoptera, Cicadellidae, Nearctic, P3036; Delphacidae, North and South American, P2041.

Japan, P1108.

lanternflies, Ful goroidea, South American, P3184, 3189; Trinidad, P3184; Phrictus, P3194.

leafhoppers, drynnid parasites of rice, India, P2309: Errhomenellini, P3036; Gypona, review, P2289; Nearctic, P3036; Typhlocibinae, P1138; Typhlocyba, revision, P2619.

Margarodinae, Maskell species, P2463.

Maskell species, P2407, 2463, 2689.

mealy-winged flies, aleyrodids, P1362.

Megaridinae, synopsis, P2721.

Miridae, District of Columbia, P2784.

Monophlebinae, Maskell species, P2463.

Nabidae, Neotropical, P2647.

Oriental, P3182.

Phrictus in National Museum, P3194.

plant lice, jumping (Psyllidae), New World, B85.

Ploiariinae, revision, P2573.

Psyllidae, New World, B85.

scale insects, collecting and preserving, directions for, B39l; food plants, P1122; geographical distribution, P1026.

South American, P3184, 3189.

Trinidad, P3184.

Typhlocibinae, American, P1138.

Typhlocyba, P2619.

white flies, Aleyrodinae, P2156; cecidomyiid parasite of, P2444.

Hymenoptera, Acoenitini, North American, P2320.

Aculeata, wasps of subfamily Pseninae, P2967.

Africa, P2252.

Aldabra Island, P973.

Andrena, North American, P2064. Anteoninae from the Americas, P2704.
INSECTS, Hymenoptera (continued).

Anthidium and allies, names applied to, P2045.

ants, Honduras and Guatemala, P2434; Microdon from nests of, $\mathrm{P} 2441$.

Apanteles, revision, P2349.

Aphelininae, notes on, P2279.

Aphycus, revision, $\mathrm{P} 2136$.

Apoidea, Dominican, P2048.

Arctic America, B15.

Ashmead, notes on genera of $\mathrm{Cy}$ nipidae proposed by, P2378.

Asia, new ichneumon-flies, P2880; wasps, P2814.

Assumption Island, P973.

Augochlora, West Indian, P1717.

bees, Andrena, North American, $\mathrm{P} 2064$.

Augochlora, West Indian, P1717.

Bolivian, P2684.

collections in National Museum, P1674, 1806, 1818, 2264, 2413. contributions to knowledge of, P1920.

eucerine, names applied to, P1932.

Halictus, new American, P2532.

Lithurgus, Anthidium, and allies, P2045.

Nomada, names applied to, P1852.

Osmia, names applied to, P1897.

Siberian, P2607.

type species of genera and subgenera, P3156.

Victoria, Mexico, P2476.

Bembicini, generic revision, P2776; north of Mexico, P2173.

Bolivia, P2684.

bothriothoracine, P1025.

Brachycistiinae, notes on, P2604.

Brachycyrtus, P2999.

Bracon, Nearctic, P2178.

braconid-flies, parasitic on aphids, P2657.

Braconidae, new, P760.

Braconinae, American, P2642.

California, P2202.

Callimome, review, P2663.

Canada, P1739.

Central America, P2704.

Cerocephala, review of genera related to, P3203.

Ceylon, P1092.

chalcid-flies, Aphelininae, P2279.

Callimome, review, P2663.

Chalcidinae, revision, $\mathrm{P} 3082$.

Chalcidoidea, type species, B124.

Chrysoplatycerus, revision, P2423.

Decatomini (Eurytomidae), revision, P2894.

Encyrtidae, P2629.

Encyrtinae, P1202. 
INSECTs, Hymenoptera, chalcid-flies

(Continued).

Eupelmidae, North and South American, P3173.

Harmolita, American, P2281.

Leucospidinae, P2427.

Monodontomerus, P3116.

notes and descriptions, P2213.

parasitic on aphids, Formosa, P2657.

Perilampus, P2990.

Pseudaphycus, new with key to species, P3200.

Chalcididae, biology of the fam. ily, P881.

Chalcidinae, revision, P3082.

chalcidoid genera related to Cerocephala, review, P3203.

Chalcidoidea, Dominican, P2048; Eulophidae, P2140; Homalotylus and Isodromus, P2293; Javan, P2161; new species, P2332, 3137; parasitic on cactus insects, P2995; Signiphorinae, P1977; type species of genera, B124.

China, P3119.

Chloralictus, new, P2532.

Chlorioninae, North American and West Indian, P1487.

Chrysoplatycerus, revision, P2423.

Cladiinae and larvae, North American, P2396.

Clistopyga, North American, P2399.

Coccophagus, revision, P2850.

Cremastini, revision, P2219.

Cryptanura, tropical American, P3193.

Cynipidae, from galls, P3178; notes on genera proposed by Ashmead, P2378; producing galls on acorns, P2440; producing subterranean galls on oak, P2368.

cynipidous galls and gall-wasps in National Museum, P1102.

Cynipoidea, new, P2332; type species, P2208, 2266.

Decatomini (Eurytomidae), revision, P2894.

descriptions of, with synonymical notes, P2676.

Didineis, new forms, P2837.

Dimorphopteryx, larvae, P2083; synopsis, P2081.

Dominican Republic, P2048.

drynnid parasites of rice leafhoppers in India, P2309.

Ecphylus, table to species, P1991.

Eiphosoma, parasitic, P2010.

Encyrtidae, new, P2629.

Encyrtinae, genera of, P1202; new, P1142; with branched antennae, P905.

Ephialtini, North American, P2340.
INSECTs, Hymenoptera (continued).

Eucharidae, P3086.

Eulophidae, North American, P2140, 2148.

Eupelmidae, North and South American, P3173.

Eurytomidae, revision, P2894.

Exetastes, revision, P3017.

Formosa, P1794, 2657.

gallflies, Cynipidae, P2368, 2378, 2440, 3178.

Guatemala, P2061, 2434.

Halictus, North American, P2532.

Harmolita, revision, P2281.

Holarctic Ichneumoninae (Pimplinae), P2315.

Homalotylus, revision, P2293.

Honduras, P2434.

ichneumon-flies, Acoenitini, North American, P2320.

American and Asian, P2880.

Apanteles, revision, $\mathrm{P} 2349$.

Ashmead's genera, genotypes, P3150.

Brachycyrtus, P2999.

Clistopyga and Schizopyga, P2399.

contributions to knowledge of, P1920.

Cryptanura, P3193.

Ephialtini, P2340.

Exetastes, P3017.

Ichneumoninae (Pimplinae), Holarctic, P2315.

Javan, P2249.

Labenini, Rhyssini, Xoridini, Odontomerini, and Phytodietini, P2317.

Lycorini, Polysphinctini, and Theroniini, P2326.

Macrocentrus, P2923.

Mesostenus, revision, P2761.

Meteorus, P2470.

Neoneurinae and Microgasterinae, revision, $\mathrm{P} 2436$.

Neorhacodinae, P3088.

new, P1754, 1812, 1832, 1859, 1888, 1968, 1974, 2031, 2085, 2284, 2296, 2416, 2494, 2595, 2822, 2882, 2952, 2955, 3083.

notes on, P2296, 2709.

Odontomerus, P2826.

Opiinae, P2095.

Paniscini, genera of, P2510.

Polycyrtus, notes on, P2857.

reared, new species, P1789, 2216.

taxonomic and nomenclatorial notes, P2334.

type species of the genera, B83; P2364.

Ichneumonidae, Ashmead manuscript species of Mrs. Slosson's Mt. Washington lists, P2429; in National Museum, P779.

Ichneumoninae (Pimplinae), Holarctic, P2315. 
INSECT3, Hymenoptera (continued).

Ichneumonoidea, classification, P1206; Peruvian, P1964; YalePeruvian Expedition, P2052.

India, parasites, P2299, 2309.

Isodromus, revision, P2293.

Japan, P1157, 1448, 1777.

Java, P2161, 2249.

Labenini, North American, P2317.

Leucospidinae, studies, P2427.

Lithurgus and allies, names applied to, P2045.

Lycorini, North American, P2326.

Macrocentrus, Nearctic, revision, P2923.

Mesostenus, revision, P2761.

Meteorus, revision, P2470.

Mexico, bees, P2476.

Microbracon, revision, P2580.

Microgasterinae, African, P2252; North American, revision, P2436.

Monodontomerus in National $\mathrm{Mu}$ seum, P3116.

Mount Washington (N. H.), Ichneumonidae, P2429.

Myrmilloides, revision, P2505.

Nearctic, Bracon, P2178; Macrocentrus, P2923; sawflies, P1981.

Neoneurinae, revision, P2436.

Neorhacodinae, P3088.

Neotropical sawflies, P2366.

new, P1804, 1830, 1855, 1880, 1927, $1942,1979,1984,2029,2035$, 2087, 2105, 2195, 2312.

Nomada, names applied to, P1852.

Nomia, North American, P1745.

Nyssoninae, notes on, P2374.

Odontomerini, North American, P2317.

Odontomerus, revision, P2826.

Odynerus tempiferus macio, nest, P3005.

Opiinae, revision, P2095.

Oryssoidea, studies, P1925.

Osmia, names applied to, P1897.

Paniscini, P2510.

parasitic, P1730, 2068, 2197, 2517, 2831 ; on Hessian fly, P532, 2204.

Perilampus, revision, P2990.

Perreyiinae, Neotropical, P2366.

Peru, P1960, 1964, 2052.

Philippine Islands, P1387, 1413, 1416, 1424, 1722, 1733.

Phytodietini, North American, P2317.

Platygasterinae, revision, P2484.

Podalonia, P2681.

Polycyrtus, notes on, P2857.

Polysphinctini, North American, P2326.

Proctotrypidae, monograph of North American, B45.

Pseninae, review, P2967.

Pseudaphycus, new, with key to species, P3200.
IN98CTs, Hymenoptera (continued).

Pseudomethoca, revision, P250s.

reared, P2261, 2445, 2633.

Rhyssini, North American, P2317.

sawflies, collections in National

Museum, P1866; Dimorphopter-

$y x$, P2081; Japanese, P1777;

new, P2361; notes on, P1930;

Perreyiinae, Neotropical, P2366;

Siberian, P2609; Xyela, Nearctic, P1981.

sawflies and larvae, Cladiinae, North American, P2396.

sawfly larvae, Dimorphopteryx, P2083 ; North American, P2442.

Sceliphron, American, P2650.

Schizopyga, North American, $P 2399$.

Scoliidae, taxonomy of Asiatic Tiphia, P2814.

serphidoid, new, P2332.

Siberia, P2607, 2609.

Signiphorinae, monograph, P1977.

South America, Anteoninae, P2704 ; Eupelmidae, P3173 ; parasitic, P1786.

Sphecidae, descriptions of certain species, P1902.

Sphecoidea, Peruvian, P1960.

Stizini, generic revision, P2776.

Tenthredinidae, Japanese, P1157.

Tenthredinoidea, from e astern Canada, P1739; study of wings, P1438.

Tetrastichus, biological control, P3170.

Theroniini, North American, P2326.

thorax, P1774.

Tiphia, Asiatic, P2814.

vespoid and sphecoid, Guatemala, P2061.

Vespoidea, Peruvian, P1960.

Virginia, mason wasp, P3004.

wasps, bembicine, revision, P2173. Brachycistiinae, notes on, P2604.

Braconinae, P2642.

Chinese, P3119.

collections in National Museum, P1869.

cynipid, notes on, P2439, 2611.

Cynipoidea, type species, P2208, 2266.

Didineis, P2837.

digger, Cbalorioninae, North American and West Indian, P1487; Podalonia, North American, P2681.

mason, Virginia, P3004.

Microbracon, P2580.

mutillid, biological and taxonomic investigations, B143; Myrmilloides and Pseudomethoca, P2505.

new species. P1837. 
INSECTs, Hymenoptera, wasps

(Continued).

Nyssoninae, P2374.

Odynerus tempiferus macio, nest, P3005.

Platygasterinae, P2484.

Pseninae, P2967.

Sceliphron, American, P2650.

Sphecidae, P1902.

Stizini and Bembicini, P2776.

Tetrastichus, biological control, P3170.

Tiphia, Asia, P2814.

wood, studies in Oryssoidea, P1925.

Wesmaelia, P2206.

West Indies, P1487, 1717.

Xoridini, new parasitic, P1986;

North American, P2317.

Xyela, Nearctic, synopsis, P1981.

Isoptera, Amazon Basin, P2615.

America, P2496.

Antilles, P2441.

Central America, P2441.

Hawaii, P2441, 2496.

India, P2957.

South America, P2441.

termites, Amazon Basin, P2615;

American and Hawaiian, P2496;

Hawaiian, Central and South American, Antillean, P2441 ; Indian, P2957; Nearctic, revision, B108.

Lepidoptera, Acronycta, revision, P1140.

Aegeriidae, North American, B190. Africa, eastern, P1062, 1063, 1098. Agrotis, revision, B38.

Aldabra, Seychelles, and other east African islands, P1064.

Aldabra Island, P973.

Arachnis, North American, P3123.

Arctic America, B15.

Argyresthia, revision of, American, P1506.

Assumption Island, P973.

bibliographical catalog of transformations, B35.

Blastobasidae, generic table, P1567.

Bombycidae, P3063.

British America, Athabaska and Mackenzie region, P1488.

British Columbia, P1375, 1376.

budworms, Heliothis, P2617.

butterflies, danaid, North and Middle America, P3118; District of Columbia, B157; Euphydryas phaëton, P2683; Massachusetts, eastern, P1987; new American, P1262; Old World (Papilio machaon) in North America, P2934; Polygonia faunus subsp., P3013.

Callimorpha, North American species, P634.

Campometra, P1184.

Canal Zone, P2050.
INSECTS, Lepidoptera (continued).

cecidomyiid parasite of white fly, P2444.

Cerathosia, notes on, P706.

Ceruridae, new species, P2740.

Cochlidiidae, new species, P1550.

collecting, preserving, and transporting tortricids and other small moths, directions for, C27.

Colorado, P1290.

Cosmopteryx, review of American, P1463.

Cucullia, boreal American, revision, P890.

Cydosia, notes on, P706.

Depressaria, review of American, P1268.

Diatraea and allies, American, P2691.

Dicopinae, boreal American, P891.

District of Columbia, B157; P3162.

Dominican Republic, P2056.

Dyomyx, P2046.

Ennominae, geometrid moths associated with Ellopia, P3159.

Eucosminae, North American, revision, B123; notes on, P2779.

Euerythra, the species of, P633.

Euphydryas phaëton, notes on; P2683.

Florida, P1208.

forest, with descriptions of new species, larvae, and pupae, P2305.

Fundella, American, P3190.

Gelechia, restriction of genus, P3064.

Gelechiidae, revision of American, P1304.

Glyphipterygidae, pest of Albizzia, P3162.

Hadena, revision, P839.

Heliothis, Nearctic budworms, P2617.

Homohadena, revision, P838.

Hypeninae, revision, P2132.

Japan, P1412.

Kashmir, P1065.

Kerguelen Island, B3.

Laspeyresiinae, revision of North American, B132.

Leucania, boreal North American, P1283.

Luperina, revision, P839.

Mamestra, revision, P851.

Massachusetts, P1987.

Mexico, P1742, 1885, 1951, 2054, 2139, 2239.

Microlepidoptera, Panama, P2043; South America, P1815; Washington, P3149.

Morrisonia, revision of boreal American, P892.

moth larvae, Colorado, P1290.

moths, American, notes on, P2879. Arachnis, North American, P3123. 
Insects, Lepidoptera, moths (continued). Arthyresthia, revision, P1506.

Bombycidae, P3063.

Campometra, P1184.

Ceruridae (Notodontidae), new, P2740.

clear-wing, Aegeriidae, B190.

cochlidian, American, P1423.

Cochlidiidae, P1550.

collecting, preserving, and transporting, directions for, C27.

collections in National Museum, P2520.

Cosmopteryx, review, P1463.

crambid, North American, P164.9.

deltoid, North American, B48.

Depressaria, review, P1268.

Diatraea and allies, P2691.

Ennominae associated with $\mathrm{El}$ lopia, P3159.

Eucosminae, North America, revision of, B123; notes on, P2779.

Fundella, P3190.

Gelechiidae, revision, P1304.

geometrid, South American, P1456, 1601.

heterocerous, new species, P3102.

Leucania, boreal North American, P1283.

noctuid, Palindia and Dyomyx, P2046; Tropical American, P2039.

Noctuidae, B38, 44, 48; P647, $781,838,839,851,890-892$, $1140,1203,1283,1645$.

North American, life histories, P1209.

Notodontidae, P3026, 3063.

Oecophoridae, generic revision, P1644; North American, P3107.

Pero, studies on, P1753.

Phycitidae, P3053, 3190.

Rupela, P3019.

saturnian, in National Museum, P1947; new species of, P1597.

Scoparia, P2769.

South American, P1419, 1421, 1444.

syntomid, southern Venezuela, P1434.

tineid, Blastobastidae, generic table of, P1567; British Columbia, P1375; southern Texas, P1465.

Tineina, Florida, P1208.

tineoid (Microlepidoptera),

South American, P1815.

tortricid, North Carolina, P1398.

Nearctic budworms, P2617.

new species in National Museum, P2307, 2372.

Noctuidae, boreal American, B44; P890-892, 1140, 1283; new,
Insects, Lepidoptera, Noctuidae

(Continued).

P1203; North American, B38, 48, P647, 781, 838, 839, 851; species previously referred to Homoptera, P1645.

North America, bibliographical catalog of transformations, B35; list, with key, B52.

North Carolina, P1398.

Notodontidae, new species, P2740, 3026, 3063.

Oecophoridae, revision, P1644, 3107.

Olethreutidae, revision of North American Eucosminae, B123.

Olethreutinae, revision of North American, B132.

Palindia, P2046.

Panama, P2043.

Papilio machaon in North America, P2934.

Pero, North American, P1753.

Peru, P2006.

Phycitidae, revision, P3190; cactus-feeding Phycitinae, P3053.

Polygonia faunus subsp., P3013.

Pyralididae, moths of genus $R u$ pela, P3019.

Saturniidae, revision, P581.

Schoenobiinae, moths of genus $R u$ pela, P3019.

Scoparia, American, P2769.

South American, P1419-1421, 1444, 1456, 1601, 1815.

taeniocampid genera, North American, P781.

Texas, P1465.

Tineina, Florida, P1208.

tortricids, directions for collecting, preserving, and transporting, C27.

Trichostibas, new species of, P1765.

Venezuela, southern, P1434.

Washington, P3149.

Xylomiges, revision of boreal American, P892.

Xylophasia, revision, P839.

Louisiana, New Orleans, P440.

Mallophaga, biting lice from birds and mammals, P1183; Dennyus and Eureum, taxonomy and host relationships, P2843; Gyropidae, taxonomy, biology, and distribution, P2489; Neotropical, from Tinamidae, P3180; bird louse from troupials, P2201.

Neuroptera, Arctic America, Howgate Polar Expedition, B15; China, Szechwan, P3079.

Odonata (dragonflies), Aciagrion, notes on Oriental, P2547.

Aeschninae, Burma and lower Siam, P2467.

Africa, east, P1046, 1047.

Aldabra Island, P973.

Assumption Island, P973. 
Insects, Odonata (continued).

Bumping Lake, Wash., P2017.

Burma, P1389, 1571, 2467.

California, P2192.

Calopteryginae, Burma and lower Siam, P1389.

Chlorogomphinae, Cordulegasterinae, Burma and lower Siam, P1571.

collecting and rearing, directions for, B39o.

Cumberland Valley, Kentucky and Tennessee, P1928.

Gomphinae, Burma and lower Siam, P1571.

Gomphus parvidens, Maryland, P2199.

Helocordulia, naiads, P2502.

Kentucky, Cumberland Valley, P1928.

Macromia, North American, P1710.

Maryland, P2199.

Mississippi Valley, P1692.

naiads, P2390, 2502.

Neotropical, P2089.

Nevada, P2192.

nymphs in National Museum, P1371.

Oregon, P2107.

Oriental, P2547.

Siam, lower, P1389, 1571, 2467, 2666.

Tennessee, Cumberland Valley, P1928.

Urothemis, lower Siam, P2666.

Washington, P2017, 2107.

wing of, genealogic study of, P1331.

Orthoptera, Acrididae, Neotropical, P1650; new North American, P764; Paraguay, P1461; United States, notes on, P2093; Yale Peruvian Expedition, P1949, 2001.

Acridinae, South American, P1453, 1661.

Africa, P1910.

Arizona, P1333, 1403.

blattids or cockroaches, Old World, P1363.

Brazil, P1661.

Canada, Athabaska and Mackenzie region, $\mathrm{P} 1488$.

China, leaf-katydids, P3176.

cockroaches or blattids, Old World, P1363.

Colorado, P1333.

crickets, Costa Rican, P1459; Paraguay, P1450.

Decticinae, North American, P1530.

Dominican Republic, P2058.

grasshoppers, Acrididae, P2093; South American, P1453; Pyrgomorphinae and Locustinae,
Insects, Orthoptera (continued). Brazilian, P1661.

Gryllidae, Paraguay, P1450.

Java, P2675.

katydids, Costa Rican, P1459; Paraguay, P1450; Utah, P2468.

leaf-katydids, Chinese, P3176.

Locustidae, Paraguay, P1450.

Locustinae, Brazilian, P1661.

locusts, Paraguay, P1461; shorthorned, Yale Peruvian Expedition, P1949, 2001.

Mantidae, African, P1910; American, P1364.

Melanopli, revision, P1124.

Nearctic, nonsaltatorial forms, P1970.

Neotropical, Acrididae, P1650.

New Mexico, P1333.

Old World blattids, P1363.

Paraguay, P1450, 1461.

Peru, P1949, 1956, 2001.

Phasmidae, African, P1910; United States, P1335.

Pinchot South Seas Expedition, P2921.

Pyrgomorphinae, Brazilian, P1661.

Rhaphidophorinae, north of Mexico, P2130.

Siberia, P2679.

soothsayers, American, P1364.

South America, P1450, 1453, 1461, 1661, 1949, 1956, 2001.

South Seas, Pinchot Expedition, P2921.

Steiroxys hendersoni, Utah, P2468.

tettiginiid insects, North American, P2130.

Texas, P1333.

Trimerotropis, revision, P1215.

United States, unrecorded from previously, P1378.

Utah, P2468.

Virginia, P2176.

walkingsticks, United States, P1335.

western, notes on, P1599.

Xiphidiopsis, Chinese, P3176.

Plecoptera, stoneflies, directions for collecting and rearing, B39o.

Providence and Seychelles Islands, P1119.

Strepsiptera, monographic revision, B66; morphology, with records and descriptions, P2242; notes on, P1834.

thorax and articulation of wings, P1687.

Thysanoptera, Barbados and St. Vincent Islands, P1590; distribution and food plants, P200s; North American, monograph, P1310.

Thysanura, apterygotan family Japygidae, Neotropical, P3151.

Trichoptera, Siam and China, P2891.

(See also under Fossils.) 
Institute of Jamaica Public Museum, fishes from, P418.

International Boundary Commission, Mexico-United States boundary collections, hares, P1081; mammals, P1075; mollusks, P1033, 1111.

International Fisheries Commission, northeastern Pacific, fishes, P3062.

International Fisheries Exhibition. (See under London.)

Inventions, history of, synoptic series of objects in National Museum, P2404.

Invertebrates, economical, catalog of illustrations, B14, pt. 2 .

Iowa, fishes, $\mathrm{P} 470$; fossil coniferous wood, new species, P677; meteorite from Estherville, with reference to "peckhamite" and probable metamorphic nature, P2341; salamander, P1874.

Iron. (See under History.)

Isopods. (Sce under Crustaceans.)

Isoptera. (See under Insects.)

\section{$J$}

Jacamars. (See under Birds.)

Jaçanas. (See under Birds.)

Jackson, John Barnard Swett, P12.

Jackson, Robert Tracy, B103, pt. 5; P2218, 3015.

Jacobson, Edward, terrestrial Isopoda collected in Java, P2419.

Jade, of Tuxtla statuette, P2409.

Jadeite. (See under Mineralogy.)

Jaguars. (See under Mammals.)

Jamaica, boa, yellow, new name for, P1218.

ferns, Polypodium, P1374.

Foraminifera from north coast, P2360. frogs, P2767.

isopods, marine and terrestrial, P1894.

memithid worms, new genus and species of, P2527.

public museum of the Institute of, fishes received from, Pomadasys approximans and Tylosurus euryops described, P418.

James, Maurice Theodore, P3065.

[James, Thomas Potts, B3.]

James, U. P., types of Ordovician and Silurian Bryozoa, P1442.

Jamesonite, silver-bearing, P2351.

Japan, Ainos of Yezo, R1890, pt. 3, No. 6.

Alcyonaria collected by Albatross, P1923.

alcyonoid polyp, new genus and species, P346.

annelids, polychaetous, P2641.

avifauna, additions to, P906; Liu Kiu Islands, P641.

bandfishes, review of Cepolidae, P1330.

bass, giant, P14766.

birds, collected by Harry V. Henson at Yezo, P904; collected by M. Namiye, P597, 649; collections in Science College Museum, Imperial
JAPAN, birds (continued).

University, Tokyo, P874, 957; related to North American species, P390; review, P558, 578, 579, 601, $628,642,667,735,751$ : water birds, P598.

burial mounds, ancient, R1891, pt. 3, No. 5.

cardinalfishes, review, P1240.

Chimaera, white, P1356.

clingfishes, Gobiesocidae, review, P1291.

coral, new genus and species of fossil turbinolid, P1194.

cotton fiber presented to National Museum, with information as to amount of annual crop and price, P250.

cotton husbandry, account of, P251. creepers, review, P667.

crinoids, Eudiocrinus, P1551.

crow, carrion, systematic name of, P629.

crustaceans, stalk-eyed, P1307.

dragon-god (Dai-Ja), Idzumo, P2587.

eel, Anguilla manabei, P1957.

feather-stars, P1615.

fishes, Aboma, new species, P1298.

Agonidae, review, P1365.

apodal, or eels, review, P1239.

atherine, review, P1250.

berycoid, review, P1306.

Bleekeria mitsukurii, supplementary note on, P3128.

blennoid, review, P1293.

blennylike, from Port Mororan, Vulcano Bay, P1127.

Chaetodontidae and related families, review, P1296.

cirrhitoid, review, P1562.

collected by K. Otaki and by $\mathrm{Al}$ batross, P1213.

collected by L. Stejneger and N. A. Grebnitski, P1112.

collected by R. V. Anderson at Tanega and Yaku, P1462.

cottid, new, P3000.

cyclogasterid, new, P1907.

cyprinoid, review, P1334.

discobolous, review, P1259.

dragonets, Callionymidae and related fishes, review, P1305.

Echigo, P1570.

elasmobranchiate, review, P1324.

flatheads, gurnards, and other mail-cheeked, review, P1581.

Gerridae, review, P1525.

gobioid, review, P1254.

gymnodont, review, P1254.

hemibranchiate, review, P1308.

herringlike, review, P1499.

Hexagrammidae, review, P1348.

Histiopteridae, review, with note on Tephritis, P1423.

hypostomide and lophobranchiate, review, P1241. 
JAPAN, fishes (continued).

labroid and related forms, review, P1266.

Lobotidae and Lutianidae, review, P1792.

macrouroid, collected by Albatross, P2149.

new, P1445, 1489, 1635, 1688, 1836.

ophidioid, review, P1303.

pediculate, or anglers, review, P1261.

salmonoid, review, P1265.

sciaenoid, review, P1787.

scorpaenoid, review, P1351.

Shikoku, description of Gnathypops iyonis, P2011.

shore, collected by Albatross, P1909.

siluroid, or catfishes, review, P1338.

Sparidae and related perchlike families, P1875.

synentognathous, review, P1319.

trachinoid and allies, review, P1263.

flounders and soles, P1484, 2082.

flycatchers, paradise, P1721.

halfbeak, Hemiramphus mioprorus, Nagasaki, P1602.

Hemiptera presented to National Museum by K. Mitzukuri, P1108. herpetology, B58.

Hymenoptera, new, P1448; Tenthredinidae, P1157.

ibises, storks, and herons, review, P628.

Idotea, new, Hakodate Bay, P1189.

isopod, Cleantis, new species of, P1883; Ichthyoxenus, new species of, with discussion of genus, P1995.

Japanese tale, P2587.

killifishes, Poeciliidae, review, P1486.

lacquer, preparation of, and manufacture of Wakasa lacquerware, P745.

lancelots, hagfishes, and lampreys, review, P1233.

Lepidoptera, collection of early stages, P1412.

lizardfishes, Synodontidae, review, P1544.

loaches, review of Cobitidae, P1332. mole, Dymecodon pilirostris, P557.

nutcracker, Nucifraga caryocatactes macrorhynchos, P735.

ornithological notes, P383.

pigeons, review, P642.

pit-dwellers, ancient, Yezo, R1890, pt. 3, No. 5.

playing cards, P836.

Pyramidellidae, notes on, P1452.

quail, remarks on, P974.

rails, gallinules, and coots, review, P579.

reed warbler, notes on, P997.

$711175-47-18$
JAPAN (continued).

relics, ancient, R1891, pt. 3, No. 6. salmon and trout, note on, P1399.

sand lances, or Ammodytidae, review, P1464.

sawflies in National Museum, P1777. sculpins, new, P1326; review of Cottidae, P1358; Schmidtina, P1381. sea bass, Serranidae, review, P1714. sea-star, new, P2493; Plazaster and note on Parasterina, P3114; Poraniopsis, P3059.

sharks, goblin, Mitsukurina oqustoni, notes on adult, P1409; squaloid, new species, P1279.

Shinto, or mythology, R1891, pt. 3, No. 4.

shrike, gray, collected by Capt. Blakiston at Yezo, P931.

sturgeons, Acipenseridae, synopsis, P1455.

surf-fishes, or Embiotocidae, review, P1260.

surmullets, or goatfishes, Mullidae, review, P1513.

threadfin, Polynemidae, new species, P1470.

tits and nuthatches, review, P578.

tree-sparrow, new species, Liu-Kiv, P473.

triggerfishes, filefishes, and trunkfishes, review, P1287.

Turdus, review, P601.

wood-cutting and wood-cut printing, R1892, pt. 3, No. 1.

woodpeckers, review, P558.

wrens, review, P751.

Japan, Sea of, birds collected by Albatross, P1727.

Jarvis, P. W., and Cushman, Joseph A., P2914.

Java, crane flies, Tipulidae, in National Museum, P2103.

Diptera, new, P2932.

fishes, collected by D. H. Campbell at Buytenzorg, P1575; collected by O. Bryant and W. Palmer, P1919; notes on, P2682.

Hymenoptera, chalcidoid, P2161.

ichneumon-flies, notes on, P2249.

insects, orthopteroid, collected by $\mathrm{O}$. Bryant and W. Palmer, P2675.

Isopoda collected by E. Jacobson, P2419.

Java Sea, birds collected by W. L. Abbott on various islands, P2232; birds of Bawean Island, P2175.

Jaynes, Harold Andrus, and Allen, Harry Willis, P2814.

Jays. (See under Birds.)

Jefferson, John Percival, P54.

Jefferson, J. P.; Porter, Joseph Yates; and Moore, Thomas, P37.

Jellyfishes. (See under Medusae; also under Fossils, medusae.) 
Jenkins, Oliver Peebles, and Evermann, Barton Warren, P681, 698, 846.

Jerboas. (See under Mammals.)

Jewish ceremonial objects. (See under Anthropology, religion.)

Johnson, S. H., P217.

Johnston, John Robert, CNH12, pt. 2 ( $3 \mathrm{~d}$ art.).

Johnstons Island, notes on fishes, P272.

Jones, John Matthew, and Goode, George Brown, B25.

Jones, M. E., Asteraceae described by from Mexico and the southwestern United States, CNH29, pt. 2 (2d art.) ; Mexican phanerogams described by, CNH29, pt. 2 (1st art.).

Jones, Myrna Frances, P2791.

Jones, W. H., mollusks collected on west coast of South America, P854.

Jordan, David Starr, B9, 10, 12; P20, $81,84,94,104,105,159,160,178$, $288,404,405,416,422,433,437$, $438,451,466,467,485,490,500$, $503,511,526,527,550,551,565$, $593,595,630,648,652,675,682$, $719,723,732,789,822,829,845$, $916,938,1328,1399,1464,1523$, $1525,1922,1957,2273,2277,2392$, $2472,2519$.

fishes collected by at Cedar Keys, Fla., P426.

Jordan, D. S., and Bollman, Charles Harvey, P752, 770.

Jordan, D. S., and Brayton, Alembert Winthrop, B12.

Jordan, D. S., and Dickerson, Mary Cynthia, P1592, 1602, 1625.

Jordan, D. S., and Edwards, Charles Lincoln, P566.

Jordan, D. S., and Eigenmann, Carl H., P484, 587, 627.

Jordan, D. S., and Evermann, Barton Warren, B47; P586, 780, 791, 1289, 1662.

Jordan, D. S., and Fordice, Morton W., P575.

Jordan, D. S., and Fowler, Henry Weed, P1278, 1287, 1291, 1296, 1298, 1303, 1305, 1306, 1324, 1330, 1332, 1334, 1338.

Jordan, D. S., and Gilbert, Charles Henry, B16; P55, 106-111, 117-119, $125,126,129,130,132,135,136,141$, $144,146,147,150-154,156,157,161$, $162,164,167,170,171,173-176,191-$ $194,221,227,237,242,252,254,268$, $269,273,277,282,289-294,296,298$, $324-329, \quad 334-336,352,355,367-370$, 401-403, 417, 452, 549, 639, 939.

Jordan, D. S., and Herre, Albert Christion, P1499, 1544, 1562.

Jordan, D. S., and Hughes, Elizabeth G., P552, 574.

Jordan, D. S., and Jouy, Pierre Louis, P185.

Jordan, D. S., and McGregor, Richard Crittenden, P1470.
Jordan, D. S., and Meek, Seth Eugene, P427, 450, 453, 470, 483.

Jordan, D. S., and Metz, Charles William, P1915.

Jordan, D. S., and Richardson, Robere Earl, P1570, 1572, 1581, 1714.

Jordan, D. S., and Seale, Alvin, P1407, 1433, 1445, 1575.

Jordan, D. S., and Sindo, Michitaro, P1260, 1261.

Jordan, D. S., and Snyder, John Otterbein, P1213, 1233, 1235, 1239-1241, $1244,1254,1259,1263,1265,1266,1279$, $1293,1300,1356,1377,1386,1422,1455$, 1474, 1476, 1486, 1677, 1999.

Jordan, D. S., and Starks, Edwin Chapin, P1232, 1250, 1308, 1319, 1326, 1348, $1351,1358,1365,1381,1391,1462,1484$, $1493,1510,1517,1541$.

Jordan, D. S., and Swain, Joseph, P378, $414,426,434,436,447,449,465$.

Jordan, D. S., and Thompson, William Francis, P1728, 1752, 1787, 1792, 1875, 2011.

Jordan, Eric Knight, P2325, 2570.

Jouy, Pierre Louis, R1888, pt. 3, No. 5; P186, 383, 975, 1721.

birds collected by in Korea, P1735.

fishes collected by, P1235, 1391, 1433.

Korean collection, R1891, pt. 3, No. 3.

Jouy, P. L., and Jordan, David Starr, P185.

[Jouy, Mrs. Marion S. F., B53, pt. 2, sects. 2, 3.]

Juan de Fuca, Straits, new species of Paralepis ( $P$. coruscans), P171.

Juan Fernández Islands, Foraminfera, P2780.

Juday, Chancey, P2541.

Judd, Neil Merton, P2828.

Judd, Sylvester Dwight, P1084.

Jurassic. (See under Fossils.)

\section{K}

Kaburaki, Tokio, B100, vol. 1, pt. 10. Kalb, George B., and Swain, Joseph, P332.

Kamchatka, carrion crow, systematic name of, P629.

fishes collected by L. Stejneger and N. A. Grebnitski, P1112.

ornithological explorations, B29.

sea-star, Trophodiscus, P2180.

woodpecker, three-toed, Picoides albidior, P701.

Kansas, Coal Measures, labyrinthodont from, P1796.

fishes, contribution to knowledge of, P624; new, P456.

fossils, new Cretaceous invertebrate, P93.

mastodon, Gomphotherium elegans, Pleistocene, P2198. 
KANSAS (continued).

meteorites, Admire, Lyon County, P1273; Cullison, Pratt County, P1952; Scott County, second find, P1905.

plants, collected by C. H. Thompson, CNH3, No. 9 (1st art.).

rodent, horned, Miocene, P1554.

roulette, prehistoric, Wyandotte County, P3091.

Kaprotholite group, benjaminite from, P2537.

Karimata Islands, Dutch East Indies, birds collected by W. L. Abbott, P2512; mammals collected by W. L. Abbott, P1481.

Kashmir, birds collected by W. L. Abbott, P1078; Lepidoptera collected by W. L. Abbott, P1065; mammals presented by W. L. Abbott, P976; rodents, Sminthus, P1004.

Katydids. (See Insects, Orthoptera.)

Kearfott, William Dunham, P1398, 1649.

Kearney, Thomas H., Jr., CNH5, Nos.5, 6.

Kellers, H. C., fishes collected at Niuafoou Island, Tonga Group, Oceania, P2931.

Kellett, Betty, and Cushman, Joseph Augustine, P2796.

Kelley, Louis, and Berry, Willard, P2816.

Kellogg, Remington, B160; P2435, 2462 , $2482,2483,2563,2564,2600,2645,3022$, 3051.

Kellogg, Remington, and Goldman, Edward Alphonso, P3186.

Kellogg, Vernon Lyman, P1183.

Kendall, William Converse, P1089, 1763, 1814.

Kendall, W. C., and Evermann, Barton Warren, P1043, 1482, 1748.

Kennedy, Clarence Hamilton, P2017, 2107, 2192, 2390, 2502.

Kentucky, birds of, P3089. crustacean fauna from Mammoth Cave, P1285.

dragonflies, Cumberland Valley, P1928.

fishes, Whitley County, P378.

meteorites, Cumberland Valley, Whitley County, P2306; Mount Vernon, P1392.

Mississippi River bluffs and fossil flora, Columbus and Hickman, P2074.

plants, fossil, P679.

Kenya Colony, birds of Childs Frick Expedition, B153.

Kerguelen Island, natural history, Transit-of-Venus Expedition, B2, 3.

Kershner, E., collection of minerals from Kerguelen Island, B3.

Keyhole urchins. (See Echinoderms.)

Kharga, Egypt, sand-barites, P1726.

Kidder, Jerome Henry, B2, 3; P96.

Kidder, J. H., and Coues, Elliott, B3.
Kilimanjaro, east Africa, birds, P1411; chameleon, P857; ethnologic collections, R1891, pt. 3, No. 2; mammals, P814, 915.

Killifishes. (See under Fishes.)

Killip, Ellsworth Paine, CNH26, pts. 8, 10.

Kinetic evolution, example in millipeds, P1831.

Kingfishers. (See under Birds.)

Kirk, Edwin, P1846, 2038, 2414, 2569, $2649,2661,2692,2760,2763,2793,2819$, 2972, 3080, 3103, 3144.

Kirsch, Philip Henry, P754.

Kirtland formation, New Mexico, reptiles, P2978.

Kishinouye, Kamakiche, P1188.

Kitchen middens. (See under Anthropology.)

Klages, Edward A., P1434.

Klamath Indians. (See under Anthropology, Indians.)

Klaprotholite. (See under Mineralogy.)

Kloss, Cecil Boden, birds collected in the Andaman and Nicobar Islands, P1288.

Knab, Frederick, P2015, 2033.

Knab, Frederick, and Dyar, Harrison Gray, P1632.

Knight, Harry Hazelton, and McAtee, Waldo Lee, P2784.

Knives. (See under Anthropology.)

Knobstone formation, crinoid fauna, P1850.

Knowlton, Frank Hall, B39b; 53, pt. 2, sect. 3; P513, 676, 677, 679, [688], $690,784,921,998,1639,1994,2151$, 2158.

Knowlton, F. H., and Fontaine, William Morris, P821.

Knudsen, Valdemar, birds collected on Kauai Island, Hawaii, P609, 778.

Koehler, René, B84; B100, vol. 5.

Koehler, S. R., R1890, pt. 3, No. 2; 1892 , pt. 3, No. 1; C37.

[Kolliker, Herr v.], P220.

Korea, Bernadou, Allen, and Jouy collections in National Museum, pt. 3, No. 3 .

birds collected by P. L. Jouy, P1735.

fishes collected by P. L. Jouy, P1391.

flycatchers, paradise, P1721.

ludwigites, P2395.

mortuary pottery in the National Museum, R1888, pt. 3, No. 5.

paraphernalia of sorceress, in $\mathrm{Na}$. tional Museum, P2168.

Krieger, Herbert William, B134, 137, 147, 156; P2732, 2896.

Kumlien, Ludwig, B15.

Kunz, George Frederick, R1886, pt. 3, No. 2; P666.

Kuril Islands, birds, P1144.

Kutenai canoes, R1899, pt. 2, No. 4.

Kwakiutl. (See under Anthropology, Indians.) 


\section{L}

Labrador, annelids, dredged by Owen Bryant, P1703.

birds, list, P518.

Bryozoa, collected by Owen Bryant, Pi933.

coelenterates, collected by Owen Bryant, P1706.

Crustacea, dredged by expedition under W. A. Stearns, P374; freshwater, P1589; marine, review of, P375.

fishes, collected by Owen Bryant, P1763.

Grampus explorations, R1889, pt. 3, No. 7.

Mollusca and Echinodermata, dredged by expedition under W. A. Stearns, P377.

mollusks, Ungava Bay, P561.

natural history, notes on, P353.

Onchidiopsis, mollusk genus new to eastern North America, P1761.

Labyrinthodont, Kansas Coal Measures, P1796.

Lacépède, his neglected generic names of fishes, P324.

Lacquerware, Wakasa, P745.

Ladak, birds collected by W. L. Abbott, P1078.

Laidlaw, Frank Fortescue, P2467, 2547, 2666.

Lake Michigan, Uranidea policharis, P277.

Lake-of-the-Woods and connecting waters, fishes, P1778.

Lake Ontario, deep-water sculpin (Triglopsis ontariensis), new species, with notes on related species, P1728.

Lake Tanganyika, fishes collected by $\mathrm{H}$. C. Raven, P2998.

Lamp of the Eskimo, R1896, pt. 2, No. 5.

Lampreys. (See under Fishes.)

Lamson-Scribner, Frank, and Merrill, Elmer Drew, CNH13, pt. 3.

Lance formation, of Wyoming, P2127, 2137, 2875.

Lancelets. (See under Fishes.)

Lances. (See under Fishes.)

Laney, Francis Baker, P1835.

Lang, W. B., meteoric stone collected by, P2787.

Langley, Samuel Pierpont, R1897, vol. 2; C36.

Lanternflies. (See under Insects, Hemiptera.)

La Plata Basin, poecilid fishes, P1532.

Laramie group, molluscan forms, P266.

Larco, Andrea, fishes collected by at Santa Barbara, Calif., P296.

Larks. (See under Birds.)

Latimer, Homer Barker, and Evermann, Barton Warren, P1778.

Latin America, fungus beetles, Endomychidae, P3168.
Lawrence, George Newbold, B4; P19, 27. $35,45,51,57,61,103,142,166$, $216,545,653$.

published writings of, B40.

Laysan, fishes from, P1377; Recent Madreporaria, B59.

Lea, Isaac, published writings of, B23.

Leafhoppers. (See Insects, Hemiptera.)

Leaf-katydids. (See Insects, Orthoptera.)

Leavy, Joseph Britton, B105.

LeConte, John Lawrence, B15.

Leeches. (See under Annelids.)

Lefroy, H. Maxwell, fishes from, P1345.

Lefroy, John Henry, B25, pt. 2.

Le Have Bank, occurrence of Lycodes vahlii, P78.

Leiberg, John Bernhard, CNH5, No. 1.

Lemurs. (See under Mammals.)

Leonard, Emery Clarence, CNH22, pt. 10.

Lepidoptera. (See under Insects.)

Leptocardians. (See under Cephalochordata.)

Leslie, Charles C., fishes sent from Charleston, S. C., P627.

Lesquereux, Leo, P300, 606, 679, 688, 792. fossil plants identified by, P606.

Lesser Antilles. (See under Antilles.)

Leyden Museum, Holland, taxidermical methods, R1895, pt. 2, No. 7.

Liberia, birds collected by R. P. Currie, P1182; fishes, fresh-water, P3152; Smithsonian-Firestone Expedition, reptiles and amphibians, P3128.

Lice, biting. (See Insects, Mallophaga.)

Lice, plant. (See under Insects, Hemiptera.)

Lice, sucking. (See Insects, Anoplura.)

Lichens. (See under Plants.)

Lighting. (See under Anthropology.)

Lilljeborg, Wilhelm, P621.

Limestones, carbonic acid tests on weathering, P2108.

Limpets. (See under Mollusks.)

Lincoln, Frederick Charles, and Wetmore, Alexander, P2966.

Linell, Martin Larsson, P1040, 1094, 1096, 1113, 1119, 1130, 1143.

Linnaean collection, American fishes in, P510.

Linnaean names of American fishes, P527.

Linnaeus, Carl, types of American grasses described by, CNH12, pt. 3 .

Linnaeus's "Systema Naturae," nomenclature of whalebone whales, P1163.

Linton, Edwin, P636, 893, 1123, 1125, $1133,1410,1529,1560,2040,2401$, $2433,2511,2656,2722,3078,3112$.

Lions. (See under Mammals.)

Lithology, District of Columbia, P523.

Liu Kiu. (See under Riu Kiu.)

Liverworts. (See under Plants; also under Fossils, plants.)

Lizardfishes. (See under Fishes.) 
Lizard3. (See under Reptiles; also under Fossils, reptiles.)

Loaches. (See under Fishes.)

Lockhart, James G., P827.

Lockington, William Neale, P72, 97, 120-123, 140, 149, 158, 182, 209.

Locusts. (See Insects, Orthoptera.)

Loennberg, Einar, P1003, 1107.

Lohmander, Hans, P2713.

London, International Fisheries Exhibition, collections sent from the United States, B27.

Long Island, Great South Bay, notes on red snapper (Lutjanus blackfordi), P657.

Loomis, Harold Frederick, P2989, 3006, 3043.

Loomis, H. F., and Cook, Orator Fuller, P2714.

Loons. (See under Birds.)

Lord, Edwin Chesley Estes, P1173.

Louisiana, fishes, Cameron, notes on, P1734; New Orleans, collected by R. W. Shufeldt, P437.

Indian matting, Petit Anse Island, R1888, pt. 3, No. 7.

insects, New Orleans, P440.

lamprey, silver, Ichthyomyzon castaneus, P271.

maminal, Paleocene, from deep well, P2943.

Palmoxylon from, P690.

plants, fossil, P679.

pottery, Hopewell type, P2963.

World's Industrial and Cotton Centennial Exposition, New Orleans, plans for exhibition, C24, 25, 26, $29,31$.

Loveridge, Arthur, B151; P2720, 2738, 3128.

Lower California, Anthus cervinus in, P361.

birds, collected by L. Belding, P360; north of Cape St. Eugenio, P313; southern Lower California, P314, 386.

Coleoptera, Eleodiini, monograph, B63.

Conodon serrifer, Boca Soledad, P289.

fishes, Cape San Lucas, P290, 293; San Cristobal Bay, P469; Sparus brachysomus, P149; Todos Santos Bay, P376; west coast, P227.

geology and natural history, notes on, R1895, pt. 2, No. 3.

killifish, Lucania browni, from hot spring, P1572.

lizard, new, P788.

meteoric irons, Signal Mountain, P2425.

millipeds, Colobognatha, P2989.

mollusks, Bulimulus, P958; Todos Santos Bay, P536; Tres Marias, P996.
Lower California (continued).

natural history, U. S. North Pacific Surveying Expedition, B7.

plant records of expedition to, CNH16, pt. 14.

plants collected by Edward Palmer, CNH1, No. 1 (2d art.), No. 3; P749; sent to National Museum by Charles F. Pond, P725.

Rhinoptera encenadae, Todos Santos Bay, P563.

Sapindaceae, new species, CNH1, No. 9 (2d art.).

shrubs, new, CNH13, pt. 10 (6th art.).

Lucas, Frederic Augustus, R1888, pt. 3, Nos. $3,5,7$; 1893, pt. 2, No. 6; 1895, pt. 2, No. 5 ; B39c; 53, Dt. 2, sect. 2; C 33, 48; P622, 704, 798, 830, 848, 1001, $1077,1095,1164,1172,1207,1211,1212$, 1224, 1245, 1320, 1353.

Lucas, F. A., and Stejneger, Leonhard, P765.

Lucas, F. A., and True, Frederick William, R1884, pt. 3, No. 6.

Lucker, John Thomas, P2885.

Ludwigites, Idaho and Korea, P2395.

Lugger, Otto, P213.

Lungworms. (See under Nematodes.)

Lupton, Nathaniel Thomas, P46.

Lynch, James Eric, P3025.

Lynn, William Gardner, P2823.

Lynxes. (See under Mammals.)

Lyon, Marcus Ward, Jr., P1228, 1314, $1494,1496,1498,1500,1502,1505,1534$, $1552,1577,1619,1626,1680,1684,1686$, 1809, 1976, 2188.

Lyon, M. W., Jr., and Osgood, Wilfred Hudson, B62.

Lyon, M. W., Jr., and Robinson, Wirt, P1246.

\section{M}

MacCallum, George Alexander, P2588, 2655, 2892.

MacDonald, Donald Francis, B103, pt. 10.

MacFarlane, Roderick Ross, P865, 1405.

MacGillivray, Alexander Dyer, P1438.

Máckerels. (See under Fishes.)

Mackin, John Gilman, P3136.

Macy, Ralph W, P2986.

Madagascar, birds, catalog of, P1197; collected by W. L. Abbott, P1118.

Madreporarians. (See under Corals.)

Magellan. (See Straits of Magellan.)

Maiden, Joseph Henry, P1327.

Maine, black nodules in granites, P354. brachiopods, Devonian, Rensselaeria mainensis, P1527; Spirifer, Silurian, P2144.

building stones from in National Museum, P365.

Gasterosteus atkinsii, Schoodic Lakes, P71. 
MaIne (continued).

killer whale, Orcinus, notes on, P1357.

mink, extinct, from shell-heaps, P1336.

nuculites, Silurian, Washington County, P2225.

peridotite, Little Deer Isle, Penobscot Bay, P707.

Silurian fossils, Edmunds and Pembroke formations, Washington County, P1985.

Silurian mollusks, Washington County, P1908.

stickleback, Gasterosteus gladiunculus, P1089.

walrus (?), partly fossilized bones, P223.

Maize. (See under Plants.)

Malay Archipelago, basketwork, P1631, 1672; Scyphomedusae, B100, vol. 1, pt. 3.

Malay Peninsula, birds collected by Smith and Abbott, B172; lizard, agamid, P2431.

Malay Peninsula and Archipelago, pigs, notes on, P1466; porcupines, notes on, P1552.

Malloch, John Russell, P1934, 1938, 1945, 1958, 1962, 1972, 2004, 2018, 2024, 2097, $2101,2540,2604,2622,2744,2751,2858$, $2900,2967,3133$.

Malloch, J. R., and McAtee, Waldo Lee, P2525, 2573, 2585, 2721.

Malloch, J. R., and Rohwer, Sievert Allen, P2837.

Mallophaga. (See under Insects.)

Maloney, James Olsen, P3057.

MammaLs:

Africa, roundworms from, P2783.

Africa, east, in National Museum, B99: Insectivora, Chiroptera, Carnivora, pt. 1; Rodentia, Lagomorpha, Tubulidentata, pt. 2; Primates, Artiodactyla, Perissodactyla, Proboscidea, Hyracoidea, pt. 3.

Mount Kilimanjaro, P814, 915.

Smithsonian-Chrysler Expedition, P2738.

Tana River, P954.

Alaska, P399, 495, 564.

Aldabra Island, P948, 973.

Altai Mountains, P1990.

Andaman Islands, P1269.

anteater, great, Central American, P1496.

antelope, pronghorn, horns and systematic position, P1619; nematode from, P2694.

aquatic, sent to International Fisheries Exhibition at London, B27, pt. H.

armadillo, Xenurus, Honduras, P1069.

artiodactyl, development of rodentlike incisors, P2545.
Mammals (continued).

Artiodactyla, east African, in $\mathrm{Na}$ tional Museum, B99, pt. 3.

Assumption Island, P973.

Atalapha semota, P807.

badger, hookworms from, P2533.

Baltistan, P976.

Banka Island, P1498.

bats, Atalapha semota, P807.

Carollia, new species, with remarks on C. brevicauda, P824.

Cuban, P1359.

families and genera, B57.

fruit, Aldabra Island, P948.

Glossophaga, P1100, 2034.

Hemiderma, P1514.

lasiurine, number of young, P1314.

Molossus, P2013.

Myotis and Pizonyx, American, B144.

nematode from, P2677.

North American, introduction to monograph of, P919; monograph of, B43.

Nyctinomus europs and $N$. orthotis, P786.

Panama, P1882.

phyllostome, new subfamily of, P912, 913.

Rhinolophus, Nias, and Engano, P1440.

Tadarida, P2862.

Temminck's, Scotophilus temminckii, P914.

trematode from, P2928, 2986.

vampire, Diphylla ecaudata, P1099.

Vespertilio longicrus, Puget Sound, P602.

bear, cinnamon, Pennsylvania, P338.

Bering Island, P540.

Bermudas, B25, pt. 3.

Billiton Island, P1498.

bison, extermination, discovery, and

life history, R1887, pt. 3, No. 6.

Borneo, western, P1495, 1577.

Borneo and adjacent islands, P1809.

British America, P827.

Calcutta Zoological Garden, animals dying from nematodes, P2777.

California, northern, P623.

Canada, Mackenzie River district, P1405.

carabao, nematode from, P2765.

Cariacus clavatus, Central America, P734.

Cariacus columbianus, eastward distribution, P287.

carnivores, east Africa, in National Museum, B99, pt. 1; hookworm of, P2697; tapeworms from, P2980.

Carollia, new species of, P824.

Carollia brevicauda, remarks on, P824.

Castor, Mexican border, P1132. 
Mammals (continued).

cats, cacomitl, Rio Grande Valley, P1251; fluke from, P2627; ocelot, P1286; taenioid cestodes from, P2258.

Catskill Mountains, N. Y., notes on, P1147.

Central America, P734, 963, 1496.

cetaceans, Commander Islands, P344.

China, P1755, 2662, 2772.

Chiroptera, east African, in National Museum, B99, pt. 1.

Commander Islands, P344, 421, 540.

Costa Rica, P850.

coyote, nematode parasite from, P2012.

Cricetodipus parvus, P256.

Cuba, P1359.

Cumberland Sound, B15.

deer, black-tailed, eastern distribution of, P287; Cariacus clavatus, Central America, P734; mouse deer, Rhio-Linga Archipelago, P1695; Virginia deer, abnormal antlers, P358; nematode from, P2872.

Delphinidae, review, B36.

Desmodus rufus, relationships with Diphylla ecaudata, P1099.

Dicotyles, Mexican border, P1129.

Didelphis virginiana, helminth parasites of, P2939.

Diphylla ecaudata, relationships with Desmodus rufus, P1099.

Dipodomys, study of, P680.

Dipodomys compactus, Texas, P699.

Direction Island, South China Sea, P1686.

dog, cestode parasite of, P1780; hookworms from, P2533; intestinal trematodes from, China, P2415; taenioid cestodes from, P2258.

dolphin, spotted, identical with Prodelphinus doris, R1884, pt. 3, No. 4.

Dorcelaphus, Mexican border, P1129.

Dymecodon pilirostris, Japan, P557.

Echinomys semispinosus in Nicaragua, P743.

Engano Island, P1440.

extinct, represented in the National Museum, R1889, pt. 3, No. 5.

Felis concolor, R1889, pt. 3, No. 4; P323.

Florida, R1884, pt. 3, No. 5; P2546. fox, hookworms from, P2533.

gazelle, isabella, variation in skull and horns, P1890.

Geomys personatus, Texas, P699.

Glossophaga, new species, P1110, 2034.

goats, Rocky Mountain, habits, P88.

Gymnura, remarks on, P1680.

hares, tapeworms of, P1105; Mexican border, P1081.

helminths parasitic in, P2725.

Hemiderma, review, P1514.
Mammals (continued).

Hesperomys melanophrys, remarks on, P850.

Hesperomys truei, P529.

Honduras, P1069; Little Swan island, P744.

Hyperoodon semijunctus, note on, P541.

Hyracoidea, east African, in $\mathrm{Na}$ tional Museum, B99, pt 3; nematode parasites of, P2131.

Indian Ocean, P982.

Indiana, Kankakee Valley, P1537; Indiana University Farm, Mitchell, P1655.

insectivores, east Africa, in National Museum, B99, pt. 1; Gymnura, P1680; nematodes from, P2589; reptilian characters in skull, P2304.

jaguars, South American, P2069.

Japan, P557.

jerboas and jumping mice, comparison of the osteology, P1228.

Karimata Islands, Dutch East Indies, P1481.

Kashmir, P976, 1004.

Kerguelen Island, B3.

Labrador, P353.

Lagomorpha, east African, in $\mathrm{Na}$ tional Museum, B99, pt. 2; nematode parasites of, P2131.

land, North American, in National Museum, B79.

lemurs, slow, P1494.

lice, from North American mammals, P1183.

lions, effects of environment and habit on captive, P2196.

Loncheres armatus, Martinique, P468.

lynx, Canada, cranial characters, P603; cestode parasite of, P1780; Mexican border, P1126.

Macaca nemestrina group, P1436.

Maine, P1336, 1357.

Malay Peninsula and Archipelago, P1466, 1552.

Maryland, P213.

Mendenau Island, P1498.

Mephitis, Mexican border, P1126, 1129.

Mesoplodon mirum, North Carolina, P2007.

Mesoplodon stejnegeri, Bering Island, P540.

Mexico, P559, 850.

Mexico-United States boundary, B56; P1075, 1081, 1103, 1126, 1129, 1132.

mice, grasshopper, systematic account, P2057; jumping mice and jerboas, comparison of osteology, P1228; new species from Costa Rica and Mexico, P850; Phenacomys longicaudus, Oregon, P826; Sitomys decolorus, Central America, P963; Taylor's, Sitomys taylori, relationships, P972. 
Mammals (continued).

minks, American, synopsis, P1965; extinct, from shell-heaps of Maine, P1336.

moles, American, revision, P1101; Japan, P557.

Molossus, notes on, P2013.

Monachus tropicalis, West Indies, R1884, pt. 3, No. 6.

monkeys, liver fluke from, P2783; Macaca nemestrina group, P1436; Pithecus and Pygathrix, collected by W. L. Abbott, P1751; spider, review of, P3186.

moose, habits of British American, P827.

mules, in milk, P278.

Murinae, new species of, P529.

muscles of primates, brachial flexor, P2913.

muskrat, Ondatra zibethica, trematode from, P2870; Neofiber alleni, Florida, R1884, pt. 3, No 5.

Myotis, American, B144.

nematodes, fatal to animals in Calcutta Zoological Garden, P2777; from antelope, P2694; from Insectivora, P2589; from rodents, $\mathrm{P} 2749$; parasitic in intestines, P2723.

Neofiber alleni, Florida, R1884, pt. 3, No. 5.

Neomeris phocaenoides, anatomy, P2662.

Neotoma, Mexican border, P1132; in National Museum, P1006.

Nias, P1440.

Nicaragua, P743.

Nicobar Islands, P1269.

North American, new, P999, 1121; land, in National Museum, B79; Recent, check list, B128.

North Carolina, P2007.

Nyctinomus europs and $N$. orthotis, P786.

ocelot cats, P1286.

Ohio Valley Centennial Exposition, guide to collection, $\mathrm{C} 41$.

Ondatra zibethica, trematode from, P2870.

Opossum, Didelphis virginiana, helminth parasites of, P2939; nematodes from, P2897.

orang skulls, anatomical observations on, P1495.

Orcinus, Maine, P1357.

Oregon, P826.

osseous and horny tissues, preservation, P1879.

Ovis montana dalli, new geographical race of mountain sheep, P399.

Panama, P1882.

panther, Felis concolor, as fish-killer, P323.

peccary, Texas, P2945, 2956.

Pennsylvania, P338.
Mammals (continued).

Perissodactyla, east African, in National Museum, B99, pt. 3.

Peru, P2333.

Phenacomys longicaudus, Oregon, F826.

Fhilippine Islands, P1402, 1757, 2028.

Phoca, comparative anatomy of, P2736.

Phoca (Histriophoca) fasciata, skeleton, P394.

Phocaena dalli, Alaska, P495.

Phocoenoides dalli, gums of, P2771. pigs, Malayan, P1466.

Pithecus, P1751.

Pizonyx, American, B144.

Plagiodontia, P2712.

porcupines, Canada, in Maryland, $\mathrm{P} 213$; in West Virginia, P44; Malayan, P1552; tapeworm from, P2561.

porpoise, bottlenose, observations on life history, P812; cestode cysts from, P1410; Chinese, anatomy, P2662; Phocaena dalli, Alaska, P495; Phocoenoides dalli, gums of, P2771; Prodelphinus, skeletons and skulls, Indian Ocean, P982.

Primates, east African, in National Museum, B99, pt. 3; brachial flexor muscles, P2913.

Proboscidea, east African, in $\mathrm{Na-}$ tional Museum, B99, pt. 3.

Prodelphinus, skeletons and skulls, Indian Ocean, P982.

Prodelphinus doris, spotted dolphin identical with, R1884, pt. 3, No. 4 .

Pseudorca, American records, P2311.

Pteropus aldabrensis, Aldabra Island, P948.

Puget Sound, P602.

puma (Felis concolor), R1889, pt. 3, No. 4.

Pygathrix, P1751.

rabbits, cestode from, $\mathrm{P} 1629$; roundworms from, P2548, 2553; tapeworms from, P1105; trematodes from, P2792; Virginia, islands off, P1784.

raccoon, hookworm from, P2598.

raccoons and allies, genera and subgenera, P2100.

rats, cotton, Sigmodon minima, New Mexico, P994; nematode from, P2616; wood, in National Museum, P1006.

reptilian characters in skull of Insectivora and other mammals, P2304.

Rhinolophus, Nias and Engano, P1440.

Rhio-Linga Archipelago, P1485, 1502, 1684, 1695.

Rio Grande Valley, P1251. 
Mammals (continued).

Rodentia, east Africa, in National Museum, B99, pt. 2; nematode parasites of, P2131, 2749, 2788.

Sriurus, Mexican border, P1132.

Ścotophilus temminckii, P914.

sea-cow, Steller's, extermination of, P421.

sea-elephant, California, statistics relating to, P492.

seals, comparative anatomy of, P2736; West Indian, R1884, pt. 3, No. 6.

sheep, lungworms from, P2884; mountain, Ovis montana dalli, P399; nematode from, P1892.

shrews, long-tailed, eastern United States, P1825.

Sigmodon, Mexican border, P1132.

Sigmodon minima, New Mexico, P994.

Sitomys decolorus, Central America, P963.

Sitomys taylori, relationships, P972. skeletons, preparation of, B39c; C33. skins, directions for collecting, R1886, pt. 3, No. 6; directions for removing and preserving, C22.

skulls, asymmetry in, P2599; orang, anatomical observations on, P1495. (See also under Crania.)

small, directions for preparing, B39n.

Sminihus, Kashmir, P1004.

Spilogate, Mexican border, P1126.

squirrels, Direction Island, P1686; giant, Sumatra, P1534.

Sumatra, P1317, 1534, 1626; Engano Island, P1472; islands off west coast, P2188.

swine, roundworm from, P2456.

Tadarida, American, P2862.

Tennessee, P3051.

Texas, B17; Padre Island, P699.

treeshrews, Tupaiidae, P1976.

trematodes, from fur-bearing animals, P2809; from marine mammals, P2936.

Tubulidentata, east African, in $\mathrm{Na-}$ tional Museum, B99, pt. 2.

Tupaiidae, account of family, P1976. type specimens in National Museum and Biological Surveys collections, B62, 178.

Urocyon, Mexican border, P1126.

Venezuela, La Guaira, P1246.

Vespertilio longicrus, Puget Sound, P602.

Vespertilionidae, notes on genera, P920.

Vesperugo hesperus, P659.

Virgin Islands, P2244.

Virginia, islands off coast, P1784.

walrus, Atlantic, cerebral fissures, P1325.

West Indies, R1884, pt. 3, No. 6; Martinique, P468.
Mammals (continued).

West Virginia, P44, 3022.

whales, beaked, North Carolina, P2007; Ziphiidae, B73.

blue, photographs and measurements, P2544.

fishery and appliances, exhibit at International Fisheries Exhibition, London, B27, pt. E.

killer, Orcinus, Maine, P1357.

pollack, Florida, P2546.

Pseudorca, American, P2311.

whalebone, nomenclature of 10th ed. of Linnaeus's "Systema Naturae," P1163.

World's Industrial and Cotton Centennial Exposition, plan for exhibition, C29.

Xenurus, Honduras, P1069.

Zalophus, comparative anatomy, P2736.

zebra, Burchell's, in the National Museum, P1505.

Ziphiidae, account of, B73.

(See also under Fossils.)

Mammoths, circulars regarding, C48, 53. Manakins. (See under Birds.)

Mancala, national game of Africa, R1894, pt. 2, No. 2.

Manchuria, Canadian and Ordovician formations and fossils, B164; fishes from Port Arthur, P1493; silurid fish from Yalu River, P2408.

Manitoba, birds, P841.

Mann, Albert, B100, vol. 6, pt. 1; CNH10, pt. 5; P937, 2410.

Mann, William M, P2387, 2434.

Mansfieid, Wendell Clay, P2169, 2559, 2688, 2759, 2836, 2887.

Mantids. (See Insects, Orthoptera.)

Map, Medeba mosaic of Palestine, drawing in National Museum, P2111.

Marcasite after pyrrhotite, pseudomorphs, from Prussia, P1801.

Marcou, John Belknap, B30; P520, 568.

Marine animals, methods employed for preservation at Naples Zcological Station, B39m.

Marine fauna, Provincetown, Mass., P128.

Marine invertebrates, American, northeast coast, P76, 168, 284, 534; duplicates distributed by National Museum, P371; New England, P82, 230, 231.

Marlatt, Charles Lester, P1157.

Marsh, Charles Dwight, P1901, 2117, 2285, 2498, 2659, 2785, 2959.

Marshall, William Blanchard, P2122, $2209,2336,2437,2485,2550,2552$, $2576,2612,2638,2678,2699,2711$, $2748,2762,2798,2802,2825,2889$, 2937, 2949.

Marshall, W. B., and Bowles, Edgar Oliver, P2946.

Marshtits. (See under Birds.)

Marsipobranchiates, P308. 
Marsupials. (See under Fossils, mammals.)

Martinique, birds collected by F. A. Ober, P51; Loncheres armatus, occurrence, P468.

Martyn, Thomas, and the "Universal Conchologist,” P1425, 1565.

Martynov, Andrei Vasilevich, P2891.

Marx, George, P782, 951.

Maryland, Arundel formation fauna, P2389.

booby, and other bird records from Miocene, Calvert formation, P3030. Canada porcupine, occurrence, P213. cave deposit, Cumberland, Pleistocene, P2014.

dog, Miocene, P3035.

dragonfly, Gomphus parvidens, P2199.

fossil forms, some peculiar, P2688.

Lower Devonian and Ontaric formations, P1313.

peccaries, Cumberland Cave, Pleistocene, P2324.

porpoise, Calvert formation, P2482; Kentriodon pernix, Miocene, P2645.

plants, gymnospermous, Potomac Group, revision, P1821.

seal, Miocene, P1475.

squalodonts, and notes on sharktoothed cetaceans, Calvert Cliffs, P2462.

turtle, leatherback, Miocene, P1669. vertebrate fauna, Cumberland Cave, Pleistocene, B171.

whale, fossil whalebone, Calvert Cliffs, P2483.

Mason, Otis Tufton, R1884, pt. 3, Nos. 1,$2 ; 1887$, pt. 3 , Nos. 1,$3 ; 1889$, pt. 3 , No. $3 ; 1890$, pt. 3 , No. $4 ; 1894$, pt. 2 , No. $1 ; 1897$, pt. 2 , No. $5 ; 1899$, pt. 2 , Nos. 2,$4 ; 1900$, pt. 2, No. 2 ; 1902, pt. 2, No. 1; B39p; P531, 730, 776, 932, $1015,1566,1631,1672$.

Mason, O. T., and Holmes, William Henry, B39q.

Mason, Preston Walter, P2592.

Mason-wasp. (See under Insects, $\mathrm{Hy}$ menoptera.)

Massachusetts, amesite and corundophilite from Chester, analyses and optical properties, P2342.

Belone latimanus, Buzzards Bay, P5. bonito, oceanic, Vineyard Sound, P42. butterflies from eastern, P1987. cestode parasites of teleost fishes, Woods Hole region, P3112.

Copepoda and Cladocera, marine, Woods Hole region, with synopsis of Harpacticoida, P1758.

copepods, Woods Hole region, B158; P2739.

datolite from Westfield, crystallographic study of, P2385.
Massachusetts (continued).

diabantite, stilpnomelane, and chalcodite of trap quarries, Westfield, P2316.

fishes, of Provincetown, experiments on animal heat, P96.

isopod, Eurycope, Marthas Vineyard, P1598.

littoral marine fauna, Provincetown, P128.

Mollusca, deep-water, Marthas Vineyard, P284.

trematodes from fishes, Woods Hole region, $\mathrm{P} 3078$.

Mastodon. (See under Fossils, mammals.)

Materia medica. (See under Medicine.)

Matthew, William Diller, P1449.

Matthews, Washington, R1890, pt. 3, No. 8.

Matting. (See under Anthropology, Indians.)

Maxon, William Ralph, CNH8, pt. 3; 19 , pt. $7 ; 12$, pt. 9 (11th art.); 13, pt. $1 ; 16$, pt. 1 (1st art.), pt. $2 ; 17$, pts. $2,4,7$; 24, pt. 2 ; P1226, 1374, 1379.

May, Henry Gustav, P2350.

Mayer, Alfred Goldsborough, B110, vol. 1 , pt. 3.

Mayflies. (See Insects, Ephemerida.)

Mazatlán. (See under Mexico.)

Mazÿck, William Gaillard, P584.

McAtee, Waldo Lee, P2406, 2619.

McAtee, W. L., and Alexander, Charles Paul, P2344.

McAtee, W. L., and Banta, Arthur Mangum, P1443.

McAtee, W. L., and Knight, Harry Hazelton, P2784.

McAtee, W. L., and Malloch, John Russell, P2525, 2573, 2585, 2721.

McClendon, Jesse Francis, P1509.

McEwan, Eula Davis, P2297.

McGregor, Ernest Alexander, P2167, 2303.

McGregor, Richard Crittenden, P1383.

McGregor, R. C., and Jordan, David Starr, P1470.

McGuire, Joseph Deakins, R1894, pt. 2, No. $5 ; 1897$, pt. 2 , No. 5.

McIntosh, Allen, P2945.

McKay, Charles L., P197. mammals collected by near Bristol Bay, Alaska, P564.

plants collected by at Nushagak, Alaska, P513.

McMurrich, James Playfair, P930, 1315, 1967.

McNeill, Jerome, P631, 632, 1215.

Means, Philip Ainsworth, P2275.

Mearns, Edgar Alexander, birds, P1274, 1679, 1683, 2076, 2142.

mammals, B56; P994, 1075, 1081, $1103,1121,1126,1129,1132,1147$, $1251,1286,1402,1784$. 
Mearns, E. A. (continued).

plants, B56; P1147.

fishes, collected by from rivers tributary to Gulf of California, P2125; collected by in Philippines, P1491, 1568.

Mechanical collections. (See under Engineering.)

Medicine, atropia, influence on the heart, P498.

cinchona barks in National Museum, P582.

drugs, request for, C20.

drugs and medicines, classification of forms, C7.

history, directions for collecting information and objects illustrating, B39s.

materia medica collection, classification and arrangement, C6; classification of in National Museum, C19, 32.

materia medica section, memoranda for collectors, C8.

slider terrapin, variations of temperature, influence on heart, P515. (See also under Anthropology.)

\section{Medusae:}

Caribbean Sea, P528.

Cnidaria, urticating organs, P1097.

Commander Islands, P1188.

Eperetmus, trachomedusae, P2114.

Gulf of Mexico, P528.

Haliclystus stejnegeri, Commander Islands, P1188.

hydromedusae, Philippine, B100, vol. 1 , pt. 5.

Malay Archipelago, B100, vol. 1, pt. 3

Pacific Ocean, northwestern, Albatross collections, P1946.

Philippine Islands, B100, vol. 1, pt. 3 ; P1931.

scyphomedusae, Philippines and Malay Archipelago, B100, vol. 1, pt. 3. sea-nettles, urticating organs, P1097. trachomedusae, Eperetmus, P2114.

(See also under Fossils, medusae.)

Meehean, Otis Lloyd, P3087.

Meek, Fielding Bradford, bibliography of publications on fossil invertebrates, B30.

Meek, Seth Eugene, P461, 737.

Meek, Seth E., and Jordan, David Starr, P427, 450, 453, 470, 483.

Meek, Seth E., and Swain, Joseph, P428. Melander, Axel Leonard, and Argo, Naomi George, P2501.

Mendenau Island, mammals, P1498.

Menhadens. (See under Fishes.)

Mentawi Group, birds of Siberut and Sipora (Spolia Mentawiensia), P2775.

Merrill, Elmer Drew, CNH30, pt. 1.

Merrill, E. D., and Lamson-Scribner, F., CNH13, pt. 3.

Merrill, George Perkins, R1886, pt. 3, No. $3 ; 1889$, App. E; 1890 , pt. 3,
Merrill, G. P. (continued).

No. $7 ; 1893$, pt. 2 , No. $3 ; 1895$, pt. 2, No. 3 ; 1899, pt. 2 , No. $1 ; 1901$, pt. 2 , No. $1 ; 1904$, pt. 2 , No. 1.

B39i, 53, 94, 109, 118, 149.

C25, 51 .

P $341,354,363,365,410,479,497$, $523,554,694,700,707,783,985$, $987,1031,1066,1249,1273,1508$, $1511,1524,1546,1833,1905,1943$, 1952, 2084, 2098, 2108, 2153, 2157, $2163,2184,2243,2248,2259,2306$, $2341,2384,2425,2464,2487,2574$, 2578, 2670, 2693, 2700, 2718, 2742, 2787.

Merrill, G. P., and Clarke, Frank Wigglesworth, P696.

Merrill, James Cushing, P22, 88.

Mesa Verde Park, meteoric irons, P2487.

Mesozoic. (See under Fossils.)

Metabolite, meteoric, Dungannon, Va., P2464.

Metallic castings of delicate natural objects, P212.

Metallography, copper, metallic, Hampe's method of determining $\mathrm{Cu}_{2} \mathrm{O}$ in, P687. copper boulder, Ontonagon, in $\mathrm{Na}$ tional Museum, R1895, pt. 2, No. 6. meteoric iron, B184. ores in National Museum, B53. silver ore, andorite-bearing, from Nevada, P2411; miargyrite from California, P2766; stephanite from, P2479.

Metallurgy, economic, catalog of collections, B42.

Metarossite, from Colorado, P2707.

Metcalf, Maynard Mayo, B100, vol. 2, pt. $1 ;$ B120; P3077.

Metcalf, M. M., and Bell, Mary M., B100, vol. 2, pt. 2.

Metcalf, M. M., and Hopkins, Hoyt Stilson, B100, vol. 2, pt. 3.

Meteorites:

Allegan, calcium sulphide (oldhamite) in, P1622.

Alpine, Brewster County, Tex., meteoric irons, P2425.

Arkansas, meteoric irons, P2700.

Baldwyn, Miss., meteoric stone, P2578.

Bolivia, meteoric irons, P2700.

Casas Grandes, P1277.

Chicora, Butler County, Pa., P3111.

Colby, Wis., meteoric stone, P2574.

Cold Bay, Alaska, pallasite, P2425.

composition and structure, B149.

Cookeville, Putnam County, Tenn., P2153.

Cullison, Pratt County, Kans., P1952.

Cumberland Falls, Whitley County, Ky., P2306.

Dungannon, Va., metabolite, P2464.

Estherville, Iowa, P2341.

Fayette County, Tex., P2248.

Felix, Perry County, Ala., P1249. 
Meteorites (continued).

Fisher, Polk County, Minn., P2084.

Forksville, Mecklenburg County, Va., P2670.

Freda, N. Dak., P3134.

graphitic iron in meteorite, P1497.

Hendersonville, N. C., notes on composition and structure, P1511.

Indarch, Russia, meteoric stone, composition and structure, P2098.

Johnson County, Ark., P666.

Kansas City, Mo., meteoric stone, P2259.

Lake Okechobee, Fla., meteoric stone, P2163.

Mesa Verde Park, Colo., meteoric irons, P2487.

metabolite, Dungannon, Va., P2464.

metallography of meteoric iron, B184.

meteoric chromites, P1628.

meteoric irons, oxidation, P2717.

meteoric stone, Baldwyn, Miss., P2578.

Michigan, meteoric irons, P2700.

Mount Vernon, Ky., P1392.

National Museum collection, catalogs, R1866, pt. 3, No. 1; 1900, pt. 2, No. 7 ; B94.

Oakley, Idaho, iron meteorite, P2693. origin of metal in, P2742.

pallasite, Cold Bay, Alaska, P2425.

Peck's Spring, Midland County, Tex., meteoric stone, P2787.

Perryville, Perry County, Mo., meteoric iron, P1943.

Persimmon Creek, P1380.

Plainview, Hale County, Tex., P2184, 2243.

Rich Mountain, Jackson County, N. C., P1524.

San Emigdio, P700.

Sardis, Ga., P3143.

Savannah, Tenn., meteoric irons, $\mathrm{P} 248$ ?

Scott County, Kans., P1905.

Selma, Dallas County, Ala., P1508.

Sharps, Richmond County, Va., P2492.

Signal Mountain, Lower California, meteoric irons, P2425.

study of in National Museum, B53, pt. 2 , sect. 4 .

Troup, Tex., P2383, 2384.

Wallapai (Hualapai) Indian Reservation, Ariz., meteoric irons, P2718.

Whitfield County, Ga., meteoric irons, P2157.

Metz, Charles William, and Jordan, David Starr, P1915.

Mexico, Allioniaceae, CNH12, pt. 8; 13, pt. 11.

amphibians, anuran, new, P3093; tailless, in National Museum, B160; specimens collected under Walter Rathbone Bacon Traveling Scholarship, P3185.
Mexico (continued).

Asteraceae, described by M. E. Jones, CNH29, pt. 2, art. 2.

Basileuterus rufifrons, new forms, P895

batrachians and reptiles, catalog, B32: Mount Orizaba, P922.

bees, Victoria, P2476.

beetles, bark, Pityophthorini, P3147; buprestid, leaf and twig mining, P2454; new buprestid, P2968.

birds, Alta Mira, P1091; central Mexico, notes on, P975; Sonora, P385; southwestern Mexico, collected by Sumichrast, B4; Veracruz, P3164.

calamine crystals from, P1801.

censers and incense, P1887.

Crassulaceae, new species, CNH12, pt. 10 (2d art.).

crinoids, Upper Cretaceous, Tamaulipas, P2426.

crustaceans, fossil decapod, P2851; stomatopod, west coast, P3138.

Echeveria, new species of, from southern Mexico, CNH13, pt. 2.

Echini, fossil, P3015.

eel, Sidera castanea, Mazatlán, P335.

Etheostoma micropterus, Chihuahua, P8z3.

fern, Goniophlebium prinolei, P1379. Ficus, species of, CNH20, pt. 1.

fishes, collected by A. Dugès, P637, 903; Chapala Lake and Guanajuato, P94; central Mexico, P95. collected by A. Forrer, describing Heros beani and Poecilia butleri, P719.

collected by Henry E. Nichols, on west coast, P221.

collected by H. F. Emeric in Guaymas, describing Gobiosoma histrio, P433.

collected by John Xantus, Colima, P291.

fresh-water, from southern Mexico, P925.

Guaymas, Sonora, P846.

Hyporhamphus patris, from Sinaloa, with analysis of Hyporhamphus and Hemiramphus, P3195.

Mazatlán, new species, P237, 254. Platypoecilus, described, P1159.

Veracruz and Tampico, P1592.

Foraminifera, Discocyclina, Eocene, P2800; Tertiary and Cretaceous Camerinidae, P3052.

fossil forms, spiral, P2836.

gasteropod, fossil, Pueblo, P131.

Geographical and Exploring Commission collection of animals, P559.

grasses, in National Herbarium, $\mathrm{CNH} 17$, pt. 3 ; new, CNH1, No. 8 (3d art.).

ground warbler, from eastern Mexico, P1045. 
Mexico (continued).

herpetological miscellany, P3153.

insects, coleopterous, checklist of, B185.

isopod, Cassidinidea, P1886.

Lepidoptera, new, P1742, 1885, 1951, 2054, 2139, 2239.

lichens, collected by Edward Palmer, CNH1, No. 8 (7th art.).

lizard, Phrynosoma, P1437.

mice, supposed new species, with remarks on Hesperomys melanophrys, P850.

millipeds, new, P1810.

mineralogy and geology of Cerro Mercado, Durango, P2768.

mollusks, Vicksburg (Oligocene), P2731.

mussels, pearly fresh-water, P2485, 2889.

Odontophorus, supposed new species of from southern, P945.

partridge, new plumed, from Sonora, P617.

petrel, storm, new, from western Mexico, P962.

phanerogams described by M. E. Jones, CNH29, pt. 2, 1st art.).

plants, Clarion Island, P801.

collected by E. Palmer, CNH1, No. 4 (1st art.).

collected by E. Palmer, in western Mexico, CNH1, No. 3, No. 4 (1st art.).

collected by E. Palmer, Sonora and Colima, CNH1, No. 9 (1st art.).

from Pinacate region, Sonora, CNH16, pt. 1 (2d art.).

Miocene, P2465.

new species, $\mathrm{CNH} 3$, No. 5 (2d art.) ; P1427.

notes on useful, CNH5, No. 4 (6th art.).

studies of, CNH5, Nos. 3, 4 (1st art.) ; 8, pts. 1,4 ; 10 , pt. 3 ; 12 , pt. $7 ; 13$, pt. 9 .

Polypodium, study of, CNH8, pt. 3 .

Pomadasys, new species, Mazatlán, P242.

Ptelea, CNH10, pt. 2.

pulque of, P1579.

reptiles, Clarion Island, P800.

Rhinobatus glaucostigma, Mazatlán, P370.

Roseanthus, new genus of Cucurbitaceae, Acapulco, CNH3, No. 9 (5th art.).

rudistid, Cretaceous, San Felipe formation, P2379.

Sapindaceae, new species from western Mexico, CNH1, No. $9^{\circ}(2 \mathrm{~d}$ art.).

Sapium, species of, CNH12, pt. 4.

Sciaena sciera, Mazatlán, P452.

scorpions of northern Mexico, notes on, P2730.
Mexico (continued).

sharks, new, Mazatlán, P268.

shells, land and fresh-water, believed to be new, P1642 land, new, P1515, 1707, 2594, 2653; rudistid group, Upper Cretaceous of $\mathrm{Ta}$ maulipas, P2422.

snakes, checklist and key, B187; Clarion Island, P1231; Coniophanes fissidens subsp., P3127.

snakes and crocodilians collected under Walter Rathbone Bacon Traveling Scholarship, P3169.

sponges, fresh-water, P542.

stephanite in silver ore, crystallographic notes on, P2479.

Talinum, CNH13, pt. 8 (1st art.).

Thompsonella, new genus of Crassulaceae, CNH12, pt. 9 (1st art.).

throwing-sticks, P932.

trees and shrubs, CNH23: Gleicheniaceae-Betulaceae, pt. 1; FagaceaeFabaceae, pt. 2; Oxalidaceae-Turneraceae, pt. 3 ; PassifloraceaeScrophulariaceae, pt. 4 ; Bignoniaceae-Asteraceae, pt. 5.

turtles, Kinosternon, P3115.

Tuxtla statuette, jade of, P2409.

Umbelliferae collected by C. G. Pringle and E. W. Nelson at Oaxaca, CNH3, No. 5 (1st art.).

Urolophus asterias, Mazatlán, P327. Viburnum, species of, CNH26, pt. 7. violets, P1429.

Mexico, Gulf of. (See under Gulf of Mexico.)

Mexico-United States boundary, hares, new, P1081; mammals, new, P1075, 1103 ; mammals, Lynx, Urocyon, Spilogale, and Mephitis, P1126; mammals, Mephitis, Dorcelaphus, and Dicotyles, P1129; mammals, Sciurus, Castor, Neotoma, and Sigmodon, P1132; mollusks collected by International Boundary Commission, P1033, 1111.

Meyer, Adolph Bernhard, R1903, pt. 2, No. 2.

Miami Aquarium Association, pollack whale from Florida presented to $\mathrm{Na}$ tional Museum, P2546.

Miargyrite, from California, P2766.

Mice. (See under Mammals.)

Michael, Ellis Le Roy, B100, vol. 1, pt. 4.

Michaux, types of American grasses, CNH12, pt. 3 .

Michigan, amphibians and reptiles, Gogebic County, P2109; meteoric irons, Seneca Township, P2700; Middle Devonian Traverse group of rocks, P2811.

Mickel, Clarence Eugene, B143; P2505.

Microlepidoptera. (See under Insects, Lepidoptera.)

Middle America, birds, catalog, B50; new, P655; species not represented in National Museum, P215.

butterflies, danaid, notes on, P3118. fishes, catalog, B47. 
Middle America (continued).

Lonchocarpus, species of, CNH20, pt. 2.

(See also under Central America.)

Middleton, William, P2083, 2442.

Middleton, William, and Rohwer, Sievert Allen, P2396.

Midway Island, birds collected on by Paul Bartsch, P1683.

Miller, Gerrit Smith, Jr., B39n, 57, 79, 128; P1269, 1317, 1359, 1436, 1466, $1472,1481,1485,1695,1755,1757$, $1882,1890,2013,2034,2244,2311$, 2544-2546, 2712, 2771.

Miller, G. S., Jr., and Allen, Glover Morrill, B144.

Miller, G. S., Jr., and Standley, Paul Carpenter, CNH16, pt 3.

Miller, Robert Rush, P3195.

Millipeds. (See under Myriapods.)

Mills, Clark, catalog of casts of heads of Indian prisoners taken by at Fort Marion, St. Augustine, Fla., P29.

plaster casts of heads of Indian children at Hampton Institute made by, P79.

Mimetite, notes on, P2240.

Mineral industries, energy resources, United States, B102, vol. 1:

coal, resource and utilization, pt. 4. coal products, pt. 1 .

fertilizers, pt. 2 .

gas, manufactured, in the home, pt. 8.

gas, natural, production, service, conservation, pt. 7 .

petroleum, resource interpretation, pt. 6.

power, significance and needs, pt. 5 .

sulphur, example of industrial independence, pt. 3.

Mineral resources, New Orleans, World's

Industrial and Cotton Centennial Exposition, plan to illustrate, $\mathrm{C} 31$.

Mingralogy:

allophanite, P2118.

alunite, P2145.

amesite from Chester, Mass., P2342. ammoniojarosite from Utah, P2758. amphibole from Idaho, P2373.

andesites, hornblende, from Bogos-

loff Island, P479.

andorite-bearing silver ore, P2411.

anglesite, notes on, P2345.

anthophyllite, nomenclature of group, P2373; notes on, P2345.

asbestos and asbestiform minerals, P1066.

axinite, notes on, P2060.

benjaminite from klaprotholite group, P2537.

beraunite, notes on, P2060.

Bering Sea, Bogosloff Island, P479.

black sands from Idaho, P2398.

bornite, relation in copper ores of
Mineralogy, bornite (continued). Virgilina District of North Carolina and Virginia, P1835.

boulangerite, P2351.

calamine crystals from Mexico, P1801.

calcite, in silicified wood, $\mathbf{P} 2200$; notes on, P2345.

California, P2342; Randsburg Dis. trict, P2766; Tulare County, $\mathrm{P} 2417$.

Canada, P1801.

chalcocite, relation in copper ores of Virgilina District of North Carolina and Virginia, P1835.

chalcodite from trap quarries of Westfield, Mass., P2316.

chlorites, chromium-bearing, from California and Wyoming, P2342. chlorophoenicite, a new arsenate from Franklin, N. J., P2669.

chromites, meteoric, P1628.

Colorado, P2707; Italian Mountain, P2690.

Connecticut, Long Hill in Trumbull, P2348.

copper, overlaying by American aborigines, P1015.

copper ores of Virgilina District of North Carolina and Virginia, relation of bornite and chalcocite in, P1835.

corundophilite, Chester, Mass, P2342.

creedite, crystallography, and chemical composition, P2376.

datolite, notes on, P2345.

Westfield, Mass., P2385.

diabantite from trap quarries of Westfield, Mass., P2316.

diabase, Mesozoic, of Atlantic border, composition, P205.

District of Columbia, P410, 523.

Egypt, Kharga, P1726.

epsomite from Utah, P2758.

feldspar in sections of rocks, P206.

ferroanthophyllite, orthorhombic iron amphibole, P2373.

fuchsite, P2118.

gems, in National Museum, R1886, pt. 3, No. 2; 1900 , pt. 2, No. 6; handbook of, B118; plan for exhibit at World's Industrial and Cotton Centennial Exposition at New Orleans, C26.

glauconite, optical properties and chemical composition, P2628.

gouge clays from precious metal veins, P2461.

gypsum incrustations and stalactites in caves, P985.

hornblende andesites from Bogosloff Island, P479.

hydrotalcite group, chemical composition, P2329. 
Mineralogy (continued).

Idaho, B131, P2373, 2395, 2398; Challis, mordenite and other minerals from, P2509; Clearwater County, P2375.

iddingsite, origin, occurrence, composition, and physical properties, P2579.

inclusions in Maine granites, P354. intrusive Triassic diabase at Goose Creek, Loudoun County, Va., P2539.

jadeite, P395, 696.

Mogoung, Burma, analysis, P981.

jamesonite, silver-bearing variety, P2351.

Kerguelen Island, B3.

klaprotholite group, benjaminite from, P2537.

ludwigites from Idaho and Korea, P2395.

Maine, P354; Penobscot Bay, Little Deer Isle, P707.

marcasite after pyrrhotite, pseudomorphs, from Prussia, P1801.

Massachusetts, Chester, P2342; Westfield, P2316, 2385.

metarossite from Colorado, P2707.

Mexico, P1801, 2479; Cerro Mercado, Durango, P2768.

miargyrite from California, P2766.

mimetite, P2240.

mineralogical collections in National Museum, R1895, pt. 2, No. 4, P163; accessions to, P2337; catalog of series illustrating properties, R1897, pt. 2, No. 3 ; classification of, R1897, pt. 2, No. 6; list of minerals especially studied, B53, pt. 2, sect. 4; type and figured specimens, B53.

minerals, Arctic America, Howgate Polar Expedition, B15; directions for collecting, B39h; nonmetallic, guide to study of National $\mathrm{Mu}$ seum collections, R1899, pt. 2, No. 1.

minerals and synonyms, catalog, B33. moldavites and like sporadic glasses, supposed origin, P1833.

mordenite and associated minerals from near Challis, Custer County, Idaho, P2509.

naumannite, P2351.

nephrite, P696.

Nevada, P2411.

New Jersey, Franklin, P2669.

New Mexico, Silver City, P978.

North Carolina, Davidson County, P1715; Virgilina District, P1835.

olivine-diabase from Davidson County, N. C., P1715.

onyx marbles, origin, composition, uses, R1893, pt. 2, No. 3.

Oregon, Ritter Hot Spring, Grant Countv, P2737.

paligorskite from Utah, P2758.
Mineralogy (continued).

"peckhamite" in Estherville, Iowa, meteorite, P2341.

peridotite, from Little Deer Isle, Penobscot Bay, Maine, P707.

petroleum collections, circular in reference to, C3.

prochlorite from District of Columbia, P410.

Prussia, P1801.

psilomelanite, P2145.

pucherite, P2455.

pyrite, P2455.

quartz, color of amethyst, rose, and blue varieties, P2220.

rossite from Colorado, P2707.

rutile-mica intergrowth from Canada, P1801.

sand-barites from Kharga, Egypt, P1726.

siderite from Columbia River basalt, P2458.

sillimanite, P2345.

stephanite from Mexico, P2479.

stilpnomelane, P2345; trap quarries of Westfield, Mass., P2316.

Tasmania, Mount Lyell, P2005.

tetrahedrite, P2345.

thaumasite, P2240.

titanite, P2145.

topaz crystals in National Museum, P1148.

trichalcite, P2455.

triphylite, P2118.

triplite, P2345.

tschermigite, from Utah, P2758.

tungsten mine at Long Hill, Trumbull, Conn., P2348.

ultramarine, blue mineral supposed to be, P978.

Utah, P1867, 2758.

vanadates, from Colorado, P2707.

variscite, from Utah, P1867.

velardeñite, from Tulare County, Calif., P2417.

Virginia, Goose Creek, Loudoun County, P2539; Leesburg, P2565; Virgilina District, P1835.

vivianite encrusting a fossil tusk from Clearwater County, Idaho, P2375.

Washington, Spokane, $\mathrm{P} 2458$.

wavellite, P2240, 2455.

wolframite, notes on, P2060.

Wyoming, P2342.

Yellowstone National Park, Obsidian Cliff, minerals of, P2618.

zeolites, from Oregon, P2737.

Minks. (See under Mammals.)

Minnesota, Bison occidentalis, fossil remains, P2473.

lichens, CNH14, pt. 1.

meteorite, Fisher, Polk County, P2084.

shells, Heron and Eagle Lakes, P1190. 
Minnows. (See under Fishes.)

Miocene. (See under Fossils.)

Mississippi, fishes, eastern, P179.

Hybognathus hayi, P467.

Indian village site, prehistoric, excavations, P2898.

meteoric stone, Baldwyn, P2578.

Mississippi River, Amiurus ponderosus, P90.

Mississippi River bluffs at Columbus and Hickman, Ky., fossil flora, P2074.

Mississippi Valley, dragonflies collected during the Pearl Mussel investigation, P1692; striped bass, occurrence in lower part, P430.

Mississippian conodonts, P2613, 2701.

Missouri, archeological investigations, Platte and Clay Counties, B183; Ste. Genevieve County, P2042. fishes, P470.

Hopewellian remains near Kansas City, P3045.

meteoric iron, Perryville, Perry County, P1943.

meteoric stone, Kansas City, P2259.

Unio, new species, Ozark region, P651.

Mites. (See under Arachnids.)

Mitman, Carl Weaver, B119, 127.

Mitzukuri, K., Hemiptera presented to National Museum, P1108.

Mockingbirds. (See under Birds.)

Mohr, Charles, CNH6.

Moldavites and similar sporadic glasses, supposed origin, P1833.

Molds, paper, instructions for taking, C23.

Moles. (See under Mammals.)

MollusKs:

Acar, west coast of North America, P2909.

Achatinidae, west African, P2960.

Africa, west, P940, 2960.

Alaba, west America, P1781.

Alabina, Recent and fossil, west coast of America, P1790.

Alaska, P1, 48, 1711, 2160.

Albatross. (See under Albatross, mollusks.)

Alectrionidae, west coast of America, P2166.

Alvania, west American, P1863.

America, land shells, manual of, B28; northeast coast, P76, 168; northwest coast, San Diego to Polar Sea, B112; west coast, new marine, P1564, 2193; west coast, new species, P1034, 2660.

Amphidromus, Philippine, B100, vol. 1 , pt. 1.

Amphithalamus, west American, P1854.

Anatinacea, west coast of America, P2116.
Mollusks (continued).

Annulariidae, American, classification, P2327; Cuban, P3096; Hispaniolan and Bahaman, B192.

Anodontites, new Brazilian, P2122; South and Central American and Mexican, P2889.

Antillean region, P1185, 3161.

Arctic region, P48.

Arctic Seas, near Labrador, P561.

Astartidae, synopsis, P1342.

Auriculacea, eastern United States, P519.

Australia, P2711.

Bahama Archipelago, Annulariidae, B192; P2016.

Barlecia, west American, P2331.

Bering Island, P562.

Bering Sea, P571.

Bermuda, P1820, 1861.

Bittium, west coast of America, P1826.

Bolivia, P2937.

Brazil, P2053, 2122, 2699, 2762.

Bulimulus, Bolivia, P2937; Lower California, P958.

California, P18, 584, 1191, 2170; San Diego, P536; San Pedro Bay, P898; Trinidad, P2325.

Cardiidae, synopsis, P1214.

Central America, P2638.

cephalopods, Hawaiian, P1713, 1996; Pacific Ocean, P1838, 2310; western Atlantic, P2335.

Cerithiopsis, Alaskan, P1711; west coast of America, Recent and fossil, P1823.

Chilina, new species of, P2550; South American, P2949.

chitons, Alaska and Arctic regions, P48; east coast United States, P246; genera of, P228; northwest Pacific, P2223; Pacific coast of America, P2283.

Chondropominae, Cuban, P3039.

Chrysodomus, north Pacific Ocean, P2234.

Cingula, west American, P1871.

Cochlostyla, Philippine, B100, vol. 6, pt. 9.

Cochlostyla rufogaster and races, B100, vol. 6, pt. 7 .

collecting, directions for, B39g.

Commander Islanc's, Bering Sea, P442, 562.

"Conchological Illustrations," generic names first mentioned in, P2079.

Conus, Pacific coast of America, P1741.

Corbicula, Brazilian, P2699; Uruguayan, P2552, 2699.

Corneocyclas, Ecuador, P1584.

Costa Rica, P11.

Criocardium, note on, P92.

Cuba, P790, 3039, 3096; Camagüey and Santa Clara Provinces, P2369. 
Mollusks (continued).

Cumberland Sound, B15.

cyclophorid operculate land, American, B181.

Cytherea (Tivela) crassatelloides, notes on, P1149.

Diastoma, west coast of America, Recent and fossil, P1802.

Dimya, Philippine, P1983.

Diplodon, South American, P2209.

District of Columbia, P2782.

Ecuador, P1584; Santa Elena Bay, P2551, 2646.

Engina, Panama, P2881.

Epiphragmophora traskii group, P2170, 2246.

Epitonium and allies, Pacific coast of America, P2217.

Ethmocardium, note on, P92.

Eulima, new, P1548.

Eumeta, west America, P1799.

exhibit sent to International Fisheries Exhibition at London, B27, pt. D.

Florida, P384, 519, 2741, 2917, 3070.

Florida and the Southeastern States, P911.

Galápagos Islands, P942.

Gnathodon, monograph, P988.

Guatemala, P1707, 2336.

Gulf of California, P996.

Haliotis, California, P1191; Pourtales's, rediscovery of, P2091; west American, P3094.

Hawaiian Islands, P1032, 1713, 1996, 2878.

heteropods collected by Albatross from Norfolk, Va., to San Francisco, Calif., P943.

Hispaniola, Annulariidae, B192.

Hyalina, new species of, P710.

Hyria, Brazilian, P2053.

identification by National Museum, C47.

Indian Territory, P740.

Indiana, P2321.

Indopacific, P1452.

Japan, P1452.

Kerguelen Island, B3.

Labrador, P377, 1761; Ungava Bay, P561.

land, fresh-water, and marine shells from U. S. Dept. of Agriculture, P844, 971.

land shells, American, manual of, B28.

Leptonacea, North American and West Indian, P1177.

Liguus, Florida, P2741.

Lima, giant species, P1978.

limpets, Alaskan and Arctic regions, P48; east coast of United States, P246.
Mollusks (continued).

Lower California, P958; Todos Santos Bay, P536; Tres Marias, P996.

Lucinacea, synopsis, P1237.

Macromphalina, west coast of America, P1522.

marine bivalves, northwest coast of North America, P2183.

Marthas Vineyard, P284.

melanellid, west American, P2207.

Mexico, P1515, 1642, 1707, 2485, $2594,2653$.

Mexico-United States boundary, P1033, 1111.

Minnesota, Heron and Eagle Lakes, P1190.

money, primitive, made from, R1887, pt. 3 , No. 4.

mussels, Diplodon, South American, P2209.

District of Columbia, P2782.

Hyria, Brazil, P2053.

Mexican and Uruguayan, P2485.

microscopic sculpture, P2576.

pearly fresh-water, classification and distribution, P1068; synopsis, P1205.

South American, P2437, 2678.

South and Central America and Mexico, P2889.

naiads, new, P1454.

new, unfigured, or imperfectly known shells, chiefly American, P1264, 2668.

New England, southern, P169.

Nodulus, west American, P1858.

Norfolk, Va., to San Francisco, Calif., pteropods and heteropods collected by the Albatross, P943.

North America, Atlantic coast, deep water, revision, P1139.

North and South America, west coast, P941.

Nucella, northwest coast of America and adjacent regions, P2124.

Obba, Philippine, B100, vol. 6, pt. 8.

Obba marmorata and races, B100, vol. 6 , pt. 7 .

Onchidiopsis, Labrador, P1761.

Opisthoporus, Philippine, B100, vol. 6 , pt. 6.

Oregonian faunal area, P1574.

Oreohelix, Arizona, P2802.

oyster, pearl, Hawaiian, P2878.

Ozark Mountains, P2126.

Pacific Ocean, new species from, P2002, 2295.

Panama, P2250, 2881.

Peru, P1704, 1736.

Philippine Islands, B100, vol. 1, pt. 1 ; vol. 2 , pt. 5 ; vol. 6 , pts. 6,7 ; P1512, 1518, 1705, 1709, 1978, 1983, 1993, 2104, 2272. 
Mollusks, Philippine Islands

(Continued).

Luzón, P2848.

Mindoro Province, B100, vol. 6, pts. 8, 9.

Pisidium, Alaskan, P2160.

Planorbis, Philippine, P1512.

Planorbis magnificus, notes on, P1587.

Point Barrow, P460.

pteropods collected by Albatross from Norfolk, Va., to San Francisco, Calif., P943.

Pupidae, new subgenus of, P726.

pyramidellid, monograph of west American, B68; Oregonian faunal area, P1574; west American, P1903; zoogeographic study, P1906.

Pyramidellidae, notes on Japanese, Indopacific, and American, P1452.

Rangia, monograph, P988.

Rissoellidae, west American, P2331.

Rissoina, Recent and fossil, west coast of America, P2094.

scaphopod, East American, B111.

Schistoloma, Philippine, P2104.

Selenites duranti, note on, P584.

shipworms, American, B122; Philippine, B100, vol. 2, pt. 5; Venezuelan, P2874.

snails, pond, Philippine, P1518, 1709.

Solenidae, North American and Antillean, P1185.

South Africa, B91.

South America, P854, 2209, 2437, 2638, 2678, 2825, 2949.

Sphaerium, new species of, P415.

Sphyradium species, with inquiry as to generic relationships, P1865.

Synceratidae, west American, P2331.

Tahiti, P1238.

Tellinidae, synopsis, P1210.

Thersites bipartita and allies, P2711.

Triphoris, West American, P1569.

Turbinella pyrum, dentition, P521.

Turritidae, Florida, P3070; notes on nomenclature, P2238; west coast of America and adjacent regions, P2288.

types, illustrations of in National Museum, P2554.

Unio, Ozark region, P651.

Unionidae, Florida and the Southeastern States, P911.

United States, Pacific coast, P1610; southeast coast, Albatross dredgings, P2667; southeastern coast, catalog of shell-bearing marine forms, B37; western States, new land shells, P2155.

"Universal Conchologist," P1425, 1565.

urocoptid, American, P1483; Mexican, P2653.

Uruguay, P2485, 2552, 2699, 2762.
Mollusks (continued).

Veneridae, synopsis, P1312.

Venezuela, P2874.

Veronicella, notes on, P1671; Tahitian, P1238.

Vertigo, study of American species, P726.

Vertigo cubana, P790.

Virginia, Chincoteague Island, P2055.

Vitrinellidae, west coast of America, P1520, 1785.

Vivipara, Philippine, P1518, 1709.

West Indian region, P1011, 1177, 2929.

Xenophora, Florida, P2917.

(See also under Fossils.)

Moluccas, starfishes from Albatross Philippine cruise, P1944, 2022.

Mona Island, Puerto Rico, ground dove, P1418.

Money, primitive, R1887, pt. 3, No. 4.

Mongolia, Inner, birds collected by $\mathrm{Na-}$ tional Geographic Society's CentralChina Expedition, P2838; southern, plants collected by R. C. Ching, CNH28, pt. 4.

Monkeys. (See under Mammals.)

Montana, alligator, fossil, Hell Creek beds, P1860.

dinosaurian reptiles, Two Medicine formation, P2839, 3066. P3066.

flora, Glacier National Park, $\mathrm{CNH} 22$, pt. 5.

fossil footprints from the Fort Union (Paleocene), P2750.

Great Falls coal field, P918.

liverwort, fossil, Fort Union beds, P1639.

mammalian faunas, fossil, Fort Union, Crazy Mountain field, B169.

mammals, fossil, Fort Union, Paleocene, P2981.

mosquito, new, with list of species from State, P2794.

plants, fossil, Fort Union, P921.

rhinoceros, fossil, Diceratherium armatum, Gallatin County, P2848.

rocks, eruptive, Gallatin, Jefferson, and Madison Counties, P1031.

wood, new species of fossil coniferous, P677.

(See also under Fossils, Fort Union.)

Montandon, Arnold Lucien, P924.

[Moodey, Margaret Whittaker, B53, pt. 2 , sects. 2,$3 ; 118$.]

Moodie, Roy Lee, P1696, 1796, 1828.

Mook, Charles Craig, P3122.

Moore, Charles, R1895, pt. 2, No. 6.

Moore, John Percy, P1160, 1703.

Moore, M. A., P202.

Moore, Thomas; Jefferson, John Percival; and Porter, Joseph Yates, P37. 
Moose. (See under Mammals.)

Moose district of Hudson's Bay Co., birds of, P518.

Mordenite. (See under Mineralogy.)

Morgan, Alfred Cookman, P2008.

Morrison, Harold, P2178.

Morrison, Harold, and Morrison, Emily, P2407, 2463, 2689.

Morrison, Joseph Paul Eldred; Torre, Carlos de la; and Bartsch, Paul, B181.

Morse, Edward Sylvester, R1893, pt. 2, No. 10.

Mortensen, Theodor, B74; 100, vol. 6, pt. 4 ; 100, vol. 14 , pt. 1 .

Morton, Conrad Vernon, CNH26, Nos. 7, 9; CNH29, pt. 1 ; pt. 2 (1st art.); pt. 3.

Mosaic from Carthage, Roman, in $\mathrm{Na}$ tional Museum, P393.

Mosquitoes. (See under Insects, Diptera.)

Mosses. (See under Plants.)

Moths. (See under Insects, Lepidoptera.)

Motmots. (See under Birds.)

Moundbirds. (See under Birds.)

Mounds. (See under Anthropology.)

Mount Rainier, Hesperogenia, new genus of Umbelliferae, CNH5, No. 4 (3d art.).

Mount Vernon, stone age at, P730.

Mount Washington, Ashmead manuscript species of Ichneumonidae of Mrs. Slosson's lists, P2429.

Mud-eel. (See under Fishes.)

Muesebeck, Carl Frederick William, P2349, 2436, 2470, 2580, 2633, 2642, 2882, 2923.

Mules, in milk, P278.

Mulford Biological Exploration, Amazon Basin, bees, P2684; Cleridae, P2674; Coleoptera, P2568; nematodes, P2526; termites, P2615.

Mullets. (See under Fishes.)

Murbach, Louis, P1097.

Murdoch, John, R1884, pt. 3, No. 3; P459, 702 .

Museum, U. S. National. (See under National Museum.)

Muséum d'Histoire Naturelle, Paris, American fishes in collection of, P81; fishes described by Cuvier and Valenciennes, P593.

Museum für Naturkunde, Berlin, crinoids, P1937.

Museum of Comparative Zoology, Astacidae in collection, P1136.

Museum-Gates Expedition, archeological field work in northeastern Arizona, R1901, pt. 2, No. 4; culture of ancient pueblos, New Mexico and Arizona, B87.

Museum specimens, preservation from insects and dampness, R1887, pt. 3, No.7.

Museums, anthropological, classification and arrangement of exhibits, R1901, pt. 2, No. 3.

European, American Asteraceae in, CNH26, pt. 5.

museums of the future, R1889, pt. 3, No. 1.
Museums (continued).

public, plea for (If public libraries, why not public museums?), R1893, pt. 2, No. 10.

studies of institutions of New York City, Albany, Buffalo, and Chicago, with notes on European, R1903, pt. 2, No. 2.

taxidermy for, R1892, pt. 3, No. 3.

(See also under names of various museums.)

Music, contributions to history of scales, R1900, pt. 2, No. 4.

Musical instruments, handbook of $\mathrm{Na}$ tional Museum collection, B136.

Muskrat. (See under Mammals.)

Mussels. (See under Mollusks.)

Myers, Frank Jacob, P2190.

Myers, George Sprague, N2998, 3007, 3008.

Myers, Paul Revere, P2052, 2204, 2206.

Myology, rapid preparation of large specimens, P243.

MYRIAPODS:

Africa, P951, 1042, 1137, 1170.

Loanda, P968.

Arizona, P1810, 2714.

California, P2741.

centipedes, Central American, P2402.

Central America, P2402, 2403.

chilopods, Geophilidae, arrangement of, P1039; Geophilus attenuatus, P1038; Henicops dolichopus, Utah, P1270.

Colobognatha, Arizona and California, P2714; Tennessee, Texas, and Lower California, P2989.

Congo, P1036.

Costa Rica, P1810.

Cuba, P720.

diplopods, African, P1036, 1170; oniscoid, American, P1154; Oxydesmus, Congo, P1036; Polydesmoidea, east African, P1042; Priodesmus, new genus, P1037; Striariidae, P1169; Strongylosomatidae, tropical African, P1137.

Florida, Escambia County, P631.

Fontaria pulchella, Tennessee, P714.

Geophilidae, arrangement, P1039.

Geophilus attenuatus, P1038.

Gomphodesmidae, African, P1170.

Henicops dolichopus, Utah, P1270.

Indiana, P632, 731 .

Lithobiidae, notes on, P625; Salt Lake County, Utah, P1242.

Lower California, P2989.

Lysiopetalidae, North American, P181, 3006.

Merocheta, American oniscoid Diplopoda, P1154; tropical, with example of kinetic evolution, P1831.

Mexico, P1810.

millipeds, cambaloid, United States, P3043.

Central American, P2403.

Colobognatha, Arizona and Cali- 
MYRIAPODS, millipeds (continued).

fornia, P2714; Tennessee, Texas, and Lower California, P2989.

hothouse, as a new genus, P1842.

Lysiopetalidae, P3006.

Merocheta, tropical, with example of kinetic evolution, P1831.

Texas, Arizona, Mexico, and Costa Rica, P1810.

West Indian, P2431.

National Museum collection, P722.

North American, B46; P670.

Oxydesmus, Congo, P1036.

Polydesmoidea, east African, P1042.

Priodesmus, P1037.

Scolopendrellidae, genera of, P280.

Scutigeridae, notes on, P625.

Striariidae, P1169.

Strongylosomatidae, tropical African, P1137.

Surinam, P1037.

Tennessee, P714, 721, 2989.

Texas, P1810, 2989.

Utah, P1242, 1270.

Virginia, Luray Cave, P181.

West Indies, P2431.

Mythology, Shinto, Japan, R1891, pt. 3, No. 4 .

Myzonts, P308.

Naiads. (See under Mollusks.)

Namaqualand, Great, Southwest Africa, birds, P2951

Namiye, M., birds collected by in Idzu, Japan, P649; in Liu Kiu Islands, P597.

Naples Zoological station, methods employed for preserving marine animals, B39m.

Naskopie (Nagnagnot) drum, P736.

National Gallery of Art. (See under Art.)

National Geographic Society, birds collected by Central China Expedition, P2838.

birds collected in China by J. F. Rock, P2654, 2907.

birds collected in Inner Mongolia, Chihli, and Kansu, on expedition to central China, P2838.

National Geographic Society-Yale University Expedition to Peru, amphibians and reptiles, P2352; birds, B117 ; mammals, P2333.

National Museum:

account of, R1896, pt. 2, No. 1.

buildings occupied, R1903, pt. 2, No, 1.

Bulletin 112, additions to, P2478.

circular addressed to friends of, C2. collections, installation plans, C16.

condition and progress, R1881 through 1946.
National Museum (continued). contributions and their acknowledgment, C17.

establishment and officers, C5. genesis, R1891, pt. 3, No. 1.

letters on work of, C10.

library, circulars prepared to obtain accessions, C43, 44, 45; circular requesting material for, C14.

Museum classification, outline of scheme of, C13.

Natural History Building, descriptive account of, PSO.

organization and objects, C15.

organization and regulations, plan of, $\mathrm{C} 1$.

publications, list of, B51, 193; C18.

reports, R1881 through R1946.

type specimens, lending, C35.

Natuna Islands, birds, B159.

Natural history surveys, State, history of, B109.

Naturalists, American, bibliographies of, B20, Baird; 22, Ward; 30, Meek, White, Walcott ; 40, Lawrence; 41, Girard.

Naturforscher, "Hermaphrodite fishes," translation, P441.

Naumannite, P2351.

Navajo. (See under Anthropology, Indians.)

Naval architecture, European, R1891, pt. 3, No. 7 ; Norsk, P583.

Nealley, G. C., plants collected by in Rio Grande region, Tex., CNH1, No. 2.

Nebraska, flora of the sand hills, CNH3, No. 3; Miocene hawks from, P3003; volcanic dust and sand, P497.

Needham, James George, B39o; P1331, 1371.

Needlecases, decorative designs, P1616.

Negroes, crania, P2696.

Nelson, Edward William, P395, 399. Umbelliferae collected in Mexico, $\mathrm{CNH} 3$, No. 5 (1st art.).

Neison, Elias, P1230.

NEMATODES:

Acuariinae, key to genera, P2871.

African animals, roundworm from. P2783.

America, northeast coast, P76.

Ancylostoma pluridentatum, and review of genus $A n c y l o s t o m a$. P2697.

Ascaridia, Tonkin, Indo-China. P2538.

Brazil, from land-tortoise, P2526.

Calcutta Zoological Garden, animals dying from, P2777.

China, P2614.

Cooperia from the carabao, P2765.

eggs from shark, P2588, 2655.

Epomidiostomum from bird, P2864.

Filarioidea, from animals in Calcutta Zoological Garden, P2777.

from Amphibia, P2947.

from bat, P2677. 
Nematodes (continued).

from birds, B140; P893, 2864.

from carabao, P2765.

from fishes, P1560, 2977.

from intestines of mammals, P2723.

from land-tortoise from Brazil, P2526.

from mammals of the Rodentia, Lagomorpha, and Hyracoidea, P2131.

from northwestern belted kingfisher, P2871.

from opossum, P2897.

from prong-horn antelope, P2694.

from rat, P2616.

from Rhea, P2958.

from Rodentia, Lagomorpha, and Hyracoidea, P2131.

from rodents, P2749, 2788.

from sage grouse, P2869.

from sheep, P1892.

from Texas peccary, P2956.

from Virginia deer, P2872.

Gongylonema from domestic swine in United States, P2456.

Hastospiculum, review, P2919.

hookworms (Uncinaria), from carnivores, P2697; from dog, fox, and badger, P2533; from raccoon, P2598.

Indo-China, Tonkin, P2538.

Jamaica, P2527.

larval, Porrocaecum from mammals (Insectivora), P2589.

lungworms from ruminants of North America, P2884.

mermithid, from Jamaica, P2527.

Nematodirus, observations on, with descriptions of new species, P2350.

Nematodirus antilocaprae from antelope, with key to species of Nematodirus, P2694.

new genera, with note on neglected nematode structure, P2386.

new genera and species, P2866.

new internal parasites, P2603.

new parasitic, P1864, 2890.

Ostertagia, new species, P2872.

Ostertagia bullosa, parasitic in sheep, P1892.

Ostertagia lyrata, note on, P2872.

Philippine Islands, P2765.

Porrocaecum from Insectivora, P2589.

Rictularia splendida from coyote, with notes on other coyote parasites, P2012.

roundworms, from African animals, P2783; from domestic swine in U. S., P2456; from rabbit, P2548, 2553.

Sincosta aberrans, from rodent, P2788.

Strongylata, Ascaridata, and Spirurata, bird parasites, B140.
Nematodes (continued).

Strongylidae from intestines of mammals, P2723.

structure, neglected, note on, P2386.

Trichostrongylus from rabbit, P2548.

Uncinaria from dog, fox, and badger, P2533.

Viannaia bursobscura, from opossum, P2897.

Nemerteans, America, northeast coast, P76.

Neocene corals, United States, P1193.

Nephrite, P696.

Nero, steamer, data compiled on oceanography of the Pacific, B55.

Neuroptera. (See under Insects.)

Nevada, andorite-bearing silver ore, P2411.

cyprinoid, Leuciscus turneri from Miocene, P1212.

dragonflies, life history and ecology, P2192.

fish, fossil stickleback, P1528.

flora, $\mathrm{CNH} 25$; Esmeralda formation, P2719.

reptiles, P2078.

sculpin, fossil, P2519.

sponge fauna, early Ordovician, P3126.

New Brunswick, amphipod crustaceans, P2827, 2888; shell mounds, aboriginal, notes on, P229.

New England, Brachyura and Anomura collected by U. S. Fish Commission, P343.

Cladocera, P1848.

Crustacea dredged by U. S. Fish Commission, P172.

fishes, diagnosis of flounders, and genus related to Merlucius, P165; Lopholatilus chamaeleonticeps, P77; obtained by U. S. Fish Commission, P177.

Isopoda, notes on, P75.

mackerel, frigate, Auxis rochei, P183.

marine invertebrates, distributed by National Museum, P230, P231; distributed by U. S. Commission of Fish and Fisheries, P82.

Mollusca, catalog, P169.

shell mounds, aboriginal, notes on, P229.

Thyrsitops violaceus, P658.

(See also under names of New England States.)

New Guinea, new genus and species of percoid fishes, Centropomidae, P3191.

New Hampshire, Sunapee Lake, new species of char, Salvelinus aureolus, P671.

New Jersey, chlorophoenicite, a new arsenite from Franklin, P2669; reptile, Triassic, P2728; serpentine of Montville, P694; sponge, Cretaceous, P2019.

New Mexico, baskets, Basket Maker, P2933. 


\section{New Mexico (continued).}

blue mineral, supposedly ultramarine, Silver City, P978.

botany, bibliography, CNH13, pt. 6 (2d art.).

cotton rat, Sigmodon minima, P994. crustacean, Spilaeroma, P1128.

Diptera, parasitic and predaceous, from northeastern, P2070.

field sparrow, new, P432.

flora, CNH19.

Hemiptera-Heteroptera collected by E. A. Schwarz and H. S. Barber, Las Vegas Hot Springs, P1360.

mammal remains from prehistoric village sites, $\mathrm{P} 1500$.

Orthoptera, notes on, P1333.

Pinna, new Cretaceous, P115.

pit house village at Luna, exploration, P2280.

plants, new, CNH16, pt. 4 ; Triassic, notes on, P821; type localities, CNH13, pt. 6 (1st art.).

Pueblos, culture of ancient, Upper Gila River region, B87.

reptiles, Kirtland formation, P2978. ruminant, Pleistocene, P1447.

wood, fossil, Araucarioxylon arizonicum, P676.

New Orleans. (See under Louisiana.)

New World, chigger mites (Trombiculinae), P2908, 2970; Embioptera, P3175; plant lice, jumping (Psyllidae), monograph of, B85.

New York, crabeater, Elacate canada, lower Hudson Valley, P811.

mammals of Catskill Mountains, with remarks on fauna and flora, P1147.

museums of Albany, Buffalo, and New York City, studies of, R1903, pt. 2, No. 2.

plants of Erian (Devonian), P928.

rocks, serpentinous, New York City and Essex County, P783.

shell beds, Westchester, P351.

New Zealand, recent For aminifera, P2302.

Newberry, John Strong, P306.

Newfoundland, amphipods, P2827, 2888.

Crustacea, fresh-water, P1589.

explorations of Grampus, R1889, pt. 3 , No. 7.

Notacanthus phasganorus, Grand Banks, P184.

Owen Bryant collections:

annelids, P1703.

Bryozoa, P1933.

coelenterates, P1706.

Niagaran strata. (See under Fossils.)

Nias, bats, Rhinolophus, collected by W.

L. Abbott, P1440.

Niblack, Albert Parker, R1888, pt. 3, No. 1; C23; P718.

Nicaragua, ant thrush, new, P1090. birds, P391, 947.
Nicaragua (continued).

Echinomys semispinosus, occurrence, P743.

fishes, collected by L. F. H. Birt, P732.

salamander, new, P1538.

Nichols, Henry E., fishes collected by:

Alaska and British Columbia, P255, 387.

Gulf of California and Lower California, P227.

Mexico, west coast, P221.

Nicobar Islands, birds collected by W. L. Abbott and C. B. Kloss, P1288; mammals, P1269; races of Megapodius nicobariensis, P2278.

Nicoya, Gulf, Costa Rica, birds, P295.

Nierstrasz, Hugo Frederick, and Brender à Brandis, Gerard Abraham, P2832.

Niles, Cornelia, CNH24, pt. 6.

Niuafoou Island. (See under Oceania.)

Noble, Gladwyn Kingsley, and Barbour, Thomas, P2352.

Nomenclator Zoologicus, B19.

Norfolk, Va., to San Francisco, Calif., pteropods and heteropods collected by Albatross, P943.

North Carolina, Annelida Polychaeta, Beaufort, report on, P852.

bear-animalcule from coast, P2203. birds, notes on, P3117.

bornite and chalcocite in copper ores, Virgilina District, P1835.

Caranx beani, P178.

fishes, Beaufort, P55, 550; Cane River and Bollings Creek, P1339.

goby, Garmannia spongicola, P2185. Hadropterus aurantiacus, French Broad River, P504.

invertebrate faunas, Upper Cretaceous, P2706.

meteorite, Hendersonville, notes on composition and structure, P1511; Persimmon Creek, P1380; Rich Mountain, Jackson County, P1524. mollusks from the Miocene, P2759.

olivine-diabase, Davidson County, P1715.

Phycis regius, note on occurrence, P124.

plant covering of Ocracoke Island, CNH5, No. 5 .

plant life of Ellis, Great, Little, and Long Lakes, CNH13, pt. 10 (2d art.).

salamander, new, P1457.

whale, beaked, Mesoplodon mirum, P2007.

North Dakota, Freda, meteorite, P3134.

North Pacific Surveying Expedition, contributions to natural history of Hawaiian and Fanning Islands and Lower California, B7; Phronimidae, P258.

Norway, naval architecture, P583.

Notman, Howard, P2583, 2586.

Nova Scotia, amphipod crustaceans, P2827, 2888. 
Nova Scotia (continued).

annelids, polychaetous, dredged by Owen Bryant, P1703.

Bryozoa collected by Owen Bryant, P1933.

Liparis ranula, Halifax, P65.

Nuculites, Silurian, Washington County,

Maine, P2225.

Nukualofa, echinoderms, P2905.

Nutcrackers. (See under Birds.)

Nuthatches. (See under Birds.)

Nutting, Charles Cleveland, B100, vol. 6, pt. 3 ; SB4; P295, 391, 1171, 1624, 1658, 1923.

birds collected by in Costa Rica, P305.

Nye, W., birds collected by, P420.

Oak. (See under Plants.)

Ober, Frederick A., birds collected by: Antigua and Barbuda, P35.

Dominica, P19.

Grenada, P45.

Guadeloupe, P57.

Lesser Antilles, P61.

Martinique, P51.

St. Vincent, P27.

Oberholser, Harry Church, B86, 98, 159; P1080, 1153, 1180, 1182, 1195-1197. $1258,1271,1276,1281,1352,1354$, $1370,1373,1411,1469,1657,1803$, $1840,1847,1881,1916,1939,2088$, $2090,2106,2121,2175,2230,2232$, $2262,2265,2268,2276,2278,2282$, 2512,3018 .

Obsidian Cliff, Yellowstone National Park, minerals and origin, P2618.

Oceania, design areas in, P2896; echinoderms, Tonga Archipelago, Niuafoou, and Nukualofa, P2905; fishes, P2931.

(See also under Fiji, South Seas, etc.) Ocelots. (See under Mammals.)

Ochs, Georg, P2774.

Odonata. (See under Insects.)

Ogle, Fletcher, and Eigenmann, Carl H. P1556.

Ohio, catalog of harvest spiders (Phalangiidae), $\mathrm{P} 950$.

cloth fragment taken from mound, P347.

Maumee Valley, note on fishes of, P737.

Warren and Clinton Counties, Richmond faunal zones, P2671.

Ohio Valley Centennial Exposition, Cincinnati, contributions of department of transportation and engineering, C38; of section of graphic arts, C37; of section of Oriental antiquities, C39; exhibit by department of prehistoric anthropology, C40; guide to collection illustrating mammals, C41.

Ohshima, Hiroshi, P2073.

Okada, Yaichiro, P2935.

Oken's names of fish genera, P1346.
Okhotsk Sea, birds collected by Albatross, $\mathrm{P} 1727$.

Okinawa, fishes, P1541, 1913.

Oklahoma, cactus, Echinocereus baileyi, CNH12, pt. 9 (7th art.).

plants, late Tertiary, P2256; observations on, CNH1, No. 6 (2d art.).

(See also under Indian Territory.)

Oldhamite in Allegan meteorite, P1622.

Oldroyd, Thomas Shaw, P2535.

Old World, birds in National Museum, catalog of, P234; butterfly, P2934; forficulids and blattids, P1363.

Olenellus zone, new genera and species, P763.

Oligocene. (See under Fossils.)

Oligochaetes, branchiobdellid worms in National Museum, P2267.

discodrilid worm, Colorado, P1912; new genus and species, P2071.

e a rthworms, Burmese, summary, P2781; Chinese, P3040; Diplocardia, Texas, P2549; Lumbricidae, North American, P2174; Megascolecidae, P3009; Moniligastridae, P2263.

Olivine-diabase, Davidson County, N. C., P1715.

Oman, Paul Wilson, P3036.

One Hundredth Meridian, fossil turtles from west of, P1747.

Ontaric formations, Maryand, P1313.

Ontario, Hamilton, dendroid graptolites of the Niagaran dolomites, B65.

Onychophores, Panama and Canal Zone, P3197; West Indies and Central America, P3027.

Onyx marbles, origin, composition, uses, R1893, pt. 2, No. 3 .

Oolites. (See under Petrology.)

Oology. (See under Birds' eggs.)

Opahs. (See under Fishes.)

Ophiurans. (See Echinoderms.)

Opossum. (See under Mammals.)

Orangs. (See under Mammals.)

Orchids. (See under Plants.)

Orcutt, Charles Russell, and Dall, William Healey, P536.

Ordovician. (See under Fossils.)

Oregon, dragonflies, life history and ecology, P2107.

fishes, collected by Charles Bendire, P265; Clackamas River, notes on, P20.

mouse, Phenacomys longicaudus, P826.

plants, fossil, P679; used by Klamath Indians, CNH5, No. 2.

reptile, pterosaurian, Cretaceous, P2745.

"smelt," atherinoid, new species from Yachats River, P1999.

whitefish, Coregonus oregonius, McKenzie River, P1677.

zeolites, Ritter Hot Spring, Grant County, P2737. 
Oregonian faunal area, pyramidellid mollusks, P1574.

Ores. (See under Metallography.)

Oriental plant bugs in National Museum, P3182.

Ornithology, American, use of trinominals, P413.

(See also under Birds.)

Orthoptera. (See under Insects.)

Ortmann, Arnold Edward, P1480, 1591.

Osborn, Henry Fairfield, R1897, vol. 2.

Osborn, Raymond Carroll, P1933.

Osgood, Wilfred Hudson, and Lyon, Marcus Ward, Jr., B62.

[Osten Sacken, Charles Robert, B3.]

Osteology, of Amphipnoidae, P825; of Anguillidae, P803; of Antigoniidae, P1297; of Antrodemus (Allosaurus) and Ceratosaurus, B110; of Baptornis, Diatryma, Hargeria, Hesperornis, P1320; of berycoid fishes, P1366; of Desmostylus and Cornquallius, P2521; of Dinolestes lewini, P1186; of hemibranchiate fishes, P1301; of Hemitripteridae, P835; of jerboas and jumpingmice, P1228; of Lutjaninae, P444; of Muraenosocidae, P815; of Nothura maculosa, P622; of Opheosaurus ventralis, P245; of Paridae, Psitta, and Chamaea, P830; of Percesoces, P1179; of Polyglyphanodon, P3148; of Procniatidae, P1077; of Simenchelyidae, P817; of Sinopa, P1449; of spotted tinamou, P622; of Steganopodes and Tubinares, P713; of Stegosaurus, B89; of Synaphobranchidae, P804; of thrushes, Miminae, and wrens, P704; of Triceratops, $\mathrm{P} 2260$; skeletons of Dimetrodon gigas, P2300; of Diplodocus, P2941; preparation, B39c; C33.

Ostracods. (See under Crustaceans; also under Fossils, Crustaceans.)

Otaki, Keinosuke, fishes collected in Japan, P1213.

Ovenbirds. (See under Birds.)

Owls. (See under Birds; also under Fossils, birds.)

Oyster, pearl. (See under Mollusks.)

Oystercatcher. (See under Birds.)

Ozark Mountains, fresh-water shells, P2126.

Ozawa, Yoshiaki, and Cushman, Joseph Augustine, P2829.

Pacific Islands, plants, B7; botanical bibliography, CNH30, pt. 1 .

Pacific Ocean, birds recorded by Pinchot Expedition, P2876. cephalopods, P1838.

chub-mackerels, comparison with

those of Atlantic Ocean, P1748. crustaceans, Albuneidae, P1367. oceanography, contribution to, B55. shells, new, P2002.
Pacific Ocean, north, Asteroidea, B76.

barnacles, P3081.

birds collected by Albatross, P1727.

capelin, Mallotus catervarius, redescription, P3029.

Chrysodomus and other mollusks, P2234.

crinoids, P1543, 1559.

diatoms of Albatross voyages, $\mathrm{CNH} 10$, pt. 5.

Foraminifera, monograph, B71.

hydrocorals, P3024.

Mollusca, new, P2295.

ophiurans in National Museum, B75.

worms, echiuroid, P3198.

Pacific Ocean, northeastern, annelids, Nephtyidae, P3034.

ascidians, simple, in National MuP1989.

fishes collected by International Fisheries Commission, P3062.

Pacific Ocean, northwestern, cephalopods, collected by Albatross, P2310.

chitons, collected by Albatross, P2223.

holothurians collected by Albatross, P2073.

isopods, collected by Albatross, P1701; Dajidae, P1586.

Janiridae, new genus and species of, P1843.

medusae and siphonophorae collected by Albatross, P1946.

sponges, collected by Albatross, P2247, 2935.

Pacific Ocean, tropical, apodal fishes collected by the Albatross, P856.

Foraminifera (Astrorhizidae to Trochamminidae), B161, pt. 1; Lagenidae to Alveolinellidae, B161, pt. 2; Heterohelicidae and Buliminidae, B161, pt. 3.

Pacific Ocean, western, cottid fishes from, with revision of Stlengis, P2987.

Packard, Robert L., P978.

Paine, John Howard, P2201.

Painter, Joseph Hannum, CNH13, pt. 10 (2d arr.).

Paleocene. (See under Fossils.)

Paleolithic. (See under Anthropology.)

Paleontology. (See under Fossils.)

Paleozoic. (See under Fossils.)

Palestine, Medeba mosaic map, drawing in National Museum, P2111.

Paligorskite from Utah, P2758.

Pallasite from Cold Bay, Alaska, P2425.

Palmer, Edward, plant collections:

Arizona, CNH1, No. 4 (1st and 2d arts.).

California, CNH1, No. 8 (7th art.).

Carmen Island, CNH1, No. 5 (1st art.).

Lower California, CNH1, No. 1 (2d art.), No. 3 ; P749.

Mexico, CNH1, No. 4 (1st art.); No. 8 (7th art.); No. 9 (1st art.). 
Palmer, William, P819, 1669. bats collected by in Cuba, P1359. fishes collected by in Java, P1919. insects collected by in Java, P2675.

Palms. (See under Plants; also under Fossils, plants.)

Pamlico, echinoids, P3113.

Pan American Exposition. (See under Buffalo.)

Panama, annelid, polychaetous, P2186. batrachians, P1857.

bats, P1882.

chigger mites, Trombicula, P2970. culture of people of southeastern Panama, B134.

fishes, collected by Albatross, P840; collected by F. H. Bradley, in Yale University Museum, P329; collected by J. M. Dow, P292; collected by Rev. Rowell, P294; $M$ y. rophis vafer and Chloroscombrus orqueta, P334.

geology and paleontology, contribu. ticns to, B103: fossil decapod crustaceans, pt. 7 ; biologic character and geologic correlation of sedimentary formations, pt. 11.

isopods, Cubaris, P1911; Livoneca, P1430, 1891; Pelaegyge and Probopyrus, P1914.

Microlepidoptera, new genera and species, P2043.

mollusks, new marine, with figure of Engina, P2881.

mosses, new or interesting, CNH16, pt. 1 (4th art.).

onychophores, P3197.

Piperaceae, CNH26, pt. 2.

Rotatoria, report on, P2062.

Sciaena sciera, P452.

shells, new marine, P2250.

snake, new, P1681.

Thalassophryne dowi, P639.

Urolophus asterias, P327.

Panama Canal, comparison of sponges near Pacific end with those at Caribbean end, P2993.

Panama Canal Zone. (See under Canal Zone.)

Panthers'. (See under Mammals.)

Paraguay, Acrididae, synoptic list, P1461. birds, collected by W. T. Foster, P1281; observations on, B133.

Locustidae and Gryllidae collected by W. T. Foster, P1450.

Paris Exposition, anthropology at, R1890, pt. 3, No. 10.

Parish-Smithsonian Expedition, Cuba and Haiti, birds, P2925.

Parker, Frances Lawrence, and Cushman, Joseph Augustine, P2903.

Parker, John Bernard, P2173, 2776.

Parker, J. B., and Böving, Adam Glede, P2513.

Parker, Ralph Robinson, P2227.

Parr, Albert Eide, P2807.

Parrots. (See under Birds.)
Parsee religious ceremonial objects in National Museum, P2432.

Partridges. (See under Birds.)

Patagonia, ferns, CNH1, No. 5 (2d art.$3)$.

isopods, Jaeropsis, new species of, P1675; Notasellus, from east coast, P1720.

lichens, CNH1, No. 5 (2d art.-6).

liverworts, CNH1, No. 5 (2d art.-5). mosses, CNH1, No. 5 ( $2 \mathrm{~d}$ art. -4 ).

Pate, William Franklin, and Bassler, Ray Smith, P1621.

Patella in birds, P439.

Patera of Rennes, R1894, pt. 2, No. 3.

Payson, Edwin Blake, CNH20, pt. 4.

Peale, Albert Charles, B53, pt. 2, sect. 3.

Pearl mussel investigations on the Mismissippi River, dragonflies, P1692.

Pearse, Arthur Sperry, P1594, 1936, 1998, 2123, 2381, 2924, 3044.

Pearse, A. S., and Walker, Henry Atchinson, P3067.

Peccaries. (See under Mammals; also under Fossils, Mammals.)

Peck, James Ingraham, P943.

"Peckhamite" in Estherville, Iowa, meteorite, P2341.

Pelicans. (See under Birds.)

Pembroke formation, Washington County, Maine, fossils, P1985.

Penhallow, David Pearce, P928, 929.

Pennell, Francis Whittier, CNH20, pt. 9.

Penney, James Theophilus, P2965.

Penney, J. T., and Wilson, Henry Van Peters, P2805.

Pennsylvania, cinnamon bear, P338. meteorite, Chicora, Butler County, P3111.

oolite, Bethlehem, P2102.

Philadelphia, International Exhibition, classification of collection to illustrate animal resources of United States, B6, 14.

plants, notes on Erian (Devonian), P928; Triassic, P2154. rocks, serpentinous, Easton, P783. sandstone, Potsdam, Berks County, note on, P341.

Pentremite, new American, P1467.

Perch. (See under Fishes.)

Peridotite, Little Deer Isle, Penobscot Bay, Maine, P707.

Perkins, Janet Russell, CNH10, pt. 4.

Permian, lower, insect, Grand Canyon, P2695.

Perry, Stuart Hoffman, B184.

Perry, Stuart H., and Henderson, Edward Porter, P3134.

Persepolis, casts in National Museum, R1893, pt. 2, No. 8.

Peru, amphibians and reptiles, Yale University-National Geographic Society Expedition, P2352.

amphipods, P1767, 1768.

barnacles, collected by R. E. Coker et al., P1700. 
PERU (continued).

batrachians and reptiles, Yale Expedition, P1992.

bird life, distribution in Urubamba Valley, B117.

birds, guano, habits and economic relations, P2298.

fish scales, fossil, P2355.

fishes, collected by P. O. Simons, P1468; shore fishes, catalog of, B189: west coast and Titicaca Basin, B95.

grasses, $\mathrm{CNH} 24$, pt. 8.

Hymenoptera, Yale Expedition, P1960, 1964, 2052.

isopods, collected by R. E. Coker, P1729.

Lepidoptera, Yale Expedition, P2006.

lizard, amphisbaenoid, P1856.

Mammalia, collected by E. Heller, Yale University-National Geographic Society Expedition, P2333.

Muscisaxicola, new, Lake Titicaca, P643.

mussels, fossil, Upper Amazon, P2748.

Orthoptera, Yale Expedition, P1949, 1956, 2001.

palm fruit, middle Eocene, P2652.

plants, Miocene, P2270.

shells, collected by Hiram Bingham, P1736; report on, with summary of littoral marine Mollusca, P1704.

skeletal remains, Chicama, Moche, and Virú Valleys, P3160.

slings, ancient, in National Museum, P2275.

Peru and adjacent coast, stalk-eyed Crustacea, P1766.

Petrels. (See under Birds.)

Petrified Forest National Monument, Ariz., Triassic insects, P3033.

Petrography:

Colorado, Italian Mountain, P2690.

lamprophyric dike rocks of Coeur d'Alene mining district, P2318.

limestone conglomerate, Triassic of Leesburg, Va., P2565.

United States-Mexico boundary, P1173.

Petroleum. (See under Mineral industries and under Mineralogy.)

Petrology:

basalt, Columbia River, siderite from, P2458.

carbonic acid tests on weathering of marbles and limestones, P2108.

cave pearls in Carlsbad Caverns, P2813.

crystalline schists of the District of Columbia, P363.

diabase, intrusive Triassic, Goose Creek, Loudoun County, Va., P2539; Mesozoic, Atlantic border, P205.

glasses, sporadic, supposed origin, P1833.
Petrology (continued).

granites, black nodules in Maine, P354.

limestones and marbles, carbonic acid tests on weathering, P2108.

onyx marbles, origin, composition, uses, R1893, pt. 2, No. 3.

oolites, Bethlehem, Pa., P2102; Carlsbad Caverns, P2813.

rocks, eruptive, from Gallatin, Jefferson, and Madison Counties, Mont., P1031; serpentinous, Essex County and New York City, N. Y., and near Easton, Pa., P783.

sandstone, metamorphism in siliceous, P1546; phosphatic, from Florida, P263; Potsdam, Berks County, Pa., P341.

sandstone concretions, formation, P987.

serpentine of Montville, N. J., P694. stalactites and gypsum incrustations in caves, P985.

Petropaulovski, birds collected at by $L$. Stejneger, P345.

Phalaropes. (See under Birds.)

Pheasants. (See under Birds.)

Philadelphia, International Exhibition, classification of collection to illustrate animal resources of United States, B6, 14.

Philately. (See under Stamps.)

Philip, Hoffman, Abyssinian ethnological collection, P1819.

Philippine Islands, annelids, polychaetous, Albatross, B100, vol. 1, pts. 8,9 ; vol. 6 , pts. 2 , 5 .

ascidians, Albatross, B100, vol. 1, pt. 2.

barnacles, Albatross, P1904.

beetles, buprestid, new, P2438; fungus, Endomychidae, P3168.

birds, collected by Paul Bartsch, P1683; list of, P1679; Philippine and Palawan Islands, P1134.

Bryozoa, Albatross, B100, vol. 9.

Calcarina, Tinoporus, and Baculogypsina, relationships, Albatross, B100, vol. 1, pt. 6 .

Chaetognatha, report on, Albatross, B100, vol. 1, pt. 4 .

crabs, Goneplacidae, Albatross, P2067; Grapsidae and Ocypodidae, Albatross, P2044; Inachidae and Parthenopidae, Albatross, P2135.

crinoids, Proisocrinus, Albatross, P1756; Recent, P1673; unstalked, P1798, 1849.

crustaceans, euphausiacean, Albatross, P2129.

diatoms, marine, Albatross, B100, vol. 6 , pt. 1.

Echinoidea, Albatross, B100, vol. 6, pt. 4 ; vol. 14 , pt. 1 .

Eucalyptus, identification of species, P1327. 
Phimprine Islands (continued).

fishes, P2448.

anacanthine, Albatross, P1924.

$A$ mia, Cheilodipteridae, Albatross, P1853.

Amiidae, Chandidae, Duleidae, and Serranidae, B100, vol. 10.

Banjosidae, Lethrinidae, Sparidae, Girellidae, Kyphosidae, Opleg. nathidae, Gerridae, Mullidae, Emmelichthyidae, Sciaenidae, Sillaginidae, Arripidae, and Enoplosidae, Albatross, B100, vol. 12.

Brotulidae and Carapidae, Albatross, P1948.

Callionymidae, Albatross, P3106.

Capriformes, Ephippiformes, and Squamipennes, Albatross, B100, vol. 8.

Chaetodontidae, Albatross, P1822.

Cheilodipteridae, Albatross, P1868.

chimaerioid, Albatross, P1899.

collected by Bashford Dean, Negros, P1407.

collected by E. A. Mearns, P1491, 1568.

Elasmobranchii, Holocephali, Isospondyii, and Ostarophysi, Albatross, B100, vol. 13.

macrouroid, Albatross, B100, vol. 1 , pt. 7.

new species obtained by Albatross, B100, vol. 14, pt. 2; P3032.

pediculate, Albatross, P1896.

Pomacentridae, Labridae, and Callyodontidae, Albatross, B100, vol. 7.

Pseudochromidae, Lobotidae, Pempheridae, Priacanthidae, Lutjanidae, Pomadasyidae, and Teraponidae, Albatross, B100, vol. 11.

flies, Cyrtidae, P2705; sapromyzid, P2751; Sarcophaga, P2227.

Foraminifera, Albatross, B100, vol. 4; P1759, 1898, 1973, 2172.

frogs and gecko, new, P1397.

Hydroida collected in the region, Albatross, B100, vol. 6, pt. 3 .

hydromedusae, siphonophores, and ctenophores, Albatross, B100, vol. 1 , pt. 5.

Hymenoptera, P1387, 1413, 1416, 1424, 1722, 1733.

lizards, new, P1576, 1583, 1606, 1776.

mammals, land, in National Museum, P2028; new genera and species, P1402, 1757.

medusae, Albatross, P1931.

mollusks, Amphidromus, Albatross, B100, vol. 1, pt. 1.

Cochlostyla, Mindoro Province, Albatross, B100, vol. 6, pt. 9.

Cochlostyla rufogaster and Obba marmorata, Albatross, B100, vol. 6, pt. 7 .
PhilipPine IsLANDS, mollusks

(Continued).

Dimya, Albatross, P1983.

land, new, P1705, 1993, 2272.

Lima, giant species, Albatross, P1978.

Luzón, P2848.

Obba, Mindoro Province, Albatross, B100, vol. 6 , pt. 8 .

Obba marmorata, Albatross, B100, vol. 6 , pt. 7 .

Opisthoporus, Albatross, B100, rol. 6, pt. 6.

Planorbis, P1512.

Schistoloma, P2104.

Vivipara, notes on, P1518, 1709.

ophiurans, Albatross, B100, vol. 5.

Salpidae, Albatross, B100, vol. 2, pt. 1.

Scyphomedusae, Albatross, B100, vol. 1 , pt. 3.

shark, notidanoid, representing new family, Albatross, P1872; hemiscylliid, with description of new species from China Sea, P1997; squaloid, Albatross, P1877.

shipworms, Albatross, B100, vol. 2, pt. 5.

sponges, fresh-water, Albatross, P1702; in National Museum, P1690; siliceous and horny, Albatross, B100, vol. 2, pt. 4.

starfishes, Albatross, B100, vol. 3; P1827, 1944, 2022.

titmouse, elegant, Pardaliparus elegans, geographical forms, P2142.

toads, new, P1578.

turbellarians, polyclad, Albatross, B100, vol. 1, pt. 10.

weapons and armor, primitive, in National Museum, B137.

weevils, Eurhoptodes, new genus, P3100.

Phillips, Barnet, C10.

Phillips, William Jeter, and Emery, Walter Titus, P2281.

Phlox. (See under Plants.)

Phoenix Islands, fishes collected by U.S.S. Bushnell Expedition, B180.

Phyllopods. (See under Crustaceans.)

Picado, C., terrestrial isopods collected in Costa Rica, P1954.

Pierce, William Dwight, B66; P1604, 1708. 1834, 1889, 1988, 2159, 2242, 2840.

Pigeons. (See under Birds.)

Pigs. (See under Mammals.)

Pilsbry, Henry Augustus, B60, 93, 103, pt. 8; P1700, 1904, 2362, 2515, 2960.

Pinchot South Seas Expedition, birds, P2876; fishes, P2906; Orthoptera, P2921.

Pipefishes. (See under Fishes.)

Piper, Charles Vancouver, CNH10, pt. $1 ; 11 ; 16$, pt. 5 (1st to 4 th arts.) ; 20 , pts. 11,$14 ; 22$, pts. 2,9 .

Pipes and smoking customs among American aborigines, R1897, pt. 2, No. 2. 
Pipits. (See under Birds.)

Pirz, Anthony, P226.

Pittier, Henri, CNH12, pt. 2 (1st and $2 \mathrm{~d}$ arts.) pts. 4, 5; $\mathrm{CNH} 13$, pts. 4, 7, 12 ; CNH18, pts. 2, 4, 5, 6; CNH20, pts. 2, 3, 12; CNH26, pt. 1.

PLANTS:

aboriginal uses, B39j; CNH7, No. 3.

Acacia, new species of the Filicinae, CNH12, pt. 9 (10th art.).

A canthospermum, revision, $\mathrm{CNH} 20$, pt. 10 (1st art.).

acorns, gallflies producing galls on, P2440.

Adopogon, revision, CNH13, pt. 10 , art. 4.

Alabama, CNH6.

Alaska, CNH13, pt. 3; P397, 772; Nushagak, P513; Yakutat Bay, $\mathrm{CNH} 3$, No. 6.

Albatross collections. (See under $\mathrm{Al}$ batross, plants.)

Aldabra Island, P973.

algae, collecting, B39b; Cumberland Sound, B15; Lithothamnieae, Canal Zone, B103, pt. 1; marine, West Indies, CNH28, pt. 3.

Allioniaceae, Central American and Mexican, CNH13, pt. 11; United States, with notes on Mexican species, CNH12, pt. 8.

Allocarya, CNH22, pt. 2.

Alopecurus stejnegeri, Commander Islands, P620.

America, tropical, $\mathrm{CNH} 29$, pt. 1 ; ferns, CNH10, pt. 7 ; 13 , pt. 1 ; 16 , pt. $2 ; 17$, pts. $2,4,7 ; 24$, pt. 2 ; phanerogams, $\mathrm{CNH} 17$, pt. 5 ; 18 , pt. $3 ; 20$, pt. 6 .

Andes, CNH26, pts. 8, 10.

Anhalonium, revision, $\mathrm{CNH} 3$, No. 2 .

Annona, classification, CNH18, pt. 1.

Annona sericea and allies, CNH16, pt. 10.

Annonaceae (Raimondia), Colombian, CNH16, pt. 5 (6th art.).

Antennaria, revision, P1230.

Anthoxanthum odoratum, notes on flowers, P910.

Apetalae, western Texas, CNH2, No. 3.

Apocynaceae, Tonduzia, Central American, $\mathrm{CNH} 12$, pt. 2 (2d art.).

Aquilegia, North American, CNH20, pt. 4.

Aristida, North American, CNH22, pt. 7.

Arizona, CNH1, No. 4 (1st and 2d arts.); 12 , pt. 9 (6th art.).

Asia, Pteridophyta, CNH26, pt. 6.

Asplenium andrewsii, relationship, CNH16, pt. 1 (1st art.).

Asteraceae, American, CNH22, pt. $8 ; 26$, pt. 5 ; Mexican and south-
Plants, Asteracae (continued). western United States, CNH29, pt. 2 , art. 2 .

Asterella, North American species, CNH20, pt. 8.

Atlantic Ocean, off Delaware Bay, Diatomaceae, P937.

Baccharidinae, new genus of, $\mathrm{CNH} 20$, pt. 13 (3d art.).

Berberis aquifolium and $B$. repens, identification, $\mathrm{CNH} 20$, pt. 11 .

Bering Island, P462.

Bermudas, B25, pt. 2.

Besleria, revision, CNH26, pt. 9.

Bibliography, botanical, Pacific Islands, CNH30, pt. 1.

Bignoniaceae-Asteraceae, Mexican, CNH23, pt. 5.

Bolivia, CNH24, pt. 8.

Botrychium virginianum and forms, CNH16, pt. 13 (1st art.).

Bouteloua and related genera, CNH14, pt. 3.

Brachiaria, North American species, CNH22, pt. 1 (3d art.).

Brazil, P2534.

British America, grasses, CNH3, No. 1.

British Guiana, CNH22, pt. 6.

Bromeliaceae, Psychodidae from, P2015.

cacao, branching and flowering habits, $\mathrm{CNH} 17$, pt. 8.

Cactaceae, studies, CNH16, pt. 7.

cactus, Chalcidoidea parasitic on cactus insects, P2995.

Guatemala, CNH12, pt. 9 (8th art.).

Oklahoma, CNH12, pt. 9 (7th art.).

Phycitinae feeding from, P3053.

Cactus, revision of species, CNH3, No. 2.

Caesalpiniaceae, new genus of, CNH12, pt. 9 (9th art.).

California, CNH1, No. 8 (7th art.); 13, pt. 10 (1st art.); Mendocino County, CNH7, No. 3 ; southern, CNH1, No. 1 (1st art.); 17 , pt. 1.

Calochortus, revision of subgenus Cyclobothra, CNH13, pt. 10 (3d art.).

Canal Zone, B103, pt. 1 ; CNH27.

Canavalia, American, $\mathrm{CNH} 20$, pt. 14.

Caperonia palustris, CNH16, pt. 13 (2d art.).

Carmen Island, CNH1, No. 5 (1st art.).

Castilla, treatment of, CNH13, pt. 7.

Cenchrus, North American species, CNH22, pt. 1 (4th art.).

Central America, CNH12, pt. 2 (2d art.), pt. $4 ; 13$, pt. $11 ; 20$, pt. 1 ; 24 , pt. $9 ; 26$, pt. 1.

new or noteworthy, CNH12, pt. $5 ; 13$, pts. 4,$12 ; 18$, pts. 2,4 , 6 ; 20, pts. 3,12 . 
Plants, Central America (continued). studies of, CNH5, Nos. 3, 4 (1st art.) ; 8, pts. 1,4 ; 10 , pt. 3 ; 12 , pt. $7 ; 13$, pt. 9 .

Cereus, North American, $\mathrm{CNH} 3$, No. $7 ; 12$, pt. 10 (1st art.).

Cereus nudiflorus, rediscovery, CNH12, pt. 9 (4th art.).

Chaetochloa, North American, CNH22, pt. 3 (4th art.).

China, CNH12, pt. 9 (11th art.); Kansu Province, CNH28, pt. 4.

Clarion Island, P801.

Cocos Island, CNH1, No. 5 (2d art.-1).

collecting, directions for, B39b, 39j.

Colombia, CNH12, pt. $5 ; 13$, pts. 4 , $12 ; 16$, pt. 5 (6th art.), pt. $6 ; 18$, pts. $2,4,6 ; 20$, pts. 3,12 .

Colorado, CNH1, No. 8 (4th art.).

Columbia River region, $\mathrm{CNH}_{3}$, No. 9 (4th art.).

Commander Islands, P462, 463, 620.

Commelinaceae, new genus of (Treleasea), CNH5, No. 4 (5th art.).

Conzattia, new genus of Caesalpiniaceae, CNH12, pt. 9 (9th art.).

Copper Island, P462.

Costa Rica, CNH10, pt. 6 ; 12 , pt. 2 (1st art.) ; 26, pts. 3, 4 .

cotton fiber presented to the National Museum, P250.

cotton husbandry in Japan, P251.

Crassulaceae, Guatemalan, CNH12, pt. 9 (3d art.) ; Mexican, CNH12, pt. 9 (1st art.), pt. 10 (2d art.).

Crepis occidentalis and allies, CNH3, No. 9 (2d art.).

Cuba, CNH12, pt. 6.

Cucurbitaceae, new genus of from Mexico, CNH3, No. 9 (5th art.); Tumamoca, CNH16, pt. 1 (3d art.).

Cumberland Sound, Annanactook Harbor, B15.

Cyclobothra, subgenus of Calochortus, revision, $\mathrm{CNH} 13$, pt. 10 (3d art.).

Cymbia, revision, CNH13, pt. 10 (4th art.).

Cynthia, revision, $\mathrm{CNH} 13$, pt. 10 (4th art.).

Cyperaceae, Costa Rica, CNH10, pt. 6.

Death Valley, CNH4.

Delphinium simplex and allies, CNH16, pt. 5 (2d art.).

Diatomaceae, Atlantic, off Delaware Bay, P937.

diatoms, collecting and preparing, P2410; Pacific Ocean, CNH10, pt. 5 ; Philippine, B100, vol. 6, pt. 1.

Diplostephium, key, CNH24, pt. 3.

Dismal Swamp region, CNH5, No. 6.

District of Columbia, B22; C46, CNH21.
Plants (continued)

Echeveria, Mexican, CNH13, pt. 2.

Echeveria carnicolor, rediscovery, CNH12, pt. 9 (2d art.).

Echinocactus, North American, CNH3, No. 7.

Echinocereus baileyi, Oklahoma, CNH12, pt. 9 (7th art.).

Echinochloa, North American species, $\mathrm{CNH} 22$, pt. 3 (3d art.).

Ecuador, CNH24, pts. 5, 8.

Epiphyllum and allies, CNH16, pt. 9.

Eucalyptus, Philippine, P1327.

Fagaceae-Fabaceae, Mexican, $\mathrm{CNH} 23$, pt. 2.

ferns, Jamaican, P1374.

Mexican, P1379.

Patagonian, CNH1, No. 5 (2d art.$3)$.

tropical American, CNH10, pt. 7 ; 13 , pt. $1 ; 16$, pt. $2 ; 17$, pts. 2,4 , $7 ; 24$, pt. 2 .

ferns and fern allies, America north of Mexico, P1226.

Festuca, North American species, CNH10, pt. 1 ; 16 , pt. 5 (1st art.).

Ficus, Mexican and Central American, CNH20, pt. 1.

Filicinae, new Acacia, CNH12, pt. 9 (10th art.).

Florida, CNH1, No. 8 (5th art.).

Florida Keys, CNH16, pt. 8.

Flourensia, revision, CNH20, pt. 10 (2d art.).

food of scale insects (Coccidae), P1122.

food of Thysanoptera, P2008.

Fuegia, CNH1, No. 5 (2d art.-4).

Galápagos Islands, CNH1, No. 5 (2d art.-2).

Gamopetalae, western Texas, CNH2, No. 2.

Georgia, P1428.

Gleicheniaceae-Betulaceae, Mexican, CNH23, pt. 1.

Gloriosa Island, P973.

goldenrod, United States, CNH16, pt. 5 (7th art.).

Gongylocarpeae, monograph, CNH16, pt. 12.

Goniophlebium pringlei, Mexico, P1379.

grasses, Alaskan, $\mathrm{CNH} 13$, pt. 3. American types, CNH12, pt. 3.

British Guiana, CNH22, pt. 6.

Central American, $\mathrm{CNH} 24$, pt. 9.

Commander Islands, P620.

Cuban, CNH12, pt. 6.

Ecuadorean, Peruvian, Bolivian, CNH24, pt. 8.

grama, CNH14, pt. 3.

Mexican, CNH1, No. 8 (3d art); 17 , pt. 3.

North America, Pacific coast, CNH1, No. 8 (1st art.); revision of, CNH22, pt. 1 (1st-4th arts.), pt. 3 . 
Plants, grasses (continued).

United States, CNH1, No. 8 (2d art.).

United States and British American, $\mathrm{CNH} 3$, No. 1.

West Indian, $\mathrm{CNH} 18$, pt. 7.

Greenland, Disko Island, B15.

Guam, CNH9.

Guatemala, CNH8, pt. 3 ; 12 , pt. 9 (3d, 5th, 8th arts.) ; 24, pts. 1, 4. Gyrophoraceae, California, CNH13, pt. 10 (1st art.).

Harperella, new species of, CNH13, pt. 8 ( $2 \mathrm{~d}$ art.).

Hauyeae, monograph, CNH16, pt. 12.

Hemibaccharis, new genus of $\mathrm{Bac}$ charidinae, CNH20, pt. 13 (3d art.).

Hesperogenia, Mount Rainier, CNH5, No. 4 (3d art.).

Heuchera cylindrica, identity, CNH16, pt. 5 (3d art.).

Hoffmanseggia, North American, CNH1, No. 5 (3d art.).

Homalium, American, CNH20, pt. 7 (1st art.).

Honduras, $\mathrm{CNH} 24$, pts. 1, 4.

Hydrocotyle americana, P741.

Hymenophyllium, American species, CNH29, pt. 3.

Ichnanthus, North American species, CNH22, pt. 1 (1st art.).

Idaho, Coeur d'Alene Mountains, CNH5, No. 1; northern Idaho, CNH3, No. 4.

Illinois and Indiana, Lower Wabash and White River Valleys, P264.

Indian Territory, CNH1, No. 6 (1st art.).

Inga, revision, CNH18, pt. 5 .

Irarteaceae, Colombian, CNH16, pt. 6.

Isachne, North American species, CNH22, pt. 3 (1st art.).

Jamaica, P1374.

Japan, P250, 251, 745.

jumping seeds and galls, P330.

Kansas, southwestern, CNH3, No. 9 (1st art.).

Kerguelen Island, B3.

Krigia, revision, $\mathrm{CNH} 13$, pt. 10 (4th art.).

Labrador, P353.

Lasiacis, North American, CNH22, pt. 1 (2d art.).

Lecythidaceae, Central American, CNH26, pt. 1 ; Costa Rica, CNH12, pt. 2 (1st art.).

Leguminosae, Puerto Rican, $\mathrm{CNH} 10$, pt. 4.

Leibergia, Columbia River region, CNH3, No. 9 (4th art.).

lichens, Alaska, P397.

California, CNH17, pt. 1.

California and Mexico, CNH1, No. 8 (7th art.).
Plants, lichens (continued).

Cumberland Sound, Annanactook Harbor, B15.

Minnesota, CNH14, pt. 1.

Patagonia, CNH1, No. 5 (2d art.6).

Liriodendron, notes on the leaves, P794.

Lithothamnieae, Canal Zone, B103.

liverworts, southern Patagonia, CNH1, No. 5 (2d art.-5).

Lonchocarpus, Middle American, CNH20, pt. 2.

Lophophora, revision, CNH3, No. 2.

Lower California, CNH1, No. 1 (2d art.), No. 3, No. 9, (2nd art.) ; 13, pt. 10 (6th art.); 16, pt. 14; P725, 749.

maize, apogamy in, CNH12, pt. 10 (4th art.).

Manihot, injured by Chloropidae, P2534.

Meibomia, American species, CNH16, pt. 5, art. 5 .

Mexico, CNH1, No. 8 (3rd and 7 th arts.) ; 3 , No. 5 , pt. 2 ; 5 , No. 3 , No. 4 (1st art., 6th art.) ; 8, pts. 1,3 , and $4 ; 10$, pts. 2 and $3 ; 12$, pt. 4, pt. 7, pt. 9 (1st art.), pt. 10 (2d art.) ; 13, pt. 8 (1st art.), pt. 9 , pt. $11 ; 17$, pt. $3 ; 20$, pt. 1 ; 23 ; vol. 26 , pt. 7 ; 29 , pt. 2 (1st and 2d arts.) ; P1427, 1429. Acapulco, CNH3, No. 9 (5th art.). Oaxaca, CNH3, No. 5 (1st art.). Sonora and Colima, CNH1, No. 9 (1st art.).

southern, CNH13, pt. 2 .

western, CNH1, No. 3, No. 4 (1st art.); No. 9 (2d art.).

Middle America, CNH20, pt. 2.

Minnesota, CNH14, pt. 1 .

Mongolia, southern, CNH28, pt. 4.

Monocotyledonae, western Texas, CNH2, No. 3.

Montana, Glacier National Park, CNH22, pt. 5 .

mosses, Costa Rica, CNH26, pt. 3; Fuegia and Patagonia, CNH1, No. 5 (2d art.-5); Panama, CNH16, pt. 1 (4th art.).

Mount Rainier, CNH5, No. 4 (3d art.).

Nebraska sand hills, CNH3, No. 3.

Nephromeria (section), species of Meibomia, CNH16, pt. 5, art. 5. CNH16, pt. 5, art. 5 .

Nevada, CNH25.

new, descriptions of, CNH1, No. 8 (6th art.).

New Mexico, CNH13, pt. 6 (1st and 2 d arts.) ; 16, pt. 4; 19.

New York, Catskill Mountains, P1147.

Nopalea lutea, Guatemala, CNH12, pt. 9 (8th art.). 
Plants (continued).

North Carolina, Ellis, Great, Little, and Long Lakes, CNH13, pt. 10 (2d art.); Ocracoke Island, CNH5, No. 5.

Nymphaea, North American species, CNH16, pt. 3.

oak, gallflies producing subterranean galls on, P2368.

Oklahoma, CNH1, No. 6 (2d art.); 12 , pt. 9 (7th art.).

Onagraceae, monograph of Hauyeae and Gongylocarpeae, CNH16, pt. 12.

Oplismenus, North American species, CNH22, pt. 3 (2d art.).

Opuntia, Arizona, CNH12, pt. 9 (6th art.); revision, $\mathrm{CNH} 3$, No. 7. orchids, Mordellidae from, P3016.

Oregon, CNH5, No. 2.

Oxalidaceae-Turneraceae, Mexican, CNH23, pt. 3.

Oyedaea, revision, $\mathrm{CNH} 20$, pt. 10 (3d art.).

Pacific coast, CNH1, No. 8 (1st art.) ; 16 , pt. 5 (4th art.).

Pacific islands, bibliography, CNH30, pt. 1 ; B7.

palms, American, key to families, CNH16, pt. 8.

cocoa, origin and distribution, CNH7, No. 2.

coconut, history of American, CNH14, pt. 2.

false date, Florida Keys, CNH16, pt. 8.

ivory, relationships, CNH13, pt. 5 . stilt, Colombia, CNH16, pt. 6.

Panama, CNH16, pt. 1 (4th art.); 26 , pt. 2.

Panicum, North American, CNH15; 17 , pt. 6.

Paspalum, North American, CNH28, pt. 1.

Passifloraceae-Scrophulariaceae, Mexican, CNH23, pt. 4.

Patagonia, CNH1, No. 5 (2d art.-3 and 4); southern, CNH1, No. 5 (2d art.-5 and 6).

patashte, branching and flowering habits, CNH17, pt. 8.

Pennisetum, North American, $\mathrm{CNH} 22$, pt. 4.

Pereskia, Guatemalan, CNH12, pt. 9 (5th art.).

Peru, CNH24, pt. 8.

Phanerogams, Mexican, CNH29, pt. 2 (1st art.).

North American, CNH1, No. 5 (4th art.); No. 7. tropical American, CNH17, pt. 5; CNH18, pt. 3 ; CNH20, pt. 6. western Texas, CNH2.

Phaseolineae, American, CNH22, pt. 9.

Philippine Islands, B100, vol. 6, pt. 1 ; P1327.
Plants (continued).

phlox, cecidomyiid flies from, P3120.

Pilea, Andean, $\mathrm{CNH} 26$, pts. 8, 10.

Piperaceae, Costa Rican, CNH26, pt. 4 ; Panama, CNH26, pt. 2.

Polypetalae, western Texas, $\mathrm{CNH} 2$, No. 1.

Polypodium, Jamaican, P1374; Mexican and Guatemalan, CNH8, pt. 3.

Ptelea, United States and Mexican, CNH10, pt. 2.

Pteridophyta, Asian, CNH26, pt. 6; North American, CNH1, No. 5 (4th art.), No. 7; western Texas, $\mathrm{CNH} 2$.

Puerto Rico, CNH8, pt. 2; 10, pt. 4.

Raimondia, Colombia, CNH16, pt. 5 (6th art.).

Rinorea, American, $\mathrm{CNH} 20$, pt. 13 (1st art.).

Rocky Mountain States, central, CNH20, pt. 9.

Roseanthus, Acapulco, Mexico, CNH3, No. 9 (5th art.).

St. Croix, B13.

Sapindaceae, Mexican and Lower Californian, CNH1, No. 9 (2d art.).

Sapium, Mexican and Central American, CNH12, pt. 4.

Sapodilla, nomenclature, CNH16, pt. 11.

Sapote, nomenclature, CNH16, pt. 11.

Scrophulariaceae, central Rocky Mountain States, CNH20, pt. 9.

Scutellaria, North American, CNH22, pt. 10.

Selaginella rupestris, $\mathrm{CNH} 20$, pt. 5 . shrubs, Lower California, CNH13, pt. 10 , art. 6.

Smith, John Donnell, botanical library, catalog, CNH12, pt. 1.

Socorro Island, P801.

Sonora, Pinacate region, CNH16, pt. 1 , art. 2.

South America, $\mathrm{CNH} 20$, pt. 7 (2d art.) ; 24, pt. 7 (2d art.).

South Dakota, Black Hills, CNH3, No. 8.

spermatophytes, South American, CNH20, pt. 7 (2d art.).

Sphaerocionium, American species of Hymenophyllium, CNH29, pt. 3.

Sphenoclea zeylanica, CNH16, pt. 13 (2d art.).

spleenwort, Chinese, CNH12, pt. 9 (11th art.).

Stipa, North American, CNH24, pt. 7 (1st art.); South American, CNH24, pt. 7 (2d art.).

Talinum, Mexican, CNH13, pt. 8 (1st art.).

Texas, CNH1, No. 8 (4th art.).

Rio Grande region, CNH1, No. 2; western, $\mathrm{CNH} 2$; western and southern, P535. 
Plants (continued).

Thibaudieae, American, CNH28, pt. 2.

Thompsonella, Mexico, CNH12, pt. 9 (1st art.).

Tithonia, revision, CNH20, pt. 10 (4th art.).

Tonduzia, Central American, CNH12, pt. 2 (2d art.).

Tradescantia, new, CNH5, No. 4 (4th art.).

trees, lower Wabash Valley, P1010; lower Wabash and White River Valleys, Illinois and Indiana, P264; Mexican boundary, B56.

Treleasea, new genus of Commelinaceae, CNH5, No. 4 (5th art.).

Tumamoca, new genus of Cucurbitaceae, CNH16, pt. 1 ( $3 \mathrm{~d}$ art.).

Umbelliferae, Columbia River region, CNH3, No. 9 (4th art.). Georgia, P1428.

Hesperogenia from Mount Rainier, CNH5, No. 4 (3d art.).

Mexican, CNH3, No. 5 (1st art.).

North American, CNH7, No. 1; 12 , pt. 10 ( $3 \mathrm{~d}$ art.).

United States, CNH3, No. 5, pt. 2. eastern, CNH13, pt. 10 (5th art.) ; 16 , pt. 5 ( 7 th art.).

northwestern, CNH5, No. 4 (2d art.).

Pacific coast, CNH16, pt. 5, art. 4.

Utah, CNH25.

Venezuela, CNH20, pt. 13 (2d art.) ;

La Guaira, CNH12, pt. 2 (3d art.).

Viburnum, Mexican and Central American, CNH26, ot. 7.

Violaceae, North American, C49.

violets, Mexico, P1429.

Virgin Islands, B13.

Wabash Valley, P1010.

Washington, CNH11.

Wenderothia, American, CNH20, pt. 14.

West Indies, CNH18, pt. $7 ; 28$, pt. 3. wokas, food of Klamath Indians, R1892, pt. 2, No. 3.

Wyoming, Big Horn Mountains, CNH3, No. 9 (3d art.).

(See also under Fossils.)

Plateau, Félix, P243.

Plecoptera. (See under Insects.)

Pleistocene. (See under Fossils.)

Pliocene. (See under Fossils.)

Plovers. (See under Birds.)

Poey, Felipe, P3.

Pogonip sponges, P3126.

Pogue, Joseph Ezekiel, B102, pts. 2, 3 ; P1715, 1726, 1801.

Pogue, J. E., and Gilbert, Chester Garfield, B102, vol. 1, pts. 4-6; P2005.

Pohl, Erwin Robert, P2811.

Point Barrow Expedition, mollusks, P460.

Pollacks. (See under Fishes.)
Polychaetes:

Alaska, P459, 2397.

Aphrodita magna, Uruguay, P2584.

Arenicola glacialis, account of, P1772.

Arenicolidae, North and South American, P1772.

Argentina, P2797.

Brazil, P2347.

California, P2994.

Chesapeake Bay, P2867.

Chile, P2536.

China, P2641; Amoy, P2984.

Costa Rica, P2757.

Euphrosyne, new species of, with notes on $E$. borealis, P3049.

Fiji, P2641.

Hawaii, P2186.

Japan, P2641.

Labrador, Newfoundland, Nova Scotia, P1703.

Myzostoma, new marine worms of the genus, P5109.

Nephtyidae, northeast Pacific, P3034.

Nereidae, California, P2994.

Nereis, Brazilian, P2347.

Nereis (Ceratonereis) alaskensis, Alaska, P2397.

new species, P2902.

North Carolina, Beaufort, P852.

Pacific Ocean, Nephtyidae, P3034.

Panama, P2186.

Philippine Islands, B100, vol. 1, pts. 8,$9 ; 100$, vol. 6 , pts. 2, 5 .

Phyllodoce, Costa Rican, P2757.

Polynoidae in National Museum, types, P3046.

Polyodontidae in National Museum, types, P3046.

Samoa, P2641.

South America, Arenicolidae, P1772.

Uruguay, P2499, 2584.

Polyclads, North America, east coast, P3044; United States and Canada, Atlantic coast, P3101.

Polyp, alcyonoid, Japanese, P346.

Polyzoans. (See under Bryozoans.)

Pond, Charles F., plants from Lower California, P725.

Poole, Arthur James, and Schantz, Viola Shelly, B178.

Pope, Thomas Edmund Burt, and Smith, Hugh McCormick, P1489.

Popenoe, Wilson, CNH24, pt. 5.

Porcelains. (See under Ceramics.)

Porcupines. (See under Mammals.)

Porifera. (See under Sponges; also under Fossils, sponges.)

Porites in National Museum, P635.

Porpoise-oil, manufacture, P9.

Porpoises. (See under Mammals; also under Fossils, mammals.)

Port Arthur, fishes collected by J. F. Abbott, P1493.

Porter, Bennet Allen, P2650. 
Porter, John Hampden, R1887, pt. 3, No. 2.

Porter, Joseph Yates, P200.

Porter, J. Y.; Jefferson, John Percival; and Moore, Thomas, P37.

Porto Rico. (See Puerto Rico.)

Potomac group. (See under Fossils.)

Potomac tidewater region, archeology, P776.

Potoos. (See under Birds.)

Pottery. See under Anthropology; also Ceramics.)

Potts, Edward, P542.

Power. (See under Mineral industries.)

Powers, Sidney, and Shimer, Hervey Woodburn, P2019.

Prairies, short-grass (southwestern U. S.), phyllopod crustacean, P3136.

Pratt, Richard Henry, P29, 79.

Precious stones. (See Mineralogy, gems.)

Prentiss, Daniel Webster, P1336.

Prentiss, D. W., and Coues, Elliott, B26.

Preston, Francis William; Henderson, Edward Porter; and Randolph, James Robbins, P3111.

Pribilof Islands, Alaska, amphipods, P1998.

Price, Emmett William, P2694, 2725, $2749,2789,2809,2824,2865,2870,2883$, 2936.

Primates. (See under Mammals; also under Fossils, mammals.)

Prime, Temple, P415.

Pringle, C. G., Umbelliferae collected in Mexico, CNH3, No. 5 (1st art.).

Printing. (See under Graphic arts.)

Prochlorite from District of Columbia, P410.

Protozoans, Cyclammina, foraminifer commensal on, P2290; from beetle larva, P2964.

(See also under Infusorians.)

Proudfit, Samuel Victor, P810.

Providence Island, insects collected by W. L. Abbott, P1119.

Prussia, pseudomorphs of marcasite after pyrrhotite from, P1801.

Psilomelanite, notes on, P2145.

Ptarmigans. (See under Birds.)

Pteropods. (See under Mollusks.)

Pterylography of American birds, P1018; of Procniatidae, P1077.

Pucherite, notes on, P2455.

Pueblos, Upper Gila River region, N. Mex. and Ariz., P87.

Puerto Rico, beetles, synopsis of Mordellistena, P3020.

corals, fossil, B103, pt. 9.

ground dove, Mona Island, P1418.

herpetology, R1902, pt. 2, No. 2.

insects, dipterous, report on, P1198.

Leguminosae, CNH10, pt. 4.

mollusks, Tertiary, Orthaulax, P2491.

owl, new, P238.
Puerto Rico (continued).

plants, economic, CNH8, pt. 2.

spiders and other Arachnida, P1253.

Puffbirds. (See under Birds.)

Puget Sound, Artedius fenestralis, P326. bat, Vespertilio longicrus, P602.

Bathymaster jordani, P753.

fishes, notes on, P1414.

flounders, Parophrys ischyrus and Hippoglossoides elassodon, P147.

Hydroida from, P1171.

Nemichthys avocetta, P170.

pollack, wall-eyed, Pollachius chalcogrammus fucensis, note on, P939.

pycnogonids from, P2991.

Pulo Taya, Berhala Strait, Sumatra, birds collected by W. L. Abbott, P2268.

Pulque of Mexico, P1579.

Pumas. (See under Mammals.)

Punta Arenas, new species of Thalassophryne (T. dowi), P639.

Purpus, Josef Anton, and Rose, Joseph Nelson, CNH13, pt. 2.

Purus River, Brazil, Indians, R1901, pt. 2, No. 5.

Pycnogonids, Puget Sound, P2991.

Pyrite, notes on, P2455.

Quail. (See under Birds.)

Quaintance, Altus Lacy, and Baker, Arthur Challen, P2156.

Quartz, color of amethyst, rose, and blue varieties, P2220.

Quaternary. (See under Fossils.)

Quillehute Indians, taking surf smelt, P112.

\section{R}

Rabbits. (See under Mammals.)

Raccoons. (See under Mammals; also under Fossils, mammals.)

Radcliffe, Lewis, P1853, 1868, 1896, 1924, 1948, 2185.

Radcliffe, Lewis, and Evermann, Barton Warren, B95.

Radcliffe, Lewis, and Smith, Hugh McCormick, P1822, 1917.

Radlkofer, Ludwig, CNH1, No. 9 (2d art.).

Rafinesque's "Analyse de la Nature," note on, P648.

Rafinesque's memoirs on North American fishes, review, B9.

Rails. (See under Birds; also under Transportation.)

Randolph, James Robbins; Preston, Francis William; and Henderson, Edward Porter, P3111.

Ransom, Brayton Howard, B69; P1844, 1864, 2322, 2533.

Ransom, B. H., and Hall, Maurice Crowther, P1892.

Rathbun, Mary Jane, B97, 103, pt. 7, $129,138,152,166$. 
Rathbun, Mary J. (continued).

P901, 927, 933, 959, 979, 980, 984, $986,1070,1071,1104,1158,1162$, $1199,1272,1307,1309,1647,1766$, $1971,2030,2044,2047,2067,2135$, $2138,2182,2214,2343,2477,2504$, 2727, 2786, 2851.

Rathbun, Mary J., and Benedict, James Everard, P858.

Rathbun, Rirhard, R1899 through R1917; 1903 , pt. 2, No. 1.

B27, pts. B, G; 70, 80, 101.

C50.

P82, 128, 230, 231, 371, 454, 491, $544,547,569,572,604,635,646$, 664.

Rats. (See under Mammals.)

Rattlesnakes. (See under Reptiles.)

Rau, Charles, C21; P253.

Raven, H. C., fishes collected by in Lake Tanganyika, P2998.

Ravenel, William de Chastignier, R1918 through 1924.

Ray, Eugene, P3016, 3020, 3075.

Rays. (See under Fishes.)

Reardon, Lucy, P2782.

Reeside, John Bernard, Jr., P2518, 2557.

Reeside, J. B., Jr., and Weymouth, Andrew Allen, P2860.

Rehder, Harald Alfred, P3161.

Rehder, H. A., and Bartsch, Paul, P3070.

Rehn, James Abram Garfield, P1363, $1364,1432,1453,1459,1650,1661$, 1910.

Reid, Earl Desmond, P3002.

Reid, E. D., and Schultz, Leonard Peter, P3074.

Reid, Savile Grey, B25, pt. 4.

Reinhard, Henry Jonathan, P2817, 2877, 2886, 2973.

Religion. (See under Anthropology.)

Rennes, golden patera, R1894, pt. 2, No. 3.

Report of the National Museum, R1881 through R1946.

REPTILES:

Aepidea, identity, P2643.

Africa, B151; P857, 862, 969, 970, $2720,2738,3128$.

Albatross 1887-88 cruise, P769; Clarion and Socorro Islands and Gulf of California, P800.

Aldabra Island, P973.

A mastridium, neglected genus, $\mathrm{P} 2524$.

Anniella, relationship of genus, $\mathrm{P} 1005$.

Arizona; P1800; Huachuca Mountains, P1282.

Assumption Island, P973.

Bahama Islands, P645; Green Cay, P1219.

Barissia, North American, P809.

Bermudas, B25, pt. 6 .

boa, yellow, new systematic name for, P1218.
Reptiles (continued).

California, P623, 689, 766, 878, 944, 977, 1020, 1044; San Francisco Peninsula, P2179; Sausalito Peninsula, P2051.

Caretta remivaga, $\mathrm{P} 1605$.

Central America, B32.

chameleon, Kilimanjaro, East Africa, P857.

Charina, California, P689; snakes of the genus, P808.

Chelys, shell, and armor of turtles in general, P2724.

China, P2562, 2715, 2944.

Clemmys guttata, sexual differences in coloration, P2382.

Cnemidophorus, study, B154.

collecting, directions for, B39e.

Coniophanes fissidens subsp., Mexico, P3127.

Costa Rica, P1542.

crocodilians, Mexican, collected under Walter Rathbone Bacon Traveling Scholarship, P3169; North American, R1898, pt. 2.

Crotalus willardi, Arizona, P1800.

Ctenosaura, lizards of the genus, P2733.

Cuba, P2205.

District of Columbia, P615.

Eutaeniae, southeastern Indians, P729.

Fanning Islands, B7.

Florida, P727, 1003, 1107, 1773.

Formosa, P1731.

gartersnakes. (See under Snakes.)

gecko, Philippine, P1397; Tanganyika Territory, Africa, P2720.

Gekko, Chinese, P2944.

Guatemala, P1151.

Gulf of California, P800; San Pedro Mártin, P863.

Haiti, P2543.

Hallowell's snake genera Megalops and Aepidea, P2643.

Hawaiian Islands, B7; P1174, 1383, 2224.

helminths parasitic in, P2940.

Hispaniola, B177.

Honduras, Utilla Island, P1217.

iguana, spiny-tailed, Guatemalan, P1151; Honduran, P1217.

Indiana, southeastern, P729.

Jamaica, P1218.

Japan and adjacent territory, B58.

Kinosternon, Mexico, P3115.

Labrador, P353.

Lampropeltis, revision, B114.

Liberia, P3128.

Lichanura, snakes of California genus, P878.

lizards, agamid, Malay Peninsula, P2421.

amphisbaenoid, Peruvian, P1856.

Barissia, P809. 
Reptiles, lizards (continued).

California, P944.

Ctenosaura, P2733.

Florida, P1773.

flying, Philippines, P1583.

geckoid, Philippines, P1576.

Gekko from China, P2944.

gerrhonotine, Costa Rican, P1542.

Hawaiian, P2224.

iguanoid, Green Cay, Bahama IsIlands, P1219.

Lower California, P788.

North American, R1898, pt. 2.

Philippine, P1606, 1776.

Phrynosoma, Mexico, P1437.

San Pedro Mártir, Gulf of California, P863.

Sauromalus, new, P864.

scincoid, east African, P862.

South American, P2849.

teiid, Cnemidophorus, B154.

Uta mearnsi, California, P1020.

Verticaria beldingi, California, P977.

Lower California, B7; P788.

Malaclemys, observations on the genus, P908.

Malay Peninsula, P2421.

Megalops, identity, P2643.

Mexico, B32, 187, P559, 1437, 3115, $3127,3153,3169$; Clarion Islands, P1231, Mount Orizaba, P922.

Michigan, Gogebic County, P2109.

Natrix vibakari, variations, P2020.

Nevada, P2078.

new species in National Museum, P299, 359.

North American, checklist, B1, 24.

Opheosaurus ventralis, osteology, P245.

Panama, P1681.

Peru, P1856, 1992, 2352.

Philippine Islands, P1397, 1576, 1583, 1606, 1776.

Phrynosoma, Mexican, P1437.

Pituophis, variations and relationships, B175.

pit viper, green, Trimeresurus gramineus, in China, P2715.

Pseudemys rugosa, influence of temperature on heart, $\mathrm{P} 515$.

Puerto Rico, R1902, pt. 2, No. 2.

rattlesnake, Crotalus willardi, Arizona, P1800.

Sauromalus, new North American, species, P864.

Sceloporus variabilis, notes on, and its geographical distribution in United States, P873.

Siam, P2834.

skeletons, preparation, B39c.

Smithsonian-Firestone collections, Liberia, P3128.

snakes, $A$ mastridium, neglected genus, P2524.

blind snakes (Typhlophidae), Congo Free State, P969.
RePTILES, snakes (continued).

breeding habits, P909.

Butler's garter snake, P1021.

California, P766.

characters and variations, North American, P882.

Charina, P808.

Clarion Island, Mexico, P1231.

coachwhip, specific name, P1022.

colubrine, new genus and species, P802.

congo, Ampliiuma, in Virginia, P1150.

Coniophanes fissidens subspp. Mexico P3127.

eggs, P909.

Florida, P727.

garter, variations and relationships, B61; variations exhibited by Thamnophis ordinoides, P2051, 2179.

Hibakari, variations, P2020.

king, Lampropeltis, revision, B114.

Lichanura, California, P878.

Megalops and Aepidea, identity, P2643.

Mexican, checklist and key, B187; collected under Walter Rathbone Bacon Traveling Scholarship, P3169.

North American, R1888, pt. 2 ; P876.

Panama, P1681.

Pituophis, variations and relationships, B175.

poisonous North American, R1893, pt. 2, No. 1.

South American, P2596.

Tantilla eiseni, California, P1044.

Thamnophis ordinoides, variation exhibited by, P2179.

Trimorphodon, $\mathrm{P} 3130$. young, P909.

Socorro Island, P800.

South America, lizards, P2840; snakes, P2596.

Storeria dekayi anomola, P678.

Tantilla eiseni, California, P1044.

terrapin, slider, Pseudemys rugosa, influence of temperature on heart, P515.

Testudo denticulata, nematode para. sites of, P2526.

Texas, B17; San Diego, P728.

Thamnophis ordinoides, variations exhibited by, P2051.

tortoise, box, Florida species, P1107; North American, P1019.

land, Xerobates, P249.

Testudo denticulata, nematode parasites of, P2526.

Trimeresurus gramineus in China, P2715.

Trimorphodon, $\mathrm{P} 3130$.

Tropidonotus, District of Columbia, P615.

turtles, Kinosternon from Mexico, P3115. 
Reptiles, turtles (continued).

Malaclemys, P908.

musk, rehabilitation of species from Southern States, P2452. sea, existing species, P1605.

shell of Chelys and constitution of armor of turtles, P2724.

spotted, Clemmys guttata, sexual differences in coloration, P2382.

Typhlopidae, Congo Free State, P969.

Uta mearnsi, California, P1020.

Venezuela, La Guaira, P1248.

Verticaria beldingi, California, P977.

Virgin Islands, P2244.

Virginia, P1150.

Xerobates, North American, P249.

Yale Peruvian Expedition, P1992.

(See also under Fossils.)

Reptiles' eggs, P909.

Resser, Charles Elmer, P2806, 2899.

Reynosa formation, Texas, mollusks, P2798.

Rhea. (See under Birds.)

Rhinoceros. (See under Fossils, mammals.)

Rhio-Linga Archipelago, mammals, Batam Island, P1502; collected by W. L. Abbott, P1485; notes on, P1684; mouse deer, specific differentiation under uniform environment, P1695.

Rhizocephalans. (See under Crustaceans.)

Rhoades, Rendell, P3129.

Rhode Island, Newport, sand flies (amphipods), P1084.

Rice, William North, B25, pt. 1.

Richardson, Charles Howard, P2078.

Richardson, Harriet, B54; P1128, 1175, $1189,1222,1294,1295,1350,1369$, $1400,1430,1479,1535,1586,1593$, $1598,1618,1633,1653,1663,1675$, $1678,1701,1718,1720,1729,1770$, $1775,1779,1811,1841,1843,1883$, $1886,1891,1894,1911,1914,1918$, 1926, 1929, 1954, 1995.

(See also under Searle.)

Richardson, Robert Earl, and Jordan, David Starr, P1570, 1572, 1581, 1714.

Richmond, Charles Wallace, P947, 1024, $1078,1083,1090,1091,1118,1200$, $1201,1267,1288,1318,1656,2221$, 2664.

Richmond, C. W., and Robinson, Wirt, P1093, 1247.

Richmond faunal zones, Warren and Clinton Counties, Ohio, P2671.

Ricker, Percy Leroy, [CNH10, pt. 5], 14, pt. 1.

Ridgway, Robert, R1890, pt. 3, No. 1. B21, 27, pt. C, 39a, 50, pts. 1-8. P7, 21, 38, 39, 56, 60, 102, 138, 155, $188,189,198,215,219,234-236$, $238,240,247,259,262,264,270$, $285,305,311-313,[314], 315,339$, $345,356,360-362, \quad[386], 390$, $[391], 392,400,411,412,420$, $432,446,457,458,471,472,474$ $478,480,481,488,493,494,496$,
RIDGWAY, R. (continued).

$522,524,538,539,555,556,567$, $573,588-591,599,600,605,611$, $612,616-619,626,643,644,650$, $654-656,660,661,665,674,691$, 693, 694a, 708, 750, 761, 762, 767, $768,796,828,867-872,877,895$, $923,945,953,955,956,960-962$, $964,1007,1008,1010,1045,1067$, 1074, 1076, 1079, 1116.

Ridgway, Robert, and Friedmann, Herbert, B50, pts. 9, 10.

Riley, Charles Valentine, B39f; P330, $532,951$.

Riley, Joseph Harvey, B172; P1418, 2255, 2506, 2654, 2775, 2835, 2838, 2907.

Rio Grande do Sul, poecilid fishes, P1532.

Rio Grande Valley, cacomitl cat, P1251.

Riouw. (See under Rhio-Linga.)

Ripley formation, Foraminifera, P2816.

Ritter, William Emerson, P1989.

Riu Kiu Islands, fishes, P1635, 1688, 1836. (See also Okinawa.)

Robbins, Wilfred William, and Cockerell, Theodore Dru Alison, P1671.

Robinson, Wirt, P733.

Robinson, Wirt, and Lyon, Marcus Ward, Jr., P1246.

Robinson, Wirt, and Richmond, Charles Wallace, P1093, 1247.

Rock, Joseph F., birds collected by in China, P2654, 2907.

Pteridophyta collected by in Asia, CNH26, pt. 6.

Rockfishes. (See under Fishes.)

Rockhill, William Woodville, R1893, pt. 2, No. 7.

Rocks. (See under Geology; also under Petrology.)

Rocky Mountain States, central, Scrophulariaceae, CNH20, pt. 9.

Rocky Mountains, Eocene insects, P2313.

Rodents. (See under Mammals; also under Fossils, mammals.)

Roe, Glenwood C, P2788.

Rohwer, Sievert Allen, P1722, 1739, 1777, $1794,1837,1866,1869,1925,1930$, $1960,1981,1986,1991,2061,2081$ $2105,2195,2202,2249,2309,2312$, $2317,2361,2366,2374,2609$.

Rohwer, S. A., and Cushman, Robert Asa, P2315, 2320.

Rohwer, S. A., and Fagan, Margaret Mary, P2208, 2266.

Rohwer, S. A., and Malloch, John Russell, P2837.

Rohwer, S. A., and Middleton, William, P2396.

Rosaries. (See under Anthropology, religion.)

Rose, Joseph Nelson, CNH1, No. 4 (1st and $2 \mathrm{~d}$ arts.), No. 5 (1st art.; 2d art.-1 and 2), No. 8 (6th art.), No. 9 (1st art.) ; $\mathrm{CNH} 3$, No. 5 (2d art.), No. 9 (3d art.) ; CNHs, No. 3, No. 4 (1st, 4th-6th arts.); CNH8, pts. 1, 4; CNH10, pt. 3 ; 
Rose, J. N. (continued).

CNH12, pt. 7, pt. 9 (2d-10th arts.), pt. 10 (2d art.) ; $\mathrm{CNH}_{13}$, pt. 8 (2d art.), pt. 9; CNH16, pt. 1 (3d art.).

P1427, 1428.

Rose, J. N., and Britton, Nathaniel Lord, CNH12, pt. 9 (1st art.), pt. 10 (1st art.) ; CNH16, pts. 7, 9.

Rose, J. N., and Coulter, John Merle, $\mathrm{CNH} 3$, No. 5 (1st art.); $\mathrm{CNH} 3$, No. 9 (4th art.) ; CNH5, No. 4 (3d art.); CNH7, No. 1; CNH12, pt. 10 (3d art.).

Rose, J. N., and House, Homer Doliver, P1429.

Rose, J. N., and Purpus, Josef Anton, CNH13, pt. 2.

Rose, J. N., and Smith, John Donnell, CNH16, pt. 12.

Rose, J. N., and Standley, Paul Carpenter, $\mathrm{CNH} 13$, pt. 8 (1st art.) ; CNH16, pt. 1 (2d art.), pt. 5 (5th art.).

Rose, J. N., and Vasey, George, CNH1, No. 1 (1st and 2d arts.), No. 3 ; P749, 801.

Ross, Clarence Samuel, P2628.

Ross, C. S., and Shannon, Earl Victor, P2509, 2579.

Ross, Edward Sherman, P3175.

Rossite, from Colorado, P2707.

Rothrock, Joseph Trimble, P397.

Rotifers, California, Los Angeles and vicinity, P2190.

collecting and fixing, P1893.

District of Columbia, P2032.

Lepadella and Lophocharis, revision, P2164.

Panama, P2062.

synopsis, B81.

Roulette, prehistoric, Wyandotte County, Kans., P3091.

Roundworms. (See under Nematodes.)

Rowell, Rev., fishes collected at Panama, P294.

Ruedemann, Rudolf, P2893, 2954.

Ruminants. (See under Fossils, mammals.)

Russell, I. C., fossil plants collected at Black Creek, near Gadsden, Ala., P688.

Russia, Indarch, composition and structure of meteoric stone, P2098.

Gustavas Vasa Fox souvenirs in National Museum, P1725.

Ruthven, Alexander Grant, B61, P1874.

Rutile-mica intergrowth from Canada, P1801.

Rydberg, Per Axel, CNH3, Nos. 3, 8.

Ryder, John Adam, P145, 181, 280, 398, 501, 502, 553.

Ryder, J. A., and Gill, Theodore, P381, $382,408$.

\section{$\mathrm{S}$}

Sable Island Bank, fish, Argentina syrtensium, P41.
Sacramento River, Ptychochilus harfordi, P193.

Safford, William Edwin, CNH9; CNH13, pt. 5 (6th art.); CNH16, pt. 10 ; CNH18, pt. 1.

St. Christopher, Loxigilla, new subspecies, P216.

St. Croix, bones of birds collected by $\mathrm{T}$. de Booy from kitchen-midden deposits, P2245; flora, B13.

St. George, Raymond Alexander, P2514.

St. Georges Banks, occurrence of Hippocampus antiquorum, P17.

St. Lawrence Island, Bering Sea, birds, P2912.

St. Lucia, Port Castries, birds collected by Albatross, P768; fishes collected by Albatross, P769; warbler, new, P311.

St. Michaels, Alaska, Hippoglossus vulgaris, P70; Stichaeus punctatus, P47.

St. Pauls and St. Peters Islands, Straits of Magellan, Mesozoic fossils, P793.

St. Thomas, bones of birds collected by $T$. de Booy from kitchen midden deposits, P2245.

St. Vincent, birds collected by F. A. Ober, P27; thysanopterous insects, P1590.

Salamanders. (See under Amphibians.)

Salmon. (See under Fishes.)

Salps. (See under Tunicates.)

Samoan Islands, annelids, polychaetous, P2641; fishes collected by Bushnell Expedition, B180.

San Emigdio, meteorite, P700.

San Felipe formation, Mexico, rudistid, P2379.

San Francisco. (See under California.)

San Juan Islands, Wash., barnacles, P2362.

San Pedro series. (See under Fossils, California.)

San Pedro Valley, Ariz., late Cenozoic vertebrate fauna, P3155.

Sand-barites from Kharga, Egypt, P1726.

Sandberg, J. H., plants collected in northern Idaho, $\mathrm{CNH} 3$, No. 4.

Sand fleas. (See under Crustaceans, amphipods.)

Sandground, Jack Henry, P2783.

Sandhouse, Grace Adelbert, P2532, P3156.

Sandhouse, Grace A., and Clark, Austin Hobart, P3005.

Sandhouse, Grace A., and Cockerell, Theodore Dru Alison, P2380.

Sandstone. (See under Petrology.)

Sandwich Islands. (See Hawaiian Islands.)

Santa Barbara Islands, fishes collected by Albatross, P880.

Santa Catalina Island, fishes, P107, P1510.

Santa Cruz Mountains, brittle-star, upper Miocene, P1620; fossils, Cretaceous and Tertiary, P1617. 
Santa Elena Bay, Ecuador, mollusks, P2551, 2646.

Santo Domingo, new fishes from, P1478.

Sasaki, Madoka, P2310.

Satoh, H., Ri894, pt. 2, No. 4.

Savannah. (See under Transportation.)

Savannah Bank, sparoid fish, Sargus holbrookii, P28.

Sawflies. (See Insects, Hymenoptera.)

Saylor, Lawrence Webster, P3028, 3048, 3095, 3145.

Schaeffer, Charles, P2365.

Schaller, Waldemar Theodore, P1867.

Schant7, Viola Shelly, and Poole, Arthur James, B178.

Schaus, William, P1262, 1420, 1444, 1597, $2039,2132,2307,2372,2520,2740$, $3026,3063,3102$.

Schizopods. (See under Crustaceans.)

Schmidt, Peter, P1390, 2685.

Schmitt, Waldo Lasalle, P3132. sea stars collected by in South America, P2859.

Schuchert, Charles, B39k; 53, pt. 1 ; 88; P1'17, 1192, 1313, 1467.

Schultz, Leonard Peter, B180; P3029, $3038,3047,3085,3152,3172,3181$, $3187,3191,3192,3204$.

Schultz, L. P., and Hubbs, Carl Leavitt, P3060.

Schultz, L. P., and Reid, Earl Desmond, P3074.

Schwa rtz, Benjamin, P2538, 2561, 2589, 2598, 2614, 2677, 2697, 2723, 2765.

Schwartz, Benjamin, and Alicata, Joseph Everett, P2956.

Schwarz, Eugene Amandus, P1085.

earwigs collected by in Guatemala, P1563.

Hemiptera-Heteroptera collected by at Las Vegas Hot Springs, N. Mex., P1360.

spiders collected by in Arizona, P1284.

Sclater, Philip Lutley, published writings of, B49.

Scofield, Norman Bishop, and Gilbert, Charles Henry, P1131.

Scollick, Joseph William, P926.

Scorpions. (See under Arachnids.)

Scribner, F. Lamson. (See under Lamson-Scribner.)

Scudder, Newton Pratt, B23.

Scudder, Samuel Hubbard, B15, 19; P1124.

Sculpins. (See under Fishes; also under Fossils, fishes.)

Scyphomedusae. (See under Medusae.)

Sea and fresh waters, scientific investigation of, catalog of exhibit sent to International Fisheries Exhibition at London, B27.

Sea-anemones, actinians, collected by $\mathrm{Al}$ tross, P930; Edwardsiella, southern California, P1967; Sagartia paguri, P1315.
Sea-cow. (See under Mammals; also under Fossils, mammals.)

Sea-elephants. (See under Mammals.)

Seahorses. (See under Fishes.)

Sea-nettles. (See under Medusae.)

Sea-stars. (See Echinoderms.)

Sea-urchins. (See under Fossils, Echinoderms.)

Seal, William P., fishes collected in Chesapeake Bay at Cape Charles City, Va., P843.

Seale, Alvin, and Bean, Barton Appler, P1568.

Seale, Alvin, and Evermann, Barton Warren, P1491.

Seale, Alvin, and Jordan, David Starr, P1407, 1433, 1445, 1575.

Seals. (See under Mammals; also under Fossils mammals.)

Seals, Oriental, in National Museum, P2630.

Searle, Harriet Richardson, P2419.

(See also under Richardson.)

Seiwell, Harrv Richard, P2739.

Sellers, Wendell Folsom, P3157.

Semper's method of making dry preparations, P220.

Serpentine of Montville, N. J., P694.

Seton, Ernest Thompson. (See Thompson, Ernest Evan.)

Seton-Karr, Heywood Walter, R1904, pt. 2, No. 3.

Setzler, Frank Marvl, P2963.

Seychelle Islands, W. L. Abbott collections: birds, P1079; insects, P1119; Lepidoptera, P1064.

Shad. (See under Fishes.)

Shamel, Henry Harold, P2862.

Shannon, Earl Victor, B131; P2316, 2318, $2339,2342,2345,2348,2351,2373$, $2375,2385,2395,2398,2411,2417$, $2455,2458,2461,2479,2537,2539$, 2565, 2717, 2758, 2766.

Shannon, Earl V., and Cross, Whitman, P2690.

Shannon, Earl V., Hewett, Donnell Foster, and Gonyer, Forest A., P2737.

Shannon, Earl V., and Ross, Clarence Samuel, P2509, 2579.

Shannon, Raymond Corbett, P2635, 2647, 2658.

Shannon, Raymond C., and Dyar, Harrison Gray, P2636.

Shantz, H. L., notes on Entomostraca collected by in Pikes Peak region, P2531.

Sharks. (See under Fishes.)

Sharpbills. (See under Birds.)

Sharpe, Richard Worthy, P1347, 1651, $1750,1758$.

Sheep. (See under Mammals.)

Sheldon, C. S., plants collected in Indian Territory, CNH1, No. 6 (1st art.).

Shell beds and heaps. (See under Anthropology, mounds.)

Shells. (See under Mollusks; also under Fossils, mollusks.) 
Shimer, Hervey Woodburn, and Powers, Sidney, P2019.

Shinto, Japanese mythology, R1891, pt. 3, No. 4.

Shipworms. (See under Mollusks.)

Shoemaker, Clarence Raymond, P2626, 2827, 2861, 2888.

Shoemakers, Navajo, P697.

Shofar, use and origin, R1892, pt. 3, No. 4; P936.

Shrews. (See under Mammals.)

Shrikes. (See under Birds.)

Shrimps. (See under Crustaceans.)

Shrubs. (See under Plants.)

Shufeldt, Robert Wilson, R1892, pt. 3, Nos. 3, 7; 1895 , pt. 2, No. 7; $\mathrm{P} 245,439,440,529,638,683,711$, $713,859,860,889,902,2215$.

fishes collected by in vicinity of New Orleans, P437.

Siam, birds, collected by Hugh M. Smith and W. L. Abbott, B172; new, from lower, P1201; northern Thailand, B186.

dragonflies, Aeschinae, P2467; Calopteryginae, P1389: Cordulegasterinae, Chlorogomphinae, and Gomphinae, P1571; Urothemis, P2666.

fishes, fresh-water, B188; new genera and species, P2873.

herpetological collections made by Dr. Hugh M. Smith, P2834.

insects, Trichoptera, P2891.

(See also under Thailand.)

Siberia, bees, halictine, from Maritime Province, P2607.

beetles, burprestid, from Maritime Province, P2608.

birds, collected by Copley Amory, Jr., in northeastern, P2255.

crane flies, from Maritime Province, P2605.

crania, non-Eskimo, P3171.

fishes, new collected by Yukon, P210.

insects, orthopteroid, from Maritime Province, P2679; Tertiary, from Kudia River, Maritime Province, P2606.

Miocene fauna, subtropical, from Arctic, P946.

sawflies, from Maritime Province, P2609.

Siberut, birds (Spolia Mentawiensia), P2775.

Siderite, from Columbia River basalt, P2458.

Sillimanite, notes on, P2345.

Silurian. (See under Fossils.)

Silver. (See Metallography.)

Simons, P. O., fishes collected in Ecuador and Peru, P1468.

Simpson, Charles Torrey, P740, 911, 952, 1011, 1068, 1072, 1205, 2741.

Simpson, George Gaylord, B169; P2943, 2981.
Sindo, Michitaro, and Jordan, David Starr, P1260, 1261.

Siphonaptera. (See under Insects, Aphaniptera.)

Siphonophores. (See under Hydrozoans.)

Sipora, birds (Spolia Mentawiensia), P2775.

Sipunculids. (See under Annelids.)

Sirenians. (See under Fossils, Mammals.)

Skates. (See under Fishes.)

Skeletal remains. (See under Anthropology.)

Skeletons. (See under Osteology.)

Skimmers. (See under Birds.)

Skin-dressing, aboriginal, R1899, pt. 3, No. 3.

Skinker, Mary Scott, P2890, 2980.

Skins. (See under Mammals.)

Skuas. (See under Birds.)

Skulls, animal. (See under Fossils; also under Mammals.)

Skulls, human. (See under Anthropology.)

Slade, Elisha, P409.

Slings, pre-Columbian American, Peru, P2275.

Sloane, types of American grasses, described by, CNH12, pt 3 .

Slosson, Mrs. Annie Trumbull, lists of Mount Washington Ichneumonidae compiled by, on the Ashmead manuscript species of, P2429.

Smelts. (See under Fishes.)

Smith, Albert Charles, CNH28, pt. 2.

Smith, Frank, P2174, 2549, 3009.

Smith, Frank, and Green, Bessie Rose, P2263.

Smith, Hobart Muir, P3127, 3130, 3153, 3169.

Smith, Hobart M., and Taylor, Edward Harrison, B187; P3185.

Smith, Hugh McCormick, B188; P806, $1150,1872,1877,1899,1997,2003$, 2873.

birds collected by in Siam and $\mathrm{Ma}$ lay Peninsula, B172.

herpetological collections made by in Siam, P2834.

Smith, Hugh M., and Pope, Thomas Edmund Burt, P1489.

Smith, Hugh M., and Radcliffe, Lewis, P1822, 1917.

Smith, John Bernhard, B38, 44, 48; P581, 633, 634, 647, 706, 747, 781, 838, $839,851,890-892,1184,1203,1283$, 1645.

Smith, John B., and Dyar, Harrison Gray, P1140.

Smith, John Donnell, catalog of the botanical library of, CNH12, pt. 1.

Smith, J. D., and Rose, Joseph Nelson, CNH16, pt. 12.

Smith, Rosa, P133, 187, 208, 286, 337, $372,373,376,469,563$.

Smith, Rosa, and Swain, Joseph, P272. 
Smith, Sidney Irving, B3, 15; P83, 99, 172, 343, 374, 375, 455, 506, 507.

Smith, Silas B., P244.

Smithsonian biological survey, Canal Zone, Lepidoptera, P2050.

Smithsonian-Chrysler Expedition, east Africa, vertebrates, P2738.

Smithsonian-Firestone Expedition, Liberia, reptiles and amphibians, P3128.

Smithsonian-Hartford Expedition, West Indies, echinoderms, P3056; marine algae, CNH28, No. 3 ; ophiurans, P3054.

Smithsonian-Harvard Expedition, Altai Mountains, mammals, P1900.

Smulyan, Marcus Thomas, P2990.

Snails. (See under Mollusks.)

Snakes. (See under Reptiles; also under Fossils, reptiles.)

Snappers. (See under Fishes.)

Snipes. (See under Birds.)

Snodgrass, Robert Evans, P1687, 1774.

Snyder, John Otterbein, P1513, 1595, $1635,1643,1688,1836,1909,1913$, 1961, 2125, 2224, 2236, 2333, 2357, 2508.

(See also under Jordan and Snyder.)

Snyder, Thomas Elliot, P2441, 2496, 2615, 2957.

Snyder, T. E., and Banks, Nathan, B108.

Soapfishes. (See under Fishes.)

Socorro Island, plants collected by Albatross, P801; reptiles collected by $\mathrm{Al}$ batross, P800.

Soles. (See under Fishes.)

Somaliland, new birds from, P1373; corals collected in French Somaliland by Charles Gravier, P1526.

Soothsayers. (See Insects, Orthoptera.)

Sorceress, Korean, paraphernalia in $\mathrm{Na}$ tional Museum, P2168.

South Africa, Turton collection of marine mollusks, report on, B91.

South African Bushmen, crania, P2696.

South America, annelids, Arenicolidae, P1772.

birds, new, P1276; list of forms not represented in National Museum, P215.

crustaceans, Aegla, P3132; new isopod, P1929.

Diptera, Dolichopodidae, P2755; new, P2746.

Eupelmidae, P3173.

fishes, catalog of fresh-water, P842; sciaenid, new species of Ophioscion, P3192.

flatworms, new species, P3055.

flies, borborid, P2621; muscoid, new, Andean and Pacific coast regions, P1935; Syrphidae, review of, P2658.

Foraminifera, P2796, 2903.

grasshoppers, Acridinae, P1453.

Hymenoptera, parasitic, P1786, 2704. insects, coleopterous, checklist, B185. dipterous, revision of Ptychopteridae, P1953.
South America, insects (continued). homopterous, Delphacidae, contribution toward monograph, P2041.

jaguars, new, P2069.

lanternflies, Fulgoroidea, P3184, 3189.

lizards, in National Museum, P2849. mollusks, Chilina, P2949.

collected by W. H. Jones, west coast, P854.

land and fresh-water, new, P2638, 2825.

west coast, P941.

moths, new, P1419-1421, 1444, 1456, 1601; tineoid, Microlepidoptera, P1815.

mussels, fresh-water, Anodontites, P2889; Diplodon, P2209; new, P2437, 2678.

Myiarchus, new species, Orinoco District, P589.

sea-star collected by W. L. Schmitt, P2859.

snakes in National Museum, P2596. Spermatophytes collected by $\mathbf{H}$. M. Curran, CNH20, pt. 7 (2d art.).

sponges, fresh-water, in National Museum, P1712.

Stipa, species of, CNH24, pt. 7 (2d art.).

termites, P2441.

South Carolina, cephalopod, Eocene nautiloid, Eutrephoceras sloani, P2518.

fishes, Alleghany region, B12; notes on, P328; sent by C. C. Leslie from Charleston, P627.

hake, Phycis earllii, P124.

sponge, fresh-water, P2965.

Upper Cretaceous invertebrate faunas, P2706.

South Dakota, flora of Black Hills, CNH3, No. 8.

Cretaceous crabs, P2182.

dinosaur, Stegosaurus marshi, Lower Cretaceous, P1224.

rhinoceros, Trigonias osborni, Miocene, P1207.

South Seas, fishes collected in Tahiti by

Henry P. Bowie, P1422; from Tahiti, P2682; obtained by Pinchot Expedition, P2906.

(See also under Fiji, Oceania, etc.)

Southwest Africa, Great Namaqualand, birds, P2951.

Sowerby, Arthur de Carle, P2408.

Sparrows. (See under Birds.)

Spearheads, prehistoric, R1897, pt. 2, No. 7.

Spiders. (See under Arachnids.)

Spleenwort. (See under Plants.)

Spolia Mentawiensia. (See under Birds.) SPONGES:

Albatross collections. (See under $\mathrm{Al}$ batross, sponges.) 
SPONGES (continued).

America, northeast coast, P76.

Australia, P1690.

calcareous, northwestern Pacific, P2247.

California, marine and fresh-water, P2927.

Camaraphysema, new type, P145.

China, P1737.

Ephydatia japonica and allies, P1771.

exhibit sent to International Fisheries Exhibition at London, B27, pt. B.

fresh-water, Australian, P1690. Heteromeyenia radiospiculala, type of new genus, P1839.

Mexican, P542.

North and South American, P1712.

Philippine, P1690, 1702.

South Carolina, P2965.

with description of new Spongilla from China, P1737.

with note on Ephydatia japonica and allies, P1771.

Heteromeyenia radiospiculata, type of new genus, P1839.

hexactinellid, northwestern Pacific, P2935; Rhabdocalyptus, P2805.

horny, Philippine, B100, vol. 2, pt. 4.

Mexico, P542.

Panama Canal, P2993.

Philippine Islands, B100, vol. 2, pt. 4; P1690, 1702.

Rhabdocalyptus darwsoni and the species of Rhabdocalyptus, P2805.

silicious, Philippine, B100, vol. 2, pt. 4.

South America, fresh-water, P1712.

South Carolina, P2965.

Spongilla, Chinese, P1737.

(See also under Fossils.)

Springer, Frank, B115; P1664, 1850, 2426, 2516, 2577, 2581, 2590.

Springer, Stewart, P3058.

Springtails. (See under Insects, Collembola.)

Squalodonts. (See under Fossils, Mammals.)

Squirrels. (See under Mammals.)

Stalactites. (See under Petrology.)

Stamps, postage, and stamped envelopes of the United States and possessions, B105.

Standley, Paul Carpenter, CNH12, pt. 8; CNH13, pt. 6 (1st and 2d arts.), pt. 10 (4th art.), pt. 11 ; CNH17, pt. 5 ; CNH18, pt. 3 ; CNH20, pts. 1, 6; CNH22, pt. 5; $\mathrm{CNH} 23$; CNH27.

mosses collected by in Costa Rica, CNH26, pt. 3.

Standley, Paul C., and Goldman, Edward Alphonso, CNH13, pt. 10 (6th art.).
Standley, Paul C., and Hitchcock, Albert Spear, CNH21.

Standley, Paul C., and Miller, Gerrit Smith, CNH16, pt. 3.

Standley, Paul C., and Rose, Joseph Nelson, CNH13, pt. 8 (1st art.); CNH16, pt. 1 (2d art.), pt. 5 (5th art.).

Standley, Paul C., and Wooton, Elmer Ottis, CNH16, pt. 4; CNH19.

Stanton, Timothy William, [B53, pt. 1, sect. 1] ; P1109, 1135, 1257, 1813, 2379.

Starfishes. (See Echinoderms.)

Star-gazers. (See under Fishes.)

Starks, Edwin Chapin, P1155, 1179, 1186, 1201, 1297, 1366, 1468.

Starks, Edwin Chapin, and Jordan, David Starr, P1232, 1250, 1308, 1319, $1326,1348,1351,1358,1365,1381,1391$, $1462,1484,1493,1510,1517,1541$.

Starks, Edwin Chapin, and Thompson, William Francis, P1744.

Starlings. (See under Birds.)

State geological and natural-history surveys, history, B109.

Stearns, Robert Edwards Carter, R1887, pt. 3, No. 4 ; P346, 813, 844, 854, 940$942,971,996,1145,1149,1190,1191$, 1256.

Stearns, Silas, P25, 548.

fishes from Pensacola, Fla., collected by, P74, 404, 465, 565.

Stearns, Winfrid Alden, P353.

Crustacea collected by in Labrador, P374.

Mollusca and Echinodermata dredged by off Labrador, P377.

Stebbing, Thomas Roscoe Rede, P1341, 1490, 1609.

Steele, Edward Strieby, CNH13, pt. 10 (5th art.); CNH16, pt. 5 (7th art.).

Steere, Joseph Beal, R1901, pt. 2, No. 5. fishes collected by in Amazon River, P1503.

Steindachner, Franz, P36.

Steiner, Gotthold, P2527.

Stejneger, Leonhard, Birds, B29.

P239, 260, 261, 275, 301, 413, 425, $473,530,558,560,570,576-579$, $592,597,601,609,610,614,628$, $629,640-642,649,667,686,692$, $695,701,735,751,778,874,875$, $904,906,931,957,974,997,1144$, 1220.

Mammals, P344, 421.

Plants, P463.

Reptiles and amphibians, B39e, 58; R1893, pt. 2, No. 1 ; 1902, pt. 2, No. 2.

P766, 788, 802, 808, 809, 857, 862$864,873,876,878,894,944,969$, $970,977,1020-1023,1044,1088$, $1151,1174,1178,1217-1219,1231$, $1248,1252,1282,1321,1397,1406$, $1437,1457,1471,1538,1542,1576$, $1578,1583,1606,1681,1731,1773$, 
Stejneger, Leonhard (continued).

$1776,1856,1857,1992,2205,2452$, 2562, 2643, 2715, 2944, 3115.

birds collected by on Commander Islands and Petropaulovski, P345.

Entomostraca collected by on Bering Island, P621.

fishes collected at Commander Islands, P1106; in Kamchatka and Japan, P1112.

Mesoplodon collected by on Bering Island, P540.

Mollusca collected by on Commander Islands, Bering Sea, P442.

plants collected by in Commander Islands, P462.

Stejneger, Leonhard, and Lucas, Frederic Augustus, P765.

Stejneger, Leonhard, and Test, Frederick Cleveland, P847.

Stephanite, from Mexico, P2479.

Stephen, Alexander MacGregor, P697.

Stephenson, Lloyd William, P2422, 2706, 2815.

Sterki, Victor, P726, 2160.

Stewart, Thomas Dale, B183, P3160.

Sticklebacks. (See under Fishes; also under Fossils, fishes.)

Stiles, Charles Wardell, P1105.

Stilpnomelane. (See under Mineralogy.)

Stilts. (See under Birds.)

Stomatopods. (See under Crustaceans.)

Stone, Livingston, P323.

Stone age. (See under Anthropology.)

Stoneflies. (See under Insects, Plecoptera.)

Storks. (See under Birds.)

Straits of Magellan, birds collected by Albatross, P768.

fishes collected by Albatross, P2133.

skeletons of birds collected by $\mathrm{Al}$ batross, P798.

St. Pauls and St. Peters Islands, Mesozoic fossils, P793.

Straus, William Louis, Jr., and Howell, Alfred Brazier, P2913.

Streets, Thomas Hale, B7; P258.

birds' sterna and skulls collected by, P638.

Strepsiptera. (See under Insects.)

Strike-a-light, Eskimo, P705.

Strohecker, Henry Frederick, P3168.

Stull, Olive Griffith, B175.

Sturgeons. (See under Fishes.)

Sturtevant, Alfred Henry, P2330.

Sulphur. (See under Mineral industries.)

Sulphurous acid. (See under Chemistry.)

Sulu Archipelago, carcharioid shark,

Albatross Philippine Expedition, P2003.

Sumatra, bats, Rhinolophus, from Engano, $\mathrm{P} 1440$.

birds collected by W. L. Abbott, P1318; Pulo Taya, Berhala Strait, P2268; Simalur Island, P2282.

fishes, notes on, P2682.
Sumatra (continued).

mammals, collected by W. L. Abbott, P1317, 1626, 2188; Engano Island, P1472.

squirrels, giant, P1534.

Sumichrast, Francis E., birds collected by in Mexico, B4.

Sun-bitterns. (See under Birds.)

Sun-grebes. (See under Birds.)

Surfbirds. (See under Birds.)

Surf-fishes. (See under Fishes.)

Surinam, Priodesmus, new genus of Diplopoda, P1037.

Surmullets. (See under Fishes.)

Surveys, State geological and natural history, B109.

Swain, Joseph, P283, 379.

Swain, Joseph, and Jordan, David Starr, P378, 414, 426, 434, 436, 447, 449, 465.

Swain, Joseph, and Kalb, George B., P332.

Swain, Joseph, and Meek, Seth Eugene, P428.

Swain, Joseph, and Smith, Rosa, P272.

Swaine, Peter Tyler, and Hegewald, John Frederick Charles, P257.

Swales, Bradshaw Hall, and Wetmore, Alexander, P155.

Swallows. (See under Birds.)

Swan, James Gilchrist, P112, 143.

fishes collected by in Washington, P388.

Swartz, types of American grasses described by, CNH12, pt. 3.

Swastika, R1894, pt. 2, No. 6.

Swiftlets. (See under Birds.)

Swifts. (See under Birds.)

Swine. (See under Mammals.)

Swordfishes. (See under Fishes.)

Swords, American and European in $\mathrm{Na}$ tional Museum, B163; corrugation in African blades, P703.

"Systema Naturae," Linnaeus's, nomenclature of whalebone whales, P1163.

\section{$T$}

Tachinid flies. (See under Insects, Diptera.)

Tadpoles. (See under Amphibians.)

Tagdumbash Pamir, birds collected by W. L. Abbott, P1083.

Tahiti, fishes, collected by Henry P. Bowie, P1422; notes on fishes, P2682; slug, Veronicella, P1238.

Tambelan Islands, China Sea, birds of, P2262.

Tanagers. (See under Birds.)

Tanganyika Territory, Africa, fishes collected by $H$. C. Raven from Lake Tanganyika, P2998; new gecko from, P2720.

Tanners, Navajo, P683.

Tapaculos. (See under Birds.)

Tapeworms. (See under Cestodes.)

Tardigrades, bear-animalcule, North Carolina, P2203. 
Tasmania, Mount Lyell copper district, P200r.

Tasmanians, crania, P2696.

Tassin, Wirt, B39h; B53, pt. 2, sect. 4. R1895, pt. 2, No. 4; 1897, pt. 2, Nos. 3,$6 ; 1900$, pt. 2, Nos. 6, 7.

P1277, 1380, 1392, 1497, 1511, 1524, 1622, 1628.

Tattersall, Walter Medley, P2634.

Taxidermy, classification of collection illustrating, C12; methods of Leyden Museum, R1895, pt. 2, No. 7; scientific, for museums, R1892, pt. 3, No. 3. Taylor, Edward Harrison, P3093.

Taylor, E. H., and Smith, Hobart Muir, B187; P3185.

Taylor, Ernest Leonard, P2754.

Taylor, Frank Augustus, B173.

Taylor, W. Edgar, P1019.

Taylor, William, Batrachia and Reptilia brought from San Diego, Tex., P728.

Taylor, William Randolph, CNH28, pt. 3.

Temblor Range, Calif., Miocene mollusk, Haliotis, P2938.

Tennessee, birds, P3050.

caddis case, lower Eocene, P2686.

crinoids, summary of Troost's manuscript, B64.

crustacean fauna, Nickajack cave, P1292.

dragonflies, Cumberland Valley, P1928.

fishes, Alleghany region, B12.

Foraminifera, Ripley formation, Coon Creek, P2816.

insects, Fontaria pulchella, Jefferson County, Strawberry Plains, P714.

late Niagaran strata, P1621.

mammals, P3051.

meteoric irons, Savannah, P2487.

meteorite, iron, Cookeville, Putnam County, P2153.

millipeds, Colobognatha, P2989.

Myriapoda, Mossy Creek, notes on, P721.

Waverlyan period, P1851.

Termites. (See Insects, Isoptera.)

Terns. (See under Birds.)

Terrapins. (See under Reptiles.)

Tertiary. (See under Fossils.)

Test, Frederick Cleveland, P1156.

Test, F. C., and Stejneger, Leonhard, P847.

Tetrahedrite, notes on, P2345.

Texas, amphibians, B17.

batrachians, blind tailed, P1088; brought by William Taylor from San Diego, P728.

birds, B17; southwestern, observations on, P673; Fort Brown, P22.

$B u f o$, new species, P715.

coral, Cretaceous, P2820.

crabs, Eocene, P2727.
Texas (continued).

crustaceans, new, from well, San

Marcos, P1087.

dragonfly naiads, P2390.

earthworm, Diplocardia, P2549.

fishes, B17, P549; Galveston, notes on, P282; Galveston Bay, parasites of, P2977.

flora, from western and southern, report on, P535.

Geothlypis, new, Brownsville, P964.

helminths, parasitic in opossum, P2939; in Amphibia and Reptilia, Houston, P2940.

invertebrate fossils, new Cretaceous, P93.

mammals, B17; Pleistocene, Xenathra, P2147.

mastodons, Anancus brazosius and Gomphotherium cimarronis, P2572.

meteorite, from Troup, P2383, 2384.

meteorite finds, Fayette County, P2248.

meteoric irons, Alpine, Brewster County, P2425.

meteoric stones, Peck's Spring, Midland County, P2787; Plainview, Hale County, P2184, 2243.

millipeds, Colobognatha, P2989; distribution, P1810.

mollusks, Ostrea and Exogyra, Austin Chalk, P2815; Reynosa formation, P2798.

moths, tineid, from southern, P1465.

nematodes, parasitic in peccary, P2956.

Orthoptera, notes on, P1333.

phanerogams and pteridophytes from western, manual, CNH2.

pipefish, Siphostoma scovelli, Corpus Christi, P1043.

plants, collected by G. C. Nealley, Rio Grande region, CNH1, No. 2; fossil, Trinity Division, Comanche series, notes on, P934; new, CNH1, No. 8 (4th art.).

Pleistocene vertebrates, from southwestern, P2625.

ray from coast, and top minnow new to fauna of eastern part, P2393.

reptiles, B17; brought by William Taylor from San Diego, P728.

rodents, Geomys personatus and Dipodomys compactus, Padre Island, P699.

tick, Dermacentor halli, from peccary, with key to genus, P2945.

trematodes, Hasstilesia, from rabbits, P2792.

Unios, new Triassic, Staked Plains, P1072.

zoological position of, B17.

Textiles, cloth fragment from mound in Ohio, P347.

cotton, raw, presented to the $\mathrm{Na}$ tional Museum by the Inter- 
Textiles (continued).

national Cotton Exposition, Atlanta, Ga., P333.

exhibition plan for at World's Industrial and Cotton Centennial Exposition at New Orleans, C24.

fibers and fabrics in the National Museum, R1886, pt. 3, No. 4.

preparation of microscopical mounts of vegetable fibers, R1886, pt. 3, No. 5.

Thailand. (See under Siam.)

Thaumasite, notes on, P2240.

Thian-Shan Mountains, birds collected by W. L. Abbott, P1083.

Thick-knees. (See under Birds.)

Thomas, Cyrus, C28.

Thomas, Oldfield, P2333.

Thompson, C. H., plants collected by in southwestern Kansas, CNH3, No. 9 (1st art.).

Thompson, Ernest Evan ( $=$ Ernest Thompson Seton), P841.

Thompson, Joseph Cheesman, P2020, 2051, 2179.

Thompson, J. C., and Gilbert, Charles Henry, P1414.

Thompson, William Francis, P2133.

Thompson, William Francis, and Jordan, David Starr, P1728, 1752, 1787, 1792, 1875, 2011.

Thompson, W. F., and Starks, Edwin Chapin, P1744.

Thomson, William Judah, R1889, pt. 3, No. 2.

Threadfins. (See under Fishes.)

Throwing-sticks, Mexican and Californian, P932.

Thrushes. (See under Birds.)

Thysanoptera. (See under Insects.)

Thysanura. (See under Insects.)

Tibet, notes on ethnology, R1893, pt. 2, No. 7.

Ticks. (See under Arachnids.)

Tidestrom, Ivar, CNH16, pt. 13 (1st and 2d arts.), CNH25.

Tierra del Fuego, mosses, CNH1, No. 5 (2d art.-4).

Timber of submarine structures, Chelura terebrans destructive to, P83.

Timberlake, Philip Hunter, P2136, 2293, 2423, 2629.

Tinamou. (See under Birds.)

Tinkham, Ernest R., P3176.

Titanite, notes on, P2145.

Titmice. (See under Birds.)

Toadfishes. (See under Fishes.)

Toads. (See under Amphibians.)

Todd, Walter Edmund Clyde, P2752.

Todies. (See under Birds.)

Tokuno, T., R1892, pt. 3, No. 1.

Tokyo University, Diptera presented by to National Museum, P1146; woods presented by to National Museum, P232.

Tonga Group. (See under Oceania.)
Tonkin. (See under Indo-China.)

Topaz crystals in National Museum, P1148.

Torpedos. (See under Fishes.)

Torre, Carlos de la, and Bartsch, Paul, P3039, 3096.

Torre, Carlos de la; Bartsch, Paul; and Morrison, Joseph Paul Eldred, B181.

Torre, Carlos de la, and Henderson, John Brooks, P2369.

Tortoises. (See under Reptiles; also under Fossils, reptiles.)

Tortugas, destruction of fish near, P37.

Toucans. (See under Birds.)

Townsend, Charles Haskins, P492, 799, 800.

birds collected by in Alaska, P960; on islands in Caribbean Sea and Honduras, P665.

fishes collected by in San Cristobal Bay, Lower California, P469.

mammals collected by in eastern Honduras and Little Swan Island, P744.

Townsend, Charles Henry Tyler, P1935, 2115, 2128, 2152, 2301, 2942.

Trachomedusae. (See under Medusae.)

Tracks. (See under Transportation.)

Transit-of-Venus Expedition, Kerguelen Island, oology, B2; oology, botany, geology, mammals, fish, mollusks, insects, crustaceans, annelids, echinoderms, Anthozoa, minerals, Chionis minor, B3.

Transportation, canoes of the Kutenai and Amur, R1899, pt. 2, No. 4.

department of, contributions to the Ohio Valley Centennial Exposition, Cincinnati, C38.

human beast of burden, R1887, pt. 3, No. 3.

naval architecture, European, R1891, pt. 3, No. 7 ; Norsk, P583.

primitive, R1887, pt. 3, No. 3; 1894, pt. 2, No. 1.

rail, development of American, R1889, pt. 3, No. 6 .

Savannah, log of, R1890, pt. 3, No. 9. track, development of American, R1889, pt. 3, No. 6.

travel, primitive, R1894, pt. 2, No. 1. watercraft collection in National Museum, catalog, B127.

Travel. (See under Transportation.)

Traverse group. (See under Fossils.)

Treadwell, Aaron Louis, B100, vol. 1, pt. 8 ; vol. 6, pts. 2, 5; P2186, 2347, $2397,2499,2536,2584,2601,2641$, 2757, 2797, 2867, 2902, 2984, 3049.

Trees. (See under Plants.)

Treeshrews. (See under Mammals.)

Trelease, William, CNH26, pts. 2, 4.

Trematodes, Amphiuma means, P2471.

Apophallus and related genera, P2883.

Brachycoelium, observations on, P3010. 
TREMATODES (continued).

distome, viviparous, P2040.

Eucotyle from North American birds, P2824.

fluke, liver, from African monkey, P2783; Parametorchis noveboracensis, from cat, P2627.

from bass, white, P2430.

from bat, little brown, P2986.

from birds, P893, 2722.

from dog, China, P2415.

from fishes, P1133; Bermuda, P1560; Galveston Bay, P2977; Woods Hole region, Mass., P3078.

from goose, Canada, P2846.

from hen's egg, P636.

from mammals, marine, P2936.

from mud-eel, P3014.

from muskrat, P2870.

from rabbits in Texas, P2792.

Haematotrephus fodiens, relationship to new trematode from loon, P3071.

Hasstilesia, from rabbits, P2792.

Heterophyidae, synopsis, P2322; with note on Apophallus and related genera, P2883.

MacCallum collection, redescription of species, P2865.

Onchocotylinae, new species, P2892.

Ornithobilharzia, from Canada goose, P2846.

Parametorchis from fur-bearing animals, P2809.

Parametorchis noveboracensis, from cat, P2627.

Plagiorchiidae, new genus and species, P2885.

Pleurogenetinae, key to genera, P2986.

Pronocephalidae, note on, P2865.

Schistosomidae, synopsis, P2789.

Styphlodora bascaniensis, with blind Laurer's canal, P1817.

Urotrema from bats, P2928.

Trenton. (See under Fossils.)

Triassic. (See under Fossils.)

Trichalcite, notes on, P2455.

Trichoptera. (See under Insects.)

Triggerfishes. (See under Fishes.)

Trilobites. (See under Fossils.)

Trinidad, algae, calcareous, Lithothamnieae, Lower Miocene, P2453.

beetles, buprestid, Agrilus, P3167; new, P3183.

flora, Pleistocene, P2558.

Foraminifera, Upper Cretaceous, P2914.

gastropods and scaphopods, Miocene, P2559.

lanternflies, Fulgoroidea, P3184, 3189.

Triphylite, notes on, P2118.

Triplite, notes on, P2345.

Tristan, J. F., isopods collected in Costa

Rica, P1775.

Trogons. (See under Birds.)
Troost, Gerard, summary of unpublished manuscript on crinoids of Tennessee, B64.

Trout. (See under Fishes.)

Trowbridge, Harry Martin, and Wedel, Waldo Rudolph, P3091.

Truckee group, fossil mollusks, P267.

True, Frederick William, R1884, pt. 3, Nos. 4 , 5 ; 1889 , pt. 3 , No. $4 ; 1896$, pt. 2, No. 1 ; 1901, pt. 2, No. 1.

B27, pt. H, 36, 73.

C29, 41, 49.

P249, 256, 338, 358, 394, 419, 468, $495,540,541,557,564,580,602$, $603,623,659,699,734,743,744$, $812,814,826,915,948,954,963$, $972,976,982,999,1004,1006$, 1069, 1101, 1163, 1357, 1475, 2007.

True, F. W., and Lucas, Frederic Augustus, R1884, pt. 3, No. 6.

Trunkfishes. (See under Fishes.)

Tschermigite, from Utah, P2758.

Tsetse flies. (See under Fossils, insects.)

Tubangui, Marcos A, P2415.

Tuckerman, Edward, B15.

Tungsten mine at Long Hill, Trumbull, Conn., P2348.

Tunicates, America, Arctic, B15; northeast coast, P76, 534.

ascidians, Philippine, B100, vol. 1, pt. 2; simple, northeastern $\mathrm{Pa}$ cific, P1989.

Kerguelen Island, B3.

Philippine Islands, B100, vol. 1, pt. 2 , vol. 2 , pt. 1 .

salpas (Salpidae), Philippine, B100, vol. 2, pt. 1; taxonomic study, B100, vol. 2, pt. 2.

Tunnies. (See under Fishes.)

Turbellarians, polyclad, Philippine Islands, B100, vol. 1, pt. 10.

Turkestan, eastern, birds collected by W. L. Abbott, P1083.

Turkeys. (See under Birds.)

Turner, Lucien McShan, P279, 518, 736. mollusks collected by at Ungava Bay, Labrador, and the Arctic Seas, P561.

Turnstones. (See under Birds.)

Turtles. (See under Reptiles; also under Fossils, reptiles.)

Turton, W. H., collection of South African marine mollusks, B91.

Tusks, fossil, Clearwater County, Idaho, P2375.

Tuxtla (Mexico), jade of the statuette, P2409.

Two Medicine formation, Montana, dinosaurian reptiles, $\mathrm{P} 2839$.

Udden, Johan August, P2383.

Ugashagmut. (See under Anthropology, Eskimos.) 
Ugashak River, ethnological specimens from Ugashagmut tribe, P364.

Uhler, Philip Reese, P1108, 1360.

Ulke, Henry, P1275.

Ulrich, Edward Oscar, P2818.

Ulrich, E. O., and Bassler, Ray Smith, P1446, 1646, 2613, 2847.

Ultramarine, blue mineral supposed to be, P978.

Ulu. (See under Anthropology, knife.)

Underwood, Lucien Marcus, B46.

Ungava district of Hudson Bay Co., birds of, P518.

United States Department of Agriculture, Death Valley Expedition, botany, CNH4.

North American land and freshwater shells received from, P844.

North American mollusks from, P971.

United States Eclipse Expedition, west Africa, fishes, P2294; insects, P951.

(See also under United States Naval Eclipse Expedition.)

United States Fish Commission, Brachyura and Anomura collected off New England, P343.

Crustacea dredged off southern New England, P172.

decapod Crustacea, east coast of U. S., P455.

fishes, collected by, P723; obtained by off Atlantic and Gulf coasts of America, P543; off southern New England, P177.

Liparis ranula obtained by, $\mathrm{P} 65$.

Lycodes paxillus obtained by, P64.

starfishes and ophiurans collected by, P1000.

United States-Mexican boundary, mammals, with summary of natural history and list of trees, B56; petrographic report, P1173.

United States National Museum. (See under National Museum.)

United States Naval Eclipse Expedition, Oceania, fishes, P2931.

(See also under United States Eclipse Expedition.)

United States North Pacific Surveying Expedition, Hawaiian and Fanning Islands, and Lower California, B7.

United States Scientific Expedition, west Africa, crustaceans, P949; mollusks, P940.

"Universal Conchologist," P1425, 1565.

Uruguay, annelid, polychaetous, Aphrodita magna, P2584; heteronereis phase, P2499.

birds, observations on, B133.

fishes, collected by Albatross between Montevideo and Tome, Chile, P2133.

mollusks, Corbicula, P2552, 2699.

mussels, pearly fresh-water, P2485.

shells, fresh-water and marine bivalve, P2762.
Utah, Basketmakers, crania, P2845; catostomids, including type of Pantosteus virescens, Bonneville system, P2508.

chilopod, Henicops dolichopus, P1270. flora, CNH25.

invertebrate fossils from Mesozoic and Cenozoic rocks, P137.

katydid, Steiroxys hendersoni, P2468.

lizards, Upper Cretaceous, osteology, P3148, 3163.

mammalian faunas, Paleocene, P3121.

myriapod family Lithobiidae, Salt Lake County, P1242.

reptile, Upper Cretaceous, P3158.

tschermigite, ammoniojarosite, epsomite, celestite, and paligorskite from, P2758.

variscite, crystallized, P1867.

Utah Lake, notes on fishes, P175; Squalius aliciae, P186.

\section{V}

Vanadates, from Colorado, P2707.

Van Cleave, Harley Jones, P2346, 2430.

Vancouver Island, goby, Gobiosoma ios, P298.

Van Duzee, Millard Carr, P2490, 2560, 2755.

Van Duzee, M. C.; Cole, Frank Raymond; and Aldrich, John Merton, B116.

Van Eseltine, Glen Parker, CNH20, pt. 5.

Van Name, Willard Gibbs, B100, vol. 1, pt. 2.

Van Rensselaer, Mrs. John King, P836.

Variscite, from Utah, P1867.

Vasey, George, CNH1, No. 8 (1st-3d arts.) ; CNH3, No. 1; P620, 725, 772.

Vasey, George, and Rose, Joseph Nelson, CNH1, No. 1 (1st and $2 \mathrm{~d}$ arts.), No. 3 ; P749, 801.

Vaughan, Thomas Wayland, B59, 103, pts. 9, 11; P1194, 1401, 1473, 1477, $1526,2680,2800$.

Vaughan, T. W., and Cole, William Storrs, P2996.

Velardenite, from Tulare County, Calif., P2417.

Velie, J. W. fishes collected by in the Gulf of Mexico, P98.

Venezuela, hatrachians and reptiles, $\mathrm{La}$ Guaira, P1248.

birds, P555, 3073; La Guaira, P1247; Margarita Island, Guanta, and Laguayra, P1093.

Crustacea, Lake Valencia, P2381.

fishes, catfishes, P3172; Characinidae, P3181.

mammals, La Guaira, P1246.

moths, syntomid, P1434.

Phacellodomus, new species, P619. 
Venezuela (continued).

plants, La Guaira, CNH12, pt. 2 (3d art.) ; new, $\mathrm{CNH} 20$, pt. 13 (2d art.) ; Tertiary, P2388, 2988.

shipworm, P2874.

worms, acanthocephalous, from fishes, P2346.

Verrill, Addison Emory, B3, 15; P76, 168, 169, 284, 534, 1000.

Verrill, A. E., and Bush, Katharine Jeannette, P1139.

Vertebrate Paleontology, history of division in National Museum, P3109.

Vertebrates, cold-blooded, from Indiana University Farm, Mitchell, Ind., P1655.

deep-sea fishlike, P380.

(See also under Fossils.)

Vicksburg (Oligocene) mollusks, Mexico, P2731.

Vienna Natural History Museum, types of American muscoid flies in the collection, P2703, 2764.

Viereck, Henry Lorenz, B83; P1754, $1789,1812,1832,1859,1888,1920$, 1942, 1964, 1968, 1974, 2031, 2364.

Viereck, H. L., and Cockerell, Theodore Dru Alison, P2064.

Vincentown limesand, bryozoans, B165.

Violets. (See under Plants.)

Vireos. (See under Birds.)

Virgin Islands, bones of birds collected by $T$. de Booy from kitchen midden deposits, P2245; flora, B13 ; mammals and reptiles collected by T. de Booy, P2244.

Virginia, amphipod, new fresh-water, with notes on its biology, P1746.

Brachyura collected by Albatross, Norfolk to San Francisco, Calif., P1162.

copper ores, relation of bornite and chalcocite in, Virgilina District, P1835.

diabase, intrusive, mineralogy and petrology of Triassic, Goose Creek, Loudoun County, P2539; Leesburg, P2565.

fishes collected by W. P. Seal, Chesapeake Bay at Cape Charles City, P843.

Hampton Institute, list of Indian children, plaster casts of whose heads were made by Clark Mills, P79.

iron manufacture, early, P489.

meteoric metabolite, Dungannon, P2464.

meteorite, Sharps, Richmond County, P2492; Forksville, Mecklenburg County, P2670.

mollusks, littoral marine, Chincoteague Island, P2055; Miocene, P2759.

Mount Vernon, stone age at, P730. myriapod, blind, Luray Cave, P181. Orthoptera, field notes on, P2176.
VIRGINIA (continued).

plants, gymnospermous, Potomac Group, revision, P1821.

rabbit, new, from islands off coast, P1784.

snake, congo, Amphiuma, occurrence, P1150.

wasp, mason, P3004.

Vivianite encrusting a fossil tusk, P2375.

\section{W}

Wabash Valley, lower, notes on native trees, P1010.

Wade, Bruce, P2359.

Wagtails. (See under Birds.)

Walcott, Charles Doolittle, R1897, 1898; P738, 739, 746, 763, 775, 820, 1002, $1086,1120,1152,1229,1299,1395$, $1415,1458$.

bibliography of his publications on fossil invertebrates, B30.

Walker, Alfred Osten, P1767.

Walker, Bryant, P2321.

Walker, Egbert Hamilton, $\mathrm{CNH} 28$, pt. $4 ; 30$, pt. 1 (2d art.).

Walker, Francis, types of Tachinidae, P2910.

Walker, Henry Atchinson, and Pearse, Arthur Sperry, P3067.

Walker, Myrl Vincent, P3033.

Walker, S. T., P349, 396.

Walker Expedition to Santa Marta, Colombia, crustaceans, P2123.

Walking-sticks. (See under Insects, Orthoptera.)

Wallapai (Hualapai) Indian Reservation, meteoric irons, P2718.

Walrus. (See under Mammals; also under Fossils, mammals.)

Walsingham, Lord, P1567.

Walton, Arthur Calvin, P2947.

Walton, William Randolph, P2070.

Warblers. (See under Birds.)

Ward, Lester Frank, B22; [P232], P680, 1141.

Warren, William, P1421, 1456, 1601.

Washington, barnacles, San Juan Islands, P2362.

dragonflies, Bumping Lake, notes on, P2017; life history and ecology, P2107.

fairy shrimp of the genus Branchinecta, P3025.

fishes, Acrotus willoughbyi, P672; Ascelichthys rhodorus and Scytalina cerdale, Neah Bay, P144; collected by C. Bendire, P265; collected by J. G. Swan and new species of Macrurus, P388.

flora, CNH11.

Microlepidoptera, P3149.

Odonata, Bumping Lake, notes on, P2017.

pit house village site, prehistoric, Columbia River at Wahluke, Grant County, P2732. 
WAshington (continued).

siderite and associated minerals from Columbia River basalt, Spokane, P2458.

surf-smelt, method of taking by Quillehute Indians, P112.

Uranidea rhothea, Spokane River, P286.

Washington, D. C. (See District of Columbia.)

Washington, George, relics in National Museum, P2092.

Washington, Henry Stephens, P2409.

Wasps. (See under Insects, Hymenoptera.)

Water. (See under Chemistry.)

Watercraft. (See under Transporation.)

Watkins, John Elfreth, R1889, pt. 3, No. 6, 1890, pt. 3, No. 9; C38.

Watson, Thomas Leonard, P2492.

Watson, T. L., and Beard, Robert Edmund, P2220.

Wavellite, notes on, P2240, 2455.

Waverlyan period of Tennessee, fossils, P1851.

Waxwings. (See under Birds.)

Wead, Charles Kasson, R1900, pt. 2, No. 4.

Weapons, primitive, Philippine, B137.

(See also under bows, harpoons, slings, swords, throwing-sticks.)

Weaverbirds. (See under Birds.)

Weaving. (See under Anthropology.)

Webb, DeWitt, P966.

Webber, Ray Trask, P2853, 2863, 3108.

Webber, Ray T., and Aldrich, John Merton, P2486.

Webster, Harrison Edwin, B25, pt. 7.

Weckel, Ada Louise, P1507, 1768.

Wedel, Waldo Rudolph, B183, P3045.

Wedel, W. R., and Hill, Asa Thomas, P3141.

Wedel, W. R., and Trowbridge, Harry M., P3091.

Weed, Alfred Cleveland, and Bean, Barton Appler, P1682, 1694, 1723, 1764, 1816, 1824, 1919.

Weed, Clarence Moores, P950.

Weevils. (See under Insects, Coleoptera.)

Wehr, Everett Elmer, P2869, 2871, 2958.

Weld, Clara Jamieson, P2427.

Weld, Lewis Hart, P2368, 2378, 2439, 2440, 2611, 3178.

Weller, Stuart, P1549.

Wells, John Grant, P596.

Wells, John West, P2975.

Welsh, William Welsh, P2449.

[Wermch, Dr.], P218.

West Indian region, distribution of land and fresh-water mollusks, and evidence concerning past changes of land and sea, P1011.

West Indies, algae, marine, SmithsonianHartford Expedition, CNH28, pt. 3 .

Aphodiinae, revision of scarabaeid subfamily, P3092.
West INDIES (continued).

bees, Augochlora, P1717.

beetles, ceramybycid, P2922, 2979;

Eucnemididae, new, P3188; long-

icorn, Lamiinae, P2623; melolonthine, larvae, P3146; Staphylinidae, monograph, B182.

birds, collected by Albatross, Santa Lucia, P768.

collected by F. A. Ober, Antigua and Barbuda, P35; Dominica, P19; Grenada, P45; Guadeloupe, P57; Lesser Antilles, P61; Martinique, P51; St. Vincent.

Grenada, P45, 596.

Guadeloupe, P57, 545.

Turdidae, new species, Dominica, P103.

Coleoptera, revision, Buprestidae, P2522.

coot, new, P446.

corals, fossil, P2975.

crabs, hermit (pagurids), new symmetrical, P1236; new, P1104.

crinoid, Tertiary, P2516.

crustacean parasites, Sacculinidae, P2726; of fishes and land crabs, P1950.

crustaceans, Tertiary decapod, P2343.

echinoderms of Smithsonian-Hartford Expedition, and other records, P3056.

echinoids, B74.

fishes, P595.

Foraminifera, Operculina and Operculinoides, Tertiary, P2996.

geology and paleontology, contributions to, B103, pts. 1-11.

grasses, CNH18, pt. 7 .

guineafowls, B50, pt. 10.

Icterus, new, P166.

insects, Apterygota, P2702; coleopterous, checklist, B185.

Leptonacea, synopsis of Recent and Tertiary, P1177.

millipeds, notes on, P2431.

mollusk faunula, new, P2929.

Myadestes, synopsis, P260.

Numididae, B50, pt. 10.

onychophores from, P3027.

ophiuran, new, P1724.

seal, Monachus tropicalis, R1884, pt. 3 , No. 6.

sedimentary formations of Panama, relation to geologic history, B103, pt. 11.

shells, fossil land, P2254.

wasps, digger, Chlorioninae, P1487.

(See also under Antilles, Trinidad, Virgin Islands, etc.)

West Virginia, birds, P3021.

mammals, P3022.

porcupine, Canada, occurrence, P44. pottery, early, R1899, pt. 2, No. 3.

Wetmore, Alexander, R1925 through 1946; B133; P2059, 2191, 2245, 2251, 
WETMORE, A. (continued).

$2495,2821,2925,3003,3021,3030$, $3031,3050,3073,3089,3105,3117$, $3164,3179$.

Wetmore, Alexander, and Fisher, Albert Kenrick, P2876.

Wetmore, Alexander, and Lincoln, Frederick Charles, P2966.

Wetmore, Alexander, and Swales, Bradshaw Hall, B155.

Wetzel, Rudolf, P2846, 2864.

Weymouth, Andrew Allen, and Reeside, John Bernard, Jr., P2860.

Weymouth, Frank Walter, P1734.

Whales. (See under Mammals; also under Fossils, mammals.)

Wheatears. (See under Birds.)

Wherry, Edgar Theodore, [B118]; P2060, 2102, 2118, 2145, 2154, 2200, 2240.

Whippoorwills. (See under Birds.)

White, Charles Abiathar, R1892, pt. 3, No. 2; P86, 91-93, 113-116, 131, 137, 207, 266, 267, 366, 793, 995. bibliography of his publications on fossil invertebrates, B30. published writings of, P1813.

supplement to catalog of his writings, $\mathrm{P} 1135$.

White, David, B53, pt. 2, sect. 3 ; P1256, 1873.

Whitebread, Charles, P2528, 2582.

Whitefishes. (See under Fishes.)

White Mountain Apache Indian Reservation, Ariz., exploration of ruins, P2856.

Wickenden, Robert Thomas Daubigny, and Cushman, Joseph Augustine, P2780.

Wickham, Henry Frederick, P1982, 2189.

Wilkes Exploring Expedition, fishes, P2488.

Willey, Arthur, P2673.

Williams, Henry Shaler, P1527, 1596, 1600, 1908, 1985, 2144, 2225.

Williams, Robert Statham, CNH16, pt. 1 (4th art.).

Williamson, Edward Bruce, P1389, 1571, 1710, 2089.

Williamson, Martha Burton, P898.

Willis, Merritt, P351.

Williston, Samuel Wendell, B31; P1540.

Wilmot, Samuel, P43.

Wilson, Charles Branch, B158; P1302, $1368,1404,1504,1531,1573,1580$, $1652,1692,1783,1788,1805,1900$, $1928,1950,2063,2194,2274,2286$, 2354, 2377, 2400, 2507, 2915, 3177.

Wilson, Henry Van Peters, B100, vol. 2, pt. 4.

Wilson, H. V., and Penney, James Theophilus, P2805.

Wilson, Thomas, R1888, pt. 3, Nos. 6-8; 1890 , pt. 3 , No. $10 ; 1892$, pt. 3 , No. 6 ; 1894, pt. 2, Nos. 3, 6; 1895, pt. 2, No.
Wilson, T. (continued).

$8 ; 1896$, pt. 2 , No. $2 ; 1897$, pt. 2 , No. 7 ; C40, 42; P777.

Wilson, William Lyne, R1897, vol. 2.

Winslow, Francis, B27, pt. D.

Wisconsin, Colby, notes on the meteoric stone, P2574.

Wokas, food of Klamath Indians, R1892, pt. 2, No. 3 .

Wolcott, Albert Burk, P2370.

Wolffishes. (See under Fishes.)

Wolframite, notes on, P2060.

Wolpai, maid of, P889.

Wood, Elvira, B64.

Wood, Horace Elmer, 2d, P2948.

Wood, Japanese, presented to National Museum, P232.

timber of submarine structures, Chelura terebrans destructive to, P83.

(See also under Fossils.)

Wood-cuts, Japanese, R1892, pt. 3, No. 1.

Woodhewers. (See under Birds.)

Woodpeckers. (See under Birds.)

Woodring, Wendell Phillips, P2491, 2938.

Woods Hole. (See under Massachusetts.)

Wooton, Elmer Ottis, and Standley, Paul Carpenter, CNH16, pt. 4; CNH19.

Worcester, Dean Conant, and Bourns, Frank Swift, P1134.

World, genotypes of elaterid beetles, P2353.

systematic classification for birds of, P2821.

World's Columbian Exposition, system of classification, R1891, pt. 3, No. 8.

World's Industrial and Cotton Centennial Exposition. (See under Louisiana.)

Worms. (See under Annelids, Cestodes, Entozoa, Flatworms, Helminths, Nematodes, Oligochaetes, Polychaetes, Polyclads, Trematodes.)

Wortman, Jacob Lawson, P2304.

Wrens. (See under Birds.)

Wren-thrushes. (See under Birds.)

Wren-tits. (See under Birds.)

Wright, Albert Hazen, P2756.

Wyer, Samuel S, B102, pt. 7 ; pt. 8.

Wyoming, chlorites, analyses and optional properties, P2342.

crocodile, Leidyosuchus sternbergii from Ceratops beds, P1762.

dinosaur, Lance formation, P2875; Thescelosaurus, Lance formation, osteology, P2127.

fern, Gleichenia, Upper Cretaceous, P1994.

insects, Eocene, P2358.

invertebrate fossils from Mesozoic and Cenozoic rocks, P137.

lizards, Oligocene, P3124; xaranid, Saniwa ensidens, new description of, P2418.

mollusks, Cretaceous, Aspen shale, P2860. 
Wroming (continued).

owl, Eocene, P3031.

plants, Aspen shale, P2953.

Big Horn Mountains, CNH3, No.

9 (3d art.).

reptile, rhynchocephalian, Jurassic, "Quarry 9," P1698.

Testudo, Oligocene, notes on species, P3199.

turtles, Lance formation, P2137.

\section{$\mathrm{X}$}

Xantus, John, fishes collected by at Cape San Lucas, P290; at Colima, Mexico, P291.

\section{Y}

Yakutat Bay, Alaska, botany, $\mathrm{CNH}$, No. 6.

Yale Dominican Expedition, Hemiptera, P2269; Hymenoptera, P2048; Lepidoptera, P2056; Orthoptera, P2058.

Yale Peruvian Expedition, batrachians and reptiles, P1992; Hymenoptera, P1960; Hymenoptera Ichneumonoidea, addendum, P2052; Lepidoptera, P2006; Orthoptera, P1949, 2001.

Yale University Museum, fishes from Panama collected by Bradley, P329.
Yale University-National Geographic Society Expedition, Peru, amphibians and reptiles, P2352; birds, B117 ; mammals, P2333.

Yalu River, south Manchuria, silurid fish, P2408.

Yarrow, Harry Crécy, B24; P299, 359.

Yellowstone National Park, minerals of Obsidian Cliff and their origin, P2618.

Yucatán, birds collected by Albatross, Cozumel Island, P539.

Cyclorhis, new subspecies of, P588. hawk, new, Cozumel Island, P494. warbler, new, P476.

Yukon, fishes collected by, P210.

Yukon Territory, extinct horse, Equus lambei, from Pleistocene, P2212.

\section{Z}

Zebras. (See under Mammals.)

Zeledón, José Castulo, P499. remarks on Carpodectes antoniae, P605.

Zeliff, Clarke Courson, P2926, 2964, 3014.

Zeolites, Oregon, P2737.

Zetek, James, and Clark, Austin Hobart, P3197.

Zeuglodons, P1211, 1975.

Zimmer, Carl, P2992.

Zimmerman, Elwood Curtis, P3100. 


\section{$2 \mathrm{BHL}$ Biodiversity Heritage Library}

1947. "A list and index of the publications of the United States National Museum (1875-1946)." Bulletin 193, 1-306.

https://doi.org/10.5962/bhl.part.10067.

View This Item Online: https://www.biodiversitylibrary.org/item/32696

DOI: https://doi.org/10.5962/bhl.part.10067

Permalink: https://www.biodiversitylibrary.org/partpdf/10067.

\section{Holding Institution}

Smithsonian Libraries

\section{Sponsored by}

Smithsonian

\section{Copyright \& Reuse}

Copyright Status: NOT_IN_COPYRIGHT

This document was created from content at the Biodiversity Heritage Library, the world's largest open access digital library for biodiversity literature and archives. Visit BHL at https://www.biodiversitylibrary.org. 